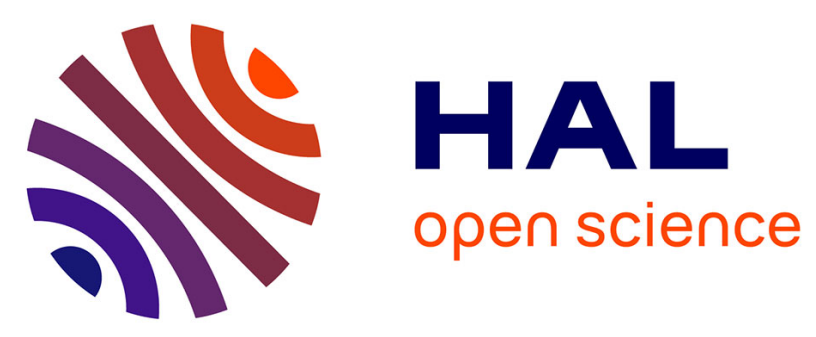

\title{
Governing the Empire. Provincial Administration in the Almohad Caliphate (1224-1269)
}

\author{
Pascal Buresi, Hicham El Aallaoui, Travis Bruce
}

\section{To cite this version:}

Pascal Buresi, Hicham El Aallaoui, Travis Bruce. Governing the Empire. Provincial Administration in the Almohad Caliphate (1224-1269): Critical Edition, Translation, and Study of Manuscript 4752 of the Hasaniyya Library in Rabat Containing 77 Taqādìm ("Appointments"). Brill, 3, pp.xxviii et 540, 2012, "Studies in the History and Society of the Maghrib", 10.1163/9789004239715 . halshs00804491

\section{HAL Id: halshs-00804491 \\ https://shs.hal.science/halshs-00804491}

Submitted on 18 Jan 2017

HAL is a multi-disciplinary open access archive for the deposit and dissemination of scientific research documents, whether they are published or not. The documents may come from teaching and research institutions in France or abroad, or from public or private research centers.
L'archive ouverte pluridisciplinaire HAL, est destinée au dépôt et à la diffusion de documents scientifiques de niveau recherche, publiés ou non, émanant des établissements d'enseignement et de recherche français ou étrangers, des laboratoires publics ou privés.

\section{(ㅇ)(1) $\$$}

Distributed under a Creative Commons Attribution - NonCommercial - NoDerivatives| 4.0 


\title{
Pascal BURESI
}

and

Hicham El AALLAOUI

Governing the Empire.

\section{Provincial Administration in the Almohad}

\author{
Caliphate
}

(1224-1269) 
Critical edition, translation, and study of manuscript 4752 of the Hasaniyya Library in Rabat containing 77 taqā $\bar{\imath} m$ ("appointments")

Travis Bruce (English translation) 

Abbreviations
'Abd al-Razzāq: AL-ṢAN 'ĀNĪ, 'Abd al-Razzāq, al-Muṣannaf, 11 vols, Beirut, al-maktab al- islāmī, 1987
DIHA:
LÉvi-ProvenÇAL, Évariste (ed., trans., and introd.), Kitāb akhbār al- Mahd̄̄ Ibn Tūmart wa-bidāyat dawlat al-muwahhidìn, Documents inédits d'histoire almohade. Fragments manuscrits du legajo 1919 du fonds arabe de l'Escurial, Paris, Geuthner, 1928
EI $I^{2} \quad$ Encyclopédie de l'islam, Leiden-Paris, E. J. Brill-G. P. Maisonneuve et Larose, $2^{\text {nd }}$ ed., 1960-2009, 13 vols.
HPIA: HUICI MiRANDA, Ambrosio, Historia política del imperio almohade, 2 vols. Tétouan, Editora Marroquí, 1956-1959
Ibn Ḥibbān: IBN BALABBĀN, Șaḥịh Ibn Hibbān bi-tartīb Ibn Balabbān, 18 vols, Beirut, al- risāla, 1997
MG: $\quad$ Mehdi Ghouirgate
Muslim, Sahịh: AL-NAWĀWĪ, al-Minhāj sharh Ṣahịḥ Muslim b. al-Hajjāj, 18 vols, Beirut, Dār al-ma rifa, 1999
NLA: 'AZZĀWĪ, Aḥmad, Rasā’il muwaḥhidiyya. Majmū'a jadīda (Nouvelles lettres almohades), annotated and commented ed. of new Almohad letters, Université Ibn Tufayl, Kénitra, 1995
NLA 2:
'AZZĀWĪ, Aḥmad, Rasā'il dīwāniyya muwaḥhidiyya, Rabat, 2006
RIEIM:
Revista del Instituto de Estudios Islámicos de Madrid
ROMM: $\quad$ Revue de l'Orient musulman et de la Méditerranée 
Phonetic transcriptions

\begin{tabular}{|c|c|}
\hline Transcription & Arabic Letter \\
\hline$\overline{\mathrm{a}}$ & 1 \\
\hline $\mathrm{b}$ & ب \\
\hline $\mathrm{t}$ & $ت$ \\
\hline th & ث \\
\hline $\mathrm{j}$ & ج \\
\hline ha & $\tau$ \\
\hline $\mathrm{kh}$ & $\dot{\tau}$ \\
\hline $\mathrm{d}$ & د \\
\hline $\mathrm{dh}$ & ذ \\
\hline $\mathrm{r}$ & J \\
\hline $\mathrm{z}$ & j \\
\hline $\mathrm{s}$ & س س \\
\hline sh & ش \\
\hline ș & ص ص \\
\hline d̦ & ض \\
\hline$t$ & $b$ \\
\hline $\mathrm{z}$ & ظ \\
\hline ' & $\varepsilon$ \\
\hline gh & $\dot{\varepsilon}$ \\
\hline $\mathrm{f}$ & ف \\
\hline$q$ & ق \\
\hline $\mathrm{k}$ & ك \\
\hline 1 & J \\
\hline $\mathrm{m}$ & 5 \\
\hline $\mathrm{n}$ & ن \\
\hline $\mathrm{h}$ & 。 \\
\hline $\mathrm{w}, \overline{\mathrm{u}}$ & 9 \\
\hline $\mathrm{y}, \overline{\mathrm{1}}$ & ي \\
\hline
\end{tabular}

Table 1: Phonetic transcriptions 


\section{Prologue}

The conquest of Marrakesh in 1147 by the troops of 'Abd al-Mu'min ended the Almoravid era in Morocco, but this was much more than a simple change in power at the local level. It constituted, in fact, an essential step in the Maghrib's emancipation from Eastern centers of influence. This military victory, prepared by more than a dozen partial victories and stinging defeats, resulted also in the death or execution of the last rulers of the Saharan Almoravid dynasty (1071-1147). It represents the moment of birth for the new Empire which, though not always easily, took the place of the toppled regime. More than a principality, less than an Empire, the new power was undergoing transformative growth. It exercised authority over the region of Marrakesh, over the major urban centers of northern Morocco, spreading then over al-Andalus and proceeding simultaneously to the unification of the entire Maghrib, from the Atlantic to Tripolitania. Only the Sahara escaped its grasp, from whence came the Lamtūna-Banū Turjūt, founders of the Almoravid Empire. Despite the new rulers' affirmation of a total rupture with the previous regime, symbolized in the beheading of the last Almoravid ruler, many elements continued on from one regime to the next. Without them, it would be difficult to understand the development of what can be considered the largest MaghribīAndalusī empire in history.

Despite, or because of France and North Africa's shared, often painful, past, French researchers passed over the medieval Maghrib during the second half of the twentieth century. The great historical works on this region written over half a century ago in a colonial context have not been renewed. Governing the Empire is meant to serve as part of a renewal in North African studies. It aims to correct in part our ignorance of medieval political systems in the Western Mediterranean. With the edition, translation, and study of a specific documentary corpus, seventy-seven provincial appointments preserved in a manuscript in the Hasaniyya (formerly Royal) Library of Rabat, we will treat a number of themes through the Almohad example, such as the preservation of administrative memory in the medieval Islamic world, the behavior of imperial powers before the advent of the modern state, as well as the means of controlling populations and lands in a territory characterized by the complimentary qualities of vast nomadic spaces and the exceptional vitality of its cities, which were among the most important in the Mediterranean basin at the time. 
Introduction 
GOVERNING THE EMPIRE

\section{Context}


The birth of the Almohad Empire refers as much to myth as it does to history: Ibn Tūmart's journey to the East, his meeting with the Almoravid authorities, the first bay ' $a$ by his disciples in the Atlas Mountains, the first battles against the plains powers, the death of the Mahdī, and the conquest of Marrakesh. The Almohads have caused much ink to flow. As founders of an excessively bureaucratic Empire, they wrote numerous documents many of which are still extant. Lead by a dynasty carried to power by 'Abd al-Mu'min (d. 1162), they surrounded themselves with scholars dedicated to singing their exploits in the form of panegyrics, heroic poems or chronicles. Bearing a complex dogma and original ideology, they rewrote history in their favor, recycling time, directing Maghribī space, and erasing the words of their predecessors to engrave their own. Nevertheless, the originality of the structure that they put into place could not stray from the framework they contributed to formalizing. Therein lies the dialectic of distinction through conformity, i.e. the conformity of distinction, that is at the heart of this study.

A new imperial structure emerged at the end of the eleventh century, one whose political, cultural, artistic, or religious importance historians have often underestimated. Under the aegis of Saharan Berber nomads, the Almoravids, this empire united the eastern Maghrib and alAndalus - the part of the Iberian Peninsula belonging to Dār al-Islām. For the first time in history, a Maghribī power controlled both shores of the Straits of Gibraltar. The Almohads followed the path opened by the Almoravids, reinforcing the political unity of the Maghrib and al-Andalus, with the center of power in North Africa. Both dynasties came from religious reform movements and bear witness, each in its own way, to the growing islamization of the Maghrib to which they contributed. Both empires, moreover, were led by Berber rulers whose power was based on the military strength of confederated Berber tribes. For two centuries, from 1071 to 1269 , the capital of this territorial ensemble was Marrakesh, founded by the Almoravids, while al-Andalus, on the other side of the Straits, was home only to secondary capitals.

There were, despite these continuities, significant differences between the two empires. The Almoravids were Saharan nomads from the Șanhāja confederation, with their own anthropological specificities. Their tribes were matriarchal-which is atypical for the Islamic world-; women were not veiled and held important social power, while men wore veils over their mouths (lithām), whence the sobriquet mulaththamūn ("veiled") given to the Almoravids. 
The Almohads, for their part, were sedentary inhabitants of the Atlas Mountains, members of the Mașmūda confederation, with a patrilineal society. Both groups were Berber speakers, and the psychological war lead by the Almohads against the Almoravids has characterized comparisons of the two throughout history. ${ }^{1}$ The Almoravids were said to be illiterate. Worse still, concerning legal affairs - viz. justice - they had forgotten the Law by not referring more directly to the Koran and the Sunna, preferring exclusively the large compilations of juridical consultations that form the basis of the Mālikī school of law dominant in the Maghrib and al-Andalus since the ninth century. Comparing the Almoravid and Almohad chancelleries, however, reveals that continuing out of the taifa period, a time when writers, poets, and chancellery secretaries acted as "king makers", adab, the classical literary culture at the core of the educated honest Muslim, exerted a strong influence over the Almoravid chancellery, contradicting Almohad accusations of illiteracy. Moreover, the important influence of Berber language during the Almohad period also becomes clear, as shown by the founder of the Almohad movement, Ibn Tūmart, who preached in Berber and wrote his profession of faith in the same language. It was probably not until the reign of the second Almohad caliph, Yūsuf Abū Ya 'qūb (1162-1184) that Ibn Tūmart's works were translated into Arabic.

There is another important link between these two Berber-founded empires: despite their geographic origins, both regimes referred to the Arabic East. A prince with the title of amir al-muslimin ("Prince of the Muslims") ruled the Almoravid Empire, a title modeled after amīr al-mu'minin ("Prince of the believers"), which was adopted by the caliph 'Umar (634-644), a close companion to the Prophet and his second successor. This refusal to carry a title of caliphal rank reveals that the Almoravid ruler did not claim the leadership of the entire community of believers, only a "diverted" authority over a portion of Dār al-Islām. The religious reform that he defended was part of an extreme legalism and referred back through a series of acts to the superior authority of the Abbasid caliph in Baghdad, thus in particular opposition to the Shiites and as a continuation of the eleventh century. It accorded an essential role to the Mālikī jurists for legitimating political decisions taken by the rulers and so placed the Maghrib and al-Andalus in the lap of the East. The Almoravids accepted a subaltern place for the territories their reformist dynasty led and drew even a glorifying theme or legitimacy from the dependence and theoretical respect that they gave the signs of recognizing the central Iraqi power.

\footnotetext{
1 N. BARBOUR, "La guerra psicológica".

2 B. SORAVIA, Les fonctionnaires épistoliers.
} 
The Almohad Empire (1130-1269), on the other hand, was led by a caliph who manifested his "universalist" ambition of guiding the entire Dār al-Islām, and who rivaled in his titles, prerogatives, legitimacy, and, more generally, ideologically, the Abbasid caliphs in Baghdad (750-1258) and the Fatimids in Cairo (969-1171). The Almohads' religious reform came out of a kind of "encore revelation" and reproduction of the "Muhammadan" act that recast in a way the original Islamic empire in the West. In a religion that presented itself as an end result, Muhammad being the seal of the prophets, in a history where the weight of tradition dominated and innovation was automatically seen as "condemnable," the only possible reform meant coming as close as possible to the constantly rebuilt referential model during the first decades of the Muhammadan revelation and the emergence of the caliphate (612-end of the seventh century). Pushed to its extreme under the Almohads, this tendency led to a repetition of the origins, in a cyclical and eschatological perspective, with the Muslim historical present merging with its beginnings.

The messianic dimensions of Almohad power are confirmed first in the mahdī status attributed to the movement's founder; this Shiite-inspired term had strong eschatological connotations. Fictitious genealogies, a concession to the constraints of the period that accorded importance to the nobility of one's ancestry, traced the bloodline of not only Ibn Tümart (d. 1130), but also the first caliph, 'Abd al-Mu'min (r. 1130-1162) back to 'Alī, the prophet's sonin-law and cousin. ${ }^{3}$ Finally, more generally, the terminology of early Islam was applied almost systematically as a veneer onto the history of the Almohad Islamic West. After the Mahdi (the end time), the caliphal era begins again (which follows immediately on the initial era of the Muhammadan prophecy). ${ }^{4}$ The first four Almohad caliphs, at the beginning of the thirteenth century, thus received the title rāshidūn ("orthodox"), on coins and in textual sources, like the first four caliphs of Sunni Islam - Abū Bakr (632-634), 'Umar (634-644), 'Uthmān (644-656) and 'Alī (656-661). Their military expeditions were likewise described in the same terms as the futūhăt, the "conquests" of the first generation sanctified by the Sunna. ${ }^{5}$

\footnotetext{
${ }^{3}$ M. FIERRO, "Las genealogías de 'Abd al-Mu'min".

${ }^{4}$ See M. García Arenal's brilliant and complete treatment of messianism and mahdism in the medieval Maghrib, Messiansim and Puritanical Reform. See also M. Fierro, "Sobre monedas de época almohade", 465: "En suma, el mahdismo de Ibn Tūmart era, ante todo, una fórmula político-religiosa para crear un Estado. De hecho, este tipo de mahdismo no es sino la actualización — post-Muhammad — del modelo profético de los orígenes del islam".

${ }^{5}$ For the precise references of the chronicle texts, see P. Buresi, "La reaction idéologique dans la péninsule lbérique".
} 
Moreover, in this messianic context, the Almohads reinvented a relic: a copy of the Koran (mușhaf) attributed to 'Uthmān ${ }^{6}$ is systematically mentioned in textual sources and was the object of a cult on the part of the dynasty alongside the book (mușaf) written by the Mahdi Ibn Tūmart. ${ }^{7}$ These two precious copies were shown during military parades, carried on the backs of a white she-camel and a mule. They were both kept in the sanctuary mosque of Tinmāl, the burial place of Ibn Tūmart. In this manner, and many others, the Almohad caliphate was totally "orthodox." Referring exclusively to the Koran and the Sunna, it proclaimed its absolute orthodoxy. There could, moreover, be no other, since Almohad Mahdism was molded on the Muhammadan prophecy. To counter the risk of being accused of heterodoxy and Shiism, of which, in fact, this Mahdism was incontestably a continuation, the Almohads chose to celebrate the tutelary figure of 'Uthmān and the legacy of the Umayyads, the irreducible and hated enemies of all Shiites from the eighth to the twelfth century. ${ }^{8}$ They chose white as the color for their banners, emblematic of the Damascene, then Cordovan Umayyad dynasty, against the black of the Abbasids. ${ }^{9}$ They even decided for a time, in 1161, to restore the fallen former capital of al-Andalus, at the expense of its rival, Seville, which had taken its place. The Almohad reform thus affirmed in the twelfth century the preeminence of the western territories of Islam over all other parts of the Muslim world. This vision of power was closely tied to the history of the Umayyad Cordovan caliphate and its emancipation from Eastern capitals, with the Almohad reform successfully bringing together the histories of the Maghrib and al-Andalus.

The concept of niyāba ("delegation") was dominant during the Almoravid period. The $n \bar{a}$ ' $i b$ was exactly the prince's substitute, by delegation, with all his prerogatives. The Almoravid governors, in fact and in the law, were largely independent, though this does not indicate weakness on the part of the central regime, as Vincent Lagardère had posited. ${ }^{10}$ In fact, the Almoravid emir had strong control over the governors, appointing and dismissing them; the

\footnotetext{
${ }^{6}$ According to Islamic tradition, 'Uthmān was the harrāq al-kutub (the "book burner"), who supposedly caused the disappearance of all divergent versions of the word of God, especially those of 'Ali's partisans, the Prophet's son-in-law and cousin, and, at the same time, who brought together the first complete and definitive version of the Koranic corpus. Recent historians have argued for a later date for the foundational corpus (Koran and hadith), the beginning of the tenth century. See M. Arkoun, Essais sur la pensée islamique, and more recently A.-L. de Prémare, Les fondations de l'islam and Aux origines du Coran, and F. Déroche, Le coran.

7 Cf. P. Buresi, "Une relique almohade".

8 'Uthmān, one of the first converts to Islam, was a member of the Banū Umayya in Mecca, rival clan to the Prophet Muḥammad's, the Banū Hāshim. He was the third rāshidūn caliph, ruling from 644 to 656 . Accused by 'Alīs partisans of favoring his clan to the detriment of Muhammad's family, he was assassinated. The 'Alids handled poorly the circumvention of their champion in the succession, and the fact that the late converts Banū Umayyad, whom they had fought from 622 to 631, were receiving commanding posts in the budding Empire.

9 M. J. VIGUERA, "Las reacciones de los Andalusíes", 705-735.

10 V. LAGARDĖRE, Les Almoravides.
} 
governors' independence was equal only to their responsibility. Any political, military or fiscal failure in the provinces was the fault of the provincial governor. He was the one who organized each year the military expeditions of just war (jihād) against the Christians, manifesting the independence of outlying provinces in relation to the center of Maghribi power. The governors likewise controlled monetary production.

The Almohad period, however, saw the power of provincial governors decrease, even though they were no longer recruited from among the ruling sovereign's tribe, as had been the case under the Almoravids, but exclusively from the ruling Almohad caliph's descendants, the sayyids. ${ }^{11}$ The new vision of territory that came out of this provides an interesting matter for study. What were the consequences of reducing the pool of recruits to the core ruling family, and more precisely to the descendants of 'Abd al-Mu'min, the first Almohad caliph? It would indeed seem that the consequences were not greater regional autonomy, from 1147 to 1228 , but in fact growing submission to the caliph, as if on top of the political authority of the sovereign over his provincial administrators was added the "natural" authority of a father over his sons.

The decision-making process was concentrated in the hands of the caliph who led in person the expeditions of just war, with local administrators seeing their role reduced to preparing ceremonies to welcome the caliph and supply his armies. This leads to the question then of the impact of Almohad centralization on the territorial coherence of the Afro-European Empire and on the legal formalization of relations between the central power and the provinces. As caliph, the Almohad ruler was supreme judge in the name of God's Law. According to the chronicles, he retained for himself the equivalent of "high justice" in the medieval West, and a death sentence could not be carried out without his approval. This system thus reinforced ties between the prince's central authority, the hadra ("[His] Presence"), and peripheral territories in the Maghrib and al-Andalus. This centralization resulted, from a quantitative point of view, in an explosion in the number of informative letters issued to the prince by provincial chancelleries. $^{12}$

This centralization likewise resulted in the displacement of local populations: the Almohad leaders collided with nomadic Arab groups who, since their arrival in the middle of the eleventh century, had perturbed the eastern peripheries of the Empire (modern Libya and Tunisia). Beginning in the 1160s, these tribes, militarily defeated a number of times, were sent

\footnotetext{
${ }^{11}$ In the Almohad period, this term designated first the sons of the first Almohad caliph, 'Abd al-Mu'min (r. 11301162), then their descendants.

12 P. BURESI and H. EL AALLAOUI, "La chancellerie almohade".
} 
either to al-Andalus to fight against the Christians, or to the "Extreme" Maghrib (al-Aqșā). This caliphal, centralized Empire, organized around an original and coherent doctrinal system did not appear ex nihilo. These characteristics emerged over the course of decades of territorial expansion, with a growing definition of its territorial and demographic contours, faced with the Mālikī Almoravid provinces of the Maghrib and al-Andalus, with the Christian polities of the Iberian Peninsula, and the Ifrìquyan borderlands where sub-Saharan or Arab tribes from the East lived as nomads. 


\section{Historiography}

Scholars from a number of very different historiographical currents have examined the Almohad period since the middle of the twentieth century. These include authors from the French colonial period, Spanish scholars and Arabists, French and Anglo-Saxon anthropologists, Eastern and Western Arabic authors, and researchers from the Iberian Peninsula whose national history and the ties of their country with Morocco provoked interest in the medieval and modern history of this land. It is a valid question then to ask what another study would add to this long list. What theme, source or theoretical problem could the attention and erudition of these scholars have ignored?

The first source of knowledge for an historical period is its sources. The edition and translation of narrative sources concerning the Almohad Empire thus led to the first historical works on the subject. ${ }^{13}$ The principal works are the general chronicles such as Ibn 'Idhārī's Bayān al-Mughrib fì akhbār al-Andalus wa-l-Maghrib (14 ${ }^{\text {th }}$ c.), ${ }^{14}$ al-Marrākushī's Kitāb al$m u$ 'jib fì talkhīs akhbār al-Maghrib (13 ${ }^{\text {th }}$ c.), ${ }^{15}$ Ibn al-Qatțān's Naẓm al-jumān li-tartīb mā salafa min akhbār al-zamān $\left(13^{\text {th }}\right.$ c.) ${ }^{16}$ and Ibn Abī Zar's Raw ḍ al-qirțās (first third of the $14^{\text {th }}$ c.). ${ }^{17}$ Also important are the specifically Almohad chronicles, such as al-Bayḍaq's Kitāb akhbār al-Mahdī Ibn Tūmart wa btidā' dawlat al-Muwaḥhidīn ${ }^{18}$ and Ibn Ṣāḥib al-Ṣalā's Mann bi-limāma (after 600/1203). ${ }^{19}$ It was essentially on these chronicles, supplemented by contemporary Eastern sources such as Ibn al-Athīr's Kämil fì l-ta'rīkh (d. 1233), or by later sources that compile or complete them, such as works by Ibn al-Khațīb ${ }^{20}$ Ibn Khaldūn (13321406), ${ }^{21}$ or al-Maqqari $\overline{1},{ }^{22}$ that the pioneers of Almohad history relied in writing an essentially political history of the Maghrib and al-Andalus. The most complete of these was most certainly

\footnotetext{
13 See R. Millet, Les Almohades.

14 IBN 'IDHĀRĪ, Bayān, t. 4 ; t. 5, Almohad part ; trans. A. HUICI MIRANDA.

15 'A. al-W. AL-MARRĀKUSHĪ, Kitāb al-mu jiib, Spanish trans. A. HUICI MIRANDA.

16 IBN AL-QATṬ̂̄N (13 ${ }^{\text {th }}$ C.), "Six fragments inédits" ; Naẓm al-jumān.

17 IBN ABĪ ZAR' al-Fāsī (1 ${ }^{\text {st }}$ third of $14^{\text {th }} \mathrm{C}$.), al-Anīs al-muțrib bi-rawọ al-qirțās ; Rawọ al-qirțās, trans. A. HUICI MIRANDA.

18 The Kitāb akhbār al-Mahdī is actually composed of the Kitāb al-ansāb fĩ ma rifat al-așhāb, of which only a summary is extant (al-muqtabis min kitāb al-anșāb fi ma rifat al-așhāb) and another section entitled Ta'rīkh al-muwahhidīn. Évariste Lévi-Provençal edited and translated this work under the title Kitāb akhbār al-Mahdī, 1928 (hereafter DIHA).

19 IBN ȘĀHIB AL-ṢALĀ, al-Mann bi-I-Imāma ; Spanish trans. A. HUICI MIRANDA.

20 IBN AL-KHATĪB, al-Ihāța fĩ akhbār Gharnāṭa.

21 IBN KHALDŪN (732/1332-784/1406), Muqaddima; Kitāb al-'Ibar; Histoire des Berbères, trans. DE SLANE.

${ }^{22}$ AL-MAQQARĪ, Nafḥ al-țīb.
} 
Ambrosio Huici Miranda's Historia política del imperio almohade. ${ }^{23}$ This work of over 700 pages, divided into 240 chapters [sic], followed a chronological order, taking its inspiration from the rhythm of the chronicles. Less a study, it was more a very complete summary of the political history of the Almohad dynasty, attempting to bridge the gaps and variances between the different narrative sources.

Concomitantly with the linear history of the steps in the political and military construction of Almohad power, researchers were also interested in its founder, Ibn Tūmart. ${ }^{24}$ They were drawn to the very original ideology he initiated, ${ }^{25}$ as well as to the chronology of the reform, then rebellion, and finally the revolt opened by the Mahdī's faithful against the declining power of the Almoravids. ${ }^{26}$

A second group of studies covers the political structure put in place by the Almohads after Ibn Tūmart's death in 1130: first the process of building a territorial ensemble from the Atlantic to Tripolitania and from the Moroccan South to the central Iberian Peninsula, ${ }^{27}$ then the internal organization of this Maghribī Empire with at times some confusion between the structures of the movement begun by the Mahdi ${ }^{28}$ and the Empire at its height. ${ }^{29}$ Because of a lack of contemporary sources, few researchers have been attracted to the period of decline that began in the $1220 \mathrm{~s} .{ }^{30}$ All of the studies mentioned rely on the same documentary corpus, not only for narrative sources, but also for writings attributed to the founder of the movement, Ibn

${ }^{23}$ A. HUICI MIRANDA, Historia política del imperio almohade [hereafter HPIA].

24 'Abd al-H.. S. ZAGHLŪL, Muḥammad Ibn Tūmart; 'Abd al-M. AL-NAJJĀR, al-Mahdī Ibn Tūmart. Dominique Urvoy insists on the absence of originality in this last work, on its lack of rigor as well as its "political" objective: Annales islamologiques, 6, 1989, 56-7.

${ }^{25}$ R. BOUROUIBA, "La doctrine almohade" ; Ibn Tūmart ; S. A'RĀB et C. ADANG, "Mawqif al-muwaḥhidīn" ; M. FLETCHER, "Al-Andalus and North Africa" ; C. AdANG, "Zāhirīs of Almohad times" ; M. FIERRO, "Las genealogías de 'Abd al-Mu'min".

${ }^{26}$ M. Asín PALACIOS, "Origen y carácter de la revolución almohade" ; A. HUICI MIRANDA, "La leyenda y la historia" ; É. LÉVI-PROVENÇAL, "La naissance d'un Empire".

${ }^{27}$ A. Merad, "Abd al-Mu'min à la conquête de l'Afrique du Nord" ; R. Le TourneAu, "Du mouvement almohade à la dynastie mu'minide" and The Almohad Movement; R. BouroulBA, 'Abd al-Mu'min, flambeau des Almohades.

28 J. F. P. HOPKINS, "The Almohad Hierarchy".

${ }^{29}$ A. HUICI MIRANDA, "La participación de los jeques" and "El reinado del califa almohade al-Rashīd" ; É. FRICAUD, "Les țalaba".

${ }^{30}$ Except for Mina Karmi Blomme's unpublished dissertation, La chute de l'Empire Almohade, which uses the little information provided by later historians such as Ibn Khaldūn, and represents, though using only narrative sources, a very serious summary of the political, intellectual, and economic evolution of the Empire after al-Ma'mūn's reign, no study examines exclusively the period 1220-1269. Half the dissertation, though, focuses on the development of Almohad power, the instauration of the Mu'minid caliphate and "classic" Almohad doctrine. 
Tūmart. ${ }^{31}$ Biographical (tabaqāt) ${ }^{32}$ and geographical dictionaries, ${ }^{33}$ as well as travelogues, help complete the information offered by this corpus of sources. María Jesús Viguera Molíns directed a work in 1997 that summarized the state of knowledge on the Almohad Empire and provided a bibliography of both Western and Arabic authors. ${ }^{34}$ The contributors, Spanish specialists on the question, addressed their respective sections by first drawing up a summary of previous studies, on political, ${ }^{35}$ administrative, ${ }^{36}$ and judicial institutions, ${ }^{37}$ on economic and fiscal structures, ${ }^{38}$ on religious and theological aspects, ${ }^{39}$ and also military organization. ${ }^{40}$

The perspective for this book was decidedly Iberian, and the Almoravid and Almohad Empires were treated in so much as they played a major role in the political, social, economic and religious history of al-Andalus between 1086 and the $1230 \mathrm{~s}^{41}$ The focus is obviously widened at times beyond the geographic borders of the Iberian Peninsula in an effort of coherence and adaptation to sources concerned with the Muslim West as a whole. El retroceso territorial de al-Andalus does, however, present two major handicaps: the title itself indicates how this monumental work as a whole takes the perspective of how the Almoravid and Almohad political constructions impacted the Iberian territory, while its authors and Andalusī focus adopt a peripheral point of view in regards to the Maghribī rationale of these Berber Empires. Despite the scholarly quality of the texts and the exhaustiveness of the themes treated, the problem of center and periphery, which is essential for understanding these medieval Empires, is quite naturally not the principal angle of approach. Studies on the Almohad

31 IBN TŪMART, A'azz mā yuțlab; R. BRUNSCHVIG, "Sur la doctrine du Mahdī lbn Tūmart"; R. LE TOURNEAU, "Sur la disparition de la doctrine almohade".

${ }^{32}$ In particular Ibn al-Abbār, al-Hulla al-siyāra'. Other references will be given over the course of the text.

${ }^{33}$ Mainly YĀQŪT (m. 1229), Mu jam al-Buldān ; G. 'ABD AL-KARĪM (trad.), La España musulmana en la obra de Yãqūt, as well as a Maghribī author, AL-ḦIMYARĨ (d. 1326), La péninsule ibérique au Moyen Âge.

${ }^{34} \mathrm{M}^{\mathrm{a}} \mathrm{J}$. VIGUERA MOLínS (dir.), El retroceso territorial.

${ }^{35}$ R. CASTRILLO MÁRQUEZ, "Instituciones políticas", 136-145.

${ }^{36}$ L. MOLINA MARTíNEZ, "Instituciones administrativas", 150-167.

${ }^{37}$ F. RODRíGUEZ MEDIANO, "Instituciones judiciales".

${ }^{38}$ E. MOLINA PÉREZ, "Economía, propiedad, impuestos", 213-225, 234-244, and 249-256.

39 M. FIERRO, "La religión".

40 V. AGUILAR SEBASTIÁN, "Instituciones militares", from her Ph.D. dissertation, Tribus árabes en el Maghreb almohade.

${ }^{41}$ See also Ma J. VIGUERA MoLíns, "Al-Andalus en época almohade", 9-29, Los reinos de taifas, spec. 205-347 and "La fuerza de la fe: la reacción almohade", 138-146. On the place of al-Andalus in the respective African and Iberian historiographies, see the recent updated summary in M. MARín (ed.), AlAndalus / España. 
Empire's military structure and on the incorporation of the Arab Ifrīqiyī tribes and ghuzz into the Almohad army, among other complimentary works, have shed light on additional aspects. ${ }^{42}$

Alongside political history, Arabic authors were, in fact, primarily concerned with the Almohad regime's internal organization. Muḥammad 'Abdallāh 'Inān's 'Aṣr al-murābițīn wal-muwahhidin offers an overall view of the Maghrib and al-Andalus in the Almoravid and Almohad periods. ${ }^{43}$ Though it takes into account the contemporary peninsular Christian kingdoms, this work does not break with Huici Miranda's narrative and non-analytical approach. ${ }^{44}$ 'Izz al-Dīn 'Umar Mūsá's al-Muwaḥhidūn fĩ l-Gharb al-islāmī. Tanẓimātu-hum wa nazmu-hum, though much more recent is no more innovative in the matter. It seeks to examine the Almohad Empire's administrative system using the entirety of sources available, but does not take sufficiently into account their respective natures. This scholar does, nevertheless, offer a summary and organization superior to those of his predecessors, adopting a thematic outline and building tables based on cross-referenced data (the status of individuals and their offices, for example). ${ }^{45}$ The result is a systematic and painstaking presentation of the Almohad imperial political organization, attentive to the geographic dimensions of political power. $^{46}$

Researchers have likewise attempted other approaches to the history of the medieval Maghrib. A number of researchers continued in the line of studies from the 1950s, 60s, and 70s on African and more specifically North African societies, applying anthropological methods to sources from the Almohad period. ${ }^{47}$ They focused in particular on the family and tribal structures of Maghribī society, fascinated by the exotic character of not only the endogamous

42 F. KALĀS, "Al-jaysh 'inda I-muwaḥḥidīn”, 197-218 ; V. AGUILAR SEBASTIÁN, "Política de 'Abd al-Mu'min con los árabes de Ifrīqiya”, 17-30 ; “Aportación de los árabes nómadas”, 393-415 ; A. T. AL-Tīīī, "AlAghzāz wa qudūmu-hum", 87-100 ; "Banū Hilāl wa dūru-hum", 73-86.

43 M. 'ABD ALLĀH 'INĀN, 'Așr al-murābițīn wa-l-muwaḥhidīn.

44 This is also the case for 'A. A. 'Alī 'Allām's al-Da'wa al-muwahhidiyya.

45 Presentation of sources, studies, and historical context, then a study of the hierarchy of the movement, the political organization of the caliphate or administration of the Empire (distinguishing the central and provincial administrations), the juridical-religious, military, and fiscal organization.

46 'I. al-D. Musá, al-Muwaḥhidūn fì l-Gharb al-islāmī, continuing on an article published twenty years earlier: “Al-tanz̄imāt al-hiizbiyya”, 53-89. We should also mention 'Abdellatif Sabbane's unpublished dissertation, Le gouvernement et l'administration de la dynastie almohade, which, though more recent (1999), belongs to the same historiographic current as the works mentioned above. All the tables reproduced in the dissertation, or in the annexes, were taken from 'Izz al-Dīn Mūsá's work in Arabic, without citation.

${ }^{47}$ Morocco produced most of the major studies in this field, with the works of R. MONTAGNE, Les Berbères et le Makhzen, 1930, J. BERQUE, Structures sociales du Haut-Atlas, 1955, E. GELLNER, Saints of the Atlas, 1969 (French trans. P. COATALEN, Saints de l'Atlas, 2003) or C. GEERTZ, Islam observed, 1968 (French trans. J.-B. GRASSET, Observer I'Islam, 1992). 
systems specific to steppe and desert societies, but also nomadism, "Eastern" urban traditions, and even the cult of saints. ${ }^{48}$

This approach was possible because of the richness of extant materials, such as the genealogies, real or fictitious, of Ibn Tūmart and 'Abd al-Mu'min reproduced with variations, first in the Kitāb al-ansāb fì ma'rifat al-aṣhāb, edited by Évariste Lévi-Provençal in his Documents inédits d'histoire almohade, and next in later works like Ibn Khaldūn's, ${ }^{49}$ as well as biographical dictionaries of the great Maghribī sufis. ${ }^{50}$ It seems that the false impression of immobility associated with North African societies led some to believe that the study of contemporary structures would allow for an understanding of how past societies functioned, or inversely that a reading of Ibn Khaldūn's analyses would provide keys to the present. The use of the same terms over the centuries reinforced this certitude that tribes were eternal, as were the terms of their relations with the central power of the makhzan.

The cult of saints in the Maghrib saw similar treatment. In a continuation of numerous studies on "sanctity," Mahdism or maraboutism, ${ }^{51}$ on the reformist movements or revolts that they sparked, Mercedes García-Arenal recently completed an ambitious and illuminating work that places the social and religious dynamics of North Africa within the more general context of the messianic and eschatological movements of the greater medieval Muslim world. ${ }^{52}$ Indeed, inscribing the Almohad imperial structures in both the political systems born of the Muslim expansion of the seventh to thirteenth centuries and the history of the Maghrib since the Arab-Muslim conquest allows us to describe and understand the profound originality of this period.

The merits of all these studies are considerable. They provided a framework and basis for later works. They regularly reinvigorated this historical field, confirming the originality of the political system put in place during this period, but they prove at the same time that our knowledge of the Almohad period is still growing. The diversity of approaches according to the

48 A. HAMMOUDI, "Segmentarité, stratification sociale", 156-160 ; M. SAHA, "Structures tribales", 275280 ; 'A. SADKI, "La montagne marocaine et le pouvoir central", 15-28.

49 IBN KHALdūn, 'Ibar, 1988 ; M. FleTCHER, "The Anthropological Context", 25-51; C. HamÉs, "De la chefferie tribale à la dynastie étatique", 101-141.

50 Such as Abū Ya'qūb Yūsuf b. Yaḥyá Ibn al-Zayyāt AL-TĀDILİ's Tashawwuf ilá rijāl al-tașawwuf (m. 617/1220), 1984, French trans. FENOYL, Regards sur le temps des soufis, 1995, a biographical dictionary of Morrocan Sufis between the fifth and seventh century of the Hijra $\left(11^{\text {th }}-13^{\text {th }} \mathrm{C}\right.$.).

51 See the numerous articles and works by Halima Ferhat, for example: H. FERHAT and H. TRIKI, "Faux prophètes et Mahdis", 7-23, H. FERHAT, Le Maroc aux XII' et XIII' siècles, 1993, "As-Sirr al-Mașūn de Ṭāhir aș-Ṣadafī", 273-288, "Souverains, saints et fuqahâ", 375-390 or "Saints et pouvoir au Moyen Âge", 239-247.

52 M. Garcia Arenal, Messianism and Puritanical Reform. 
different centers of interest - political history, political thinking, administration, philosophy, theology, diplomacy, anthropological structures - reveals the richness of the period and extant materials and has made the Almohad period a particularly well-tilled historical field over the past century.

The study proposed herein addresses the provincial administration of the Empire through a documentary corpus that has been particularly neglected. This question was previously raised a number of years ago by an English researcher, author of a small work entitled Medieval Muslim Government in Barbary until the Sixth Century of the Hijra. ${ }^{53}$ The approach of this 1958 publication on the internal organization of the Berber powers deserves a few comments. In his presentation of the sources, J.F.P. Hopkins describes the documentary basis used by historians of the period:

The basic materials for the present study have been culled in their majority from an armful of books, none of which bear directly on the subject. For the East there is a small but disproportionately valuable body of literature devoted expressly to institutions and administrative questions - Māwardī, Ibn Sallām, Maqrīzī — from which the investigator can get a coherent picture, detailed enough for him to perceive the general pattern and so distinguish, if not truth from falsehood, yet typical from aberrant, probable from improbable. For the West there is nothing of this kind, and material must be gathered from sources written with other ends in view. ${ }^{54}$

These few remarks that evoke the existence in the East of a literature dedicated to institutional and administrative problems, a literature that was lacking in the West, as well as the need to rely on non-specialized literature, raises three major problems: the nature and conservation of sources and archives in the medieval Muslim world, the imbalance between our knowledge of the Muslim East and the Muslim West, and the historian's difficulties in exploiting marginal sources. If it is true, as it is repeated to surfeit, that medieval Islam did not leave historians the same kind of archives as those carefully left to posterity by the monastic, ecclesiastical, monarchical, or pontifical institutions of the Latin West, the number of extant manuscripts written in Islamic lands between the eighth and fifteenth centuries nevertheless far exceeds the number of Latin or Byzantine manuscripts, written or extant, by a ratio of 100 to 1 . Is it not conceivable that our lack of knowledge about the medieval Muslim world is not tied as much to the nature of the extant sources as it is to our inability to find the keys to exploit them? The theoretical tools of modern French, European, or Anglo-Saxon historians were progressively developed in the invention and study of documents from Western archives. Those

53 J. F. P. HOPKINS, Medieval Muslim Government, 1958.

54 J. F. P. HOPKINS, Medieval Muslim Government, XI. 
tools are not necessarily pertinent in the exploitation of Arab-Muslim documents from the Middle Ages. To get the most out of these, we still need to find the right questions to ask of them. ${ }^{55}$

The second question raised by Hopkins' introduction touches this time not on the differences between "Western" Latin sources and those from the medieval Muslim world, but on the supposed imbalance between the Mashriq and the Maghrib. In this case, the former provides theoretical works that ask questions concerning government, authority, or the exercise of power, while the latter completely lacks them. Did Islam not appear in the East? Do the Arabs not come from this region? Are they not the conquerors who created, with their religion, a Law and model of government, the centralized caliphal empire, whose authority they attempted to impose throughout the Mediterranean world, adapting it somehow or other to the diversity of populations and legacies that they integrated into their empire? Was the East not the birthplace that defined the norm, and the West long a rebellious land of missionizing? Beyond the fact that the discovery of numerous Maghribī manuscripts puts this point of view profoundly in question, and that recent studies on the Umayyad Caliphate and the early Islamic era have reconsidered this traditional though still well-alive vision, readings of al-Māwardī's Aḥkām al-sulțāniyya (eleventh century) or al-Maqrīzī (d. 845/1442) do not necessarily provide ideal information for understanding the real exercise of power. ${ }^{56}$ In addition, in placing authors from very different eras on the same plane, we find the same fault as the Orientalists of the nineteenth and twentieth centuries who considered that the Muslim world was invariable over time and geographically homogenous. Hopkins' observations reveal not only the documentary basis for researchers working to write the history of the medieval Maghrib in the middle of the twentieth century, especially political and administrative history, but also the methods used.

Historians came to know of non-narrative sources such as chancellery documents in the second half of the twentieth century. Lévi-Provençal thus edited a fairly large ensemble of thirty-seven Almohad documents in 1940-41, with a study that strayed somewhat from methods applied to narrative sources, presenting standards for diplomatics. ${ }^{57}$ The translation, however, touches only on those elements most applicable to events and political history then favored by

\footnotetext{
55 See the summary by Christophe Picard in his "De l'usage de l'écrit documentaire en Islam", 127-141. ${ }^{56}$ These are not necessarily recent discoveries. See Abū Bakr al-Ṭuț̣̄shî̀'s Sirāj al-mulūk, Ibn 'Abdūn's hisba manual, or all the adab al-kitäba treatises the Muslim West produced during the Almoravid or Almohad periods, such as the Ihkām sanā 'at al-kaläm by Ibn 'Abd al-Ghafür, or al-Balawì's 'Ațā'al-jazìl.

57 É. LEVI-PROVEnÇAL (ed.), Majmū' rasā'il muwahhịidiyya and "Un recueil de lettres officielles almohades".
} 
historians. Lévi-Provençal announced an analysis of these thirty-seven documents, but each of these "analyses" takes up only one page while the original Arabic text extends for nearly ten. This analysis reproduces only the principal pieces of information from the texts: secretaryauthor, addresser, addressee, reason for the letter and essential data, such as dates and events described. Repetitive elements from the documents are treated as useless, such as initial and final protocols, commendations, addresses, date and location clauses. General considerations developed by Claude Cahen two decades later served to complete this very useful diplomatics analysis. ${ }^{58}$ Nevertheless, the perspectives opened by these great scholars do not concretely lead anywhere. Yet it is in those extremely codified parts, which differ nevertheless from each other, of chancellery documents that the kuttāb's talent shows itself, where his skill comes through, and that their message is developed with the most finesse. The chancellery documents used by Lévi-Provençal had the advantage of being "complete." The letter dates and the names of their addressers and addressees, where they were written and sent, as well as the locations concerned were all noted. Aḥmad 'Azzāwī’s complete edition, including not only those letters published and translated into Italian by Michele Amari at the end of the nineteenth century ${ }^{59}$ and reedited by 'Abd al-Hādī al-Tāzīi, ${ }^{60}$ but also, in the second volume, all the letters published and "analyzed" by Lévi-Provençal in 1941, has the merit of being exhaustive. It justly draws attention to the different types of extant documents and to the different channels of conservation: original archives for exchanges with the Latin powers of the Middle Ages, the inclusion of letters considered as models in literary or poetic anthologies, in the biographies of certain famous kuttāb from the Almohad period, in the geographic entries for great battles such as Las Navas de Tolosa ( $a l$ - ' $q \bar{q} \bar{a} b)$, or in chronicles, as well as in chancellery manuals. ${ }^{61}$ As for the seventy-seven taqāìm studied here, they form an exceptional ensemble since they are grouped together in one unique manuscript which resembles no other type of document. Manuscript 4752 of the Hasaniyya Library of Rabat forms a kind of omnibus of standard examples of appointment acts. The administrative organization that comes through in these acts is in fact quite different from that presented by Hopkins in the work cited above. From a political

58 C. CAHEN, "Notes de diplomatique arabo-musulmane".

59 M. AMARI, Diplomi Arabi.

60 'A. al-H. AL-TAZI, al-tarīkh al-diblumāsī, t. 6.

${ }^{61}$ AL-ḤIMYART̄, al-Rawḍ al-Mi țār, s.v. al-'Iqāb, no 125. 
and administrative point of view, these documents allow us to completely remake our understanding of the Almohad Empire's provincial government. ${ }^{62}$

While historians of the Islamic West take into account works produced by Middle Eastern authors, the reverse is not true. A real lack of knowledge exists of works produced on the peripheries of the Islamic world on the part of specialists of the medieval Middle East, as communications by Sylvie Denoix ${ }^{63}$ and Anne-Marie Eddé demonstrate. ${ }^{64}$ One example of this indifference points in fact to an underestimation of the influence of the provinces on the constitution of chancellery norms, and more generally of the participation of the peripheries on the elaboration of a doxa attributed indiscriminately to the heartland of Islam. Sylvie Denoix thus claims that al-Qalqashandī's Subh al-a sh $\bar{a}$ fì șinā 'at al-inshā describes only the norms and practices of the Mamlūk chancellery and that his work was a model for periphery chancelleries. ${ }^{65}$ This would be possible only if we omit the fact that this Egyptian author knew, cited and used the production of famous secretaries from the peripheries of Islam, some of whom were Almohad. Al-Qalqashandī's work can thus also be considered as a summary meant to establish a chancellery tradition, on the model of the prophetic tradition, one with an origin, the "beginnings of Islam," and, from there, developing a linear set of examples up to the Mamlūks while including along the way the Fatimid legacy. Indeed, al-Qalqashandī's project seems an attempt to establish the centrality and linearity of Egyptian Islamic history by aggregating and annexing to the Middle Eastern heart of Islam, in a "unitary" perspective, those traditions, though just as "foundational," from the peripheries of Islam. The parallelism with the political and religious thinking elaborated during the Almohad period is striking. The same type of logic was prevalent among the Almohads who claimed to their advantage this centrality that modern historians attribute without questioning to regions and political systems using works elaborated with that intention.

Since Charles-André Julien ${ }^{66}$ and Henri Terrasse's ${ }^{67}$ histories of Morocco and North Africa, and except for Pierre Guichard's contribution to a collective work directed by Francesco Gabrieli, ${ }^{68}$ few scholars have attempted a new analysis of the exercise of power in the states of

\footnotetext{
62 I have treated this same question in two previous articles: P. Buresi, "Administration territorial d'alAndalus" and "L'Empire almohade".

63 S. DENOIX and B. GALLAND, "La constitution des "corpus"”.

${ }^{64}$ A.-M. EDDE, "Documents et archives d'Orient".

65 S. DENOIX and B. GALLAND, "La constitution des "corpus"”, 250.

${ }^{66}$ Ch.-A. JULIEN, Histoire de l'Afrique du Nord.

67 H. TERRASSE, Histoire du Maroc.

68 P. GUICHARD, "Les États musulmans du Maghreb".
} 
the Maghrib in the Middle Ages and in the medieval Muslim world as a whole. Social and other auxiliary sciences for history, do, however, offer some options for the Almohads. Naturally enough, the fields of art history, architecture, and numismatics first showed promise for this work, with reflections on the interactions between ceramics, coinage, and epigraphy and the Almohad doctrine. ${ }^{69}$ This type of reflection is an integral part of art history in general which questions the form and sense of material elements from a specific period. It is now time to ask the same questions of textual sources, especially given the exceptional documentary corpus left by the Almohads to posterity. Indeed, if these chronicles, dictionaries, or chancellery documents constitute a mine of information, we should also question the very nature of these sources.

69 M. AcIÉN AlMANSA, "Cerámica y propaganda en época almohade" ; S. FONTENLA BALLESTA, "La numismática almohade", "Numismática y propaganda almohade" and Ma A. MARTINEZ NUÑEZ, "Epigrafía y propaganda almohades". 


\section{General outline}

Michele Amari published the first chancellery texts concerning the Almohads at the end of the nineteenth century ${ }^{70}$ but they represented only a fraction of the Pisan archival documents housed now in Florence. In addition, other than Amari himself and Mas Latrie, only those interested in diplomatic relations between Christendom and Islam used these texts. ${ }^{71}$ For more than a century and a half, these documents were cited through Amari's edition and Italian translation, or through Mas Latrie's use of them, until their partial re-edition by 'Abd al-Hādī Tāzī, or 'Aḥmad 'Azzāwī's complete edition. ${ }^{72}$ These successive editions follow three different approaches: the study of relations between Christendom and Islam through Western archives, the analysis of Morocco's diplomatic relations, or the exhaustive presentation of documents produced by the Almohad chancellery. The latest edition, logically, is the most rigorous, and the Moroccan editor generally indicates in notes the manuscript's original when he makes changes to the text. Nevertheless, despite all its qualities, 'Azzāwī's edition, like its predecessors, does not address the question of the documents themselves. Thus, when the same act contained an Arabic document and its Latin translation, 'Azzāwī provides only the Arabic, even though much of the act's signification resides in the nature of the document, in its materiality, in the existence or not of a contemporary Latin translation, and its presence on the same or a different archival piece.

In addition, although the scribes included the tashkil on almost all the diplomatic documents, the editors neglected this "detail", indicating only almost randomly the diacritical signs they thought pertinent, without relation to the original, which moreover is the case for most current editions in the Arabic world. Yet, as Frédéric Bauden has shown in a study of two treaties signed between the Banū Ghāniya and Genoa in 1181 and 1188, the detailed study of the original tashkil can provide valuable information on the scribe's education and his eventual mastery of the rules of Koranic reading. ${ }^{73}$ This example, as well as my own edition of the different documents exchanged between Pisa and the Almohad authorities of Tunis at the end of the thirteenth and beginning of the fourteenth century, both confirm the epistemological need for a re-edition of the chancellery documents, with the greatest respect for the original manuscripts as an indispensable condition for a new approach to and renewed reading of the period's sources. ${ }^{74}$

The present work is part of a larger project financed by the European Research Council (FP7-ERC2010-StG 263361) entitled "Imperial Government and Authority in Medieval Western Islam."75 Through the study of a corpus of very specifically delimited sources (with their face-to-face edition and translation in the

\footnotetext{
70 M. AMARI, Diplomi Arabi.

71 M. L. de MAS LATRIE, Traités de paix.

72 'A. al-H. AL-TAZI, Al-tarīkh al-diblumāsī, t. 6 ; A. 'AZZAWI, Nouvelles lettres almohades, [hereafter NLA and NLA 2].

73 F. BAUDEN, "Due trattati di pace".

74 P. BuRESI, "Les documents arabes et latins", "Les plaintes de l'archevêque" and "Traduttore traditore".

75 Along with myself, Hicham El Aallaoui (CNRS), Mehdi Ghouirgate (CNRS), Hassan Chahdi (EPHE) and Travis Bruce (CNRS) are participating in this program (2010-2015).
} 
second half of this work), this volume offers a much larger reflection on the originality of Almohad power (1147-1269) in the Maghrib and al-Andalus. It aims in particular to articulate the technical approach of the texts and the political language structures in use at the time, with the concrete administration of the Empire, including the manners for appointing imperial officials, relations between subjects and ruler, and the role, function, and education of mediators, in order to better discern the ideological foundations of the Almohad imperial construction. ${ }^{76}$ This study thus naturally concerns historians of the Maghrib and al-Andalus, but also through its approach may interest the more general public of scholars of the medieval Muslim world (in particular the Middle East), and, through the critical edition and translation of the entire ensemble of formulary acts, it seeks to enrich the referential corpus for linguists and specialists of the medieval and modern Arabic language.

${ }^{76}$ This is something that has not been done for the Islamic world. Benoit Grévin's work on the dictamen serves as a methodological reference for the study of the ties between the codified and standardized administrative language reserved to a "caste", the kuttāb ("scribe-secretaries") and the continuous recreation of those treatises of the Arab-Islamic political discourse considered "classic" and unchangeable in the medieval period (see B. Grévin, Rhétorique du pouvoir medieval). 


\section{Part One}

The Imperial Territory: from Conquest to Rupture 
Governing the Empire

Chapter 1: the Origins of the Empire 


\section{Governing the Empire}

The origin of religious movements is often lost in the fogs of myth and the ensemble of characters who progressively appear over time are more often than not retrospectively tied to a foundational hero. The Almohad reform does not stray from this rule. Though sources are not lacking for the slow rise of the Mașmūda Berber tribes of the Atlas Mountains, for their struggle over two decades against the Almoravid power, for the death of the last rulers of the LamtunaBanū Turğūt dynasty, and for the progressive conquest of the entire Maghrib and al-Andalus, the narrative concerning Ibn Tümart ${ }^{77}$, the founder of the movement, includes far too many doubts and contradictions for current historians to determine the amount of truth contained therein. The much more hagiographic than biographic nature of these texts and their insertion in the literary framework of the chronicle, or more generally of $a d a b$, contribute to the legitimate doubts of historians on the historical realities of reported elements. The oldest sources, closest to the related events, suffer from their partisanship, and more recent sources, whether local or more distant, echo most often an official version reconstructed as a measure of the historic destiny of the political constructions put into place. One difference, fractional though essential in the eyes of history, separates Ibn Tūmart's revolt from that of someone like al-Māssī (or al-Massātī ${ }^{78}$ ) in 1148: the former won, the latter was defeated. The disciples of the former founded an Empire, those of the latter died under the weapons of the former.

\section{A. "The Prophetic Tribe" or the religious reform}

The summary presented below of Ibn Tūmart's life should be taken less as a bankable truth than as a staple of the Almohad imperial ideology as it was progressively elaborated over the twelfth and thirteenth centuries. This does not, however, mean it is devoid of certain concrete historical elements. Our intention, at any rate, is not to know and present the authentic life of the Mahdī Ibn Tūmart, which has been attempted already many times, but to describe

\footnotetext{
77 In the form Tūmart or Tūnart, this name, signifying "joy", was very common among the Mașmūda. The anonymous author of the Kitāb al-ansāb reports that at Ibn Tūmart's birth, his mother said in Berber, $\bar{A}$ tūmert-īnū issak ā-yīwī, ("My joy is with you, my son") and yak tūmert ("he will become joy"). I would like to thank Mehdi Ghouirgate (CNRS), who joined my project group ERC StG 263361 "Imperial Government and Authority in Medieval Western Islam" in November 2011. All notes concerning the anthroponymy, sense, and orthography of Berbers names are his. Hereafter his contributions are followed by the initials (MG).

78 "From Māssa" or, in this case, "bound" to this village in the Sūs where a reformer rebelled in the middle of the twelfth century. This toponym is an action noun based on the Berber root MS which refers to river rapids. It appears in the toponyms Tlemcen (Tili msān) and Sijilmāsa (Sig il-mās). To create a nisba from this name, medieval Arabic authors hesitated between the Berber form Massāt, and the arabicized Māssa (MG).
} 
the environment of the foundational narrative in which the Almohad scholars and rulers organized their system of government and the administration of their subjects. ${ }^{79}$

\section{IBN TŪMART}

Sources place Ibn Tūmart's date of birth sometime between 469/1076 and 474/1082. Descended from the Hargha Berber tribe, part of the Mașmūda group, Ibn Tūmart is said to have studied in Cordova at the side of a $z \bar{a} h i r \bar{\imath}$ master, then in the Middle East with al-Ghazālī, meeting al-Ṭurtushī along the way in Alexandria. In short, he would have drawn knowledge from the most famous sources of the time, though at times contradicting the historical timeline. Historians in general accept the idea of a journey, but contest the meeting with the famous Middle Eastern scholar, the author of The Revival of Religious Sciences, since the mystical thinker would have lived in Khurasān at the time. Whether these two episodes are true, possible, or fabricated is less relevant than the fact that from a narrative point of view, these biographical elements, reproduced with a few variations by most of the chroniclers, belong to the formative matrix of the Almohad movement. ${ }^{80}$

On his return from the East around 1116-7, Ibn Tūmart positioned himself as a "Sunnī" moral censor, virulently incarnating the ascetic puritanism that held favor among the inhabitants of the rural Maghrib. ${ }^{81} \mathrm{He}$ began rebuking the Almoravids in 1120 for their corruption, heresy and anthropomorphism. The movement's starting point thus does not reside in 'Alid genealogical aspirations or a Shiite conception of the imamate, but in a reform of morals and juridical practices. It likewise stemmed from the contestation of Almoravid political practice, in the name of an austere and rigorist vision of both social norms and legitimate authority. Faced with the problems provoked by Ibn Tūmart, 'Alī b. Yūsuf b. Tashfīn (1106-43), the ruling emir reputed for his piety, and his fuqahā' announced their desire to debate with this troublemaker concerning his doctrine. Forewarned of the risks he ran in accepting this meeting, the Almohad founder sought refuge in his native village of $\operatorname{Ig}_{1} 1 \overline{1} z^{82}$, near Tārūdānt: this was his "first Hegira."

\footnotetext{
${ }^{79}$ AL-NAJJAR, al-Mahdī Ibn Tūmart, R. BASSET, "Ibn Toumert, chef d'État" or R. BOUROUIBA, Ibn Tūmart. ${ }^{80}$ For a discussion of the plausibility of these meetings, using all of the sources that mention them, see al-Najjār's al-Mahdī Ibn Tūmart, 24-30.

${ }^{81}$ I insist on the "Sunnī" character of Ibn Tūmart's first message in reference to Maribel Fierro's recent works, with whom I discussed the question. Fierro recently developed the idea of a "sunnization" of the Almohad ideology. This concept which I had thought to be able to confirm in studying the relic of the mușhaf 'uthmāni, postulates the centrality of Shiite theosophy at the heart of the Almohad movement. 82 This toponym means "rocky spur" (MG).
} 
There, with his partisans, he declared himself, and was recognized as, imām and mahd $\bar{l}$, thus manifesting aspirations as political as they were spiritual and religious, while organizing his troops, the conquest of Almoravid power, and the tawhid ("Unicity") ideological system.

A second period began around 1124, when Ibn Tūmart sought refuge in the Moroccan South, in Tinmāl ${ }^{83}$, which would become the birthplace and first capital of the Almohad movement. This would also be the resting place of the founder and of the leaders of the Empire he would give life to: it was the "second Hegira." From 1124, Ibn Tūmart had all the attributes of the Mahdī: "guided/guider" and "infallible," he became the theoretician in the religious domain of the power he put in place in the political sphere. The 'iṣma that qualified his imamate signified that he was pure of all vice, error, corruption, innovation, mistruth, or ignorance. This had an important and essential consequence: the absolute authority that he held over his contemporaries, an authority limited only by the Book of God and the Sunna of His messenger, the Book and Tradition of which he was the sole and unique interpreter. The Mahdī approach meant that the Almohad supreme judge was not chosen by men, but designated by God. Ibn Tūmart was the "vicar of God" on earth (khalīfat Allāh) like David. ${ }^{84}$

The first certain element in this succession of chronologically-confused episodes whose exact order is often unknown, is the Mahdī Ibn Tümart's use of the Berber language when addressing the Berbers. ${ }^{85}$ The Almohad authors never sought to erase this specificity, even though they did not hesitate to seek to discredit the Almoravids for their supposed illiteracy and lack of knowledge of Arabic. ${ }^{86}$ The two texts attributed to Ibn Tūmart, the definitive confection of which probably came later, the 'aqī $a$ (the "Credo") and the murshida (the "spiritual guide"), were not translated into Arabic until the reign of Abū Yūsuf Ya qūb (1184-99), almost half a century after the death of their presumed author. The translation process seems to have entailed more than a simple transfer from one language to another, but a veritable creation that participated in the canonization of the movement's origins and founder. ${ }^{87}$

\footnotetext{
${ }^{83}$ Medieval Arabic authors hesitated between writing Tīnmal, Tinmāl, and Tīnmallal. The original term seems to have been Tinmal, formed from the root ML for "bright" or "red", probably because of the color of the earth. Almohad authors evolved the name to Tinmallal, bringing it in line with the root MLL and giving it the sense of "that of the whites, or pure" in reference to the qualities of the chosen Almohad people (MG).

${ }^{84}$ IBN TÜMART, $A$ 'azz mā yuțlab, 243-248 and 250.

85 'Izz al-Dīn Mūsá has questioned for example the chronology of the movement's partisan organization in the beginning: did the bay a of the faithful happen before or after the development of the group of the Ahl al-jamā'a, the Ten, the Fifty, and the Seventy? What was the respective order of creation for these different courts? ('I. al-D. Mūsá, Al-tanżīmāt al-ḥizbiyya, 53-79).

${ }^{86} \mathrm{~N}$. BARBOUR, "La guerra psicológica".

${ }^{87}$ This is the opinion of Madeleine Fletcher who insists on the apocryphal character of these texts.
} 
Ibn Tūmart was thus a mediator for the Arab-Muslim religion in a non-Arabic milieu (al- 'ajam), a vector of Islamization in the medieval Maghrib. Some scholars have attributed the success of this Berber preaching to the tribal character of the opposition to Almoravid central power. The opposition to the Mālikī doctrine and to this juridical school's Andalusī and Maghribī fuqahā' who were pillars of the Almoravid regime, seems in fact to have been a reaction against an Arabization which, with all its complexities, was imposed by the political milieus.

This hypothesis, which attributes to ethnic elements a significant influence over the evolution of power relations in the Maghrib, neglects the much more legitimate, in my eyes, question of the Islamization and Arabization of the Berbers. The Muslim religion and Arabic language penetrated through phases, successive waves of reforms, often in doctrinal opposition to each other, related to the dominant migration flows that characterized the period, independently of the inverse flow of pilgrimage and scholarly journeys, through renewed demographic contributions from the Mediterranean Middle East. The place occupied by these Arab tribes in the administrative structure of the Empire and their participation in the development of the Almohad imperial ideology will reappear throughout this study.

\section{THE ELEMENTS OF THE ALMOHAD DOCTRINE}

The Almohad doctrine evolved in an extremely favorable context of religious effervescence. ${ }^{88}$ Among the groups that rebelled against the Almoravid order, the Almohad movement had the longest lasting influence, despite the deviations of the repudiation of the doctrine of impeccability ${ }^{89}$ by al-Ma'mūn in 1229, the subsequent Hafṣid emancipation of Ifrīqiya, and the final collapse of the Empire in 1269. The ample doctrinal elaboration of this reform spread over the entire Maghrib, from Tripolitania to the Atlantic coast, and to alAndalus, relying on the military strength of the Mașmūda Berber tribes, and led by the Hintāta. ${ }^{90}$

Ibn Tūmart gave birth, in the heart of Sunni orthodoxy, to a doctrine that drew from almost all the theological currents that had seen the day since the beginnings of Islam. In this sense, "Almohadism" was the most elaborate attempt to unite the divergent beliefs of Islam, to create a doctrinal and theological synthesis from these diverse elements. Specialists of Almohad doctrine have drawn out the following contributions:

${ }^{88}$ Perfectly described in $\mathrm{H}$. Ferhat's Le Maghreb au XII siècle-XIVe siècle.

89 Here and throughout we use impeccability in the sense of sinlessness.

90 This is the most powerful Mașmūda federation, situated on both sides of the western High Atlas, between Oued Ghaighā'iya and Oued Nfìs, extending until the north and east of Taroudant. The Berber form of this ethnonym is Yntān in the plural, and Intī in the singular. One of the gates in the Marrakesh walls, Bāb Yntān, indicated, as was customary, the direction of this federation's territory (MG). 
O Hārijī-Ibāại: justification of violence, the demand for supreme leadership of the community irregardless of ethnicity, ${ }^{91}$ the status accorded Abū Bakr and 'Umar' ${ }^{92}$ in the 'aqi $d a$ and the "excommunication" (takfir) pronounced against those who refuse to join the movement;

- Mu 'tazilī: allegorical reading of the Koran, use of kalām ("speculative theology"), adoption of the term ahl al-tawhìd ("people of Unicity") and the obligation to "enjoin good and forbid evil” (al-amr bi-l-ma 'rūf wa-l-nahyi 'an al-munkar),93

O Philosophy: participation of important intellectual masters in the Almohad government and the attempt to reconcile Reason and Revelation; ${ }^{94}$

O Mâlikī: despite the combat against the Maghribī and Andalusī 'ulamā', with recognition of the importance of Mālik b. Anas's Muwațtā ',95

O Hanbalī: in the juridical domain, refusal of reasoning by analogy (qiyas), of individual interpretation (ijtihād) and any basis other than the Koran and Sunna;

- Ash 'arī: recognition of the absolute all-power of God, refusal of freewill and the use of kalām;

O Hazmī: principal of the impossibility of applying generalities to particulars and the referral to the Koranic text for the question of attributes; differs on this point with the $M u^{\prime}$ tazilīs as well as the $A s h{ }^{\prime}{ }^{\prime}{ }^{\prime} \bar{s} s{ }^{96}$

O Sufi: mystical approach to God, importance of prayer and ascetic practices; ${ }^{97}$

O And obviously Shiite, for 'iṣma ("impeccability"), the "gift of the imamate", and the real or fictional development of 'Alid genealogies for Ibn Tūmart and his successor, 'Abd al-Mu'min. ${ }^{98}$

91 This at the price of attaching the first two rulers to the Idrīsi lineage, which allowed for a more direct filiation than the traditions that attributed a Himyarī origin to the Berbers (see G. Camps, "L'origine des Berbères," Les Berbères and Des rives de la Méditerranée).

92 Urvoy has described the coincidence between the Almohad theses and a good number of positions defended earlier by the Khārijīs. This last influence gave, according to Urvoy, the power synthesis of the Almohad doctrine its deep unity (D. Urvoy, "Les divergences théologiques"). See also A. Ben Hamadi, "Y a-t-il une influence khāriğite?".

93 They differ from the Mu'tazilis in their refusal of free choice, and do not take a position on the doctrine of a created or uncreated Koran.

${ }^{94}$ See J. LANGhade and D. MAllet, "Droit et philosophie au XII siècle" ; W. M. WATT, "Philosophy and Social Structure".

95 The Almohad doctrine skillfully keeps the foundation of the known and applied law, while condemning the Māliki juridical practice, thanks to the affirmation that the most reliable Traditions are those closest to the Prophet, that is those from the school of Medina, contained in the Medina scholar's Muwattā'.

96 'I. al-D. MūsÁ, "Al-tanzīimāt al-ḥizbiyya", 66.

${ }^{97}$ A. BEL, "Le Sûfisme" ; A. FAURE, "Le Tasawuf".

$98 \mathrm{Ibn}$ Tūmart's writings differ from Shiism in establishing a specific line from the imāms, neither Sevener, nor Twelver: Adam, Noah, Abraham, David, Jesus, Muhammad, Abū Bakr, 'Umar. The third and fourth 
This synthesis is by its very nature in full contradiction with the monolithic Mālikism of the Almoravids and constitutes an attempt at an alternative to the dominant Mālikī juridical system. In rejecting the plurality of the juridical schools and preaching the unicity of the message and its interpretation, the Almohad doctrine was in total opposition with the official doctrine of the Almoravids, with Mālikism, and with the mass of commentaries and interpretations accumulated by jurists in their fur $\bar{u}$ ' treatises ("juridical applications"). ${ }^{99}$ Attacks were thus violent against the Almoravid power. ${ }^{100}$ The Almoravids were presented as heretical, accused of anthropomorphism because of their routine interpretation of the Koran and hadiths, and of having strayed from the essential doctrine of Islam which is the divine Unicity, a traditional accusation of the Shāfi 'îs against the Hanbalīs.

The Unicity of God, tawhid, became the central axis of Almohad propaganda to the point of giving them its name, the Muwaḥhidūn. The radical nature of the Almohad contestation of Almoravid power allowed them to preach jihād against the Almoravids. ${ }^{101}$ Unlike what happened at the end of the eleventh century, the Almohads did not feel the need to justify their jihād through scholars, as the Almoravids had against the taifa princes, accusing them of collecting non-Koranic taxes from their subjects and of having betrayed the Muslim cause by allying with the Christian kingdoms of the northern Iberian Peninsula. For the Almohads, jihād imposed itself, it was a requirement that came directly from the Revelation. This radicalism, in line with the Khārijīs, rejected non-Almohad Muslims to the camp of impiety ( $k u f r$ ).

In addition, the notion of the "Mahdī" reveals an eschatological dimension in Ibn Tūmart's preaching. It lends an immediacy to the moral reforms and the conquest of power. Both types, the Mahdī and the imām, complete each other to give Ibn Tūmart's authority its absolute and obligatory character. ${ }^{102}$ After so many centuries loaded with dishonor and injustice, the imām-Mahdī renewed the great line of imāms interrupted shortly after the Prophet Muhammad's death. Following the steps of his predecessors, he guided his coreligionists to Salvation, combating error, reestablishing truth, justice and the law, and organizing the new Community. Placing himself within the prophetic tradition, he presented himself as the sole

caliphs of Sunnī Islam, 'Uthmān and 'Alī, are not explicitly mentioned, but, in general, the successors of the Prophet during the first thirty years after his death belong to the line of the imāms, after which it ends.

99 J.-C. GARCIN (dir.), États, sociétés et cultures, 209.

100 DIHA, 11.

101 R. BASSET, "Ibn Toumert, chef d'État", 438-439.

102 Fierro justly notes that Ibn Tūmart was not necessarily considered as "Mahdī" during his lifetime and that this quality was likely attributed to him under his successor, the caliph 'Abd al-Mu'min (M. FIERRO, "Le mahdi Ibn Tûmart et al-Andalus"). 
possessor and unique interpreter, infallible, of the Law as it was delivered by God to men, through the Muhammadan Revelation (Kitāb Allāh), and completed by the Tradition of the Prophet (sunnat rasūli-hi).

\section{B. "The Party of Unicity” or the Almohad Revolution}

Ibn Tūmart began building the foundations of his movement in 1124 while hiding in Tinmāl with his followers. The narrative at this point continues, however, to conjugate events with myth. The founder's doctrinal power mixes with the political power he exercised in taking the reins of the revolt against the princes of the cities and plains. An organization destined to lead the Almohad state slowly emerged from the group of followers. The "people of the sword" joined the "people of knowledge," the former spreading and defending the message that the latter, charged with guiding and leading their common fight, elaborated.

1. THE PARTISAN ORGANIZATION: THE PYRAMIDAL FRAMING OF THE FAITHFUL

The sources relate with abundant details the organization developed by Ibn Tūmart, but though they agree for the most part on the generalities, they disagree on the details. This organization was temporary, and though it referred to real relations within the movement, it lasted at most a few decades before being replaced by a distinctly more classic imperial and dynastic administration. Its memory was however kept for much longer, especially during later imperial ceremonies - the oath of allegiance $\left(b a y^{\prime} a\right)$ to the caliphs, processions, and military parades.

It is possible that certain authors, such as Ibn Khaldūn, overestimated the importance of this basically tribal structure. And yet, despite their lateness in relation to the events, Castrillo Márquez relied almost exclusively on them in describing the "Instituciones políticas" of the Almohad Empire in her El retroceso territorial de al-Andalus, directed by Viguera Molíns. ${ }^{103}$ Indeed, this organization was like manna from heaven for the Maghribī theoretician of the grandeur and decadence of empires which, according to him, emerged through the vital energy of tribes and disappeared in the cities after a few generations. This organization is particularly interesting because it preceded the imperial administration which he superimposed on it. The study of acts of appointment should allow us to discern surviving elements from the initial movement, beyond those which appear in ceremonial tributes.

${ }^{103}$ R. CASTRILlo MÁRQUEZ, "Instituciones políticas", 127-145. 
Other than a few exceptions, including 'Abd al-Mu'min and one of the Mahdī's principal lieutenants, the shaykh Abū Hafs 'Umar Intī or Hintātî̀ ${ }^{104}$ from the Hintāta tribe, Ibn Tūmart's first supporters belonged to his own tribe, the Hargha, ${ }^{105}$ and generally to the Mașmūda tribal group: Hargha, "people of Tinmāl,"106 Hintāta, Ğadmīwa, ${ }^{107}$ Ğanfīsa, ${ }^{108}$ Qabā'il, and Haskūra. ${ }^{109}$ Scholars generally insist on the strictness of the hierarchical structure put into place by Ibn Tūmart and on the influence of the tribal structures it reflects. Indeed, the Mahdī decided to ensure, in addition to specifically tribal categories, a certain representativeness for the different groups within authorities put into place - the Council of Ten or ahl al-jamá 'a, the Council of Fifty and/or of Seventy. ${ }^{110}$

The origin of the system created has been attributed to a formalization inspired by the Muhammadan prophetic model, with a very strong hierarchical component. A certain number of "categories" were created to frame all of the partisans. 'Izz al-Dīn Mūsá, who has worked on this question, notes that the list of categories differ depending on the authors, ${ }^{111}$ for example alBaydhaq and al-Yasa' cited by Ibn al-Qatțān, or Ibn Șāḥib al-Șalā and 'Abd al-Wāḥid alMarrākushī:

O al-Yasa': the Ten, the Fifty, the Seventy, the "Learned" (talaba), the "Guardians" ( huffā $\bar{z}$ ), the "people of the house" (ahl al-dār), the Hargha, the "People of Tinmāl" (ahl Tinmāl), ${ }^{112}$ the Ğadmīwa, the Ğanfissa, the Hintāta, the "people of the tribes or

\footnotetext{
104 His original name was Faska, literally "the feast", a name given to children born on the day of the feast of the sacrifice. According to sources, Ibn Tūmart named him Abū Hafș 'Umar in remembrance of Umar Ibn al-Khațțāb, to highlight his military qualities and his indefatigable attachment to the Almohad cause (MG).

105 The Berber form of this ethnonym is Arghān, mentioned by al-Marrākushī. This tribe was found in the Anti-Atlas southwest of Taroudant (MG).

106 This group does not seem to have existed before the preaching of Ibn Tūmart and was created to support the cause and defend the first Almohad capital (MG).

107 The Berber form of this ethnonym is Igadmiwān. This group, still known under this name, was situated in the plains and mountains around Asif al-Māl (MG).

108 The Berber ethnonym is Ig-Nfīs, "those that overlook the Nfís". This federation was situated to the west of the western High Atlas, separated from Atlantic only by the Hāha tribe. According to alMarrākushī, they spoke the purest Berber of anyone. Ibn 'Abd al-Halīm, among others, described the important role played by the ribāt of Nfís in the process of conversion and Islamicization of the Mașmūda (MG).

109 The form of this ethnonym is Iskūrn, "the partridges". It is one of the many cases where an ethnonym comes from the animal kingdom. This powerful federation ranged across both sides, Saharan and Atlantic, of the High Atlas, from Oued al-'Abīd to Oued Dadès. Many of the commercial routes linking Sub-Saharan Africa and the Mediterranean went through their territory. The modern city of Skūra derives its name from this federation (MG).

110 M. TALBI, "Ibn Tūmart" ; Ch.-A. JULIEN et alii (ed.), Les Africains, 139-165.

111 I. al-D. MūSÁ, "Al-tanẓīmāt al-ḥizbiyya", 54-55.

112 Tribal grouping named after their place of residence ('I. al-D. MūSÁ, "Al-tanẓīmāt al-ḥizbiyya", 62).
} 
of Qabā'il (ahl al-qabā'il), ${ }^{113}$ the army (jund), and the "combatants of the faith" (ghuzzāt);

O al-Baydhaq: the ahl al-dār, the "Members" (ahl al-jamā'a), the Fifty, the Hargha, the ahl Tinmāl, the Hintāta, the Ğadmīwa, the Ğanfĩsa, the Kūmya, the Qabā'il, the Haskūra, the Sanhāja, the servants ('abīd) of the makhzan, the muhtasibs (responsible for policing the markets and for moral reform), the sakkākūn (responsible for monetary production), the muezzins, the ghuzzāt, the huffāz, and the ahl al-hizb ("people of the party [of the tawhīd]").

For Mūsá, the lack of concordance between the two lists is due to the confusion between the partisan organization, administrative and military structures, and religious functions, but these were in fact different levels that corresponded to many phases of development. The only categories that would shed light on the partisan organization are: the Ten or ahl al-jamā' $a$, the Fifty, the Seventy and the Seven, the talaba, the huffäz, and the rest of the population, the "totality" $(a l-k \bar{a} f f a) .{ }^{114}$ The narratives agree on the fact that these groups were created after the oath (bay'a) sworn to Ibn Tūmart, when he was auto-proclaimed and recognized as Mahdī. ${ }^{115}$

\section{AHLAL-JAMĀ'Ā OR THE COUNCIL OF TEN}

The term Ten, which refers to the number of "Members" generally transmitted by the sources, seems to be more a name than the exact number of individuals composing this council. Thus, al-Yasa', as told by Ibn al-Qatțān, gives only seven names, while the Kitāb al-ansāb counts twelve. Mūsá hypothesizes that the name ahl al-jamā ' $a$ was given first, then, when the number of members reached ten, the numeral imparted its name to the group, echoing the tradition of the Prophet's ten companions to whom Paradise was promised. Indeed, the composition of this council evolved: for example, Ibn Tūmart had one of its members killed, an Ifrīqiyan faqīh who voiced some doubts about the ișma ("impeccability") of the Mahdī and

113 This name designates a tribal grouping gravitating around Marrakesh: Hazmīra, Haylāna, and Hazrāja ('I. al-D. MūSÁ, "Al-tanẓīmāt al-ḥizbiyya", 62).

114 'I. al-D. MūsÁ, "Al-tanzīmāt al-ḥizbiyya", 55.

115 'l. al-D. Mūsá, "Al-tanzīmāt al-ḥizbiyya," 56. Al-Yasa' sets this creation at the moment of its oath (bay'a): the first ten to swear constitute the first group, the next fifty, the second, the next seventy, the third. However, Mūsá finds this origin suspect. The Ten were all companions of Ibn Tümart before the bay 'a, except Abū Hafș 'Umar b. Yahyá al-Hintātĩ who joined the group after the "Almohadization" of the Hintāta tribe. Mūsá suggests that this appointment was a concession made to the numerous members of this tribe. In exchange for their joining the movement which considerably weakened the Almohad attacks, they obtained the participation of their leaders in the Almohad leading courts. However, among these, there is not a single Hargha, the Mahdi's tribe, the first to rally to his message. It would seem that at least one Hargha would be a part of the first ten people to swear the oath to Ibn Tūmart when he proclaimed himself the Mahdī. 
who refused the massacre of the Hazmīra. ${ }^{116}$ Moreover, half the members died in the al-Buhayra defeat, and we do not know with any certainty if the Mahdī replaced them. Based on the data given by the chronicles, Mūsá thinks that this was the case. The following are names of Council members at one time or another:

O First those on whom all the sources agree: 'Abd al-Mu'min b. 'Alī al-Kūmī, Abū Hafṣ 'Umar b. 'Alī al-Ṣanhājīị, ${ }^{117}$ Abū Ḥafs 'Umar b. Yaḥá al-Hintātī, Abū Yaḥyá Abū Bakr Ikīd;

O Next those on whom the sources diverge: Abū Muḥammad 'Abd Allāh b. Muḥsin al-Bashīr al-Wānsharīsī (absent from al-Marrākushī's $M u$ 'jib), Abū Ibrāhīm Ismā '̄il b. Yaslālīi18 al-Hazrājīi, ${ }^{119}$ Abū l-rabī‘ Sulaymān b. Makhlūf al-Haḍramī (both omitted by Ibn al-Qaț̣ān, and the latter corresponds undoubtedly with Ismā'îl b. Makhlūf mentioned by the Hulal al-mawshiyya), Abū 'Umrān Mūsá b. Tammārā al-Jadmīwī, Abū 'Abd Allāh Muhammad b. Sulaymān ${ }^{120}$ min ahl Anis $\bar{a},{ }^{121}$ 'Abd Allāh Ibn Ya 'lá al-Zanātī al-Tāzī, also known as Ibn Malawīya;

O Finally, those who appear in only one source: Abū Mūsá 'Isá b. Mūsá al-Ṣawdī, ${ }^{122}$ Abū Muhammad 'Abd al- 'Azīz al-Ghayghā' ${ }^{123}$ (in K. akhbār al-Mahdī), mentioned

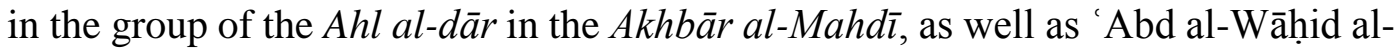
Sharq̄î and Abū Muhammad Wasnār (al-Marrākushī’s Mu jib), also mentioned in the group of the Ahl al-dār in the Akhbār al-Mahdī and by Ibn al-Qatțān.

There are some indications as to the precise functions exercised by some of the members of this group. They were first of all the Mahdī's advisers, the familiars in whom he had full

\footnotetext{
116 'I. al-D. MūsÁ, “Al-tanẓīmāt al-ḥizbiyya”, 58.

117 He was also known as 'Umar Aznāg. Aznāg, "dark-skinned," is the Berber form of Șanhājī (MG).

118 As was often the case during the Almohad period, this person carried a double name, one in Arabic (Ibrāhīm), the other in Berber (Iggīg, "thunder"). He appears in most of the sources as Ibrāhīm Iggīg (MG).

119 The Berber form of this ethnonym is Ili Zarguan, "the freckled ones." Like the Hazmīra, the Hazrajī territory ranged from the Atlas foothills to the south of Aghmāt Ūrika and part of the mountainous peaks that dominated the Hawz plain, around Ayt Ūrir and Imī n'zāt (MG).

${ }^{120}$ This man, who was blind and from the Mașmūda tribe, was qāḍi in the village of Ansā. As a sign of honor, one of his daughters married 'Abd al-Mu'min. The future caliph Abū Ya 'qūb Yūsuf and the sayyid Abū Hafṣ were both born of this marriage (MG).

121 This is the town of Ansā, in the Anti-Atlas, not far from Igīlīz and modern-day Taliouine. Al- 'Abdarī, the famous Merinid period traveler, stopped there before continuing to the East, and wrote a brief description. As proof of the adhesion of the inhabitants of the region (Ayt Wānsā) to the Almohad cause, they were fully included in the Ahl Tinmāl, even though they belonged to the Imādidan tribe (MG).

122 The nisba Sawdī refers to the Sawda tribe, whose territory ranged from the foothills and wester High Atlas Mountains, around the current locality Chichaoua. The Berber form of this ethnonym is Unzutt. The particular sound of the first letter, between $z \bar{a}$ ' and $s a \bar{a}$, , led medieval Arabic authors to hesitate between transliterating the name as Șūda or Zūda (MG).

${ }^{123}$ The Berber form of this ethonym is Ighaighāyīn. This tribe, situated near the first rise of the western High Atlas mountains, near modern Asni, was then part of the Hintāta (MG).
} 
confidence for grave affairs and to whom he entrusted the responsibility of carrying out his decisions. Al-Bashīr was a talented military leader, responsible most of the time for the direction of military expeditions, even if, occasionally, 'Abd al-Mu'min, 'Umar Aṣnāğ, and Mūsá b. Tammār shouldered this responsibility in his place; Sulaymān Ahadrī ${ }^{124}$ was charged in particular with the kitāba, Ismā '̄il al-Hazrājī as a judge, Mūsá Ibn Tammār with the goods of the $\breve{G} a m \bar{a}{ }^{\prime} a$, Muhammad b. Sulaymān with the direction of the farā'id on the order of the Mahdī, Ayyūb al-Jadmīwī with the division of goods and lands (al-iqtāa ) among the Almohads. ${ }^{125}$ All these tasks were executive and sometimes implicated people outside the group. This council of Ten thus represented the most influential advisers and the highest military, administrative, judicial, and political officials; the selection of its members seems to have been the result of a thorough examination and a detailed investigation on the part of Ibn Tūmart.

\section{The Council of FifTY AND OF SEVENTY}

The Council of Ten, or Ahl al-jamā' $a$, an echo of the elected ten of Sunni tradition, was thus at the head of the pyramid meant to frame Almohad society, while the Council of Fifty brought together, in addition to the Ten, about forty tribal delegates. ${ }^{126}$ The existence of these two councils, "the Fifty" and "the Seventy", refers either to two successive steps for the same institution, depending on the evolution in the number of members, or to the creation of a theoretical organization (the Seventy) designating all of the existing councils - ahl al-jamā' $a$, ahl khamsin (Council of Fifty), and ahl al-dār ("the people of the house") - without any formal concrete existence. For example, more than ten new members were added after the tamyiz (the "sorting" or "purge"), that happened in 524/1130. Ibn Șāhib al-Ṣalā says that the council counted only forty-one members and he cites only thirty-nine names; we should perhaps add the group of seven that brought together the most important Almohads of the Hargha, ahl Tinmāl, and Hintāta tribes for punctual matters that did not concern everyone. This sub-group would have had quite an influence within the council of Fifty, which constituted on its own the general assembly meant to give its opinion on everyday affairs.

\footnotetext{
${ }^{124}$ Maḥmūd 'Alī Makkī, in his edition of Naẓm al-jumān, erroneously transcribed this name (al-Hadramī). AlBaydhaq provides the correct form (Sulaymān Ahadrī). The name come from the Berberization of the Arabic term haḍra or hădira, meaning a large city or capital. As al-Baydhaq specifies, this person was from Aghmāt Ūrīka, long known as Hāāirat al-Mașāmida (MG). 125 'I. al-D. MüSÁ, "Al-tanżìmāt al-ḥizbiyya", 59.

126 J.-Cl. GARCIN (dir.), États, sociétés et cultures, t. 1, 209.
} 
The assembly of Fifty included representatives from the Almohad tribes present at the foundation of the movement: Hargha, ahl Tinmāl, Hintāta, Ğadmīwa, Ğanfīsa, Șanhāja, Qabā'ill, and Haskūra. Though the first five supported the movement as early as Igīlīz and participated in all the battles at Ibn Tūmart's side, the Haskūra violently fought him before joining his successor, 'Abd al-Mu'min, like the Șanhāja who began serving the Almohad power in 520/1135. The council was thus gradually established, through the addition of supplementary representatives as tribes gathered to the movement. Here again, Mūsá claims that the name of the Fifty does not seem to refer to the number of members of the Council, a number that fluctuated according to the successive additions of Maghribī Berber tribes, but derived more from the internal organization of the Berber tribes and their Aït Arb 'in ("Council of Forty"), an assembly of around fifteen men.

In a table summary copied here below, Mūsá gives the composition of the council of Fifty by tribe, depending on the two sources that mention it: al-Baydhaq (before and after the purge) and Ibn Șāhib al-Ṣalā. The council's composition confirms the preponderant role played by the Tinmāl tribes, as well as Ibn Tūmart's role in this consultative council.

\begin{tabular}{|c|c|c|c|c|c|c|c|c|}
\hline Haskūra & Qabā'il & Ṣanhāja & Ğanfìsa & Ğadmīwa & Hintāta & ahl Tinmāl & Hargha & Tribes/source \\
\hline 4 & 1 & 3 & 4 & 4 & $2 ?$ & 19 & 8 & Before the purge (al-Baydhaq) \\
\hline 4 & 1 & 3 & 5 & 4 & $8 ?$ & 21 & 8 & After the purge (al-Baydhaq) \\
\hline 3 & 1 & 3 & 4 & 2 & 3 & 14 & 6 & Ibn Șāḥib al-Ṣalā \\
\hline
\end{tabular}

Table 2: Tribal representation within the Council of $50^{127}$

\section{THE TALABA (“LEARNED”)}

Mūsá suggests that the talaba category was created before the Fifty, based on the indication that even before his recognition as Mahdī, Ibn Tūmart sent learned men to the tribes to gather them to his cause. This group of talaba or tulba (tolba for traditional historians) was numerous and brought together before the bay ' $a$ of 1124, during Ibn Tūmart's first preaching at Igîlizz (1121-1124). ${ }^{128}$ During his stay in the family homeland, the Mahdi dedicated most of this time to forging and teaching his doctrine. His disciples in return were charged with spreading the message, first in the Sūs in 516/1121, to gather neighboring tribes, and this mission did not cease over time. Besides this missionary action, the talaba seem also to have exercised military functions, as indicated by their frequent participation in the large martial expeditions.

127 Table from 'I. al-D. MūsÁ, “Al-tanẓīmāt al-ḥizbiyya”, 63.

128 Igīlīz n'warghān is the original Berber form (MG). 


\section{THE OTHER “CATEGORIES” AND THE KĀFFA}

A number of other groups constituted the base of the pyramid for this first militant organization, namely the eight classes of "servants" ('abid) of the makhzan (archers, drummers...), the muhtasibs ("moral censors"), the mint officials (sikka), the object of major reforms on the part of the Almohads, the regular army soldiers (comprising in principal the inhabitants of Aghmāt), ${ }^{129}$ the muezzin, in relation to the importance given to prayer, and finally the volunteers for jihād.

Except for the two upper echelons of the pyramid, the organization put into place at the time of the Mahdī was not so much a bureaucratic administrative apparatus as it was an attempt to organize the partisans under a unitary concept of God and the community. Subsequent sources chose to describe this embryo of power with a religious foundation pared of the complicated trappings characteristic of urban powers, with bare rituals such as the bay ' $a$ sworn to the Mahdī Ibn Tūmart at Igīlīz under a carob tree, and without any honorific titles. This original simplicity, austerity, and absence of splendor contrasts with the wealth of material, spiritual, and religious construction of the Empire still to be born, which the chroniclers delight in describing to insist on the Mu'minid miracle, made possible only by the grace of God.

129 The name of this former Mașmūda capital is formed from the root GH M T, which refers to dyeing. This may be related to al-Idrīsī's report that the Mașmūda dyed their hair (MG). 


\section{Governing the Empire}

\section{Chapter 2: "From Guidance to conquest" or the state of war}

The Mahdī himself decided to transform the religiously founded, almost "prophetic" authority he exercised over "his" community into a political sovereignty exercised over the Maghrib. The expeditions launched against the Almoravid power that held the Atlantic plains began in the middle of the 1120s. The political transition after Ibn Tümart's death caused only a temporary interruption in the expeditions, before the Mahdī's successor (khalīfa), 'Abd alMu'min, took them up again after having assured his place at the head of the Almohads, probably around 1132. We do not know if Ibn Tūmart named 'Abd al-Mu'min as his successor or not, but subsequent sources insist on the administrative and military responsibilities entrusted to him to prepare the succession. ${ }^{130}$ In particular, when he was sick after the al-Buhayra defeat by the Almoravids, the Mahdī followed the Prophet's example with Abū Bakr and confided prayer leadership to 'Abd al-Mu'min. Whether the Almohad tribes were reluctant, or whether 'Abd al-Mu'min showed an excess of prudence, the succession seems to have been difficult. This explains why the Mahdī's death was kept secret for nearly three years, from 1130-1132, perhaps as Mūsá suggests between the bay'a khāṣsa (the oath by the Almohad elite) and the bay'a 'ämma (the general recognition). ${ }^{131}$

Three members of the Council of Ten, 'Umar al-Șanhājīi (Aznāg), 'Umar b. Wumzāl132 Intī and 'Abd Allāh b. Sulaymān from Tinmāl, exercised power at 'Abd al-Mu'min's side during this transition. At the end of the period, the Almohads recognized the new sovereign during the bay'a ceremony that took place for three days (rabī' I 562/February 1132) in the Tinmāl mosque. From this date, Viguera notes through an evolution in ceremonial forms changes in the system of command. ${ }^{133}$ From a system that played on austerity, asceticism, and simplicity under a carob tree for the bay 'a sworn to the imām Ibn Tūmart, in ramadān 515/Nov.Dec. 1121, emerged the splendor of urban allegiances such as those in the polities of Dār alIslām. ${ }^{134}$

\footnotetext{
130 Roger Le Tourneau claims, citing an argument by Ibn Abī Zar', that it was because he was a stranger to the Mașmūḍa tribes that 'Abd al-Mu'min succeeded. Outside the internal quarrels that, at Ibn Tūmart's death, threatened to disintegrate the original Almohad tribes, he was consensually accepted (IBN ABI ZAR', Rawd al-Qirțās, 119 and R. LE TOURNEAU, The Almohad Movement, 48).

131 'I. al-D. MūsÁ, al-Muwahhidūn fí l-Gharb al-islāmī, 115-117.

132 This may be a proper name, with Wa corresponding to Arabic ibn, but is more probably a nisba signifying the person's belonging to the well-known Ayt Ümzāl tribe, located not far from Taroudant (MG). ${ }^{133}$ See Ma J. VIGUERA, "Céremonias y símbolos".

$134 \mathrm{M}^{\mathrm{a}} \mathrm{J}$. VIGUERA (dir.), El retroceso territorial, 81.
} 
'Abd al-Mu'min b. 'Alī b. 'Alwá al-Kūmī, a Zenata Berber born in Tāğrā, a village in the region of Tlemcen, at the end of 487/1095, received an 'Alid genealogy like the Mahdī. The chronicles spare him no praise, and their largely hagiographic descriptions adorn him with almost legendary qualities; al-Baydhaq in particular makes the meeting between the Mahdi and his caliph into a crucial moment in the history of the Almohad movement. As Mūsá notes, 'Abd al-Mu'min received a number of laqabs, each significant in its meaning:

9 amìr al-mu'minin: "prince of the believers," of which the origin attributed to 'Umar Ibn al-Khațāa is most often recalled in chancellery document preambles;

(9 imām, since he inherited his power from the Mahdī, which implies there is no difference between the Mahdī and his successor who defends his cause after him. ${ }^{135}$ He also took the title of khalifa, "successor." The succession was not, however, due to a public or secret designation by Ibn Tūmart, but to the will of God as portrayed by al-Baydhaq's description of the meeting between Ibn Tūmart and 'Abd alMu'min. ${ }^{136}$

The important political mutations witnessed throughout the Maghrib and al-Andalus during the three decades of this ruler's reign led to a reevaluation of his role in defining the Almohad doctrine and governmental forms versus the Mahdī himself. 'Abd al-Mu'min was the architect and spirit behind the Almohad imperial construction, the strategist who designed its lasting outlines. He was the real conqueror: he intensified the fight against the rulers of the time and harvested the posthumous fruit of the political, religious, theoretical, and doctrinal message that Ibn Tūmart had elaborated against the Almoravid powers and their Mālikī 'ulamā' and fuqahā' supporters. During the first eight years of his reign, he gained the submission of the Atlas Mountains. Then, between 1139 and 1146, during the "seven year war", he directed the final assault against the Almoravids, taking their land and capital, and physically eliminating the members of the dynasty. He next broke with Almoravid strategy and oriented his main forces towards the central Maghrib, privileging expansion towards the east, rather than southern conquests towards the original Almoravid lands, or towards the north and al-Andalus which nevertheless was not neglected. This strategy would lead to the first large-scale territorial unification of North Africa by an indigenous power. The conquest did not come about without resistance, nor without temporary or lasting losses.

135 'I. al-D. MūsÁ, al-Muwaḥhidūn fĩ l-Gharb al-islāmī, 121.

136 For a rapid presentation of this passage, see P. BURESI, “L'Empire almohade...”, 221-222. 


\section{A. Martial administration}

During an initial period of transition between the prophetic structure of the Mahdi Ibn Tūmart's political organization and the imperial administration that would emerge after the Almoravids' disappearance, 'Abd al-Mu'min led the Almohads out of the Atlas Mountains to conquer the plains and Almoravid cities, with Marrakesh as the final objective. Tinmāl, the new Medina with its Anșār and Muhäjirūn, served as the military base for these conquests. The city is located in an Atlas valley, surrounded by high summits and not far from the Tizi n-Test Pass. The site houses not only a mosque dating probably from the reign of 'Abd al-Mu'min rather than the Mahdi - it was considerably restored in the 1980s - but also fragments of the wall that surrounded the apparently far-spread town. 'Abd al-Mu'min led his military actions against the Almoravids from this base in Tinmāl, taking the city of $\operatorname{Igl} \overline{1},{ }^{137}$ first in 529/1134-1135, and definitively in 535/1140, as well as Tārūdānt. ${ }^{138}$ He used his conquests to consolidate his power over the Almohad tribes and Atlas Mountains.

\section{THE CONQUEST OF MOROCCO}

The main cities of Morocco fell into the hands of the troops sent out by 'Abd al-Mu'min within ten years, despite the merits of the Almoravid designated successor, Tāshfiñ b. 'Alī (wāli al- 'ahd beginning in 533/1138) and his best military leader, the Catalan noble Reverter (killed in 537-538/1144-1145). 1145 was a decisive year, since, having lost Tlemcen, the Almoravid emir Tāshfīn accidentally died while besieged in Oran and seeking to join the fleet of the Andalusī admiral Muhammad b. Maymūn sailing before the city. The Almohads conquered Tlemcen, Oran, Ujda, and the Guercif region in that year, Fez in dhū 1-qa 'da 540/April 1146, after which Sijilmāssa, Meknes, Salé and Ceuta (for the first time) submitted. The Andalusī leaders, like another member of the Banū Maymūn family, the admiral 'Alī b. Maymūn who commanded the fleet at Cadix, rallied to the rising power of the Muwaḥhidūn.

The Almohads began harassing Marrakesh in 523/1128-1129, and finally took the city on 17 shawwāl 541/March 22, 1147, after a nine-month siege, thus ending the Almoravid Empire. ${ }^{139}$ The Almohads succeeded in imposing their sovereignty at the expense of the Almoravids within fifteen years. Inheriting the Almoravid imperial organization, the Almohads became the rallying point for all oppositional movements in the Maghrib and al-Andalus. They

137 This should not be confused with Igîlizz-des-Hargha, the place of birth of the Mahdī lbn Tūmart and his first sanctuary in 1120. See, with a confusion of the sites A. J. Fromherz, "The Almohad Mecca," and the correction by A. Fili and J.-P. Van Staevel, "Wa wașalnā 'alā barakat Allāh ilā İgīlīz".

138 See NLA, n० $3,50-52$.

$139 \mathrm{M}^{\mathrm{a}} \mathrm{J}$. VIGUERA (dir.), El retroceso territorial, 73. 
were thus solicited and responded rapidly, for example sending troops to Ibn Qasī in 1146-1147, even before the fall of Marrakesh.

This first conquest did not go unopposed. The literate urban milieu of the Malikī 'ulamā' and fuquhă ' were extremely reticent before the Almohad doctrine and the Mașmūda rural style. Even in territories conquered a first time, acts of rebellion were frequent, not to mention resistance from some members of the Almoravid elite, such as Ibn al-Ṣaḥrawiyya, a member of the ruling family who attempted to organize resistance against the Almohad advance by instigating troubles wherever he passed (he did not join until 550/1155-1156). Though Ceuta had recognized 'Abd al-Mu'min's authority, it rebelled under the $q \bar{a} \underline{d} \bar{l}$ 'Iyāḍ, supported from Algeciras by Yahyá b. Ghāniya, the descendant of a Mussūfa leader and a relative of Yūsuf $b$. Tashfîn named Ghāniya. ${ }^{140}$ The Almohads did not definitively occupy the city until June 1148. They also needed to take Salé and Tangiers to ensure their control of the Strait of Gibraltar.

\section{THE CONQUEST OF THE CENTRAL MAGHRIB}

Even though 'Abd al-Mu'min sent troops early on into al-Andalus, he remained during this time on the southern shores of the Mediterranean, where he organized the conquest of the central Maghrib. The expansion towards the east was long and difficult, but the Almohad troops pushed through to Tripolitania, eliminating all the independent powers they encountered along the way. Ambrosio Huici Miranda's detailed political history of the Almohad Empire based on all extant sources provides a complete chronology of events ${ }^{141}$. After the disappearance of the Almoravid dynasty from Marrakesh (17 shawwāl 541/March 22 1147) and the foundation of Rabat in 1150, 'Abd al-Mu'min, supported by two important members of the first community founded by Ibn Tūmart, Abū Ḥaf̣̣ 'Umar Intī and Ismā' '̂l b. Igīg, brought his troops together at the end of 546/beginning of 1152. Heading towards Ceuta, he pretended to embark for alAndalus before veering at the last moment for the Hammādid principality in Bougie, which had sent troops to support the Almoravids. ${ }^{142}$

The situation in Ifrīqiya and in Tripolitania was then unclear: after taking Jerba in 1135, the Norman kings of Sicily had progressively occupied most of the Ifrīqiyan coast where the urban populations were left to protect themselves. In the middle of the twelfth century, the Normans had put an end to the Zirid dynasty in Mahdīya in 1148 and had taken Tripoli;

\footnotetext{
140 IBN 'IDHĀRT̄, Bayān, t. 5, 32. See H. E. KASSIS, “Qāọī 'Iyāọ’s rebellion”.

141 HPIA, $161 \mathrm{ff}$. See also A. MERAD, “'Abd al-Mu'min”.

142 DIHA, ar. 112, trans. 185 and IBN KHALDŪN (al-'Ibar, t. 6, 315, trans. t. 2, 189) place 'Abd al-Mu'min's expedition just after the i tirāf, in 546/1151, but other sources place it two years later.
} 
Qayrawān had been almost completely emptied of its inhabitants. Christian domination spread to most of the coastal cities, except Tunis governed by the Banū Khurāsān, and Kelibia. The resistance that the Normans had encountered (rebellions in Sfax in 1157 and Tripoli in 1159) had not been enough to chase them from their positions before the Almohad intervention in 1159-1160. Lastly, Bāja was in the hand of the Arab Riyāḥ.

'Abd al-Mu'min took Algiers on the way, defeated the Șanhāja troops and conquered Bougie with the least resistance, the governor ( $q \bar{a}^{\prime} i d$ ) having turned the town over in exchange for important responsibilities. ${ }^{143}$ The Almohad troops, directed by 'Abd Allāh, one of 'Abd alMu'min's sons, attacked the Qal'a of the Banū Hammād, razing it to the ground, killing the governor and an Arab shaykh from the Athbağ tribe who was the de facto leader of the region. As a result, Constantine capitulated. The Arabs, who exercised a sort of protectorate over these regions from which they also subsisted, began to harrow 'Abd al-Mu'min's troops.

Yaṣlātan ${ }^{144}$ b. al-Mu 'izz, a blood relative of the Mahdī, was named along with Abd Allāh b. Wānūdīn (ou Wānnūdīn), 'Abd al-Mu'min's son-in-law, at the head of the army destined to combat the Arabs in Ifrīqiya after the expedition to Bougie which had begun at the end of 546/first quarter of 1152 and would finish with the fall of the city in 547 (April 8, 1152-March 28, 1153). The sources report, however, that Yașlātan b. al-Mu'izz betrayed Abd Allāh b. Wānūdīn, reproaching him his alliance with 'Abd al-Mu'min. He abandoned him, provoking the failure of this first Almohad expedition against the Central Maghrib Arabs, as well as 'Abd Allāh's imprisonment and execution by the Arabs. After this setback, 'Abd al-Mu'min sent a second army to defeat the Arabs at Wādī l-Aqwās, near Sétif, in rabī' I 548/May 1153. This battle ended with the complete defeat of the coalition Arab tribes. ${ }^{145}$

This episode is generally considered a pivotal moment in the life of the Almohad Empire: Roger Le Tourneau, as well as Ambrosio Huici Miranda, judges severely 'Abd alMu'min's attitude which incorporated the Arabs in the Almohad troops after this date, "betraying the Berber cause compromising with the Arabs." 146 However, Le Tourneau's claim that " Abd al-Mu'min thus deprived the Almohad movement of its soul and, while ensuring

${ }^{143}$ É. LÉVI-PROVEnÇAL, Majmū rasāil muwahhhidiyya, nº 4, 6-10, "Un recueil de lettres officielles", $n^{\circ} 4$, 23-24, NLA 2, n० 11, 31-33.

144 Al-Baydhaq gives Yașlāsan (MG).

145 É. LÉVI-PROVENÇAL, Majmū rasāill muwahhidiyya, n 9, 26-34, "Un recueil de lettres officielles", $n^{\circ} 9$, trans. 29-31 ; NLA 2, n 19, 53-58 ; DIHA, 114-115, trans. 188-190 ; IBN AL-ATHĪR, Kāmil, t. 9, 245-246.

146 "En esta ocasión, el jefe y fundador del más grande imperio bereber traicionó, sin saberlo ni quererlo, la causa de su raza, al transigir con los Árabes y quizá pensó solamente en agrupar todas las fuerzas del Islam norte-africano para la guerra santa contra los cristianos españoles y normandos" (HPIA, t. 1, 167). For a more nuanced and revised vision, see V. AGUILAR SEBASTIÁN, "Política de 'Abd al-Mu'min". 
power to his descendants, he also unsuspectingly prepared their ruin, for he took away the support of the entire Almohad community in order to ensure the support of a few families of well-off nobles or only recently rallied [to the cause]" is largely anachronistic and constitutes a fairly simplistic explanation for the Empire's subsequent collapse. ${ }^{147}$

Indeed, the entire strategy of 'Abd al-Mu'min and his successors, founded on familial control over the developing state apparatus relied simultaneously on both doctrine, more and more elaborate and rigid and still being determined, and a large opening that allowed the integration into leadership positions in the Empire of all defeated or converted enemies from previous overturned regimes. ${ }^{148}$ In addition, the Almohad caliph's attitude on this occasion was not only coherent with all that he had done previously when he had pardoned those nobles, tribes, elites, and others who after having served the Almohads' enemies had decided, sensing the wind's changing direction or convinced by the Almohads' message, to join the cause. It was likewise an essential pillar of the developing Almohad ideology: the original people of Islam, the tribes of the Arabian Peninsula, birthplace of the Muhammadan prophecy, were submitting to the prince who incarnated the renewal and renaissance of this same prophecy; the establishment of this prophecy in the new center of Islam, the Western Maghrib, rejected the Arab origins to a faraway eastern periphery.

The conquests were again not definitive and the Almohads had to struggle against rebellions that arose when their troops were left in insufficient numbers to hold the land. Tunis and Mahdīya were conquered in 1160, and Tripoli in 1161, after the victory of Sétif which put a temporary end to the Arab unrest. We can imagine that, during these early troubled times immediately after the war, the administration of the new territories had a strong military character and that the principal charge of the regional governors was to lead the army and reaffirm Almohad authority through the slow and deliberate placement of Almohad judges. Tax collecting probably continued through those previously responsible under the Almoravids, with only the allocation of the sums collected changing with the arrival of a new administration.

\section{THE CONQUEST OF AL-ANDALUS}

The intervention in the Maghrib slowed any efforts to move into al-Andalus. The chronicles describe the passage into al-Andalus of Abū Isḥāq Barrāz b. Muḥammad al-Masūfí,

\footnotetext{
147 On the role of the Arabs in the Almohad army, see, in addition to the article cited in the previous note by the same author, V. AGUILAR SEBASTIAN, Tribus árabes en el Maghreb almohade ; "Aportación de los árabes nómadas" et "Instituciones militares," passim.

148 On the Almohad Empire's capacity for integration, see P. BURESI, "L'apogée almohade," passim.
} 
'Umar b. Șāliḥ al-Șanhājī, and Aḥmad b. Qas̄̄ with their troops. Heading first towards Jérez, the Almohads crossed the Guadalquivir to march on Niebla, and from there to Mértola, Silves, stopping to besiege the city, and finally Beja. The governors of Niebla, Yūsuf al-Bițrūjī, and Beja, Sidrāy b. Wazìr, came out to meet and to submit to the Almohads. The entire Gharb and center of al-Andalus quickly recognized the new lords from the Maghrib. The allied troops, augmented by garrisons from conquered towns, marched on Seville, besieging it by sea and land. The Andalusī city was conquered on Wednesday, 12 sha 'bān 541/January 17, 1147. Thus, in the same year, Marrakesh and Seville both fell to the Almohad troops, after violent combat. In the Maghrib, as in al-Andalus, the occupation was brutal, and regions that spontaneously accepted their authority were rare. A few enclaves in the Algarve were the exception, prepared in advance by the religiously mystical-founded revolt of Ibn Qasī.

The sayyid Abū Ya'qub Yūsuf b. 'Abd al-Mu'min was forced to asked his father for help because of the difficulties due to resistance in certain regions and pressure from the Christian kingdoms of the Iberian Peninsula. 'Abd al-Mu'min announced from Constantine in rabī' I 555/March-April 1160 after a victorious campaign in Ifrīqiya that he was arranging his passage into al-Andalus, and ordered the Straits readied in preparation. ${ }^{149} \mathrm{He}$ received delegations from all regions who renewed their oaths of loyalty. These ceremonies reveal the important caliphal dimension of the new power. Thanks to the magnitude of their conquests, the Almohads aspired to all the emblems of classical Islamic sovereignty and strongly insisted on the elements of protocol, court ceremonial, with as much importance placed on narrative references and mis en scène as the sermons of the great preachers and apologetic poems recited by scholars converted into courtiers.

'Abd al-Mu'min stayed for two months in Gibraltar. He confirmed his son the sayyid Abū Ya'qūb Yūsuf as governor of Seville, leaving him Almohad shaykhs and the vizier Ibn 'Atiyya as advisers. He kept his other son the sayyid Abū Sa'īd 'Uthmān in Granada, and installed the shaykh 'Umar Intī as governor of Cordova. Upon returning to Marrakesh, he sent troops under the direction of another Almohad shaykh, Yūsuf b. Sulaymān of the Council of Fifty, to lead Carmona which had been taken by the Almohads at the end of 1161 or the beginning of 1162. In addition, he sent tribal Mașmūda and Arab contingents to reinforce the Almohad garrisons in al-Andalus. After a pious visit to the tomb of the Mahdī Ibn Tūmart in Tinmāl, 'Abd al-Mu'min fell sick, then died on 6 or 8 jumādā II 558/May 12 or 14, 1163.

$149 \mathrm{M}^{\mathrm{a}} \mathrm{J}$. VIGUERA (dir.), El retroceso territorial, 87. 


\section{B. The Enemies of the Empire}

The conquest was not immediately definitive anywhere. The Christian kingdoms of the Iberian Peninsula took advantage of the Almoravid crisis and transitional period to militarily intervene in al-Andalus. Alfonso VII of Castile-León ceaselessly harrowed Yaḥyá b. Ghāniya in Cordova and took Úbeda and Baeza. He succeeded even in penetrating the former Umayyad capital in 1147 and creating a corridor to Almería conquered in the same year and held for ten years thanks to a certain number of relay points (including Baeza and Úbeda). Alfonso's death in 1157 led to a short-term pause in the Castilian attacks with the short reign of Sancho III. Attempts at expansion began again in earnest under his successor, Alfonso VIII, in 1158, and especially from 1169-1170, when Alfonso, now an adult, personally took the reins of power.

\section{THE EMPIRE'S BORDERS WITH THE CHRISTIAN KINGDOMS: WAR AND PEACE}

The permanent state of war in al-Andalus thus allowed the Christians of the North to seize the cities and regions of Lisbon, Tortosa, and Lérida. The Portuguese seized Beja a first time on 22 dhū 1-hijja 557/December 1, 1162. They pillaged the town, but were unable to hold onto it after April of the next year. During the same period, Count Ximeno of Ávila ( $A b \bar{u} l$ $\operatorname{Bar}\left(\bar{a} \bar{a}^{\prime} a\right.$ ) pillaged the region of Seville where the caliph was taking care of supplying Badajoz, resettling Beja, and directing attacks against Talavera and Toledo. ${ }^{150}$ After a few years of reprieve, the Christian offensives began fiercely anew in 560/1165. Giraldo Sempavor, the "Portuguese Cid," a military leader in the service of the Portuguese king, seized the Almohad cities of Cáceres, Trujillo, Évora, and Beja. When, because of internal problems, Castile and Portugal solicited a truce in the summer of 1173, Giraldo Sempavor changed over to the Almohads and served in the Maghrib with other Christian soldiers who constituted the personal guard for the Almoravid, Almohad, and subsequent rulers. ${ }^{151}$ Abū Ya 'qūb Yūsuf returned to the Maghrib in 571/1176 where the Almohads were faced with new insurrections. ${ }^{152}$ The Leonese, rivals of both young Portugal to the west and Castile to the east, quickly broke their traditional alliance with the Almohads to attack Cáceres in 577/1183.

Alfonso II of Aragon attacked Valencia in May 1171, anxious about the disappearance of his ally Ibn Mardanīsh. Hostilities with León resumed between 1174 and 1177. Alfonso Enríquez of Portugal raided the Sevillian Aljarafe in the summer of 1178. The Muslims definitively evacuated Beja. Alfonso VIII took Setefilla. The Leonese besieged Cáceres in

\footnotetext{
150 'Ațā' al-jazîl, fo 1-3, ed. NLA, n 27, 130-134.

151 cf Ch.-E. DufourcQ, L'Espagne catalane et la Maghreb, and I. al-Q. BUTSHISH, "Al-jāliya almasīhiyya".

$152 \mathrm{M}^{\mathrm{a}} \mathrm{J}$. VIGUERA (dir.), El retroceso territorial, 94.
} 
1183. When the caliph returned to al-Andalus in May 1184 with Arab and Mașmūda troops, it was to die during the siege of Santarem. Yūsuf's death, kept secret until the army's return to Seville, opened the doors of the caliphate to his son, Abū Yūsuf Ya qūb, acknowledged in the Andalusī capital the 10-11 August 1184. ${ }^{153}$ The Christians took advantage of the Almohad ruler's absence to advance their pieces and seize strongholds in al-Andalus. Alfonso VIII of Castile harrowed Cordova and Seville, allied with 'Abd Allāh b. Ghāniya of Majorca, and seized Magacela in June 1190. A band of Crusaders on their way to Jerusalem (conquered by Saladin in 1187) helped Sancho I of Portugal take Silves in September 1189 after a four-month siege, as well as a few minor enclaves like Alvor.

In April 1190, the caliph disembarked at Tarifa and went directly to Cordova. He accepted truces with Castile and León to free himself for action against Portugal. From the Guadiana valley, he sent troops along the Tagus against Silves and Évora, seized Torres-Nova, and returned to Seville on June 26, 1190, after a partial defeat at Tomar. He seized Alcacer in April 1191, then Silves in June. The Portuguese begged for a truce, which allowed Abū Yūsuf Ya 'qūb to return triumphantly to the Maghrib. The Almohad caliph returned to al-Andalus in 1195. He arrived at Tarifa on June $1^{\text {st }}$, headed to Seville, then Cordova (June $23^{\text {rd }}$ ). He crossed the pass of Muradiel and set up his army on the plain of Salvatierra and in Campo de Calatrava where Alfonso VIII of Castile came out to meet him. ${ }^{154}$ The turning movement of his troops allowed al-Manșūr to win the battle of Alarcos (al-Arak). The Almohads pushed their advantage to take back a number of fortresses: Alarcos, Guadalferza, Malagón, Benavente, Calatrava la Vieja, and Caracuel. Abū Yūsuf Ya 'qūb al-Manșūr refused the Castilian truce offer and accepted an alliance with León to whom he provided troops to attack Castile in Tierra de Campo. He, himself, took Montánchez, Trujillo, Santa Cruz, and Plasencia, raiding lands in Talavera, Santa Olalla, and Escalona without succeeding in taking Máqueda. He remained before Toledo for ten days then returned to Cordova. The caliph renewed the șayfiyya the next year, and raided the lands of Talavera, Máqueda, Oreja, Madrid, Alcalá de Henares, Guadalajara, Huete, Uclés, Cuenca, and Alarcón. Returning to Seville the $19^{\text {th }}$ of August, he accepted truces with Castile to take care of troubles instigated by the Banū Ghāniya in Ifrīqiya.

The chronicles show a great contrast between the Almoravid period, with practically no truces, and the Almohad period, when they were frequent with all the kingdoms concerned, except Navarra - with no common border with al-Andalus, Navarra was the traditional ally of

$153 \mathrm{M}^{\mathrm{a}} \mathrm{J}$. VIGUERA (dir.), El retroceso territorial, 96. $154 \mathrm{M}^{\mathrm{a}} \mathrm{J}$. VIGUERA (dir.), El retroceso territorial, 98. 
the Muslim powers against Castile and Aragon until 1212. This does not mean that the state of war was permanent at the beginning of the twelfth century, and that peace reigned during the second half of the century. An absence of official truces, first of all, does not necessarily imply the existence of military expeditions (the borderlands must have been spared, in particular, in winter). Next, an agreement did not prevent transgressions, and, finally, the treaties passed by the Almohad Empire never concerned all the Christian kingdoms at once. The Mu'minid dynasty was in fact perpetually at war with one or many of the Christian kingdoms. It is, however, incontestable that the end of the twelfth century, and even more so after the Christian victory at Las Navas de Tolosa ( $a l$ - 'Iq $\bar{a} b$ ), saw an institutionalization of diplomatic relations, as witnessed by the exchange of emissaries, negotiations, and renewed accords.

The truces were all temporary, except the alliance with León, and they seem to have been negotiated, established for a fixed time, with the possibility of renewal. The duration was generally fixed at five years. ${ }^{155}$ All truce proposals were not accepted: they came out of a common accord that considered the power struggle between two polities. The truce, moreover, was passed in the name of the central power. ${ }^{156}$ The ruler, or his representative, signed the accord after having negotiated terms. The negotiations appear to have been bitter, and Muslim sources mention more often the arrival of Christian ambassadors than the expedition of Muslim ambassadors. ${ }^{157}$ The Christians do not seem to have been held to pre-established rules in

155 Morabia recalls that because of the Koran $(115, I X, 3)$, treaties were authorized four months of the year. Al-Shafi' 'T's Kitāb al-umm (IV, 190) accepts the signing of armistices without paying tribute or truces the duration of which was to be determined. They had to be less than ten years for the Shafi' ites, and less than four for the Malīkites and Hanafites, based on the Prophet's example at Hudaybiyya, when he broke a truce originally meant to last ten years (A. Morabia, Le Gihad, 319).

156 This point is discussable, for, on the Muslim side, the taifas who separated from the central government during the crises (middle of the twelfth and middle of the thirteenth centuries), passed treaties with the Christian kingdoms. However, these were not "private" accords, but in fact "public", for the territorial rulers claimed legitimate power over al-Andalus. This was the case for Ibn Mardanīsh, Sayf al-Dawla, or later Abū Zayd or al-Bayāsī.

${ }^{157}$ As shown by this passage from the Bayān concerning the renewal of treaties in 618/1221-1222: "In 618, treaties and the peace were renewed (al-muhādana wa-I-mușālaḥa bayna wulāti I-Andalusi mina I-sādati wa-I-muwahhhidīna bi-amri amīri I-mu'minīn al-Mustanșiri bi-Llāhi, wa bayna al-nașārá) between the Almohad sayyids, governors of al-Andalus in the name of the amīr al-mu'minin al-Mustanșir bi-Llāh and the Christians, may God annihilate them; the vizier Abū Yaḥyá Zakariyā b. Abī Zakariyā wrote to the queen of Castile, Doña Berenguela, daughter of the king of Castile and Toledo, a letter written by Ibn 'Ayyāsh, in which he notified her of the peace (yukhbiru-hā bi-I-salami lladhi n'uqida bayna-hu wa bayna rasüli-him) signed between him and the Christian envoys: 'Your emissary was sent back to you with what you will learn from him concerning the peace established, may its star shine, agreed upon between Almohads and you with this eminent information which he brings you and the gifts he carries you and which will arrive in his hands, as a sign of good will (mukhālașat wa thamrat al-muwāșala) and it is good that all that relates to this treaty between us be respected (yanbaghi an yakūna mutaqabbilan) and interpreted in the best way (wa 'alá ahssani al-muta'awwalāti muta'awwilan inshā' Allāh) if God wills it and yourself with God's help may you stay with the terms of peace, may you keep it, and may you punish all those who plot against the Muslims, for loyalty is the distinction of kings (fa-inna al-wafäa 
negotiated truces. They thus adapted to the norms applicable in Dār al-Isläm. ${ }^{158}$ The appearance of early indicators of troubles, complaints on the eve of truce expirations bear witness on the contrary to the respect they warranted. ${ }^{159}$ Giraldo Sempavor's departure for North Africa after the truce signed between Portugal and the Almohads confirms that it would have been inconceivable for this nobleman to go against the agreement signed by his king. ${ }^{160}$

\section{THE ALMORAVIDS AND THE ARABS}

Resistance to Almohad imperial power was not restricted to the Empire's northern borders with the Christian kingdoms. It sprang even from the interior lands of Islam, by Almoravid leaders who were defending their erstwhile masters, local powers hoping to take advantage of the troubles and transition between the Almoravid and Almohad dynasties to affirm their independence, more or less heterodox religious reformist movements, or even from the eastern edges of the Empire.

\section{a. The second taifas}

Certain Almoravid leaders who held through delegation (niyāba) great autonomy within the Almoravid provincial government defended their authority with impressive tenacity. The governor of Cordova, Ibn Ghāniya, thus entered into a pact with Barrāz, the Almohad general, delivering him Cordova and Carmona around November 1148, in exchange for a safe-conduct pass, and when Alfonso VII ended the siege of Jaén, he seized Granada, where he died in 543/December 1148-January 1149. Stuck once again between the Christian Iberian hammer and the Islamic Berber anvil, the principal Andalusī cities resolved to turn to their coreligionists and cousins from the south. In 545/1160, the city leaders of Beja, Évora, Niebla, Jérez and Ronda, Badajoz, and Tavira proclaimed their acknowledgement of the caliph, except for Ibn Qasī, who

shi'āru I-mulūk wa 'alay-him fî-hi yajibu al-sulūku), and they are obliged to follow its paths.'” Ibn 'Idhārī, Bayān, t. 3, 246, trans. A. HUICI, 1953, 282).

158 The Muslim rulers, however, seem to have sought reassurance from Islamic law. In 1197, for example, after the last Almohad activity around Toledo, Ibn 'Idhārī claims the treaties were granted to the Christians according to the precepts of Islamic law: wajjahū irsāla-hum fíțalbi l-șulhi 'alá mā 'ahada min shurūṭi I-aḥkāmi fa-s afū fî-hi 'alá ḥukmi sharī'ati l-islāmi (Ibn 'Idhārī, Bayān, t. 3, 204, trans. A. HUICI, 1953, 203).

159 The intention of the Spanish military orders at the beginning of the thirteenth century of participating in the Eastern Crusades illustrates for example the military inactivity that resulted from the treaties passed in 1197 (See E. BENITO RUANO, "Baudouin II de Constantinople" ; "Las Ordenes Militares españolas" ; "Santiago, Calatrava y Antioquía"). Even before Honorius III's oriental incitements, the pope Innocent III had called on the brothers of Calatrava and Uclès in 1205 to delay their war efforts along the Aragonese frontier with Islam (Patrologie Latine, 215, 666 and ed. D. MANSILLA, La documentación pontificia hasta Inocencio III, $\left.\mathrm{n}^{\circ} 321,351\right)$.

$160 \mathrm{lbn}$ 'Idhārī, Bayān, t. 5, 130 (trans. 13-14). Officially in the service of the Almohads, Giraldo Sempavor became an informer for the Portuguese king. He sent the king a letter proposing a naval attack plan on the Almohad Empire. This message was intercepted by the Almohads and led to his downfall. Ibn 'Idhāri claims indeed that Giraldo was imprisoned by the caliph and executed in Sijilmāssa. 
had nevertheless been among the first to seek his help and who died in the turn around. The Almohads held Guadix from 1151, Malaga from 1153, Granada from 1154-5 or 1156-7, and the entire West of al-Andalus from 1157-8.

The resistance of Muḥammad b. Sa 'd Ibn Mardanīsh, whose capital was Murcia and whose power extended to Serranía de Segura (where Ibn Mardanīsh's son-in-law ruled), Jaén (conquered in 1159), Écija and Carmona (conquered in 1160 and 1161), meant constant harassment for the Almohad forces in Seville. This strong resistance from the Andalusī Levant incarnated the third option for Islam in al-Andalus, alongside administrative integration into the Maghribi Almohad structure, or the kingdoms of the Christian North, with the correlating Mudejarism: local autonomy playing the rivaling powers off of each other, taking advantage of their rivalries and existing conflicts and, possibly, accepting the military support of the Christians.

The unification of al-Andalus under the Almohad rod thus took many decades, with the conquest of Almería in 1157, Jaén in 1169, the Levant in 1172, ending only with the conquest of the Balearic Islands at the beginning of the thirteenth century. The Murcian Levant, led by Ibn Mardanīsh with the sometime support of his son-in-law Ibn Hamushk, slowed the Almohads for three decades, preventing them from concentrating on their fight against the Christians to the north. Though he was often successful, defections around Ibn Mardanīsh gradually indicated his imminent end: Ibn Hamushk in Jaén, Yūsuf, Ibn Mardanīsh's brother in Valencia, Ibn Dallāl in Segorbe, and Ibn 'Amrūs in Játiva all entered Almohad service.

The new caliph, Abū Ya qūb Yūsuf, crossed the Straits on 27 ramaḍān 566/June 3, 1171 to finish with Ibn Mardanīsh. ${ }^{161}$ The rebel died in rajab 567/March 1172 at the age of 48. Hilāl, one of his eight sons, went before the caliph in Seville to obtain a peaceful transition. Those who helped and surrounded the Rey Lobo, as he was known to Christian sources, were reconfirmed in their positions: some of his sons held responsibilities in Denia, Játiva, and Alcira. Al-Baydāq reports that Abū Ya qūb Yūsuf reinforced his control over the situation first in appointing Yūsuf b. Muhammad b. Ighīt in Valencia, before reinstating Ibn Mardan̄̄sh's brother, Yūsuf. He likewise established a number of different Arab and Berber tribes in the region: Arabs and Zanātas in Valencia, Șanhāja and Haskūra in Játiva and Murcia, people from Tinmāl in Lorca, and Kūmya in Almería and Purchena. ${ }^{162}$

$161 \mathrm{M}^{\mathrm{a}} \mathrm{J}$. VIGUERA (dir.), El retroceso territorial, 92. $162 \mathrm{M}^{\mathrm{a}} \mathrm{J}$. VIGUERA (dir.), El retroceso territorial, 94. 
The last stage in the conquest of al-Andalus did not come about until the beginning of the thirteenth century. After having suppressed a tribal and messianic revolt that had arisen among the Șanhāja of Sūs, the Ğazūla, ${ }^{163}$ traditionally hostile towards the Almohads (597598/1201-1202), the caliph al-Nāșir armed a fleet of 300 ships and raised a large army to conquer Minorca (598/1202) and Majorca (599/1203). The Banū Ghāniya were expelled from the Balearic Islands where they had found refuge and maintained the Almoravid governmental system by creating a powerful maritime and Mediterranean polity. ${ }^{164}$

b. The Alliance between the Almoravids and the Arabs

The Arab tribes revolted a number of times after 'Abd al-Mu'min's initial conquest of Ifrīqiya. The caliph Abū Ya'qūb had to tame the Riyāḥ Arabs in 575-77/1180-1181: his expedition ended with the execution of one of their leaders who was in monitored residence in Bougie, and, in shawwāl 576/March 1181, with the taking of Gafsa, the capital of the Banū 1Rand, who belonged to the Riyāh group, since the arrival of the Banū Hilāl. This intervention had only a limited impact.

Al-Andalus had hardly been pacified when the Almoravid Banū Ghāniya sparked a revolt with the complicity of local forces across the central and eastern Maghrib from 1184 to 1220. This would revive the embers of tension, provoking the intervention of the new caliph, Ya'qūb Abū Yūsuf, the future al-Manșūr. Shortly after being proclaimed caliph in Seville, he went to Marrakesh to affirm his power. This was where he learned of the Banū Ghāniya's landing in Ifrīqiya and the conquest of Bougie in sha 'bān 580/ November 1184. Using the port as their base, the Banū Ghāniya seized Algiers, Miliana, Ashīr, and the Qal'a Banū Ḥammād. A maritime and land Almohad expedition retook Bougie (Bajāya) in șafar 580/May 1185 and forced 'Alī b. Ghāniya to abandon the siege of Constantine. However, aided by the Riyāh and Jushām Arabs and by the Lamtūna and Massūfa Berber groups (traditional supporters of the Almoravids), 'Alī b. Ghāniya took Tozeur, then Gafsa (1186), before heading for Tripoli, then governed by Qaraqūsh. Qaraqūsh was a Mamlūk of Armenian origin who belonged to a nephew of Saladin and was sent by the Cairo authorities with a contingent of Turkic Ghuzz against the Almohad "heretics". 'Alī b. Ghāniya was able to dominate the Jarīd, while the Mamlūk Qaraqūsh, leader of the Ghuzz, set himself up at Gabes. In 582/1186-1187, 'Alī b. Ghāniya took

\footnotetext{
163 The Berber form of this ethnonym is Igzūlan, "the people of small size." This federation dominated the entire southeast Anti-Atlas, living partly as nomads in the desert.

164 See G. PISTARINO, "Genova e l'islam".
} 
back control of the Balearic Islands and seized all of Ifrīqiya, except for the cities of Tunis and Mahdīya.

Faced with the gravity of the situation and the call for help from the governor of Tunis, the Hafṣid shaykh 'Abd al-Wāhịid b. 'Umar b. 'Abd Allāh al-Hintātī, the caliph Abū Yūsuf Ya 'qūb came personally to Tunis in 583/1187. After the disastrous defeat of his first army sent to al- 'Umra in the South of Ifrīqiya, the caliph was victorious at al-Hamma, between Gabes and Nefta. 'Alī b. Ghāniya fled into the desert.

The Ifrīqiyan resistance of the Banū Ghāniya and the Arabs did not cease, however. For twenty years, they spread trouble throughout this part of the Almohad Empire, not to be totally defeated until the beginning of the thirteenth century. The Almohad troops crushed Yahyá b. Ghāniya and his army, composed mostly of Arabs in rabī‘ I 602/October 1205 near Gabès. They retook Mahdīya after a four-month siege. Tripolitania submitted in 603/1206. Before returning to Marrakesh, the caliph al-Nāṣir appointed 'Abd al-Wāḥid b. 'Umar b. 'Abd Allāh al-Hintātī, the victor of Rā's Taghra, as governor of Ifrīqiya with great autonomy. In 604/1207, this governor repaid the caliph's confidence in winning another victory over Yahyá b. Ghāniya in the Shabrū valley, near Tebessa.

\section{RELIGIOUS RESISTANCE}

Another type of resistance to the propagation of the Almohad doctrine and reform was tied to the religious effervescence that affected the entire Maghrib at this time. ${ }^{165}$ The Sūs Ğazūla revolted against the caliph of Marrakesh under the direction of their religious leader Muhammad b. 'Abd Allāh Ibn Hūd al-Māssī. This was the name he adopted when he too proclaimed himself Mahdī. Al-Baydhaq gives his name as 'Umar b. al-Khayyāt and gives him also, as it was frequent, the Berber name of Bū Ykandīi ${ }^{166}$. Apparently of humble origins, he appeared for the first time in the ribāt of Māssa, near Sūs, forty-five kilometers south of Agadir. The revolt that he led began a year after 'Abd al-Mu'min's occupation of Marrakesh. According to the Almohad dynasty chronicles, fugitives from different regions came together under his banner. The inhabitants of Sijilmāssa and Dar'a recognized his power, as well as the Dukkāla,

\footnotetext{
165 H. FERHAT, Le maghreb au XIIe siècle- XIVe siècle.

166 This is probably a disparaging nickname, whose structure resembles those given to Almohad opponents such as Bū-wasardūn "the man with the mule" or Bū-waghyūl "the man with the ass," a Șanhāja who rebelled in the Middle Atlas (MG).
} 
Ragrāga, ${ }^{167}$ Huwāra, and Tāmesna. ${ }^{168}$ Al-Baydhaq cites the tribal territories that revolted in his name: Ğazūla, Hāạha, ${ }^{169}$ Hazmīra, Haskūra, Dukkāla, and Banū Wariaghel were joined by the cities of Ceuta, Tangiers, and Almería. According to Ibn 'Idhārī, the entire land except for Marrakesh and Fez "apostatized". ${ }^{170}$ Another revolt, apparently inspired by the Sufis against 'Abd al-Mu'min's authority, was led by Yaddar' ${ }^{171}$ al-Dukkālī, among the Dukkāla, called the ahl al-rakawāt. The rakwa was considered a distinctive sign of the Sufis and itinerant ascetics, and the region of Dukkāla was known as an important Sufi zone, mainly because of the influence in the region of the ribāt of Tīt, ${ }^{172}$ founded by the Banū Amghār. ${ }^{173}$

The revolt of al-Massātī, or al-Māssī, thus left the Almohads with only the Atlantic coast, Fez, and Marrakesh. Meknes, Sijilmāssa, ${ }^{174}$ and the region of Dar ${ }^{\prime} a,{ }^{175}$ as well as Tangiers and Ceuta joined the rebellion. Ceuta's participation was significant: led by its $q \bar{a} d \bar{l} \bar{\imath}$ 'Iyāḍ, the city had pledged its submission in 540/1146 and received an Almohad governor. The town's inhabitants, like some regions of al-Andalus, thinking the end of the Almohads near, took advantage of al-Massātī's insurrection to revolt against the governor and kill the Almohad officials. The Almohads were not able to crush this grave sedition until the end of 543/May 1149, killing Ibn Hūd al-Māssī. Ibn 'Ațīyya's report on this Almohad victory brought the famous secretary to the caliph's attention. The letter revealed the violence of the battles and the cruel defeat of Ibn Hūd, the rebel's ties to the ribāt of Māssa, as well as the Sufi preaching that had prepared the insurrection and Ibn Hūd's success. ${ }^{176}$

Roger Le Tourneau analyzes these movements as a reaction to the Almohads' development, like Muḥammad, of a new society that broke with the tribal structures and blood

\footnotetext{
167 The Berber form of this ethnonym is Irgrāgān, "the blessed." This name comes from the root ĀRG, the Berber equivalent of the Arabic BRK. They received the name supposedly because their were the first Mașmuda to convert to Islam and played an eminent role in its spread throughout the region. More probably, they formed a barrier against the Barghawātă, building a series of ribāts to contain them. Their territory ranged from Oued Tansift to the north, not far from Safi, to modern Essouira to the south (MG).

168 This name in Berber means "the plain". It covered the great Atlanic plain from Habt to Oued Umm Rabī'. For centuries it belonged to the Barghawāta (MG).

${ }^{169}$ Ihāanān in Berber. This tribe's territory was located on the coast south of the Ragrāga and west of the Ganfīsa. According to local legend, this ethnonym came the Iḥāhān habit of pronouncing $k h a^{\prime}$ as $h \bar{a}^{\prime}$ (MG).

170 M. García ARENAL, Messianism and Puritanical Reform, 193-195.

171 This named is based on the Berber root DR, meaning "life" (MG).

172 The complete name of this ribāt, located some kilomaters from modern El Jadida, is Ṭît n'Ufțar, "the source of the instrument" which served to measure the quantity of wheat given for the zakāt (MG).

173 'I. DANDASH, "Dukkāla min khilāl al-Tashawwuf', 199 ; V. J. CORNELL, "Ribāț Tīṭ-n-Fițr", 23-36.

${ }^{174}$ In Berber, Sig Il-mās signifies above the active waters. The name of the capital of king Syphax, Siga, refers to the same root (MG).

175 This name comes from the Berber Idra, "the other side of the mountain", which conforms with this region's location in regards to the High Atlas (MG).

176 AL-NĀṢIRĪ, Kitāb al-istiqșā, 52, IBN AL-KHAṬīB, al-Ihāța, t. 1, 269.
} 
lines characteristic of the nomadic populations, to move towards a community of faith, united in the respect for the divine Law. ${ }^{177}$ This interpretation may be somewhat anachronistic, ascribing to the time of the Mahdi ideological elements developed later, under the reign of 'Abd al-'Mu'min, or even his son and successor, Abū Ya qūb Yūsuf (1163-1184). The caliph, nevertheless, had much difficulty in suppressing these movements, and it was the "recognition" ( $i^{\prime}$ tirāf) of Almohad power, in reality a second bloody purification, concerning also the Almohad hierarchy, that "pacified" the regions of the Empire. ${ }^{178}$ According to Ibn 'Idhārī, the Barghawāta maintained their obedience to al-Māssī, even after his defeat and death, and continued to fight against the troops of 'Abd al-Mu'min. ${ }^{179}$

These religiously-based revolts shed light on the weak control over conquered territories by the new masters of the Maghrib. When news of al-Māssī's rebellion reached al-Andalus, Seville rose up against the two brothers of the Mahdī Ibn Tūmart who governed the city and its region. They claimed to have assassinated the ruler of Niebla, al-Bitrūjīi, who then renewed his alliance with the Almoravids who still remained in al-Andalus. Only Ibn 'Azzūn, leader of Ronda and Jérez, stayed faithful to the Almohads. Ibn Ghāniya seized Algeciras and met up with the resistance in Ceuta. The Almohads, forced to flee to Bobastro with only Ibn 'Azzūn's help, were finally able to retake Algeciras. ${ }^{180}$ The Mahdī’s brothers were recalled to Marrakesh, where they opposed the caliphal changes that were sweeping them and the Mahdī's primitive organization aside. This general insurrection lasted three years. The Almohad troops were only able to restore control over Seville, Niebla, Silves, Santa María del Algarve, and Badajoz after these troubles were settled. ${ }^{181}$

These religiously-based revolts were chronic throughout the Almohad Empire and concerned each of the caliphs. Around 1188, for example, Abū Yūsuf Ya 'qūb was retained in the Maghrib by the insurrections of al-Jazīrì (in Marrakesh) and al-Ashall (in the Zāb). In both cases, the rebels' political and religious pretensions revealed strong social tensions.

\section{The Administrative consequences of the conquest}

Mūsá's hypothesis about a progressive construction of partisan structures only partially contradicts Viguera Molíns's claim that the Almohad movement's initial period was

\footnotetext{
177 R. LE TOURneAu, The Almohad Movement, 47.

${ }_{178}$ Al-Baydhaq mentions the death of 32,780 victims (É. LE TOURNEAU, The Almohad Movement, 54).

179 IBN 'IDHĀRIT, Bayān, trans. Huici, 1963, 293.

180 B. ROSENBERGER, "Le contrôle du Détroit".

${ }^{181} \mathrm{M}$ a J. VIGUERA (dir.), El retroceso territorial, 85.
} 
characterized by a rigorous and firmly established organization. Both historians agree that the passage out of the original Mahdī structures gradually took place over time, with the initial disappearance of tribal representation and the creation of the Empire. ${ }^{182}$ This retrospective reconstruction of institutional history indeed seems to be at the origin of a perception that once again tends to make this initial moment into a model, established ex abrupto, of social, political, and religious organization that was gradually betrayed by the founder's successors. The organization's appearance, as well as its disappearance, was gradual. There was thus not any real rupture between the time of the Mahdī and the Empire, but an empirical adaptation to new political conditions by structures that were always more or less informal and fluid. As much as the Mahdī asked the opinions of the members of the Council of Ten (ahl al-jamā ' $a$ ) and charged them each with particular tasks, 'Abd al-Mu'min called on the surviving members of the "Assembly" (jamā'a) to exercise the new functions demanded by the administration of the Empire. Thus, the shaykh Abū Hafṣ 'Umar Intī, a member of the Council of Ten, was appointed governor of Cordova and left the partisan organization to enter the imperial administration. This appointment, and comparable others, led to a weakening of the structures slowly put into place during the movement's early days.

More than twenty official letters from the time of 'Abd al-Mu'min written in his name help fix the chancellery style typical of the dynasty and show the attention the ruler paid his entire territory. The founder of the Empire seems to have used the chancellery to promote the cohesion of the Empire, sparking a "pre-national" sentiment through public readings of circular letters in all the Great Mosques of the provincial capitals. Each conquest and victory was

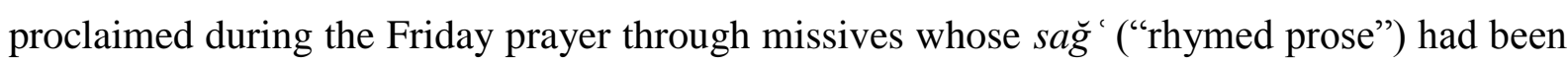
composed by the great writers of the Empire. The logic is fairly obvious behind this system that combined the elaboration of an imperial discourse, the rapidity of transportation, and public readings in an immense Empire where communications were only as fast as a horse's gallop. There was of course a propaganda effect in the publicity of victory, calling most often on the topoi of religious and political thought, or even the literature and poetry of the medieval ArabMuslim world, that is $a d a b$, but these public announcements with the organization that they required had also other implications. They completed the traditional "signs of recognition" of power, such as pronouncing the caliph's name in the khutba or on coins, the minting of gold, or the bay ' $a$, by imposing over the entire territory the same administrative language with its own

$182 \mathrm{M}^{\mathrm{a}} \mathrm{J}$. VIGUERA (dir.), El retroceso territorial, 79. 
specific codes, a time of obligatory listening for all men and shared festivities to celebrate the sovereign's success. The imperial cult was thus developing around a doctrine, a ruler, specific rites, and a history to which these administrative documents contributed.

The victories over the Arabs, during the conquest of Gafsa and the campaign of 11591160, with the submission of the Banū Sulaym, received its own particular treatment in the letters of victory, and so also in the chronicles and later literature. The same is true of the demonstrations of joy and festivities organized in Seville after the fall of Mahdīya and the expulsion of the Normans by 'Abd al-Mu'min in șafar 555/February-March $1160 .{ }^{183}$ At the same time, the imperial governmental system gradually broke with the original "prophetic" structure. A new organization saw the light, with its own specific personnel, including not only the sons of 'Abd al-Mu'min, among them a few in particular, such as the governor Abū Ya 'qūb Yūsuf b. 'Abd al-Mu'min, but also an administrative hierarchy with the appearance of original title forms, including the shaykhs, sayyids, țalaba, and huffāz.

\section{FROM THE "COUNCILS" TO OFFICES: THE SHAYKHS}

The members of the Councils of Ten and of Fifty seem to have been those who received the title of shaykh, the honorific title referring to their having belonged to the group of leadership in the past. Those holding this title exercised the highest responsibilities:

9 Military directorships: 'Umar al-Ṣanhājī', 'Umar al-Hintātī, Yūsuf b. Sulaymān, Ibn Zaggū, Ibn Yumūr Waykhlaf; ${ }^{184}$

9 Governorships in conquered regions: Sulaymān b. Wānūdīn, Yūsuf b. Makhlūf, and 'Abd al-Wāhiid al-Sharq̄ī, ${ }^{185}$ as well as Mūsá b. Sulaymān appointed by 'Abd alMu'min over Tinmāl. ${ }^{186}$

Mūsá has hypothesized that the passage from the group of Ten to the use of the shaykh title for members of the ahl al-jamā' $a$ happened during the revolt of Ibn Malwìya in 527/1133. However, it was not until the conquest of Marrakesh that this title became an official category. The first function for these persons was consultative. Then, when 'Abd al-Mu'min appointed his sons as governors of the provinces (551/1156), he sent with them certain shaykhs as advisers.

183 See $M^{a}$ J. VIGUERA (dir.), El retroceso territorial, 86 and, on the development of this Maghribi history of Islam, see P. BURESI, "D'une Péninsule à l'autre" beginning with the passage by lbn al-Athīr on the conquest of Mahdīya (IBN AL-ATHĪR, al-Kämil, t. 9, 6).

${ }^{184}$ Ykhlaf was the name given to a boy born after the death of one of his brothers. In this case, with $\mathrm{Wa}$, the Berber equivalent of Arabic $I b n$, he was the son of a man born after the death of one of his brothers (MG).

${ }^{185}$ It seems that this person, originally from the village of Mallāla, near Bougie, was first called Yazrijān, which in Berber refers to joy and happiness. As with Abū Hafș 'Umar, Ibn Tümart renamed him for the needs of the cause. Indeed, the name 'Abd al-Wāhid is in direct connection with the Almohad tawhīd (MG).

186 'I. al-D. MūsÁ, "Al-tanẓīmāt al-ḥizbiyya”, 72. 
Others held high executive positions, such as the vizierate (for the sons of Abū Hafṣ 'Umar alHintātī or Ibn Jāmi ').

Most of the shaykhs belonged to the Hintāta and the "People of Tinmāl", on whom 'Abd al-Mu'min had learned to rely. There are no Hargha named among the Almohad shaykhs and Mūsá ascribes this absence to the attempted revolt by the Mahdī's brothers against 'Abd alMu'min. This episode led the ruler to distance them from the centers of power. The Hargha tribe remained nevertheless the most important tribe in ceremonies since it had been the Mahdī's. Furthermore, shaykhs who did not belong to the founding tribes of the Almohad movement were appointed, namely members of the Kūmya, 'Abd al-Mu'min's tribe. This new organization allowed for an integration of tribes not present at the foundation, bringing more than just the Mașmūda into the consultative proceedings.

During 'Abd al-Mu'min's reign, the shaykhs constituted the highest, most powerful category in the hierarchy. Governors sent information on their provinces to them. They were the first to swear the bay ' $a$ to the new caliph. They participated in decisions concerning military problems, and more generally in matters regarding defense, administration, and the budget. Because they recognized the Almohad call and because they were loyal to the first caliphs, they occupied a preeminent place in the Empire's organization, to the point that some rulers, such as during the time of al-Nāṣir, feared them. They were the first to recover the reigns of real power after the ruler's death, and they may have even been at its origin. ${ }^{187}$

The shaykhs did not all hold an important place in the Almohad hierarchy. The sons of the Ten and Fifty had the most influence, which confirms that the structure of the shaykhs was an extension of earlier councils. For Mūsá, the gradual passage from the initial organization to the imperial administration was tied to the events faced by 'Abd al-Mu'min, a foreigner whose tribe only joined the Almohads in 556/1161, so that he had to use much diplomacy with the founding tribes to assure his power. Only territorial expansion and the integration of numerous populations outside the founding tribes allowed this transition. The existence of consultative proceedings with the Almohad shaykhs eased the later creation of similar councils among the

\footnotetext{
187 Mūsá compares their power to that of the Turks under the Abbasid Caliph, but this comparison is hardly pertinent because the situations are very different: the geographic origins, social organization, and military functions of the Turks have nothing to do with the Almohad shaykhs, with the power struggles set in place from the origins of the Almohad movement between the ruler and these influential people from the movement, alienated from the caliphal office to the benefit of this "stranger", 'Abd alMu'min, but who also participated in the central and provincial decisional process.
} 
Arabs and Andalusīs: shaykhs from among the Arabs and from the Andalusī army thus appear in the sources.

The Arab shaykhs were recruited from among the Hilālī leaders when they submitted to the Almohads. The Almohad caliphs did not appoint the Arab shaykhs; the tribal leaders received the title when they submitted. Four taqāìm from the manuscript edited and translated in the second part of this work refer in fact to relations between the Almohad caliphs and the Arab tribal shaykhs. ${ }^{188}$ These documents attest that tribes still held a certain autonomy for designating their leaders in the middle of the thirteenth century. The caliph, though, did exercise a relative power of intervention, since we see him removing a son who had inherited the office of shaykh from his father to name the uncle instead. ${ }^{189}$ The tone of these acts confirms that during this period of weakening caliphal authority, the Almohad rulers made important concessions to the Arab tribes to buy their military strength. The possession of the region of Casablanca was thus confirmed for the Banū Sufyān. ${ }^{190}$ Granting the title of shaykh eased the integration of those, such as the sons of Abū Muhammad Sīdrāy b. Wazīr or those of Ibn Mardanīsh, who had initially resisted Almohad authority. These two groups of shaykhs in particular had a limited consultative role in the military, over all operations for the Arab shaykhs, and only over expeditions in al-Andalus for the Andalusī shaykhs.

As for the ahl al-jamā' $a$ as an executive council, it disappeared from the Empire, replaced by the different dawāwin ("offices") responsible for carrying out the ruler's orders.

\section{THE STRUCTURE OF THE TaLABA}

Mūsá and Fricaud have shown that the first talaba were the disciples of the Mahdī Ibn Tūmart. ${ }^{191}$ 'Abd al-Mu'min continued to send these missionaries among the tribes to spread the Almohad dogma, thus maintaining this structure, but transforming it from an informal group of missionizing disciples into an institutional corps of inspector-theorists: the "Learned". There is little information on the period before the conquest of Marrakesh, but a letter from 543/1148 addressed to the talaba of al-Andalus ${ }^{192}$ and another to the Șanhāja talaba of Tāsghirt ${ }^{193}$ shed light on the responsibilities confided to them: they were primarily charged with amr bi-l-ma 'rūf

\footnotetext{
188 See below, taqādīm 38-41.

189 Taqdīm 39.

190 Taqdīm 41.

191 É. FRICAUD, “Les țalaba”, 344.

192 IBN AL-QATTṬĀN, Najm al-jumān, 212.

193 Al-Baydhaq gave the correct form in Berber, Tisghart. This fraction of the Sanhāja was situated in the Dukkāla plain. Around the town of Azemmour. The saintly Banū Amghār family of the Ribāt of Ṭịt belonged to this tribe (MG).
} 
wa-l-nahy 'an al-munkar ("enjoining good and forbidding evil"), the first task that the Mahdi had set for himself on his return from the East. All other educative, scientific, juridical, and administrative functions came from this moral, social, and political duty. The talaba also gradually acquired military responsibilities. The Empire was created through arms, and the talaba thus received responsibilities in the army and especially the fleet. ${ }^{194}$ Leadership of military campaigns fell to the governors who delegated lower military command to the talaba who sometimes also led certain operations. ${ }^{195}$

Fricaud has identified categories other than the talabat al-hadar mentioned by the sources. Contrary to what has often been written, the most important were not the talaba "of the capital," but those of the "Presence". They constantly followed the caliph wherever he went. The talabat al-muwahhidin were the regional or provincial talaba, designating originally the first țalaba sent by Ibn Tūmart among the Almohad tribes in $520 \mathrm{H} \cdot{ }^{196}$ Fricaud's chronology reveals that from 1156, when the sons of 'Abd al-Mu'min were appointed governors of the provinces while the sons of the shaykhs received the title of $h \bar{a} f i z$, none of the principal leaders of the Mu'minid government carried the title of țălib. The original corporation of talaba with specific functions and rank were organized outside the governmental sphere. ${ }^{197}$

'Abd al-Mu'min's appointment of talaba to lead Gafsa after the conquest of the city indicates the talaba's administrative functions. In addition, they fulfilled muhtasib responsibilities where they were sent. The first rank granted the local talaba in the letters written in the name of the caliph departs from what we know of the Almohad hierarchical scale under Ibn Tūmart as well as that developed by 'Abd al-Mu'min. In terms of protocol, the local talaba came theoretically after the sayyid governor's general staff: great shaykhs, shaykhs-hăfiz, and high administrative officials, but they are cited first. ${ }^{198}$ Charged with developing official interpretation on all matters, spreading caliphal directives, specialists of the Almohad "propaganda", and serving as members of the courts of justice that pronounced on matters of corruption for high officials or doctrinal deviations for scholars, the talaba also participated in multiple supply and maintenance tasks. ${ }^{199}$ Nevertheless, the talaba probably held the most

194 See É. LÉVI-PROVEnÇAL, Majmū rasāil muwaḥhidiyya, letters n 16, 74 and 80, n²0, 102, n²0, 174 and $n^{\circ} 34,221-222$.

195 See É. LÉVI-PROVENÇA, Majmū 'rasāîl muwahhidiyya, letter nº 20, 102.

196 AL-BAYDHAQ, 132 quoted by É. FRICAUD, "Les țalaba", 346.

197 É. FRICAUD, "Les țalaba", 347.

198 É. FrICAUD, "Les țalaba", 368.

199 É. FRICAUD, "Les țalaba", 385. 
power in the fleet, which came completely under the authority of the talabat al-usțūl. ${ }^{200} \mathrm{Abd}$ al-Mu'min may have intended the increased privileges for the talaba to counter balance the influence of the Ten, the Fifty, and the Almohad shaykhs by developing a corps of officials that owed everything to him. ${ }^{201}$

\section{THE HUFFĀZ: THE "GUARDIANS"}

It is not clear when this category first appeared. We do know that 'Abd al-Mu'min's sons had been among them when they were named in rabī' 551/1156. ${ }^{202}$ 'Abd al-Mu'min selected in the larger cities of the Empire, such as Seville, Cordova, Fez, or Tlemcen, 3,000 young men (fifty of whom from Seville) from among the great families to form them in Almohad doctrine. Certain authors, however, claim that they were recruited from the Almohad tribes, while others indicate only the Maṣmūda, which contradicts the name of certain huffāz. These boys were chosen at the age of about six to be able to learn quickly. Their teachers were the best kuttāb, fuqahā', and poets from across the land and 'Abd al-Mu'min himself took care of them every Friday. ${ }^{203}$ The huffa $\bar{z}$ received a theoretical and practical education, and studied the writings of the Mahdi on the doctrine of tawhìd and the law, on the Koran and Muslim's sahịh, as well as works on the administration of governorships. In addition, they learned equestrianism, archery, swimming in a lake made by 'Abd al-Mu'min in his gardens, and mastery of the rules of navigation.

'Abd al-Mu'min thus sought to form an elite capable of assuming all the functions of military and naval administration. He gradually distanced the Almohad shaykhs from the governorships, keeping them as advisers, naming the Guardians (huffäz) in their place. The chronicles show them in leading positions in the military directorships and in the direction of the provinces and districts. This category must have been created sometime in the middle of the 1150s, during the transformations that made the Almohad movement a dynastic Empire. 'Abd al-Mu'min used the pretext of corruption among certain Almohad elements to tie some of them to him and to recruit their sons as huffäz. The letter that he addresses to the talaba of al-Andalus serves as proof of this corruption. It is not clear if the formation of more huffāz continued after the reign of 'Abd al-Mu'min, or if the existence of huffāz in the thirteenth century was due to the transmission of the office from father to son.

200 See É. LÉVI-PROVEnÇAL, Majmū rasāill muwaḥhidiyya, letter nº 29, 173, 174, 177.

201 'I. al-D. MŪSÁ, "Al-tanẓīmāt al-ḥizbiyya", 76.

202 See É. LÉVI-PROVENÇAL, Majmū 'rasā'il muwahhịidiyya, letter n 14, 66.

203 'I. al-D. MūsÁ, "Al-tanẓīmāt al-ḥizbiyya”, 78. 


\section{PROVINCIAL DIVISIONS}

During all the years of conquest, his entire reign, 'Abd al-Mu'min does not seem to have taken on the burden of reinventing the provincial divisions. Those divisions were the fruit of a historical, geographical, urban and territorial rational, and any reorganization would have required energy that the caliph dedicated to enlarging his Empire, not to mention that it would have gone against the policy of recruiting local elites that Ibn Tūmart's successor promoted. The Almohads were able to stabilize their conquests by integrating the great families within the movement, buying their future loyalty. The governorship of Bougie thus continued the erstwhile Banū Ḥammād kingdom, those of the Maghrib al-Aqșá corresponded in general with those of the Almoravids, and the governorship of Ifrīqiya (sometimes called Tunis) to the kingdom of the Banū Bādīs ${ }^{204}$ from Mahdīya to which had been added lands conquered by the Almohads to the east, such as Tripoli. This policy was the fruit of a veritable strategy. We join Mūsá in noting as proof the fact that 'Abd al-Mu'min maintained Meknes as an independent governorship at the beginning of his reign, naming a wăli there. After the declaration of the heredity of the caliphate, however, Meknes is mentioned as a governorship no longer, and the region was apparently attached to the governorship of Fez which carried the name wilayat al-Maghrib and extended from the ribāt of Tāzā ${ }^{205}$ to the ribāt of Meknes. ${ }^{206}$ The Almohads sometimes modified some details, as in the case of Salé. The Almohads made the city an independent governorship from its conquest, with a particular result: the fortress of Ribāt al-Fath, the construction of which was begun under 'Abd al-Mu'min, continued under Yūsuf, and finished under al-Manșūr, was the base of departure for Almohad armies carrying out jihād in Ifrīqiya or al-Andalus.

In al-Andalus, too, the Almohads preserved in general the Almoravid administrative divisions. The declarations of the heredity of the caliphate led to some adjustments there as well: to reward local support, the Almohads maintained the Gharb as an independent governorship, but in 1157-58, the province was joined with Seville, the qāa $\bar{l}$ of the Andalusi city representing the Gharb population before the caliph. Under the caliphate of Yūsuf (11631184), the Almohads once again separated the two provinces, even if there was sometimes only one governor for both regions. The region of Malaga was initially joined with the governorships

\footnotetext{
204 From the Berber Bū-Adīs, "paunchy", as recalled by Ibn Khaldūn (MG).

205 This name of this Almohad-created town means "pass" or "defile" in Berber, conform with the location on the passage between the central and western Maghrib (MG).

206 'A. 'INĀN, 'Așr al-murābițīn wa-l-muwaḥhidīn, t. 1, 415.
} 


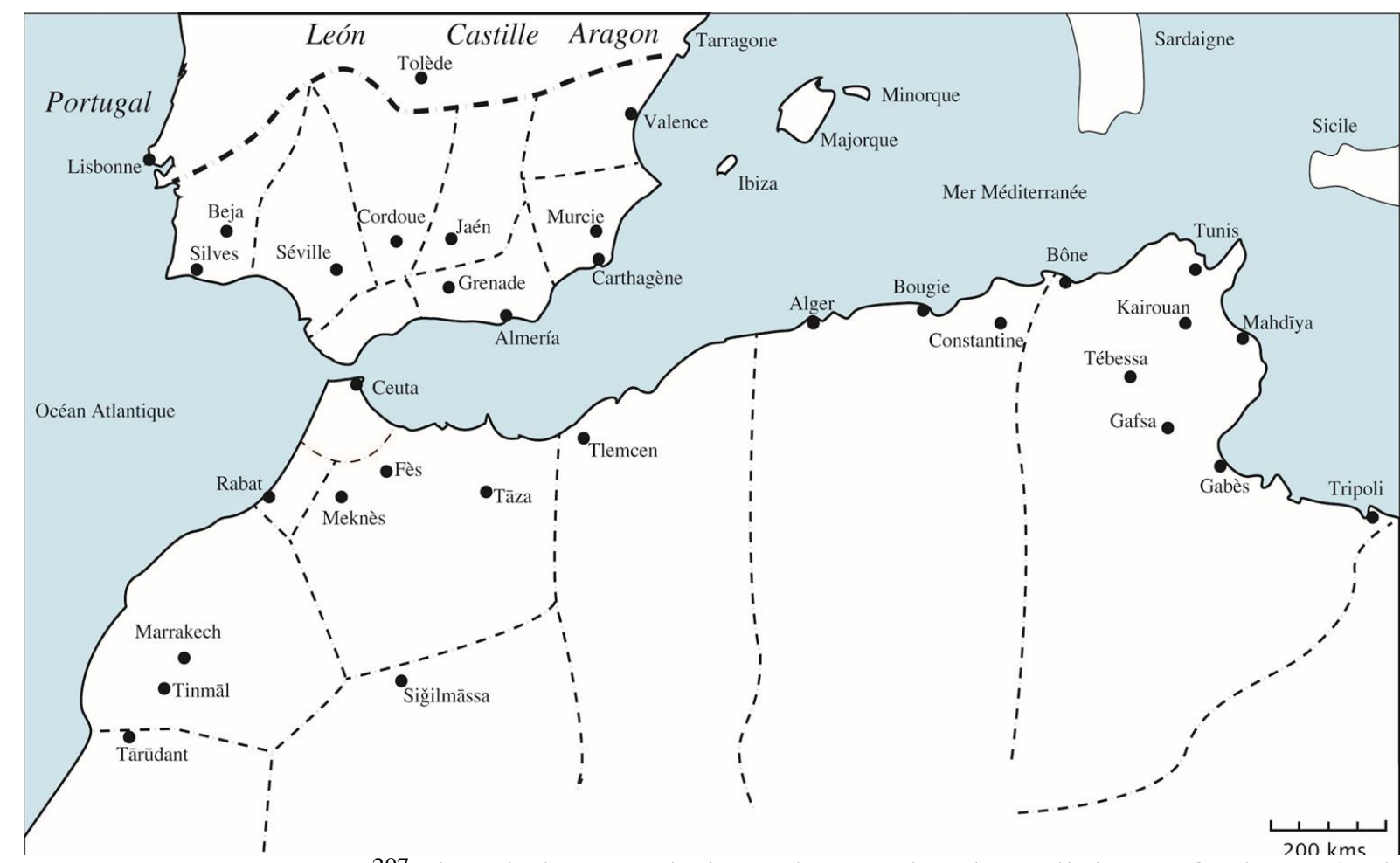

of Ceuta and Granada, ${ }^{207}$ then it became independent under the caliphate of Abū Ya'qūb Yūsuf. ${ }^{208}$

The choice of Seville as the capital meant only that the city was the usual place of residence for the caliphs, and the seat of the central administration for al-Andalus. In fact, during the first period of the Almohad Empire, when the caliphs travelled the Empire from one battlefield to the next, the city served as a gathering point for armies before the jiha $\bar{d}$ campaigns. Occasional organizational changes were made, however, as when the armies left from Cordova for al-Manșūr's expedition against Seville, while supplies were sent from Seville. The caliph settled in Seville on his return from the campaign. During the reigns of the first Almohad caliphs, the idea of a capital was essentially administrative. Tinmāl, burial place of the Mahdī Ibn Tūmart and where 'Uthmān b. 'Affān's muṣhaf was conserved, constituted the regime's symbolic capital, while the caliphal court followed the ceaseless journeys of the rulers who travelled the Empire without settling anywhere for long. ${ }^{209}$

207 IBN AL-ATHIR, Kāmil, t. 11, 223.

208 'I. al-D. MūsÁ, al-Muwaḥhidūn fĩ l-Gharb al-islāmī, 175.

${ }^{209}$ On the itinerant court during the Almohad period, see M. Fierro, "Algunas reflexiones" and J. Dakhlia, "Dans la mouvance du prince". 


\section{Chapter 3: The "Government of the Sons and the Brothers" or the Dynastic Empire}

Rallying to the tawhìd implied at first religious adhesion, but over time it came in essence to mean a political submission to the Mu'minid ${ }^{210}$ Almohad caliphate. This difference led 'Abd al-Mu'min to establish a classification of the Almohads into categories, imitating 'Umar b. al-Khattāāb (d. 634-644): the "first companions" (al-sābiqūn al-awwalūn) who had sworn the bay ' $a$ to the Mahdī Ibn Tūmart and had accompanied him on his military expeditions, then those who had submitted between the defeat at al-Buhayra and the conquest of Wahrān $(539 / 1145),{ }^{211}$ and finally those who had joined after the conquest of Marrakesh in $1147 .{ }^{212}$ This classification may have had financial implications, with larger revenues being reserved for the higher categories, but it is also possible that it was meant to guarantee the loyalty of the original Almohads during the transition between the partisan system and imperial administration. Though the hierarchy was theoretically unquestionable since it was based on an incontestable chronology, 'Abd al-Mu'min did not hesitate to promote tribes who had joined later, in particular his own tribe, the Kūmya Zanātas, placed in second rank of the Almohad hierarchy just after the first category people of Tinmāl. This obviously did not go without provoking some discontentment.

\section{A. The dynastic line, or the succession of the sons}

The decisive change came in 549/1155, when 'Abd al-Mu'min transformed the original structures of Almohad power, which certain historians have described as a "tribal theocratic oligarchy", into a dynastic, autocratic, and hereditary monarchy for his own bloodline. This decision was taken in a chronologically unclear series of events that implicated members of the Mahdī Ibn Tūmart's family discontent with changes in the way power was distributed within the leading councils. They probably also spoke for a number of Almohad shaykhs. Indeed, relations between the caliph 'Abd al-Mu'min and the brothers of Ibn Tūmart, who had died without descendants, broke down after the latter were relieved of their governorship over Seville, where their clumsy rule had provoked the population's revolt in $1148 .{ }^{213}$ Regardless of the actual order of causes, this tension between the interests of the Mahdī's close family, or his tribe, and those of 'Abd al-Mu'min, founder of the Empire, unraveled in the latter's favor.

\footnotetext{
${ }^{210}$ Ibn 'Idhārī and Ibn 'Abd al-Malik al-Marrākušĩ give the most likely vernacular Berber name Mu'minide, rather Imūmnan, for one of the uncles of al-Rašīd (MG).

211 Wahrān in Berber, "the lions" (MG).

212 See É. LeVI-PROVENÇAL, Majmū rasāil muwaḥhidiyya, letter n 12, 47-55 ; NLA 2, n² 20, 59-64. ${ }^{213}$ On this question, see the exhaustive summary byR. LE TOURNEAU, "Du mouvement almohade", 111116.
} 
Indeed, though not without problems, the Almohad caliph succeeded in establishing a dynastic system for his lineage, the Mu'minids, after having removed or crushed those who had not failed to oppose him.

\section{THE DEVELOPMENT OF THE DYNASTIC SYSTEM}

Following the victory of Sétif in 1153, two of Ibn Tūmart's brothers, perhaps nephews, 'Abd al- 'Azīz and 'Īsa, led a failed plot against the caliph 'Abd al-Mu'min's life. ${ }^{214}$ The official letter written after this incident specifies that the plot was discovered in time and that all of the conspirators were executed, except Ibn Tūmart's brothers. In secret, however, 'Abd al-Mu'min ordered the death of Yaṣlātan b. al-Mu izz who, we should remember, had betrayed 'Abd Allāh b. Wānūdīn, the caliph's son-in-law, during the conquest of the Central Maghrib in 547/1153. ${ }^{215}$ Le Tourneau considers that this plot was a symptom of a fairly general discontentment, and 'Abd al-Mu'min avoided touching the Mahdī's brothers and took precautions getting rid of their relative Yașlātan. ${ }^{216}$

'Abd al-Mu'min nevertheless took two measures after the expedition against Bougie which could not but offend the partisans of a more collegial imperial leadership. First of all, he had his eldest son, Muhammad, recognized as his heir apparent. Muhammad, like all his sons, bore the honorific title of sayyid, or received it on this occasion. ${ }^{217}$ He likewise imposed the pronouncement of the name of this wāli al- 'ahd ("heir apparent") in the khutba, during a kind of early bay' $a$ ceremony. Finally, he named all of his younger sons as governors of the main provinces, to the detriment of the ranking Almohad figures. ${ }^{218}$

Abū Hafṣ 'Umar Intī of the Council of Ten, one of the Mahdī’s earliest companions, should have succeeded 'Abd al-Mu'min according to the movement's original tribal traditions. He seems, however, to have renounced fairly easily his claims to power, showing a loyalty to 'Abd al-Mu'min's family that never failed and that won him and his descendants an

214 É. LÉVI-ProvenÇAL, Majmū rasāil muwaḥhidiyya, letter $n^{\circ} 11,38-47$, “Un recueil de lettres officielles", trans. 32-33 ; NLA 2, n 22, 69-75; DIHA, ar. 118-120, trans. 195-199, AL-MARRĀKUSHĪ, Mu'jib, 166-168, trans. 200-202.

215 DIHA, ar. 115-116, trans. 190-191.

${ }^{216}$ The official letter mentioned refers only to the depravation of the Mahdī's brothers as a reason for the caliphal discontent. Al-Baydhaq places Yașlātan's execution in 546/April 20, 1151 - April 7, 1152, and the promotion of 'Abd al-Mu'min's son in 548/March 29, 1153-March 17, 1154 (DIHA, 115/190 and 116/191).

217 É. LÉVI-PROVENÇAL, Majmū' rasā'il muwahhịidiyya, letter n' ${ }^{\circ} 13,55-61$ and "Un recueil de lettres officielles", letter $n^{\circ} 13,35-36$; NLA 2, $n^{\circ} 21,65-68$. This letter announces the designation of 'Abd alMu'min's eldest son as his heir apparent.

${ }^{218}$ An official letter transmits the appointment of a number of the caliph's sons as provincial governors (É. LÉvi-ProvenÇAL, Majmū rasā'il muwahhhidiyya, letter n 14, 61-66 and "Un recueil de lettres

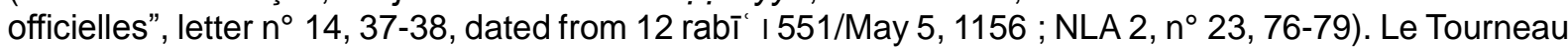
believes this appointment to be a response to the plot led by Ibn Tūmart's brothers, as a kind of legitimate defense (R. LE TOURNEAU, "Du mouvement almohade", 113). 
uninterrupted gratefulness from the different Almohad rulers, in the form of important offices and missions.

\section{THE LINE OF DIRECT SUCCESSION (1163-1224)}

The system developed by 'Abd al-Mu'min after 1155 operated without too many conflicts until 1224, through four successive and direct transmissions of power from father to son: in 1163 Abū Ya 'qūb Yūsuf (Yūsuf the $1^{\text {st }}$ ) succeeded his father 'Abd al-Mu'min, in 1184, Ya 'qūb Abū Yūsuf al-Manșūr succeed him, then Abū 'Abd Allāh Muhammad al-Nāṣir in 1199, and finally Yūsuf II al-Mustanșir in 1213.

a. The son of 'Abd al-Mu'min: Yūsuf Abū Ya 'qūb (11631184)

'Abd al-Mu'min replaced Muhammad with Abū Ya'qūb Yūsuf in the succession the year before his death, because of his eldest son's loose morals and alcohol abuse. Contradictory narratives nevertheless claim that Muhammad held the caliphate for forty-five days, from jumādā II to sha 'bān 558/May-July 1163, before being deposed by Abū Ya 'qūb Yūsuf, helped by his brother Abū Hafṣ 'Umar who, acting as vizier, had assured the transition during the sickness of their father 'Abd al-Mu'min and organized the proclamation of his uterine brother.

Abū Ya 'qūb Yūsuf was twenty-five when he rose to power. ${ }^{219}$ He initially took only the title of $a m \bar{i} r$, then, in jumādā II 563/March 1168, he took on the titles of caliph and amīr almu'minin. The decision was taken in Marrakesh and the provinces ratified the new title and caliphal succession. From them on, the chancellery documents were sent in the name of the "commander of the believers, son of the commander of the believers." 220 This ruler, like his father, but unlike all of his successors, does not seem to have taken a laqab, or honorific regalia title. However, in a letter written by the kātib Abū al-Ḥakam Ibn 'Abd al- 'Azīz Ibn al-Murkhī, after the conquest of Gafsa in 1180, the invocation $\left(d u^{\prime} \bar{a}\right)$ was addressed "to our lord and master the imām al-Manșūr ("the invincible") al-Nāṣir li-dīn Allāh ("the victorious for the religion of God"), the commander of the believers." ${ }^{221}$ It is very difficult to know if this was really a double laqab, of which there is no other mention, neither in the chronicles, nor in the coins from his reign, a purely rhetorical designation used by the $k \bar{a} t i b$, or even something added a posteriori by a zealous scribe recopying the manuscript and attributing to the father the laqabs of his two

$219 \mathrm{M}^{\mathrm{a}} \mathrm{J}$. VIGUERA (dir.), El retroceso territorial, 89.

$220 \mathrm{NLA}, \mathrm{n}^{\circ} 18,112-113$.

221 NLA, n० 30, 144-149:

Li-sayyidi-nā wa mawlā-nā al-imāmi I-manșūri I-nāșiri li-dīni Llāhi amîri I-mu’minīna

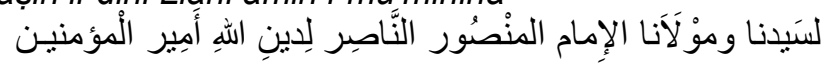


successors. There is also the possibility that Abū Yūsuf Ya qūb b. Yūsuf the First (r. 1184-1199) and his son, Abū 'Abd Allāh Muhammad (r. 1199-1214) used as their respective laqabs the two parts of the title attributed to their father or grandfather.

b. The son of Abū Ya 'qūb Yūsuf: Abū Yūsuf Ya'qūb alManșūr (1184-1199)

The direct line of succession continued when Abū Ya'qūb Yūsuf died of wounds received at the siege of Santarem in 1184. His son, Abū Yūsuf Ya'qūb, born around 1160, succeeded him. Though he had not been formally designated during his father's lifetime, he still managed to impose his candidature, helped probably by his role as vizier. Like his predecessor, he advanced prudently, and initially took only the title of amir to avoid any violent reactions from his rival brothers or uncles. The first years of his reign were marked by measures meant to confirm his power, while the last were characterized by the great victory of Alarcos (19 sha 'bān 592/July 18 1195) in the Iberian Peninsula against the troops of Alfonso VIII of Castile, and by the poorly explained disgrace of Ibn Rushd (Averroes) in 1198.

This crisis of trust between al-Manșūr and the man who had been the qāậ of Cordova, a doctor, philosopher, and royal advisor, was not unrelated to the ruler's relaxation of the Almohad doctrine concerning the "impeccability" of the Mahdī Ibn Tūmart. Many things in fact have been said about the denial of the Almohad doctrine based on a sole later witness, a document written in the name of the caliph al-Ma'mūn, son of al-Manșūr. Indeed, in 1229, the last Almohad caliph to have reigned over al-Andalus justified his denial of the doctrine of the imamate and the iṣma of the Mahdī by the fact that his father, al-Manșūr, had already begun this plan, but without carrying it to its term.

c. The son of Abū Yūsuf Ya qūb al-Manșūr: Abū 'Abd Allāh Muhammad al-Nāṣir li-Dīn Allāh (1199-1214)

Ya 'qūb Abū Yūsuf al-Manșūr died in Marrakesh the $12^{\text {th }}$ or $22^{\text {nd }}$ of rabī' I 595/12-22 January 1199, only somewhat after Ibn Rushd whom he had only recently rehabilitated. The caliph's death came after his return to the Maghrib after having signed a truce with Castile, where he had led repeated incursions into the region of Toledo on the heels of the victory of Alarcos (19 sha'bān 592/July 18 1195). He had designated his son, Abū 'Abd Allāh Muhammad, then age 10, as his heir apparent in the fall of 1191, and the designation was confirmed seven years later in 1198. Abū 'Abd Allāh Muhammad b. al-Manșūr was proclaimed the week after his father's death. He immediately took the laqab of al-Nāṣir li-dīn Allāh and 
kept the ruling team his father had built around the vizier 'Abd al-Raḥmān b. Yujjān, nephew of Abū Ḥaș 'Umar Intī, deceased in 572/1177.

Al-Nāṣir's reign was contrasted. He began on a positive note, with the disappearance of the last vestiges of the Almoravid Empire and the conquest of the island stronghold of the Banū Ghāniya who had been a source of considerable harm for the Empire for a number of decades. The Almohad fleet in a combined attack seized Minorca in 598/1202, Majorca in 599/1203, and, in 1205-1206, the caliph even succeeded in retaking Ifrīqiya, which he entrusted with much autonomy to the Almohad shaykh Abū Muhammad b. Abī Hafṣ. The end of his reign, however, was catastrophic. The broken truce with Castile in 1210 provoked the caliph's personal intervention at the head of the Almohad army in 1211. The siege of Salvatierra was a pyrrhic victory, for even though the Almohads were able to expel the knights of the Order of Calatrava from the fortress, the next year they were roundly defeated at the battle of $a l$ - Iq $\bar{a} b$ (Las Navas de Tolosa) where they faced the reconciled kings of Castile, Aragon, and Navarre under the aegis of the Pope. Al-Nāșir died in Marrakesh at the age of 32, seventeen months after the defeat of Las Navas, the $10^{\text {th }}$ of sha'bān $610 /$ December 25,1213 , probably poisoned by one of his viziers.

d. The son of Abū 'Abd Allāh Muḥammad al-Nāṣir: Yūsuf II al-Mustanșir (1213-1224)

This entire first period of the Empire was characterized by the government of sons, first the sons of 'Abd al-Mu'min, one of whom inherited the throne while the others in extension occupied positions as governors in the main provinces of the Empire. Next, the sons of the sons, with the caliphal office passing through the direct bloodline until the reign of Yūsuf II alMustanșir (1214-1224), and the governorships passing either to the first generation sayyids or to their descendants, all of whom shared with the sons of the Almohad shaykhs. For four generations this transmission functioned fairly well, despite the tensions we will address below. During this period, family solidarity prevailed over fragmentation and the majority of the brothers fell in line behind he among them who imposed his rule the quickest. Nevertheless, with this last succession, the system began to malfunction. Against all the rules of political transmission in Islam, a child of ten years came to power. He was, in fact, a puppet in the hands of his uncles and certain Almohad shaykhs. 


\section{B. Equality and competition between brothers}

Knowledge of the anthropological structures of Berber society, shared with the majority of desert and steppe societies, whether Arab, Turkish, or Persian, allows us to understand the rationales and tensions within the ruling spheres. Power struggles within the endogamous families from the Southern Mediterranean are characterized on the one hand by strong paternal authority, and on the other by equality between brothers, whether uterine or not. 'Abd alMu'min's choice to impose his sons on the governorships of the different regions was thus, during his reign, a guarantee for the cohesion of the immense territorial ensemble he was building. However, with the succession of his son, Abū Ya 'qūb Yūsuf (Yūsuf the First) to the detriment of all his brothers who each could have legitimately hoped to inherit the throne, the other agnatic lines effectively ended. The memory of the founder of the Empire, even after his death, seems to have sufficed to guarantee solidarity between brothers and Abū Ya 'qūb Yūsuf imposed his rule without too much difficulty, even if he did have to show prudence in not taking the title of caliph and "commander of the believers" until many years after having risen to power. Gradually, however, ambition began to express itself more clearly.

1. UNDER THE AUTHORITY OF THE FATHER, THE SOLIDARITY OF BROTHERS: THE GOVERNOR SONS

The reform of 1155, which instituted the dynastic system for the caliphal office, was likewise accompanied by an equally important measure that concentrated the gubernatorial offices in the hands of 'Abd al-Mu'min's twenty sons. The Empire was then managed as a patrimony and those brothers excluded from the succession received the most important posts in the provinces. 'Abd al-Mu'min thus controlled not only the caliphal office, monopolized by his bloodline, but he also held undivided authority over the different regions of the Empire while reinforcing his political legitimacy through his paternal authority.

a. The brothers of Abū Ya 'qūb Yūsuf (1163-1184)

Paternal authority may have guaranteed cohesion for the territorial ensemble under 'Abd al-Mu'min, but the brothers' theoretical equality had grave consequences on his death. Indeed, once the paternal authority had disappeared, if the successor had not been clearly confirmed before the father's death or if the heir apparent had not shown himself to be up to the imminent task, his brothers found themselves in competition with him and could contest his legitimacy. Thus, three of Abū Ya 'qūb Yūsuf's thirteen (or seventeen) brothers and diverse Almohad notables opposed his accession to power in 1163. During this first period for the Empire, the possibilities of retribution and reward allowed the best placed candidate, who had built the best clientele and disposed of the largest means, to take power without too much trouble. 
To impose his power over the opposition, Abū Ya qūb Yūsuf had to dismiss the large army that his father had brought together at Gibraltar and to put off his intervention in alAndalus until 1171, eight years after his accession to power. Though some of his brothers resisted, others rallied more or less voluntarily to his cause. Thus, on Abū Ya 'qūb Yūsuf's nomination (1163), the caliph's brother and governor of Seville received new instructions concerning the ruler's titles and took charge of having them applied throughout al-Andalus. Other brothers, all bearing the title of sayyid, were appointed as local governors (Bougie, Tlemcen, Fez, Ceuta, Sūs), probably to replace certain uncles of the new caliph. They were doubled in their posts by viziers chosen from among the aristocracy of the Almohad shaykhs, which helped in assuring or confirming the support of the Empire's principal actors. ${ }^{222}$

The brothers' loyalty was rewarded with the non-exclusive leadership of the armies, in addition to their gubernatorial posts. Thus, the sayyids Abū Ḥaș 'Umar and 'Abū Sa'īd 'Uthmān, governor of Seville, were appointed at the head of the major military expeditions meant to affront Giraldo Sempavor and Ibn Mardanīsh. ${ }^{223}$ They both returned to Marrakesh at the end of July 1165 with Arab reinforcements from Riyāḥ, Athbağ, and Zughba. They took Andūjar in September, and from there ravaged Galera, Caravaca, Baza, Sierra de Segura, seized Cúllar and Vélez-Rubio, then marched on Murcia where they obtained the victory of Faḥs alJallāb. ${ }^{224}$

The sayyid Abū Hafș 'Umar then took the head of the Maghribī troops to lead them across the Strait and to their homes, but took advantage of their presence during the summer of 1167 to put down a rebellion by the Ghumāra Berbers between Ceuta and Alcazarquivir begun in 562/1166. The sayyid Abū Sa'īd 'Uthmān, for his part, received the governorship of the province of Cordova. $^{225}$

\section{b. The brothers of Abū Yūsuf Ya qūb (1184-1199)}

Ya'qūb, the future al-Manșūr, was proclaimed caliph while in Seville, where he remained for a month before traveling to the Maghrib, arriving in Sale on September $9^{\text {th }}$, leaving his brothers Abū Isḥāq, Abū Yahyá, and Abū Zayd as governors of the different Andalusī provinces.

\footnotetext{
222 J.-C. GARCIN (dir.), États, sociétés et cultures, t. 1, 213.

${ }^{223} \mathrm{M}^{\mathrm{a}} \mathrm{J}$. VIGUERA (dir.), El retroceso territorial, 91

224 The news arrived in Marrakesh sixteen days later, on dhū 1-hijja 23, 560/October 31, 1165.

225 During this time, Giraldo seized Trujillo, Cáceres and Évora in 1165, Montánchez and Serpa in 1166, Badajoz in 1169 (which led Fernando II of León [1157-1188] to ally with the Almohads to retake the city with them).
} 


\section{SEGMENTAL RATIONALE OR THE EXCLUDED BROTHERS}

The rivalry of his brothers certainly required the entire attention of the ruling sibling, but the next succession added rival uncles and cousins, those from excluded segments. The new ruler had to affront not only his brothers, but also those of his father who could possibly express their frustration at having been put aside for the previous succession. If the reign was long, as was the case for Abū Ya 'qūb Yūsuf, despite his violent death in combat against the Northern Iberian Christians (a little less for Abū Yūsuf Ya qūb al-Manșūr, and even less so for Abū 'Abd Allāh Muḥammad al-Nāṣir), the designated heir had ample time to face his uncles' resistance, to prepare his accession to power by building his wealth and clientele.

Abū Yūsuf Ya 'qūb was forced to negotiate his uncles' adherence for a heavy price before taking the title of amīr al-mu'mininn. ${ }^{226}$ Troubles in Ifrīqiya, however, and news of the defeat of al- 'Umra, near Gafsa ( $\mathrm{rabī}^{\prime}$ II 15, 583/June 24, 1187) against the troops of 'Alī Ibn Ghāniya, were the signal for a new revolt against the caliph. Two of his uncles, the sayyids Abū Ishāa Ibrāhīm and Abū 1-rabī' Sulaymān, respectively the governors of Tlemcen and Tadla, 227 participated, as well as his own brother, Abū Ḥaf̣̣ 'Umar al-Rashīd, governor of Murcia, who allied with Alfonso VIII and raised taxes to strengthen his position.

After conquering Gabès (583/1188) and reestablishing order in Ifrīqiya, Abū Yūsuf Ya 'qūb returned to Tunis in 584/1189. He left a loyal sayyid there as governor, Abū Zayd 'Abd al-Raḥmān, before returning in haste to Marrakesh to order the imprisonment and execution of his plotting uncles and brother. ${ }^{228}$ These Maghribī revolts were equally encouragements for the Christians, and they postponed the caliph's intervention in al-Andalus until 1190. Rivalries within the ruling family around the caliphal office thus had grave repercussions on the administration of the Empire and on relations with neighboring states.

When Abū Ya 'qūb Yūsuf al-Mustanșir came to power, he was ten or fifteen years old, and his uncles and two Almohad shaykhs held de facto power until his death in 1224. The sources disagree on the reasons for this: he was either poisoned by his vizier Ibn Jām ', or gored by a cow according to Ibn al-Khațîb. His reign was marked by the rise to power of his uncles. The caliph no longer held any real power, and he left Marrakesh only to go to Tinmāl.

226 HPIA, 317, Ma J. VIGUERA (dir.), El retroceso territorial, 96.

${ }^{227}$ Huici Miranda claims that Abū Isḥāq Ibrāhīm was not in fact the governor or Tlemcen, but that he had been exiled there for a lack of loyalty to the caliph al-Manșūr, his nephew (HPIA, 339).

228 J.-C. GARCIN (dir.), États, sociétés et cultures, t. 1, 219. 


\section{Governing the Empire}

\section{Chapter 4: The Dislocated Empire}

Chronic revolts, incessant Christian attacks, and increasing rivalry within the leading family of 'Abd al-Mu'min's descendants led inexorably to the gradual break up of the Empire. Despite the constant efforts of the successive rulers to pacify and doctrinally unify the different territories of Tripolitania, the Central Maghrib, Morocco and the Iberian Peninsula, either by suppressing religious movements or by canalizing the military strength of the nomadic, Turkic, and especially Arab populations from the East, despite all the energy they spent in creating clients and reconciling those excluded from the caliphal leadership, after the defeat of Las Navas de Tolosa, 18 șafar 609/July 16, 1212, and the (natural?) death of the still-young caliph al-Nāṣir, the rise to power of a child and the power struggles surrounding the caliph led to the disintegration of the Empire.

\section{A. An Abandoned al-Andalus}

After the Almohad defeat at Las Navas de Tolosa ( $a l$ - 'Iqāb) against the kings of Castile, Aragon, and Navarre, the Christians seized Baeza, Vilches, Baños de la Encina, Tolosa, Castro Ferral, and Úbeda, pushing the border to the limits of Andalusia. The death of Alfonso VIII of Castile and Peter II of Aragon at Muret in 1213, and the subsequent truce interrupted the Christian advance. The Northern Iberian Christian kingdoms would not take advantage of the rivalries at the head of the caliphate until the 1220s.

The last detailed list of appointments and transfers of officials in Ibn 'Idhārī's Bayān significantly concerns 607/1210-1211. The sayyid Abū 'Abd Allāh b. Abī Hafṣ was then appointed in Valencia, transferred from the governorship of Majorca. Abū 'Imrān b. Yāsīn alHintātī was appointed in Murcia. Abū Muhammad b. Hawṭ Allāh, qā ḍ̂̄ of Murcia, was sent to Majorca and replaced by Abū 1-Ḥasan al-Qashțāî. The Maghribī Abū Ibrāhīm b. Yaghmūrê29 was appointed $q \bar{a} d \bar{l}$ of Valencia. ${ }^{230}$ The fact that Ibn 'Idhārī mentions no more lists of this sort after this date is fairly indicative of the crisis that the central government began to experience in the 1220s. The government of Valencia seems under al-Mustanșir to have been given to another sayyid, Abū 'Abd Allāh b. al-Manșūr, then in 619/1222-1223 to the sayyid Abū Zayd 'Abd al-Raḥmān, son of Abū 'Abd Allāh b. Ab̄i Hafṣ, who had received the same office ten years earlier. The sayyid Abū Muhammad 'Abd Allāh b. al-Manșūr was appointed governor of

229 This name refers to abundance in Berber (MG).

230 P. GUICHARD, Les Musulmans de Valence, t. 1, 136. 
Murcia, also in 1222-1223. Thus, until this date, the patrimonial system developed by 'Abd alMu'min continued, and the more important governmental posts were given to the descendants of 'Abd al-Mu'min, all of whom bore the title of sayyid.

\section{FROM BROTHERLY DEMANDS TO HOMICIDAL UNCLES}

After al-Mustanșir's accidental or provoked death in 1124, power no longer transferred from father to son. The late caliph's great uncle, Abū Muhammad b. Yūsuf b. 'Abd al-Mu'min, known as al-Makhlū' (the "Deposed"), succeeded him, but his reign lasted only eight months (620-621/1224). His ascension marked the beginning of the wars of succession. His nephew, Abū Muḥammad 'Abd Allāh al-'Ādil (621/1224-624/1227), the son of al-Manșūr, then governor of Murcia proclaimed himself caliph on 13 șafar 621/March 6, 1224 in Murcia, at the instigation of his vizier, Ibn Yujjān. ${ }^{231}$ He appointed his brother, Abū l- 'Alá Idrīs, the future alMa'mūn, as governor of Seville, and one of his cousins, the sayyid 'Abd Allāh al-Bayāsī, as governor of Cordova. With the help of other brothers, the governors of Malaga and Granada, he received the support of all al-Andalus, except Valencia, Denia, Játiva, and Alcira, governed by one of his cousins, the brother of al-Bayāsī, the sayyid Abū Zayd or Ceyt Abu Ceyt, grandnephew of Yūsuf I, who had remained loyal to the caliph in Marrakesh (al-Makhlū'), and who was rapidly assassinated in September 1224.

Al- 'Adil was easily recognized in the Maghrib at the end of 1225, but in al-Andalus he faced the revolt of the sayyid 'Abd Allāh al-Bayāsī, who allied with Fernando III and fortified his position in Baeza (hence his shuhra). The Leonese pillaged the region of Seville, which was defenseless because of the military conflict with al-Bayāsī. Fernando III entered Murcia and Abū Zayd (Ceyt Abu Ceyt), al-Bayāsī's brother, declared himself his vassal in the summer of 1225. Al-Bayāsī was able to take Cordova, but his alliance with the Christians alienated the population, leading to a revolt and his execution in the summer of 1226. Sometime between alBayāsī's death, and al-Ma'mūn's claim to the caliphal title, the future ruler issued taqdīm 4 from manuscript 4752, so sometime between the summer of 1226 and September 1227. Indeed, the copyist indicates in the title: 'in the name of al-Ma'mūn Abū al- 'Alá, before he became caliph." Moreover, the act was written in Cordova. The taqdim served to appoint a shaykh as governor $(w \bar{a} l \vec{\imath})$ of a region, with important prerogatives: direction of the affairs and interests of the entire region ( $u f q)$ and its districts ( $a n z \bar{a} \bar{r})$, combating "the party of corruption" (ahl alfasād), applying and executing the law (tanfìdh al-haqqī wa mọà'i-hi), and collecting taxes

${ }^{231}$ P. GUICHARD, Les musulmans de Valence, t. 1, 137. 
(istīfă' al-wājibi wa qtid̄a 'i-hi). ${ }^{232}$ Al- 'Ādil had left the Peninsula to his brother, al-Ma'mūn (624/1227-629/1232), who also declared himself caliph in September 1227, leading to al'Ādil's assassination in Marrakesh (22 shawwāl 624/October 5, 1227). Al-Ma'mūn then marched on the Maghrib impose his power over that of his nephew, Yahyá al-Mu tașim (624/1227-633/1236), son of Muhammad al-Nāṣir and brother of al-Mustanșir, who had been proclaimed in Marrakesh.

Al-Ma'mūn arrived in October 1228 and chased al-Mu'tașim from Marrakesh where he had himself recognized as caliph and renounced shortly thereafter the Almohad doctrine of the 'iṣma of the Mahdī Ibn Tūmart. He thus ordered the suppression of the Mahdī's name from the $k h u t ̧ b a$ and from coinage. There is perhaps a trace of al-Ma'mūn's ideological rupture in the taqāìm of manuscript 4752, in the five judicial appointments ascribed to him. ${ }^{233}$ In the first two, the only foundations mentioned on which the judge should rely in pronouncing the law are "The Book of God and the Tradition of His messenger" (kitābu Llāhi wa sunnatu rasūli-hi), ${ }^{234}$ or simply "the Book and the Tradition" (al-kitāb wa l-sunna). ${ }^{235}$ In the following three, however, these two pillars are joined by a third, the "consensus of the Community" (ijma $\bar{a}$ ' $l$ lummati), ${ }^{236}$ or even, in the case of taqdìm 51, a fourth: the "juridical consultations of the imāms" (wa fatāwá al-a'immati). ${ }^{237}$

A veritable purge of his adversaries in Marrakesh accompanied this doctrinal reorientation, in particular within the Hintāta tribe. This purge had very important consequences, since, as we shall see, it led to Ifrīqiya seceding. Al-Ma'mūn sought then to reestablish ties with the remaining pieces of Islamic Spain, notably Seville, where the Almohads were still solidly entrenched and from whence he had come. He consequently tried to take Ceuta from his brother, Abū Mūsá 'Imrān, who had revolted against him, but failed. ${ }^{238}$ The taqādìm

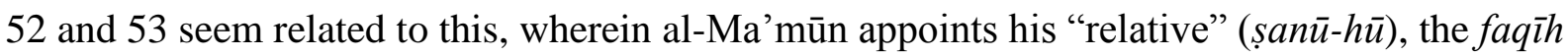
Abū Muḥammad, as judge of Jérez, in the middle of shawwāl 626/1229, then of Algeciras in șafar of the same year. Taqdìm 57, in which the caliph al-Rashīd (629/1232-640/1242) appoints the same person, Abū Muhammad, to the judgeship of Jérez in dhū 1-Qa da 636/1238, is the

232 See taqdīm 4.

233 See below taqādīm 49 to 53.

234 f० 32 r, I. 18.

235 f० $33 r$, l. 1

$236 f^{\circ} 33 v$, I. $10-11, f^{\circ} 34 r$, I. 16 and fo $35 r$, I. 5.

237 f० $33 \mathrm{v}, \mathrm{l} .12$.

238 IBN 'IDHĀRII, Bayān, t. 3, 281, quoted by B. ROSENBERGER, "Le contrôle du Détroit”, 27. 
last act of power by the Almohad caliphs in the Iberian peninsula. Al-Ma'mūn's departure from al-Andalus thus represents a rupture in the history of the Iberian peninsula: he was the last Almohad ruler to have resided there and, despite a few nominal later associations with the Almohad rulers of Marrakesh, we can consider the peninsula no longer under North African authority

\section{THE THIRD TAIFAS}

This episode of political fragmentation in al-Andalus appears clearly in manuscript 4752, since four long taqādìm came from one of the new powers that emerged thanks to the weakening of Almohad power in the Peninsula. ${ }^{239}$ Even before al-Ma'mūn left, an Andalusī officer who claimed to descend from the kings of the Hūdid taifa of Saragossa from the beginning of the twelfth century rebelled in rajab 625/May 1228 in Murcia. Abū 'Abd Allāh Muhammd b. Hūd took the Almoravid title of amīr al-muslimīn and the laqab of al-Mutawakkil in his fight against al-Ma'mūn. ${ }^{240} \mathrm{He}$ tied his emirate to the Abbasid Caliphate in Baghdad, adopted the color black for his banners instead of the Almohads' white, and received a diploma of investiture from the Eastern caliphs. This move to place himself under the Abbasids appears clearly in the four taqāìm from manuscript 4752 attributed to al-Mutawakkil. Indeed, the Abbasid caliph is named in the tardiya, that part of the initial protocol usually reserved for the Mahdī Ibn Tūmart in Almohad documents. The manuscript's author explicitly attributes taqāìm 5, 54, and 55 to Ibn Hūd in the titles for each document, ${ }^{241}$ while the tardiya in the name of the "Abbasid imäm, commander of the believers who collected the sword, baton, and mantle of the messenger of God, his (paternal) cousin" indicates taqdìm 30 was also produced by the Murcian ruler. ${ }^{242}$

Ibn Hūd's power was heavily influenced by the mystical-Sufism of Ibn Sab 'īn. ${ }^{243}$ This began the period known as the third taifas. Abū 'Abd Allāh Muhammad b. Hūd al-Mutawakkil led the adamantly anti-Almohad movements who won all of al-Andalus in only a few months.

239 These were taqādīm 5, 30, 54, and 55 written, in the name of Ibn Hūd al-Mutawakkil, first in Granada, and then probably in Murcia.

240 See P. Guichard, Les Musulmans de Valence, t. 1, 139 and E. Molina LóPEZ, "De la Murcia musulmana", t. 3, 187-263.

241 Taqdīm n' 5: "This is what he wrote - May God have mercy on him — in the name of Ibn Hūd" ; taqdīm $n^{\circ}$ 54: "In the name of Ibn Hūd, appointment..." (wa 'ani bni Hūdin fì taqdīm ...) ; taqdīm n 55: "In the name of the same, collective allocution" (wa 'an-hu mukhātabatu jumhūriyyatu...).

242 See taqdīm $n^{\circ}$ 30, fo 24r, I. 1-2: wa nurḍ̄ an al-imāmi l- 'abbāsī amiri l-mu'minīna al-ladhì ahraza husāma Ibn 'ammi-hi rasūli Llāhi wa qaụībi-hi wa burdi-hi.

243 P. GUICHARD, Les Musulmans de Valence, t. 1, 143. 
Seville rallied to his cause in dhū l-hijja 626/October 1229. He seemed then on the verge of building an autonomous Muslim power in al-Andalus, but his hopes would not last.

The Almohad sayyid, Abū Zayd, was driven from power in Valencia by the head of his cavalry, Zayyān Ibn Mardanīsh, at the beginning of 626/end of 1228-beginning of 1229. In 628/1231, al-Mutawakkil was gravely defeated at Alange by Alfonso IX of Leon, who had begun conquering the Muslim cities of Estremadura (Badajoz in 1229, Cáceres in 1230, Mérida in 1231). Seville rejected al-Mutawakkil's authority in 629/1231-1232 and recognized as their ruler their qā probably refers to this moment. In this act, dated from 8 ramaḍ̄n 630/1232, Ibn Hūd alMutawakkil calls his vizier, Abū 'Abd Allāh Muhammad Ibn Ramaymī, dhū l-wizaratayn and governor of Almería, to his side, and replaces him with his son, the "ra'îs Fulān." "244 The Balearic Islands, led by Almohad governors since their conquest by al-Nāșir at the beginning of the twelfth century, fell to James I of Aragon in 1230.

Around the same time, in 629/1232, Muhammad b. Yūsuf b. Naṣr Ibn al-Ahmmar became an independent power in Arjona in the region of Jaén and succeeded in enrolling that town, then Granada, which became his capital. In 636/1238, the Almohad caliph al-Rashīd was formally recognized in Seville then Ceuta. The Nașrid emir of Granada, Ibn al-Aḥmar, did the same soon after to distance himself from Ibn Hūd al-Mutawakkil in Murcia, who had recognized the Abbasid caliph. ${ }^{245}$ The reestablishment of the Almohad caliphate under al-Rashīd was more apparent than real, though, and al-Andalus was de facto on its own. ${ }^{246}$ Moreover, after the Christian conquest of Cordova (1236), Valencia and Seville (1248), Granada was in fact the only remaining part of al-Andalus.

\section{B. Emancipated Ifrīqiya}

Ties between the Moroccan centers of Almohad power and Ifrīqiya had always been tenuous. Al-Manșūr had already lost control of Ifrīqiya in the 1180s, and it was his son, al-Nașîr who had succeeded in reestablishing Almohad control over the region. He had left as governor an eminent Almohad, the Ḥafṣid shaykh 'Abd al-Wāḥid b. 'Umar b. 'Abd Allāh al-Hintātī, who

\footnotetext{
244 See taqdim $n^{\circ} 5$.

${ }^{245}$ For references to the chronicles mentioning these different bay as under al-Rashīd, see A. 'AZZĀWī, al-Gharb al-islāmī, t. 1, 41-42.

${ }^{246}$ Taqdīm 57 from manuscript 4752 refers to this formal act of recognition of the caliph.
} 
provided the inhabitants of Ifrīqiya with long years of peace. They agreed to replace him on his death with his son, Abū Zayd 'Abd al-Raḥmān b. 'Abd al-Wāḥid. The Almohad government was aware of the dangers of allowing the Hafșids to take root in Ifrīqiya, and so refused, sending as governor the sayyid Abū l-'Alá Idrīs b. Yūsuf b. 'Abd al-Mu'min, one of the sons of Abū Ya'qūb Yūsuf I. The new governor sent his own son, also named Abū Zayd 'Abd al-Raḥmān (b. Abī l-'Alá), to fight against the Banū Ghāniya near Tunis. This expedition ended in 620/1223 with a nearly definitive victory over Yahyá b. Ghāniya in Majdūl. ${ }^{247}$ After this date, the Almoravid leader was little more than a gang leader, pushed to the edges of the Sahara and forced to move over immense distances between Tripolitania and Sijilmāssa until his death in 633/1237-1238.

Abū Zayd's victory over the Banū Ghāniya helped secure his succession as governor when his father, the sayyid Abū 1-'Alá Idrīs, died in 620/1223. However, the chronicles report that his arbitrariness and tyranny alienated his subjects, and the caliph al- Ádil dismissed him in 623/1226, appointing in his stead a son of 'Abd al-Wāhìid al-Hintātī, the shaykh Abū Muḥammad 'Abd Allāh, who was accompanied by his brother, Abū Zakariyā Yaḥyá. When alMa'mūn renounced the Almohad doctrine and massacred many officials and notables, mostly from Tinmāl and Hintāta, Abū Zakariyā, himself Hintātī, led the Almohads of Ifrīqiya who refused this decision, obtaining his brother's deposition, who was guilty of late payments. Abū Zakariyā was then recognized as emir, against the authority and will of the Almohad caliphs in Marrakesh.

Abū Zakariyā maintained for a few months formal recognition of Yahyá al-Mu'tașim (624/1227-633/1236), who claimed the caliphate against al-Ma'mūn. ${ }^{248}$ He later eliminated the caliph from the khutba, having the prayer pronounced "in the name of the Mahdi and the orthodox caliphs" (beginning 627/Februrary 1229). It was only in 634/1237 that he had himself publicly declared caliph with his own name in the khutba.

Although the numerous sayyids and governors of the larger cities enjoyed great power, equaled by their spirit of independence and ambition, the principal of a centralized state (with a rotation of gubernatorial appointments) was not questioned in Ifrīqiya until the end of this

247 This toponym, extremely common throughout the Maghrib (Amagdūl, Tamagdūlt, Tameddūlt, Timidelt, Tasagdelt) refers to a fortified granary (MG).

${ }^{248}$ Son of Muhammad al-Nāṣir and brother of al-Mustanșir. 
troubled period. The Almohad caliphs succeeded until the end of the 1220 s in removing "local" candidates, and in appointing their own. Al-Ma'mūn's reign marks a rupture in that it gave the Hafṣids of Ifrīqiya the pretext to free themselves in the name of loyalty to the Almohad doctrine and the founding ideals of the Empire. The same motives for the integration and conquest of Ifrīqiya were thus invoked to justify its independence at the beginning of the thirteenth century.

\section{The Central Maghrib in Revolt}

After al-Andalus and Ifrīqiya left the Almohad orbit, the Central Maghrib became the new frontier for the Empire. Yaghmurasān b. Zayyān was first recognized as governor and emir of Tlemcen in 638/1239 in exchange for the bay ' $a$ he swore to the caliph al-Rashīd. ${ }^{249}$ This was no longer an appointment, however, but the acknowledgement of the Almohads' historic role and the memory of their former strength. This circumstantial alliance continued under the caliph al-Mu'taḍid bi-Llāh al-Sa'īd (640/1242-646/1248), whom Yaghmurāsān supported in his struggle against the Banū Marīn. The Tlemcen dynasty, known as the Zayyānids or the 'Abd al-Wādids, played on the rivalry between the caliphs of Marrakesh and Tunis, until Hafṣid pressure from Ifrīqiya grew. In 628/1230, Tunis brought its control over Bougie and Constantine, Algiers and a number of Central Maghribī tribes (the Zanāta Banū Mandīl and Banū Tujīn) the next year, pushing on to Chélif. They arrived in Tlemcen in 639-640/Summer 1242, and Yaghmurāsān was forced to negotiate with the Ḥafșid and recognize his authority. He was then restored to his former governorship and recognized by the Marinids who sought to give political substance to their power.

\section{Morocco in disintegration}

The occupation of the Balearic Islands in 600/1203 and the forceful submission of Ifrīqiya in 1205, both incontestable successes against the Banū Ghāniya, were erased by the disaster of Las Navas de Tolosa in 610/1212 and the death of the caliph al-Nāșir the next year. From that date and from Yūsuf II al-Mustanșir's reign (1213-1224), we can see contradictory influences, parallel powers, and struggles between clans at the summit of the state with a return of influence for the shaykhs, the descendants of the Mahdī's companions. The new caliph, Yūsuf II al-Mustanșir, who was very young, left Marrakesh only to go on pilgrimage to Tinmāl. He seems to have exercised no governmental activity, and it was his vizier, Ibn Jāmi', with the

249 NLA, n 124, 396-398. 
shaykhs present in Marrakesh, who had to suppress the half-tribal, half-religious rebellions that began to multiply. This weakening of the caliphal office, in a highly centralized and hierarchical Empire built around a ruler who still held the power to decide jihād, royal justice, appointments of governors, provincial governors or tax collectors, led to territorial disintegration and paralysis in the provinces. The link between the central caliphal power and provincial authorities was broken and this disconnection opened the door to the dismemberment of the Empire.

\section{THE WEAKENING OF THE CALIPHAL OFFICE}

The initial reigning years for 'Abd al-Wahīd al-Rashīd (629/1232-640/1242), son of alMa'mūn and a Christian slave, continued the civil war between the different candidates for the caliphal office, marked by the rivalry between his partisans and those of Yahyá al-Mu 'tașim b. al-Nāṣir and by an attempt to restore caliphal authority over the Central Maghrib and alAndalus. Al-Rashīd employed and increased the number of his father's Christian mercenaries. The Arab tribes installed by the Almohad caliphs (mainly Sufyān and Khulț) made up the principal military force, but Berber tribes such as the Haskūra, with the meddling Ibn Waqārīt ${ }^{250}$ at their head, also played an important role. The Almohads chased from Marrakesh by alMa'mūn's persecutions rallied around Yahyá b. al-Nāṣir, while the Khulț supported al-Rashīd. These alliances then reversed in part because of Ibn Waqārīts intrigues. The Almohads returning to the caliph in Marrakesh obtained from him the official restoration of the Almohad doctrine (beginning 632/fall 1234). The Khult and Haskūra attacked the capital, forcing alRashīd to abandon them. The caliph, with the Almohads loyal to him, fled to the Atlas Mountains, then Sijilmāssa (end 632/summer 1235). Yahyá al-Mu'taṣim occupied Marrakesh during this period.

Al-Rashīd and his supporters were able to reestablish their position at the beginning of 633/1235 thanks to the wealth of Sijilmāssa. Reinforced by many Christian mercenaries, they headed to Fez where they increased their means by drawing on the public treasury. They thus won the support of the Sufyān Arabs, the enemies of the Khulț, and marched with them on Marrakesh. Taqdīm 41 is probably the result of this alliance with the Sufyān Arabs since the

\footnotetext{
250 In Berber this name refers to the son of the qirāt or of someone who posses a qirāt. The qirăt was a division of a dinar $\left(1 / 24^{\text {th }}\right)$. The term gave the current form of aqarid in Tašelhit to refer to money. It is not possible to know if this was the case in the seventh/thirteenth century (MG).
} 
caliph concedes to them Ānfā (Casablanca) and its region with ample prerogatives. ${ }^{251}$ The Khult and Haskūra, along with their caliph (Yahyyá al-Mu'tāṣim b. al-Nāṣir), met them near Umm $\mathrm{Rab}^{`}$ ' in Awğidhān. After ten days of combat, the concussive power of al-Rashīd's Christian mercenaries won the day in a final battle that saw the massacre of Yahyá al-Mu'tașim's supporters (middle of 633/spring 1236). Taqdìm 39 may have been related to the Khult's previous reversal, since the text mentions the alliance with the father, the betrayal of the son and then his replacement by the father's brother, the ousted shaykh's uncle. ${ }^{252}$ For their part, Ibn Waqārīt and certain Khult leaders, after having abandoned Yahyá al-Mu tașim b. al-Nāṣir, went to al-Andalus to ask the help of Ibn Hūd al-Mutawakkil, but the Andalusī was assassinated in jumādā I 635/January 1238. Seville, whose leader was then Abū 'Amr b. al-Jadd, officially recognized al-Rashīd and delivered to him Ibn Waqārīt who was executed. Yahyá al-Mu taṣim b. al-Nāșir was assassinated by the Ma'qil Arabs with whom he had sought refuge in shawwāl 633/July 1236 while they were living as nomads between Fez and Tāzā.

\section{THE PARTICULAR SITUATION IN CEUTA}

Somewhat like Seville, Ceuta had a particular destiny. Because of its situation, the port maintained privileged, commercial, political, and military relations with the Iberian peninsula. The Almohad fleet's base there was the grounds for these relations, and the qã 'id al-ustiul of Ceuta was usually the admiral of the Almohad fleet. The city played on its situation as a commercial crossroads between the Maghrib, the Latin West, and al-Andalus. Depending on the circumstances, Ceuta transferred its activities between these different zones, and in favorable periods profited from the circulation between these spaces. When the political situation in the Maghrib was disturbed after al-Mustanșir's death (1224), the city decided its own policies, freeing itself from the Maghribī hinterland and privileging its commercial interests with the Italians (especially the Genoese, well-implanted in the city), though sometimes also symbolically joining with the power in Marrakesh by swearing allegiance to the reigning caliph, as under al-Rashīd.

Thus, at the beginning of this period, during the conflict between al-Ma'mūn and Yahyá al-Mu'tașim b. al-Nāṣir, the governor of Ceuta, the sayyid Abū Mūs, al-Ma'mūn's brother, proclaimed an ephemeral caliphate in 631/1229 that maintained relations with Ibn Hūd, then master of Algeciras. Al-Ma'mūn laid siege to the city by land for three months without

251 See taqdīm 41.

252 See taqdìm 39. 
succeeding in taking it. The city recognized Ibn Hūd who appointed the admiral al-Ghustī as governor. Ceuta rapidly revolted against him and chased him away. Al-Yanashtī, one of the city's main merchants, took the title of al-Muwaffaq bi-Llāh and governed the city for five years from 630/1233 and 635/1238. The city was then independent and maintained its place thanks to the port and its commercial Mediterranean networks, especially its agreements with the Genoese, who maintained a considerable quarter in Ceuta. Al-Yanashtī used, moreover, the Genoese as a scapegoat for his difficulties and incited the Ghumāra Berbers to pillage their neighborhood in 632/1234-1235. This episode led the inhabitants of the city to depose alYanashtī, and their new ruler, one of the Ghumāra shaykhs, Abū al- 'Abbās b. Abī Sa'īd, to recognized the caliph al-Rashīd in Marrakesh (635/1238), as confirmed by monetary emissions. ${ }^{253}$ The city quickly recovered its autonomy since the Almohad ruler left control of the customs and the city government to Abū 'Alī Ibn Khalāṣ, an Andalusī notable, like alYanashtī. Taqdīm 2 seems indeed to date from this period: the Almohad ruler appoints in a

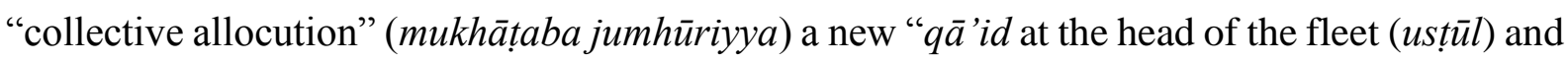
maritime affairs (ashghāl al-bahr)," with important prerogatives that included "customs (dīwān), the mint (sikka), inheritances (mawārīth), and tithes (zakāt)." ${ }^{254}$ This act may well concern Ibn Khalāṣ al-Balansī, who held his office until his death in 640/1243, when the city joined the Hafșid emir Abū Zakariyā, with Tangiers doing the same. The two Moroccan ports remained under the Tunis Hafșids until the death of Abū Zakariyā and the ascension of al- 'Azafì who proclaimed his allegiance to the caliph al-Murtaḍa. ${ }^{255}$ In exchange, the caliph granted him an official investiture, probably taqdim 6, in response "to the desire [of the population of the city] to see appointed the illustrious legal expert (faqīh) Abū 1-Qāsim al-'Azafĩ over their land. ${ }^{256}$ This long document mentions events the exact nature of which are hard to define, but which bear witness to the strategic situation of the region: spreading rumors are firmly condemned as "lies" (ufk, zūr) and "slander" (bahtān, baht), the interference of the "associators" (ahl al-shirk) and the intervention of the two "brothers" from a Christian monastic order (ifrayriyyān) reveal the weakness of the caliphal power in northern Morocco. Not only did the caliphate tolerate the contestation, but it was moreover incapable of putting it down other than through words.

\footnotetext{
${ }^{253}$ B. ROSENBERGER, "Le contrôle du Détroit de Gibraltar (XIIe-XIII" siècles)", 29.

254 See below taqdìm 2, fo 3 r, I. 23-3v, I. 1 and fo $3 v$, I. 17.

${ }^{255}$ A. 'AZZĀWī, al-Gharb al-islāmī, t. 1, 46-47.

256 See below taqdìm 6.
} 


\section{E. The Marinid rise}

The Berber Zanāta tribes of the high Algerian-Moroccan plains, the Banū Marīn, began to irrupt through Tāzā in the region of Fez in 1213. They do not seem before this date to have gone beyond Muluya or Guercif, where, as nomads in zone between Sijilmāssa and Figuig, they came to stock up on grains.

The restoration of caliphal authority under al-Rashīd was not enough to reestablish the Empire's position, as shown by events in the Gharb. In 635/1238, to consolidate a situation that seemed to be improving, the caliph named one of the principal Almohad leaders, 'Abd Allāh b. Wānūdīn al-Hintātī, as governor of the Gharb and the Ghumāra, a vital zone for the caliphate and extremely troubled by the tribal agitation of Arabs (Riyāḥ) and Zanāta (Banū Marīn). 'Abd Allāh b. Wānūdīn al-Hintātī tried to play on the rivalry between the two branches of the Banū Marīn, the Banū 'Askar and the Banū Hamāma. He allied with the former to combat the latter, but, in 637/1239-1240 when the battle came, the Banū 'Askar defected; the Almohad, Riyāh, and Christian mercenary army was crushed by the Banū Hamāma. Having undergone this defeat and provoked the discontent of the local population with his fiscal demands in the Ghumāra districts and the cities of Meknes and Fez, and accused of too much independence and too many mistakes, 'Abd Allāh b. Wānūdīn al-Hintātī fled to his tribe, the Hintāta of the High Atlas.

Al-Rashīd's premature death at 24 in 640/1242, plunged Morocco into anarchy. 'Alī Abū l-Hasan, the son of al-Ma'mūn, was acclaimed on his brother's death, with the laqabs of al-Mu'taḍid bi-Llāh and al-Sa'īd (640/1242-646/1248). Relying on the Arabs, he attempted to reestablish Almohad authority over Morocco and the Central Maghrib, while the Hafșids spread their power to Tlemcen and the Marinids pushed as far as Meknes where they collected taxes. Taqādìm 42 and 65 are explicitly attributed to him, but 66 and 77 were probably also written on his initiative. During this time, Ceuta and Sijilmāssa joined the Hafṣids. Al-Mu taḍid bi-Llāh al-Sa '̄id pressured the Marinids, who submitted. Their leader, Abū Yaḥyá b. 'Abd al-Ḥaqq helped the Almohads attack the 'Abd al-Wād. However, the caliph died in an ambush fighting against the Yaghmurasān. The Marinids took advantage of the situation to turn against the Almohad army and massacre them at Guercif, near the Muluya crossing, before capturing Fez.

The Marrakesh makhzan then proclaimed caliph a nephew of al-Manșūr, Abū Ḥafș 'Umar al-Murtaḍa (646/1248-665/1266). His long reign, from which five taqādìm are extant in 
the manuscript 4752, did not prevent the dynasty's further weakening. ${ }^{257}$ The Marinids established their capital in Fez and organized their makhzan there. Abū Yaḥyá, then Abū Yūsuf, led the Marinids in their attempt to conquer the Moroccan south. The Almohad caliph was even forced to pay them tribute to save Marrakesh in 1262, but the respite bought was to be short. The threat in the end came not from outside, but from within the reigning family. In 1266, Idrīs Abū 1- 'Ulá Abū Dabbūs al-Wāthiq (665/1266-668/1269), Abd al-Mu'min's grandson, sought to overthrow his cousin. He obtained helped from the Marinid Abū Yūsuf Ya qub against alMurtaḍa in exchange for one-third of his future conquests. Thanks to the 3,000 warriors the Marinids supplied him, and the Christian militia that joined him, he seized Marrakesh by surprise. Al-Murtaḍa fled to Azemmūr, to one of his sons-in-law, who turned him over to Abū Dabbūs al-Wāthiq for execution. The new caliph, confident in his strength, after having put down a rebellion in Sūs, refused to give the Marinid his share of conquests. Abū Dabbūs vainly sought the help of Yaghmurasān who created a diversion in eastern Morocco, but the Marinids marched on Marrakesh and seized it in 1269, putting an end to Almohad power.

\section{Conclusion: from an itinerant court to a capital under siege}

The conquering Empire (1147-1214) was succeeded by an imperial Morocco. With alNāṣir's return to Marrakesh after the defeat at Las Navas de Tolosa, the sphere of action for the Almohad caliphs gradually decreased over a dozen years to the Western Maghrib, and the caliph shut himself off in his capital at Marrakesh. The first Empire had no real capital, even though Marrakesh and Seville were the official capitals, Tinmāl the symbolic capital, and the caliphal court the itinerant center of authority. ${ }^{258}$ From 1214-1229, we can see an increasing immobilization of the caliph, and a sedentarization of the ruler and the central administrations. The caliphate was effectively under siege from the moment the Marinids began to increase their pressure from the north of Morocco. The caliph's trips little by little were reduced to the journey between Tinmāl and Marrakesh, the sphere of influence shrank by symbolic steps to the cradle of the Almohad movement. Provincial officials traveled to see the caliph in his capital, while until the reign of al-Nāṣir, the caliph was at home wherever he went. The court was itinerant, and governors, judges, and representatives were appointed or dismissed when the ruler arrived.

257 Taqādīm 6, 43, 44, 47, and 48, and probably 45 and 46.

258 Jocelyne Dakhlia has studied the tradition of "itinerant" power in the Maghrib (J. DAKHLIA, "Dans la mouvance du prince"). The Almohads began this tradition: initially the court's nomadic habits responded to the needs of the conquests, but they rapidly became "consubstantial" with the caliphal office (see M. Marín, "El califa almohade", 457). 


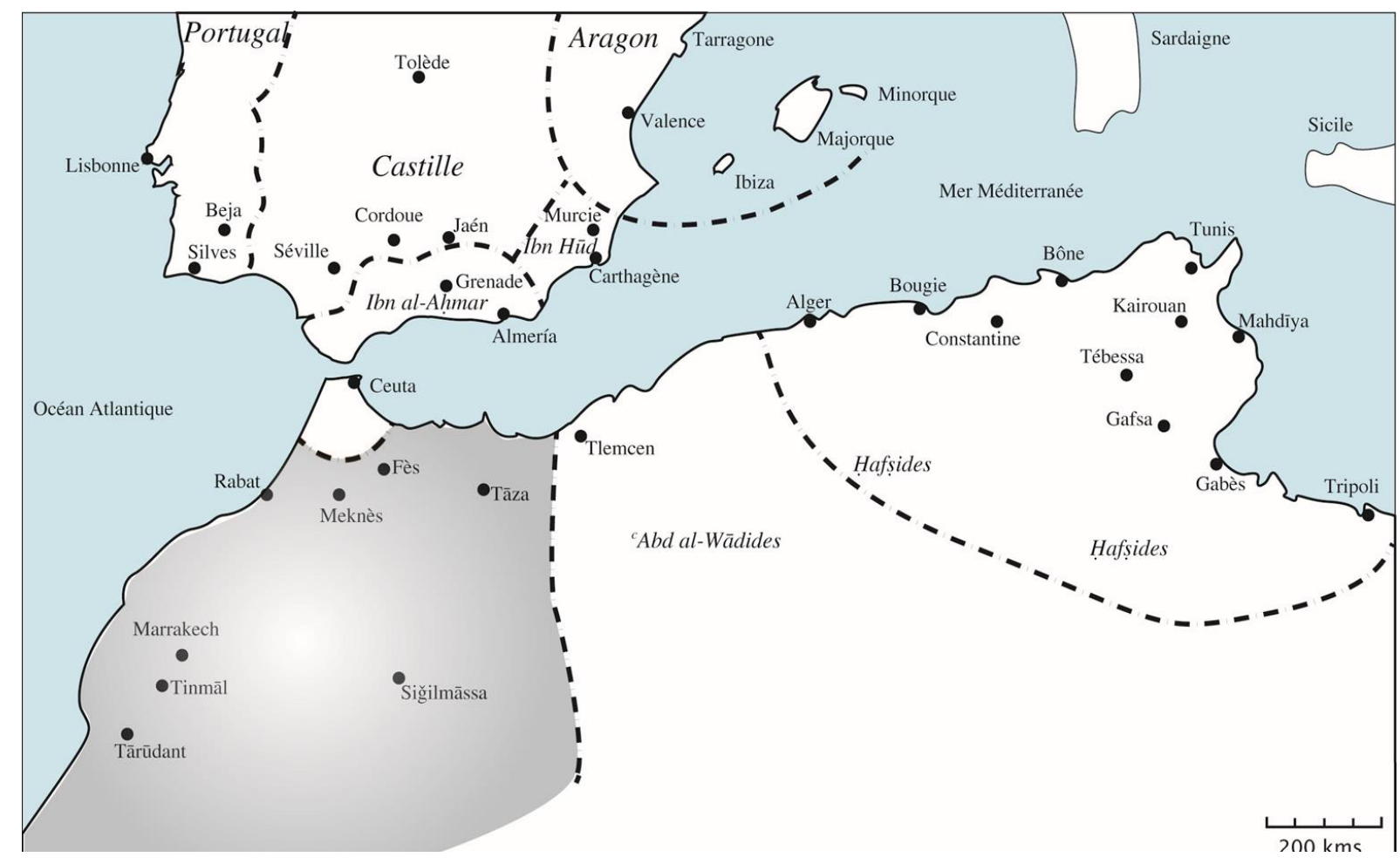

Thus, while the Empire disintegrated, the caliphs lost their power over most of the Empire's territories. The governors of many regions became independent, like Muhammad b. Yūsuf b. Naṣr in Granada, Yaghmurāsān in Tlemcen, Ibn Khalāṣ, then al-'Azafī in Ceuta, 'Abd Allāh b. Zakariyā al-Hazrajī, Abū Zayd 'Abd al-Raḥmān b. Zakariyā al-Ğadmīwī and Muḥammad al-Qițān̄ī ${ }^{259}$ in Sijilmāssa. In many cities, the population was able to choose its own leaders, as in Tunis, Seville, or Ceuta. Beginning with the reign of al-Ma'mūn, only the governors of the Maghrib al-Aqșá came under the caliph's power, where the regime had to face the revolts of Arab tribes and the Marinids in the countryside. Outside the important governmental capitals, the caliph's power extended only to the main cities: Tāzā, Azemmūr, ${ }^{260}$ Aghmāt, Dar'a and Meknes. ${ }^{261}$

This evolution was formed not only by sibling rivalry, the drive of the Christian powers, of the Latin world in general and the Iberian peninsula in particular, but also economic,

259 Ibn 'Idhārī thus referred to him to underline the absolute scandal that came of the rise to power of someone from the lower classes, since he was apparently a tar seller (qitrānn). The weakening of Mu'minid power was thus accompanied by unprecedented troubles or deregulation, since even the lower classes were taking power (MG). 260 "Olive tree" in Berber (MG).

261 'I. al-D. MūsÁ, al-Muwaḥhidūn fĩ l-Gharb al-islāmī, 178. 
demographic, and social difficulties that are hard to discern, but which played a role that historians in general have underestimated due to a lack of sources allowing to measure them. Unlike the breakup of the Almoravid Empire, whose regions emancipated themselves very quickly after the disappearance of the Banū Tashfinn dynasty while also determinedly resisting the Almohad expansion, the disappearance of the Mu'minid Empire was the fruit of a gradual erosion and the detachment of territories reduced little by little the sphere of influence of a ruler parked on an increasingly reduced territory. This different evolution is due in part to the respective organizations for provincial administration: decentralization and provincial autonomy for the Almoravid period versus centralization and concentration of powers for the Almohads. Messick's distinction between the "imāmic state", whose description corresponds to the Almohad Empire until 1214 - the imāmic territory is created in large part by the movements of the imāms and their armies throughout the countryside - and the "modern state" - where filled space is not produced, but fixed and structured by an armature that is polarized and sedentarized - places the bureaucratic Almohad Empire of the taqādìm period within the second category. ${ }^{262}$ The heterogeneity of Maghribī society in the thirteenth century, the presence within of autonomous groups and exterior pressure help explain the fragility of this construction that prefigured what could have been a Maghribī "modern state".

262 B. MEssick, The Calligraphic State, 248. 
Governing the Empire

Part Two

Appointments and Officials of the Imperial State 
Governing the Empire

Chapter 5: Presentation of "Yaḥyá's" Manuscript 


\section{Governing the Empire}

The manuscript edited below is a unicum present in the Rabat Hasaniyya Library, the former Royal Library. It is referenced under the code 4752. The manuscript was published for the first time by Aḥmad 'Azzāwī in 1995 in his Nouvelles lettres almohades. ${ }^{263}$ These taqādìm served as the conclusion for his own compilation of Almohads letters which he had composed by referencing letters cited in whole or in part in all published sources, chronicles, literary anthologies, and bio-bibliographic dictionaries (tabaqāt, taräjim) or geographic dictionaries. In addition to these non-epistolary sources, 'Azzāwī included documents from the Pisan archives, first published by Michele Amari at the end of the nineteenth century, as well as letters from in number of unpublished manuscripts in Morocco, including n. 4752 and the annexes (zawä'id) to manuscript 6148 of 'Ațâ' al-jazīl by the thirteenth-century Almohad kātib Aḥmad al-Balawī. The author did not see fit to include in his Nouvelles lettres almohades those documents published by Évariste Lévi-Provençal in 1941, though he did include them in his second volume, Rasī'il diwāniyya muwahiddiya, published in $2006 .{ }^{264}$ The two volumes together then represent a more or less complete ensemble of the extant official (sultāniyyat) epistolary documents produced by the Almohad chancellery. More recently, and as a continuation of this vast enterprise, 'Azzāwī reproduced these taq ādīm in his multi-volume work entitled al-Gharba al-islāmī. In doing so, however, he broke up the compilation's organization, thus disregarding the internal logic on which this, our present work, insists. In addition, he does not differentiate between the original documents, partial or complete citations in works from the Almohad period - such as al-Baydhaq's akhbar al-Mahdī or Ibn Șāḥib al-Ṣalā’s Mann bi-l-imāma - from those much later - such as Ibn Khaldūn's 'Ibar or al-Maqqarī's Nafh al-Ṭ̄ib -, or even letters found in chancellery manuals.

The letters compiled in 'Azzāwī's works merit some commentary. The compilation is, first of all, a very useful tool for investigative research. It also makes accessible to interested scholars an ensemble of texts which otherwise would have remained either unknown or underused. All modesty aside, without this work, the present study would not exist. On the advice of Mannūn̄i, 'Azzāwī made public a half-century after Lévi-Provençal's first sketch a very rich documentary corpus that scholars have only begun to exploit. Moreover, by bringing together documents excerpted from very different sources, he gives an artificial and modern unity to this dispersed collection. In doing so, 'Azzāwī does not seem to betray notions current

263 NLA, 409-517.

264 É. LÉVI-PROVENÇAL, Majmū' rasā'il muwaḥḥidiyya, 1941. 
when the documents were produced, but he does orient the conditions of analysis and study for this corpus.

The translation proposed here is thus the pretext for a new edition of these documents. Why, when there are still so many unpublished documents from the Muslim World, reedit a technical corpus published fairly recently? 'Azzāwī's is not a bad edition, on the contrary, and it has the great merit of having drawn attention to the exceptional ensemble of Almohad chancellery documents. We are deeply indebted to him. We should also add that, in publishing these sources at a time when historians of the Latin West were renewing their approach to chancellery documents, 'Azzāwī brought historians of medieval Islam into this historiographical renewal. Nevertheless, his edition does not correspond entirely to "Western" demands for the critical edition of medieval sources. Also, it focuses attention after the fact on the contents of the document, rather than in advance on its constitution. Yet, as scholars complain of the absence of archives and the disappearance of original documents from the medieval Muslim World, it is certainly useful and interesting to investigate the reasoning behind the composition and conservation of the compilations that are extant.

\section{A. The Critical Edition of Arabic Manuscripts}

'Azzāwī's edition is very good. It indicates in the margins the manuscript pages, points out for the most part when it "corrects" the text, specifying in notes the modifications proposed. However, the modernized spelling and adaptation to grammatical forms according to the commonly held standard of classical Arabic place a veil between today's reader and yesterday's scribe. By removing or adding vocalic or orthoepic signs, and modernizing the consonantic line, contemporary editors erase the local specificities of political-administrative language. 'Azzāwi takes more precautions with the unicum manuscript 4752 , but he still guides the original text according to his notions of what is "correct".

The publishing rules in the modern Arab World thus do not correspond to those observed in critical editions of, for example, medieval Latin texts. Because of the relative, and often apparent, proximity between medieval and modern literary Arabic, publishers often pay little attention to elements that stray from the linguistic norms they know and practice, and consider these differences to be errors or signs of regional idioms in regards to an Arabic language the norms of which should be universal and intangible. In doing so, they contribute to the "dogma" of the immutability of an immutable written Arabic, one that is atemporal and untied to any geographical, social, or cultural context. Only ill-considered, dialectal, vernacular languages 
evolve. However, that which might be seen today as an error, imperfection, or fault, may have been a practice of recognized and valued writing earlier.

I had the opportunity of comparing the documents conserved in the Pisan archives with their different editions, ${ }^{265}$ and noted the gradual erasure of the practices of medieval writing, as well as the loss of information in the modern edition of these medieval texts. ${ }^{266}$ The tashkil (vocalization) of the edited text, when it exists, seemingly at random, does not generally correspond with the original text, and often contradicts it. ${ }^{267}$ Yet, scholars in the Middle Ages, and the copyists who served them, took meticulous care in indicating the vocalic and orthoepic signs on the consonantic line, providing historians with precious indications on the linguistic usages of the chancellery milieu. Editors today should appreciate original documents and manuscripts over modern linguistic beliefs. The present study thus also addresses linguistic specialists interested in the (written or oral) historical evolution of the language, completing and complementing 'Azzāwî̀'s, which, as noted above, is an excellent work, though incomplete on some points. ${ }^{268}$

\section{PHYSICAL DESCRIPTION OF THE DOCUMENT}

The manuscript is found in the Rabat khizānat al-hasaniyya. It is a unicum of fortyseven folios entitled rasā'il muwahidiyya in the library catalogue, with the reference number 4752. Though this is the manuscript's title in the archival catalogue, the sole biographical notice concerning the compilation's author, found in al-Ru aynī's Barnamaj, seems to indicate the title of this compilation of Almohad-era documents could have been Majmū 'Yahyá or Kitāb Yahyá, as we will see below in the presentation of the author. ${ }^{269}$

The volume is in a good state of preservation, on paper, measuring $21 \mathrm{~cm}$ by 17 . The surface covered with writing measures $18 \mathrm{~cm}$ by 12.5 . There is no visible numbering on the pages, but that may be due to wear over time on the edges of all the pages. To avoid mixing the

\footnotetext{
265 M. AMARI, Diplomi Arabi ; 'A. al-H. AL-TĀZĪ, Al-tarīkh al-diblumāsī, t. 6 ; NLA and NLA 2.

266 See P. BURESI, "Traduttore traditore", 297-309, "Les plaintes de l'archevêque", 99-135 and "Les documents arabes et latins", to be published in 2012.

267 Absent, for example, from Amari's edition.

268 If these rules of critical edition for Arabic texts were adopted, the study of Arabic language and writing practices, as well as regional comparisons, would be much easier. New dictionaries, complementing the invaluable Dictionnaire arabe-français by Kazimirski, and the Supplément aux dictionnaires arabes by Dozy, could provide all scholars with the means to work on often obscure administrative or literary texts. ${ }^{269}$ AL-TUJīBİ AL-RU'AYNĪ, Barnamaj, n 86, 164. On this work, see A. RAMOS CALVO, "Le 'Barnāmağ' d'alTuğ̄īî”, 291-298. I would like to thank Ḥāyat Qāra (Université Muḥammad V de Rabat) for pointing out this reference to me.
} 
pages, numbering in Arabic numerals was recently added in blue pen ink from 1 ( $f^{\circ} 2 r$ ) to 94 ( $f^{\circ} 49 r$ ), but the first and last pages are absent of any writing.

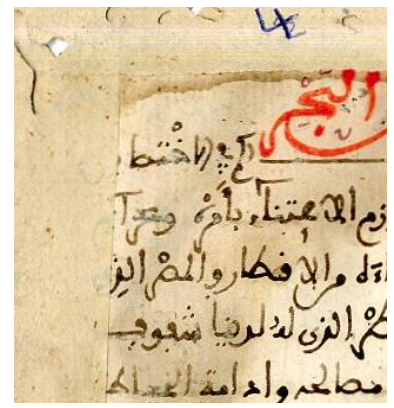

The pages have been restored by gluing a strip of paper to reinforce their edges, which are in a state of advanced disintegration. This paper strip sometimes covers the end of a line of script, but the writing can still be deciphered. The exact date for the restoration is unclear.

Illustration1: signs of manuscript restoration and modern page numbering. $f^{\circ} 3 \mathrm{v}$, p. 4 .

The volume contains a few folders, but most of the stitching has disappeared and the folders are imperfectly preserved: two isolated folios follow a folder, then a folder of two folios, one of eight, of four, again of eight, of two, of eight, and finally a sole folio. The entire manuscript is contained in a recent cardboard covering, and the ensemble is placed in a simple red leather box. The entire volume, with the cardboard cover, measures $2.2 \mathrm{~cm}$ thick $(2 \mathrm{~cm}$ without the cover).

The paper and ink are very well preserved, except for the chewed edges. No watermark is visible, the chain lines are vertically oriented, and it is very difficult to date the manuscript. The number of lines per page varies depending on the presence, or not, of titles of larger size, but it remains between twenty and twenty four lines. No regulating lines appear, however, it seems that for the margins the scribe followed the vertical grain, and he sometimes elongates a letter to finish the line, sometimes moderately, sometimes over half the length of the line. The number of words per line also varies between nine and thirteen, with on average a dozen.

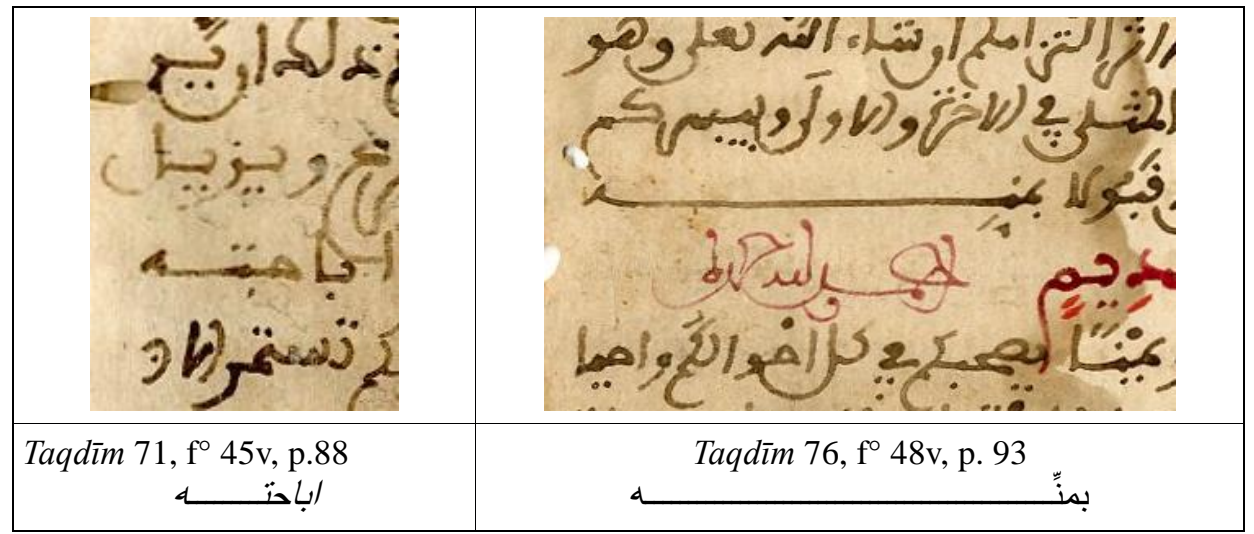

Illustration 2: Vertical margin, end of the line, elongation of letters.

Other than the absence of a colophon and signs of identification, the acephelous and incomplete manuscript does present a few strange aspects. Indeed, the first "page", $\mathrm{f}^{\circ} 2 \mathrm{r}$, is empty, with the copy beginning abruptly only on page 2 , on the verso of the same folio. Ahmad 
Shawqī Benebine, the director of the khizānat hasaniyya, and who was kind enough to examine the manuscript with me, roughly dated the manuscript fabrication, based on his own experience with manuscripts and his knowledge of the archives he directs, to the sixteenth or seventeenth century. My lack of knowledge in Maghribī manuscripts leads me to accept and follow his evaluation.

\section{THE GRAPHIC SYSTEM AND WRITING PARTICULARITIES}

Arabic writing is consonantic. Vocalization $\left(i^{\prime} r \bar{a} b\right)$ is an interpretive act, as is sufficiently proven by the debates and studies on seventh-century Koranic manuscripts, which completely lack any diacritic points or vocalic signs. Andreas Kaplony on the Zurich Orientalische Seminar website gives a few examples of possible reading errors in the absence of precise indications. ${ }^{270}$ This is why, beyond the choices we have personally made for the translation, we have reproduced the tashkill (vocalic indicators) as it appears in the manuscript, unlike Aḥmad 'Azzāwī who largely ignored it and published his own reading of the text rather than the scribe's original proposal. In the end, the reading, or recitation, which brings together the consonants and vowels, allows for the production or reproduction of the text. ${ }^{271}$ These considerations allow an at least partial understanding of the scribe's rational in indicating the tashkill, which might otherwise seem random.

The manuscript's writing is in cursive, traced in black ink, with a feather or flexible reed with a round tip. The writing is regular, the lines straight, even if there is no sign of ruled lines, though some relaxation does occur, then the stems incline to the right, the writing becomes more insistent, and "simplifications" more frequent.

\section{a. Maghribī forms}

\section{Fà' and qā̂f}

The first remark concerns the Maghribī specificity of writing the letter $f \bar{a}$ ' with a subscript dot and the letter $q \bar{a} f$ with a superscript dot. ${ }^{272}$ This practice allows a particular design for $f i$, with three dots in a triangle under the letter.

\footnotetext{
270 For examples and exercises in deciphering papyrus manuscripts, see the excellent site: http://orientx.uzh.ch:8080/aps_test_2/home/

271 See B. MESsick, The Calligraphic State, 26.

272 See O. HOUDAS, "Essai sur l'écriture maghrébine", 83-112, 85-112 ; F. DEROCHE, Le livre manuscrit arabe, 67-112 ; A. KAPLONY, "What Are Those Few Dots For?", 94.
} 


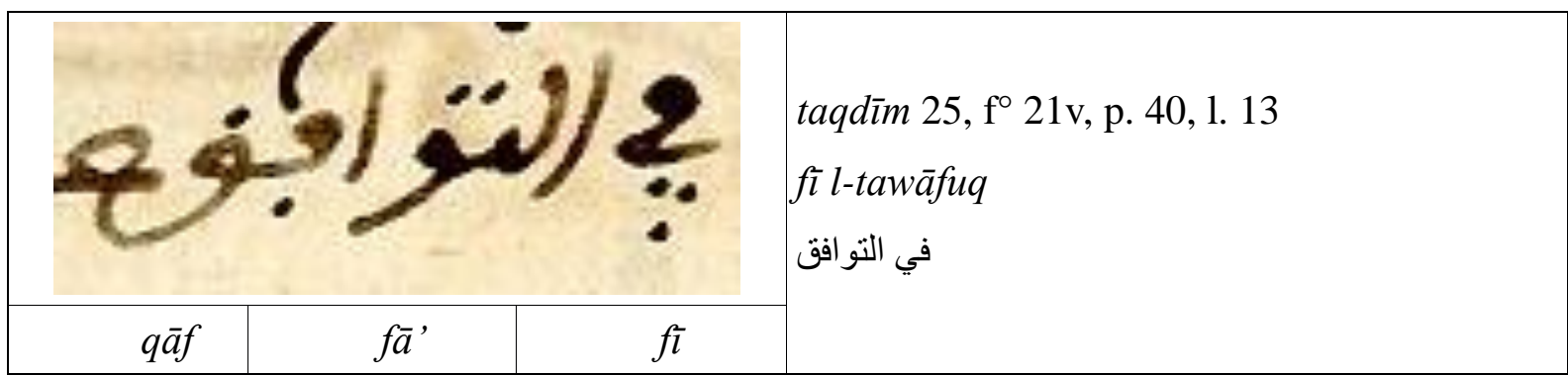

Illustration 3: $f \bar{a}$ ' and $q \bar{a} f$

It is possible that a few dialectical forms have made their way into the manuscript, in the use of $d a l$ instead of dhal, for example in writing badl instead of badhl in badl al-juhd, ${ }^{273}$ or li-dalikum instead of li-dhalikum, but this may also be the forgetful omission of a dot. ${ }^{274}$ 'Azzāwī himself inserts a Maghribism in transcribing the $z \bar{a}$ ' in 'an mazann with a dad, 'an madann. ${ }^{275}$

\section{The kâf at the end of a word}

One graphic trait, which may be specifically Maghribī, concerns the two different designs of $k \bar{a} f$ in final position. It seems, in fact, that the "classical" form appears only for the term dhalika, while all the other final $k \bar{a} f s$ are written as in the middle or beginning of a word.

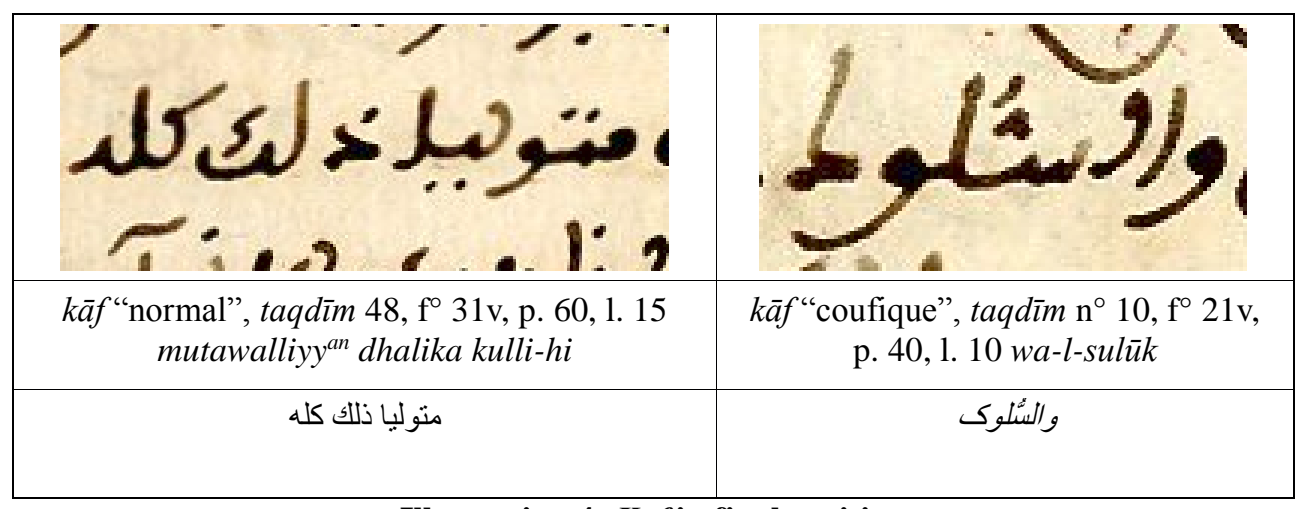

Illustration 4: $K \bar{a} f$ in final position

b. Some letter endings

The specificities of medieval writing styles appear essentially in the final letters of words. We should note first that classically punctuation is not indicated under final $y \bar{a}$, which is written like alif maqsüra: $s$. There are, however, some exceptions: the $y \bar{a}$ ' in $f \bar{l}$ always receives its dots (in a triangle with the dot for the $f \bar{a}^{\prime}$ ), as well as in some terms like tastawi (taqdīm $4, \mathrm{f}^{\circ} 5 \mathrm{v}, 1.17$ ), or al-ra'y al-rājiḥ (taqdīm $\left.11, \mathrm{f}^{\circ} 12 \mathrm{v}, \mathrm{p} .22,1.19\right)$. In addition, these two

273 Taqdīm 61, f $^{\circ} 41$ r, p. 79 , I. 4 et I. 17.

274 Taqdìm 65, fo 42 r, p. 81, I. 6

275 Taqdīm 50, fo 33r, p. 63, I. 10. 
letters (final $y \bar{a}^{\prime}$ and alif maqsüra) are sometimes simplified. We have preserved these occurrences in using a specific symbol with the letter looping towards the right:

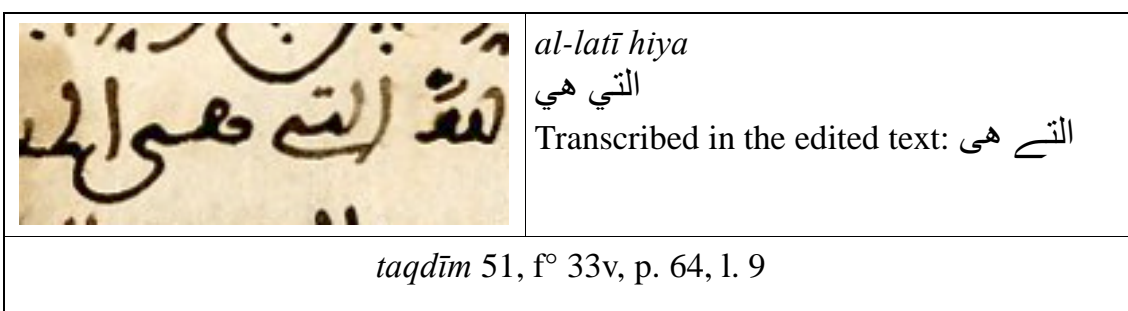

Illustration 5: $y \bar{a}$ ' at the end of a word

The absence of a dot does not mean mean the absence of any indication at all. Thus, the tashkil may be indicated, even if the dots are not, as in the following example

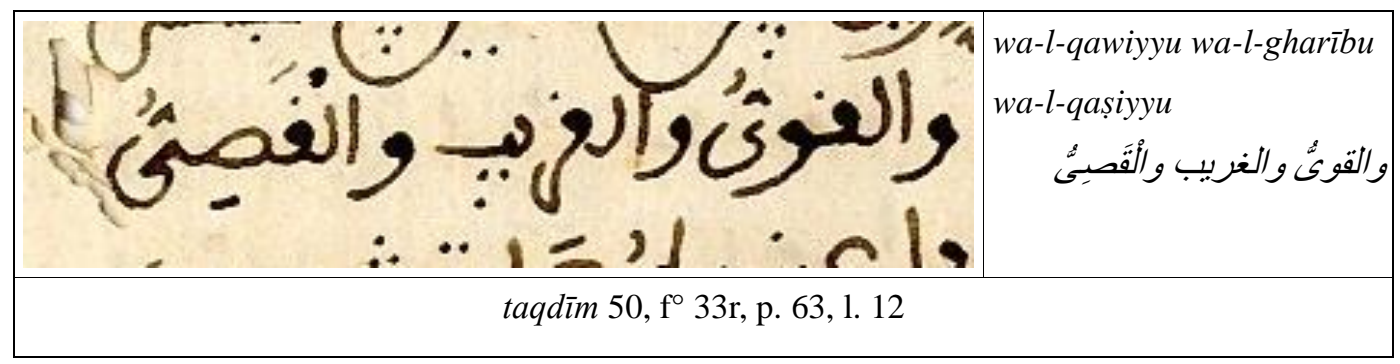

Illustration 6: Absence of the dots for final $y \bar{a}$ ' with shidda and damma

Final $y \bar{a}$ ' may sometimes carry a dot, but final $n \bar{u} n$ never does, and is very regularly written with a large loop descending below the line of writing:

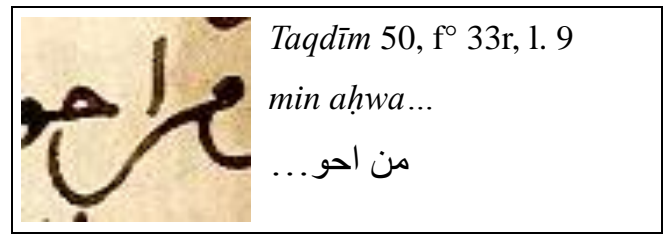

Illustration 7: Final $n \bar{u} n$

Final $h \bar{a}$ ' and $t \bar{a}$ ' marbutța, however, show some differences, depending whether they are attached or not and whether the dots are indicated or not:

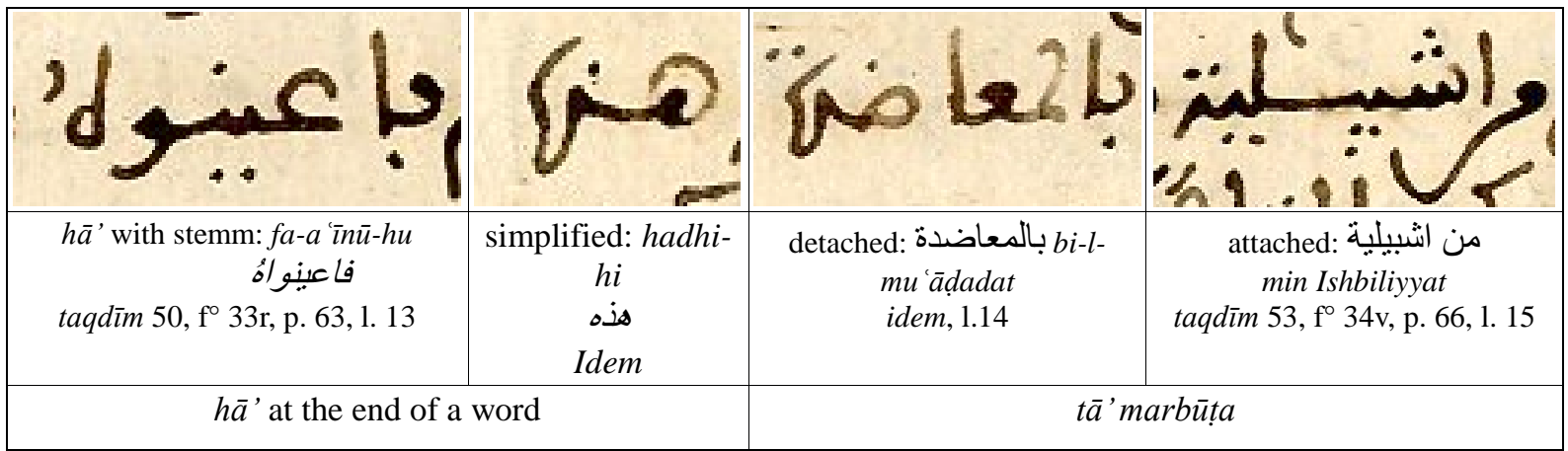

Illustration 8: Final $\boldsymbol{h} \bar{a}^{\prime}$ and $t \bar{a}$ ' marbūta

We should also note that the manuscript has no abbreviations, in particular for ta 'âlá (تع or șallá Allāh 'alay-hi wa sallam (صلعم), which are always fully written. 
A dot is occasionally “decoratively” used for $d \bar{a} d(ض)$ and $z \bar{a}$ ' (ظ) inside the letter's loop, most often in letters based on the $W D \underline{H}$ root: wädih, awdah, or $N Z R R$, but also more rarely for $D M M, N Z M$ or $R D Y$.

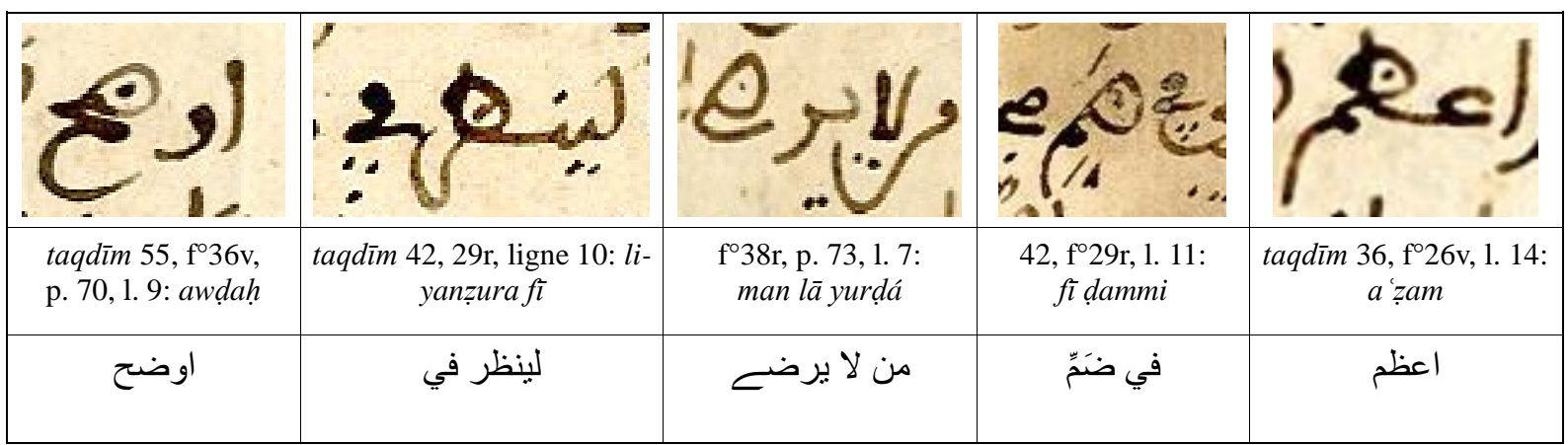

Illustration 9: $\mathbf{z} \bar{a}$ ' and $\boldsymbol{d} \bar{a} d$ with dots inside the loop

\section{STOPS AND PUNCTUATION}

Another particularity of the writing consists in the breaks in words, something which is now prohibited by Arabic spelling usage. The scribe breaks words to take full advantage of the length of his lines, but obeys certain rules: the words are cut off at the end of the line only after

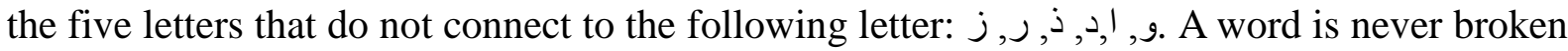
if it would lead to a modification of the consonantic line. There is thus a scripta continua, even if in general, but not always, the space between words is slightly longer than the space that separates two parts of the same word with one of the five noted letters.

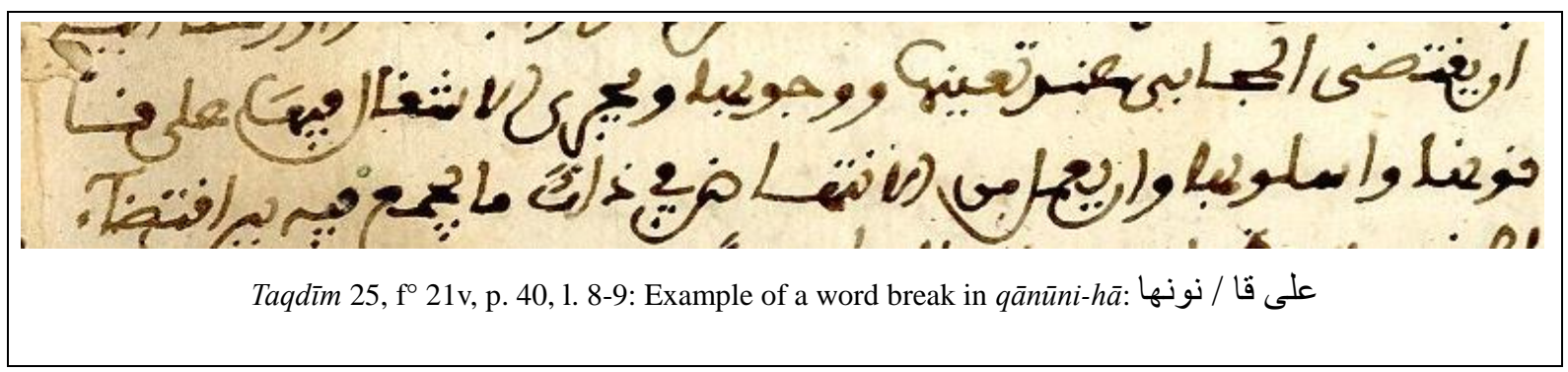

\section{Illustration 10: Word break}

There are a number of punctuation markers used in the manuscript, but the scribe uses them neither frequently nor systematically. The first is used at the beginning and end of a title, a backwards "c" with a dot inside; the second, a $h \bar{a}$ ', at the end of many taqdim, is an abbreviation for intiha ' ("end"), almost systematically after the term bi-manni-hi ("By His grace"); finally, the third is made up three dots in a triangle in the body of the text. 


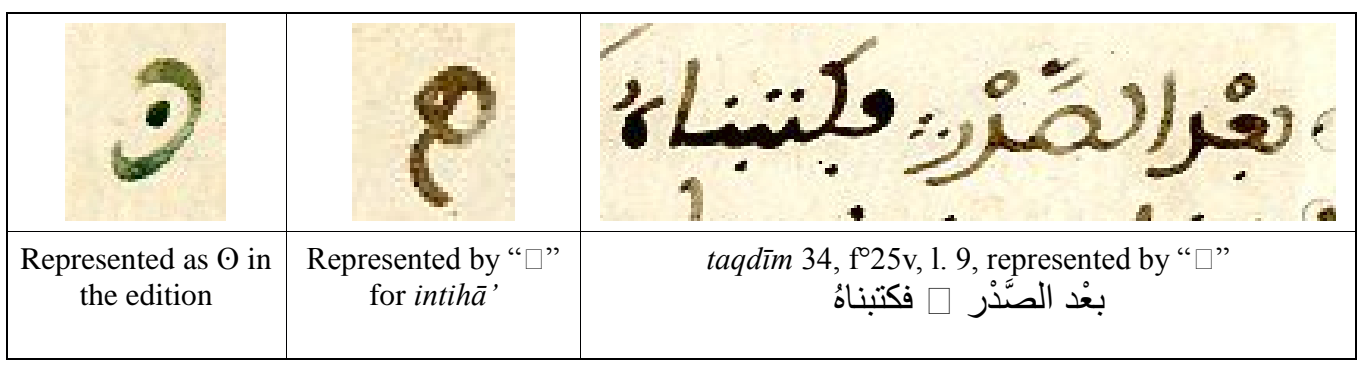

Illustration 11: Punctuation marks

e. CORRECTIONS AND DELETIONS

There are, in addition, a half dozen deletions in the manuscript, or reduplication of terms. 'Azzāwi generally mentions the reduplications, but does not take the time to indicate the deletions. In this edition, we have included them with the corresponding translation barred, as in the original text. In the manuscript, the line of correction is in superscript and placed between two symbols that indicated the beginning and the end of the correction zone.

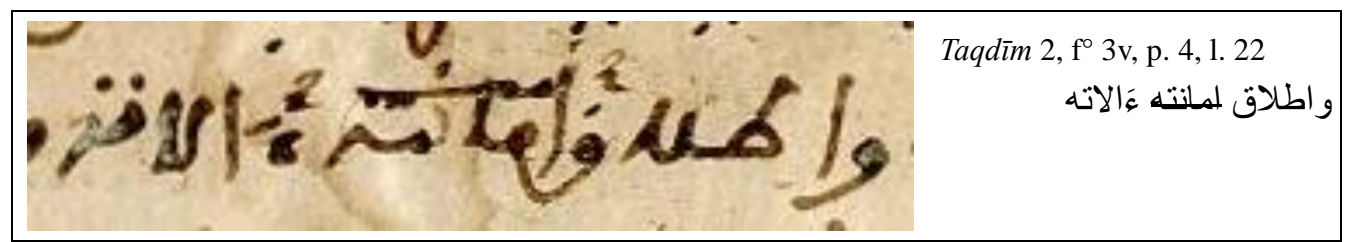

Illustration 12: Example of deletion

f. HEADINGS AND TITLES

'Azzāwī does not make clear when the titles in his edition are his own or the manuscripts. However, the scribe uses a clear system between the different taqādim which he separates them from one another using space and a larger title, a thicker stylus and different colors. He applies great care to the titles: changing the stylus, the color, sometimes with a thin dark line underling the contours of the stylus line. The titles are generally red, with only a few exceptions, two of which are dark green perhaps because of a degradation of a black metallic ink. Many different reds are used for the titles: a bright red and a blood red. When the consonantic line is bright red, the tashkīl is drawn in either blood red or black. When the consonantic line is blood red, the tashkil is in black.

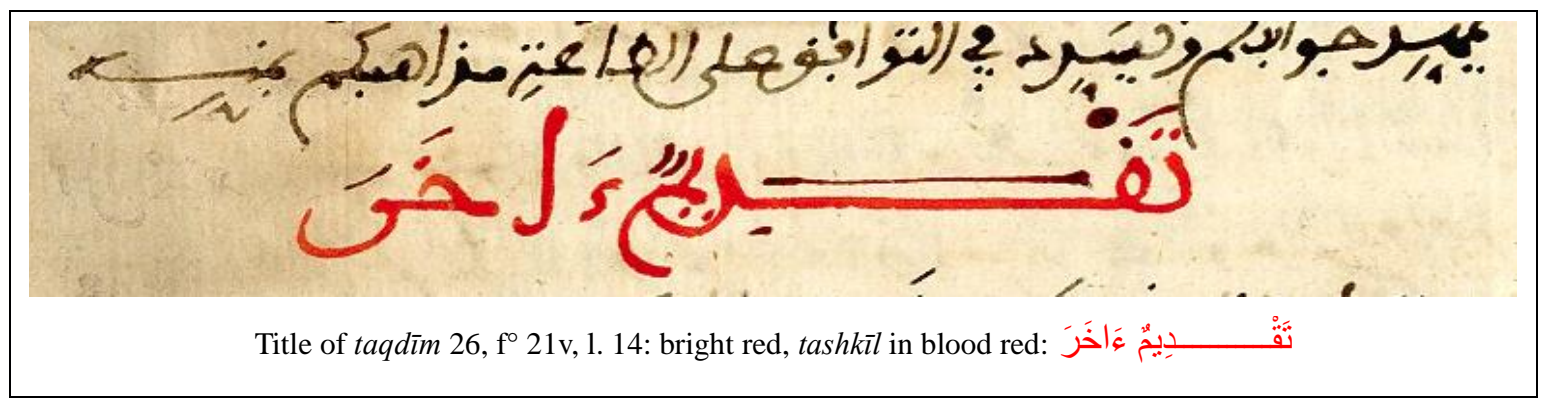

Illustration 13: Bright red title (taqdīm 26) 


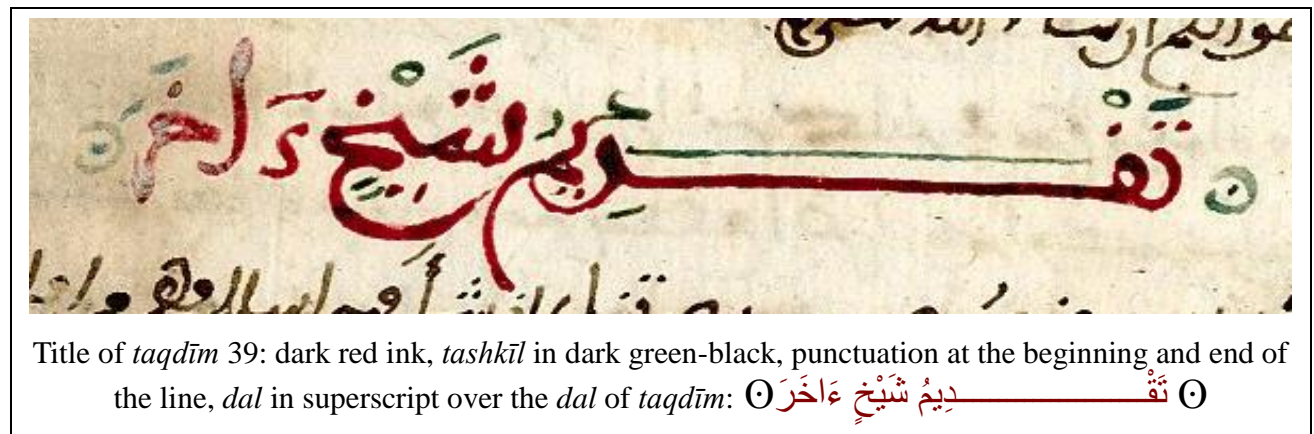

Illustration 14: Dark red title (taqdīm 39)

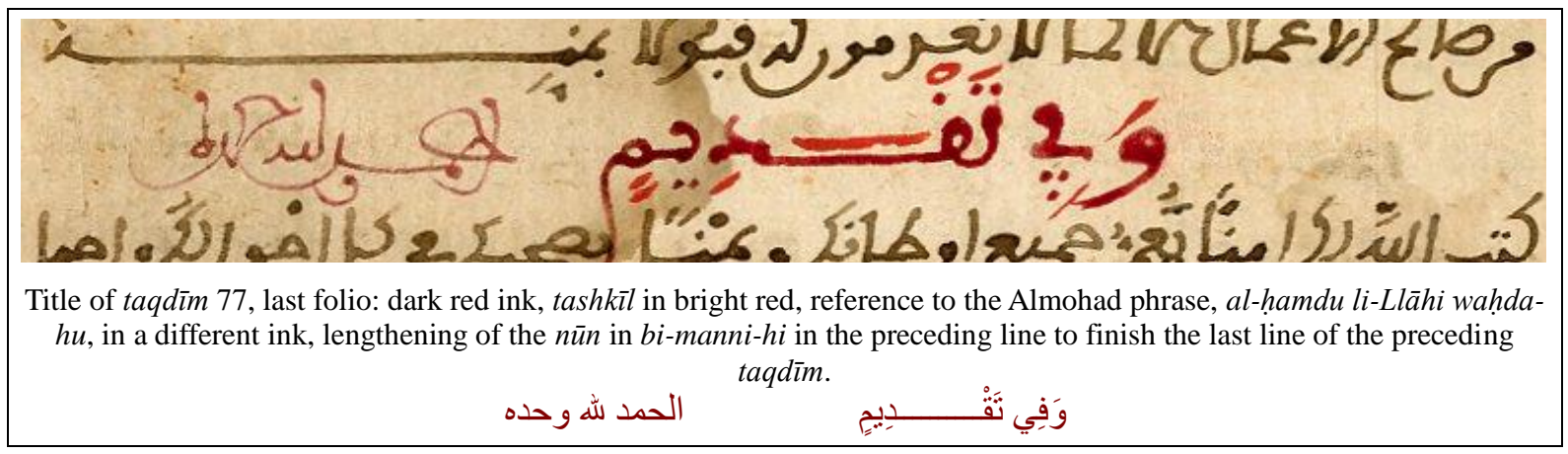

\section{Illustration 15: Title of the last taqdìm}

\section{DIACRITIC, VOCALIC, AND ORTHOEPIC MARKERS}

The scribe's treatment of diacritic, orthoepic, and vocalic markers gives an indication of the care taken in writing the manuscript, on its destination, and on its content. The copyist of manuscript 4752 partially indicates the tashkill and takes care to specify the meaning of certain non-punctuated consonants (al-hurūf al-muhmala) by reproducing them smaller and slightly above or below, to avoid confusion. ${ }^{276}$ The writing of hamza, kasra, and madda does show some classical particularities.

\section{A. THE TREATMENT OF HAMZA}

In general, hamza, sometimes called nabra, is placed between its support and the vowel that accompanies it. However, in practice, the kasra is often separated from the hamza that carries it, the one on the consonantic line, the other below. In manuscript 4752 , no matter what the vocalic marker - fatha damma, tanwin, sukün, which is usual, and also, which is less so, for kasra - the hamza is placed between it and its support. ${ }^{277}$

\begin{tabular}{|c|c|c|c|c|c|}
\hline hamza + damma & hamza +fatha & hamza + sukūn & $\begin{array}{c}\text { hamza }+ \\
\text { kasra }\end{array}$ & $\begin{array}{c}\text { hamza+ } \\
\text { tanwinn }\end{array}$ & $\begin{array}{c}\text { hamza }+ \\
\text { tanwīn }\end{array}$ \\
\hline
\end{tabular}

276 For an exhaustive presentation of the different marks accompanying consonants in Arabic manuscripts, see W. Wright, $A$ Grammar, t. 1, 4, §1, A-C.

277 W. Wright, A Grammar, t. 1, 17, §15, Rem. c. 


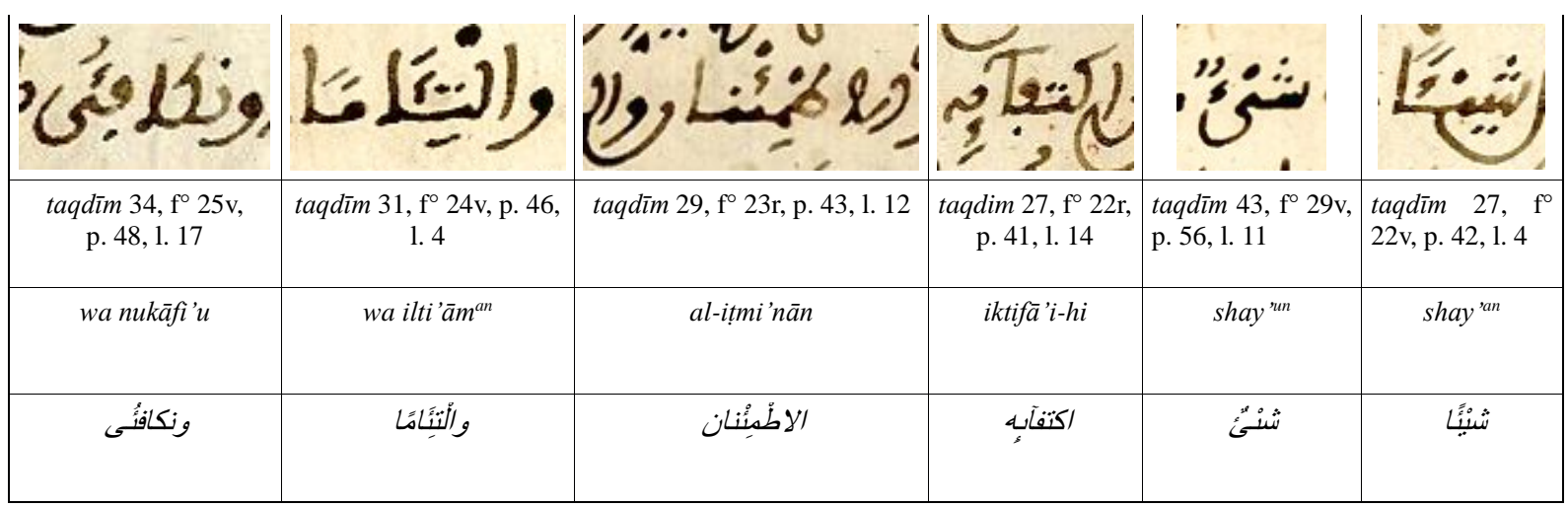

Illustration 16: Hamza position

B. MADDA OR ALIF MAMDÜDA

The scribe's traditionalist character also comes through in his particular writing of alif mamdūda at the beginning of words, whether it follows the definite article or not. Thus, instead of using the combination of a vertical line (alif) and a long horizontal accent (i), which he uses in the middle of words, the scribe indicates a hamza followed by a lengthened vocalic alif. This is seen in the two following examples, one without the article, the other with, the hamza being then separated from the alif.

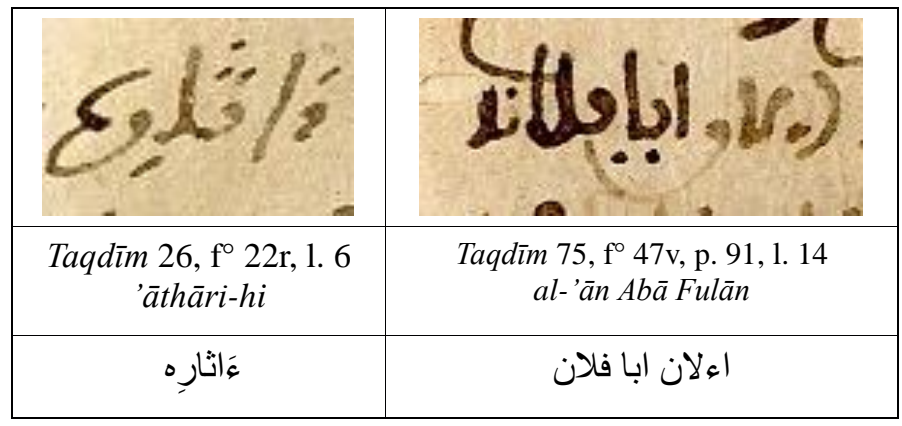

Illustration 17: alif mamdūda

c. ShIDDA

The writing quality likewise shows in the use of the geminate tashdi $d$ for derived forms, but also the euphonic tashdì $d$ for solar letters. ${ }^{278}$ This attests to the purpose of the oral reading or proclamation of the documents reproduced. The scribe does not systematically specify in this way. When he marks the shidda, the scribe sometimes indicates a vocalic mark, above for damma, below for fath $\bar{a}$, and both above the consonantic line and below the vocalic marker for kasra. Because the scribe respects this convention throughout the manuscript, our edition, for

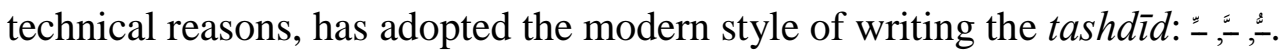

\begin{tabular}{|l|l|c|}
\hline shidda + damma & shidda + fatha & shidda + kasra \\
\hline
\end{tabular}

278 On the difference between the two, see W. WRIGHT, A Grammar, t. 1, 15, § 12-14. 


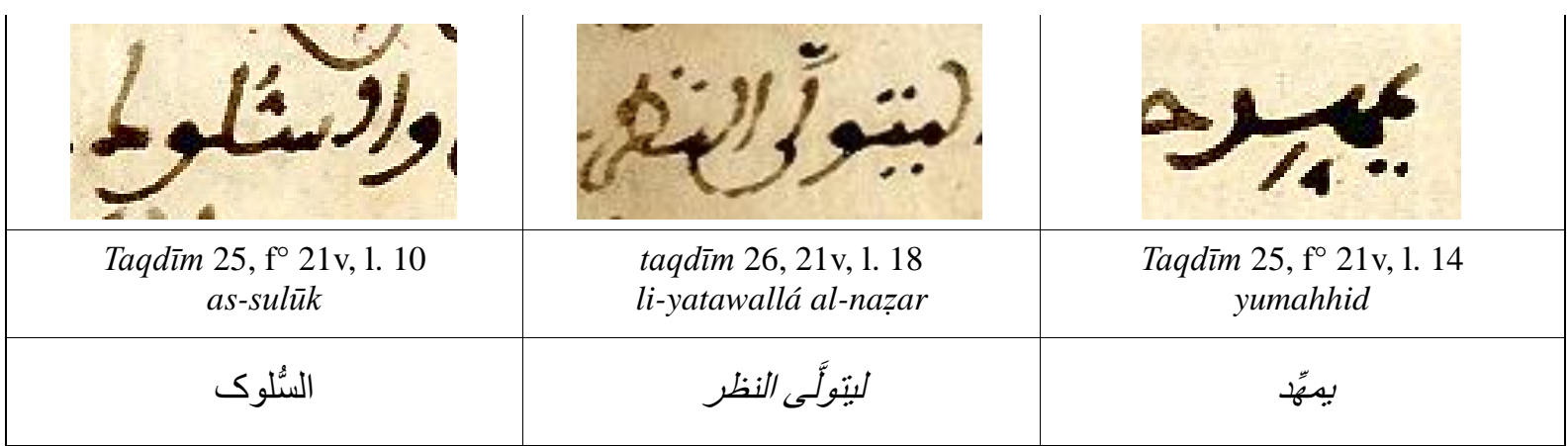

\section{Illustration 18: Position of shidda}

The scribe may not systematically indicate the tashdid, but he does take care to use it when it can signal a modification in the reading of the last consonant of the preceding word, which denotes a person who perfectly masters the techniques of Koranic reading and confirms that the texts should be read aloud. ${ }^{279}$ These practical indications were thus intended to the person charged with reading the acts, probably in the cathedral mosque of the capital to which the official was appointed. The shidda is also used to mark gemination when final and initial consonants are identical. ${ }^{280}$

\begin{tabular}{|c|c|c|c|}
\hline Reference & Arabic text & Read... & and not... \\
\hline Taqdìm $17, \mathrm{f}^{\circ} 16 \mathrm{v}, 1.22$ & من وُوفْقَ & miw wufq & $\min w u f q$ \\
\hline Taqdìm $17, \mathrm{f}^{\circ} 17 \mathrm{r}, 1.3$ & من لَّزم & mal lazima & man lazima \\
\hline Taqdìm 17, fo 17r, 1.17 & مُشَرَََّكًا مَّعَ & musharrakam ma'a & musharrak ${ }^{a n}$ ma'a $^{\prime}$ \\
\hline Taqdìm 24, fo 21r, 1.19 & مهادرًا مُُسـار عا & muhādiram musāri ${ }^{\text {'an }}$ & muhādir ${ }^{a n}$ musāri ${ }^{\text {can }}$ \\
\hline Taqdīm 25, fo $21 \mathrm{v}, 1.5$ & و امرناهُ انَيَّنْرف & amarnā-hu ay yașrifa & amarnā-hu an yașrifa \\
\hline Taqdìm 27, fo 22r, 1.22 & هنالكم مَّا & hunālikummā & Simple gemination \\
\hline Taqdìm 29, fo $23 \mathrm{v}, 1.11$ & حقِّ لََّّيكم & haqqil laday-kum & haqqin laday-kum \\
\hline Taqdìm 30, fo 24r, 1.15 & اصلاحا لَّها & iṣlāhal la-hā & iṣlāh $h^{a n} l a-h a$ \\
\hline Taqdìm 32, fo 25r, 1.16 & من مَّصسالح & mim mașālih & min mașālih \\
\hline Taqdìm $38, \mathrm{f}^{\circ} 27 \mathrm{v}, 1.13$ & من نَّظر مُصلح & min nazarim mușlihin & min nazarin mușlihin \\
\hline
\end{tabular}

279 See W. WRIGHT, A Grammar, t. 1, 15.

280 See the fifth and last examples in the following table. 


\begin{tabular}{|c|c|c|c|}
\hline Reference & Arabic text & Read... & and not... \\
\hline Taqdìm 40, fo $28 \mathrm{r}, 1.16$ & يدًا و احدة مَّعكم & yad $^{a n}$ wāhnidatam ma'a-kum & yad ${ }^{a n}$ wāḥidat ${ }^{a n}$ ma'a-kum \\
\hline Taqdìm 46, f $30 \mathrm{v}, 1.9$ & من مَّصـالح & mim maṣāliḥ & min mașālih \\
\hline Taqdìm 59, fo 40r, 1.19 & باتفاقكم مَّعَه & bi-ttifāqi-kumma'a-hu & Simple gemination \\
\hline Taqdìm 65, $\mathrm{f}^{\circ} 42 \mathrm{r}, 1.13$ & في ان بَّكون & fì ay yakūn & fì an yakūn \\
\hline Taqdīm $68, \mathrm{f}^{\circ} 43 \mathrm{v}, 1.14$ & وَمِن مُخَاطَبَةِ & wa mim mukhātabatin & wa min mukhātabatin \\
\hline Taqdìm 68, $\mathrm{f}^{\circ} 44 \mathrm{r}, 1.6$ & وان يُّسَوِي & wa ay yusawwi & wa an yusawwi \\
\hline Taqdìm 69, fo 44r, 1.19 & لمن يَّكون & li-may yakūn & li-man yakūn \\
\hline Taqdìm 71, f $\mathrm{f}^{\circ} 45 \mathrm{v}, 1.14$ & مو اليًَا لَّه & muwāliyal la-hu & muwāliyan la-hu \\
\hline Taqdìm 74, $\mathrm{f}^{\circ} 47 \mathrm{v}, 1.6$ & خصصناكم مَّنه & khașșașnā-kummin-hu & Simple gémination \\
\hline
\end{tabular}

Table 3: Euphonic tashdīd

d. Superscript and subscript letters

Sometimes, though it is not possible to determine why, the scribe specifies the nature of the consonant with a miniature sub- or superscript of the consonant. This is the case for certain $h \bar{a}, s \underline{a} d$, 'ayn or dal, but this is far from systematic.

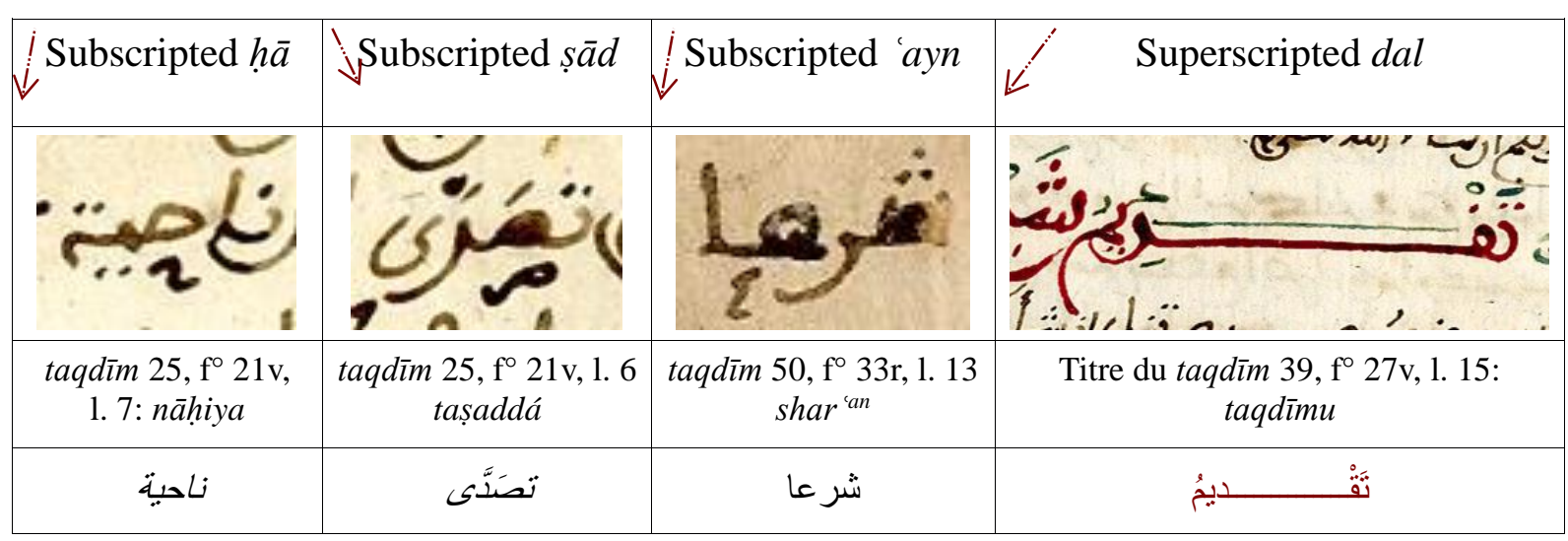

\section{Illustration 19: Super- or subscript letters}

\section{CONCLUSION: THE WRITING AND THE READING}

Great care was taken in producing this manuscript, as much in the choice of paper and inks, as in the writing, the titles, the vocalization and a certain number of indications we have detailed. It is nevertheless incomplete. It starts directly on a verso after a blank page, in the 
middle of a sentence, and its nature, function, and intention remain fairly unclear. We might imagine that in the sixteenth or seventeenth century, the owner of a copy of the folder of original notes, noting its decomposition, ordered a copy made. Given the manuscript's current state, no alternative hypothesis seems obvious, and other copies or fragments would need to be found to come to more precise conclusions using paleographic data. The study of the manuscript's contents allows, nevertheless, a more certain understanding of some of the steps in the conservation of the manuscript as well as the intention of this compilation.

\section{B. Composition of the Manuscript}

The manuscript ends after forty-seven folios, as abruptly as it begins. This presents a considerable inconvenience for determining the manuscript's author and purpose. In addition, the documents in the manuscript vary considerable, even if they are always taqādim, or appointments. Some are very long, ${ }^{281}$ while others take only a few lines, ${ }^{282}$ though those are exceptions to the average of about one page and a half per taqdim. Complete documents, with preamble, initial and final protocols, and date clauses are rare, but they then mention in general complete names, toponyms and dates, which helps to contextualize them. They are, however, exceptional, since the vast majority of taqāì̄m replace names with Fulān $n^{283}$ or Abu Fulān $n^{284}$ for people and Fulāna for places, like in compilations of juridical consultations (fatāwá or nawāzil). This indicates that the documents were not conserved for their concrete or contextual information, but for their form and practical utility for learning chancellery norms. The composite character likewise confirms, if there were a need, that this is a compilation of different kinds of documents, the origins of which we will see below.

The absence of the manuscript's first and last pages means also the absence of a possible introduction detailing the author's plan and how and where he found the documents (originals, copies, manuals) he used in building his own collection. The authors does, nevertheless, provide some information through four passages situated between taqādìm 3 and 4, 48 and 49, 56 and 57, and 59 and 60. These passages provide essential clues as to the work's compilation.

\footnotetext{
${ }^{281}$ At six pages, taqdim 6 is the longest, then comes taqdim 55 at five pages.

282 For example numbers 45 and 63.

283 "So and so", fulano in Spanish.

${ }^{284}$ Anonymization of the kunya: "Abū So and so"
} 


\section{THE AUTHOR}

We know the author's name comes to us only through the mention of his ism, Yahyá, in the middle of the text, all the more important since the manuscript lacks an introduction. Qāra nevertheless identifies the author as most likely Yahyá al-Khadhūj, a scholar from the end of the Almohad period. ${ }^{285}$ Indeed, this scholar, whose full name was Abū Zakariyā Yahyá b. Ibrāhīm al-Aṣhabī al-Ḥakīm al-ma 'rūf bi-l-Khadhūj, lived during the time of al-Ru'aynī (1196-1268) who, in the sole biography we know of him, claims to have met him. Al-Ru'aynī attributes to Yahyá al-Khadhūj a number of summaries (mukhtașirāt), a book entitled alKhiyara min a-dhakhīra (The Flower of the Treasure), a sermon, a large work entitled al-Aghānī al-Andalusiyya ("The Songs of al-Andalus"), and a chess treatise known as al-Shatranj almuṣawwir li-l-ḥakìm al-muṣaghghir. Al-Ru'aynī specifies that Yahyá was an author and music composer (mustatrif wa ma'lüf). The reference that interests us here concerns the "collection of letters which he would have entitled with his name for he had collected them."286 This reference, though not definitive proof, corroborates Qāra's hypothesis that the author of manuscript 4752 was Yahyá al-Khadhūj who lived at the end of the Almohad period, which would have allowed him to consult and procure the documents used to write his majmū' ("collection").

\section{INFORMATION CONCERNING THE AUTHOR}

What are these four texts, and what conclusions can we draw from them? Yahyá alKhadhūj, the original author, intervenes at various points throughout the manuscript, unless some of these are the work of the copyist. The references are sometimes vary short, briefly indicating breaks made in the reproduced documents. They appear in the form of ba' $d$ al-sadr ("after the preamble"). ${ }^{287}$ Other contributions, however, are much longer and provide precious information meant probably to complete the missing introduction. These four passages, presented here below, refer to each other, especially the first two. They give some indication of the author's sources and described the work's thematic organization.

9 Passage 1 between taqādìm 3 and 4 (fol. 7):

Yahyá - May God assist him - said: Thus ends the list of appointments of governors over the land or confirmations of military leaders $(q u w w \bar{a} d)$ able to close the borderlands to keep them well in hand. I myself found appointments that were not in the collection and had not been included in this project; if God wills it, I will record some with these,

\footnotetext{
285 | would like to thank again Hayāt Qāra who suggested to me the connection with Yahyá of the manuscript and who gave me a photocopy of the entry in the Barnamāj for Yahyá al-Khadhūj.

${ }^{286}$ AL-TUJīBİ AL-RU AYNĪ, Barnamaj, nº 86, 164: wa majmu āt tarsīl yu 'anwinu-hā bi-smi-hi wa anna-hu al-jāmi la-hā.

${ }^{287}$ Taqādīm 3, 6, 34, 49 et 65.
} 
so that they will be related to them and complete them, so that they will be found together in the presentation, forming a continuation and coherent ensemble; thus those appointments will find their proper place, their own exposure will shed light on them and their resemblance will put them fully into the light.

I will then add appointments of judges, those in the collection and those I found elsewhere, to define and delimit the titles (laqab) I wanted, and to make what I reveal useful.

After which I will add authentic acts, decrees, etc. that do not belong to those chapters ( funün) and do not enter into those excerpts; they will be placed aside and will give their contents, so that there is no error in the book and its parts be joined.

If, after finishing [my] project, I find something that belongs to these categories and I managed to acquire it, then I will set them out in full if God wills it and I will publish them like a full moon.

It is God who helps things to be done well, and He who brings projects to their end and answers needs.

9 Passage between taqādìm 48 and 49 (fol. 61)

Yahyá - May God help him - said: here end the writings concerning the appointments of governors that I found in the collection and copies (mubayyadat $t$ ). I have reported the appointments of judges that are in the chapter in the collection, and I added the contracts and writings found either in or outside the collection/chapter.

9 Passage 3, between taqādìm 56 and 57 (fol. 75)

Yahyá - May God help him - said: Thus end the appointments that I found in the chapter that holds the shaykh's collection - God's mercy be upon him. Within the collection, among the appointments, I found what was written in the name of the caliph al-Rashid for the appointment of his relative Abū Muhammad to the position of judge of Sharīsh (Jérez) and in [the region] under it.

(9 Passage 4 between taqādìm 59 and 60 (fol. 78)

Yahyá - May God on High help him - said: Thus end what was in the collection which I noted, found, and discovered; I placed [the elements] one after the other and I edited [all of them]. Here begin the appointments that I found elsewhere than the collection whose fruits I harvested, whose rivers I caused to flow, and the scent of whose flowers I breathed; I organized the pearls for the masters of $a d a b$ and of intelligence so that [the project] ends with the most beautiful and [we] take solace in that which humanity sows in the night. Among others...

\section{a. Sources}

These few remarks spread throughout the manuscript indicate a few different levels of writing or editing:

O The anonymous copyist contributes to the manuscript he copies, which is ascribed to Yaḥyá, probably al-Khadhūj. He thus reproduces the previously existing manuscript, or the annexes of this work, and introduces his own personal remarks with phrases such as "Yahyyá - May God assist him - said." 
O Yahyá al-Khadhūj sits on a second level, as kātib and scholar from the Almohad period, the author of the extant collection. Indeed, his final remark (Passage 4) is one of nostalgia, commenting on the dispersion of these texts over the course of the period of Almohad "decadence," indicating sympathy for the Almohad regime and its former grandeur.

O Yahyyá al-Khadhūj gives some indication of the composition of his work, mentioning the sources he used, creating a third multiple level: the collection (majm $\left.\bar{u}^{\prime}\right)$ constitutes the main material for his work. Yahyá added different complementary pieces to the collection, but does not give the name of the shaykh who wrote or owned the collection, nor is it possible to know if the term shaykh refers to an important member of the tribes and Almohad regime (Passage 3), or simply a respected scholar with governmental responsibilities. Thus on the same level as the shaykh's foundational collection, Yahyá mentions a work of research and manuscript acquisition, as well as composition and classification of the documents by theme. These documents come "outside the collection" and some are mubayyadāt, copies kept by scribes of documents they had written (Passage 2). There are a few indications of the extent of Yahyá's research, such as the sentence at the end of taqādim 70: "Thus ends what was found concerning this allocution" (intahá mā ulfiya min hādha l-khițāb). This suggests that the collection's creator was himself dependent on an incomplete source, whether personal notes or partial manuscripts.

O The fourth level is made up of the documents used by the shaykh in creating the collection that served Yahyá for his own. It is hard to determine the exact moment of “anonymization" for the documents, when Fulāna replaced the place names, and Fulān or $A b \bar{u}$ Fulān replaced people's names, but it was probably done by the original shaykh. Indeed, Yahyá did not take the same care to erase dates or place names for the acts originals, copies, or notes - that he used to complement the "shaykh's collection." He seems to have simply copied what was before him, anonymously from the shaykh's form collection, because he had no choice, but completely for the documents he had in his possession and that provided him with more information.

\begin{tabular}{|c|c|c|c|c|c|c|}
\hline \multirow{4}{*}{$\begin{array}{l}\text { Manuscript } \\
4752\end{array}$} & \multirow{4}{*}{4} & \multirow{4}{*}{$\begin{array}{l}\text { Yahyá al-Khadhūj's } \\
\text { collection }\end{array}$} & \multirow{4}{*}{4} & \multirow{3}{*}{$\begin{array}{l}\text { Shaykh's } \\
\text { collection }\end{array}$} & \multirow{3}{*}{4} & Manual? \\
\hline & & & & & & Original acts (personal)? \\
\hline & & & & & & Copies? \\
\hline & & & & Mubayyạ & & \\
\hline
\end{tabular}




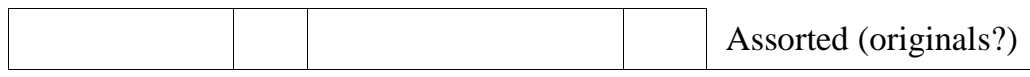

Table 4: Composition of manuscript 4752.

Yahyá seems concerned about the usefulness ( fä 'ida) of his work (Passage 1), which is intended for the "masters of $a d a b$ and intelligence" ( $\bar{u} l \bar{l} l-\bar{a} d a b$ wa l-albāb). He specifies his goals of exhaustiveness, organization, clarity, and coherence for his work, while still confessing the selection that came to play in its creation. He is successful in large part, though he does commit some errors which the copyist does not correct, such as citing two perfectly identical taqādìm, numbers 35 and 44. Yahyá's desire to conserve the memory of the finest literary and administrative creations from the Almohad period is explicit. The images evoked ("pearls," "perfumes," "rivers," "moons" etc.) are typical for this type of composition and, along with the mention of those intended to read it, place this work in the category of $a d a b$, a literary didactic tool for posterity.

\section{b. The Thematic organization of Yahyá's collection}

Yahyá's indications provide information on a number of points. Passages 1 and 2 mention an important part that is missing - "authentic acts" (șukūk) and "decrees" (zawāhir), or "contracts" ( $u h \bar{u} d)$ and "writings" (mukātabāt). Another point concerns the work's internal divisions. Documents 1 to 48 are appointments of "governors" (wulāt or 'ummāl), and documents 49 to 77 are appointments of judges. Within these two subsections, the difference between the acts is related to the sources used by the author.

\section{Gubernatorial appointments (taqādīm 1-48)}

(1) The first three gubernatorial appointments were included in the collection used by Yahyá. There may have been other appointments before them, but that part of the manuscript does not remain. These acts concern important appointments:

(9) The first legitimizes an already constituted power in al-Andalus that has sent a delegation to ask for caliphal recognition. Their investiture gives the Andalusī authorities important attributes, since they can name Guardians (huffāz), governors ('ummāl) or judges. The investiture thus equals a delegation of power, recognition, and legitimation more than an appointment. The act would seem then to postdate 1224, the year of alMustanșir's death. Indeed, before then, it is unlikely that the caliph in Marrakesh would have allowed a power to ensconce itself without prior approval at a time of high centralization for the Empire. 
9 The second act concerns the appointment of an admiral of the fleet ( $q \bar{a}$ ' $i d$ alusțūl) who receives important attributions. 'Azzāwī suggests that this act concerns Ceuta, which is very likely.

9 The third taqdim is of lesser importance. The context is more difficult to establish, but it does seem to concern an important governor named by the central power over a well-controlled zone. The shaykhs and elite ( $a$ 'yān) must go out to meet the person invested by the act and receive him as well as possible.

(10) The following forty-five appointments are not from the shaykh's collection. They are a heterogeneous group including complete acts with preambles, dates, names of protagonists and mention of places concerned, ${ }^{288}$ acts that are almost complete, ${ }^{289}$ and incomplete acts missing their beginnings and lacking a date clause. This heterogeneity coincides with Yahyá's explanations: it is due to the nature of the material he used, documents of diverse provenance, copies, drafts (mubayyadāt), original acts, of which he chose to cite only those parts that seemed pertinent.

\section{Judicial appointments (taqādīm 49-77)}

(1) Taqdim 49 begins the list of judicial appointments. The group is again heterogeneous, which explains Yahyyá's intrusions to give a few precisions.

(9 Taqāìm 49 to 59, judicial appointments, are from the shaykh's collection.

(9) Yahyá however intervenes before taqdìm 57 to specify that the following documents concern the appointment of a relative of the caliph al-Rashīd (629/1232-640/1242) as judge of Jérez (Sharīsh). However, it seems that only taqdim 57 fits this description. The next is written in the name of the same caliph, ( 'an-hu), without mentioning Jérez, nor the name of the caliph and the third may be from al-Rashīd, though this is not certain.

\footnotetext{
288 Taqādìm 5, 30, and 54. Taqdìm 5 is dated from 8 ramaḍān 630/June 18, 1233, taqdìm 30 from the end of ramaḍān 635/May 1238, and taqdīm 54 is dated from rabī' II 634/December 1236. All three were written in the name of Ibn Hūd al-Mutawakkil (1228-1238), so are not strictly speaking Almohad, but anti-Almohad.

289 With preamble, but without date, taqādīm 4 and 17; without preamble but with date: taqdīm 6 carries the date 14 rajab 648/October 12, 1250, and taqdīm 43 is dated jumādā / 657/May 1259, both corresponding to the reign of al-Murtadá (646/1248-665/1266); taqdīm 52 is dated from the middle of shawwāl 626/beginning of September 1239, taqdìm 53 from șafar 626/January 1229 corresponding to the reign of al-Ma'mūn (1227-629/1232); taqdīm 57 is dated to the "first moon" of dhū I-qa 'da 636/June 5, 1239 and the reign of al-Rashīd (629/1232-640/1242), taqdīm 65 is dated from shawwāl 640/24 March-22 April 1242, during the reign of al-Mu tadid (640/1242-646/1248).
} 
(9 Taqāìim 60 to 77 are judicial appointments found by Yahyá outside the shaykh's collection, in addition to those he drew from it. Each lacks a beginning and, except for taqdim 65, they all lack date clauses. ${ }^{290}$

In conclusion, the shaykh's collection seems to contain only Almohad acts, probably personal notes meant as a support for his memory and to help in preparing official acts. This would confirm the idea that its author was a member of the regime, probably a secretary, and belonged to an Almohad family. Extant documents in his collection date from the reigns of alMa'mūn (ns. 49-53), al-Rashīd (57 and perhaps 58 and 59). For the documents after the shaykh's collection used by Yahyá, some come from Ibn Mutawakkil's Valencian anti-Almohad polity (1228-1238). These are moreover the only complete documents with a preamble and date clause (taqādìm 5, 30, and 54).

\section{c. The Taqādìm in context}

Only about $13 \%$ of the taqāìm in the manuscript can be dated precisely, and date clauses are extant for only ten of the entire group. However, specifications given by the scribe in the passages cited above and in the titles that he adds before each document push that percentage to $23 \%$. Passage 3 thus announces an act written in the name of Caliph al-Rashīd

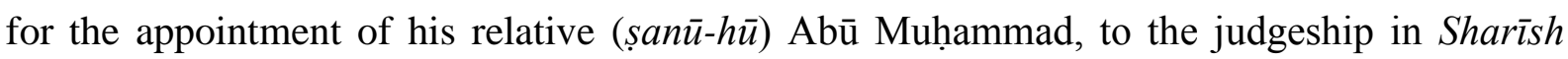
(Jérez), while the following document carries the title wa 'ān-hū fì taqdìm äkhar ("In the name of the same, another appointment".) This information gives an interval of ten years for the two or three acts concerned (57-59), between 629/1232 and 640/1242. These titles that attribute an act to an Almohad ruler (or another), thus allow an approximate date for at least eight acts, and perhaps nine (59, already cited). In addition, a dozen more acts may be attributed to one reign or another depending on a number of criteria: their place in the collection and their content.

The table below shows that within both of the two major thematic groups - gubernatorial appointments, judicial appointments - the author has taken pains to class the documents chronologically, reflecting on the care for order and coherence mentioned in Passage 1. Barring major errors on the part of the author, this rigorous classification means all the acts were written between 1224 and 1266, during the period of deep crisis for the Almohad regime, with the accumulation of succession disputes, defeats by the Christians and the territorial disintegration of the Empire.

\begin{tabular}{|l|l|l|l|}
\hline Taqdīm & Sponsor & Date clause & Period \\
\hline
\end{tabular}

290 Taqdīm 65 is dated from shawwāl 640/March 24 - April 22, 1242. 


\begin{tabular}{|c|c|c|c|}
\hline 2 & $\begin{array}{c}\text { Al-Rashīd: see infra } \S \text { VI-B-2-a. "Military } \\
\text { functions/direction of the fleet: the qā'id al- } \\
\text { usțūl" }\end{array}$ & missing & 629/1232-640/1242 \\
\hline 4 & $\begin{array}{l}\text { Abū l- 'Alá al-Ma'mūn before his rise to the } \\
\text { throne }\end{array}$ & missing (title) & $\begin{array}{c}\text { Summer 1226-Sept. } \\
1227\end{array}$ \\
\hline 5 & Ibn Hūd al-Mutawakkil & 8 ramaḍān 630/18 June 1233 & $1228-1238$ \\
\hline 6 & al-Murtaḍá & 14 rajab 648/12 Oct. 1250 & 646/1248-665/1266 \\
\hline 30 & Ibn Hūd al-Mutawakkil & end ramaḍān 635/May 1238 & $1228-1238$ \\
\hline $38-41$ & $\begin{array}{c}\text { Al-Rashīd: see infra } \S \text { VI-A-2-b. "The } \\
\text { Arabs" }\end{array}$ & Missing & $629 / 1232-640 / 1242$ \\
\hline 42 & al-Mu'taḍid & missing (title) & 640/1242-646/1248 \\
\hline 43 & al-Murtaḍá & jumādā I 657/May 1259 & $646 / 1248-665 / 1266$ \\
\hline 44 & al-Murtaḍá & missing (title) & 646/1248-665/1266 \\
\hline 47 & al-Murtaḍá & missing (title) & $646 / 1248-665 / 1266$ \\
\hline 48 & al-Murtaḍá & missing (title) & $646 / 1248-665 / 1266$ \\
\hline 49 & $\begin{array}{l}\text { al-Ma'mūn (before denying the Almohad } \\
\text { doctrine) see infra } \S \text { VI-B-2-b. "The law } \\
\text { between Almohadism and Malikism" }\end{array}$ & missing & $\begin{array}{c}2 \text { shawwāl 624/15 } \\
\text { Sept. 1227-626/1229 }\end{array}$ \\
\hline 50 & Idem & missing & idem \\
\hline 51 & $\begin{array}{l}\text { al-Ma'mūn (after the denial) see infra } \S \text { VI- } \\
\text { B-2-b. }\end{array}$ & missing & $1229-1232$ \\
\hline 52 & al-Ma'mūn & mid-shawwāl 626/beg. Sept. 1229 & 624/1227-629/1232 \\
\hline 53 & al-Ma'mūn & șafar 626/January 1229 & $624 / 1227-629 / 1232$ \\
\hline 54 & Ibn Hūd al-Mutawakkil & rabīì II 634/December 1237 & $1228-1238$ \\
\hline 55 & Ibn Hūd al-Mutawakkil & missing (title) & $1228-1238$ \\
\hline 56 & Idem? & missing (title) & $1228-1238 ?$ \\
\hline 57 & al-Rashīd & 1 dhū l-qa da 636/5 June 1239 & 629/1232-640/1242 \\
\hline 58 & al-Rashīd & missing (title) & $629 / 1232-640 / 1242$ \\
\hline 59 & $\begin{array}{l}\text { al-Rashīd (before the return of } \\
\text { Almohadism) see infra } \S \text { VI-B-2-b. "The } \\
\text { law between Almohadism and Malikism" }\end{array}$ & missing & 629/1232-640/1242? \\
\hline 62 & Idem? see infra $\S \mathrm{VI-B-2-b.}$ & missing & 629/1232-640/1242? \\
\hline 65 & al-Mu taḍid & shawwāl 640/24 March-22 April 1242 & 640/1242-646/1248 \\
\hline 74 & al-Murtaḍá & 1 dhū l-qa' da 648/25 January 1251 & $646 / 1248-665 / 1266$ \\
\hline
\end{tabular}

Table 5: Taqūīim dates

\section{Origins and destinations for the taqādīm}

Most of the place names were replaced by the generic term Fulāna, as mentioned above, though not systematically. The destination village or region remains in eight cases, and the origin is known for three. 5 and 53 are the only taqāìm with both the origin and the destination, the first being written in the name of Ibn Hūd al-Mutawakkil in Granada for the people of Almería and Malaga, and the second in the name of Abū 1- 'Ulá, before he became al-Ma'mūn, from Seville for the people of Algeciras (al-Jazìrat al-khadra ${ }^{\prime}$ ). There is one case in which we can identify the destination through information in the act. Taqdim 2 appoints a $q \bar{a}$ ' $i d$ of the fleet, and so naturally is destined for a coastal town. 'Azzāwī suggests Ceuta (Sabta), though it could also be Tunis or Bougie where the Almohads also stationed their fleet and which still came under Almohad authority before the emancipation of Hafșid Ifrīqiya. Taqdìm 24 mentions

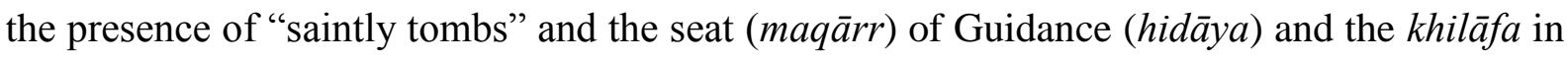


the city or region concerned by the appointment, most likely Tinmāl, as 'Azzāwī suggests. ${ }^{291}$ In addition, taqdīm 41 is addressed to the Sufyān Arabs and gives them control (nazar) over $\bar{A} n f a ̄$ (Casablanca). Finally, three taqādìm mention the frontier nature of the destination region $(11,12$, and 21).

Three taqādìm, 1, 51, and 69, mention the "Presence" (hadra) of the Almohads. ${ }^{292}$ This does not mean the capital, even if the term appears in this sense in taqdim 5 (min hadrati Gharnāta), as Fricaud has shown for the talaba. It refers instead to the itinerant caliphal "Presence". Nevertheless, in this case, the "Presence" probably was in Marrakesh, since from 1213-1266 the caliph traveled very little in a territory moreover that was increasingly reduced. For the other taqādìm, the caliphal court was the issuing center, wherever it was, which most likely was Marrakesh. Indeed, almost all of the acts carry the phrase fa-idhā wâa $\bar{a}$-kum (kitābu$n \bar{a}$ or wāl $\bar{l}-k u m$ ), meaning "When he arrives among you..." (sometimes “our letter", more often "your governor"). This clause indicates a physical movement from the center towards the destination region and meeting between the decision or appointee and the population or region concerned. The administrative appointment procedure implies the physical displacement of the designated candidate to the caliph or the court ministers to obtain the appointment act. Only then could the fortunate chosen one return to assume their post. In the immense majority of cases, then, the taqādìm were issued from the capital in Marrakesh where the caliph resided on a semi-permanent basis.

\begin{tabular}{|c|c|c|c|}
\hline Taqdīm & Origin & Destination & Date or period \\
\hline 1 & Marrakesh? & Al-Andalus (al-jazīra) & \\
\hline 2 & Marrakesh? & Ceuta & $\begin{array}{l}\text { 629/1232-640/1242: see infra } \S \mathrm{VI-B}-2-\mathrm{a} \text {. } \\
\text { "Military functions/direction of the fleet: the } \\
\qquad \bar{a} \text { 'id al-ustūll" }\end{array}$ \\
\hline 4 & Cordova & Fulāna & Before 1227 (Abū l-'Ulá al-Ma'mūn) \\
\hline 5 & Granada & Almería, Malaga & 1228-1238 (Ibn Hūd) \\
\hline 6 & min hạdrati-nā bi-Fulāna & Ceuta (Sabta) & 14 rajab 648/12 October 1250 (al-Murtadá) \\
\hline 11 & & frontier (thaghr, pl. thughür) & \\
\hline 12 & & frontier (thaghr, pl. thughür) & \\
\hline 17 & & Sijilmāssa & \\
\hline 21 & & frontier (thaghr, pl. thughür) & \\
\hline
\end{tabular}

291 "Because of the holy (țāhira) tombs found there in abundance and because the reunion of the seats of guidance and of the caliph distinguish it with innumerable glorious titles" (dhālikum li-shtimāli-hā 'alá al-ajdāth al-țāhira wa imtiyāzihā min al-iḥtiwā' 'alá maqārr al-hidāya wa-l-khilāfa bi-l-mafākhir al-mukāthira).

292 "Your delegates advanced into our Presence" ('alá hādhi-hi l-haḍrati), "We have sent him to you from our (hādhi-hi) Presence" (naqalnā-hu 'an hādhi-hi l-ḥaḍrati ilay-kum) and "This is because you have distinguished yourselves in the Presence of the Almohads by the reports of neighbors" (dhālikum li-mā tamayyaztum bi-hi li-ḥāọrati Imuwaḥhidīna min al-jiwār). 


\begin{tabular}{|c|c|c|c|}
\hline 24 & & Tinmāl & Before 1227 or after 1233 \\
\hline 30 & & Algeciras (jazīrat al-khaḍa $\left.\bar{a}^{\prime}\right)$ & ramaḍān 635/May 1239 (Ibn Hūd) \\
\hline 41 & & $\begin{array}{l}\text { Control of Ānfā given to } \\
\text { Sufyān Arabs }\end{array}$ & \\
\hline 51 & Marrakesh? & & \\
\hline 52 & & Jérez (Sharīsh) & shawwāl 626/beg. Sept. 1239 (al-Ma'mūn) \\
\hline 53 & Seville & $\begin{array}{l}\text { Algeciras (Jazīrat al- } \\
\left.\text { khaḍa } \bar{a}^{\prime}\right)\end{array}$ & șafar 626/January 1239 (al-Ma'mūn) \\
\hline 54 & & Malaga & rabī' II 634/December. 1236 (Ibn Hūd) \\
\hline 57 & & Jérez (Sharīsh) & 1 dhū l-qa da 636/5 June 1239 (al-Rashīd) \\
\hline 69 & Marrakesh? & & \\
\hline
\end{tabular}

Table 6: Origin and destination of the taqādīm

Potential air of application for the taqādīm depending on their context

All the acts reproduced in the manuscript address the period of gradual disintegration for the Almohad Empire. The imperial power covered the following provinces during the period of expansion: Sūs, Sijilmāssa, Marrakesh, Fez, Salé, Ceuta, Tlemcen, Bougie, Ifrīqiya, Malaga, Gharb al-Andalus (Silves-Shalab), Seville, Cordova, Jaén, Granada, Murcia, and Valencia. With al-Ma'mūn's departure from al-Andalus in 1227, the Iberian peninsula followed its own trajectory, and caliphal power no longer held sway, even if rival candidates in Granada, Seville, or Jérez occasionally turned to Almohad authority (as opposed to the Abbasids in Baghdad, or Hafṣids in Tunis) in seeking legitimacy. Ifrīqiya broke away at the end of the 1220 s under its Almohad governor, then the Central Maghrib. Thus, the provinces actually concerned by the taqādìm were limited to Sūs, Sijilmāssa, Marrakesh, Fez, Salé, Tlemcen, and at least nominally, Ceuta. 


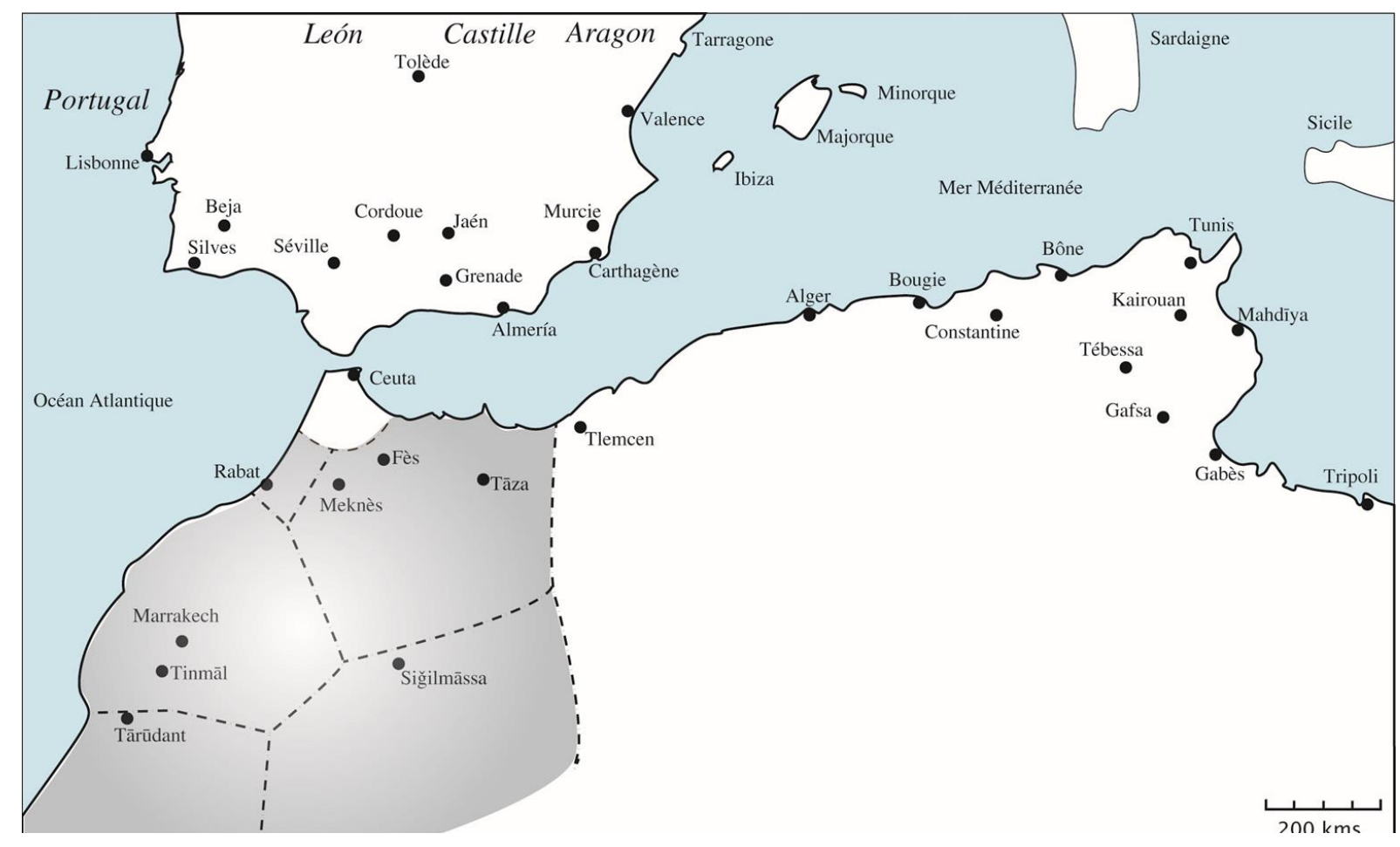

\section{INTERNAL STRUCTURE AND DIPLOMATIC CHARACTERISTICS}

We should forget that these are not original documents, that they are copies. In addition, few are complete and those that are were not produced by the Almohad chancellery, but by the anti-Almohad Ibn Hūd al-Mutawakkil. Nevertheless, a comparison of original Ifrīqiyan chancellery acts and those acts in Yahyá's manuscript that are almost complete allows a clear idea of the usual structure for the taqādim, which is marked by a respect for the characteristic norms of medieval chancelleries. ${ }^{293}$ This then, in short, is the basic theoretical structure for the taqādìm, noting also the differences present in the extant documents.

The presented documents follow this model:

\section{a. Preamble}

A preamble (sadr) that includes (or should include):

0 the basmala and the taṣliya (never reproduced)

\section{Address}

The address is composed of three parts:

293 The subject of diplomatics study, this structure has been less studied for the Arab-Muslim world than for medieval Latin Christendom. Despite a number of more or less recent studies, the historiographic gap is far from being filled. (É. LEVI-PROVENÇAL, "Un recueil de lettres officielles", 1941 ; C. CAHEN, "Notes de diplomatique arabo-musulmane"; 'A. al-H. AL-TAZI, Al-tarīkh al-diblumāsī, t. 6 ; H. EL AALLAOUI, L'art du secrétaire entre littérature et politique; G. KHAN, "Remarks on the Historical Background" ; P. BURESI, "Les plaintes de l'archevêque" and "Les documents arabes et latins"). 
the addresser: the scribe never copies this except occasionally when he adds it to the title, not with the usual particle min, but 'an.

Y the addressee: sometimes presented very simply - "To the population of Fulāna" (ilá ahli Fulāna) - sometimes as a list of addressees, with a collective commendation. The list of addressees naturally comes after the addresser whose status, by the nature of the act itself, is superior. ${ }^{294}$

0 the salutation, ${ }^{295}$ sometimes very simple (salām), ${ }^{296}$ sometimes very elaborate $\left(\right.$ salām $^{u n}$ karīm $^{u n}$ 'alaykum ayyuhā al-awliyā'u al-mukarramūn al-awuddā'u). ${ }^{297}$

$$
\text { Ba'diyya }
$$

The ba 'diyya is introduced by ammā ba' $d$ ("and after..."), ${ }^{298}$ and contains:

a a hamdala, praise to God, specified with modifiers (al-ghālib wahda-hu, al-mun im, al-mulhim, al-muyassir) ${ }^{299}$ or comparatives (al-ladh $\left.\bar{\imath}\right)$.

( a taṣliya, in the form nuṣallì 'alá... (6 and 30) or al-ṣalà 'ala... (30, 54, and 55), a prayer for the Prophet Muhammad, his family, and his Companions. ${ }^{300}$

( the tardiya, or prayer for the imām. In taqādìm 5, 30, 54, and 55, written in the name of Ibn Hūd al-Mutawakkil, the tardiya was for the Abbasid caliph. For taqdìm 6, however, in the name of al-Murtadá, the tardiya is for the Mahdī, though neither his ‘ṣma nor his hidāya are mentioned. The prayer also includes the "orthodox" caliphs, masters of the East and the West (al-khäfiqayn), the continuation of which allows us to understand that these were not the "orthodox" caliphs of Sunni Islam, Abū Bakr (r. 632-634), 'Umar b. al-Khaț̣āb (r. 634-644), 'Uthmān (r. 644-656) and 'Alī b. Abī Tâalib (r. 656-660), but those of the Almohad regime. ${ }^{301}$ This reutilization of an

294 On the noted order of addressers and/or addressees and on the hierarchy implied, see P. GIGNOUX, "Lettres privées", 830-831.

${ }^{295}$ Absent from taqādīm 17, 30, 52, 53, and 54. It is difficult to know if the elimination of the salutation is due to the copyist or not.

${ }^{296}$ For example, taqdīm 4.

297 Taqdīm 5.

298 Present only in taqādīm 5, 6, 30, 54, and 55.

299 Taqādīm 6 and 30.

300 This prayer is particularly developed in taqdīm 6, since it includes another hamdala, Koranic citations, and it is redoubled by the form al-șalā.

301 The term "orthodox caliphs" attributed to the four first successors of Ibn Tūmart, on the model of the first four caliphs of Islam, is well-known to specialists and appears on Almohad coins and in the chronicles from the thirteenth century. I have studied a letter that bears witness to the early usage of this reference to the auctoritas of "Sunni" Islam during al-Nașî's lifetime (1199-1214), the fourth "successor" of Ibn Tūmart (P. Buresi, "Les documents arabes et latins"). The use of this title by the Almohads contributes to the "Sunnization" of Almohadism studied by M. Flerro ("Las genealogies de 'Abd al-Mu'min"). 
appellation uniformly accepted throughout Sunni Islam to designate the first four successors to the Prophet Muhammad reaffirms the Almohad ideology organized around imitation of the beginnings of Islam.

(] The $d u^{\prime} \bar{a}$ ', or prayer to God to extend the victories and conquests of the reigning caliph, though habitually present in Almohad chancellery documents, is absent.

The body of the document follows.

\section{b. Body of the taqdìm}

Various equivalent formulas whose form is more carefully chosen than might seem introduce the body.

(] First

(10) katabnā-hu (taqādìm 62 and 63),

(10) fa-katabnā-hu (4 and 34),

(1) wa innā katabnā-hu, ${ }^{302}$

(10 fa-innā katabnā-hu 5, 30, 54, and 55). Interestingly, only the "anti-Almohad" Ibn Hūd al-Mutawakkil's taqādìm start with fa-innāa. This may be only a detail, but the nuance was significant enough for the $k u t t a \bar{b} b$ to notice.

(10) Wa hādha kitābu-nā (36).

( Next

(10) a prayer following the form of kataba Allāhu la-kum "May God have written for you...," reusing the verb from the intial formula. The first expression (katabnā-hu, fa-katabnā-hu, fa-innā katabnā-hu, etc.) does not appear in a certain number of taqādim because the excerpt copied in the manuscript begins with the formula kataba Allāhu la-kum. ${ }^{303}$

(10 or following the form kataba-kum Allāhu mina l-ladhīna... or mimman... For both of these, the first formula is absent (20 and 58) and in taqdìm 36 it follows the original phrase hādhā kitābu-nā ilay-kum.

(- After this prayer which most of the time concerns the "general state" $(a h w \bar{a} l)$ of the region and/or the "actions" ( $\left.a^{\prime} m \bar{a} l\right)$ and "hopes" ( $\left.\bar{a} m \bar{a} l\right)$ of the population three terms that have the merit of rhyming and contributing to the $s a j{ }^{\prime}$ - come the date and place: "from Seville, Cordova, Granada, etc." in the form of $\min +$

302 Taqādīm 6, 7, 14, 16-18, 25, 28, 31, 41-43, 45, 47-53, 57, 60, and 66-75.

${ }^{303}$ Taqādīm 8, 10-13, 19, 21-24, 32, 35, 38, 40, 44, 46, 59, 61, 65, 76, and 77. 
name of the city or min hadratī-nā bi-Fulāna ("from Our Presence in Fulāna"). ${ }^{304}$

\section{The captatio benevolentiæ}

The captatio benevolentice indicates the general tone of the message. It is generally introduced by the formula "Know that...": ${ }^{305}$ wa an ta 'lamū anna, ${ }^{306}$ thumma i lamū anna (6 and 11), wa l-ilm, or wa thumma l-ilm $(53,69)$, sometimes preceded by the expression "We know only goodness..." (wa lā muta 'arraf illā l-khayr). ${ }^{307}$ This part is dedicated to the affirmation of the caliphal power, and is adapted to the context of the appointment and situation of the addressees. The kitāb insists on the importance of choosing a good governor or judge; he reminds the reader that the central government is attentive to and protects all of its subjects, that it is always forbearing and just in its decisions, that its only care is to keep watch over the region in question and its inhabitants who hold a unique place in the mind of the central power $(-n \bar{a})$. This passage is sometimes short, but can also include prayers to God that He guide the ruler in his choices, or insist on the importance of choosing well the regional servants of the state.

For this part, the acts of Ibn Hūd al-Mutawakkil (5, 30, 54, and 55) differ from the Almohad taqāìm with their own specificity. The Hūdid captatio benevolentia is introduced with “And we”: wa nahnnu... naghlabu bi-Llāhi ta 'ālá (30), natawakkalu 'alá Llāhi ta 'ālá (54 and 55), ${ }^{308}$ and its different parts insist on submission to God using verbs conjugated in the plural first person.

- We deliver ourselves into the hands of God (natawakkalu Llāhi ta 'ālá)...

- We implore Him (nastakhiru-hu)...

- We ask Him (nas'alu-hu)...

- We welcome His favors (wa natalaqqá ni 'ama-hu)...

— We pass on His assistance (wa nastamiddu min tawfiqi-hi ... māa)...

- We thank Him (nashkuru-hu)...

— We praise Him (nahmadu-hu)...

— We ask of His help (wa nastamiddu min 'awni-hi)...

In the Almohad taqādìm, this section is often more impersonal. In all cases though, the subject is relations between "us", the central power, and the regions, the attention to justice and protection that motivates the authorities or the place of choice that the region and its inhabitants hold in the ruler's mind.

304 Taqdīm 6.

305 Or by "You know that..." wa qad 'alimtum anna $\left(n^{\circ} 4\right)$.

306 Taqādīm 3, 7-14, 16-29, 31, 35, 37-43, 45-52, 57-59, 65-68, 70-72,74, 75 and 77.

307 Taqādīm 4, 33, 35, 44, 61, 62 and 64.

308 Taqdìm 5 starts the same, but since three lines are missing, we cannot read what follows wa nahnu. 
This passage continues on to the conclusion that there is nothing more important than choosing a governor/judge, choosing someone who will take as their responsibility the interests at stake. The captatio benevolentice in the Almohad taqādìm sometimes ends with a prayer for God to guide the ruler's choice, while the entire passage is one long invocation of God in taqūdìm of Ibn Hūd al-Mutawakkil. ${ }^{309}$ These specific traits relate to the respective ideologies involved: the Almohads see the caliph, guided and inspired by God, as the absolute master of his decisions, while the Hūdid regime, heavily influenced by Sab īnī Sufism, sees the ruler as an intercessor with God. ${ }^{310}$

\section{Selection and/or/ appointment}

The captatio benevolentice expresses the appointment itself in a variety of ways, but always insists on the logical relation of direct causality. Different expressions systematically underline the link between cause and effect and the logical progression between the generalities of the beginning and the act itself: wa ilá hadhā fa-innā... wa bi-hasbi hadhā... li-dhalikum... wa bi-muqtaḍá dhalikum / hadha l-qașd...wa bi-hadhāl-i'tibāri... mimmā yūjibu-hu... dhalikum li-anna... wa bi-mujibi hadhā l-qașdi...wa li-hadhā waqafa l-ikhtiyāru... or wa qad iqtaḍa al-nazaru l-karimu ... an qaddamna.$^{311}$ The selection and appointment of an official thus appear as the logical conclusion of the central power's good intentions for region and population in question, which are always supposed to hold a privileged place within the imperial administration.

The appointment itself comes next, sometimes preceded by the chosen candidate (nakhtāru, natakhayyaru). These are terms used for the appointment: qaddamnā (al-ān) appears most often, more seldom are 'ayyanna $\bar{a},{ }^{312}$ asnadnā, istanhaḍ $\bar{a}-h u,{ }^{313}$ or even ihtarnā li-tawallì, when the selection and appointment are the same. ${ }^{314}$ There is no fixed place for the selection process. It can appear in the captatio benevolentice, before or after the prayer to God, or just

309 Wa Llāhu I-kafîl... (n 9, 48), wa Llāhu ta ālá yujrī-kum... (n 11), wa Llāhu ta ālá yamuddu-nā... (n 12, 28), wa bi-Llāhi 'azza wa jalla... (n 13), wa Llāhu ta 'ālá yu'ārrifu-kum... (n 19, 40, 71, 74), wa Llāhu ta ālá yūjidu-kum... ( $\left.\mathrm{n}^{\circ} 20\right)$, wașala Llāhu ta 'ālá... ( $\left.\mathrm{n}^{\circ} 24\right)$, wa Llāhu ta ālá yasluku bi-kum... (nْ 32), wa-l-ḥamdu li-Llāhi... (nº 35, 44, 47), wa Llāhu ta ālá yahmilu-nā... (nº 37), wa li-Llāhi al-ḥamdu 'alá... ( $\left.n^{\circ} 38\right)$, wa bi-Llāhi ta 'ālá na taḍidu...( $\left.n^{\circ} 42\right)$, wa bi-Llāhi ta'ālá nasta'inu... (n`49,50,53) or wa Llāhu ta ālá yu î̀nu... (n52).

310 P. GUICHARD, Les musulmans de Valence, t. 2, 143.

311 Taqdīm 47: "Our generous leadership... has decreed that we appoint".

312 Taqdīm 27.

313 Taqdīm 12.

314 Taqādīm 29, 30 (in the form: takhayyarnā li-wilāya... dhalikum khāșșatu-nā Fulān), 43 (wa bi-ḥasbi dhalikum takhayyarnā al-ān...), 68 (wa bi-muqtaḍá al-naz̦ari... takhayyarnā li-tawallī al-aḥkām...), 76 (wa li-dhalika khtarnā al-ān li-khuțțati al-qaḍ̂āi bayna-kum Fulānan). 
before the appointment itself, when it does not take its place. It can exceptionally be integrated into the appointment, as in taqdim $51 .{ }^{315}$ It sometimes does not appear at all, or, when it is distinct from the appointment, can be fairly short:

(10 "We thus choose for you the governor who will purify your affairs when he takes charge of them" 316

(10 "As a result, we choose for [your land] the most courageous and illustrious of our servants" 317

(10 "We keep this in mind when choosing officials for you and making the best possible selection for the one that we name to lead your provinces" 318

(10 "Considering this, to render justice for you we choose someone who has qualified himself by the satisfaction he has given, and to take charge of your affairs, our preference goes to someone whose virtue is known and for whom competence is a habit" $" 319$

(10 "We have decided, after having asked the help of God on High, to choose to occupy the office of judge for you one on whose purity and virtue we can rely, someone who, in the responsibilities he exercises deserves confidence by the righteousness of his intentions"

Sometimes, though, this section is more developed. ${ }^{321}$ It then insists on the general principles expressed in the captatio benevolentice, applying them to the region's particular situation, or it can elaborate on the prayer to God and recall the individual qualities necessary for exercising the office. Two of Ibn Hūd's taqādìm are notable in their use of the demonstrative

\footnotetext{
315 "This is why, after selection, election, meditation, and consideration, we have designated Fulān for you" (wa li-dhalikum 'ayyannā la-kum ba 'da l-takhayyuri wa-l-intiqā'i wa-l-ta'ammuli wa-l-irtiyā'i Fulānan).

316 Taqdīm 18: wa innā nakhtāru la-kum mina l-wulāti man tașlaḥu bi-hi umūru-kum ḥinna yatawallā-hā.

317 Taqdīm 21: wa bi-muqtaḍa dhalikum nakhtāru la-hā al-anjad wa al-amjad min khudamāi-nā.

318 Taqdīm 52: wa bi-ḥasbi dhalikum natakhayyaru l-musta 'malīna fi-kum wa nujīdu l-intiqā'a li-man nuqaddimu-hu fi nawāhī-kum.

319 Taqdīm 57: wa bi-hadhā l-i tibāri natakhayyaru li-aḥkāmi-kum man yu 'ayyinu-hu al-irtiọā'u wa nūthiru bi-taqalludi ashghāli-kum man 'urifa min-hu al-șalāḥu wa ulifa laday-hi al-ghanā'u.

320 Taqdīm 69: wa qad ra'aynā ba'da istikhārati Llāhi ta'ālá an nakhtāra li-l-qaḍāi la-kum man yustanāmu ilá zakā'i-hi wa naqā'i-hi wa yūthaqu fi-mā yatawallā-hu bi-sadādi anḥā'i-hi.

321 Numerous examples, such as taqdìm 9: "Thus in terms of these objectives..." until "There is no god but Him" (bi-muqtaḍá hādhā l-qașd... lā rabb siwā-hu), taqdīm 11: "[all that] is part of what is necessary in choosing the person... by His grace" (mimmā yūjibu-hu takhayyuru man... bi-manni-hi), taqdīm 13: "Of God... we will always choose to govern... the brightest paths" (wa bi-Llāhi... lā nazālu natakhayyaru li-tawallī... wa ajlá subuli-hi), taqdīm 14: "Thus we... choose for ... the ișdār and l'īrād" (fa-nahnnu... wa natakhayyaru li-... fī l-îrādi wa-l-ișdāri), taqdīm 50: "Since the judgment of affairs..." until "in whom the traits of purity and virtue” (wa li-mā kānat al-aḥkāmu... man ijtama 'at fi-hi awșafu al-zakā'i wa-l-niqā'i), taqdīm 71.
} 
dhalikum in presenting the appointment person: "It is Fulān, our close friend" (dhâlikum khāșṣatu-nā Fulān) for number 30 and "It is Fulān" (54).

A more or less expanded list of the designated appointee's general attributions is directly linked to the act of appointment. The terms used are broad and are specified in the following parts of the taqdìm: li-l-nazari fì..., li-tawalla + acc., li-yaqūma bi-, li-yuqīma bi-, or simply lior $f i$ followed by “affairs" (fiscal, economic, financial), or 'alá “over... your regions, you, etc.”.

\section{The qualities of the designated person}

The qualities of the chosen person follow, often introduced by wa huwa ("and he") or by wa la-hu ("and he has"). We can class these into different categories: reputation, rank, character, loyalty, political faithfulness, genealogy, experience. The kuttāb obviously adapt these passages to the person in question, despite the reoccurrence of specific terms.

9 Attributes and qualities:

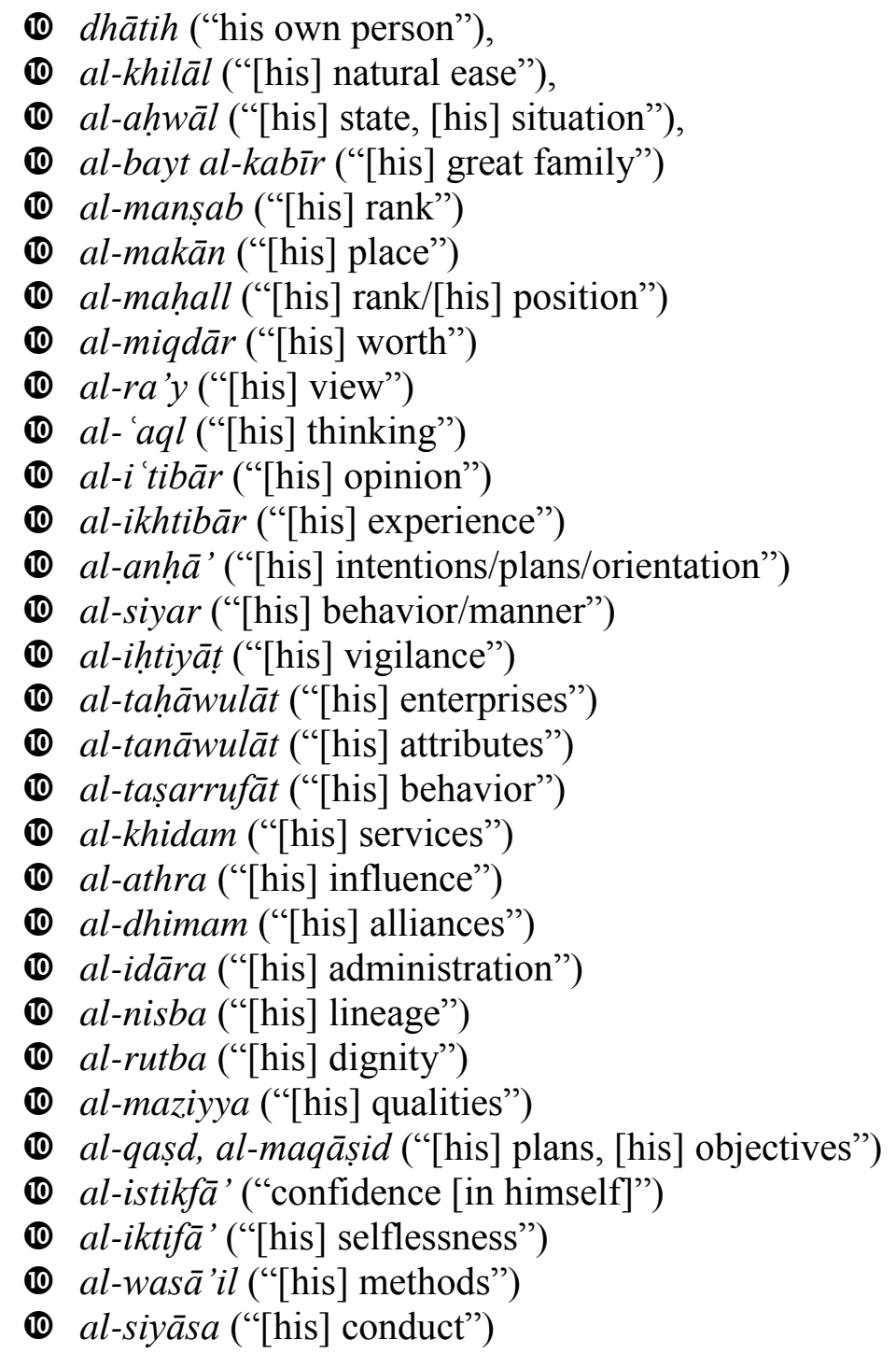




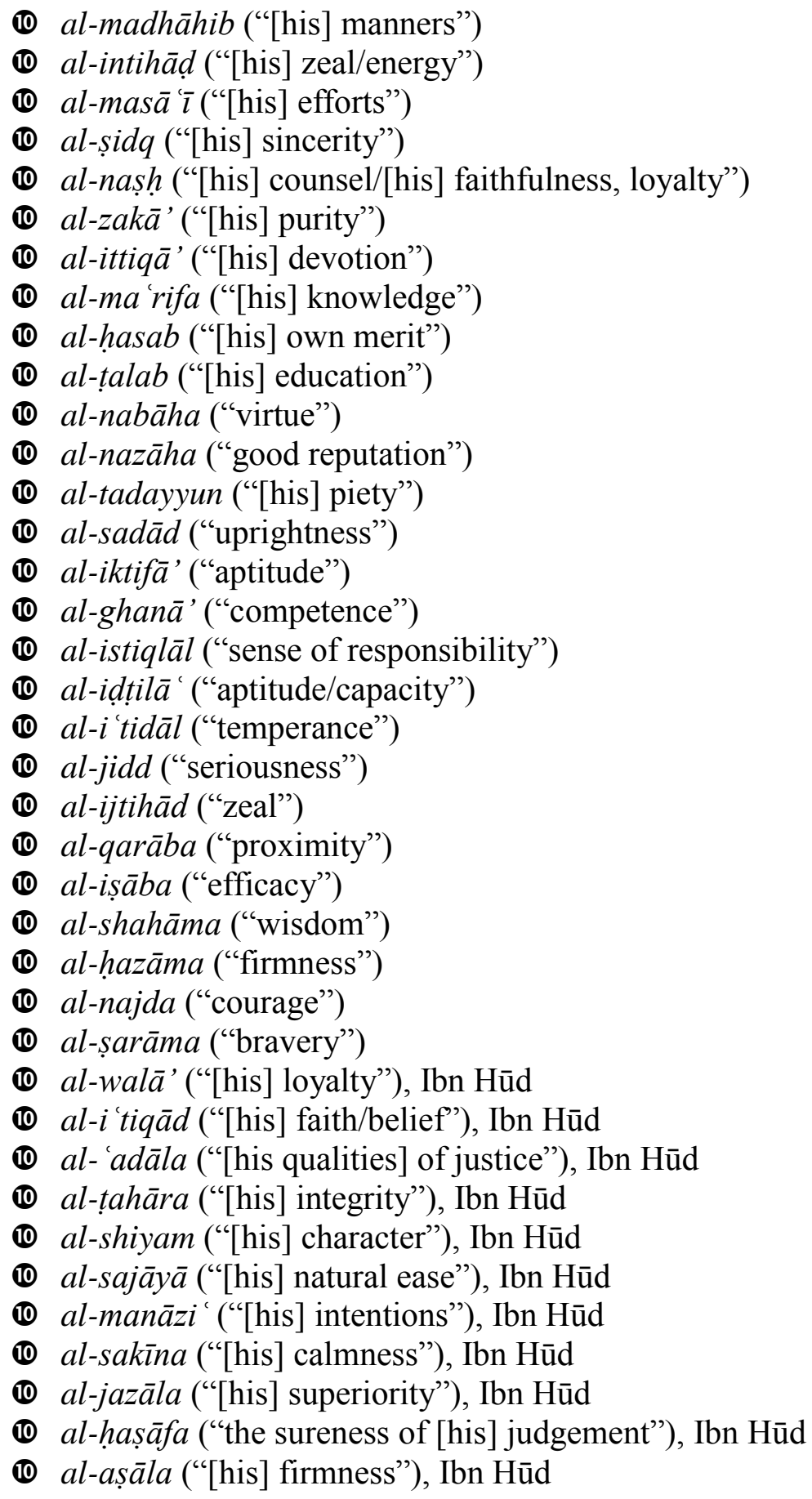

Verbs:
(10) tamayyaza ("he distinguishes himself")
(10) ittașafa ("he characterizes himself")
(10) bāna ("he is clear, patent")
(10) tabayyana min ("he is obvious")
(10) taqarrara ("he is established")
(1) takarrara ("has repeated")
(1) tahaqqaqa ("has been verified")
(1) tanāsaba ("equaled") 
(10) izdāna ("beautified")

Qualities:

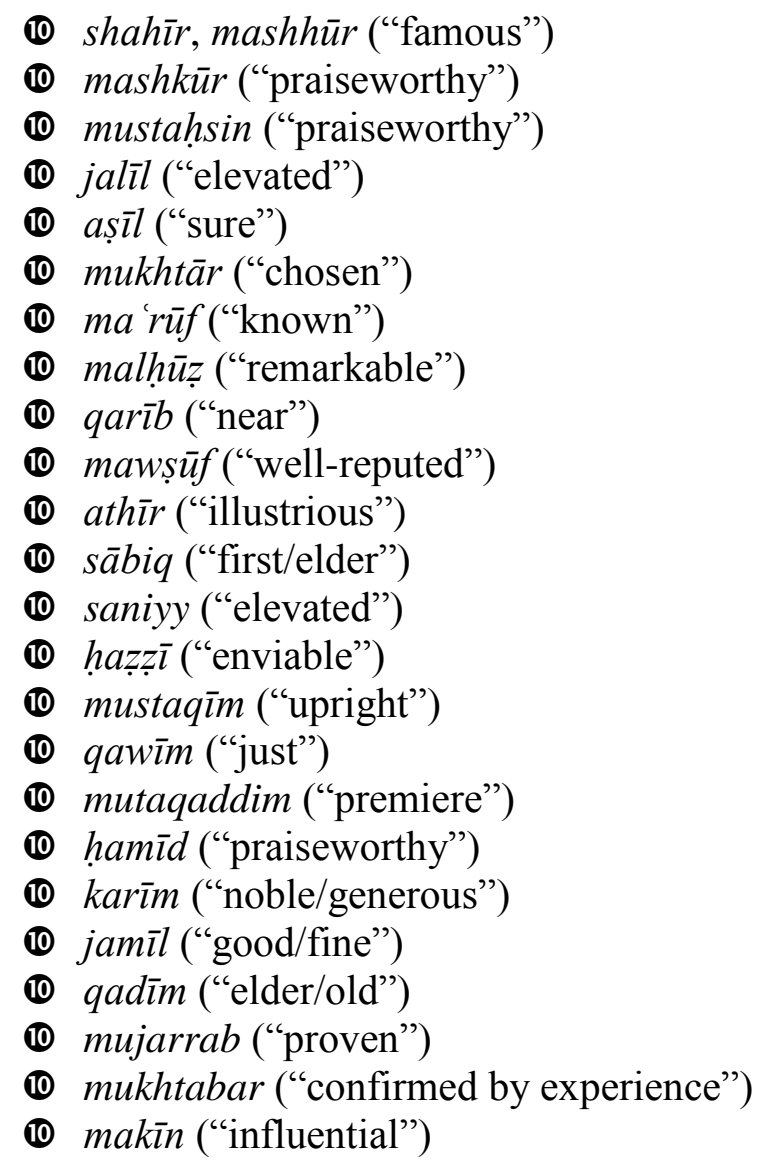

The secretaries draw from this lexical reservoir depending on the context in a variety of combinations. The constraints of $s a j$, addressed below, lead the $k \bar{a} t i b$ to often use pairs, built on the same verbal form (taqarraraltakarrara, i 'tibār/ikhtibār), the same root (istikfā'liktifā') or the same structure (hasab/nasab).

\section{Instructions}

After this part, which does not appear in all of the taqādim, a series of active or passive verbs follows that insists on the missions attributed to the appointee. The number of these verbs is limited, and their order can vary from one act to another. They reveal the nature of the bond between the ruler and his representative. In general, a wișayya immediately follows the appointment, an "instruction” to fear God on High (bi-taqwá Llāhi ta 'ālá), as awșaynā-hu (7, 28, 52, 53, and 60), wașṣanā-hu bi-, ${ }^{322}$ wa yu 'limu mā fāwaḍā bi-hi min al-wișāyā (13), wa qad talaqqá min wiṣāyā-nā la-hu bi- (24, 31, and 76), wa qad wuṣsiya bi- (27, 59, 71, 75),

322 Taqādīm 8, 9, 10, 14, 15, 16, 18, 19, 20, 22, 25, 26, 32, 33, 34, 37, 42, 43, 48, 49, 56, 61, 62, 64, 67, $68,69,70$, and 74 . 
wa qad ūṣiya bi- (46 and 73), fa-huwa muwașṣá bi- (51, 57, and 72), wa qad tuquddima ilay-hi bi-l-wașiyya (65), wa haddadnā la-hu al-wiṣāya bi- (66). The form of this instruction is particular in Ibn Hūd's taqādìm, ${ }^{323}$ as well as in number 29: wa qad alqaynā la-hu min alwiṣāya $(54,55)$. This refers to a Koranic verse, explicitly cited in taqdīm 13: "Fear God! This is what we instructed those who were given the Book and yourselves." 324

A number of verbs follow this, sometimes in the passive: amarnā-hu ("we have ordered him"), akkadnā 'alay-hi ("we have insisted that he"), asnadnā ilá ("we have entrusted to [him]), șarrafnā ilay-hi ("we have entrusted to him"), haddadnā-hu ("we have enjoined him"), aw'aznā-hu ("we have recommended that he"), awza'nā ilay-hi ("we have incited him"), 'ahadnā la-hu ("we have imposed on him to"). The official's activities are set out in this series of verbs, which also provide interesting elements concerning the official's attributions and Almohad imperial ideology.

\section{THE FINAL PROTOCOL}

The final protocol systematically includes a number of parts introduced by the expression fa-idhā wāfa-kum, "When it/he arrives among you (our allocution/your governor)." There are a few exceptions when the formula with $w \bar{a} f \bar{a}-k u m$ is modified:

— taqdìm 3: wa idhā istaqbala tilkum al-jihāti ("When he comes before your regions")

— taqdìm 47: fa-idhā ijtāza 'alay-kum ("When he passes among you"), which may refer to the "passage" over the Strait of Gibraltar

— taqdīm 49: fa-idhā quri'á 'alay-kum kitābu-nā ("When this missive is read to you").

The formula is absent from taquadim 1, 2, 3, 4, 5, 13, 20, 23, 31, 33, 35, 36, and 65. This obviously does not include those taqādim missing the end, since it is impossible to know if this passage was present in the complete version. ${ }^{325}$

\section{The arrival}

This part proves that in the majority of cases, the official went to the ruler, or his chancellery, to obtain his accreditation document. It suggests travel by state officials between the ruler's or his legal representative's capital and the assigned region. A series of orders follows in the imperative addressed as a conclusion to the subjects of the region in question: they must

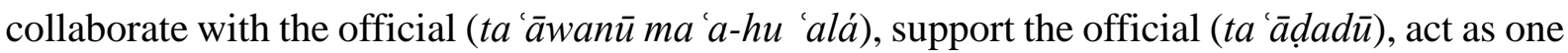
hand united with him (fa-kūnū ma'a-hu yad ${ }^{a n}$ wāhidat $\left.{ }^{a n} f \grave{l}\right)$, obey him (wa 'tamirū li-, inqāa $\bar{u}$

\footnotetext{
${ }^{323}$ Absent from taqdim 30 written in the name of the same ruler.

324 Citation from Koran 4:131.

${ }_{325}$ Taqādīm 38, 39-41, 44, 45, 61, 63, 70, and 77.
} 
ilay-hi), trust him (wa 'tamidū 'alá). They must obey him, collaborate with him, help him, act in solidarity with him, all which will bring them well-being "if God on High wills it." In addition, they owe the ruler gratitude and thanks.

\section{Promise}

A prayer ends the document, written always on the same model: "And $\mathrm{He}$ - May He be glorified - He..." (wa huwa subhāna-hu...). This is intended to assure the subjects of divine support by the rewards and favors it solicits for the addressees and ends with the expression "By His grace" (bi-manni-hi).

\section{Date}

The date appears only in the complete taqa $\bar{d} \bar{\imath} m,{ }^{326}$ in the form kutiba fi... ${ }^{327}$ or altarīkh... ("Date"). ${ }^{328}$

\section{d. Conclusions}

Except for a few exceptional examples, notably the following:

(10) The four taqāì̄m by Ibn Hūd, ${ }^{329}$

(10 Taqdim 1, a collective appointment, or delegation of power, further treated below,

(1) Taqdim 6, a response (jawāb) by the caliph al-Murtaḍa to a letter sent by the leaders and/or inhabitants of Ceuta,

(1) Taqdìm 20, which is not exactly an appointment, but more an order to the population and governor of a city (Sijilmāssa?) to build fortifications around their city,

(10) Taqdim 36, sent to the shaykh-governor and population of a region to confirm the former and threaten the latter in case rumors and rumor mongering continue against the leader in whom the central power has renewed its confidence,

besides these eight particular pieces, all the other documents are built on the same canvas. Whether long or short, addressed to Arab tribes, localities in al-Andalus or cities in the Maghrib, whether they concern the Learned (talaba), shaykhs, governors ( 'ammil or wālī) or judges $(q \bar{a} d \bar{l})$, these acts have the same overall structure. Certain parts may be more or less developed depending on the importance of the office, the region or the appointed person, but they all obey the same order.

\footnotetext{
${ }^{326}$ Taqādìm 5, 6, 30, 43, 52, 53, 54, 57, and 65.

${ }^{327}$ Except in taqdim 30: kutiba 'aqiba

328 In taqādīm 43, 54, and 65.

329 Taqā dīm 5, 30, 54, and 55.
} 
Why then did these successive authors, the shaykh, then Yahyá al-Khadhūj, feel the need to compile these different acts, if their structure is so identifiable and constant? In fact, in the subgroup made up of forty shorter taqādìm, more succinct for the captatio benevolentia, briefer for the choice and appointment, quicker for the qualities of the appointee, rudimentary in their prayers and eulogies, even though the lexical stock is limited, no act is exactly like another. ${ }^{330}$ The language, structure, and lexical basis are identical, yet each of these chancellery acts presents a unique example through a linguistic segment that constantly improvises by playing on the constraints that the author must follow in the name of tradition, insh $\bar{a}$ '. This codification of the taqädim contrasts with the much greater diversity of appointment documents from the Almoravid period. The development of new rules for producing these documents explains why an author from the Middle Ages would think of collecting these acts in one specific collection; the attention paid to the structure, vocabulary, and style of these political acts fits incontestably with a larger goal of completely reestablishing the basis of sovereign power. More than any other, the Almohad regime was attentive to form and styling - note their square dirhams or the hawd ("basin") of Marrakesh - and they considered this styling as a sense, authority, and mirror and foundation of their legitimacy.

${ }^{330}$ Except taqādīm 35 and 44, noted above, but this seems an error on the scribe's or collection author's part. 


\section{Chapter 6: Almohad Imperial Administration}

The Almohad Empire from al-Rashīd to al-Wāthiq was no doubt a continuation of the previous period, recuperating titles, honors, and structures developed under the first caliphs. The few acts written for al-Ma'mūn, who renounced the Almohad doctrine in 1229, ${ }^{331}$ or for Ibn Hūd al-Mutawakkil, ${ }^{332}$ who brought his territory under the Abbasid Empire in Baghdad provide an interesting counterpoint to shed light on how Almohad specificity differed from their neighbors or enemies.

The Empire was on the decline, breaking apart, when these acts were written. It is probably not a coincidence that the only extant collection of appointment acts, Yahyá alKhadhūj's, comes from this period of disintegration for the Empire and not from its time of political grandeur. The appointments of officials mention persons, often anonymous, bearing titles the outlines of which historians have struggled to define. Chronicles have heretofore been the principle source for understanding these titles and the offices they cover. However, though authors in the medieval Islamic world took care to describe and explain the advent of new categories, offices, and titles, they usually neglected to trace their evolution or disappearance in a process of infinite accumulation.

The taqādim shed additional light on these titles born by the important members of the Almohad state, as well as on certain elements of the Empire's population. They provide a means to study how the state functioned: the reality and nature of power, decisional centers and provincial relay points, administrative, fiscal, military, or juridical-religious functions. Finally, by their very nature and repetitive character, they provide a lexicon of the language of power in the Maghrib during the Almohad period.

\section{A. The different protagonists}

A number of specific references concerning the inhabitants of the Empire appear in the taqādìm. Certain individual titles have a specific sense for the Almohad period: shaykh, țalaba ("Learned"), hăfiz (“Guardian"). These occur less often and concern only about $20 \%$ of the seventy-seven documents. Because these acts were addressed to the population of a region and meant to be read aloud in the principal mosque, almost all of them mention the subjects (ra iyya), and their different social and political elements: "the elite" (khāṣsa, kubarā', a yānn)

331 Taqādīm 4 and 49 to 51.

332 Taqādìm 5, 30, 54 and 55. 
and "the masses" (jumhūr more often than 'ämma). Temporary political structures are occasionally mentioned, such as embassies carrying letters, or delegations (wafd, pl. wufüd), official representatives of the population of a city or region. Finally, some acts concern relations between the ruler and the Arab tribes and confirm the idea that the tribes were distinct from the rest of the Empire's population, in their administration and their behavior, for imperial rational and their autonomy.

\section{THE PRINCIPAL “BODIES” OF THE EMPIRE}

Modern historical descriptions of these principal "bodies" of the Almohad state are based on narrative sources, mainly the Akhbār al-Mahdī by al-Baydhaq, ${ }^{333}$ a Berber author writing during the beginning of the Almohad movement, the Mann bi-l-imāma ("Gift of the imāmate") by Ibn Șāḥib al-Șalā, an Andalusī official in the Almohad makhzan at the end of the twelfth century during the reigns of 'Abd al-Mu'min, Yūsuf I, and al-Manșūr, ${ }^{334}$ and Ibn 'Idhārī's Bayān al-mughrib, the most complete chronicle for the history of the Maghrib and alAndalus until the end of the Almohad period. ${ }^{335}$ This last work was finished in 1312, and, to quote Fricaud, seems to have undergone a "de-Almohadisation." 336 Relying on this type of document incurs also a dependence on it point of view which is turned always towards the caliph. The authors are attentive to the smallest events concerning the ruler, and notice delegates or peripheral elements only when they enter into contact with the ruling "sphere", either perturbing its power or soliciting its help. For the thirteenth century, not only do the first two of these works offer nothing, but their use can alter or even deform our vision of the administrative personnel through the artificial application of the reality they describe from a later time period.

The few appearances of these titles in the taqāìm would hardly profoundly change our understanding of Almohad power in the thirteenth century, especially since the sources used come from the central services of the Almohad power. Nevertheless, since they do appear later in non-narrative documents in a way that is basically different from the chronicles, they confirm in these acts of government usage what otherwise could only be an essentially discursive construction. In addition, because medieval vocabulary and titles are often imprecise,

\footnotetext{
333 DIHA.

334 IBN ȘĀHỴIB AL-ȘALĀ, al-mann bi-I-Imāma, Spanish trans. A. HUICI MIRANDA.

335 IBN 'IDHĀRT̄, al-Bayān, t. 5, Spanish trans. A. HUICI MIRANDA.

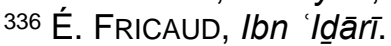


something which we will come back to often, these documents offer a valuable contribution for understanding the meaning of these terms at a specific point in time.

\section{A. THE SHAYKHS AND SAYYIDS}

The title shaykh appears the most often in the taqāìm. We explained above the Almohad specificities of this title which designates the eminent members of the founding tribes of the Almohad movement, perhaps the members of the Council of Ten and the ahl al-jamā' $a$, after the conquest of Marrakesh. These dignitaries, serving a primarily consultative role (shüra), received governorships and military responsibilities from 'Abd al-Mu'min until 1157. After that, the Almohad caliph began designating one of his sons as heir apparent by requiring the Almohad leadership to swear the bay 'a to him, and naming his other sons as governors of the provinces with the tile of sayyid ( $\mathrm{pl}$. sādat). Most of the shaykhs who then formed an important part of the developing central and provincial imperial administration were relegated to secondary positions as advisers to the governor-sayyids. Some did, however, retain considerable power in the ruler's shadow, such as Abū Hafṣ 'Umar al-Hintāti and his descendants, founders of the Hafṣid dynasty in Ifrīqiya.

We should note that the status of shaykh appears in none of the judicial appointments. It seems obvious, given the title's history, that it refers not to a faqīh ("doctor of the Law"), but to a non-religious official of the Empire. Thus, only the first half of Yahyá's compendium is concerned in this discussion. The term appears explicitly in the body of eight $\operatorname{taq} \bar{a} \operatorname{dim}(4,7,16$, $17,30,36$, and 43 ), and the collection's author adds it to the title of two more acts (38 and 39: fi taqdìm shaykh qabìla and taqdìm shaykh äkhar). It does not always refer to the appointee, but, sometimes in the plural (ashyākh) to the addressees, as in taqdìm 30 for Ibn Hūd. In this case, it does not relate to the category of shaykhs, the representative dignitaries of the founding tribes of the Almohad movement, against which Ibn Hūd al-Mutawakkil (1228-1238) was fighting, but the "Elders" or respected persons of the town of Algeciras. For act 17, though, even though the ashyākh of Sijilmāssa appear among the addressees, the 'ämil was indeed a shaykh since the document states "He and his ancestors were among the first shaykhs of this eminent power" (wa huwa al-sābiqu bi-dhāti-hi wa salafi-hi fì ashyākhi hadha l-amri). This act, which is one of the few complete documents, thus concerns a shaykh and addresses at the same time a groups of Almohad shaykhs present in Sijilmāssa.

Taqdìm 43 specifies that the shaykh is "famous and influential in the party (hizb) of Unicity (tawhìd)." This indicates that taqādim 3, 9, 19, 20, 21, 24, and 29, which mention that 
the appointee belongs to the "party" (hizb or ța 'ifa) of Unicity (tawhìd) and his place in it, concern most likely also the shaykhs, and that membership in the "party of the Tawhìd" constitutes a paraphrase for shaykh. It is obviously not impossible that other appointees were also shaykhs, even if they were not explicitly designated as such, in particular the "commander of the fleet" (qā'id al-usțūl) in taqdìm 2. Indeed, Mūsá has identified in the narrative sources two shaykhs as heads of the fleet between 1214 and 1269, but not one sayyid. ${ }^{337}$ Thus, out of forty-eight appointments of governors of military leaders, of which forty-six are Almohad, sixteen concern without a doubt the shaykhs, about $30 \%$ of the total. This proportion is notably less than what Mūsá has proposed for the same period.

This author has distinguished three steps in the respective proportions of shaykhs and sayyids among the governors: ${ }^{338}$

(10) Before 'Abd al-Mu'min's declaration of the hereditary caliphate (1157), the governors were recruited from among the shaykhs and the chronicles mention only one of his sons in this office. Over this same period, 'Abd al-Mu'min had not yet fully established his power, and he needed the support of the Almohad tribes, the backbone of the Almohad movement. He used the gubernatorial office to rally to his cause the local elites, the sābiqūn, those who had first joined the Almohads, in particular in al-Andalus. However, when the Berber tribes rebelled against 'Abd alMu'min after the fall of Marrakesh in 1148, the Andalusī provincial elite took advantage of the situation to become independent. Thus, when he managed to reestablish his authority in the Iberian peninsula, 'Abd al-Mu'min kept only Abū Bakr Muḥammad b. Sīdrāy Ibn Wazīr of Beja as governor, since he had remained loyal to the caliph. Ibn Wazīr was named to lead Silves and its region, a post that he held until 552/1157, when the Gharb region was joined with Seville. ${ }^{339}$ Abū Ya qūb Yūsuf (1163-1184) continued his father's policy of integration. When Ibn Mardanīsh died in 1172, and the Sharq al-Andalus entered the Almohad fold, the ruler appointed a member of the Banū Mardanīsh as governor of Valencia.

(1) After caliphal power was declared hereditary, 'Abd al-Mu'min enjoyed almost absolute power. He established an institution alongside his sons to form the new

337 See below, Table 5: Origin of the leaders of the Almohad fleet (adapted from 'I. al-D. MūsÁ, alMuwaḥhidūn fĩ l-Gharb al-islāmī, 269).

338 'I. al-D. MūsÁ, al-Muwaḥhidūn fí l-Gharb al-islāmī, 182 and sq.

339 IBN AL-ABBĀR, Hullat al-Siyarā', t. 2, 271. 
Empire's administrators, the "Guardians" (hăffiz, pl. huffāz), among whom were many sons of shaykhs. In 551/1156, the caliph "accepted the suggested made to him" to name his sons as governors, redoubling through parental authority the central caliphal power. His successors imitated this policy, which allowed for numerous descendants, since the three first caliphs had at least fifteen sons each. During this second period, $75 \%$ of the governors were sayyids.

(1) The situation changed significantly with the reign of al-Mustanșir (1213-1224). The caliphs depended on their entourages and were compelled to reconcile the leaders of the all-powerful Almohad tribes. Nevertheless, despite the influence of the shaykhs and the caliph's weakness, the proportion of sayyids appointed as governor during period remained high. The caliph's sons still incarnated the Almohad caliphate, and the subjects considered it a mark of respect to have at their head a member of the Mu'minid family and not an anonymous appointee. According to Mūsá's analysis of the narrative sources, the governors were then recruited more or less equally from among the shaykhs and the sayyids. ${ }^{340}$ At this time, the sayyids were no longer the caliph's sons, too young, but his brothers and uncles.

\begin{tabular}{|c|c|c|c|}
\hline Caliphs & Sayyid & Shaykh & “local" leaders \\
\hline 'Abd al-Mu'min before 1157 & 1 & 9 & 3 \\
\hline 'Abd al-Mu'min after 1157 & 9 & 3 & \\
\hline Abū Ya qūb Yūsuf (1163-1184) & 17 & 3 & 3 \\
\hline Abū Yūsuf Ya 'qūb al-Manșūr (1184-1199) & 13 & 2 & 2 \\
\hline Abū 'Abd Allāh Muḥammad al-Nāṣir (1199-1213) & 14 & 6 & \\
\hline Abū Ya 'qūb Yūsuf al-Mustanșir (1213-1224) & 7 & 5 & \\
\hline 'Abd al-Wāḥid al-Makhlū' (1224) & 8 & 1 & \\
\hline Abū Muhammad 'Abd Allāh al-'Ādil (621/1224-624/1227) & 4 & 4 & \\
\hline Abū Zakariyya Yaḥyā al-Mu’tașim (1227-1229) & & 1 & \\
\hline Abū al-'Alá al-Ma'mūn (1227-1232) & 6 & 1 & \\
\hline 'Abd al-Wāhịid al-Rashīd (1232-1242) & 3 & 4 & 1 \\
\hline Abū l-Ḥasan 'Alī al-Mu' taḍid bi-Llāh al-Sa '̄id (1242-1248) & 3 & 2 & \\
\hline 'Umar al-Murtaḍá (1248-1266) & 1 & 5 & \\
\hline Abū Dabbūs al-Wāthiq (1266-1269) & 1 & 2 & \\
\hline Total & 87 & 48 & 9 \\
\hline
\end{tabular}

Table 7: Group origins for provincial governors. ${ }^{341}$

340 'I. al-D. MūsÁ, al-Muwaḥḥidūn fī I-Gharb al-islāmī, 184.

341 'I. al-D. MūsÁ, al-Muwaḥhịidūn fĩ I-Gharb al-islāmī, 181. 
The data from the taqāìm coincides only partially with what Mūsá has garnered from the chronicles. The total absence of sayyids appointed in the acts is remarkable. The only one mentioned is the sayyid "perfect prince (al-țähir) Ibrāhīm," close to the reigning caliph alMurtaḍa in taqdim 6, with the text maintaining the confusion between the sayyid's sobriquet ("Tähir") and the meaning of this term ("pure, perfect"). He is not appointed as governor, but appears in the preamble as a beneficiary of the tardiya, after the imām al-qū'im bi-amri Llāhi, the Mahdī, whose impeccability (ișma) is not mentioned, and the Almohad orthodox caliphs (al-khulafä'al-rashidīn), as in the chancellery documents from the beginning of the thirteenth century. ${ }^{342}$ Indeed, the following sentences, recalling the conquests in the East and West as well as the enemies of the faith, border defense and, especially, the "adorers of the cross," refer to the Almohad caliphs, as much as the inclusion of the ruler's father in the tardiyya, continuing in the pure tradition of the Almohad chancellery of the triumphant Empire.

Nevertheless, this is the only time a sayyid is mentioned in the collection. Yet, according to 'Izz al-Dīn Mūsá, the sayyids, whose title was worn indifferently by all of 'Abd al-Mu'min's descendants, no matter which generation, still represented about half of the governors. Thus, unless chancellery norms imposed the non-inclusion of an appointee's belonging to 'Abd alMu'min's lineage, which would be fairly surprising given the fact that the choice of a sayyid as governor of a province was considered an honor, we can consider that except for those that promote local leaders (6 and 12), all the gubernatorial appointments in the manuscript concern shaykhs. ${ }^{343}$ The exceptional taqāìm with sayyid appointments were excluded, unless they existed in another form and the procedures for designating sayyids as governor were different. Moreover, Mūsá does not mention a single local leader for the period in question (during the reign of al-Rashīd), but at least two of these occur in Yahyá's collection (6 and 12), to which we can add the Arab shaykhs (38, 39, and 41), also "local leaders". Thus, out of less than fifty appointees, five were members of allied elites, outside the founding tribes of the Almohad Empire, more than $10 \%$ of the total, especially if we add the delegation of power (1). These documents demonstrate this even in their form, since they do not include the usual concluding

342 'Abd al-Mu'min (1130-1163), Abū Ya'qūb Yūsuf (1163-1184), Abū Yūsuf Ya'qūb al-Manșūr (11841199), al-Nāṣir (1199-1213).

343 This only slightly contradicts Mūsá's claim that "When al-Ma'mūn abandoned the symbols of Mahdism, the existence of the body ceased" since the restoration of the Almohad doctrine under the caliph al-Rashīd, son of alMa'mūn, led to the restoration of the erstwhile titles and privileges: 'I. al-D. MŪsÁ, al-Muwahhidūu fì l-Gharb alislāmī, 146. 
formula $f a-i d h \bar{a}$ wăfa $-k u m .$. ("When he arrives among you...") since the empowered person or persons was already there.

\section{B. The TheORISTS OF THE REgIMe (TALABA) AND THE "GUARDIANS" (HĀFIZ)}

These two categories, which date from 'Abd al-Mu'min's reign and the period of establishment of the imperial dynastic system, appear only three times in the entire manuscript. Even then, the only reference concerning a talaba (13) appears not in the body of the taqdim, but in the title added later by the compilation's author (the copyist, Yahyá?): wa fi taqdìmi aḥadi l-țalabati ("for the appointment of a talaba"). 'Abd al-Mu'min had begun again Ibn Tūmart's practice of sending preachers-missionaries to promote the Cause ( $d a$ ' wa) of Unicity (tawhìd) among the tribes to spread the Almohad doctrine, making the informal group of the Mahdī's disciple missionaries into an institutional corps of inspector-theorists. Taqdim 13 seems to indicate that this office may have continued into the thirteenth century, being the only act to mention the "didactic" responsibilities of the appointee: wa yu 'limu mā fāwaḍā-hu bi-hi min al-wiṣāyā al-latī wașṣá Allāhu ta 'ālá bi-hā 'ibāda-hu fì qawli-hi... ("and he will teach the recommendations that we have maintained, those that God on High addressed to his subjects in His word..."). The appointee, moreover, was very prestigious, since they are called "the most illustrious of the great notable Almohads" (al-muqaddam fi l-jalla min kubarā'i-hā) and they may have been tied to the reigning family by blood or marriage, as the expression wa huwa min-nā al-qarību l-qarābati may indicate. This taqdīm is one of the rare acts to use the root NWB, discussed below, in the form manābu-hu. Niyāba ("delegation”) was the Almoravid mode of government, abandoned by the Almohads for caliphal centralization. ${ }^{344}$ It is not surprising, though, to see this root and concept reemployed in the acts produced in the name of Ibn Hūd al-Mutawakkil. ${ }^{345}$

The hăfizs appear twice in the documents, in different contexts. In taqdìm 1, the ruler delegates the power to appoint to an official from al-Andalus. The appointments are limited to trusted persons and three specific positions: "Guardian" (hâafiz), tax collector ('ämil), and judge

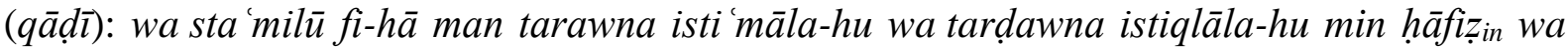
$q \bar{a} \underline{d}_{\text {in }}$ wa 'ammil $l_{\text {in }}$ (“Appoint as Guardian, judge, or tax collector those whom you judge [competent] and whose sense of responsibility you value"). It seems that in taqdim 10 "your

${ }^{344}$ About this question, see P. BURESI, "Administration territoriale d'al-Andalus", 129-145.

345 Taqādīm 5, 30, 54 et 55. 
hăfiz" refers to Fulān, the appointee, but this does not exclude the possibility that it refers to someone else, and that both may belong to the category of wulatti-kum ("your governors"), mentioned at the end of the act. It thus appears from these two acts that the term hăfiz designates the group of "Guardians" [originally of the revealed text, of the state, the dynasty, and doctrine during the Almohad period], and the best among them had the honor of being promoted to the "Learned" (talaba). The hierarchical superiority of the talaba as compared with the häfizs is confirmed by the respective order of these two groups in ceremonies described in the chronicles, as well as the lists of addressers or addressees in official epistolary documents.

\section{THE POPULATION OF THE ALMOHAD PROVINCES}

The Empire's population appears in the taqādim as the "subjects" ( $r a$ 'iyya), divided roughly into two groups according to social criteria: the elite (khāsșa) and the masses $(j u m h \bar{u} r)$. All of the appointees naturally belong to the elite, as well as the notables (a $y \bar{a} n)$, and the "elders" (ashyākh). The source also reveals that the Arabs (al-'arab) benefit from a specific status of their own.

\section{a. Local notables and delegations}

The term that most often refers to the elite members of the population, the "notables," though without strictly defining its limits, is a $y \bar{a} n$, and appears five times in the taqādìm. ${ }^{346}$ If the works were complete, the term would probably appear more often among the addressees, as in acts 5, 17, and 30. It figures in general in the penultimate position, just before the rest of the population, as in act 17 and in official letters. ${ }^{347}$ However, in taqāìm 5 and 30, the term appears before the scholars and notables (husabā'). ${ }^{348}$ Dozy's Supplément aux dictionnaires arabes claims that husabā' was used under the Almohads for people "who received a pension because they were from a royal family," ${ }^{349}$ but in the context of Ibn Hūd al-Mutawwakil's polity, the source of the only two acts containing this term, it is clear that it refers to "notables."

Another occurrence in act 3 both distinguishes and brings together the "notables" ( a $y \bar{a} n$ ) and the shaykhs. ${ }^{350}$ The document describes the composition of the delegation destined to receive the appointed governor. The social and political hierarchical order required that the

346 Taqādīm 3, 5, 12, 17 et 30. See infra for taqdīm 22 where the term a yān conveys a particular meaning.

347 "To the shaykhs, notables, and all the population of Sijilmāssa, its districts, its tribes and those under them."

348 "To the viziers, jurists (fuqahä), notables, scholars, nobles (husabā') and all principal (șudurr) figures" ( $\left.{ }^{\circ} 5\right)$ and "To the shaykhs, jurisconsults, viziers, notables, nobles (al-husabä ')" $\left(\mathrm{n}^{\circ} 30\right)$.

${ }^{349}$ R. DozY, Supplément aux dictionnaires arabes, t. 1, 285: "Sous les Almohades, les حسباء étaient ceux qui recevaient une pension parce qu'ils étaient d'une famille royale (Macc, II, 284, 20-22)".

350 "When your shaykhs and notables meet with him" (idhā jtama 'a bi-hi ashyākhu-kum wa a yānu-kum). 
shaykhs come first, while diplomatic constraints gave a sense to the order of presentation for individuals and groups in the chancellery documents. Taqdìm 12 confirms that the group a y $y \bar{a} n$ constituted at times a stable from which caliphs could recruit officers of the Empire. ${ }^{351}$ The delegations in acts 1 and 6 also seem to have been chosen from this group as members of the important families of scholars in the region. ${ }^{352}$ Another term is used for the provincial elites, the hạșşa, but appears only alongside jumhür, translated here as "people" or "masses", perhaps more precisely as "the collectivity." The khāșsaljumhūr designates in fact the entire population. 'Amma replaces jumhūr only three times $(1,12,29)$, without any obvious semantic difference, though it is the term that usually serves in narrative sources and geographical dictionaries to distinguish between the masses and the elite. Taqdìm 14, moreover, presents the variant khāṣs instead of the more frequent khāsșa. Seven times the adjective jumhüriyya ("public") is used, but only in the titles of certain taqādim $(2,4,6,9,29,55$, and 64), and to specify the type of act that follows, mukhātaba, translated here as "allocution" rather than "letter" or "missive," precisely because this text is intended for public presentation, to be read aloud in the principle mosques of the city and region in question. ${ }^{353}$

\section{b. The Arabs}

Four taqāìm stand out for the particular relation that they reveal between the ruler and the Arab tribes. 38, 39, 40, and 41 do not concern the appointment of Almohads, but people we can consider as "local," even if the group they lead is nomadic as indicated by the fairly rare mentioning of the "countryside" next to the city (al-hâa dir wa l-bāda) in document 38. These characters are in fact the Arab shaykhs being appointed to the head of their tribal group.

Over the course of 'Abd al-Mu'min's reign, the group of Arab shaykhs was made up of the leaders of the Hilālian tribes who had joined the Almohad movement. Mūsá notes that during the period of expansion for the Almohad Empire, there is no indication that any of the caliphs intervened in the choice of shayks for the tribes. However, a number of the taqādim concerning the Arabs show that during the period of imperial disintegration, the caliph

\footnotetext{
351 "By this decree, we name Fulān over you because he is the most known of your notables" $\left(n^{\circ} 12\right)$ : fa-qaddamnā bihadha al-rasmi 'alay-kum Fulānan li-taqaddumi-hi al-shahīri fĩ a yāni-kum.

352 Taqdīm 1: "Indeed, your delegates advanced into Our Presence, carriers of bay'as from your land" (wa qad kāna lwāfidūna min qibali-kum qadimū 'alá hadhihi I-ḥaḍra bi-mā awradū-hu min bay'āti tilkum al-bilād) and "Your delegation is on the verge of departing for your lands" (wa qad akhadha al-ān wafdu-kum fĩ l-iyābi ilay-kum) ; taqdīm 6: "Your two emissaries, with the missives they brought us, pushed us to this" (wa stahaththanā fĩ dhalika khațībā-kum al-wāfidān 'alay-nā wa mukhāțabāti-kum).

353"[obediance] that has been, by order of the Book and tradition (sunna), a duty (fard ${ }^{a n}$ ) weighing on each individual " (22).
} 
intervened to confirm a shaykh at the head of his tribal group. These acts confirm most of the time the sons of previous leaders (39 and 41) with "absolute" power (muțlaq). ${ }^{354}$ Mūsá has already noted in his study of narrative sources that the names of the tribal shaykhs clearly show that this office was hereditary. ${ }^{355}$ Taqdim 39 has the originality of presenting the only instance in the corpus of acts of the destitution of a son, for improper behavior, in favor of his paternal uncle, the brother of the preceding governor. ${ }^{356}$

This destitution and the other acts do not reveal so much the reinforcement of caliphal power at this time as they do the division of the tribal Arab groups and their integration into the game of rivalries between the different caliphal pretenders. The Berber Hintāta, ahl Tinmāl, and Ğadmīwa tribes were the traditional allies of the Arab Sufyān, in opposition to the Haskūra, and Khult Arabs. Thus when the Hintāta swore allegiance to 'Abd al-Wāhịid b. Yūsuf, the Haskūra and Khult joined the side of al- 'Ádil, and when the Hintāta came finally to the side of al- 'Ādil, the Haskūra turned against him, killed him and turned to al-Ma'mūn, whose arrival in Marrakesh after having renounced the Almohad doctrine and the cult of the Mahdi saw the purge of essentially Hintāta members, which led to the definitive break away of Hafṣid Ifrīqiya. Al-Rashīd's choice to reverse his father al-Ma'mūn's policies did not bring about the return of Ifrīqiya into the Almohad fold, but his reconciliation with the Hintāta shaykhs and their Sufyān Arab allies was opposed by the Haskūra and Khulț who enlisted alongside Yahyá b. al-Nāṣir. ${ }^{357}$ Given the placement of these taqādim in the collection, and assuming they were carefully organized chronologically, as argued above, the four taqāìm concerning the Arabs date indeed from the reign of al-Rashīd (629/1232-604/1242), when the conflicts raged between the different Almohad pretenders and before the reign of al-Mu'tadid whose name is mentioned in the title of the following taqdim.

A number of narrative sources show that their loyalty was bought through exceptional land concession in the Almohad political system. This practice continued in the thirteenth century, as shown by the term ashām (pl. sahm), the western equivalent of the eastern iqtā 'a

\footnotetext{
354 "We grant you full power for that, as with your father before" (wa ațlaqnā yada-kum 'alá dhalika kulli-hi ka-ițlāqi yadi-hi qabl...) for the Sufyān Arabs (taqdīm 41).

355 'I. al-D. MūsÁ, al-Muwaḥhidūn fĩ l-Gharb al-is/āmī, 148.

356 Taqdīm n० 39: "When he died, we kept his post for his son, whom we honored by naming him at the head of the Arabs because [of his father], or we believed that in [our] service he would comport himself as his father [...] Nevertheless, he delayed not in renouncing [that] favor and in calling misfortune on himself through his misdeeds. We have dismissed him and [in his place] have named his [paternal] uncle, Fulān, at the head of the Arabs" (wa lammā tuwuffiya abqaynā waladahu fí makāni-hi [...] fa-mā 'adā an kafara al-na 'mā' [...] wa akhkharnā-hu wa qaddamnā 'amma-hu 'alá l-'arabi).

357 'I. al-D. MūsÁ, al-Muwaḥhidūn fĩ l-Gharb al-islāmī, 149.
} 
(41), in the form of the masdar in the fourth form (ishām), alongside financial and monetary benefices (takrīm and in 'àm completing ishām). The Sufyān Arabs thus received in this taqdīm (41), an area to manage on their own, Ānfā (Casablanca), near the Berber lands of the Dukkāla and Banū Yadfar. ${ }^{358}$

\section{THE SUBJECTS AND THEIR ENEMIES}

All of these groups-“masses" (jumhūr, 'āmma), elite (khāșșa), notables (a yāan), "Learned” (talaba), "Guardians" (huffäz), Arabs ('arab), foreigners ('ajam)—were members of the much greater whole that encompassed them all, the ra iyya, the flock of subjects. The taqādim, despite all their categories and more or less honorific distinctions, as well as the different considerations involved, clearly show that only one hierarchy really counted: the difference between the shepherd and his flock of subjects, between the ra ' $\imath$ and the ra 'iyya (pl. $\left.r a{ }^{\prime} \bar{a} y \bar{a}\right)$.

\section{A. THE RA 'IYYA (PL. RA ' $\bar{A} Y \bar{A})$}

The term ra'iyya appears frequently in the taqajdim, either in the singular - twelve times $^{359}$ - or in the plural ( c $\left.^{\prime} \bar{a} y \bar{a}\right)$ - fifteen occurrences. ${ }^{360}$ Three other forms of the same root ( $\mathrm{R}^{\prime} \mathrm{Y}$ ) can be associated with this term (singular or plural): the ri âya ("guard, protection") which appears thirteen times throughout the acts, ${ }^{361}$ the $r a$ ' $\bar{\imath}$, pl. $r u^{\prime} \bar{a} t$ ("shepherd, guard"), ${ }^{362}$ and the tenth form of the root R'Y, the verb istar ' $a^{3}{ }^{363}$

\section{God, His shepherd and the flock of His servants}

The term istar' $a$ carries within it the other occurrences and makes explicit the relationship between God, the ruler, and the subjects. The caliph is the intermediary between God and the subjects, he is their guardian and is responsible for them. The term appears proportionally more often in the gubernatorial appointments than in those for judges, which

\footnotetext{
358 This is a variant of the Berber afa "summit, hill", indicating the original site was on the hill occupied today by the residential neighborhood "Anfa supérieur" (AL-IDRĪSIT, Description de l'Afrique septentrionale, 48: wa min Faḍāla [qui est à 12 mīā de Salé] ilá Marsá Ānfā 40 mīlan wa huwa marsá maqșud tā'ti ilay-hi al-marākib wa tuḥmal min-hu al-ḥința wa-l-sha 'îr wa yattașil bi-hi fĩ nāḥiyat al-barr 'imārāt min al-barbar min Banī Yadfar wa Dukkāla wa ghayri-himā. Wa min Ānfā ilá marsá Māzīghn 65 mīlan rūsiyya wa min Māẓighn ilá al-bayộā'dūn 30 mīlan ...) and Basaț al-arḍ, 72. See A. ADAM, s.v. "Ānfā", $E R$, t. 1, 521-522, and NLA, 469.

359 Taqādìm 1, 6, 9, 11, 14 (twice), 17, 36, 46, 47, 58, and 67.

360 Taqādīm 6 (thrice), 8, 9, 12, 13, 17, 20, 22, 28, 37, 58, 76, and 77.

361 Taqādìm 1, 5, 9, 10, 20, 29, 36, 37, 43, 54, 55, 57 and 58.

362 Taqādìm 1 and 6.

363 + doble acc. = "Prier quelqu'un d'être le pâtre du troupeau, ou d'être gardien de quelque chose ; prendre quelqu'un pour pâtre" (A. KAZIMIRSKI, Dictionnaire arabe-français, t. 1, 886). The expression appears six times throughout the taqādīm: 6 (twice), 14, 46, 48 and 67.
} 
seems to indicate that the terms of power recalled are more civil and military than religious. The authority behind $r i$ ' $\bar{y} y$ a thus refers more to the notion of coercion than to the power of justice. At the same time, this power comes from a divine order, and it is thus a duty for the sovereign, charged with protecting and leading his flock of subjects according to the rules of God: "acting in this according to the rule that God - May He be exalted and magnified imposed on the shepherds of the flock for which they were responsible." 364 The term appears also in the following citations:

(10 "all that the well-guarded flock can hope for from a shepherd who guards it" (taqdìm $1)^{365}$

(10 "all that God - May He be exalted and magnified - requires us to provide for his faithful whose care he has charged us with" (taqdim 6$)^{366}$

(10) "and that is because God - May He be exalted and magnified - entrusted us with guarding affairs [of the land] and the protection of its elites and masses" (taqdim $14)^{367}$

(10 "those whom God has entrusted to us" (taqdìm 46) 368

(10 "by the virtue of God on High having entrusted us with guarding the affairs of His subjects and His lands" (taqdìm 48) 369

(10 "Know that we, in virtue of the fact that God - May He be glorified - entrusted us with guarding the affairs and interests of the flock in all the land" (taqdīm 67) $)^{370}$

A certain type of mutual obligation results from this relationship between the ruler and his subjects, the "servants of God" ( $i b \bar{a} d$ Allāh). Those that weigh on the ruler will be presented below...

\section{The duties of the subjects}

The sovereign principally addressed his subjects in the imperative, affirmative or negative, in the second person plural, occasionally in the subjunctive or apocopic imperative. In regards to his subjects, order is the basis of the ruler's power:

\footnotetext{
364 'Āmilan fĩ dhalika bi-l-ḥaqqi l-ladhì li-Llāhi 'azza wa jalla ‘alá al-ru 'āti fī-man istar' ū-hu.

365 Afụal mā li-l-ra iyyati al-makfūlati mina ra iyyi I-kāfili.

366 Atamm mā li-Llāhi 'azza wa jalla 'alay-nā an nūfi-hi li-man istar'ā-nā min 'ibādi-hi.

367 Dhalikum li-anna Llāha 'azza wa jalla istar'ā-nā umūra-hā wa staḥfaẓa-nā khāșșa-hā wa jumhūrahā.

368 Li-man istar'ā-nā Allāhu.

${ }^{369}$ Qiyāman bi-mā istar' ā-nā Allāhu ta 'ālá min umūri 'ibādi-hi wa bilādi-hi.

370 Wa an ta 'lamū an-nā bi-ḥukmi mā istar'ā-nā Allāhu subḥāna-hu min umūri I-ra 'iyyati fi jamī'i I-bilādi wa mașālihịi-hā.
} 


\begin{tabular}{|c|c|c|}
\hline Taqdīm & Verbs transcribed & Translation (1st occurrence only) \\
\hline 2 & $\begin{array}{l}\text { fa-l-takūnū (subjunctive or apocopic) } \\
\text { wa-l-ta'lamū (subj.) }\end{array}$ & "be..." \\
\hline 3 & $\begin{array}{l}\text { fa- 'ayyinū } \\
\text { fa-lā tuqașsirirū } \\
\text { wa lā tu'akhkhirū } \\
\text { wa staqìmū } \\
\text { wa 'lamū }\end{array}$ & $\begin{array}{l}\text { "designate..." } \\
\text { "do not forswear..." } \\
\text { "hasten..." } \\
\text { "proceed straightly..." } \\
\text { "know..." }\end{array}$ \\
\hline 4 & $\begin{array}{l}\text { fa-waffü-hu } \\
\text { wa tawakhkhaw } \\
\text { wa slukū }\end{array}$ & $\begin{array}{l}\text { "acquit yourselves to him..." } \\
\text { "seek to..." } \\
\text { "follow..." }\end{array}$ \\
\hline 5 & $\begin{array}{l}\text { fa-stabshirū bi- } \\
\text { wa btahijū bi- }\end{array}$ & $\begin{array}{l}\text { "rejoice in..." } \\
\text { "be happy in..." }\end{array}$ \\
\hline 7 & $\begin{array}{l}\text { fa-nqadū ilay-hi } \\
\text { wa 'tamirū li- } \\
\text { wa 'tamidū 'alá } \\
\text { wa 'lamū an }\end{array}$ & $\begin{array}{l}\text { "submit to him..." } \\
\text { "obey..." } \\
\text { "trust..." } \\
\text { "know..." }\end{array}$ \\
\hline 8 & $\begin{array}{l}\text { fa-nqādū la-hu wa 'tamirū } \\
\text { wa stabiqū... wa btadirū } \\
\text { wa kūnū }\end{array}$ & $\begin{array}{l}\text { "hurry..." or "hasten..." } \\
\text { "be..." }\end{array}$ \\
\hline 9 & $\begin{array}{l}\text { fa-nqadū ilay-hi } \\
\text { wa 'tamirū } \\
\text { wa ta' } \bar{a} w a n \bar{u} \text { ma'a- } \\
\text { wa 'lamū }\end{array}$ & "collaborate with..." \\
\hline 10 & $\begin{array}{l}\text { fa- 'tamirū la- } \\
\text { wa ta 'āwanū } \\
\text { wa hrișīu 'alá }\end{array}$ & "ardently seek..." \\
\hline 11 & $\begin{array}{l}\text { fa-lqū bi- } \\
\text { wa 'tamidū 'alá } \\
\text { wa bdhilū } \\
\text { wa lā taddakhirū }\end{array}$ & $\begin{array}{l}\text { "entrust..." } \\
\text { “spend..." } \\
\text { "do not deprive [him]..." }\end{array}$ \\
\hline 12 & 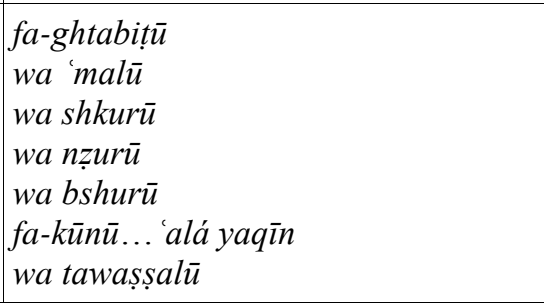 & $\begin{array}{l}\text { "rejoice..." } \\
\text { "accomplish..." } \\
\text { "thank..." } \\
\text { "look..." } \\
\text { "congratulate yourselves..." } \\
\text { "be sure..." } \\
\text { "insist..." }\end{array}$ \\
\hline 13 & $\begin{array}{l}\text { fa-stabshirū bi- } \\
\text { wa kūnū la-hu } \\
\text { wa 'lamū qadr mā }\end{array}$ & $\begin{array}{l}\text { "be for him..." } \\
\text { "know to recognized the value..." }\end{array}$ \\
\hline 14 & $\begin{array}{l}\text { fa-rji 'ù ilá } \\
\text { wa sirū fí... 'alá } \\
\text { wa kūnū ma'a- }\end{array}$ & $\begin{array}{l}\text { "refer to him..." } \\
\text { "proceed along... on..." }\end{array}$ \\
\hline 15 & 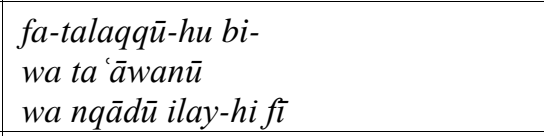 & "welcome him..." \\
\hline 16 & 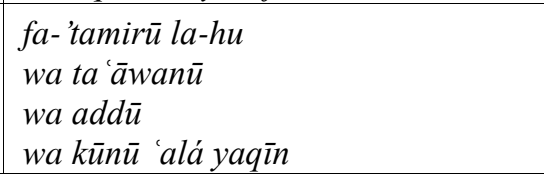 & "acquit yourselves of..." \\
\hline
\end{tabular}




\begin{tabular}{|c|c|c|}
\hline Taqdīm & Verbs transcribed & Translation (1st occurrence only) \\
\hline 17 & $\begin{array}{l}\text { fa-nqad̄u ilay-hi } \\
\text { wa ta' } \bar{a} w a n \bar{u} \\
\text { wa qdurū qadr }\end{array}$ & "measure the value..." \\
\hline 18 & $\begin{array}{l}\text { fa-talaqqū-hu } \\
\text { wa waffū-hu } \\
\text { wa jrū } \\
\text { wa shkurū }\end{array}$ & "act..." \\
\hline 19 & 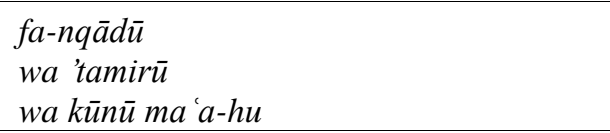 & \\
\hline 20 & $\begin{array}{l}\text { wa kūnū ma'a-hum } \\
\text { wa qbilū } \\
\text { wa waffū } \\
\text { wa kūn̄i 'alá yaqīn }\end{array}$ & \\
\hline 21 & $\begin{array}{l}\text { wa kūnū ma'a } \\
\text { wa sìrū } \\
\text { wa thiqū bi- }\end{array}$ & "believe in..." \\
\hline 22 & $\begin{array}{l}\text { fa- 'lamī } \\
\text { fa-kūnū } \\
\text { wa khdumū ma'a-hu }\end{array}$ & "work with him..." \\
\hline 23 & $\begin{array}{l}\text { Fa-kūnū } \\
\text { wa-l-yablagh 'an-kum }\end{array}$ & "may you... attain..." \\
\hline 24 & 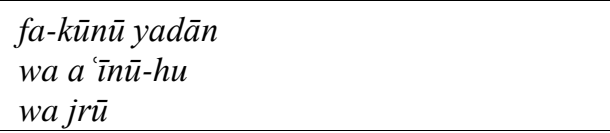 & "support him..." \\
\hline 25 & $\begin{array}{l}\text { fa-kūnū ma'a- } \\
\text { wa lamū }\end{array}$ & \\
\hline 26 & 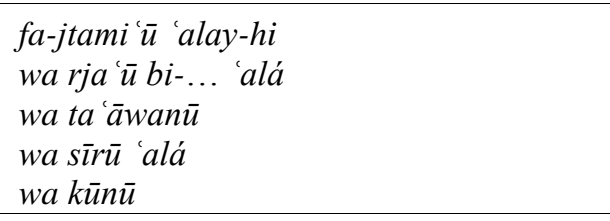 & $\begin{array}{l}\text { "unite around him..." } \\
\text { "place yourselves in his hands..." }\end{array}$ \\
\hline 27 & 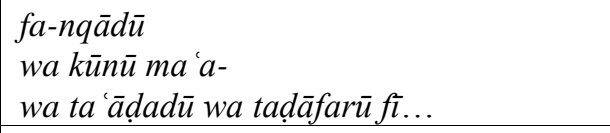 & "be united and help each other to..." \\
\hline 28 & 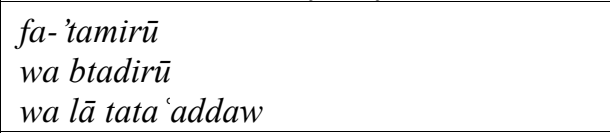 & "do not stray..." \\
\hline 29 & 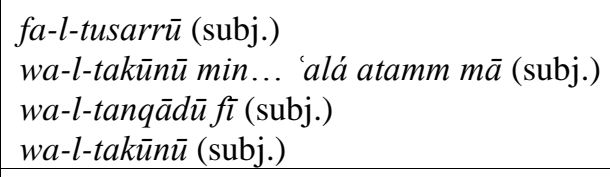 & $\begin{array}{l}\text { "rejoice..." } \\
\text { "be [obedient] in a way that..." } \\
\text { "submit..." } \\
\text { "be..." }\end{array}$ \\
\hline 30 & $\begin{array}{l}\text { fa-qdurū qadr } \\
\text { wa 'lamī } \\
\text { fa-lā taghubbū-hu } \\
\text { wa-l-tastash 'irū (subj.) } \\
\end{array}$ & $\begin{array}{l}\text { "do not deprive him of..." } \\
\text { "feel..." }\end{array}$ \\
\hline 31 & $\begin{array}{l}\text { fa-khdumī ma'a- } \\
\text { wa } n q \bar{a} d \bar{u} \text { ilá } \\
\text { wa kūnū } \\
\text { wa stamirrū min... 'alá }\end{array}$ & "continue thus..." \\
\hline
\end{tabular}




\begin{tabular}{|c|c|c|}
\hline Taqdīm & Verbs transcribed & Translation (1st occurrence only) \\
\hline 32 & 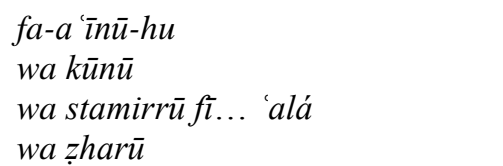 & "show..." \\
\hline 33 & $\begin{array}{l}\text { fa-talaqqū-hu } \\
\text { wa 'àmilu- } h \text { u } \\
\text { wa stash'irū } \\
\text { fa-skurū }\end{array}$ & "act with him..." \\
\hline 34 & $\begin{array}{l}\text { fa-a 'ìnu- } h u \\
\text { wa kūniu la-hu } \\
\text { wa ttafiqu }\end{array}$ & "be united..." \\
\hline 35 & $\begin{array}{l}\text { fa- 'rifī qadr } \\
\text { wa a' '̇n } \bar{u}-h u \\
\text { wa 'malū }\end{array}$ & "recognize the value..." \\
\hline 36 & $\begin{array}{l}\text { fa-stamirrū } \\
\text { wa kūnū ma'a-hu } \\
\text { wa sā'idū-hu } \\
\text { wa 'lamū }\end{array}$ & "help him..." \\
\hline 37 & $\begin{array}{l}\text { fa-ntazimū 'alay-hi } \\
\text { wa 'tamirū ilay-hi } \\
\text { wa kūnū ma' a-hu } \\
\text { wa wālū-hu al-muwālāt }\end{array}$ & $\begin{array}{l}\text { "come together behind him..." } \\
\text { "bring him your aid..." }\end{array}$ \\
\hline 38 & 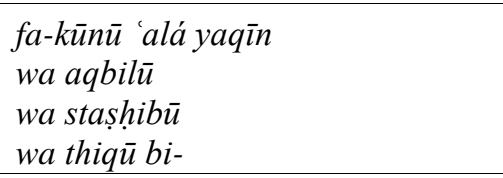 & “adopt..." \\
\hline 41 & $\begin{array}{l}\text { fa- 'lamū } \\
\text { wa tanassațū } \\
\text { wa khudhū fì l-wușūul } \\
\text { fa-bādirū }\end{array}$ & $\begin{array}{l}\text { "lend your ear..." } \\
\text { "set out..." } \\
\text { "hasten..." }\end{array}$ \\
\hline 42 & $\begin{array}{l}\text { fa-rji 'ū bi-... ilá... } \\
\text { wa a 'īnū-hu } \\
\text { wa ta' } \bar{a} w a n \bar{u} \text { ma'a-hu }\end{array}$ & \\
\hline 43 & 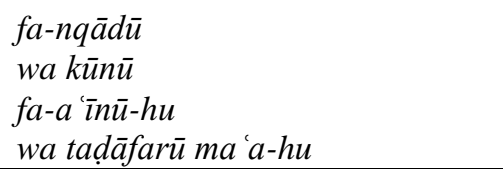 & "collaborate with him..." \\
\hline 44 & See taqdim $\mathrm{n}^{\circ} 35$ & \\
\hline 46 & $\begin{array}{l}\text { fa-'tamirū li- } \\
\text { wa kūnū ma a-hu } \\
\text { wa hrișū } \\
\text { wa 'lamū }\end{array}$ & \\
\hline 47 & 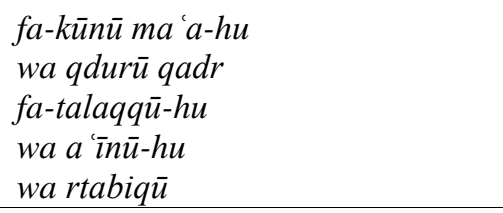 & "watch for..." \\
\hline 48 & $\begin{array}{l}\text { fa-rji 'ū ilay-hi } \\
\text { wa slukū 'alá } \\
\text { wa bādirū ilá } \\
\text { wa lta'imū 'alá } \\
\text { wa ltazimū } \\
\text { wa 'lamū an }\end{array}$ & $\begin{array}{l}\text { "be united..." } \\
\text { "devote yourselves..." }\end{array}$ \\
\hline
\end{tabular}




\begin{tabular}{|c|c|c|}
\hline Taqdīm & Verbs transcribed & Translation (1st occurrence only) \\
\hline 49 & $\begin{array}{l}\text { fa-rji 'u } \bar{u} \text { ilay-hi } \\
\text { wa ttafiqū } \\
\text { wa lā takhtalifū } \\
\text { wa lamū an }\end{array}$ & "be not in opposition..." \\
\hline 50 & $\begin{array}{l}\text { fa-a } \operatorname{c} \bar{n} \bar{u}-h u \\
\text { wa amaddu-hu bi- }\end{array}$ & "bring him..." \\
\hline 51 & $\begin{array}{l}\text { fa-talaqqū-hu } \\
\text { wa tawakhkhaw } \\
\text { wa kūnū la-hu }\end{array}$ & \\
\hline 52 & 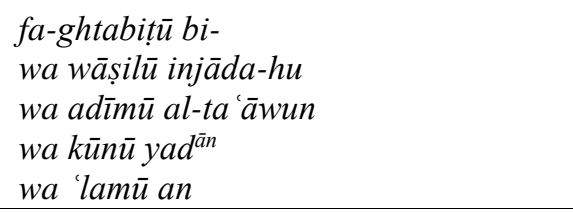 & $\begin{array}{l}\text { "ceaselessly help him..." } \\
\text { "offer him permanent collaboration..." }\end{array}$ \\
\hline 53 & $\begin{array}{l}\text { fa-a ìnū- } h u \\
\text { wa șilū yada-hu }\end{array}$ & "be at his side..." 371 \\
\hline 54 & $\begin{array}{l}\text { fa- 'lamū } \\
\text { fa-l-takūnū ma'a-hu (subj.) } \\
\text { wa-l-tuwālū-hu kull al-muwālāt (subj.) }\end{array}$ & \\
\hline 55 & 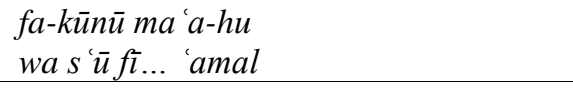 & "seek... to work..." \\
\hline 56 & $\begin{array}{l}\text { fa-ta' } \bar{a} w a n \bar{u} \text { ma'a-hu } \\
\text { wa kūnū yad }{ }^{\bar{a} n}\end{array}$ & \\
\hline 57 & $\begin{array}{l}\text { fa-ta 'āwanū ma'a-hu } \\
\text { wa tawāfaqū }\end{array}$ & "conform..." \\
\hline 58 & $\begin{array}{l}\text { fa-l-yahsuna i timāru-kum (subj.) } \\
\text { wa-l-tajmula āthāru-kum (subj.) } \\
\text { wa-l-ta 'lamū (subj.) }\end{array}$ & $\begin{array}{l}\text { "may your submission be irreproachable..." } \\
\text { "may your behavior be excellent..." }\end{array}$ \\
\hline 59 & $\begin{array}{l}\text { fa-rji ì ü ilay-hi bi- } \\
\text { wa a ìnu-hu bi- }\end{array}$ & \\
\hline 60 & $\begin{array}{l}\text { fa-a 'in̄i-hu 'alá } \\
\text { wa shārikū- } h u \\
\text { wa wāfiqū } h u\end{array}$ & $\begin{array}{l}\text { "be at his side/share with him..." } \\
\text { "collaborate with him..." }\end{array}$ \\
\hline 61 & $\begin{array}{l}\text { fa-a '̇nū- } h u \text { 'alá } \\
\text { wa 'àdidiu-hu }\end{array}$ & "support him..." \\
\hline 62 & $\begin{array}{l}\text { fa-hsunū mu 'ädadata-hu } \\
\text { wa jmalū musà̃ adata-hu }\end{array}$ & $\begin{array}{l}\text { "offer him powerful support and efficacious } \\
\text { help..." }\end{array}$ \\
\hline 64 & $\begin{array}{l}\text { fa-wāfiqū-hu } \\
\text { wa awwalū-hu (mamkana-hu) fi }\end{array}$ & "give him the possibility of ..." \\
\hline 65 & $\begin{array}{l}\text { fa-'tamirū li- } \\
\text { wa stamirrū 'alá } \\
\text { wa 'lamù an }\end{array}$ & \\
\hline 66 & $\begin{array}{l}\text { fa-kūnū ma'a-hu } \\
\text { wa lā tadhkharī } \\
\text { wa tahaqqaqū an }\end{array}$ & $\begin{array}{l}\text { "do not spare..." } \\
\text { "be sure that..." }\end{array}$ \\
\hline 67 & $\begin{array}{l}\text { fa-nqadū ilay-hi } \\
\text { wa ta' āwanū ma'a-hu }\end{array}$ & \\
\hline
\end{tabular}

371 Lit. "hold his hand". 


\begin{tabular}{|c|c|c|}
\hline Taqdīm & Verbs transcribed & Translation (1st occurrence only) \\
\hline 68 & $\begin{array}{l}\text { fa- 'tamirū la-hu fí } \\
\text { wa ttafiqū ma'a-hu 'alá } \\
\text { wa kūnū } \\
\text { wa staqbilū bi- }\end{array}$ & "receive..." \\
\hline 69 & $\begin{array}{l}f a-n q \bar{a} d \bar{u} \\
\text { wa kūnū ma'a-hu }\end{array}$ & \\
\hline 71 & 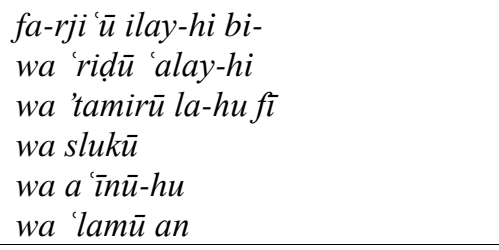 & "present him..." \\
\hline 72 & $\begin{array}{l}\text { fa-ta' } \bar{a} w a n \bar{u} m a^{\prime} a-h u \\
\text { wa kūnū ma'a-hu }\end{array}$ & \\
\hline 73 & $\begin{array}{l}\text { fa-qtassirū 'alay-hi } \\
\text { wa talaqqū-hu bi- }\end{array}$ & "address only him..." \\
\hline 74 & $\begin{array}{l}\text { fa-rji 'ū ilay-hi } \\
\text { wa qșirū alay-hi } \\
\text { wa ta'arrafū } \\
\text { wa 'lamū an }\end{array}$ & $\begin{array}{l}\text { "entrust only him..." } \\
\text { "consider..." }\end{array}$ \\
\hline 75 & $\begin{array}{l}\text { fa-ta'āwanū ma'a-hu } \\
\text { wa sìrú 'alá }\end{array}$ & \\
\hline 76 & $\begin{array}{l}\text { fa-lqū ilay-hi azimma-ta } \\
\text { wa 'tamirū li- } \\
\text { wa kūnū ma'a-hu } \\
\text { wa ltazimū }\end{array}$ & "offer him the reins..." \\
\hline
\end{tabular}

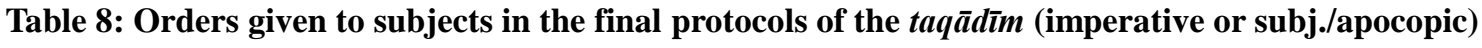

This list offers information on a numbers of points. Relations between the sovereign, who has ordered the act, and his subjects, the addressees, are clearly framed by an understanding of authority, born witness to by the number of verbs that evoke obedience, but these relations are presented as the logical consequence $(f a-)$ of preceding elements in the taqdim - the captatio benevolentice, the goodness and justice of the government, the excellent choice of officials, their qualities, the rigor of the orders given them. The subjects' obedience is thus justified in the taqāìm, which, through the systematic repetition of verbs in the imperative or subjunctive, relate to advisory letters in the rapid thematic classification of Almoravid and Almohad letters that I established in my dissertation. ${ }^{372}$ Every appointment of an official, whether for a judgeship, governorship ( ' $\bar{a} m i l$ or $w \bar{a} l \bar{l})$, as a military leader ( $\left.q \bar{a}{ }^{\prime} i d\right)$, is an opportunity for a call to order and another expression of caliphal authority.

The subjects' duties can be thematically classified by a number of categories:

372 P. BURESI, La frontière entre chrétienté et Islam, 142-145. 
- welcome, rejoicing, gratitude; ${ }^{373}$

- unity, understanding, aid, support, collaboration;374

- recourse, confidence; ${ }^{375}$

- submission, obedience. ${ }^{376}$

Accompanying verbs that incite the subjects to hasten, ${ }^{377}$ to spare no effort, ${ }^{378}$ or to reinforce the orders given above $\mathrm{e}^{379}$ are built with the mașdar of the verbs cited above. ${ }^{380} \mathrm{Few}$ of the injunctions concern the relationship of authority between subject and ruler, which underlies nevertheless the verb tense used (imperative or subjunctive/apocopic), as much as the relation between subject and appointee - governor, judge, tax collector or military leader. The obedience, aid, welcome or gratitude owed by the subjects to the appointee appear as the logical conclusion of all the elements that constitute the taqdìm and in the first place, the captatio benevolentia, present in the preamble, and affirm that government takes benevolent care of the region and its inhabitants and that it takes to heart the defense of their interests.

In addition, we can see all the possibilities for variation and creation that exist, if only in this very limited part of the taqādim. The table clearly shows that terms are frequently reused (only the translation of the first occurrence of verbal forms is mentioned) and the "blanks" in the third column express the importance of these repetitions. The most striking thing remains, however, over about seventy acts, the variety and diversity of possible combinations, a theme developed more fully in the chapter on chancellery $s a j$.

\section{b. Enemies from within and without}

One of the principal consequences of the divine character of the ruler's mission is that any resistance or revolt can be assimilated with heterodoxy or a refusal of God's law. In the first part of the manuscript, which concerns the appointments of governors and military leaders, few

\footnotetext{
${ }^{373}$ fa-talaqqū-hu bi-, fa-l-tusarrū (subj.), wa bshurū, fa-ghtabițū, fa-stabshirū bi-, wa btahijū bi-, wa 'lamū qadr mā, wa qdurū qadr, fa- 'rifū qadr, wa ta 'arrafū, wa shkurū.

374 fa-ḥsunū mu'āọadata-hu wa jmalū musā'adata-hu, wa 'āọidū-hu, wa wāfiqū-hu, wa shārikū-hu, wa șilū yada-hu, wa wāșilū injāda-hu wa adīmū al-ta'āwun, wa kūnū yadān, wa amaddū-hu bi-, wa Ita'imū 'alá, wa taḍāfarū ma'a-hu, wa wālū-hu al-muwālāt, wa kūnū ma a-hu, fa-ntaẓimū 'alay-hi, wa sā 'idū-hu, wa ta 'āwanū ma 'a-, fa-waffū-hu, wa ttafiqū, wa lā takhtalifū...

375 wa 'riḍu 'alay-hi, fa-qtașirū 'alay-hi, wa qșirū 'alay-hi, fa-lqū ilay-hi azimma-ta.

376 fa-nqadū ilay-hi, wa 'tamirū li-, wa-l-takūnū min... 'alá atamm mā, wa-l-tanqādū fi, fa-l-yahnsuna i'timāru-kum.

377 wa stabiqū... wa btadirū, fa-bādirū.

378 wa lā tadhkharū, wa s'ū fĩ... 'amal, fa-lā tuqașșirū, wa lā tu'akhkhirū, wa lā taddakhirū, fa-lā taghubbū-hu.

${ }^{379}$ wa ḥrișū 'alá, wa sirū fĩ... 'alá, wa-l-yablagh 'an-kum, wa kūnū...

380 i'timār, țā'a, inqiyād, ta 'āwun...
} 
acts do not mention troubles, rebellions, or resistance to enemy attacks, whether internal or external.

\section{External impiety}

The documents clearly distinguish between regions threatened from the inside and those on the borders of the Empire: five taqüdim mention the province's situation on the thaghr (pl. thughür). ${ }^{381}$ Not all of these provinces are identifiable. Ceuta (6) is naturally concerned because of its maritime and port situation which place it in contact with the Latin powers of the Mediterranean. Taqdìm 2, an appointment of a qā' 'id al-usțūl ("leader of the fleet"), and taqdìm 1 , which concerns an al-Andalus struggling against the generalized offensives of the Iberian Christian kingdoms, both relate to Ceuta. The troubled situation in the Andalusin provinces appears in conquest of Fulāna [2] by the troops of Fulāna [1], references to future conquests, ${ }^{382}$ and a strongly eschatological hadith that establishes a parallel between the two peninsulas, the Arabian at the beginning of Islam and the Iberian in the thirteenth century, as well as the comparison with the Hegira of Muhammad. ${ }^{383}$

In these six acts, the enemies mentioned are the enemies of Islam. They are designated by terms that sources employ traditionally in regards to Jewish and especially Christian enemies:

(1) Taqdìm 1: al-kuffār ("the impious"), al-mu 'taddīn wa l-mufsidīn ("those who attack and corrupt'), the $a^{\prime} \bar{a} d \bar{l}$ (pl. of the pl. $a^{\prime} d \bar{a}$ ' of 'aduww),

(10) Taqdìm 2: al- 'udāt ("the enemies").

(10) Taqdìm 6: opposition adwā' al-haqq ("the light of truth/the law")/zalmā' al-bātil ("the shadows of error"), abadatu l-ṣulbān ("the adorers of the cross"), the Ifrayriyyān ("the two brothers [of monastic orders]"), authors of "hidden and blameworthy lies" (al-ẓūr al-shan̄̄`al-munkar) and "pure calomnies" (al-baht al-

\footnotetext{
381 Taqdīm 1: "which will make manifest and guarantee good administration of its interests and the protection of its borders" ( wa yubayyinu wa yata'akkadu ma 'a-hu fĩ sadādi umūri-hā wa sadādi thughūri-hā al-yaqīn) ; taqdim 6: "Security was assured to [their] subjects by their justice and to the borders by their protection" (wa aminat bi-'adālati-him al-ra 'āyā wa bi-ḥimāyati-him al-thughūr) ; taqdīm 11: "to hold this frontier zone" (wa dabț dhalikum al-thaghr) ; taqdīm 12: "we have decided that affairs in your land (hunālikum) would depend on someone who rigorously takes in hand the frontier zone and closes it" (ra'aynā an takūna umūrukum hunālikum musnadata ilá man yaqūmu bi-ḍabți thaghri-kum aw saddi-hi) et taqdīm 21: "to lock down the borders" (wa yasudda thughūra-hā).

${ }_{382}$ Wa mā yarja 'u ba 'du bi-muhāwalati-kum min al-jihāti.

383 Tilkum al-jazīra al-latī al-islāmu bi-hā gharīibn, reference to the hadīth in al-Tirmidhī's Sunan ( $n^{\circ}$ 2553), in Ibn Hanbal's Musnad ( $n^{\circ} 3596$ et 8693), in Ibn Māja's Sunan ( $n^{\circ}$ 3978) et dans le Sunan d'al-Dārimī ( $n^{\circ}$ 2637): inna l-islāma badā gharīban wa sa-ya 'udu ghariban ka-mā badā fa-țūbá li-Ighurabā'... For a commentary on this hadith in the Almohad context, see the excellent article by Maribel Fierro, "Spiritual alienation and political activism", 232ff.
} 
baht), who manifest the "hate of the impious" (ghà'ilata l-kafara), the "associaters" (ahl al-shirk)

(10 Taqdìm 11: ahl al-i 'tidā' wa l-fasād ("the enemies and the party of corruption")

(10 Taqdīm 12: 'ädiyyatu 'udāti-kum ("the attacks of your enemies") which must be answered with the duty of rightful war (fard al-jihād); this leads to the "conquest that [you] hope for against the enemies of the faith" (al-fath al-ladhi fì 'aduwwi lìmān tu'ammilūna)

(1) Taqdìm 21: al-a 'dā' ("the enemies"), al- 'aduww al-ghädir ("perfidious enemy"), firqatu l-bātill ("the partisans of error"), al-kafara ("the impious"), al-mufsidīn...wa l-mu 'taddīn ("the corruptors and aggressors"), opposition between țâ'ifatu l-haqq wa anșāri-hi ("the party of the Truth and its helpers") and al-mushaqqīn al-mulhidīn ("the deviant heretics").

'Azzāwi has suggested that the enemies referred to in the last taqdìm (21) are the Marinids. The terms employed refer, however, more to non-Muslims and it would be surprising if this part of Morocco were considered as the thaghr at the time. ${ }^{384}$ Since nothing seems to corroborate 'Azzāwī's hypothesis, it seems more reasonable to consider that the taqdìm refers to a frontier, perhaps maritime province.

\section{Corruption on the inside}

Few of the taqādim mention non-Muslim enemies (six of the forty-eight gubernatorial appointments), but rebels inside the realm appear much more often. This reflects perfectly the difficulties Almohad power faced in holding the imperial territory beginning with the end of alMustanșir's reign (1213-1224). The acts no longer use the terms 'aduww ("enemy"), the plural of $a^{\prime} d \bar{a}^{\prime}$ or the plural of the plural $a^{\prime} \bar{a} d_{i n}$, but expressions that imply rebellion (al-baghi ), corruption (al-fasād), evil (al-shirr), wrongdoing (al-dirar), aberration (al-ghayy), violence (al'inād, al- 'anidīn), hostility (al-i 'tidā', al- 'udwān, al-mu'tadīn from the same root as 'aduww), and hypocrisy (al-nifāq). Most of these terms were Koranic in origin. These different terms appear isolated or in groups in twenty-six acts, sometimes more than once in each. ${ }^{385}$

384 Since the Almoravids, however, jihād against rebel Muslims, declared "impious", "deviant", or "corruptors" was not rare.

385 ahl al-fasād $\left(n^{\circ} 4\right)$, adwā' al-shirr wa-l-fasād ( $\left.n^{\circ} 7\right)$, al-ghayy et al-'inād ( $\left.n^{\circ} 8\right)$, al-'ānidīn wa-lmu tadīn, nahy kull fasād ( $\left.n^{\circ} 9\right)$, ülī l-shirr wa-l-fasād ( $\left.n^{\circ} 10\right)$, ahl al-i'tidā' wa-l-fasād ( $\left.n^{\circ} 11\right)$, al-fasād wa-l-mufsidīn... al-bāghīn wa-l-mu'tadīn, 'awādī l-shirr wa-l-fasād ( $\left.n^{\circ} 14\right)$, kaff al-fasād wa-l-ḍirar (n 15), mawādd al-fasād... dawā'i al-ikhtilāl (nْ 16), kull bāghin wa 'ādin, al-baghĩ wa-l-i tidā', ahl alfasād wa-l-'inād ( $\left.{ }^{\circ} 17\right)$, al-fasād wa-l-mufsidīn ( $\left.n^{\circ} 18\right)$, ahl al-shirr wa-l-fasād ( $\left.{ }^{\circ} 19\right)$, ahl al-baghī waI-'udwān, ahl al-baghī wa-I-nifāq ( $\left.\mathrm{n}^{\circ} 22\right)$, al-baghī wa-l-'inād, ūlī l-shirr wa-l-fasād ( $\left.\mathrm{n}^{\circ} 23\right)$, al-shirr wa-I- 
There is one exception, however, in taqdim 40. The act does not concern a "frontier" of the Empire, nevertheless, both 'aduww and the Koranic term ahl al-nifāq ("the hypocrites," "the partisans of hypocrisy") appear. Yet, this act concerns the Arabs to whom territories (jihāt) have been given and an army sent to help in combating the "enemies" and "hypocrites," from whom the territories must, in fact, be wrested. It would seem that the enemies in question were the Marinids, since the term munäfiqūn or ahl al-nifāq is attributed in the Koran to those who rallied to Islam and Muhammad only to satisfy their appetite for worldly wealth, seeking to mislead the sincere believers, refusing to participate in jiha $\bar{d}$, and betraying the Prophet whenever they could. ${ }^{386}$ The usefulness of this term is clear in ideologically justifying the Almohads' struggle against the Marinids, Muslims who betrayed and were less than steadfast in their faith.

Adding to this the six preceding taqādìm that concern regions threatened by both impious Christians and rebellious Muslims, close to $3 / 4$ of the appointments of governors, military leaders, and tax collectors mention the struggle against interior enemies. Though we will come back to the responsibilities of these offices_ 'ummāl, wulāt, or quwwād-it is clear that the insecurity that reigned over much of the territory "controlled" by the Almohad caliphs between 1220 and 1260, the restoration of the troubled situation, and the elimination of interior enemies were the principal worries for the weakened state who had a difficult time exercising its authority over a shrinking territory. Christian enemies threatened the frontier provinces, but emerging powers such as the Marinids and tribes reluctant to serve a ruler who was no more that the memory of a past power contested the authority of the Almohad caliphs. The first fortynine taqāìm, even if we remove those attributed to Ibn Hūd al-Mutawakkil, reveal the permanent efforts of the Almohad rulers to conserve or restore their power over their territory. As for the twenty-eight following acts which concern judges, their tone is quite different, probably because the juridical-religious offices were less clearly tied to a specific power than military, fiscal, or administrative offices. Indeed, while there was no doubt that measures taken by a governor, no matter what his precise responsibilities were, served a specific ruler, scholars

fasād ( $n^{\circ}$ 25), al-mufsidīn wa-l-fasād ( $\left.{ }^{\circ} 26\right)$, ūlî I-baghī wa-l-i tidā', adwā' al-shirr wa-l-fasād ( $\left.{ }^{\circ} 27\right)$, ahl al-fasād ( $\left.n^{\circ} 28\right)$, ahl al-shirr wa-l-fasād ( $\left.n^{\circ} 29\right)$, ahl al-i' tidā' wa-l-fasād $\left(n^{\circ} 31\right)$, āthār al-mufsidīn wa-lfasād ( $\left.n^{\circ} 34\right)$, ahl al-fasād ( $\left.n^{\circ} 37\right)$, ahl al-baghī wa-l-'adwān, adwā' al-fasād (nْ 38), ahl al-nifāq, al'aduww (nْ 40), āthār al-baghī wa-l-fasād ( $\left.n^{\circ} 43\right)$, ahl al-baghī wa-l-fasād ( $\left.n^{\circ} 47\right)$.

386 See M. A. AMIR-MOEZZI (dir.), Dictionnaire du Coran, s.v. “Hypocrites", 403-405. 
were still debating at this time whether judgments passed by a $q \bar{a} d \underline{\imath}$ appointed by an unjust ruler, or by one who was himself unjust, were valid or not. ${ }^{387}$

Judges in the Islamic world were not supposed to serve a particular prince, but Islam and Islamic law, and God through them. The history of Islam is rife of course with examples of $q \bar{a} d \underline{l} \bar{l} s$ removed from office after a change in the ruling dynasty, or forced to adopt a doctrine defined by the ruler, or to abjure after trials that occasionally led to the imprisonment or death of the judge being tested (mihna). These episodes bear witness to the incestuous relations between the judicial and political spheres. However, the judicial appointments that follow the "civil and military" ones in the collection present notable variations in their composition, themes, attributions, orders and advice, expressed goal, and, sometimes, the technical details of the tasks imposed. All these differences demonstrate to a certain degree that there was in fact a distinction between politics and religion in the imperial Almohad government, even though Almohadism was born from a political and religious reform that created a very original ideology and doctrine based on the complete intermarriage of the two domains.

These taqāìm and their portrayal of the Empire's territorial administration provide a unique window onto how the Almohads reconciled the distinction made between politics and religion in regards to enemies, and the religious basis for Almohad power and ideology. Was this reconciliation due to the weakening of the Almohad caliphate and doctrine during the thirteenth century? Did it correspond to two different discursive levels, theory and praxis? Did it refer to a tension that structured medieval Muslim imperial power?

\section{B. The Workings of the Imperial Administration}

The Empire's administration operated on two levels, the central administration around the caliph and the provincial administration. This distinction was not as clear as those terms might seems to indicate, since at least during the first Almohad period the central administration had no fixed seat, following the caliph's movements as he surveyed his empire. The curial offices that accompanied him thus constantly overlapped provincial administrations that fell automatically into their service. Justice, troop levies, repression of troubles, war against the enemy, military strategy, tactical decisions, fiscal administration, financial management of income and costs, appointment and dismissal of officials, and fortification and mosque construction all came under the control of the ruler and his close advisers.

387See A. CARMONA, "Le malékisme et les conditions requises", 122-158. 


\section{CENTRALITY AND ALMOHAD CALIPHAL AUTHORITY}

Questions of center and periphery do not apply well to the exercise of power under the first four Almohad rulers. ${ }^{388}$ The first caliphs were ceaselessly on the move, accompanied by their governmental apparatus, by their curial, administrative, financial, fiscal, and military services. The Almohad ruler incarnated the supreme justice of the Empire and the Community (umma), which, with him, was itinerant. The capitals of the Empire, Marrakesh and secondarily Seville, were in fact only substitutes for the caliphal Presence ( $h a d r a)$, relays for his authority in the periphery of zones from which the caliph was absent. They were neither the unique nor multiple functioning center of the Empire, simply one of its provincial bases of representation.

\section{a. Symbolic center and central power}

If there was a symbolic center of the Almohad Empire from the twelfth to the beginning of the thirteenth century, it was Tinmāl, the birthplace of the movement, tomb of the Mahdi and pilgrimage destination before becoming the imperial necropolis. The first Almohad caliph, 'Abd al-Mu'min, methodically built this place as the chronological, geographic, doctrinal, political, and religious center of the Empire he was building. ${ }^{389}$ This site, the beginning and end of the Almohad movement corresponded in space and time to the unity of God. Tinmāl was where the hidāya ("guidance") and impeccable imāmat of Ibn Tūmart were recognized, it was also his last residence. Nevertheless, the administrative and decisional center of the Empire was not associated with a fixed place, rather with the mobile and living Presence of the caliph. This, at least, was the system 'Abd al-Mu'min put into place and that his direct descendants continued.

\section{The development of a decisional structure}

The central administration was thus nomadic and coexisted with provincial relays. The Almohads developed this, their stamp, not from previous structures, but from the group of faithful and disciples who surrounded the Mahdī Ibn Tūmart, utilizing from an institutional point of view the tools and concepts worked out under the Umayyad caliphates of Damascus and Cordova, the Abbasids of Baghdad, and the Fatimids of Qayrawān and Cairo. 'Abd alMu'min's character play a determinant role in developing the decisional structure during the three decades of his reign. He was the architect and foreman of the Almohad caliphate, even

388 As formulated by geographers and taken up by Braudel, then Wallerstein in his model of the world system (Capitalisme et économie-monde, 1450-1640, Paris, Flammarion, 1980) and Samir AMIN (Le développement inégal, Paris, éd. de Minuit, 1973).

389 P. BURESI, "Les cultes rendus", 391-438. 
more so than Ibn Tümart who had died while the movement he had initiated was still only a rebellion.

The decisional structure, ordered around the caliph and adapted to the personality of the first of them, was founded from the beginning on the solidarities forged by Ibn Tümart. 'Abd al-Mu'min later introduced his own trusted relations, either members of his family - essentially his sons - or some of the major tribal representatives in whom he had absolute confidence, such as Abū Ḥaf̣̦ 'Umar al-Hintātî. We will probably never know the foundations of this trust calculated balance of power at a time when tribal organizations played an important role, tacit or explicit contractual sharing of power between two heirs to the Tumārtì message, blood brotherhood, virile friendship -, but it seems that 'Abd al-Mu'min never felt threatened by the man who nonetheless the chronicles say was supposed to succeed the Mahdi and who stood aside for 'Abd al-Mu'min.

\section{The Almohad vizierate}

A very strong concentration of decisional power characterized the original version of the Almohad caliphate. The conquest of Marrakesh marks a decisive moment in this. 'Abd alMu'min was finally at the head of a vast territory structured around large cities, and his Almoravid rivals had almost disappeared. ${ }^{390}$ There were no more states, dynasties, or dawla to oppose him in the Maghrib al-Aqșā, only regions that were sometimes hesitant, sometimes openly rebellious faced with the absence of power that inevitably follows a transition in regimes. On the one hand the Almoravids had fallen, their ruler was dead, their armies defeated, their administration was able to protect their cities neither from Christian attacks to the north in the Iberian Peninsula, nor from harassing raids launched by mountain tribes living to the south in the Atlas. On the other, the new regime had only proven itself militarily, it was simply a message of reform and an army, with no relays among the provincial elite.

This differed immensely from the way the Almoravid Empire had grown at the end of the eleventh century, whose leaders has sought support in the legal scholars and Malikism present and well-developed in the Maghribī urban centers, in the popular themes of the reduction of non-Koranic taxes and jihād against the enemies of Islam and the defense of Sunni orthodoxy through the recognition of the Abbasid caliphate in Baghdad. These elements had all allowed the Almoravids to dethrone local leaders and impose their rule with the support of the

\footnotetext{
390 It was maintained until the beginning of the thirteenth century in the Balearic Islands, then in Ifrīqiya until the middle of the century, through the Banū Ghāniya dynasty.
} 
Muslim intellectual elite and the population. The Almohads rose to power under different circumstances and with different means. First of all, they did not face small fragmented principalities, but a powerful, though weakened, empire that spread from the borders of Ghana to the center of the Iberian Peninsula. They also did not play on the integrating factor of a routine Islam, but on the distinctiveness of a renewed Islam. The Almohad rise was the proof as well as consequence of the Islamization of Maghribi populations in the twelfth century, an Islamization in which the Almoravids had played a powerful role.

Conquering Marrakesh was thus a decisive moment that gave the Almohads the opportunity to finally prove that they could do more than simply disturb the established order, that they were in fact the defenders of a new public order, of a new organization of power and efficient and just management of resources and the populations of the Maghrib. The scale of responsibilities changed, functions became infinitely more complex, and it is not surprising that in these conditions a vizier was named for the first time to assist the caliph and to direct the central administration and the offices charged with distributing the caliph's orders over a territory of imperial dimensions, with a considerable urban framework and Marrakesh at its head, and over vast regions of tribal nomads more or less well-controlled.

The vizier, in a way, headed an executive branch subject to the caliph's judicial and legislative branches. The Almohad caliph certainly fell under the Law of God, but as the imām, the khalīfa ("successor") of the "impeccable" imām and "recognized Mahdī" (al-imām alma ș̣ūm al-mahdī al-ma'lūm), and as "commander of the believers", 'Abd al-Mu'min automatically assumed the capacity of unique legitimate interpreter of divine Law, legislating within the path defined by God. The first vizier seems to have been Ibn 'Ațiyya, from the village of Cambrils in the region of Tortosa. This Almoravid kâtib who was in Marrakesh in 1147, enrolled as an archer in the Almohad army at the time of the city's fall to avoid the foreseeable punishment that his past allegiances and his family's ties with the fallen dynasty would certainly have brought on him. He was noticed more for his pen than his arrows, for he was charged with writing the announcement informing the caliph of his troops' victory over the rebel Al-Māssī (or al-Māssātī) in 1148. 'Abd al-Mu'min made Ibn 'Ațiyya his secretary, advisor, and vizier. Ibn 'Ațiyya's destiny illustrates so well the turn of the wheel of fortune so frequent in the history of the medieval Muslim world, as Dakhlia has well-demonstrated. After grandeur, decadence: an escape and talent opened the path to ascension and the doors of the most important positions, 
which, in turn, lead inevitably to execution. ${ }^{391}$ In 1158, Ibn 'Ațiyya and his brother were accused of treason, victims probably of a plot within the circles of power, and were arrested and put to death on 'Abd al-Mu'min's direct orders. The tragic end of this relationship so typical of the structures of Muslim power, since the friendship between Hārūn al-Rashīd and Ja far the Barmakid, takes on particular significance in the dynamic established by 'Abd al-Mu'min. In the Almohad structure of power, the vizier cannot follow his own personal path, he is but an instrument in the service of the ruler, he can have no individuality, cannot have his own story or legend like the Barmakids, he can only be an anonymous transmitter without his own identity. Paradoxically, Ibn 'Ațiyya entered into the ranks of viziers of legendary destiny who had risen to and fallen from the highest heights because he had not understood the specificities of Almohad power.

'Abd al-Mu'min named 'Abd al-Salām al-Kūmī as vizier after eliminating the Ibn 'Ațiyya brothers, then replaced him with this own son, the sayyid Abū Hafṣ, with the accord of the Almohad shaykhs. ${ }^{392}$ Later, Abū Sa'̄id 'Uthmān Ibn Jāmi' remained in place under the caliphs al-Nāṣir and al-Mustanșir despite the shaykhs complaints, indicating their accord was no longer necessary under the hereditary caliphate. ${ }^{393}$ The viziers that served after Ibn 'Ațiyya thus lacked historical depth. Nevertheless, the office was not unimportant, since the vizier headed the central administration. ${ }^{394}$ The chronicles sometimes mention their name, but other than a few exceptions, they do not seem to have played any real historical role. There was never more than one vizier at a time during the period of expansion for the Empire, but later both alMu 'tașim and al-Sa '̄id employed two viziers at once. ${ }^{395}$ The viziers for al-Ma'mūn, al-Murtadá, and a-Wāthiq are unknown, which probably indicates one of two possibilities: either their viziers were so ineffectual that history did not notice them, or the office had only relative importance and had become functional and emptied of decisional responsibility.

The vizier's power was in fact inversely proportional to the caliph's. During the second period of the Empire - from al-Mustanșir's reign until al-Rashīd's - the vizier's appointment came under the most influential of the Almohad shaykhs. ${ }^{396}$ His power increased along with the shaykhs' from whose sons he was traditionally chosen. The vizier was the link between the

\footnotetext{
391 J. DAKHLIA, L'empire des passions.

392 'I. al-D. MūsÁ, al-Muwaḥhidūn fī l-Gharb al-islāmī, 156.

393 Al-ḤimyaRī, Rawọ al-Mi țār, s. v. "Ğinjāla” (Chinchilla), n 70, ed. 67-70, 68, trans. 84-87, 84-85.

394 'I. al-D. MūsÁ, al-Muwaḥhidūn fĩ l-Gharb al-islāmī, 153.

395 'I. al-D. MūsÁ, al-Muwaḥhìidūn fĩ l-Gharb al-islāmī, 155.

396 'I. al-D. MūsÁ, al-Muwaḥḥidūn fĩ l-Gharb al-islāmī, 156.
} 
caliph and the Almohad institutions of state; he directed the budgetary office for the military; he was responsible for the financial offices until al-Manșūr assigned them to a different person; he organized official ceremonies, caliphal presentations; he presided over the sworn oaths to the new caliph along with the sayyids and representatives of the Almohad shaykhs. Beginning with al-Manșūr's reign, when the caliph's authority was undermined due to his age or the weakness of provincial support, the vizier's political role grew. Nevertheless, though they may appoint or depose caliphs, sign decrees, decide military policies, spend money from the state's coffers, receive envoys from Christian kings and sign truces and treaties, this was not because of their own authority but the weakening of the caliphal authority and divisions among the sayyids. Beginning with al-Rashīd's reign, the viziers returned to the subordinate role that had been theirs under the first four caliphs. 397

The sedentarization of the caliphate under al-

\section{Mustanșir}

The caliphate's situation changed substantially in the thirteenth century. Beginning with al-Mustanșir's reign (1214-1224), the caliphal Presence ceased to be nomadic, became sedentary, and Marrakesh finally became the capital of an Empire shrunken by the caliph's falling back to the rare territories of the Empire that he still managed to control: Marrakesh, Ribāṭ al-Fatḥ, Tārūdānt, Sijilmāssa, and Fez. This sedentarization of Almohad power was not a choice, but a resignation, it was symptomatic of the regime's critical state. The caliph did not even risk traveling throughout his territories when Ceuta, Granada, Seville, and Tlemcen symbolically swore bay ' $a$ oaths to al-Rashīd (629/1232-640/1242), despite efforts to restore imperial authority. This is probably the most tangible sign of the exclusively nominal and symbolic character of these forms of recognition. Later bay' $a$ oaths thus do not indicate the power of the caliph as he polarized territory around his authority, but rather local strategies of circumstantial alliances and the inscription of the Almohad caliphate among the referential auctoritates granting legitimacy to local powers.

\footnotetext{
397 Guichard insists on the honorific nature of the title of vizier, which is incontestable (P. Guichard, Les musulmans de Valence, t. 2, 314). This does not necessarily mean that the Almohad viziers had no responsibilities, or only a representational office. During the first period of the Empire - from 'Abd alMu'min to al-Nāșir - they were the working link of the central administration, the intermediary between the caliph and specialized offices. Later, their role grew at the same time as the Almohad shaykhs' at the expense of the caliph. Finally, beginning with al-Rashīd, their use and role diminished as did the imperial territory, and their attributions remained the same as during the initial period.
} 
Manuscript 4752 and the taqādim presented here date from this particular period when the Almohad regime entered into the more usual framework of a sovereignty whose power radiates from an urban center over a progressively shrinking surrounding territory. Paradoxically, there are no extant taqā $\bar{\imath} m$ from the first caliphs; history has preserved only manuscript 4752 and its documents and appointment acts from the period of weakening caliphal power and reduced imperial territory. This seems to indicate a number of hypotheses. The least probable would be the non-existence of acts dating from the first period: the caliph traveling his Empire would have carried out appointments and dismissals in the regions where he journeyed through a very personal governmental system wherein the caliph's words and the testimony of those present would have sufficed to establish local administrative, judicial, fiscal, or military authority. This hypothesis reduces the role of the dīwan al-insh $\bar{a}^{\prime}$, the chancellery offices, to that of a mediator between the caliphal Presence and the provinces through the development of discourse centered on the ruler's activities (victories, defeats). It is more likely that acts from the first period were not kept, that caliphal authority and the confidence it inspired were enough to guarantee the lasting quality of its decisions. This would seem to indicate that it was the loss of confidence in the ruler's authority that led provincial administrators to conserve and transmit acts that served as the basis of their power.

The Almohad Empire entered into an administrative center-periphery rational - attested to by the recurring use of the phrase fā idha wäfa-kum ("Thus, when he arrives among you") because of the sedentarization of the caliphal court and the weakening of its authority. This was when scribes felt the need to preserve what was left of the act of power. The dīwān al-insh $\bar{a}$, at the heart of the imperial communication system, the chamber for registering acts, the issuing and collection center for information, became then the principal actor in political life, the spokesman for a caliphal authority that was only the shadow of its former self.

b. The "Presence" of the caliph, seat of authority (12201269)

Manuscript 4752 is divided into two sections, as discussed above in chapter five. The first section concerns "secular" officials, as opposed to the second section which concerns judges ( $q \bar{a} d \bar{l} \bar{s} s$ ), those personnel who office was "religious" in nature. Yahyá al-Khadhūj seems to have developed this classification at the end of the thirteenth century, reflecting current conceptions on the nature of the responsibilities carried out. This distinction made by the medieval author between these two main types of power corresponds only partially to 
classifications commonly attributed to the Latin West - legislative, judicial, executive. However, it supports Gardet's approach which, without recognizing any real "separation" between those powers in the principles of their organization, almost constantly uses this notion of separation to expose the articulation of different public offices. ${ }^{398}$ However, the fact that the same collection contains appointment acts for governors, military leaders, and tax collectors on the one hand, and judicial officials on the other likewise supports Tyan's opposing viewpoint that the initial unit of power, source of the idea of "delegation" on which the different magistratures depend, excludes the possibility of any separation between the judicial and executive powers, since the $q \bar{a} d \bar{l} \bar{l}$ was merely the representative of the "central executive authority". ${ }^{399}$ This means that the relationship between the executive, legislative, and judicial branches in the Islamic world followed a different rational than those that developed haphazardly over the centuries in Western Europe. The study of the taqāitm collected in manuscript 4752 of the khizānat al-hasaniyya can help in understanding how medieval ArabMuslim political theory during the Almohad period approached the relationship between the Law, divine in its essence, and caliphal authority exercised on earth.

\section{The terminology of power}

The term sultān does not designate caliphal power during the Almohad period, although Guichard notes its spread beginning in the eleventh century. ${ }^{400}$ Indeed, the Almohads use the term hadra, ${ }^{401}$ which we have chosen to translate as "the Presence", rather than one of the terms proposed by Kazimirski ("majesty”, “excellence”, "highness", or "honor”). This keeps the original connotations of the root and allows an association with the term's other frequent signification in the chancellery documents, "residence-capital [of power]", as in taqdìm 5: "This is what we write from the [palace] residence (hadra) in Granada." ${ }^{402}$ The Almohads thus preferred a term to designate power which designated both the body of the ruler and an abstraction of authority. This is fairly indicative of how power was exercised during the first period, under the first four caliphs, when the caliph and his court journeyed throughout the

\footnotetext{
398 This appears even in the organization of the chapters Gardet devotes to this question in his work $L a$ cité musulmane. Vie sociale et politique, Vrin, Paris, 1976.

399 É. TYAN, Histoire de l'organisation judiciaire.

400 P. GuichARD, Les musulmans de Valence, t. 2, 278.

401 Taqdīm 1 ( $f^{\circ} 2$ v, p. 2, I. 8), 6 ( $f^{\circ} 9$ v, p. 16, I. 9), $13\left(f^{\circ} 14\right.$ v, p. 26, I. 20), 33 ( $f^{\circ} 25$ r, p. 47, I. 22), 69

(f० 44r, p. 85, l. 22).

$402 f^{\circ} 6$ r, p. 9, I. 21. This is of course an act issued by lbn Hūd, and so a ruler opposed to the Almohads, but the term is also frequent in the other Almohad chancellery documents.
} 
Empire and when the decisional, jurisdictional, and administrative center followed the ruler's itinerary.

\section{The shadow of power}

There were two main functions of this caliphal "Presence": protection and guidance. This protective function is omnipresent in the taqädim and appears in the use of the terms kanf ("wing") and zill ("shadow" in the singular) or zalāl (plural), sometimes redoubled with the adjective from the same root, zalīl ("dark"). ${ }^{403}$ The shadow or wing alluded to are those of the amān, amāna ("security”), ${ }^{404}$ 'âfiya ("salvation”), ${ }^{405}$ da 'a ("tranquility"), the already mentioned ri 'āya ("protection”), as well as 'adl ("justice”), ihsān ("beneficence”, "well-doing”), ${ }^{406}$ etc. This conception of the ruler's authority as "the shadow of God on earth" (zillu Llähi fì l-ardi) refers to a famous hadīth and is not specific to the Almohads. ${ }^{407}$ Chancellery documents, however, play on the confusion between the "shadow of God" and that of power. Thus, most of the occurrences refer to the shadow of God - the shadow of His mercy, of His favors, of His goodness... - but some also refer to the ruler, as in taqdim 33 : "the shadow of the authority of the Presence" (zill iyālati l-hadra). ${ }^{408}$

This (con)fusion of the earthly and divine levels of authority appears often in Almohad chancellery texts, particularly in the taqūdìm. This excerpt from taqdīm 8 serves as an excellent example:

May God have written for you the righteousness whose fruits you harvest now and in the future (fi hăli-kum wastiqbāli-kum), and [His] uninterrupted protection (wa stidāmat ${ }^{a n} l i-l-{ }^{\prime} a \overline{f i y a}$ ) for the correct actions (sadād a 'māli-kum) you undertake with zeal. Know that our benevolent watch (al-nazar al-jamill) extends over the interests of [our] subjects (mașālih al-ri 'äya) wherever they may be, that it commits to the straight path (al-sunan al-qawim) all that would profit them in this world and the next ( $\operatorname{din}^{a n} w a$ $d u n y^{a n}$ ) and that it welcomes them with justice and the favor of this power ( $\min$ 'adli hadha l-amri wa fadli-hi) under the expanse of its shadow (al-zill al-madìd) and its extended wing (wa-l-kanfal-wāsi ). As a result of which, we appoint as governor among you one who will improve your situation... ${ }^{409}$

This passage juxtaposes and thus brings together ruler and God by juxtaposing the prayer addressed to God and the captatio benevolentice in favor of the ruler. Parallel rhetorical constructions and semantic equivalents reinforce this effect. The binomial dīn ${ }^{a n}$ wa duny" ("in

\footnotetext{
403 Taqādīm 20 and 32.

404 Taqādīm 9, 10, 12, 14, 17, 28, 30 and 47.

405 Taqādīm 13, 22, 49 and 66.

406 Taqādīm 16 and 30.

407 A. LAMBTON, State and government, 126 and 140.

408 Taqdīm 33.

409 Taqdīm 8, fo 10v, p. 18, I. 14-18.
} 
this world and the next" $)^{410}$ corresponds with the divinely oriented fi hăli-kum wa stiqbāli-kum ("in the present and in the future"). ${ }^{411}$ In addition, the straight path (istiqāma) invoked in the prayer to God is repeated in regards to the ruler with the adjective qawim ("straight") from the same root QWM. This act of appointment appears as the necessary consequence (wa bimuqtadá dhali-kum) of the suitability between God and the "reality" (wa an ta lamū) of the sovereign power.

These remarks follow the numismatics analyses developed by Miguel and Salvador Vega Martín with Manuel C. Feria García concerning the term $a m r^{412}$ They note that the simplification of Almohad monetary inscriptions as compared to Umayyad, Abbassid, and Almoravid coins, namely the disappearance of the date, mint, and name of the official responsible, accompanies linguistic changes without precedent in al-Andalus and the Maghrib. ${ }^{413}$ The legends on the obverse and reverse sides of dirhams show a high degree of elaboration based on symmetry, parallelisms, repetitions, and gradations. ${ }^{414}$ The term amr, "thing" or "matter/affair", takes on an almost messianic dimension for the Almohads. ${ }^{415}$ Thus, when Almohad sources mention al-amr al-'aliy, ${ }^{416}$ they are designating the "elevated Enterprise", the "victorious plan", which is the Almohad state and its mission. The amr was originally the Mahdī Ibn Tūmart's individual undertaking or enterprise which became the Almohad cause. This origin moment is designated by the terms awwal hadha l-amr ("the beginning of this enterprise"). The identity of the divine amr and the "glorious" Almohad power (al-amr al- 'azìm) is explicit in a victory announcement from the first imperial period:

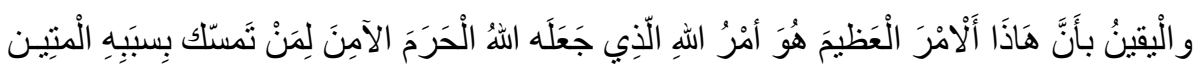

"Know that this glorious power is the power of God, that He has made it an inviolable sanctuary for he who clings to His solid rope." ${ }^{117}$

\footnotetext{
410 Lit. "religiously and secularly".

411 Lit. "in your present and in your future".

412 See M. and S. VeGA MARTín and M. C. FeriA GARCÍA, El mensaje de las monedas almohades.

$413 \mathrm{M}$. and S. VeGa MARTín and M. C. FERIA García, El mensaje de las monedas almohades, 36.

${ }^{414}$ Six nominal phrases are symmetrically organized in two series of three. They all refer to notions of mandate, power, or empire: Allāhu rabbu-nā, Muhammadun rasūlu-nā, al-Mahdiyyu imāmu-nā d'un côté, lā ilāha illā Llāh, al-amru kullu-hu li-Llāhi, lā quwwatu illā bi-Llāhi (Koran 3:154: "Say thou: 'Indeed, this affair is wholly God's"').

415 Taqādīm 2, fo 4r, p. 5, I. 14, 3, fo 4r, p. 5, I. 21, 4, fo 5r, p. 7, I. 21 (amri-hi al-a lá), 5, fo 5r, p. 7, I. 21, 7 , fo $10 \mathrm{v}$, p. 18, I. $1,8, f^{\circ} 10 \mathrm{v}$, p. 18, I. 17 and $10, f^{\circ} 12$ r, p. 21, I. $19 \ldots$

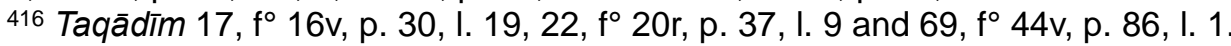

417 AL-BALAWİ, al- 'ațā' al-jazīl, fo 4 , I. 16 of the manuscript 6148 annexes. NLA, 30, 144-149: letter written by Abū al-Hakam Ibn 'Abd al- 'Azīz Ibn al-Murkhī concerning the conquest of Gafsa.
} 
Thirteenth-century Almohad taqādim thus continue perfectly the futūhāt ("victory announcements") of the twelfth century, and confirm the findings of Vega Martín and Feria García, as shown by the frequent use of certain terms: sābiqa, pl. sawābiq ("the precedent"), ${ }^{418}$ da'wa ("Cause"), ${ }^{419}$ or madhhab ("school", "current"). ${ }^{420}$ The correct order of things established for worldly affairs is identified with the divine will and plan, while the correct order of things as an expression of divine will likewise is identified with the Almohad movement. The kuttāb who wrote these acts often played on the ambiguity of the pronouns so that it is unclear whether they are referring to the Power/Order/Plan of God (amr Allāh) or of the Almohad caliph (hadha l-amr al-'aliy, al-'āzìm...). The Koran-inspired inscription al-amru kullu-hu li-Llāhi on coins is at the heart of the Almohad political message and, as al-qä'imu biamri Llāhit ${ }^{421}$ also belongs to the Mahdi religious repertoire, becomes one of the foundations of the legitimacy of all the Almohad caliphs. ${ }^{422}$ This is probably why taqdim 54, written for the violently anti-Almohad Ibn Hūd al-Mutawakkil uses this expression in regards to the Abbasid caliph in Baghdad, contesting its usage by the Almohad caliphs. ${ }^{423}$

\section{Al-nazar al-jamīl or the ruler's "benevolence"}

The various terms mentioned, which appear in all of the Almohad chancellery documents, are closely associated with the Mu'minid exercise of power. The taqādìm have their own specificity in this regard: the systematic presence of the term nazar, whose root refers to watching, jurisdiction, authority, and sovereignty. It is often associated with the adjective jamill: al-nazar al-jamīl, which we have translated as "benevolence" or "benevolent watch" depending on the context. Alternately, the verb is used in the first person plural, the "royal we": nanzuru l-bilād (or li-l-bilād) al-nazar al-ladhī...: "we watch over the land with a gaze (watch) that is..." This notion of omnipresence is often associated with the terms i tinā' or 'ināya ("care, attention"), referring to the regime's benevolence, forbearance, and care for the provinces and its subjects. Sadād ("uprightness", "right direction") is sometimes also used, referring to the ruler's justice and sound administration and rightful direction.

\footnotetext{
${ }^{418}$ AL-BALAWĪ, al- 'ațā' al-jazīl, fo 4 , I. 16 of the manuscript 6148 annexes. NLA, 30, 144-149: letter written by Abū al-Hakam Ibn 'Abd al- 'Azīz Ibn al-Murkhī concerning the conquest of Gafsa.

${ }^{419}$ Da wat al-tawhīd (taqādīm 1, fo 2v, p. 2, I. 6), al-da wat al-tawhīdiyya (12, fo 13v, p. 24, I. 4), da wat al-haqq $\left(21, f^{\circ} 19 \mathrm{v}\right.$, p. 36, I. 18), da ati-nā (6, fo 8r, p. 13, I. 16, fo 9r, p. 15, I. 15 ; 36, fo 26v, p. 50, I. 5 ; $39, f^{\circ} 27$ v, p. 52 , I. $16 ; 40$, fo 28 r, p. 53 , I. $10 ; 47$, fo 31 r, p. 59 , I. 4).

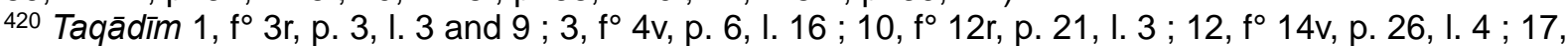
$f^{\circ} 16$ v, p. 30 , l. $10 ; 36$, fo 26 v, p. 50 , I. $14 ; 49$, fo 32 r, p. 61 , I. $12 ; 76$, fo 48 r, p. 92 , I. 18.

${ }^{421}$ Taqdīm 6, fo 7v, p. 12, I. 22.

422 M. \& S. Vega MARTín and M. C. Feria García, El mensaje de las monedas almohades, 201.

${ }^{423}$ Taqdīm 54, f० $35 \mathrm{v}$, p. 68, I. 4.
} 
Caliphal authority was thus based on the rightful direction in which it guides those under its benevolent watch. Al-sabill, the "path", its plural, al-subul, ${ }^{424}$ or al-sunan, is the most frequently used term, as in the Koran, most often associated with sawiy, sadīd or sadād rather than mustaqìm, to express rightful direction. Moreover, the expression al-șirāt al-mustaqìm ("the straight path") appears only once throughout the taqādim, in taqdìm 6 from the caliph alMurtaḍa to the authorities in Ceuta within a citation of the Surat Yūnus, verse 25: "He renders between His subjects judgments to which submit the governors and the governed and ' $\mathrm{He}$ guides whom He wills to a straight path'." The only other occurrence of șirāt is in the continuation of this taqdīm and comes from the Surat al-Shūrā, verse 53: "We can neither turn away nor stray from 'the path of God, to whom belongs whatsoever is in the heavens and whatsoever is on the earth. Do all things not come to God?" 425 These two citations together place in parallel the authority and power of God and those of the ruler: the caliph's power derives from the hukm of God, an instrument with which he guides the rulers and the ruled along the straight path that leads to Him. The second passage, which Jacques Berque claims is "decidedly theological", refers to the revelation and rather ambiguously designates God's guide for the human race, perhaps the archangel Gabriel according to some interpretations. ${ }^{426}$ In the Almohad context, however, with a Mahdī as the founder, and an imām as the ruler, this citation creates a direct link between God and the ruling dynasty.

\section{The relationship with God and the Revelation}

Many of the passages insist on the intermediary function served by the ruler between God and his subjects. This appears most frequently in the prayers addressed to God in the preamble and final protocol on behalf of the addressees:

May God have written for you to follow your predecessors in the party of Unicity (tawhìd) and to gather yourselves to win even more religious and temporal favors... Know that the best thing to bring you an improvement in your situation (...) in the present and future, is for you to follow the paths of this authority of which (...) are evident. Thus, we preserve for you the favors of God on High and wish that He grant you shares of His generous beneficence. ${ }^{427}$

Prayers for the improvement of their subjects' situation, invocations so that God will guide them along the right path and on the straight road of obedience to the ruler, consulting

${ }^{424}$ It appears 176 times in the Koran (M. A. AmIR-MoEZZI (dir.), Dictionnaire du Coran, s. v. "Ṣirāț", 840842).

${ }^{425}$ Taqdīm 6, fo $7 \mathrm{v}$, p. 12, I. 8 to 12.

$426 \mathrm{~J}$. Berque, Le Coran, 526.

427 Taqdïm 3, fo 4 r, p. 5, I. 19-f 4 v, p. 6, I. 3. 
God before choosing officials, ${ }^{428}$ as well as promises in the final protocol, ${ }^{429}$ though all classically present in chancellery documents across the medieval Muslim world, are treated among the Almohads in a way to confound divine will and ruling decision, God's Plan and the caliph's projects, religion of truth and faithfulness to the Almohad rulers. In our translation, moreover, the passage from the subjunctive ("May God have written for you") to the future (“And $\mathrm{He}$, may $\mathrm{He}$ be glorified, He will allow you to know/He will guide you/He will grant you/He will make you happy/...") is meant to communicate the change in tenses in the Arabic, from the accomplished (kataba) to the yet to happen (yu 'arrifu-kum, yujrì-kum, yus idu-kum, yumahhidu jawānibi-kum...). In this discourse, the caliph's decision, appointing a qualified official to whom obedience is due, assures the passage from the initial prayer to the final promise. In the end, and in the administrative discourse, God's attitude towards the faithful is determined by the justice of the Almohad ruler's decisions. God is of course the beginning and end of all things, but at the same time, in the textual logic of the taqdìm, the caliph's mediation - the benevolence of his watch, the choice and selection of the perfect official, advice and orders - assures that, as hypothetical and desirable as they were at first, divine rewards become reality in the end. ${ }^{430}$ In addition, by identifying the divine $a m r$ and the Almohad $a m r$, the Empire's theologians placed the caliph's decisions on the same level as divine Law.

\section{Relations with the servants of the State}

Almohad authority is thus revealed through these acts of appointment, in the motives for the choice of officials, in the advice and orders given them, and the qualities required. The construction of the taqādim themselves, and the articulations between the different parts reveal the nature of power for the rulers of the dynasty. The appointment (qaddamnā), designation ('ayyannā), or the choice (ikhtarnā) appear as the logical and necessary consequence of the preamble whose characteristics we have shown: a prayer to God and care for the subjects' interests. The connection between these two parts is made by the different expressions that each

${ }^{428}$ Ba 'da stikhārati Llāhi, "after having asked the help of God": taqādīm 9, fo $11 \mathrm{v}$, p. 20, I. 3 ; 28, fo 22v, p. 42 , I. 14 ; 32 , fo 25 r, p. 47 , I. 9 ; 46 , fo 30 v, p. 58 , I. 3 ; 48, fo 31 v, p. 60 , I. 5 ; 49, fo 32 r, p. 61, I. 14 ; 69, $f^{\circ} 44$ v, p. 86 , I. $2 ; 74, f^{\circ} 47$ r, p. 90 , I. 9 and $77, f^{\circ} 48 v$, p. 93 , I. 22.

${ }^{429}$ They are introduced by wa huwa subhāna-hu ("And He - May He be glorified") and announce the just rewards deserved by those who in obeying the official, and through him the ruler's choice, submit to the divine will.

430 This analysis may seem exaggerated since the same structure is found in the acts issued by the chancellery of the violently anti-Almohad Ibn Hūd al-Mutawakkil $(5,30,54$, and 55), but it is not impossible that a significant element in the Almohad context became a routine chancellery practice and lost its original meaning. Only a comparison with earlier appointment acts, from the Almoravids, for example, would shed light on this gradation between prayer/desire in the beginning, expressed as accomplished, and the final promise, as to be accomplished which is specifically Almohad. 
insist on the causal link justified by the description of the merits of the appointee (wa huwa: "he is..."). ${ }^{431}$ Finally, a gubernatorial designation is the convergence of three movements each with the ruling power at its heart: firstly, closely tied to the material act of appointment by repeating the same verb, kataba, successively in the first person plural - the royal we -, then the third person singular, ${ }^{432}$ the ruler's wish that God favor the subjects and their region, next the fact ( wa an ta 'lamu $)$ that he dedicates his entire attention to them, and finally that he chooses from among the best of his servants.

The second major part of the act is built around another relation of necessity: first, introduced by wa qad, the ruler's injunctions, advice, and orders for the appointee, ${ }^{433}$ next the subjects' obedience, presented as the logical consequence of the preceding elements, through the phrase fa-idhāi ("Thus, when...") in fa-idhā wäfā-kum ("Thus, when he arrives among you..."). The ruler mediates between his subjects and God through his prayers; through the conformity of his objectives with divine plans, he incarnates an authority that none can contest without being accused of impiety; through the justice of this choice and the quality of his orders and advice for those he chooses, he imposes himself as the only and best guide possible. His subjects' obedience thus flows with a kind of logical reason, a rationalization of caliphal authority on earth, and a prelude to life in the hereafter. This omnipresence of the future life, as a horizon for caliphal decisions and the necessary obedience, agrees with the eschatological aspects of the Almohad movement in the beginning. The binomial "life on earth/life in the hereafter", "present/future" appears in almost every taqdìm, in various forms: hạa $l^{a n}$ wa stiqbālan ${ }^{434}$ fì hạali-kum wa stiqbāli-kum, ${ }^{435}$ fì 'ājili-kum wa ma'āli-kum, ${ }^{436}$ fì l-ḥāli wa-lmuntazar, ${ }^{437}$ li-ḥāli wa-l-ma'āl, ${ }^{438}$ fì l-ḥāli wa-l-mustaqbal, ${ }^{439}$ fì hạli-kum wa ma'āli-kum, ${ }^{440}$

\footnotetext{
431 wa bi-muqtaḍa dhalika, wa bi-mūjibi hadha l-qasḍ, wa li-dhali-kum, wa bi-hadha l-i tibār ("this is why...", "as a result...", "because of the demands of [our] will...").

432 Wa in-nā katabnā-hu kataba Allāhu la-kum: "This is what we write - May God have written for you...". 433 wa qad amarnā-hu, wașșaynā-hu, alzamnā-hu, awza 'nā-hu, aw'aznā-hu, akkadnā 'alay-hi...

434 Taqādim 1, f ${ }^{\circ} 3$ r, p. 3, I. 21 and 73, fo 46v, p. 89, I. 12.

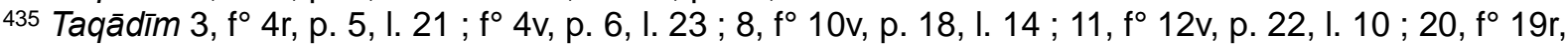
p. 35 , I. $22 ; 26$, f 22 r, p. 41 , I. 6 ; 27 , fo 22 v, p. 42 , I. 5 and 72 , fo 46 v, p. 89 , I. 4.

436 Taqādìm n ${ }^{\circ} 7$, fo $^{\circ} 10 \mathrm{v}$, p. 18, I. 13 and 12, f० 14 r, p. 25, I. 5.

437 Taqdīm 2, fo 4 r, p. 5, I. 10.

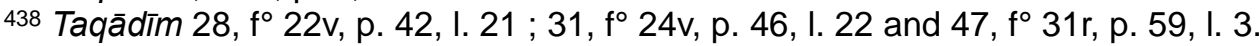

439 Taqdim 71, f० 45 r, p. 87, l. 15.

440 Taqādīm 42, fo 29r, p. 55, I. 17 and 74, fo 47r, p. 90, I. 8.
} 
fì l- 'ājili wa-l-'ājil, ${ }^{441}$ fì l-ūlá wa-l-ukhrá, ${ }^{442}$ al-dunya wa-l-dīn, ${ }^{443}$ ma 'āshi-kum wa ma 'ädikum..$^{444}$

The appointment of provincial officials is thus not a simple administrative measure, but an act that implicates the regime's subjects for the hereafter. Because Almohad power (al-amr al-'aliy) is cofounded with the divine Plan (amr Alläh) that even the least decision in the here below becomes a promise of rewards in the next life. We can understand then that in these conditions the state's choice of regional servants was the object of so much attention on the part of the central administration and the caliph.

\section{PROVINCIAL RELAYS}

Provincial administration, unlike its central counterpart was not created ex nihilo, but inherited the precedents of its Umayyad, taifal, Hammādid, Zirid, and especially Almoravid predecessors. At the beginning of the Empire, this administration relied on the local scholarly elite, especially in al-Andalus, where an elaborate juridical, literary, and administrative tradition had developed in the framework of the emirate and even more so under the Umayyad caliphate of Cordova. This Cordovan tradition was not lost during the taifa period, but in fact spread to every one of the cities of al-Andalus that aspired to independence by becoming the new Cordova. The Almoravid conquests had allowed this tradition to survive within a decentralized state where the governmental system relied on the provincial administrations and on the world of scholars. ${ }^{445}$ The Almohads themselves also benefited from the know-how of local elites in relying on previously existing structures and personnel in regions they conquered. However, for our period, from the end of al-Mustanșir's reign to al-Wāthiq's (1224-1269), after more than seven decades of Almohad reforms, especially under the aegis of the first four caliphs, the provincial administrations were profoundly "Almohadized" and owed little to the previous periods, especially considering the reduction in effectively held territory.

The taqädim use the term khidma (pl. khidam), the "service", the designate the provincial personnel and the functions it exercised. While the khihmatu l-sultān is a classic enough expression in sources from the period, the Almohad administrative acts never use the

441 Taqādīm 1, fo 3r, p. 3, l. 14 and 66, f० 42v, p. 82, I. 12.

442 Taqādīm 6, f० 8r, p. 13, l. 23 and 43, f० 29v, p. 56, I. 1.

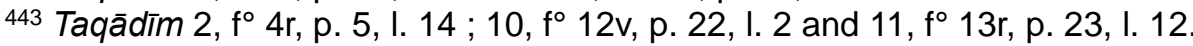

444 Taqdīm 20, fo 19r, p. 35, I. 12.

445 On decentralization during the Almoravid period, see P. BURESI, "Administration territoriale d'alAndalus." 
term; they instead use the possessive "our" (khidmatunā), in a logical abstraction of power: the service is the ruler's, and through him, God's.

a. The regional representatives of the ruling power: order and taxation

In his Musulmans de Valence, Guichard claims that "institutional uniformity makes the absence of information specifically on this region or that less regrettable for historians." ${ }^{246}$ This is without question. However, the taqādim of manuscript 4752 reveal that this institutional uniformity is not the same as that traditionally described as much in the political treatises and chronicles of the first Islamic centuries as in historical works from our own time that simply reproduce the image drawn by the Muslim sources. Yet, these same sources often tried to create order in the diversity of local situations. Faced with the fragmented local forms and the multitude of terms specific to each region and period, the authors of the eighth to eleventh centuries forcibly erased the informal character of the original structures, giving them a coherence and unity that they clearly did not have. In doing so, and through the narrative organization of this initial disorder, they contributed to the development of the myth of the prophetic or divine origin of all the political and administrative structures of the Muslim world, as well as the myth of the unity of the prophetic model and of the later and regional decline of the Prophet's message. The taqādìm do not allow us to put an end to the imprecise terminology that affects each of the administrative domains and hierarchical levels, but they do contradict certain ideas spread by modern historians based on the narrative sources.

\section{The diversity of titles and functions}

A number of different terms were used to designate appointees in the taqādìm. Yahyá al-Khadhūj distinguishes governors (wūlāt) and military leaders (quwwād) from judges $(q u d \bar{a} t) .{ }^{447}$ However, many other terms also appear, in particular in the titles of the taqãdim, though it is not clear whether they are the work of Yahyá or the collection's later editor. Of the first forty-eight acts in the manuscript, those that do not concern judges, twenty-two more or less explicitly mention the title of the office in question, though this seems sometimes to designate more the capacity of the person appointed rather than the charge with which they were invested (talaba, shaykh). Certain titles do not carry a title with a precise office, but do

446 P. GUICHARD, Les musulmans de Valence, t. 2, 313.

447 fo 5 r, p. 7, I. 3-9. 
specify “On the same subject” (fì l-ma 'ná, fi ma 'ná, fì dhalika l-ma 'ná, w'äkhar fì ma 'nā-hu), introducing taquadim 19, 25, 29, 31, 40, and 48, and so indicate the title of the office in question:

— qā'id 'alá l-ustul ("leader of the fleet, admiral”): 2

- wālì ("governor"): 3, 4, 36, and 37

— qā'id 'askar ("head of the army"): 21

— 'ámil ("agent", in fact the equivalent of "governor"): 7, 14, 16, 17, 18, and $43[6,15$, and 19]

— nāzir fì l-majbá ("person responsible for taxes"): 17 and 42

- 'alá ashghāl al-makhzan ("official in charge of Treaury affairs"): 46

— talaba ("Scholar"): 13

— shaykh: 38 and 39 [40]

Titles that sometimes appear in the body of the taqāìm can likewise complete this classification:

- wālì, pl. wūlāt and wilāya ("governor"): 6, 10, 18, 20, 21, 22, and 36

— 'àmil, pl. 'ummāl ("governor, collector"): 20

— mushtaghil ("employee"): 19 and 20

— hâfiz ("Guardian”): 10

- shaykh: 3, 4, 16, 17, and 43

The terms shaykh, hăfiz ("Guardian"), and țalaba ("Scholar") do not designate an office or function, but a title, except perhaps for the Arab tribes (taqādim 38-41). The title of the taqdim indicates then the specific character of the appointee and not their new responsibilities. The titles within the text of the taqādim do not correspond with the introductory title in at least two cases. Taqdìm 18 mentions a wälì, while the title indicates an 'ämil, as in taqdìm 19, which mentions a mushtaghil. The titles of taqādìm 7 and 16 ("Appointment of another 'àmil", taqdìm 'àmil ākhar) indicates the previous texts likewise concerns an 'amil, yet in both cases the preceding figure was a $w \bar{a} l \bar{l}$, the importance of one of whom is shown by his place as governor of Ceuta under al- 'Azafì. Finally, taqdìm 21 carries the title taqdìm qā'id 'askar and de facto the body of the act carries the phrase "we have chosen him to command the armies" (ikhtârnāhu li-qawdi l- 'asākir). However, the final section designates this official as a wālī: "Thus, when you receive our letter, act with your venerated governor as one hand united for all of your 
interests." 448 We will need to examine the clauses listing the precise attributions for these appointees, as well as the ruler's orders, to determine whether the terms 'ammil, wāli $q \bar{a}$ 'id, mushtaghil, and nāzir refer to specific administrative, civil, or military responsibilities.

\section{Financial and fiscal functions}

The taqādim employ a number of terms in reference to taxes. There are first of all the classic terms a 'māl..., ashghāl... or umūr al-makhzaniyya, translated as "fiscal questions" or "financial matters" depending on the context. ${ }^{449}$ This expression is however often completed with the $a^{\prime} m \bar{a} l . . ., u m \bar{u} r \ldots$ or ashghäl al-mașlahiyya, though the difference between the two is not clear. ${ }^{450}$ The first expression explicitly refers to the makhzan, that is the fiscal administration or Treasury. The second, however, designates the "interests" (mașlāh, pl. mașāliḥ) of the subjects and regions. We have then chosen to translate this expression with "economic affairs", everything which would allow the subjects to profit as much as possible from their activities.

The term ishrâf appears only once throughout the taqādim, though it is associated with itțilā 'i-kum 'alay-ha ("your vigilance over [the land]") and after the ashghāl of the land had been entrusted to local officials who had not traveled from al-Andalus but were represented by emissaries. This act is not characteristic of the Almohad period, during which the caliph always reserved appointments and dismissals for himself and never delegated his power. Here, however, we have in fact a delegation of power, the recognition of an authority already in place (Seville, Granada?), perhaps under al-Rashīd. ${ }^{451}$ Though it was a caliphal prerogative, and had never before been delegated, the recognized authorities thus officially receive the right to make appointments to the offices of "Guardian" (hăfiz), judge, and governor/collector ( 'āmil). ${ }^{452}$ This represents an adaptation to the difficulties experienced by the Empire in thirteenth century. The

\footnotetext{
448 Taqdīm 21, fo 19v, p. 36, I. 20: fā-idhā wāfā-kum kitābu-nā fa-kūnū ma a wālī-kum al-mukarrami fí Imașāliḥi kulli-hā ka-l-yadi al-wāhidati.

449 In the part where he suggests that the abstract acceptation of the term makhzan would diffuse throughout alAndalus and in the Maghrib beginning in the twelfth century to express the state's power parallel to the growing personalization of the term sultān. Guichard gives the translation "administrative affairs" for a māl almakhzaniyya (P. Guichard, Les musulmans de Valence, t. 2, 290) and Huici Miranda "administrative activities" for ashghāl al-makhzaniyya (Ibn Șāhịib al-Șalā, al-Mann bi-l-imāma, 207/51). The frequent mention of tax collection in the taquadìm referring to the a $m \bar{a} l$, umūr or ashghal, al-makhzaniyya leads us to prefer the choice of a translation that evokes a more precise administrative section: the collection of customs and taxes, without that necessarily invalidating the above ideas on the growing abstraction of the term makhzan, the collection of canonical taxes constituting, next to the other symbolic elements ( $k h u t b a, s i k k a)$, the recognition of a superior authority of caliphal nature. We can also wonder whether the caliph in Marrakesh received some part of the taxes collected in al-Andalus at this late date.

450 Taqādīm 7-12, 16, 25, 37, 43 and 48.

451 Taqdìm 1, fo 2v, p. 2, I. 21.

452 fo 2 v, p. 3, I. 23.
} 
term ishrāf is thus much more general than ashghāl al-makhzaniyya and designates the fiscal and economic "guardianship" of the land.

\section{Terminological imprecision: wūlāt, 'ummāal, nāasir and mushtaghil}

Of the five occurrences where the appointee's exact title is given, three are 'ummāl $\bar{a}{ }^{453}$ charged with mașlahiyya and makhzaniyya functions, and two are wūlāt. ${ }^{454}$ There does not seem to be any major difference between the two titles, since they have the same attributes. Yet, in his study on the Almohad administrative system, Mūsá claims that in the provinces the fiscal administration did not come under the governor but was tied directly to the state fiscal administration in the capital. According to the chronicles he used, in particular Ibn Șāhib alȘalā's Mann bi-l-imāma and Ibn 'Idhārī's Bayān, each province had a wālī and an 'āmil. The Almohads had thus reproduced this central administrative division on a regional scale. ${ }^{455}$

In addition, Mūsá distinguishes the șăḥib al-ashghāl, the official responsible for finances in the capital, and the șạhib al-a 'māl, the financial official in each provincial governorate, and questions the role of the mushrif. The office of $i s h r a \bar{f}$ had been present in alAndalus since the Cordovan Umayyad Caliphate, and had continued under the taifas. ${ }^{456}$ It did not appear in the Maghrib al-Aqșá until the end of the Almoravid period, and only in certain governorates. ${ }^{457}$ Its appearance in the Almohad capital dates from the reign of 'Abd alMu'min's sons and the reign of al-Rashīd, when the caliphs employed a mushrif in addition to the șăhib al-ashghāl. ${ }^{458}$ The existing mushrifs in the provinces, on the other hand, were confirmed by 'Abd al-Mu'min at the time of the conquests. ${ }^{459}$ In addition, both a mushrif and an 'âmil were present in a certain number of villages, namely Sijilmāssa, Tlemcen, Fez,

\footnotetext{
453 Taqādīm 7, 16 and 43.

454 Taqādīm 10 and 37.

${ }^{455}$ Mūsá has suggested that under the two first caliphs the vizier was responsible for the financial administration of the State. Under al-Manșūr, Abū Zayd b. Yujān was named at the head of the "ashghāl of the two shores" in 593/1197. A new office dated from this period, the șāhib al-ashghāl who served under all the later caliphs. Mūsá claims, with prudence, that this title may have been created by the Almohads, since it does not appear in any other State structure before, neither in the Maghrib, al-Andalus, nor Mashriq. Mūsá thinks that this office, for which there was only ever one appointee at a time, chosen among the sons of the shaykhs, concerned only the central administration of the capital. Charged with collecting money, regrouping it, controlling and spending, the șạhib al-ashghāl was named by order of the caliph. He directed the kâtibs who determined the amount of taxes, and showed the list to the caliph who would then sign it. The sources cited in this note come from the presentation of the Almohad makhzan in 'I. al-D. MūsÁ, al-Muwaḥhidūn fì l-Gharb al-islāmī, 168-170.

456 J. F. P. HOPKINS, Medieval Muslim Government, 51.

457 DIHA, 101.

458 'I. al-D. MūsÁ, al-Muwahhidūn fĩ l-Gharb al-islāmī, 172.

459 Especially Ibn Khayr al-Jayānī, mushrif of Fès according to Akhbār al-Mahdī (DIHA, 102)
} 
Meknes, Tāzā, Bougie, Seville, Murcia, Granada, Azemmūr, and Minorca, as well as in Ifrīqiya. In al-Andalus, before the Almohads, this person was responsible for collecting fees required for armament costs. ${ }^{460}$

This is not the situation described by the taqādìm in Yahyá al-Khadhūj's collection. The term mushrif does not appear. The ishräf does not seem to have been a specifically defined function and the attributions of this official in al-Andalus were carried out by the 'ummāl or wūlāt. The imprecisions in Ibn 'Idhārī's Bayān, moreover, lead Mūsá to conclude that "sources from the Marinid period sometimes confound 'àmil and $w \bar{a} l \bar{l}$, calling the latter 'amil or the reverse." In particular, the Bayān designates as 'ämil of Fez and of Meknes two "governors" previously called wāt $\bar{l}$. This imprecision does not stop there, since Ibn 'Idhārī calls 'āmil a mushrif, a șạhib al-madīa, a khāzin al-mal, and a hăzin al-ța 'àm. ${ }^{461}$ This does not seem the result of any confusion specific to later authors, but comes more from the generic character of the term 'ämil ("agent"), while the wāli exercised an important, non-specialized function.

Finally, whether he was an "agent" ( 'ämil) or "governor" (wāll $)$, the appointee did not carry a title that reflected exactly a certain number of his specific attributions. The taxonomic temptation seems indeed to be a modern anachronism. The fact that medieval authors, such as Yahyyá al-Khadhūj, kātib and author from the end of the Almohad period, Ibn Șāhị al-Ṣalā, or Ibn 'Idhārī use one term or another seems to prove that there was no natural distinction between the two, and indicates the relatively informal character of political and administrative offices during the medieval period in many parts of the Muslim world. This does not necessarily exclude the possibility, one which does not in fact contradict what has just been said, that between the 1220s and the end of the 1260s, the Almohad Empire was a shadow of its former self and the management of those rare and territorially limited regions still under their control required neither numerous nor specialized personnel.

\section{The attributions}

The sections of the taqadìm that contain the ruler's specific orders for the appointee attribute to the governors ( $u m m \bar{a} l$ or wūlat) a number of different tasks: ${ }^{462}$ collect in full taxes, do not favor the rich over the poor, pacify the region, assure security, fight against evil (alshirr), hypocrisy (al-nifāq), corruption (al-fasād wa l-mufsidīn), aberration (al-ghayy), violence (al- 'inād wa l- 'ànidìn), rebellion (al-baghiy), maleficence (al-ḍirar)... Taqādìm 9 and 20

460 'I. al-D. MūsÁ, al-Muwaḥhidūn fî l-Gharb al-islāmī, 172.

${ }^{461}$ For references to the source, see 'I. al-D. MūsÁ, al-Muwahhidūn fĩ l-Gharb al-islāmī, 168.

462 These correspond to the list established by E. MOLINA LÓPEZ, "Economía, propiedad", 213-300. 
mention in particular construction and fortification ( $m a$ ' $\bar{a} q i l)$, the repair of a wall to protect the city. It may be surprising to find alongside strictly fiscal attributions - the complete collection

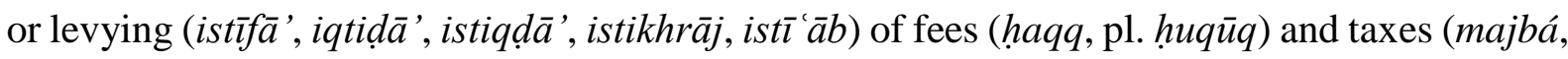
pl. majābi), the collection and conservation (damm, dabț) of surpluses (murtafa'a $\bar{t} t$ ) responsibilities that have nothing to do with taxes. However, as Mūsá reminds us concerning the 'ämil, who acted as șăhib al-makhzan in the provinces, governors were responsible not only for collecting taxes owed to the Treasury, but also for paying the salaries of officials, financing and directing construction and fortification projects, and the repair of routes and bridges.

LEVIES: HAQQ, PL. HUQŪQ, MAJBA, PL.

\section{MAJĀBI AND RUSŪM}

The taqādim do not, of course, provide a detailed description of taxes collected during the Almohad period. Remarks remain general despite the diversity of designations. The different taxes are identified by a number of terms that give the impression of interchangeability, except for rusūm, which we will come to later. Levies are designated as either haqq (pl. huquq), or with the root JBY: majbá (pl. majābī) or jibāya. These terms are sometimes combined with complements (al-makhzaniyya, li-l-makhzan, al-makhzan, al-mukhtaṣs, fì l-amwāl), and appear more than thirty times in the taqādìm from the first part of the collection. Taqdìm 67, a judicial appointment, is an exception wherein the mention of instrumentary witnesses (shuhüd) leads to the mention of their importance in determining fees payable to the state. ${ }^{463}$ This particular case does not seem to refer to a tax, but to a reparation due in connection to a judicial procedure.

The occurrence of rusumm is very interesting. Its appearance in taqdìm 10 does not describe legally recognized taxes, but illicit fees collected in the markets and at city gates. The Guardian ( $h \bar{a} f i z)$ receives the order to "eliminate taxes not authorized by the Law (al-shar ) in the markets and at the gates [of the cities]". ${ }^{464}$ This confirms Guichard's hypothesis in his Les Musulmans de Valence that during the entire time of the Empire, the Almohad caliphs made an effort to collect only Koranic taxes, remaining faithful to one of their principal arguments

463 Taqdim 67, f० 43v, p. 84, I. 5: "that he devote all his attention and thought to the instrumentary witnesses, on whom the decision to confirm or deny rests and with the help of whom payable dues are calculated" (wa an yașrifa ilá l-shuhūdi al-ladhīna 'alay-him madāru al-nafyi wa-l-ithbāti wa bi-him istikhrāju al-ḥuqūqi al-muqtaḍayāti aqwá nażari-hi wa ta'ammuli-hi).

464 Taqdīm 10, fo 12r, p. 21, I. 17-18: mim-mā amarnā bi-hi ḥāfiẓa-kum al-ijtihādu fī [...] maḥqi l-rusūmi al-latī lā yubīhu-hā al-shar'u min al-aswāqi wa-l-abwābi. 
against the Almoravids who had allowed levies over the population to multiply. ${ }^{465}$ Thus, when they came to power, the Almohads suppressed the mucus, maghārim, darā' $i b$, and qabālāt. The fact that Ibn Tūmart's message spoke of Almoravid taxes reveals the religious dimension of the tax system in the medieval Islamic world. ${ }^{466}$ Thus, when 'Abd al-Mu'min attacked Bougie, he sent a letter to the population of Constantine to limit taxes to what the Sunna allowed and to eliminate the maks, maghram, and qabāla. ${ }^{467}$

However, the fact that orders were later giver to lift the rusūm confirms that local authorities sometimes felt at ease to take liberties with the Almohad rulers' announced intentions. Given the territorial extent of the Empire, and the difficulties and slowness of communications, local officials must have often initiated measures contrary to caliphal orders. This led sometimes to their dismissal, when complaints were communicated and made their way to the ruler's ears, and the caliphs had coercive means at their disposal. When this was not the case, such behavior on the part of the governors must have discredited the ruler and his representatives.

Moreover, as Mūsá points out in the lines between religious theory and fiscal practice during the Almohad period, on the one hand there was the Law, shar ${ }^{\top} \bar{l}$, and on the other there was what rulers promoted as being legal. The Koran and the Tradition of the Prophet were recognized sources of the Law, but the imām-Mahdī (later the caliphs-a'imma) was the interpreter of these two legal foundations and his decisions were law. For revenue, the Almohad state thus depended on the zakāt (the legal alms), the 'ushr (the tithe on commercial exchange and on agricultural products), and the khums (fifth) taken from mines and booty. In the provinces, the fiscal administration kuttāb counted the zakāt, the legal alms, among the revenues of the state. ${ }^{468}$ The $q \bar{a} d \bar{l} \bar{s}$, for their part, were charged with collecting the zakāt al-fiț and redistributing it directly among the poor, without first entering it into the Treasury. It is not clear what the tithes ( 'ushür) mentioned in the Almohad letter correspond to, beyond their being a legal tax owed to the state. ${ }^{469}$ Mūsá has suggested a number of hypotheses: a land tax levied on

\footnotetext{
465 In a communiqué sent out in 543/1148 to all the provincial governors, 'Abd al-Mu'min insisted on the elimination of illegal taxes and reveals the ambition of the Almohad "call" ( $d a$ ' $w a$ ) to remain within canonical taxes.

466 See IBN TŨMART, A 'azz mā yuțlab, 261.

467 É. LÉVI-PROVENÇAL, Trente-sept lettres officielles, letter 7, 21-22 ; "Un recueil de lettres", 27-28, NLA 2, $n^{\circ} 17,46-49$.

468 'I. al-D. MūsÁ, al-Muwaḥhidūn fĩ l-Gharb al-islāmī, 279

469 É. LÉVI-PROVENÇAL, Trente-sept lettres officielles, letter 7, 21: wa lā yaltafitūna ilá mā awjaba Llāhu min al-zakawāti wa-l-a shāri.
} 
Muslim lands, a tax on ships leaving ports or on commercial exchange. ${ }^{470}$ Production from mines early on was subject to the khums, "the caliph's due". Revenue from the mines seems to have been an important part of fiscal income for the Almohad state. ${ }^{471}$ During this period, the mines of Sūs, either discovered or taken over by the central power beginning in 578/1182, must have still been used, and the Sūs was one of the rare regions that came under the caliph's direct authority. Lastly, the fifth was also collected on war spoils. During the first Almohad imperial period, the khums was an important resource, including prisoners, cattle, lands, and movable goods, the other four-fifths being divided among combatants after the caliph's share was taken. $^{472}$

'Abd al-Mu'min put the kharāj into place on his return from Tunis in 554/1159. The caliph ordered a land census taken of all the lands of Ifrīqiya and the Maghrib, from Barqa to the bilād Nūn of Sūs al-Aqșá, dividing them by longitude and latitude into farāsikh ("parasang") and amyāl ("miles"). He excluded one-third of the total as "public domain" or non-productive - mountains, rivers, roads... - and charged the mushrif with collecting the kharāj over the rest, thus forcing the population and tribes to pay him from their harvests. ${ }^{473}$ This implies that until then the fiscal systems in place in the different Maghribī lands did not include this tax which was nevertheless a constitutive part of those taxes traditionally considered as "Islamic" and imposed throughout dār al-Islām with few exceptions, like the Arabian peninsula. Indeed, Mūsá notes that before the conquest of Tunis, no tax other than the zakatt and the tithe appears in the sources. After 555/1160, however, the harāj is mentioned as an important revenue for the state. This is another example of the "return" to the fundamental elements of the Muslim doctrine which Almohad policy raised as its standard. ${ }^{474}$

The jizya, or poll tax due by dhimmis, is not mentioned in the sources because the Almohad stopped granting the dhimma ${ }^{475}$ Nevertheless, taqdìm 6, though it does not directly

\footnotetext{
470 'I. al-D. MūsÁ, al-Muwahhidūn fĩ l-Gharb al-islāmī, 281.

471 Abū Ya'qūb Yūsuf (1163-1184) is supposed to have personally gone there and built a fortress to oversee and control production ('I. al-D. MūSÁ, al-Muwaḥhidūn fí l-Gharb al-islāmī, 282).

472 In certain cases, booty was not shared, but was an occasion to create new taxes. For example, after the conquest of Tunis, the inhabitants received the right to remain in their houses in exchange for a tax, which fell on half the houses in the city ('I. al-D. MūsÁ, al-Muwaḥhidūn fí l-Gharb al-islāmī, 283).

473 'I. al-D. MūsÁ, al-Muwahhidūn fî l-Gharb al-islāmī, 283.

474 'I. al-D. MūsÁ, al-Muwaḥhidūn fĩ l-Gharb al-islāmī, 284.

475 'I. al-D. MūsÁ, al-Muwaḥhidūn fî l-Gharb al-islāmī, 280. The Almohad sources' insistence on the suppression of the dhimma under the Mu'minids contributes to the adaptation of the Muhammadan prophetic act and the identification of the movement with the beginnings of Islam and the Arabian peninsula, the only territory in dār al-Islām where the dhimma ceased to be in effect (see M. FIERRO, "Conversion, ancestry and universal religion", 157-160).
} 
mention the dhimma, does refer to the Christians living in Ceuta. ${ }^{476}$ While Ceuta's attachment to the Empire was more nominal than real and the presence of Christian merchants, especially the Genoese, is confirmed by other sources, these Christians must have contributed in one way or another to the provincial or imperial fiscal system and benefited from either an amān or a protection status that resembled the one traditionally enjoyed by the "People of the Book" elsewhere in dār al-Islām.

The notion of dhimma did not disappear from the Almohad political vocabulary, but continued in use perhaps through a semantic evolution or development in the sense of a "pact" passed with the federated peoples or tribes and the Muslims rather than with non-Muslims. We thus read in taqdìm 39, an interesting act that dismisses a son previously appointed to succeed his deceased father, replacing him with his paternal uncle as shaykh of an unnamed Arab tribe: "But among them all, we praise your services and distinguish your pact of alliance (dhimma)." "477 The Almohad da'wa ("call) is mentioned twice in this act, first in the preamble referring to the Arabs in general, ${ }^{478}$ next more specifically in the body in relation to the deceased father's long ties as shaykh with the Almohad government. ${ }^{479}$ This coincidence - mention of the Almohad "call" and the "pact" - indicates that the dhimma had not disappeared under the Almohads, but that its interpretation had considerably changed. It now applied to Muslim populations who were "foreign" to the Maghrib, in fact those Arab tribes who had recently arrived: Banū Sufyān, Banū Khulț, after the Banū Riyāḥ, Banū Sulaym, Banū Hilāl, etc. The term reappears in taqdīm 69 in a judicial appointment:

"This is because you have distinguished yourselves in the Presence of the Almohads by the reports of neighbors whose protection (dhimmatu-hu) has been confirmed and whose clauses (hurmatu-hu) with you have been and continue to be respected." ${ }^{\prime 80}$

The fact that the terms min al-jiwār ("neighboring") were suggested by 'Azzāwī for two illegible words prevents concrete conclusions, but if he is correct, the notion of neighbor or vicinity may also refer to the Arab tribes settled near Marrakesh, such as those who receive, for example, responsibility for $\bar{A} n f \bar{a}$ (Casablanca) in taqdīm $41 .{ }^{481}$

\footnotetext{
476 Taqdīm 6, f० 9v, p. 16, I. 2-3.

477 Taqdīm 39, f $27 \mathrm{v}$, p. 52, I. 18: wa antum fi-him mim-man tushkaru khidmatu-hu wa tulhaẓu dhimmatu-hu.

478 "... Know that the Arabs are known within our cause ( $\left.d a^{\prime} w a\right)$ by the abundance of our favors and the profusion of kindness that their ancestors knew."

479 "You know that Abū Fulān ([always defended?]) the eminent cause (al-da 'wa)."

480 Taqdīm 69, f’ 44r, p. 85, I. 23: dhalikum li-mā tamayyaztum bi-hi li-ḥaḍrati I-muwaḥhidīna mina I-jiwāri al-ladhī ta'akkadat dhimmatu-hu wa ru iyat la-kum qadīm ${ }^{\text {an }}$ wa hadìth ${ }^{\text {an }}$ hurmatu-hu.

481 fo $28 v$, p. 54, I. 13.
} 


\section{The muhtaṣs and specific caliphal domain taxes}

In addition, two documents set apart those taxes that belong to the mukhtașs, or private caliphal domain. The majābī al-makhzan wa l-mukhtaș ${ }^{482}$ or ashghāli-kum al-maṣlahiyya wa a'māl majābì-kum al-muhtașșiyya ${ }^{483}$ apparently designate taxes of a different nature, since they are noted apart from others. The mukhtaș was thus taxed separately from the rest of the territory, though the taqāìm provide no precise information on the subject. The ruler thus collected not only "canonical" taxes, but he also drew revenue from these territories in using their production as he saw fit. This domain seems to have been quite large, since an appointment act for two regional tax officials mention them, and because the revenue figures for these regions provided by the chronicles are quite impressive. The sale of olives produced in the Buhāyra of Marrakesh at the end of the thirteenth century brought in 30,000 dinars per year, those from Meknes, 35,000 per year, and those from Fez, 50,000 per year. ${ }^{484}$ All three of these regions came under the sphere of caliphal dominance in the thirteenth century.

Caliphal revenues were thus not limited to legal taxes, and were completed by other revenues that had nothing to do with taxes traditionally recognized as legal in the Muslim world. Mūsá reminds us also that successfully prosecuted cases against corrupt individuals or rebels led to the confiscation of their goods and the payment of large fines, all of which enlarged the Domain. This serves as an example of innovations allowed by Islamic law, with princely decisions filling in the interstices between the Book and the Tradition, when they did not pronounce on a specific problem or another. Rejecting the works of Maliki jurisprudence served the Almohads well, since it allowed them to remake an important part of the law. Indeed, an entire body of literature exists on rebellion (adab al-baghiy) that seeks to define the right of rebellion and the rights of rebels, as well as regulating the attitude of territorial powers in their regard. By dismissing the juridical validity of this tradition, the Almohad caliphs reserved for themselves the right to interpret as they saw fit and according to their own criteria the silences of the Koran and the Sunna. ${ }^{485}$

\footnotetext{
482 Taqādīm 42.

483 Taqādīm 46.

484 'I. al-D. MūsÁ, al-Muwaḥhidūn fĩ l-Gharb al-islāmī, 286.

485 Khaled Abou El Fadl, in studying the theoretical and practical juridical activity, involvement, and production of premodern jurists, who played a mediating role between the state and the God-fearing masses, has focused on the relationship between the state and the judges and doctors of the Law. He has shown that premodern juridical culture hoped to limit the state's monopoly on the use of force much more than is imagined today. Abou El Fadl has shown how in juridical discourses on rebellion and
} 


\section{Military positions}

The sources, and especially the imposing corpus of tabāqāt, or bio-bibliographical dictionaries, as well as literary anthologies and chronicles, have led many historians to overestimate the importance of individuals who held civil office or exercised juridical-religious, literary, and administrative functions as opposed to those invested with military responsibilities. The taqāìm, however, provide a different view of Almohad society, one that includes the military or "police" organization of the Empire.

The leaders of the army and of war: $q \bar{a}$ 'id, pl. quwwād

Some of the acts in Yahyá al-Hadhūj's collection concern military leaders (qā'id) or individuals with an explicit military role:

- The title of taqdìm 2 announces the appointment of a qā'id 'alá l-usțūl ("military leader at the head of the fleet")

- Taqdim 11 is the "absolute" appointment (taqdim muțlaq) of an official charged with the taxes and interests of the region, the struggle against the party of corruption (ahl al$f a s \bar{a} d)$, and, with the support of the armies (ajnād) of the region and reinforcements to be sent, the preparation of ambuscades against the enemy.

- The title of taqdìm 21 mentions a qā'id 'askar charged in the act with command of the armies (qawd al-'asākir), to lock down the frontiers, and to combat the perfidious enemy (al-'aduww al-ghädir)

- Taqdìm 23 concerns an official accompanied by troops ('asākir):

"Act with him, as with all of his troops, as one hand united to push back the party of revolt and rebellion." $\$ 86$

- Taqdìm 40 is somewhat particular since it places an individual at the head of two armies, one already in place and the second on its way:

"We have named Fulān at the head of the army we have sent you. We have also decided to name him at the head of the first army, so that both armies will fall under his command." 487

robbery, the one justifies the appropriation of goods and the death penalty, while the other implies clemency in the treatment of those found guilty. Remarkably, in the Almohad Empire, this general model does not apply. This confirms the innovative character of Almohad caliphal decisions (K. ABOU EL FADL, Rebellion \& Violence).

486 Taqdīm 23, f ${ }^{\circ}$ 20v, p. 38, I. 14-15: fā-kūnū ma 'a-hu wa ma'a kāffati man laday-hi min al-'asākiri yad an wāḥidatan fì difā 'i ahli l-baghyi wa-l- inādi.

487 Taqdīm 40, fo 28r, p. 53, I. 13-14: fa-innā qaddamnā al-ān Fulānan 'alá al-jayshi l-ladhī ashkhașnā-hu al-ān ilay-kum wa ra'aynā ayọ̣an taqdīma-hu 'alá al-jayshi l-awwali li-yarji a al-jayshān ilá nazari-hi. 
In the preceding examples, the military functions intimated par the term $q \bar{a}$ 'id could allow the translation of "general" for troop command, and "admiral" for the fleet. The only problem is the functional non-specialization of state servants in the medieval Muslims world in general, and in the Almohad Empire in particular. Indeed, of all the persons invested with a military command in the taqāìm, only one seems to have had no other attribution (taqdīm 40). In this case, the appointment concerned the Arab tribes, who appear to have been "selfgoverned", or at least fiscally independent - they received, in fact, probably much more in lands and diverse payments than they rendered to the Treasury through taxes, if they paid any at all and answered to the caliph only to affirm their loyalty and for correlated military activities. Everyone else was also charged with collecting taxes. They were thus "governor-generals" or "governor-admirals" rather than simple military officers.

Nothing specific appears on the composition of the Almohad armies, and the terms employed (ajnād, 'asākir) are too vague to provide any real indications. Except taqdìm 40, which concerns the Arab tribes, the troops mentioned were probably the basic elements of the army levied from the tribal groups: Hargha, Ğadmīwa, Ganfìsa, ahl Tinmāl, and Hintāta to which 'Abd al-Mu'min had joined the Haskūra, Șanhāja, and Kūmya. We can add to this ensemble, which the sources call "the Almohad tribes", the Almoravid tribes who rallied to the cause after 'Alī b. Yūsuf b. Tashfīn's death: the Zanāta and Massūfa, after their scission with the Lamtūna. These troops were called hasham. This policy of integration lasted until the reign of al-Nāșir (1199-1213). Other terms then appear in the chronicles: "the tribes from among the subjects" (qabā'il min al-ra'iyya), the "tribes" (qabā'il), the "tribes of the Maghrib", the "Berber categories" (așnâf al-Barbar). Nothing of the sort, however, appears in the taqādim from the years 1230-1260 during which certain tribes distanced themselves from the Almohad caliphate. Al-Ma'mūn's reign, for example, was difficult for the Hintāta and their shaykhs who were decimated at Marrakesh for their loyalty to the doctrine of the Mahdī Ibn Tūmart's impeccability. The absence of the 'abìd al-makhzan, the blacks and Christian mercenaries who formed the caliph's personal guard, is also not surprising, since they came under the central and not provincial administration. Likewise absent are the Andalusī troops stationed in al-Andalus.

The direction of the fleet: the $q \bar{a}$ 'id $a l-$ usṭūl

Almohad power reposed for a number of years on two complimentary military forces, the army and the fleet. During the mid-thirteenth century, part of the fleet had escaped caliphal 
authority, along with the ports and shipyards that housed them: Badis, Rīf, Mahdīya, Wahrān, 'Annāba, Qādis, Tunis, Bougie, Tangiers, Algeciras, Silves - where there was much wood -, Almería, and Ceuta. These last two had been the home ports for the Almoravid fleet, and Ceuta became under 'Abd al-Mu'min the permanent home for the Almohad fleet.

Picard's detailed and complete work has relieved us of the need to enter into detail concerning the organization of the Almohad fleet. ${ }^{488}$ It should suffice here to recall that through this period more than half the admirals ( $q \bar{a}$ 'id al-ustūul) were shaykhs and a third were not Almohad. Indeed, since the Mahdī Ibn Tūmart's first partisans were mountain dwellers and had no knowledge of the sea, they delegated maritime activities to those with experience - first the Banū Maymūn, then the Banū Mardanīsh (such as Ghānim and Abū al-'Alā) or Abū l- 'Abbās al-Siqillī. ${ }^{489}$ Later, two shaykhs received command of the fleet, one from the council of 50 ( $\mathrm{Abd}$ Allāh b. Sulaymān), the other from the ahl al-dār ('Abd Allāh b. Ishāâ b. Jāmi '). For this entire period, Mūsá has noted one single sayyid as qā'id al-usțūl: Abū l-'Alā Idrīs b. Yūsuf b. 'Abd al-Mu'min under al-Nāșir. ${ }^{490}$ The head of the fleet, who resided in Ceuta, carried the title of

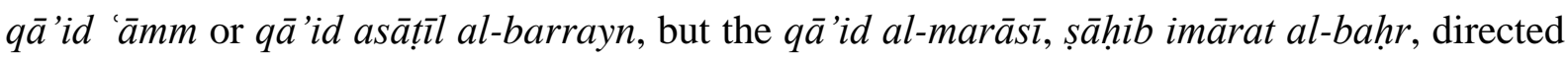
the shipyards and ports. The admiral was independent of the governor of Ceuta, and came directly under the caliph's authority. Each ship was commanded by a Scholar (talaba) or Guardian (hăfiz). ${ }^{491}$

\begin{tabular}{|c|c|c|c|c|}
\hline & Sayyid & Shaykh & Non-Almohads & Total \\
\hline 'Abd al-Mu'min & 1 & 2 & 3 & \\
\hline Yūsuf & 1 & 3 & 4 & 5 \\
\hline Al-Manșūr & & 4 & 1 & 6 \\
\hline Al-Nāșir & 1 & 4 & 1 & 2 \\
\hline 1214-1269 & & 2 & & 20 \\
\hline Total & 1 & 12 & 7 & \\
\hline
\end{tabular}

Table 9: Origin of the heads of the Almohad fleet. ${ }^{492}$

The Almohad navy began to lose power at the beginning of the thirteenth century, ceding the important role it had played in the twelfth, especially in the control of Ifrìqiya under al-

\footnotetext{
488 C. PICARD, La Mer et les musulmans ; L'océan Atlantique musulman ; "Les Arsenaux musulmans" ; "L'échec maritime musulman ?".

489 There is no need to revisit here the history of the Banū Maymūn, the dynasty of admirals under the Almoravids who rapidly rallied to 'Abd al-Mu'min and the Almohads. The subject has been treated thoroughly elsewhere, and is significantly anterior to the period in question here. See P. GUICHARD, Les Musulmans de Valence, t. 2, 323-324 and "Recherche onomastique", 'I. al-D. MūsÁ, al-Muwahhịidūn fĩ lGharb al-islāmī, 265 and C. PICARD, L'Océan atlantique musulman, 505.

490 AL-ḦIMYART̄, Rawọ al-Mi țār, s.v. "Mayūrḳa" (Majorque", ed. 188-191, 189, trans. 228-231, 229, cited by 'I. al-D. MūSÁ, al-Muwaḥhidūn fĩ l-Gharb al-islāmī, 272.

491 'I. al-D. MūsÁ, al-Muwaḥhidūn fî l-Gharb al-islāmī, 272.

492 'I. al-D. MūSÁ, al-Muwaḥhidūn fî l-Gharb al-islāmī, 269.
} 
Manșūr. ${ }^{493}$ During al-Nāṣir's reign, the population of Tripoli had asked the caliph for the fleet's help in defending the city, ${ }^{494}$ but once the Empire began to disintegrate the fleet appeared only twice in the chronicles. ${ }^{495}$ After the loss of al-Andalus and Ifrīqiya, two additional steps in the weakening of the fleet were crossed. The first involved the loss of the shipyards at Ceuta, when the sayyid Abū Mūsá, brother of al-Ma'mūn, rebelled in 629/1232. The second came with the conquest of Bougie by the Hafșids in 627/1230. Al-Ma'mūn's use of the fleet during his siege of Ceuta to counter his brother's rebellion in 628/1230-1231 marks one of the last times the fleet served the caliph. Indeed, the failure of the siege is explained by the fact that the part of the Almohad fleet based in al-Andalus and the Straits passed over to Ibn Hūd al-Mutawakkil who ordered it to supply Ceuta. ${ }^{496}$ In addition, the residents of Ceuta had rented sixteen galleys and five ships from the Genoese to support the siege. ${ }^{497}$ In fact, the caliphal successions, which were particularly numerous in the 1220 s, resulted in a lack of planning or initiatives, which translated into the dismemberment of the fleet. ${ }^{498}$

Ceuta at the time was at the center of Christian-Muslim rivalries, as well as those simply between Muslims. The city's central role in Almohad maritime policy allowed it to remain independent and autonomous as much in regards to the Almohad caliphs as to Hūdid, Hafșid, and even Genoese pretensions. This situation and the presence of the fleet gave the local authorities, such as al-Jusht̄̄, admiral of the fleet for the Hūdids, al-Yanashtī, a rich local merchant, the admiral Abū 1-'Abbās Hajbūn, and especially Abū 1-Qāsim al-'Azafī, an incontestable moral authority and member of one of Ceuta's great families, the ability to assure the city's independence between 1232 and $1270 .{ }^{499}$ Ceuta then was a veritable maritime republic, even if it did recognize caliphal authority during al-Rashīd's reign, before a brief intervention by the Hafṣid Empire and before Abū al-'Abbās al- 'Azafî’s rise to power (12481279), mentioned in taqdīm 6.

493 É. LÉVI-PROVENÇAL, Trente-sept lettres officielles, letter 29, 173-178.

494 É. LÉVI-PROVENÇAL, Trente-sept lettres officielles, letter 37, 255. For more details on these operations, see 'I. al-D. MūSÁ, al-Muwahhhidūn fĩ l-Gharb al-islāmī, 273.

${ }^{495}$ Barcelona defeated the Almohad float in the waters in front of the city and took the fortifications in the region of Valencia ('I. al-D. MūsÁ, al-Muwaḥhidūn fĩ l-Gharb al-is/āmī, 274).

496 C. PICARD, L'océan Atlantique musulman, 174.

497 See H. FERHAT, Sabta, 203-269.

498 The Banū Ghāniya thus took Ifrīqiya and entered Bougie at the time of Abū Ya qūb Yūsuf's death (1184), when the fleet was absent and without leadership. This serves as another example of the concentration of power in the hands of the caliph during the Almohad period. The Almoravid fleet would have lasted much longer, if its many successes from the Balearic Islands are any indication ('I. al-D. MūsÁ, al-Muwahhhidūn fî l-Gharb al-islāmī, 275).

499 See H. Ferhat and M. CheriF, Ceuta, $39 \mathrm{ff}$. 
Taqdim 2 refers then to the last moments of any real caliphal authority over the fleet. The act is particularly interesting for the information it provides beyond that present in the usual chronicles. The document states that the appointee is given responsibility for the fleet and jam $\bar{\imath}^{\circ}$ ashghāl al-bahr ("all maritime affairs"). Later in the document, we learn that these "affairs" include the direction of the dīwān, the mint (sikka), "successions" (mawärìth), and the tithe or legal alms (zakāt). For the particular context of this taqdìm, we have translated dīwān by "customs", because of the taxes collected, rather than "administrative offices":

"the customs office ( $d \bar{\imath} w \bar{a} n$ ) falls under his authority, complemented by the mint, successions, and the tithe." 500

"All of the surplus from customs ( $d \bar{l} w \bar{w} n)$ and annex taxes will be spent in the interests of the fleet and for the pay of its [sailor-]combatants, which will barely suffice to develop it and provide devices. Large or small, [these taxes] will all serve to pay for its supplies and cover expenses for its missions (muhimmātihi). ${ }^{, 501}$

The "admiral" is thus responsible for collecting taxes and using the surplus to improve the fleet and pay sailor-combatants (arzāq al-ghuzāt). ${ }^{502}$ Taqdìm 2 then seems to remove some of the fiscal elements theoretically under the local governor and entrusts them to the $q \bar{a}$ ' $i d$ 'alá $l$-usțūl, like the zakāt or sikka, a royal prerogative that came directly under caliphal authority. This was an exceptional delegation of power due not only to the difficult circumstances afflicting the Empire beginning with al-Mustanșir's reign (1214-1224), especially the pressure brought to bear on the Maghribī and Andalusī coasts by the Christian fleets, but also the precedent established by the "reign" of Abū l- 'Abbās al-Yanashtī.

The exceptional prerogatives of the appointed "official" in taqdim 2 in fact allows us to more precisely date and localize the document's setting. The chronicles inform us that Abu 1'Abbās al-Yanashtī took power in Ceuta after having directed customs and supervised state revenues and the mint (sikka) in the city, this with the support of the local merchant and judicial oligarchy ( $k h \bar{a} s \underline{s} a$ ) that had ousted the Hūdid representative, the Sevillian admiral Abū 1-Aṣbagh al-Jushtī. ${ }^{503}$ Al-Yanashtī was quickly rejected by his peers who did not appreciate his

500 Taqdīm 2, fo 3v, p. 4, I. 16-17: wa min amānati-hi al-dīwānu wa-l-sikkatu wa-l-mawārīthu wa-l-zakātu kamālu-hu.

501 Taqdīm 2, fo 3v, p. 4, I. 20-23: fa-kullu mā yartafi u min majbá al-dīwāni wa mā uḍîfa ilay-hi yutașarrafu fì mașāliḥi I-usțūli wa arzāqi ghuzāti-hi wa yuqșiru 'an iqāmati 'adadi-hi wa ịtlāqi 'âlāti-hi wa yusta ān biqalīili-hi wa kathīri-hi 'alá tawfiyati manāfi i i-hi wa tatmìmi muhimmāti-hi.

502 Picard confirms that in Ceuta during the Almohad period, customs revenues were used to pay recruited sailors, called the ghuzāt al-baḥr (C. PICARD, L'océan Atlantique musulman, 464).

503 IBN 'IDHĀRIT, Bayān, t. 5, 277, and 294. 
unbounded ambitions and so recognized the authority of al-Rashīd (1232-1242). ${ }^{504}$ The similarity between al-Yanashtî's fiscal and monetary attributes and those of the "official" appointed [in taqdìm 2] seems to indicate that the latter was replacing al-Yanashtī; taqdìm 2 thus concerned Ceuta during the reign of al-Rashīd and constitutes an investiture letter for alYanashtî̀'s successor; the caliph al-Rashīd place responsibilities held by al-Yanashtī in the hands of the appointed "official".

Whether this is true or not, the efforts to bring the situation back under control as shown by this taqdim did not prevent the weakening of caliphal authority over the navy. After alRashīd, under his successor Mu'tadid bi-Llāh al-Sa'īd (640/1242-646/1248), the Almohads were without any maritime power and were forced to ask the help of the Sicilian king's fleet to try, in vain, to retake Ifrīqiya from the Hafṣids (645/1247).

\section{The Arab Shaykhs}

The role of the Arab tribes in the Maghrib after the eleventh century is well-known. 'Abd al-Mu'min defeated them at Sétif in 548/1153, and they were integrated into the Almohad army after the conquest of Tunis and Ifrīqiya in 555/1160. 'Abd al-Mu'min used them at first to affirm his power versus the Almohad shaykhs, then on a regular basis in the larger military expeditions within the Empire. For example, in 579/1184, 40,000 Arab horsemen fought alongside Abū Ya 'qūb Yūsuf on his expedition to Santarem. They formed the most important contingents in the Almohad army in Ifrīqiya, in al-Andalus, and in the provinces. However, their tribal organization led the different caliphal candidates during the 1220 s to rely on certain segments to the detriment of others, dividing the bases on which the Empire's military power rested. There were 5,000 Arab horsemen in al-Andalus during al-Marrākushī's reign at the beginning of the thirteenth century. Under al-Rashīd, the Khult Arabs alone counted for 12,000 horsemen, plus foot soldiers. ${ }^{505}$

As under the first caliphs at the end of the twelfth century, the Arabs played a primarily military role in the Almohad political game at the beginning of the thirteenth, as shown in taqādìm 38-41. Under 'Abd al-Mu'min (1130-1163), and especially his son Abū Ya 'qūb Yūsuf (1163-1184), beginning with the first victories against the Arabs of Ifrīqiya and their subsequent integration into the Almohad political and military system, the Arab shaykhs intervened in the most of the military operations in the Maghrib and al-Andalus, and their counsel was solicited

\footnotetext{
504 H. FERHAT, Sabta, 213-219.

505 'I. al-D. MūsÁ, al-Muwaḥhiidūn fĩ l-Gharb al-islāmī, 224.
} 
for each expedition in which they participated. ${ }^{506}$ It is not surprising then that the acts concerning the Arabs mention armies, and taqdim 40 places two armies under the unified command of the appointed leader. However, while the Arabs constituted an important auxiliary force during the period of expansion, after having been exterior enemies, they divided during the period of decline and took an active part in the political game, supporting different Almohad pretenders and charging dearly for their services. Originally employed for the jihād against the Christians, the Arabs were used by the caliphs in the internecine quarrels between various pretenders. The phrase "enemies of the faith" thus cedes it place to "hypocrites" (ahl alnifāq). ${ }^{507}$ There is the possibility that the son dismissed in taqdim 39 found himself in that situation because he had poorly chosen his allies: his father, Abū Fulān, had been "tied" or "loyal" to the eminent Cause (al-da'wa al- 'aliyya), ${ }^{508}$ while the son, appointed as his father's successor, "delayed not in renouncing [that] favor and in calling misfortune on himself through his deeds." ${ }^{509}$ Under al-Rashīd (1232-1242), alliance reversals between the Banū Khult and the Banū Sufyān were frequent and reveal different strategies within the tribes themselves. This choice of a paternal uncle, Abū Fulān's brother, reveals rivalries within the Arab groups themselves that correspond to divergent political tendencies. The call for Arab unity and solidarity behind the shaykh, who was loyal to and appointed by the caliph, ${ }^{510}$ bears witness to the essential military force of the Arab tribes and the correlative weakening of the Berbers in the balance of power within the Maghrib in the thirteenth century. The tension within the Almohad dynasty between (vertical) tendencies towards hereditary transmission of leadership and the (horizontal) resistance of brothers is reproduced here on the tribal scale. The authorities and exterior powers play on this tension to divide the tribal groups and reign in an anthropological context of political and family instability. In their competition for favors from the Arab tribes, the Almohad caliphal contenders engaged in an escalation of gifts and favors mentioned in taqdīm 41 concerning the Banū Sufyān. ${ }^{511}$ First of all, power is maintained in the family line with the son. Secondly, control over sections of imperial territory devolve to the tribe that exercises total authority over the population, collecting taxes and living on the lands,

\footnotetext{
506 'I. al-D. MūsÁ, al-Muwaḥhidūn fĩ l-Gharb al-islāmī, 144.

507 Taqdīm 40, f० 28r, p. 53, I. 18.

508 Taqdìm 39, fo 27v, p. 52, I. 22.

509 Idem, fo 28 r, p. 53, I. 3.

510 Taqdīm 40, f ${ }^{\circ} 28$ r, p. 53, I. 19-20.

511 Taqdīm 41, f ${ }^{\circ}$ 28v, p. 54, I. 8-9: ... al-taqdīm wa-l-takrīm wa-l-an 'ām wa-l-ashām wa-l-faḍl al-ladhī sabaqtum ilay-hi fi khidmati-nā... (“...for the appointment, honors, benefices, retributions, and the favor you have received by being in our service...").
} 
in a system that recalls fiefs in the western world, with a "privatization" of public authority that benefits the tribal groups managing these property and fiscal concessions.

The taqāìim perfectly confirm Mūsá's description of provincial governors in his study of the chronicles. However, they differ in regards to fiscal functions. Mūsá claims that the governors were primarily responsible for security, while the fiscal administration did not come under their control. ${ }^{512}$ Yet, in the majority of cases, the "officials" appointed in the taqādim were responsible for taxes in the regions they were charged with protecting and developing. In addition, Mūsá claims that during the period of imperial decline shared by these taqāīim, there is no trace of any governor being dismissed or transferred because of errors such as negligence, spoliation, or rebellion. Nevertheless, the example provided above with taqdīm 39, concerning the Arabs, reveals that dismissals were not nonexistent during the period of imperial disintegration. The game and reversal of alliances often led to reprisals against "state servants" who had made a "bad" choice.

\section{Maintaining order}

Maintaining order was the primary responsibility for appointees (wūlāt, 'ummāl): fighting against evil (al-shirr), moral corruption (al-fasād), divergence (al-ghayy), rebellion (al-baghiy), violence and aggression (al- 'inād and al-i 'tinād) and their partisans (mu'tadīn, mufsidìn, 'ānidīn). This task appears in each of the taqādìm, and order seems have been a prime concern for the regime. Supplemental functions add to this responsibility for provincial governors, for example defending the borders or outfitting the fleet. Basically, the local authority was responsible for defending and developing the land. In addition to firmness, the ruler demands justice and the application of the "law" (haqq) against troublemakers. ${ }^{513}$ These injunctions sometimes become more concrete: regular tours of the province, repairs of walls, the repair or construction of walls. ${ }^{514}$

512 'I. al-D. MūSÁ, al-Muwaḥhidūn fĩ l-Gharb al-islāmī, 184.

513 Taqdīm 22, f ${ }^{\circ}$ 20r, p. 37, I. 15-17: "We have ordered him to bring the population of your land back to the obedience that gave happiness to the believers and that has been, by order of the Book and tradition (sunna), a duty (fard $d^{a n}$ ) weighing on each individual ('alá al-a yān)" (wa amarnā-hu an yasta'nifa ahla tilkum al-bilādi 'alá hadhihi l-țā 'ati l-latī su ida bi-hā ahlu l-īmāni wa kānat bi-ḥukmi l-kitābi wa-l-sunnati farọ̣an 'alá l-a 'yāni).

514 Taqdīm 14, fo 15r, p. 27, I. 11-13: "we have named Fulān to lead your regions [...] to guarantee for all regions, near and far, regular visits" (qaddamnā al-ān Fulānan 'alá jihāti-kum li- [...] yastawfiya bi-l-tațwāfi jamía dānī-hā wa shāsi i i-hā). 


\section{Fortifications}

Taqdìm 10 thus mentions the construction of fortifications (taḥsinn), ${ }^{515}$ taqdìm 9 the reinforcement of fortresses (ma' äqil), ${ }^{516} 12$ the "closing of the borders", ${ }^{517}$ but taqdìm 20 is the most detailed on this question:

We have insisted that they build the missing parts of your city (baladi-kum) walls, which surround its palm groves and protect its inhabitants from attack on its borders, that they take responsibility for watching over the final completion of these fortifications and defenses, with all the fierceness and persistence they can, that they devote themselves to these [works] to finish them in the briefest of time, with the help of God on High, and to fill in the fortifications' breaches by raising and barricading them. Our explicit order on this has been communicated to the governor ( 'ámil) - May God assist him - so that he hasten the works, with the help of God, and immediately carry out [our] instructions. ${ }^{518}$

Aḥmad 'Azzāwī has posited that Sijilmāssa is the city in question because of its palm grove (nakhla). In addition, the fact that two officials are appointed to assume the local responsibilities indicates a fairly large city and not a small locality.

Mazōlim, muḥdathāt and munkarāt: the
struggle against abuse and
"innovations"

Guichard has noted that the destitution of masharif, those charged with fiscal matters serving in the capitals, as a result of irregularities in their management are frequently indicated in the chronicles for the Almohad era. ${ }^{519}$ All of the examples cited refer to the "great" Almohad period, under the first four caliphs of uncontested authority. They are, however, much rarer during the second imperial period. Though dismissals were not nonexistent, as seen above, they concerned less financial or fiscal corruption than political betrayal. ${ }^{520}$ In addition, it would seem

${ }^{515}$ Taqdīm 10, fo 12r, p. 21, I. 9: "that he defend and fortify your lands" (wa ḥimāyati arjāî-kum wa taḥșinihā).

516 Taqdïm 9, fo 11r, p. 19, I. 21-22: "and that the important fortresses receive all they need to close all entries" (wa tantahī fĩ I-ma 'āqili I-muhimmati ilá atammi mā yafiya bi-sidādi-hā).

517 Taqdīm 12, fo 13v, p. 24, I. 6: "...someone who rigorously takes in hand the frontier zone and closes it" (man yaqūmu bi-ḍabți thaghri-kum wa saddi-hi).

518 Taqdīm 20, fo 19r, p. 35, I. 8-13: wa akkadnā 'alay-himā fí bināì mā yahtāju ilá binā'i-hi fí sūri baladikum al-muhịți bi-nakhli-hi al-ḥāmī min tațarrufi l-maḍarrati li-ahli-hi wa an yatawallayā al-naẓara fí tatmīmi dhalika bi-l-tahș̣ini wa-l-tasdīdi bi-atammi mā laday-himā min al-jiddi al-dā'imi wa al-'azmi al-shadīdi wa an ya 'kifã 'alay-hi li-yukmala bi-ma 'ūnati Llāhi ta ālá fĩ I-amaddi I-qarībi wa yunḥasam 'ilalu I-hilali bi-l-tashyīdi la-hu wa-l-ta'shībi wa unhiya min amri-nā al-jazmi fì dhalika li-l-'āmili anjada-hu Llāhu mā yubādiru bi-ḥawli Llāhi li-a 'māli-hi wa ya 'malu min fawri-hi mā yajibu min imtithāli-hi.

519 For example, IBN 'IDHĀRI, Bayān, trans. Huici, 31 (for the mushrifs of Séville and Sijilmāssa in 11781179), 59 (for Tlemcen in 1183-1184), 67 (for eighteen officials in various places in Morocco, the same year) or 195-198 (for the mushrif of Seville in 1196-1197) cited by P. GUICHARD, Les musulmans de Valence, t. 2, 330.

520 See taqdīm 39. 
that the diminishing territory under effective caliphal authority led to reinforced control over lands and personnel. Finally, the orders given in the taqādim hardly differ from those mentioned in the letter, sent in 580/1185, shortly after his rise to power, by the caliph Abū Yūsuf Ya 'qūb, the future al-Manșūr, to the governors and fiscal officials enjoining them to be just and affable with their subjects, to be careful that they suffer no oppression and to receive the complaints of all those who formulate them. ${ }^{521}$

Ten taqādìm mention "abuses, injustices, extortions" (mazālim), but none mentions a

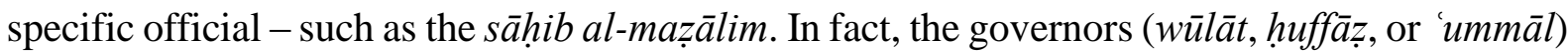
were responsible for erasing their subjects' causes of discontent. The mazālim thus appear in two different parts of the taquadim: the captatio benevolentiae, at the beginning of the act, and in the specific orders given to the appointed official. Taqdim 6 is somewhat particular, since it refers to a conflict with the Ceuta authorities, and taqādìm 68 and 74 concern a judge and not a governor:

- Taqdīm 6:

"Did we neglect [...] to eliminate the injustices (mazālim) that still blocked your ears?" 522

"and our promises to eliminate abuses and to cease innovations, he knows them well (having seen and heard them)." 523

- Taqdīm 8:

"[we have likewise insisted] that he act against injustice (mazālim) and that he abolish innovations (muhdatāt) by fully following the orders we give to all those we employ." 524

- Taqdīm 9:

"We have insisted that he eliminate innovations (muhdatāt) and abuses (mazālim), that he treat with subjects in respecting the law in the most obvious way, that he eliminate any abuse (mazlama) brought before him, that he erase any blamable act (munkar) when discovers it, in accordance with our intention to make definitively disappear all trace of injustice and its partisans, and to decide with an impartiality that knows no path that strays from the obvious paths." 525

521 É. LÉVI-PROVENÇAL, Trente-sept lettres officielles, letter 28, 164-167, HPIA, t. 1, 318-319.

$522 \mathrm{f}^{\circ}$ 8v, p. 14, I. 8-10: wa hal 'adawnā [...] an rafa' 'nā 'an-kum al-mazāilima al-latī lam tazal al-adhānu min-hā tastakku.

523 fo 10r, p. 17, I. 8: wa 'uhūdu-nā bi-raf'i I-mazāalimi wa izālati I-muhdathāti bi-mar’an min-hu wa masma:

524 fo 11r, p. 19, I. 5-6: akkadnā 'alay-hi [...] an yujriya fí raf'i I-maz̄ālimi wa izālati I-muḥdathāti 'alá atammi mā na'muru bi-hi kulla man nasta 'milu-hu.

525 fo $11 \mathrm{v}$, p. 20, I. 13-17: wa akkadnā 'alay-hi fi izālati I-muhdathāti wa-I-mazalimi wa ijrā'i I-ra 'iyyati fí Iwuqūfi bi-him ma'a I-ḥaqqi 'alá awḍaḥi I-ma'ālimi wa an yarfa'a kulla maẓlama matá intahat ilay-hi wa yamhuwa kulla munkara matá 'uthira 'alay-hi 'amalan bi-mā naqșidu-hu min țamsi kulli athar in li-Izullmi wa ahli-hi wa șad'an bi-l-'adli I-ladhī lā ma'dalata 'an wāḍịāti subuli-hi. 
- Taqdīm 10:

"Among the orders we have given your "Guardian" (hăfiz) and on which we have insisted, there is the obligation of eliminating with zeal innovations (muhdathāt), of erasing all trace of reprehensible things (munkarät), of eliminating taxes (rusūm) that are not authorized by the Law in the markets ( $a s w \bar{a} q)$ and at the gates ( $a b w \bar{a} b)$ [of the cities], and to end all that Tradition and the Book do not clearly authorize, until all that remains is the law respected by the pious ancestors of this Power and until falseness totally disappears, in spite of those committed to it. For the [Almohad] cause was only proclaimed by God on High to renew the signs that distinguish Islam, to erase, through justice, the traces of the extortion (mazālim)" ${ }^{\text {526 }}$

- Taqdīm 12:

"to eliminate abuses (mazāilim) that deserve to be abolished and eliminated"527

- Taqdīm 16:

"We have insisted that [...] he prohibit innovations (muhathāt) condemned by the Law, that he put a stop to exactions (mazālim) concerning [His] creations" ${ }^{\prime 28}$

- Taqdīm 28:

"We have enjoined him, to put an end to innovations, to combat abuse and to respect the limits and signs of the Law by which His subjects worship God on High, which is what we insist on for all those whom we appoint as governor" ${ }^{529}$

"to bring to pass what God - May He be exalted and magnified - impelled us to do to protect [our] subjects, to bring an end to complaints (shakāya $)^{, 530}$

- Taqdīm 46:

"Among the most important tasks we care about and for which we spend as much as necessary are the suppression of diverse abuses (mazālim), the elimination of innovations (muhdathāt), the prohibition of inebriating drinks, the correction of reprehensible actions (munkarāt), and, addressed to your peoples, the incitement to accomplish virtuous actions useful during their lifetime and after the death." ${ }^{531}$

- Taqdīm 68:

"We have ordered him to dedicate himself to eliminating new things (muhdathāt) not authorized by the law and to repress reprehensible actions (munkarāt) that should be fled

526 fo 12r, p. 21, I. 20-21: fa-hadhi-hi I-da watu inna-mā nașaba-hā Allāhu ta ālá li-tajaddudi mā li-l-islāmi min al-ma 'ālimi wa tu 'aqqiya bi-l-'adli 'āthāra I-mazālimi.

527 fo 13v, p. 24, I. 18: wa an yarfa 'a al-mazaālima I-latī yuḥaqqu la-hā al-izālata wa-I-raf'u.

$528 f^{\circ}$ 16r, p. 29, I. 16-17: wa akkadnā 'alay-hi [...] an yarfa'a al-muḥdathāti I-latī hiya bi-ḥukmi l-shar'i marfū 'at un wa yaḍa a I-mazālima I-latī hiyá 'alá I-khalqi mawọū 'at ${ }^{\text {un }}$.

529 fo $23 r$, p. 43, I. 4-5: wa ḥaddadnā la-hu fí izālati I-muhdathāti wa raf'i I-mazālimi wa-I-wuqūfi ma a mā li-I-shar'i I-ladhī ta abbada Allāhu ta'ālá bi-hi 'ibāda-hu min al-ḥudūdi wa-I-ma'ālimi mā lā nazālu nahuddu-hu li-kulli man nasta 'milu-hu.

530 fo $^{\circ} 22$ v, p. 42, I. 10-11: qiyāman bi-mā li-Llāhi 'azza wa jalla 'alay-nā fi hiyāțati I-ra āyā wa imāțāti Ishakāyā.

531 fo 30v, p. 58, I. 14-16: wa min ahammi mā nujīdu bi-hi al-i tinā'a wa nabdhulu fi-hi al-ghanā'a raf'u Imaẓālimi 'alá ikhtilăfi-hā wa izālatu I-muḥdathāti wa qaț ' I-muskirāti wa taghyīru I-munkarāti wa akhdhu I-nāsi hunāli-kum bi-mā yajidūna I-naf'a bi-hi min al-a 'māli I-șālihāti fì I-mahyā wa-I-mamāti. 
and forbidden, to erase all trace of them, whether in the markets or elsewhere, to follow the most direct and clearest paths to eliminate all abuses (kull mazlama) ${ }^{\prime 532}$

- Taqdīm 74:

"Among the points on which we have insisted with him, there is one which we do not cease to repeat at all times and to which we invite any official in the provinces and regions: to eliminate innovations (muhdathāt) and abuses (mazālim) and to bring them back to the state of the erased remains" ${ }^{533}$

The term mazālim is most often associated with muhdathāt ("innovations", "new things") and munkarāt ("reprehensible actions"). ${ }^{534}$ In the traditional world of the steppe and desert, and so Islam during its first centuries, any rupture with tradition is seen as a risk for the group. ${ }^{535}$ As much for commercial, social, or craft practices as political and religious, innovation is warily received by the authorities - when they are not the ones at the origin of the movement and cannot present it as the reprisal of a traditional practice - and by society. Brought together, these three notions ("extortions", "innovations", "reprehensible actions") take on a strong moral dimension. They submerge the extortions of representatives of the central authority within the ensemble of reprehensible practices without giving them a status of their own. It is however difficult to know if this situation is the result of an evolution revealed in the taqāìm or if it corresponds in the administrative language to what the chronicles describe in the narrative domain.

We should note, moreover, the complete absence of the term bid ' $a$ ("innovation"), traditionally used in the medieval Islamic world to designate any new thing, reprehensible in principle. This may be another example of an Almohad lexical innovation through the reappropriation and re-semantization of an expression that exists but is usually used in other

532 fo 44r, p. 85, I. 7-10: wa amarnā an yajtahida fí izālati I-muhdathāti I-latī lā yujizu-hā al-shar'u wa mahqi I-munkarāti I-latĩ yajibu al-zajru 'an-hā wa-I-man'u wa an yațmisa 'āthāra dhalika kulli-hi haythu kāna fĩ l-aswāqi wa siwā-hā wa yasluka fĩ raf' $i$ kulli maẓlami aqwam al-țuruqi wa ajlā-hā.

533 fo 47v, p. 91, I. 1-2: wa mim-mā akkadnā 'alay-hi fī-hi mā lam nazal nuraddidu-hu fi kulli l-anā'i wa nahuththu 'alay-hi kulla musta'mal in fî I-jihāti wa-I-arjā'i min izālati I-muḥdathāti wa-I-mazāalimi wa i'ādati-hā ka-l-țulūli l-țawāsimi.

534 This term appears alone in two taqādīm: 11, f० 12v, p. 22, I. 21: "to eliminate abusive novelties with titles [that they give themselves]" (wa an yuzīla al-muḥdathāt al-jawriyya wa alqāba-hā) and 76, fo 48r, p. 92, I. 2223: "...may he correct evil and cause it to cease, may he guard against inadvisable or forbidden innovations " (min izālati Imunkarāti wa taghyīri-hā wa-l-taḥdhīri min mamnū i I-muḥdathāti wa maḥdhūri-hā).

535 In a very constraining climatic, pedological, and, in general, geographic environment, the survival of the tribe was guaranteed by respect for rules proven over centuries. Experimentation was discouraged because it could lead to dangerous consequences for the entire community. This profound structure for nomadic Arab, Berber, Persian, and Turkish societies merits the attention of historians of the origins of Islam because it reinforces the ideas of those who espouse the longue durée concerning Islam, at the expense of those, including Muslim theologians, who defend the idea of a brutal rupture introduced by Muhammad and spread with the message of the Revelation. 
contexts. A comparison with the practices and language of chancelleries in other regions of Islam would be necessary to elucidate this question.

\section{THE HISBA}

These orders to fight against "reprehensible practices" resemble on a number of levels Chalmeta's description of the hisba in his Señor del zoco. ${ }^{536}$ Indeed, provincial governors ( 'ummāl and wülāt) received attributions similar to the muhtasibs in al-Andalus: policing the markets, moral censure, repression of fraud and non-Islamic practices. These attributions were the continuation of the moral reform incarnated by the Mahdī Ibn Tūmart on returning from his possible journey to the East. Taqdim 46, for example, in the passage cited above, preaches the suppression of alcoholic beverages (muskirāt), while taqdīm 10 charges the "Guardian" (hâfiz) with eliminating illicit taxes collected at the city gates or in the markets. Certain taqāìm even employ the emblematic watchword of the Almohad regime: al-amr bi-l-ma 'rüf wa l-nahyi 'an al-munkar. ${ }^{537}$

The governors and representatives of the central authority in the provinces were essentially charged, in the negative, with struggling against all that is reprehensible (munkar, pl. munkarāt). A number of verbs serve to signify this combat: mahww, tams, mahq ("erase"), $i k h f \bar{a}$ ' ("cause to disappear"), taghyīr ("correct"). Only one official seems to have had the positive task of enjoining the "good" ( $m a$ 'rüf), as, for example, the "Scholar" (talaba) appointed in taqdìm 13. He is ordered to "teach the recommendations we have imparted to him, those that God on High addressed to his subjects in His Word: "Verily we have directed the People of the Book before you, and you (o Muslims) to fear God." ${ }^{, 538}$

The "fear of God" (taqwá Allāh) that appears in practically every one of the taqdìm, whether in the preamble, final protocol, or in the wișaya ("counsel") is the backbone of relations between the Almohad caliph and the subjects of the Empire. It inspires the ruler and his

\footnotetext{
536 P. Chalmeta, "El Kitab fi adab al-hisba" ; "La figura del almotacén" ; "La hisba" and El 'señor del zoco'. 537 In reference to Koran 22:41, cited explicitly (qāla Allāh ta 'ālá) in taqdïm 55, fo 38r, p. 73, I. 20, and implicitly in taqādīm 14, f० $14 \mathrm{v}$, p. 28, I. 2: "be with him as one hand united to ordain good and prohibit evil" (wa kūnū ma 'a-hu yadan wāhidatan fí l-amr bi-I-ma' rūf wa-I-nahyi 'an al-munkar), 34, fo 25v, p. 48, I. 13-14: "We have ordered him to advocate good, to prohibit evil and annihilate the traces of corruptors and corruption to the point of erasing all memory and recollection of them" (wa amarnā-hu bi-l-amri bi-I-ma 'rūfi wa-l-nahyi 'an al-munkari wa mahwi 'āthāri I-mufsidīna wa-l-fasādi ḥattá lā tudhkaru wa lā yudhkaru), 35, fo 26r, p. 49, I. 8-9 et n 44, fo 30r, p. 57, I. 11: "Act, each of you, as the law imposes and requires to cause good to appear and evil to disappear" (wa 'malū jamī'an fĩ iẓhāri I-ma 'rūfi wa ikhfāi al-munkari bi-alzami haqq in wa awjabi-hi), 60, fo 40v, p. 78, I. 17: "Collaborate with him when he orders good or forbids evil" (wa wāqifü-hu fí mā ya'muru bi-hi min al-ma 'rūfi wa yunhī 'an-hu mina l-munkari) and 61, 62, 66, 68, and 76.

538 Koran 4:131; taqdīm 13, fo 14v, p. 26, I. 16: wa yu lim mā fāwaḍnā-hu bi-hi min al-wașāyā al-latī wașșá Llāhu ta ālá bi-hā 'ibāda-hu fĩ qawli-hi wa laqad wașsaynā l-ladhīna ūtū I-kitāba min qabli-kum wa iyyā-kum an ittaqū Allāha.
} 
decisions, and is supposed to guide imperial officials and motivate subjects to obedience. This fear, or awe, assures the link between the here below and the hereafter, between caliphal decisions and God's Law, between the earthly behavior of all the faithful and celestial Judgement. Jacques Berque chose to translate the Koranic verb ittaqá with "be prepared", but we have preferred to keep the idea of reverential "fear/awe" in regards to the divine omnipotence. The taqdìm sometimes associate taqwá Allāh with the verb istish 'ār ("shiver", "feel", "be sensitive to"), 539 expressing more an idea of feeling and sensitivity than that of reasoned precaution suggested by "be prepared". Likewise, frequent reoccurrence of the last judgment, of preparations for the hereafter and the next meeting with God in a strongly eschatological context excludes a translation that minimizes the expression. Finally, the identification noted above between amr al- 'aliy ("the eminent Power") and amr Allāh draws together God's punishment and the very real retribution which the ruler implicitly promises to carry out against his disobedient subjects.

b. The Judiciary institution in the provinces: the qudat and delegates

The taqāìm also provide valuable information on the judicial-religious positions which, because they are consecrated in tradition, partially escaped the imprecision noted by Guichard. Yahyyá al-Khadhūj's collection supplements the figurative dossier on administrative functions and contributes to questions concerning the nature - religious, profane, military, civil - of power and authority in the medieval Islamic world. 540 Twenty-eight appointments to the post of judge (khuttat al-qad़्ă') are given, mentioning the principal responsibility for this post, and secondary functions. We should first note that these acts are fewer and less diverse

539 Taqdìm 20, f० 19r, p. 35, I. 6-7: "We have advised them to fear God in exercising authority" (wașșaynāhumā bi-stish 'āri taqwá Llāhi fî I-ișdāri wa-l-īrādi) ; taqdīm 59, fo 40r, p. 77, I. 13-14: "We have counseled him to fear God, to keep His power in awe, to tremble at the idea that the Highest knows everything about him, in secret and in public" (wa qad wușiya bi-taqwá Llāhi wa murāqabati amri-hi wa stish 'āri iț̣ilā 'i-hi ta 'alá 'alay-hi fí sirri-hi wa jahri-hi) ; taqdim 64, f० $41 \mathrm{v}$, p. 80 , I. 11-13: "We have recommended that he fear God, for that is the traveling supplies of the blissful, the support of the pure and the virtuous, and the duty that must terrorize without end the proud $\left(a b b \bar{a}^{\prime}\right)$ '" (wa qad wașșaynā-hu bi-taqwá Llāhi fa-hiya 'uddatu I-mufliḥina wa 'amadatu I-șulaḥā'i wa-I-mușlihīna

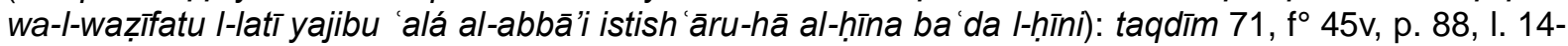
15: "to fear God on High with an absolute fear and to act as he who waits trembling for the retribution of God on the day of Judgment" (wa an yattaqiya Allāha ḥaqqa ttiqā'i-hi wa ya 'mala 'amala I-mustash 'iri li-jazā'i Llāhi yawma liqā'i-hı) ; taqdīm 72, f० 46r, p. 89, I. 16: "we have counseled him to fear God the Magnificent, to respect His design, and to tremble in fear before Him, in private as in public." (fa-inna-hu muwașșá bi-taqwá Llāhi l-'azî̀mi wa murāqabati amri-hi wa stish 'āri l-khayfati la-hu fí sirri-hi wa jahri-hı) ; taqdīm 74, fo 47r, p. 90, I. 1516: "We have counseled him moreover to fear God on High and to tremble before him" (wa qad wașșaynā-hu ma'a dhalikum bi-taqwá Llāhi ta 'ālá wa stish 'āri-hā).

540 For a summarizing presentation of the judiciary during the Almohad period, see F. RODRíGUEZ MEDIANO, "Instituciones judiciales", 169-186. 
than the first forty-eight, as if the responsibilities in question were more defined, more precise, the margin of exercise stricter, and the professional more firmly specialized. However, since the manuscripts ends abruptly, we do not know how many taqādìm the collection originally included. The informal character of the political, military, administrative, and fiscal functions reflected by the terminological imprecision of gubernatorial titles (wūlāt, 'ummāl, nāzir, mushtaghil...) contrasts with the hierarchical organization which appears clearly for the judicial appointments: qud̄āt were charged with appointing shuhüd ("instrumentary witnesses") and musaddidūn ("delegate, secondary, or deputy judges"), and the caliph headed the judicial hierarchy. ${ }^{541}$

\section{The office of judge (khuțțat al-qạ̣ā')}

Paradoxically, the secretaries writing in the caliph's name define best the importance invested in the judiciary (khuttât al-qad̄a ') in the Almohad period:

"[know also] that the most important function, the first to consider, the one that is most suitable to leading your affairs along the straight path is the judgeship, by which decrees are pronounced among you and which assures order if it is carried out according to religious rules in all disputes." ${ }^{542}$

The concrete task of this "official" is described with practically the same terms in each of the relevant taqūìm:

(10) taqdim 49:

"We have seen fit, after having asked the help of God on High, to name Fulān to judge your affairs related to the Law and to take charge of the religious aspects of your problems." 543

(10) taqdìm 50:

"We accordingly name Fulān to arbitrate and judge your disputes, to pronounce and apply the law in the questions you pose" 544

(1) taqdim 52:

541 For an exhaustive presentation of the judicial system during the Almohad period, refer to 'I. al-D. MūsÁ, al-Muwahhidūn fĩ l-Gharb al-islāmī, 191-210.

542 Taqdīm 59, fं 40r, p. 77, I. 8-9: wa ūlá muhimmati-kum bi---taqdīmi wa ahrá mā jarat fi-hi umūru-kum 'alá I-sunani l-qawīmi khutțatu I-qaḍāi al-latī tuqāmu bi-hā bayna-kum al-aḥkāmu wa yattasiqu bi-ijrā'ihā 'alá I-qawānīni I-dīniyyati li-jamĩ i i-nawāzili al-nizāmu. The idea that regulating disputes is the highest possible function appears in numerous other judicial taqādïmfor example taqdīm 50, fo $32 \mathrm{v}$, p. 62, I. 15: "Since the judgment of affairs pertaining to the Law deserves more than anything to be treated as a priority and to see its organization protected with benevolent attention..." (wa li-mā kānat al-aḥkāmu al-shar'iyyatu aḥaqqa mā quddima aḥkāmu-hu wa ḥufiẓa bi-jamīl al-i tināi niẓāmu-hu...).

${ }^{543}$ Taqdīm 49, f० 32r, p. 61, I. 14-15: wa qad ra'aynā ba 'da stikhārati Llāhi ta alá an nuqaddima li-l-qaụāi i fị shar 'iyyi nawāzili-kum wa tawallī l-naz̧ari fî I-dīnī min masāili-kum Fulānan.

544 Taqdīm 50, fo 32v, p. 62, I. 18-19: wa bi-hasbi hadha I-naẓari qaddamnā Fulānan li-I-fașli fí nawāzilikum wa-I-infādhi li-I-haqqqi fĩ masā'ili-kum wa-l-imụā'i. 
"We name Fulān alone to manage your affairs regarding the Law and to make an effort to arbitrate your religious disputes" 545

\section{(1) taqdim 66:}

"we saw fit to strengthen his arm with this allocution so that he might establish the law and justice in the affairs pertaining to him in his legal appointment (hutțāti-hi alshar'iyya), and in arbitrating among you, which is incumbent on him alone for your religious disputes; may he apply the law without fear of blame"546

\section{(10) taqdìm 67:}

"In consideration of this, we have named Fulān to rule according to the law in your differences and disputes, to arbitrate with justice the quarrels you bring before him when problems arise among you". 547

However it is phrased, and it is almost always the same, the judge is appointed to arbitrate differences (hiṣām, nawāzil, qậāya) between subjects and pronounce decrees $(a h k \bar{a} m)$. There is no mention of iftà' (“jurisprudential expertise or counsel"), which corresponds with what we know of Almohad attitudes towards fatwa collections, the destruction of which was ordered on a number of occasions. The activity of the fuqahä' and the 'ulama ' recruited to exercise an "official" activity is thus reduced, at least in the case of this activity, to its "judicial" arbitration in conflicts arising among the population. Moreover, a number of attributions traditionally considered within the responsibility of judges or their delegates are assigned to the governors or military leaders. This is the case for "successions" (mawārith) and alms (zakāt), the management of which fell to the qa' 'id 'alá l-usțūl named in taqdìm 2. ${ }^{548}$ Judges thus appear alienated from many of their previous activities as a result of a profound reorganization of relations between the ruler and his religious scholars, the fuqah $\bar{a}$ ' and 'ulama '.

Tyan has noted that in the Muslim system of public law, justice has always been the reserve of the head of the community, the caliph, and the magistrates serve only as his delegates. In periods of caliphal decline (Umayyad and Abbasid), ministers and emirs enjoy the same standing. ${ }^{549}$ The Almohad period clearly corresponds with a restoration of caliphal authority in all its prerogatives (justice, leadership of the prayer), and this restoration is reaffirmed by the

545 Taqdīm 52, fo 34r, p. 65, I. 12-13: wa innā qaddamnā Fulānan li-I-infirādi bi-I-naẓari fi aḥkāmi-kum alshar 'iyyati wa-l-ijtihādi fị l-fașli bayna-kum fî l-nawāzili l-dīniyyati.

${ }^{546}$ Taqdīm 66, fo 42v, p. 82, I. 14-17: ra'aynā an nashidda 'aḍada-hu bi-khițābi-nā hadha fĩ an yuqīma Iḥaqqa wa-l- 'adla fi mā yarij 'a ilay-hi min khuțțati-hi al-shar'iyyati wa yakhtașșa bi-hi mina l-fașli baynakum fĩ nawāzili-kum al-dīniyyati wa an yașda 'a bi-l-shar'i lā yakhāfu fí-hi lūmata lā'imin

547 Taqdīm 67, fo 43r, p. 83, I. 19-21: wa bi-hadha l-i tibāri qaddamnā al-'ān Fulānan li-l-fașli bi-I-shar'i fī qaḍāyā-kum wa nawāzili-kum wa-l-șad'i bi-l-'adli fĩ mā tūridūna 'alay-hi mina l-takhāșumi fị țawārī masāili-kum.

548 fo 3 v, p. 4, I. 17.

549 É. TYAN, “'L'autorité de la chose jugée”, 89. 
caliph's exclusive claim over "royal justice", or executions, to borrow a term from the medieval West. During the same period, the caliph's movements allowed him to affirm throughout the provinces this supreme privilege of exercising justice. While in al-Andalus in 1190, the future al-Manșūr, after a victorious attack against the Kingdom of Portugal, exercised his right and had a number of prisoners waiting in the city jails executed. ${ }^{550}$ During the second Almohad period, when the caliph scarcely left his capital in Marrakesh, he seems to have still considered justice an imperial privilege with the judges acting in the Empire's cities and regions through a "reserved delegation" of this prerogative.

The occupation of the appointed qudat tis thus limited at one end by the authority of the caliph, the supreme judge of the Empire, and at the other by the imperative that weighed on the subjects of the Empire to enjoin good and forbid evil, especially for "public" officials. ${ }^{551}$ The "moral" imperatives that traditionally framed judicial activities are reiterated in almost every act: treat equally each of those who come before justice, without regard for rank or wealth (almartaba wa l-athrā' or al-manāșib), the powerful and the weak (al-qawiyy and al-da 'if), the poor and the rich (faqīr and ghaniyy), ${ }^{552}$ those who are known and those of the people (al-sharif and $a l-m a s h r u \bar{f}$ or $a l-f a ̣ d i l$ and $a l-m a f d ̣ \bar{u} l)$. Concrete measures, showing the judges equal respect for the plaintiffs, are sometimes mentioned and refer to the acts and actions expected during court sessions. Thus, for example, in taqdim 69 , the authority enjoins the judge "to treat equally both parties when he convokes them or asks them to be seated." ${ }^{\prime 5} 33$ The fact of being present, standing or seated, mentioned a number of times in the judicial taqādìm, signified something that is in part unclear, and expressed specific marks of respect and social relational codes whose symbolic importance is evident while the rules are not. In addition, the judges are advised to not fear taking unpopular measures that lead to reproach or criticism (lawmat lā 'imin), ${ }^{554}$ to

550 IBN 'IDHĀRT̄, Bayān, t. 5, p. 207, trans. 1953, p. 163.

551 Taqdīm 56, fo 38v, p. 74, I. 19-20: "We have ordained that he enjoin good and forbid evil; that he establish the law with all this strength and all his zeal" (wa aw'aznā ilay-hi an ya'mira bi-I-ma'rūfi wa yunhiya 'an ọiddi-hi wa an yuqīma bi-aqșá wus 'i-hi wa awfá juhdi-hi).

552 In fact, the only act that cites these two terms, through a Koranic verse, is number 55 written in the name of Ibn Hūd al-Mutawakkil (Koran 4:135): "O ye who believe! stand out firmly for justice, as witnesses to God, even as against yourselves, or your parents, or your kin, and whether it be (against) rich or poor: for God can best protect both. Follow not the lusts (of your hearts), lest ye swerve, and if ye distort (justice) or decline to do justice, verily God is well-acquainted with all that ye do..."). There is no direct reference to this verse in any Almohad act, and the terms used are never ghaniyy or faqir.

${ }^{553}$ Taqdīm 69, fo 44v, p. 86, I. 12: an yusawwiya bayna I-mutakhāșimayn fî l-hudụūri laday-hi wa-l-qu 'ūdi.

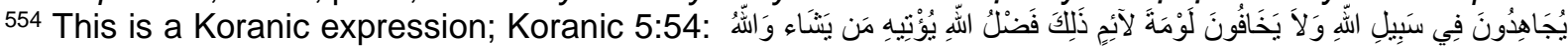

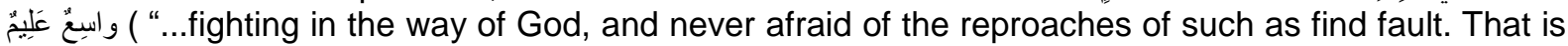
the grace of God, which He will bestow on whom He pleaseth. And God encompasseth all, and $\mathrm{He}$ knoweth all things"). 
show justice and temperance ( $\left.i^{~}{ }^{i} i d \bar{a} l\right)$, forbearance ( $r i f q$ ) or severity (shidda) when necessary. Judges occasionally receive attributions that we might consider "notarial", such as verifying contracts and previous acts. ${ }^{555}$

Provincial judges were also vested with the important attribution of appointing instrumentary witnesses (shuh $\bar{u} d$, and more rarely shuhada) and sometimes provincial deputies

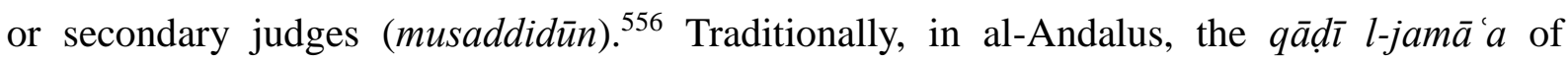
Cordova, first introduced under the Umayyads, sat at the top of the judicial pyramid. Under the Almohads this fell to Seville, though the Great Judge of Marrakesh was likewise head of the Maghribi judicial system. With the loss of the Iberian peninsula, from the end of the 1220 s to

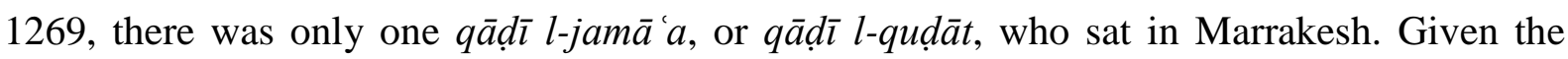
gradual diminishing of imperial territory, the taqādìm in Yahyá al-Khadhūj’s collection concern essentially the Maghrib al-Aqșá and the Sūs, the judges of which, named by the caliph, appointed representatives (musaddidūn) in the smaller localities under their judicial responsibility.

\section{Witnesses, delegates and secondary judges}

(shuhūd, nuwwāb, and musaddidūn)

Instrumentary witnesses, or shuhüd, were incontestably the most important of the judges' delegates. The judge is charged with selecting them in person and verifying with care their morality and behavior, to monitor what they do and who they are, and to dismiss them at the slightest suspicion. ${ }^{557}$ Indeed, the acts ceaselessly repeat that the witnesses "are the

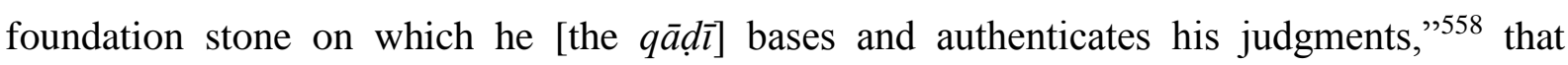
testimony (al-shahāda) "is the judge's pillar and support [...] the source of what he binds and

\footnotetext{
555 Taqdim 61, fo 41r, p. 79, I. 3-4: "nd to judge according to the incontestable law whose path he will follow and whose footsteps he will pursue. We have ordered him to verify [the worth] of contracts and instrumentary witnesses" (wa-I-hukmi bi-I-ḥaqqi al-wāḍihi yasluku sunana-hu wa yaqfū athara-hu wa amarnā-hu bi-tafaqqudi I- 'uqūdi wa-Ishuhūdi)

${ }^{556}$ Taqādīm 49, fo 32r, p. 61, I. 19, 60, fo 40, p. 78, I. 12 and 71, f० 45v, p. 88, I. 11.

557 On the importance of instrumentary witnesses in the Almohad judicial process, see R. BRUNSCHVIG, "Sur la doctrine", 146. Brunschvig demonstrates how the question of the witness's "honorability" plays an important role in "rendering probable" the veracity of his testimony, a necessary condition for the hukm ("judicial decision"). On the capacity of testimony to procure a conviction, through rhetorical procedures that play on persuasion and that leave room for doubt and the possibility of its contrary, or certitude, through information (khabar), see M. AOUAD, "La valeur épistémologique". In a short annex to this article (143-44), Guichard brings together Ibn Rushd's original positions which tie the prophetic Tradition to zann ("opinion"), rather than 'ilm yaqin ("certain knowledge") as do theologians, the disappearance of jurisprudential collections during the Almohad period and the mu tazilite approach, which "Iorsqu'elle est récupérée par le califat (dans une idée de refondation de l'État ?) [manifeste] un souci au moins virtuel de libérer le politique des normes trop contraignantes du droit."

558 Taqdīm 49, f’ 32r, p. 61, I. 19-20: fa-hum 'umdatu ta'sīsi-hi li-l-qaḍa'i wa ta'șilli-hi.
} 
unbinds in his judgments." ${ }^{559}$ He must then "accept only those whose sense of justice is obvious and whose religious or profane behavior (hālatu-hu) is without fault", ${ }^{560}$ that is

"men who have proven their intelligence, virtue and sincerity; for his judgments depend on witnesses. He relies on them to confirm or annul [a sentence]; they are the best arbitrators to determine forbidden or authorized decrees; they bring back by the bridle whoever goes to the right or left, according to justice or against it." 561

Cahen has noted that the term shähid (pl. shuhüd) refers to two categories of witnesses: those for material facts, and who change obviously from case to case, and so cannot be named in advance, and "instrumentary witnesses", those who testify by their participation to the regularity of judicial acts and who can technically form a list from which the qudat can recruit their normal deputies. ${ }^{562}$ The Almohad taqāìm simply repeat the traditional requirements of the fiqh for choosing shuhüd: wellness of mind, honorability, and absence of personal ties, family or other, with those implicated in the affair. ${ }^{563}$ Investigations (tafaqqud) were necessary to be sure witnesses indeed possessed the moral qualities necessary.

The shuhūd were thus expected to act as instrumentary witnesses during judgments, to take up notarized acts, and to guarantee contracts. The clauses of the taqādim demonstrate that they were highly dependent on the judges, who were charged with choosing them, appointing them, and monitoring their situations. The importance of testimony and instrumentary witnesses is the pronouncement of judgments is most fully developed in taqdīm 55 from Ibn Hūd alMutawakkil, with citations from the Koran and the hadith. ${ }^{564}$ The sole mention of the hisba significantly also appears in an act by Ibn Hūd, just after the instrumentary witnesses:

"May he act in the same way with the instrumentary witnesses who help in validating or annulling rights and on whose witness the detestable is rejected and the comely is accepted. We have ordered him to protect the market police (hisba) who support the resources and framework of life and to give responsibility for these, no matter where, only to one known for the purity of his initiatives and the uprightness of his methods." 565

559 Taqdīm 52, fo 34 r, p. 65, I. 23-fo 34 v, p. 66, I. 1: fa-I-shahādatu mustanadu I-hakimi wa mu tamaduhu [...] wa hiya așlu mā yahullu-hu mina qaḍāyā-hu wa ya taqidu-hu.

560 Taqdīm 53, fo 35r, p. 67, I. 7: fa-lā yaqbalu illā man tabayyanat 'adālatu-hu wa hasunat dīnan wa dunyan hālatu-hu.

561 Taqdīm 64, fo 41v, p. 80, I. 16-19: illā I-mushahhidīn bi-I-dhakāì wa-I-zakāì wa-I-șidqi fa-I-shuhūdu manāțu aḥkāmi-hi wa mustanadu naqụi-hi wa ibrāmi-hi wa-l-farūqu I-aqwá bayna ḥalāli I-fașli wa ḥarāmi-hi wa-l- 'āidūna ḥasba l-'adālati aw ḍiddi-hã dhāt al-yamīn aw dhāt al-shimāl bi-zimāmi-hi.

562 C. CAHEN, "À propos des Shuhūd," 71.

563 C. CAHEN, "À propos des Shuhūd," 75.

564 Taqdīm 55, fo 37 v, p. 72 , I. $20-f^{\circ} 38$ r, p. 73, I. 18, and Koranic citations: Koranic 43:19, Koran 65:2, and MĀLIK, Muwatțā', n' 1208.

565 Taqdīm 54, fo 36r, p. 69, I. 6-10: wa kadhalika fa-I-yakun 'amalu-hu fï l-shuhūdi al-ladhīna tușahhu Ihuqūqu bi-him wa tubțalu wa bi-shahādati-him yaruddu mā yaqbaḥu wa yaqbilu mā yajmalu wa amarnā 
Under Umayyads, then the Almoravids, the muhtasib had played an important role, as shown by Ibn Sahl's Ahkām al-kubrá (1087) or Ibn 'Abdūn's treatise from Seville at the beginning of the twelfth century. ${ }^{566}$ This official was chosen for his moral qualities, and was responsible for policing the markets, censuring morals, prohibiting alcoholic beverages, and verifying weights and measures. Yet, except for this act, which was issued by an authority hostile to the Almohads and who had built his legitimacy on a recognition of the Abbasid caliph in Baghdad and a return to the traditional values that had characterized the Almoravid Empire in the beginning, the hisba appears in no taqdìm from the Almohad period. This would again seem to point to a rupture between the Almohad system and the political and religious organization of its predecessors. Mūsá notes that though the hisba traditionally fell under the judges, the Almohads seem to have modified its nature in according the title of mustasib to the tribal leaders, enjoining them to defend good and prohibit evil. ${ }^{567}$ Thus, in the name of the obligation to amr bi-l-ma 'rüf and nahyi 'an al-munkar that fell to everyone, the hisba ceased to be the reserve of judges, or their delegates, and became an obligation for all the officials of the Almohad state.

Secondary judges came next, delegated by the judges of the principal city in the localities under their responsibility. ${ }^{568}$ Taqdìm 51 confirms, moreover, the nature of the musaddidūn's office:

"He must select secondary judges (musaddidin) to employ in the regions, appoint only those who are reputed for the purity [of their intentions] and the confidence [we can grant them]. ${ }^{, 569}$

The constraints involved in choosing these musaddids are as important as those for the shuhūd. The choice of shuhüd appears in almost every act, musaddids are less frequently mentioned. ${ }^{570}$ This is probably tied to the importance of the judge's responsibilities: only in large cities, or regions, does the judge appoint subalterns for secondary cities under his authority. Taqdìm 53 is the only one that mentions, indirectly, the judge's deputies ( $n \bar{a}$ 'ib al-

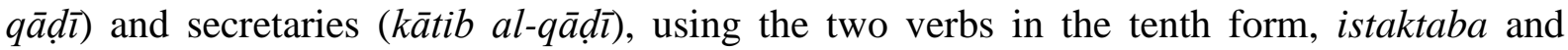

an yahtāța li-l-hisbati I-latī hiya qawāmu al-ma 'à'ishi wa-I-marāfiqi wa an lā yatawallā-hā fí mawdịi $i$ mina I-mawāọi i i illā I-shahīra la-hu bi-nazāhati I-tanāwulāti wa sadādi al-țarā'iqi.

566 IBN 'ABDŪN (twelfth century), "Un document sur la vie urbaine” ; Sevilla a comienzos del siglo XII.

567 'I. al-D. Mūsá, al-Muwaḥhidūn fĩ l-Gharb al-islāmī, 305.

568 On the responsibility of judicial deputies (administration of the possessions of orphans and those under guardianship), see H. YANAGIHASHI, "The Judicial Functions of the Sulțān".

569 Taqdīm 51, fo 33v, p. 64, I. 13-14: wa 'alay-hi an yantaqiya I-musaddīna I-ladhina yasta 'milu-hum fi ljihāti wa lā yuqaddimu illā al-mashhūra mina l-azkiyā'i I-thiqāti.

570 The musaddids are mentioned notably in taqādīm $49,51,56,71$ et 74 . 
istanāba. ${ }^{571}$ This then limits the available information for these judicial officials during the Almohad period.

\section{The law between "Almohadism" and "Malikism"}

Almohad law is known for having broken with prior practices. Ibn Tūmart limited the foundations of the law to the Koran and the Tradition of the Prophet Muhammad, while the imām himself interpreted between these two sources. This important modification of the juridical practices in place in the Maghrib and in the Iberian peninsula since the ninth century consecrated the rupture with the Maliki doctors of the Law (fuqaha' ' and 'ulama') who had organized their “corporation” on judicial careers ( $q \bar{a} d \bar{l}$, mufti, șăhib, al-mazāalim, muhtasib, etc.) and on casuistry and writing collections of jurisprudence (nawāzil and fatāwā). The Almohad caliphs remained faithful to the precepts of the Empire's founder and his first successor, 'Abd al-Mu'min, until the reign of al-Ma'mūn, who also broke with the Almohad doctrine of the impeccability ( 'ișma) of the Mahdī. They confirmed for the practice of justice the obligation to refer solely to the Book and Tradition, and the prohibition of relying on ijtihäd. Finally, they required judges to call on the caliph for obscure or difficult cases. ${ }^{572}$ Two complementary legal sources quickly appeared: the actions of the Mahdī Ibn Tūmart, considered the infallible interpreter, and the reigning caliphs, starting with 'Abd al-Mu'min, because they had inherited from the Mahdi his ability for interpretation. ${ }^{573}$ This is why caliphal decisions could go against certain usages established and validated long before by the corporation of scholars. ${ }^{574}$

Nevertheless, the taqādìm in Yahyá's collection do not exactly fit with this image of legal practice during the Almohad period. Out of twenty-eight documents, twenty-four specify

571 Taqdīm 53, f ${ }^{\circ} 35$ r, p. 67, I. 9: "to take as secretary or substitute only those persons of words and deeds worthy of confidence" ( wa lā yastaktibu wa yastanību illā man yathiqu qawlu-hu wa fa 'lu-hu).

572 See risālat al-fușūl, É. LÉVI-PROVENÇAL, Trente-sept lettres officielles, letter 23, 126-138, DIHA, ar. 134-145, $16 \mathrm{rabì}^{\prime}$ / 543/4 August 1148.

573 In the letter from the fușūl sent to all the provinces, 'Abd al-Mu'min ordered the imitation of the Mahdī's attitude with those who did note pray, who refused to pay the zakāt or who practiced illicit acts, for "sa décision et son pouvoir sont la décision, le pouvoir, la volonté et le jugement de son maître" (É. LÉVIPROVENÇAL, Trente-sept lettres officielles, letter 23, p. 135 and DIHA, 142: wa-I-rujū' ilay-hi fi amri I-dīni wa-l-dunyā farḍun li-anna qaḍā'a-hu wa amra-hu huwa qaḍā'u rabbi-hi wa amru-hu wa irādatu-hu wa ḥukmu-hu). For more details, see 'I. al-D. MūsÁ, al-Muwaḥhidūn fĩ l-Gharb al-islāmī, 192-193.

${ }^{574}$ Mūsá notes the proximity, from the juridical point of view, between Almohadism and the zāhirī school. The move towards zāhiri law began under Abū Ya 'qūb Yūsuf b. 'Abd al-Mu'min, but did not become official until the caliphate of al-Manșūr, when people relied exclusively on the Koran and Tradition. At that time, jurists form the zāhirī school took over the top judicial posts and al-Manșūr ordered Mālikī books to be burned following the unfulfilled goal of this father and grandfather of replacing Mālikī works with collections of the Tradition. This zāhirī policy apparently did not last long after al-Manșūr's reign ('I. al-D. MūsÁ, al-Muwaḥhidūn fī l-Gharb̆ al-islāmī, 194). 
the foundations of the law on which the judge should rely for his decisions. Most indicate, in addition to the Koran and Tradition, the consensus of the Community (ijmă 'al-umma), even, on two occasions, the "effort of personal interpretation" (ijtihād), ${ }^{575}$ which hardly corresponds with the Almohad doctrine described above.

There are a number of explanations for this:

$\hookrightarrow$ the first is al-Ma'mūn's rupture with the Almohad doctrine. The scribe attributes taqādìm 49, 52, and 53 to al-Ma'mūn. Since the documents are in chronological order, we can deduce that numbers 50 and 51 are also from the same ruler. Taqdim 49 is the only one to mention only the Koran and Tradition as the basis for the judge's words and deeds. ${ }^{576}$ All the others, except number 50, add a third pillar (aṣl) - the consensus (ijmāa) of the Community (umma). Taqdìm 51 even adds a fourth pillar, as do taqādìm 54 and 55 by Ibn Hūd alMutawakkil, the (jurisprudential) opinions or "words" of the imāms (fatāwá l-ayimma, or aqwāl al-ayimma for number 55). ${ }^{577}$ The first act was thus written before the renunciation of the Almohad doctrine, the others after. Taqdìm 50, if it was indeed written for al-Ma'mūn, was perhaps a transitional piece, since it does not mention ijm $\bar{a}$ ', but the path of the "pious ancestors" (sunan al-salaf al-șālih). It is not clear if this last part refers to the imāms of the Community (umma) or to the "rightly-guided" interpreters, such as the Mahdī and Almohad caliphs. Taqdìm 55, written for Ibn Hūd al-Mutawakkil, sets itself apart from the others by the length of the passage presenting the foundations on which the judge must rely for his decisions. ${ }^{578}$ The expansion of this part, due to the citations that justify each element with passages from the Koran ${ }^{579}$ or Tradition, ${ }^{580}$ expresses perhaps a desire to establish distance with Almohad law. Indeed, Ibn Hūd built his reign in opposition to the Almohads, who were contested in the Iberian peninsula, but still strong in the Maghrib.

Al-Ma'mūn's repudiation of the Almohad doctrine thus had considerable legal consequences and saw Malīkism reinstated as the official juridical school for the Empire. The

\footnotetext{
575 Taqdīm 52, fo 34r, p. 65, I. 12-13 and taqdīm 58, fo 39v, p. 76, I. 16-17: "and [finally], in cases without a text, to call on that which the words of the scholars have built on the two foundations which are reflection (nazar) and personal effort (ijtihād)" (.... wa yastaẓhira fĩ mā 'adama I-nașșu fĩ-hi bi-mā nbaná min aqwāli I- 'ulamā'i 'alá usayyi al-nazari wa-l-ijtihādi).

576 Taqdīm 49, fo 32r, p. 61, I. 18-19: "We have ordered him to base his judgments on the Book of God and the Tradition of His messenger, to use them as the basis of his words and actions" ( wa amarnā-hu bi-I-istiẓhāri fí aḥkāmi-hi bi-kitābi Llāhi wa sunnati rasūli-hi wa-l-i 'timādi 'alay-hā fì maqūli-hi wa maf'ūli-hi).

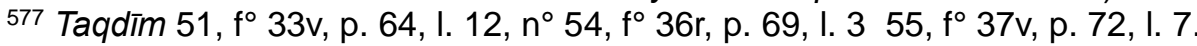

578 Taqdīm 55, fo 37r, p. 71, I. 13-37v, p. 72, I. 17.

579 Koran 41:42, fușșilat, 6:155, 17:9, 53:3, 5:92, 54:7, 4:58, 115 and 135, 3:159, and 10:57.

580 MĀLIK, Muwatțā', nº 1395 and IBN MAJIH, Sunan, n 3940.
} 
rupture caused by al-Ma'mūn, however, lasted in theory only a decade. His son, al-Rașīd (629/1232-640/1242) reversed the al-Ma'mūn's decision and rehabilitated the Almohad doctrine. It is possible that taqdim 62 bears witness to this turn, since it mentions only "the royal and exemplary path of the Law and [...] the footsteps of the Book and Tradition," without citing consensus $(i j m \bar{a}) .{ }^{581}$ To confirm this, we would have to be sure the document dates from the time of al-Rashīd, as do each of acts 57 to 64. This is likely if the acts are indeed organized according to their place of origin - whether present in the shaykh's collection or not - and then chronologically, which seems to be the case. The title of taqdim 65 specifies that it was written for al-Mu 'taḍid bi-Llāh al-Sa '̄id (640/1242-646/1248), and so we may suppose the preceding acts date from the ruler before him, al-Rashīd, in which case the nominations citing consensus $(i j m \bar{a})$ as the third foundation for judicial decisions would have been written during the first part of his reign, before the rehabilitation of the Almohad doctrine, and taqdīm 62 just after. ${ }^{582}$ $\hookrightarrow$ this constitutes the second explanation for the large number of acts mentioning the ijmā' al-umma. Indeed, except for taqdìm 62, all the other judicial acts, including those coming later from the reign of al-Mu'tadid bi-Llāh al-Sa 'îd, mention the ijmā' al-umma even though the Almohad doctrine had been officially reinstated. ${ }^{583}$ Al-Rāshīd's reversal does not seem to have had lasting effects, at least legally. Though the Mahdī's 'iṣma was once again invoked during the Friday sermons and on coins, as well as in the chancellery documents, it would seem that the Mālikī 'ulamā' had succeeded in imposing their demands and Mālikī standards on the law. ${ }^{584}$ This concession of caliphal power is doubtlessly the sign of its weakening and a sign of its lessening ambition. The Mahdī and his successors, especially 'Abd al-Mu'min, had worked to affirm their authority over the corporation of the religious elite, and to impose themselves as the exclusive interpreters of the divine Law, ensuring their autonomy and power to legislate. Al-Ma'mūn's decision put a temporary end to this historic attempt to separate the ruler and Almohad state from the control of the religious elite. For a few years, the caliph was simply the first among them, the auto-legitimizing authority, the "guide" indicating the "straight path" and

581 Taqdīm 62, f॰ 41r, p. 79, I. 14-16: "We have counseled him to fear God on High, to take the royal and exemplary path of the Law and to follow the footsteps of the Book and Tradition" (wa qad wașșaynā-hu bi-taqwá Llāhi ta 'alá wa-I-sayri 'alá jāddati I-shar'i I-muthlá wa-I-iqtidā'i bi-āthāri I-kitābi wa-l-sunnati).

582 Taqādīm 57, dated from $1^{\text {st }}$ dhū l-qa da 636/5 June 1239, and probably 58 and 59.

583 Only taqdim 70 also omits this foundation, but it is incomplete, and ends abruptly after the mention of the Koran and Tradition.

584 As attested to by the late letter from the caliph al-Murtaḍa to Pope Innocent IV, translated by E. TISSERAND and G. WIET, "Une lettre de l'almohade" and K.-E. LUPPRIAN, Die Beziehungen der Päpste, 200-203, NLA, $n^{\circ} 126,401-44$. 
deciding the correct interpretation of the Koran and Sunna. He reclaimed his wilaya ("magistrature"), certainly, the most important one, but this time in the service of the Law whose interpretation had devolved, as before and now permanently, to the specialists ( 'ulamā'). ${ }^{585}$

$\hookrightarrow$ the third and most probable explanation refers to tensions within the Almohad movement between those who accepted for better or for worse the historical experience of the Community and those who were faithful to the most "fundamentalist" position of the movement's founders and the zāhiri doctrine, and recognized only the consensus ( $\ddot{j} m \bar{a})$ of the first generations of Muslims. The phrase "consensus of the community" (ijmā' l-ummati), which the Mālikī sources seem not to use, was a voluntarily ambiguous formulation which allowed for a normalization within Sunni Islam of the Almohad doctrine, sparing the original severity without referring explicitly to Mālikism. ${ }^{586}$

Al-Rashīd's return to the original Almohad doctrine created a new complex reality for the Empire: the characteristic emblems of the Tümartī movement were reestablished concerning the theoretical position of Unicity (tawhīd) and caliphal legitimacy, and the judges remained confined to purely judicial and juridical functions. At the same time, a concession was made in the "tribunals" to the Mālikī juridical system which guaranteed the social function of the fuqahā" and 'ulamā'. This situation continues the one described by Mūsá in regards to the first period of the Empire: a certain number of jurists were Mālikī from a legal point of view and partisans of kalām from a theological point of view. ${ }^{587}$ The tension caused by the rise of the Almohad within the corporation of scholars and between them and the caliphal authority translated into the expulsion of the 'ulama 'from state service - either as judges and legal functionaries or as secretaries of the diwān al-insh $\bar{a}{ }^{, 588}$ Scholars were henceforth legitimated in their functions by the caliph's authority, whereas they had heretofore legitimated the caliph's decisions by virtue of the authority conferred on them by their religious Knowledge. A new contract seems to have been passed in the 1230s which, in a different way, allowed for collaboration between scholars

\footnotetext{
585 This is the classic schema described in the eleventh century by al-Māwardī in his Ahkām al-sulțāniyya or later by al-Wansharīsī, in his Livre des magistratures (AL-WANSHARISI, Livre des magistratures).

${ }^{586}$ I would like to thank Maribel Fierro for having suggested this explanation which has the advantage of taking into account the tensions within the Almohad movement, of revealing the empiricism of the juridical and political choices made by the chancellery secretaries, and of bringing out the originality of these choices on the religious level.

587 'I. al-D. MūSÁ, al-Muwahhịiūn fĩ l-Gharb al-islāmī, p. 198.

588 On the evolution of the recruitment of kuttāb during the Almoravid and Almohad periods, see P. BURESI and H. ELAALLAOUI, "La chancellerie almohade".
} 
and the Almohad power, without it being enough to restore caliphal authority over its erstwhile domain.

\section{c. Choice and Appointment}

The taqāìm insist in particular on the choice of the imperial "agents" in describing the qualities of those chosen. This list of virtues serves a number of purposes, the first of which is to give an air of rationality to the caliph's decision. Likewise, the appointment becomes an honor and a mark of consideration for the subjects who will benefit from the qualities described. Finally, the list of virtues makes the taqdim an inevitable meeting between a region and its governor that assures the subjects' obedience and collaboration. These qualities can be personal, family-related, or social.

\section{Personal qualities: ghanā', istiqlāl, iḍtilā', etc.}

Most of the qualities appear indistinctly for all the officials. Courage (najda) and bravery (majd) are perhaps reserved for the $q u w w \bar{a} d$, since they are more specifically military. ${ }^{589}$ The wāl $\bar{\imath}$ ("governor") in taqdìm 14 is characterized as holding najda, but this, in fact, refers to his mission to bring the subjects back into obedience. ${ }^{590}$ Ghanā' is an essential quality for imperial officials: it is mentioned in twenty-two of the forty-nine gubernatorial appointments, and in five of the twenty-eight for judges. In Carmona's excellent article on the required conditions for judicial exercise, the wealth of the candidates is put forward, leading to reading ghin $\bar{a}$ ' ("wealth") and not ghana ${ }^{, 591}$ Nevertheless, we believe it more accurate to see the means necessary to carry through a project or plan, ${ }^{592}$ which in this context evokes "competence" more than "wealth". 593 We might also add to this list istiqla ("sense of responsibilities"), iḍtilā" (“aptitude”), iktifāa' (“effectiveness"), sadād (“uprightness"), etc.

These qualities partially cover the criteria judged necessary by Mālikī jurists for exercising a judicial profession, which they limit to five or seven, based on different traditions

589 Taqādīm 21, 22 and 39. Taqdīm 22, f 20r, p. 37, I. 7-8: "we choose from among brave and capable men those who will defend it by striking with the sword and severity" (wa nakhtāru la-hā min ūlì al-najdati wa-l-kifāyati min yadhibbu bi-l-șarāmi d̦arban wa ța 'n an bi-l-sināni).

590 Taqdīm 14, f ${ }^{\circ}$ 15r, p. 27, I. 14-15: "He is known for his wisdom and reputed for his firmness, following the path of his predecessors in courage and bravery" (wa huwa al-ma 'rūfu bi-l-shahāmati al-mawșūfu bi-l-ḥazāmati al-sāliku sabīli salafi-hi fī I-najdati wa-l-șarāmati).

591 A. CARMONA, "Le malékisme". See also Gh. M. AZAD, "Qualifications of a qāọli”. 592 We would like to thank Abdallah Cheikh-Moussa for his advice and lexical help..

593 This is the term we have chosen most often. See for example taqdīm 21, fo 19v, p. 36, I. 11-13: "We are thankful for the commendable competence (ghana $\left.\bar{a}^{\prime}\right)$ he has shown in many contexts, as well as the justice of opinions he has given in [diverse] endeavors (fi-muhāwwalāt) like a seasoned expert" (wa nahnu nashkuru la-hu ghanā'an hamīdan qaddama-hu fī kathīri mina I-mawāqifi wa ra'yan sadīdan a 'mala-hu fĩ l-muḥāwalātì). 
going back to 'Umar b. al-Khațtāb (634-644), Mū'āwiya (660-680), or sometimes 'Umar b. 'Abd al-'Azīz (d. 101/720) or 'Alī b. Abī Ṭālib (d. 40/660). Carmona lists the details in his article: the knowledge of juridical precedents, an aptitude for taking council from those who are trustworthy, honesty, self-control and a disdain for criticisms. ${ }^{594}$ The first of this is, of course, absent from the taqdìm, since it concretely refers to Mālikī juridical practices. The same is true of council, since it refers to the activity of muftī. Self-control, however, and honesty and indifference in the fact of criticism or blame - lawmat lä'imin in the taqdìm - appear in the Almohad acts in one form or another through equivalent terms that evoke a sense of justice and equity ('adl), sagacity (shahāma), firmness (hazāma), seriousness (jidd), etc., which are revealed by the appointee's experience (ikhtibār), previous positions (isti 'māl), initiatives (taḥ̂̄wulāt), ease (khilāl), behavior (siyar, tașarrufāt), or attributions (tanāwulāt). The person's qualities (dhāti-hi), however, are not always enough, and integration within a family group is often a supplementary guarantee.

\section{Lineage and the heredity of office}

Family does in fact appear in the taqādìm as determinant criterion of selection for provincial officials, perhaps even more than personal qualities. These can be divided into two types of examples: well-known lineage (salaf, bayt $)^{595}$ or simply the transmission of an office from father to son. ${ }^{596}$ This type of transmission appears in the collection a number of times: firstly in certain particular and personalized taqā $\bar{d} \bar{\imath} m$, like number 5 by Ibn Hūd concerning Ibn Ramaymī ${ }^{597}$ or 6 by al-Murtadá meant for Ceuta and al- 'Azadī; next, in the taqādìm concerning the Arabs (39 and 41); finally in a number of judicial appointments $(50,51,72,73$, and 75). It seems indeed that the transmission of provincial imperial functions from father to son obeyed different necessities depending on the context.

In the case of the recall of Ibn al-Ramaymī, who was replaced by his son as governor of Almería, there is a monopolization of leadership positions in the hands of a few families close to the ruler. Beyond the Almohad Empire, this situation is comparable to relations the Mu'minids maintained with the descendants of Abū Hafṣ 'Umar al-Hintātī, a loyal companion of Ibn Tūmart and his successor 'Abd al-Mu'min. In both cases, limits are maintained between

\footnotetext{
${ }^{594}$ A. CARMONA, "Le malékisme", 126.

595 Taqādīm 7 (bayt), 14, 17, 20, 29, 59, 67 and 68 (salaf).

596 Taqādìm 5, 6, 30, 33, 39, 41, 50, 51, 72, 73, 74 and 75 (mention of father-son ties).

${ }^{597}$ For the phonetic transcription of Ibn Hūd's vizier's name, we have followed the tashkil present in the document (Ibn al-Ramaymī, $f^{\circ} 5 \mathrm{v}$, p. $\left.8, \mathrm{I} .22\right)$ rather than the transcription usually found in works by historians (Ibn al-Ramimì).
} 
the need to justly reward unfailing faithfulness and effective independence. Also in both cases, autonomy of action emerges through the transfer of trust from an individual to a lineage: in 1238, Ibn Hūd's vizier, Ibn al-Ramaymī, assassinated him, and at the end of the 1220s, the powerful Hafșid governors of Ifrīqiya used the pretext of al-Ma'mūns rejection of the Almohad doctrine to declare their independence from Marrakesh.

This pattern can be compared to the transmission of the function of shaykh from father to son among the Arabs. ${ }^{598}$ The heredity of this responsibility was clearly a limit to caliphal authority, a concession offered to groups whose support was sought and whose defection would have gravely weakened the ruler. It seems in particular to have developed with the reign of alMustanșir (1214-1224). Whereas it had previously served as a government strategy to assure the loyalty of provincial elites, it became a symptom of a crisis of authority and the ruler's weakened means of action and coercion. As on the caliphal level, the ruler played on the competition between the brothers and sons of the deceased to impose his power. Taqdim 39 is a perfect example of this strategy of division among the Arab families with the dismissal of a son in favor of his paternal uncle, and so a support for lateral legitimacy to the detriment of vertical legitimacy and direct parentage:

When he died, we kept his post for his son, whom we honored with an appointment at the head of the Arabs because [of his father], for we believed that in [our] service he would comport himself as his father, and that his plans would not stray from the praiseworthy paths his father had followed. Nevertheless, he delayed not in renouncing [that] favor and in calling misfortune on himself through his misdeeds. We have dismissed him and [in his place] have named his [paternal] uncle, Fulān, at the head of the Arabs, to manage their affairs and govern them as well as possible. ${ }^{599}$

The mention of fathers in the judicial taq ādìm or in act 5 concerning al- 'Azafī of Ceuta is different. In this case, paternal ascendancy is not the sign of a family autonomy rivaling the ruling authority, but of the transmission of knowledge through the family, in particular religious and juridical. Al- 'Azafî's case is a bit particular, of course, since the monopoly of knowledge transmitted by his father, the famous faqīh Abū l-'Abbās al- 'Azafī, opened the doors of power in Ceuta to a member of the family. However, this occurred during a dynastic crisis for the central Almohad power, and the competition that resulted between Ibn Hūd of Murcia, the

\footnotetext{
598 Taqādīm 39 and 41.

599 Taqdīm 39, fo 28r, p. 53, I. 1-5: wa lammā tuwuffi abqaynā walada-hu fí makāni-hi wa nawwahnā bitaqdīmi-hi 'alá al-'arabi mina shāni-hi wa qaddarnā fî-hi anna-hu yasluka fĩ l-khidmati maslaka wālidi-hi wa an lā ya 'dila 'an mashkūri maqāșidi-hi fa-mā 'adā an kafara I-na 'mā'a wa jalaba ilá nafsi-hi bi-sū'i af'âli-hi al-aswā'i wa akhkharnā-hu wa qaddamnā Fulānan 'amma-hu 'alá l- 'Arabi li-yaḍbița umūra-hā wa yasūsa ahsan siyāsat jumhūra-hā.
} 
Hafșids of Ifrīqiya, and the Italian city-ports for the control of this strategic port. As during the second taifa period in al-Andalus (1144-1157), the great judicial families were a source of stability during a time of political crisis.

This popular confidence in religious authorities, despite the Almohad struggle against institutional Mālikism, attests to the failure of Ibn Tūmart and 'Abd al-Mu'min's ambitions and the powerful inertia of religious institutions in their relations with political authority. ${ }^{600}$ The power of this resistance can be related to the family structures that played a role in the transmission of knowledge, whether professional or craft-related, artistic or literary, military or religious. ${ }^{601}$ The mentions of "we appreciated that he followed in his father's footsteps,"602 "and he steadfastly followed in the footsteps of this father and his (paternal) uncle,"603 "he placed his steps in those of his father," ${ }^{\circ 04}$ justify the appointment by transmission, with the paternal specialization and knowledge, reputation and respectability.

In addition, judges were often from the localities where they were appointed. ${ }^{605}$ The phrase fa-idha wa $f \bar{a}$-kum in the taqādim proves only that they went to the caliphal court to received their act of investiture. It is difficult, however, to evaluate the share of "foreigners" from al-Andalus among the judges appointed, even if the proportion must not have been negligible, at least for the more important positions. The majority of the studies on juridicalreligious institutions focus on al-Andalus, but they all reveal efforts by families to monopolize judicial offices within a network of family relations: Muḥammad b. 'Abd Allāh Ibn Ḥawṭ Allāh al-Hārithī (d. 607) ${ }^{606}$ held the post of șăhib al-aḥkām in Cordova and Murcia for his father, the $q \bar{a} d \underline{l} \bar{l}$ Abū Muḥammad 'Abd Allāh, who was $q \bar{a} d \underline{l} \bar{l}$ of different cities in al-Andalus and North Africa. Makhlad b. Yazīd b. 'Abd al-Raḥmān al-Umawī (d. 622) ${ }^{607}$ held the hutțat 'aqd almanākih for his brother Ahmad when he was judge of the city. These examples, taken from

600 On the institutional character of the scholarly world in dār al-Islām in the Middle Ages, see M. ChamberLain, Knowledge and Social Practice.

601 This process of dynamic construction of a religious identity developed most completely in situations where the population was politically subject, as with the Mudejars of Aragon in the thirteenth and fourteenth centuries, when the family played in full its role of conserving the collective memory and the identity of the group, as shown by Kathryn MILLER in Guardians of Islam.

602 Taqdīm 50, fo 32v, p. 62, I. 21: wa quddira fi-hi al-iqtidā'u bi-abi-hi.

603 Taqdīm 51, fo 33v, p. 64, I. 8: al-mutaraddid bayn abī-hi wa 'ammi-hi bi-l-iqtidāi wa-l-iqtifā'i.

604 Tadīm 73, fo 46v, p. 89, I. 10: wa hadhā hadhwu abī-hi.

605 'I. al-D. MūSÁ, al-Muwahhịiūn fị i-Gharb al-islāmī, p. 201.

${ }^{606}$ See J. LiROLA Delgado et J.M. PuerTA VílCHEZ (dir.), Biblioteca de al-Andalus, t. 3, s.v. "Ibn Hawt Allāh, Abū Muhammad," n 566, 321-325, p. 324.

607 IBN AL-ZUBAYR, Șilat al-șila, 76, nº 101. 
sources other than the taqā $\bar{\imath} m$, shed additional light on the family management of offices tied to judicial authority in al-Andalus and the Maghrib in the twelfth and thirteenth centuries.

\section{Belonging to the circles of power}

The ultimate criterion of selection for provincial officials is loyalty to the regime, especially when added to the previous two criteria: personal qualities and long-term relations between the chosen official's lineage and the Almohad regime. Taqdim 33 gives a perfect example of the unique and exceptional character conferred by the accumulation of these three through the personal qualities inherited by way of the sound and upright education received through contact with the court by way of the family's long-term faithfulness to the regime:

we have named Fulān, who has long been a servant [of the state], a loyal being whom we have sought out and whose company we have kept because of his excellent nature, someone whom His Presence has raised in the lap of his guardianship, that was cast into the shadow of his power, refined of all suspicion. He has ancestors who were faithful in the service [of the state], deserving of praise and favors, spending all of their energy and possible deeds in the service of this power. ${ }^{608}$

Familiarity with the ruler and the court is thus a mark of nobility and a standard of quality that will allow the subjects, if they are worthy, to come closer to God in the hereafter. Taqdim 72 reveals that proximity with God in the hereafter hangs on this factor in the here below:

"in addition, he has merited to be close and near [to Our Presence] because of the services rendered (was $\bar{a}$ ' $i l)$ by his father, a servant known and eminently respectable." 609

This is another example of the parallel established between the earthly Almohad caliphal power and the celestial power of God: "the amr al- 'azim is the amr of God", and proximity and familiarity with the caliphal prefigures proximity with God.

\section{d. Conclusions}

This presentation of the seventy-seven taqādìm in Yahyá's collection offers an image of provincial officials that differs considerably from that present in the chronicles and literary sources. There are a number of reasons for this, related either to the nature of the sources used,

608 Taqdīm 33, fo 25r, p. 47, I. 21-fo 25v, p. 48, I. 2: qaddamnā Fulānan wa huwa al-khadīmu I-qadīmu waI-nāșihu I-ladhī nastașhibu ḥusna I-țawiyyati wa nastadīmu wa man rabbat-hu al-ḥaḍratu fĩ hajri kafālatihā wa ḍarrajat-hu I-muhadhdhabu l-aryabu fi zilli iyālati-hā wa la-hu al-salafu al-akīdu I-khidmati alkhalīqu bi-shukri l-ni 'mati al-mufná fị khidmati hadhā l-amri al-āliyyi wus'a l-țāqati wa mamkana Ihimmati.

609 Taqdīm 72, fo 46r, p. 89, I. 14-15: wa taqāọat la-hu wasāilu abī-hi al-athīri l-ḥurmati al-shahīri Ikhidmati maziyyata I-taqrïbi wa-l-izdilāfi. 
chronicles, geographic or bio-bibliographical dictionaries and literary anthologies versus chancellery documents, or to the context illuminated by these respective sources.

\section{Delegation of power versus centralization}

The imprecision of the term 'ämil revealed by Guichard is relative. The word certainly means "agent" and can be used indistinctly in the narrative sources for all levels of administration, ${ }^{610}$ but in Yahyyá's collection it always designates an important official with an authority equivalent to the $w \bar{a} l \bar{l}$ and holding identical and defined prerogatives: policing and maintaining order, tax collection and economic management in their regions of appointment. As for the duality noted by Guichard between an administrative structure that is essentially fiscal and a more political organization, each relatively independent of the other, though the second obviously trumps the first, this would seem to be a deformation of the sources used or perhaps a reflection of the Almohad Empire's situation in the twelfth rather than the thirteenth century. ${ }^{611}$ Indeed, in the Maghrib from the end of the 1220 s to the disappearance of the Almohad dynasty, this duality is not glaring. The only clear distinction shown by the appointment acts comes not between the administrative and political functions, but between the fiscal, military and administrative functions and the judiciary.

Nevertheless, we would agree with Guichard's recognition of the financial dependence on the state of not only the military, but also those elites and officials charged with maintaining order. The non-privatization of royal prerogatives (coinage, army, justice) and the enlistment of provincial elites in the administration constitutes "one of the fundamentals traits of the Islamic socio-political system and one of the major differences with the largely feudal structures of the contemporary Latin kingdoms." ${ }^{612}$ Mūsá recalls that some governors received a total delegation of financial matters and coinage from the government, explained either by the caliph's confidence in them, or by the inherent necessities of the region in question. ${ }^{613} \mathrm{We}$ can also add that the large autonomy occasionally granted to certain regions, as in taqdim 1 , with in particular the delegation of power to appoint regional officials, was not the cause of weakened central power, rather its consequence. For the provinces, this corresponds to a political dynamic of putting different "legitimizing" authorities in competition with each other - the Abbasids in

610 P. GUICHARD, Les musulmans de Valence, t. 2, 366.

611 P. GUICHARD, Les musulmans de Valence, t. 2, 337.

612 P. GUICHARD, Les musulmans de Valence, t. 2, 367.

613 'l. al-D. MūsÁ, al-Muwaḥhidūn fî l-Gharb al-islāmī, 185. 
Baghdad, the Almohads in Marrakesh, and the Hafșids in Ifrīqiya - and, for the capital, it conveys an effort to restore the prestige of an increasingly fragile and contested caliphate.

It is remarkable that the term niyāba ("delegation") does not appear in the collection, with one exception, not even in taqdim 1 . This governmental practice was emblematic of the Almoravid provincial administration, and contrasts with the extremely centralized system developed by the first Almohad rulers. ${ }^{614}$ In fact, niyāba occurs only in taqdìm 20, where it does not reflect a real delegation of power so much as the quality of the appointee, the importance of the missions entrusted to him and of the city placed in his hands:

\begin{abstract}
We have issued a delegation decree (rasm al-niyāba) to keep Fulān in his post among you, thus choosing the qualification [given him by] (tanāwulāt) his righteousness and efficiency. We have named together with him for all [your affairs] Fulān because of his prestigious rank in the community ( $t \bar{a}$ ' $i f a$ ) of Unicity (tawhid) and his faithfulness to his ancestors' just and righteous path. ${ }^{615}$
\end{abstract}

\title{
Associated nominations
}

The above citation from taqdim 20 also sheds light on the practice of associated appointments, which do not seem exceptional. Yet, they are grouped in the collection from taqdim 15 to 20, excepting taqdìm 16. This would indicate that the provinces in question and their fiscal stakes were important. The "shared" appointments were probably also motivated by the desire to ensure the mutual control of each of the officials in the decisions and actions of the other. The reduced size of the Empire and the weakening of caliphal authority explain thus the contrast between the information present in the chronicles for the Empire's period of expansion and organization, and those present in the taqāìm written during the phase of political and territorial crisis.

The size of the cities and provinces entrusted to the "servants of the state" during the first period necessitated more specialization than in the middle of the thirteenth century, when the authority of the caliph in Marrakesh covered only the territory of present-day Morocco. The non-specialization of the officials named in the taqāìm may then be simply the symptom of the crisis endured by the Almohad regime beginning with the reign of al-Ma'mūn, while the specialization reported in the chronicles would not necessarily have been a principle of government - the separation of military and fiscal responsibilities, of military operations and

\footnotetext{
${ }^{614}$ We should also mention the verbal form wa yanūbu aḥmad manāb in taqdīm 26 (fo 21 v, p. 40, l. 19.). On the comparison between the Almoravid system of delegation and the Almohad centralized management of provincial administration, see P. Buresi, "Administration territoriale," 129-145. ${ }^{615}$ Taqdìm 20, fo $18 \mathrm{v}$, p. 34, I. 15-17.
} 
the maintenance of interior order - but an empirical adaptation to the complex management of vast and populated territories.

\section{The respective place of judges and territorial administrators}

The functions attributed to the central power's civil and military representatives in the regions encroached in fact on the religious domain. As for the judges, while they may have obtained an arrangement of the Almohad doctrine in the juridical domain, their activities seem to have been restricted to the resolution of disputes between the Empire's subjects. Their opinion had been sought in all domains, political, social, and religious, under the Almoravids, but the taqādìm reveal that under the Almohads not only did they depend on the central regime, but in addition they received exclusively "judiciary" attributions. No more the solicitations for advice on political decisions, no more their universal expertise, the qādis under the Almohads were judges in the name of the Law, in the service of the central administration, and no more.

\section{Al-īrād wa l-iṣdār: authority and its practice}

The translation of this notion is difficult, because the dictionary definition does not correspond with reality: this notion, twofold in fact, appears in the great majority of the taqādim, either as the binomial $\bar{\imath} \bar{a} d-i s ̣ d \bar{a} r$, or more rarely as wird-șadr. ${ }^{616}$ Dozy claims in his Supplément aux dictionnaires arabe-français that this couple designated in Egypt, under the Mamluks, "income and expenses". This translation is difficult to accept in the Almohad context. The term appears as much in those acts concerning judges as those for governors (wulāt or 'ummāl), and includes as much the Almohads as the Arabs. Also, certain formulations indicate a quality, a function, or a more abstract and general activity, and less "budgetary" than that represented by income and expenses:

"May, for him, the strong and the weak, the noble and the [man of the people] be equal, no matter the decree he issues or receives (mā yūridu-hu aw yușdiru-hu min qaḍa' $i-$ hi). ${ }^{617}$

or also:

"Thus when he arrives among you, may your submission to his authority [which he holds from us] be irreproachable (li-ișdāri-hi wa ìrādi-hi)." ${ }^{\prime 618}$

Moreover, $\bar{r} r \bar{a} d$ and $i s \underline{a} \bar{r}$ concern not only the appointees, but also the caliph:

616 In taqādīm 11, 53, and 54.

617 Taqdīm 73, f० 46v, p. 89, I. 16-17: wa an yakūna 'inda-hu l-qawiyyu wa-l-ḍa îfu wa-I-mashrūfu wa-Isharīfu siwā'an mā yūridu-hu aw yușdiru-hu min qaḍāi-hi.

618 Taqdīm 58, fo 40r, p. 77, I. 2: fā-idhā wāfā-kum fa-l-yaḥsuna i'timāru-kum li-ișdāri-hi wa īrādi-hi. 
"May God on High grant us the continuation of that with His aid and His support and may His assistance accompany us in the exercise of our authority (literally "in the ișdar and $\left.\bar{i} r \bar{a} d^{\prime \prime}\right) . " 619$

We should note that, as in the preceding example, all the passages concerning the $\bar{r} r \bar{a} d$ and $i s \underline{a} r$ of the ruler are prayers asking God for His help, His support or His direction in this area. The mention of $\bar{i} \bar{a} d$ and $i s \underline{d} \bar{a} r$ for officials, however, appears in sections where the caliph lists the orders, advice, or injunctions he has given to the designated governor or judge.

The complementary terms of $\bar{r} \bar{a} d$ and $i s ̣ d \bar{a} r$ (wird-șadr) evoke a double movement of sending or transmitting and reception. They can thus concern not only revenues and expenses, but also orders and information. They situate the person exercising this $\bar{\imath} r \bar{a} d$ and $i s ̣ d \bar{a} r$ at the center of a twofold movement: that to which he submits and that which he exercises. They thus place the official, most often, and ruler, more rarely, in a position of articulation in the chain of power. The quality of the person concerned is then measured by the obedience he manifests to the superior obligation of his office, for the caliph, to the ruler's orders, for the provincial officials, at the same time as the manner in which he acts as a well-oiled and extremely reliable mechanism between God and the faithful. At the higher echelons, the binomial $\bar{\imath} r \bar{a} d-i s ̦ d \bar{a} r$, which articulates the message from God (Koran and Sunna) towards the faithful, gives the caliph his legitimacy and confirms him as an intermediary between the earthly world and God, an obligatory interpreter of the divine word; at lower echelons, the transfer of this same binomial reproduces the higher hierarchy and implicitly places the official in a relationship with the caliph that is almost identical to that which the caliph maintains with God. The caliph exercises his $\bar{\imath} r \bar{a} d-i s ̦ d \bar{a} r$ through prayer and the help of God, the official practices it in obeying the superior authority of the ruler, on the one hand, and governing as justly as possible, on the other.

This conception of authority, from God to His representative on earth, the Almohad caliph (khalīfat Allāh), and from him to the provincial officials, and through them to the subjects of the Empire, all within the framework of the "fear of God" (taqwá Allāh), is based on an organic and hierarchical vision of Creation. This vision differs greatly from the much more functionalist one present in the Ahkām al-sulțāniyya by al-Māwardī (d. 450/1058), the Ahkām

619 Taqdīm 14, fo 15r, p. 27, I. 8-9: wa Llāhu ta ālá yamuddu-nā fí dhalikum bi-l-ta'yīdi wa-l-injādi wa yaj'alu tawfiqa-hu la-nā rafíq ${ }^{a n}$ fì l-ișdāri wa-I-irāàdi. Other examples in taqādīm 6, 9, 25, 38, 62, and 77. 
al-kubrá by the Andalusī jurist Abū l-Aṣbagh 'Īsā b. Sahl (d. 486/1093), or later in alWansharīis̄’s Kitāb al-wilāyāt. ${ }^{620}$

\section{THE CHANCELLERY, CENTRAL MECHANISM OF THE IMPERIAL POWER}

Yahyá's collection does not lend itself to a detailed study of how the chancelleries that produced these documents functioned. The names of kuttāb are not mentioned, so we cannot know if known secretaries wrote these acts, or if they were secondary scribes. Other sources, such as bio-bibliographical dictionaries, will have to serve for a prosopographical study. ${ }^{621}$ The following presentation of the Almohad chancellery is thus limited to the general framework of exercise for the kitäba, to the general structure of the secretaries' activity and will more precisely address the detail of the acts in themselves and the procedures of production as indicated in Yahyá's manuscript.

\section{A. THE KITĀBA, THE KUTTĀB, AND THE $D \bar{I} W \bar{A} N A L-I N S H \bar{A}{ }^{\prime}$}

In a previous work, we noted the distinction between the group of $k u t t a \bar{b}$ charged with juridical-religious functions and the body of kuttāb termed "lettered" (udabā) ${ }^{622}$ Indeed, the Almohads had taken firm control of state institutions, including the kitāba, and had introduced selection criteria different from the sole, and traditional, literary performance. This notable social-political evolution is confirmed by a rapid thematic analysis of the corpus of documents.

\section{The juridical education of the kuttāb under the}

\section{Almohads}

Although the description of a major historic event had traditionally allowed its reporter to be cited by the chronicles, under the Almohads there seems to be a generalization of anonymity. The kuttāb behind the numerous important letters are unidentified and this silence, which results probably from the specific means of transmission of memory in medieval Islam, reveals also a depersonalization of the state administration during the Almohad period. The omnipresent literary ornaments are no longer there to glorify the particular $k \overline{a t i b}$, but participate in celebrating the regime. After Ibn 'Ațiyya's execution in 1158, the choice of secretaries seems progressively to obey new criteria different from the literary and poetic competencies that had allowed this Almoravid scholar to become secretary, vizier, and councilor to 'Abd al-Mu'min.

\footnotetext{
$620 \mathrm{H}$. BRUNo and M. Gaudefroy-DemOMBYNES (ed. and trans.), Le livre des Magistratures. 621 Using for example the database developped by Mustapha Benouis in his dissertation Le système juridico-judiciaire almohade en al-Andalus et au Maghreb, 542-668/1147-1269, defended June 29, 2002, under the direction of Pierre Guichard at the Université Lumière Lyon 2.

622 P. Cressier, M. Fierro, and E. Molina (dir.), Los Almohades, and in particular our article "La chancellerie almohade", t. 2, 477-503. The list of kuttāb provided in our article can be completed with that provided by 'I. al-D. MūsÁ and presented below in Annexes 4.
} 
According to the tabaqāt, the kuttāb no longer distinguished themselves only by their literary or poetic talent, but also, and especially, by their juridical-religious knowledge: hadìth, ūṣūl alfiqh ("foundations of the law"), qira 'ät (Koranic readings), lugha (language), Koran, 'ulüm allisān ("sciences of the Arab language").

At the beginning of the twelfth century, in the continuance from the taifa period studied by Bruna Soravia, the chancellery secretaries (kuttāb al-insh $\bar{a}$ ') were still tied, with few exceptions, to the lettered milieu ( $u d a b \bar{a}^{\prime}$ ). Beginning with the Almohad period, however, the bio-bibliographical dictionaries reveal that these $k u t t a \bar{b}$ frequently exercised judiciary or

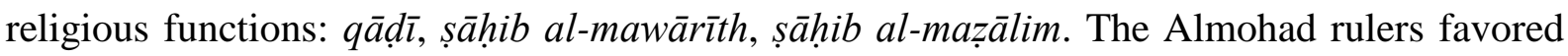
the juridical-religious criteria rather than the strictly literary or worldly qualities of their kuttāb. Contrary to their predecessors, they used judges ( $q \bar{a} q \bar{l} \bar{l})$ and doctors of the Law (fuqahā') in attributing them the function of kātib and vice-versa. ${ }^{623}$ Contrary to what we claimed in our earlier work, this was not a sign of flexibility for the Almohad administrative system, but a reformulation of the social role of the fuqahä' and 'ulama ', who were barred from juridical service but still enrolled in the chancellery services that, in a way, took the place of the body of scholars to issue the law.

The geographic origin of the kuttāb: alAndalus and the Maghrib

This functional evolution was accompanied by a modification in recruitment that consolidated the emergence of the Maghrib in the profession of letters. Under the Almoravids, no secretaries came from the Maghrib. Andalusī scholars totally dominated the Almoravid chancellery and each of these Andalusīs had honed their skills in the courts of the taifa kings.

623 The careers of Ibn al-Abbār and Ibn 'Amīra are a perfect illustration of the ties between chancellery activities and judicial-religious functions. After having served as kātib for the last Almohad governor of Valencia, the sayyid Abū Zayd (c. 1220-1229), then his successor Zayyān b. Mardanīsh (1229-1238), Ibn al-Abbār was named qāọī of Denia in 633/1236. As Guichard notes in his Musulmans de Valence, the family environment of this scholar carried him towards judicial and religious activities.. He was trained as a faqih his father had been the prayer leader at the Zaidia mosque (al-Sayyida) in Valencia, and his principal teacher had been the traditionist Abū l-rabī' Sulaymān al-Kilā' Ṫ. In addition, his most important work, with the Takmila and Mu 'jam, was dedicate to figh. As for Ibn 'Amīra, after having served as kătib for Almohad governors, then various local rulers (Murcia, Alcira, Mallorca, Valencia), he fled alAndalus to enter into the service of the Almohad caliph al-Rashĩd, whom he served as secretary for a number of years. He then was named qāộ̄ of Hilāna, Rabat, and Salé. During the reign of al-Mu'țaḍid bi-Llāh al-Sa 'îd, Ibn 'Amīra became qāọī of Meknés. After the assassination of the caliph al-Mu'țaḍiḍ bi-Llāh al-Sa' T̄d, in 1248, Ibn 'Amīra fled once again, this time to Ifrīqiya where he joined other Andalusīs, such as his friend lbn al-Abbār. After working in Bougie in the chancellery of the ḥafșid prince Abū Yaḥyā Zakariyā b. Abī Zakariyā, he left after the ruler's death for Tunis in 1249. He was named qāọī of Gabès, then Constantine. These biographical elements are drawn from Hicham EL AALLAOUI's dissertation (L'art du secrétaire, 386-391) citing M. Benshrīfa, Abū l-Muțarrif Aḥmad b. 'Amīra. 
In the Almohad period, of the thirty-one kuttāb al-inshā' named by 'Azzaoui, fifteen came from al-Andalus, and six from the Maghrib; two probably came from al-Andalus given their careers, but no source specifies their place of birth, three were Mu'minids, and so members of the ruling family and from the Maghrib. No information is available for the last five. The prevalence of the Andalusīs is more flagrant if we take into account the number of letters extant: a kätib like Ibn 'Ațiyya, for example, has left sixteen letters, many more than any of the Maghribī secretaries. The kitāba's Andalusī character continued then under the Almohads (between half and two-thirds of the kuttāb close to the caliph), but much less systematically than under the Almoravids. The Maghribīs were beginning to penetrate and make a place for themselves in those domains from which they had heretofore been completely excluded.

Mūsá claims that during the first decades of Almohad domination, when the Andalusī scholars went to Marrakesh in search of fame only available through service to the ruler, their interests continued to focus on matters in al-Andalus. Beginning with the crisis, they headed for the court of the Hafșids in Ifrīqiya - like Ibn al-Abbār and Ibn 'Amīra - while those who continued to serve the Almohads in the Maghrib al-Aqșá stayed only a short while. According to his study then, we can hypothesize that excepting those taqāìim issued by Ibn Hūd's chancellery $(5,30,54$, and 55), and those by al-Ma'mūn while he was in Granada (4), a large number of the acts in Yahyá's collection were written by Maghribī secretaries, though we cannot know which.

\section{B. THE IMPORTANCE OF THE KITĀBA IN CONTROLLING TERRITORY}

The office of kâtib does not, in theory, imply governmental responsibility, since the secretary's vocation was simply one of transcribing in the de rigeur literary style directives given by the ruler to his subjects or to subordinates invested with a wilāya or khuțta. A kātib wrote always "in the name of" ( 'an), as shown in the title of a large number of the taqãdim in Yahyá's collection. ${ }^{624}$ Nevertheless, as in the Latin chancelleries from the same period, the highranking $k u t t a \bar{b}$ often held a power that largely exceeded their original attributions. They led offices of central government, the antechamber of the distinction of vizier, and took second place hierarchicaly behind the vizier. However, in valorizing these exceptional persons, famous because their names, talents, and power were memorized in other sources (chronicles, anthologies, bio-bibliographical dictionaries), there is the risk of neglecting those secretaries of

624 Taqādīm 4, 5, 6, 42-44, 47-49, 52-55, 57, 58, and 65. 
inferior rank, often anonymous, collectively charged with preparing and writing the caliphal message and Almohad ideology.

\section{The diffusion of chancellery documents}

Information circulated slowly in the Middle Ages, at best at the speed of a galloping horse or carrier pigeon. ${ }^{625}$ Chronicles sometimes give indications on the temporal dimension of circulating information in the Empire: forty days were necessary for a letter written in Mahdīya to arrive in Granada, sixteen from Murcia to Marrakesh. ${ }^{626}$ It is difficult to imagine in modern societies, where the transfer of information and finance are practically instantaneous, the situation and dimension of premodern empires, as well as the correlative role of time and the mastery of information for controlling a territory and its inhabitants, for the management of resources and establishing an enduring power. The importance in these vast empires of the postal services (barị̂ ) and mounted couriers, carriers of official messages, is understandable. In the Almohad period, the courier was called the raqqās. ${ }^{627}$

The kuttāb prepared the message, wrote the acts of bay ' $a$, letters of information, acts of appointment or dismissal, caliphal orders or decrees. These texts were then read from the minbars in the great mosques of the cities of the Empire. The writing of these texts carries thus an fundamental importance in the relationship between the ruler and his subjects. It is of course not possible to evaluate the impact of what resembles a service of "institutional state propaganda", nor to measure the adhesion of the subjects vis-à-vis the transmitted message. Nevertheless, the attention the caliphs give the mention of their names in the khutba (Friday sermon) and on coinage, and in general to "signs of recognition" indicates that these manifestations of obedience and allegiance must have had a certain social effectiveness, at least symbolically. ${ }^{628}$ They justified and legitimized taxes, the respect for social, political, and religious norms, and they gave a sense to relations with foreign powers.

\section{The taqdìm as an act of power}

Framed by these ideological and political-religious tenets, it is understandable that the texts written to announce the arrival of a new administrator, judge or governor demanded the talents of the greatest $k u t t a \bar{b}$ in the Empire and that, despite the disappearance of the

\footnotetext{
625 See Y. RAGHEB, Les messagers volants.

626 É. LÉVI-PROVENÇAL, Trente-sept lettres officielles, letter 19, p. 95-99.

627 See R. DozY, Supplément, t. 1, 547.

${ }^{628} \mathrm{Cf}$. the chapter titles from GUICHARD's, Les Musulmans de Valence, t. 2, 275: "Le pouvoir sultanien et ses signes de 'reconnaissance' dans les villes de l'Andalus oriental" and 305: "Les 'signes du pouvoir' dans les capitales de l'Espagne orientale".
} 
Almoravids, or perhaps because of it, scholars felt the need to preserve the contents of these acts, which a quick reading may make seem daunting and repetitive. Indeed, these texts are an expression of authority, they are power in action, as attested by the numerous performative verbs - "we order, name, council, enjoin..." - and the presence of orders, underlying threats, and prayers.

The name even of these documents, taqdim, is a performative, the mașdar of the verb in the second form: qaddama. It is noteworthy that it differs from the terms taqlid - though built on the same construction as taqdim from the root QLD -, sijill or 'ahd, usually used by the other territorial powers, Fatimids, Abbasids, or Umayyads. This choice clearly reveals a desire on the part of the Almohads to set themselves apart by semantically renewing an existing expression, renewing the language, while also respecting tradition. The proof from a contrary position of the fundamentally Almohad character of the term taqdim comes from those acts issued by Ibn Hūd al-Mutawakkil. In the four acts issued by this ruler from Murcia $(5,30,54$, and 55), the term appears only once (5), in a comment-worthy context. The three other documents do not use the root QDM, but prefer $Q L D$ (second and fifth forms). ${ }^{629}$ Taqdìm 5, where the term qaddamna $\bar{a}$ is used, is significantly one of the rare acts to use the notion of niyāba. The text claims that the Dhü l-wizäratayn (Ibn al-Ramaymī) had been sent to "represent" (li-yunība) the regime, as a substitute for the ruler. When he recalls his vizier, Ibn Hūd suggests that the son of his official take his place, and uses the term qaddamna ${ }^{630}$ The verb here is constructed without the maf'ül muṭlaq (qaddamnā Fulān ${ }^{a n} \operatorname{taqdīm}^{a n} \ldots$...) and without the complement, introduced by the particle $l i$ - (+ noun or verb $)^{631}$ or the preposition 'alá) $)^{632}$ which usually accompany it in these acts and indicate the prerogatives, area of competence, or the nature of the office. Contrary to Almohad acts, it is followed only by a precision of place,

629 Taqdīm 30, fo 24r, p. 45, I. 10-11: "we have chosen, to govern your interests and defend your [countries], near and far, someone whom we could not have not chosen” (takhayyarnā li-wilāyati mașālihi-kum wa himāyati dānī-kum wa nāziḥi-kum man lam ya 'du-hu al-ikhtiyāru) ; Taqdīm 54, fo 35v, p. 68, I. 13-14: "We called to arbitrate disputes among its inhabitants someone whose good reputation, purity of intentions, equity, and merit we know well" (wa nanhaḍu li-taqalludi I-fașli fĩ l-aḥkāmi bayna ahli-hi man 'arafnā-hu bi-l-nabāhati wa-I-nazāhati wa-I'adālati wa-I-faḍilati) ; taqdim 55, f० 36v, p. 70, I. 17-18: "With this in mind, we choose with the greatest care the person we will appoint as governor among you and whom we will order to lead you. We make him responsible for assuring a task in your regions, more specifically the function of judge" (wa bi-hadhā l-i tibāri nujiddu l-ikhtiyāra li-man nasta 'milu-hu fi-kum wa nastanhiḍu-hu li-tawallī-kum wa nuqallidu-hu shaghlan min ashghāli nawāḥikum wa bi-khāșșat in khutțāta l-qaḍā'i).

630 First person plural of the past tense of the second form of the root QDM.

631 Li-I-naz̄ār, li-l-istibdād, li-l-fașl, li-l-infirād bi-I-naẓar, li-khutțati l-qaḍā', li-l-ishtighāl bi-ahkāmi-kum, litawallī, li-yatawallá al-naz̧ar, li-ḍabț, li-yanzuura, li-yujriya l-hukma...

632 'Alá jamī' al-ashghāl, 'alay-kum, 'alá tilkum al-bilād, 'alá l-'arab, 'alá l-jaysh, 'alá a 'māli-kum, 'alá jihāti-kum li-yaqūma bi-mașāliḥīhā, 'alay-kum li-l-qaḍā'... 
"in your region" ( $f i$ qatri-kum). This is why we have translated the verb with its original sense "cause to advance", "place before", rather than "appoint". ${ }^{633}$ This lexical choice is not innocuous, for it is the act itself of sovereign power that is at stake, the essence of the authority to appoint and dismiss. The adoption of a new term fully reveals that the Almohads aspired to exercise an authority different from that of their predecessors and of their rivals in legitimacy, the Abbasids in Baghdad. The chancellery was a vector for these ambitions, the place of expression for a new manner of exercising power and the center of conceptualization of the historic political and religious reform that the Almohads had put in place.

\section{c. Chancellery writing: between tradition and innovation}

The internal organization of the documents points to the very strict rules and norms of writing for the chancellery. These took their root in an empirical practice of literature and administration that had developed over time, and had periodically been the object of theoretical essays. We refer here to works by Cahen, Sourdel, Cheikh-Moussa, Soravia, and El Aalloui. ${ }^{634}$ The education of a good kätib supposed the study and knowledge of an ensemble of notions and texts the mastery of which was not formally verified, as in an examination. Recruitment relied on an informal process, a compromise between choice, social and family reproduction, and recognition by one's peers through "confraternal" epistolary exchanges (ikhwāniyyāt). The opportunity to benefit from the study of classics under the direction of recognized masters in the places of the court designated for this was in and of itself a criterion of selection for the $k u t t a \bar{b} .^{635}$ A rapid comparison of the Almohad taqādīm in Yahyá's collection with some Almoravid appointments will help sort out the Almohad specificities in structure, lexical and style choices, within the constraining framework of chancellery practices.

633 Taqdīm 5, f० 6v, p. 10, I. 9-12: "Dhü l-wizäratayn ("the man with two vizierates") [...] s heading toward your country - May God protect it - to represent us in the administration of your affairs and fill our place to ease the success of your hopes" (wa bi-ḥasbi hadhā kāna tawajjuhu waliyyi-nā Dhī I-wizāratayn [...] ilá qațri-kum al-mubārak hāțahu Llāhu li-yunība 'an-nā fì mubāsharati ahwwāli-kum wa yaqūma maqāma-nā fĩ taysīri amāli-kum) and $f^{\circ} 7 r$, p. 11, I. 3-4: "[This decision] is to put forward (qaddamnā), in your land with all its provinces, near and far, the leader ( ra'īs) Fulān, son of our companion Dhü l-wizāratayn" (wa dhalika an qaddamnā fĩ qațri-kum wa jamī i jihāti-hi dānī-hā wa nāziḥi-hā al-ra'îs Fulānan ibn waliyyi-nā Dhī l-wizāratayn).

634 D. SOURDEL, "Le "Livre des secrétaires," 115-153; C. CAHEN, "Notes diplomatique arabomusulmane," 65-80 ; A. CHEIKH MousSA, Le "scribe" et le pouvoir (in Arabic and not consulted) ; B. SORAVIA, Les fonctionnaires-épistoliers, non published, "Un traité andalou," 4-20, "Entre bureaucratie et littérature," 165-200 ; EL AALLAOUI, L'art du secrétaire.

635 B. SORAVIA, Les fonctionnaires-épistoliers, 47. 


\section{Almoravid appointments vs. Almohad taqādīm}

The following passage borrows from Hicham El Aallaoui's presentation of Almoravid appointments. ${ }^{636}$ The general structure of both Almoravid and Almohad acts is similar, but the Almoravid appointment carries the name taqlid or tawliya, and the date is indicated at the end of the preamble rather than the end of the act. The usual investiture phrase for state officials was wa qad ra'aynā an nuwalliya Fulān ("we have decided to invest Fulān"), followed by the place of appointment. The ruler directly addresses the appointee in certain documents, in the second person singular: nata 'ahhadu ilay-ka... ("we entrust you...") or wa nataqaddamu ilay$k a$ ("we grant you..."). As in Almohad documents, however, the taqwā Llāh is the essential element in the wașiyya ("command"). The respective construction for the judicial and gubernatorial appointments is similar, but the style for governors is marked by rhetorical effects - for example the accumulation of a series of prohibitions constructed in rhyming pairs ${ }^{637}-$, while for judges the terms are juridical and religious. The taqālìd are more explicit than their Almohad equivalents in warning the 'amma against any opposition to the new investiture. The governor is institutionally the emir's $n \bar{a}$ ' $i b$, his "substitute". Unlike the Almohad documents, the acts concerning judges mention numerous subordinate responsibilities, such as the khuttat al-ahkām ("official responsible for judgments") or the khuțtat al-mawārìth ("guardianship of successions"), which totally disappear under the Almohads. The Almoravid writing employs a rhymed prose ( $s a j$ ) illustrated by Koranic verses concerning justice and the last judgment.

\section{Koranic citations}

These Almoravid and Almohad documents merit likewise a thorough literary analysis, not just historical, even if the two are closely related in the world of the kitāba and little difference was made between the administrative writing of the dīwān al-insh $\bar{a}$ ' and literature $(a d a b)$. A strictly literary study would make little sense, but likewise a historical study that ignored the words and styling would miss the political dimension of letters in the medieval Islamic world. Comparing the styles, rhetorical effects, and $s a j$ ', respectively of the Almoravids

\footnotetext{
${ }^{636}$ In addition to these acts, we can add those presented and edited by Maḥmūd 'Alī MAKKİ in his "Wathā'iq tārīkhiyyat jadīda." The image that comes through, in the process of official appointments and in the style and structure, is very different from that present in the Almohad-era taqādīm (M. 'A. MAKKĪ, "Wathā'iq tārīkhiyyat jadīida," doc. 7, 176-177, 8, p. 177, 15, 183-184, 17, 185-186, and 18, p. 186). 637 For example, in document 7 of M. 'A. MAKKİ, "Wathā'iq tärīkhiyyat jadīda," doc. 7, p. 176-177: this document was written in the name of 'Alī b. Yūsuf b. Tashfin, from his camp in the suburbs of of Cordova. It confirms the appointment of a governor and enjoins the inhabitants of the region concerned to obey him without trouble.
} 
and Almohads, would exceed the limits of this study of the taqāìm. We should note, however, the importance and the role of Koranic citations, since the documents in Yahyá's collection differ greatly on this point. It may seem strange that the Almohads, who valued the Koran so much in practicing the law, explicitly cite it less often than the Almoravids do, especially in their appointments acts. This choice carries large political significance, since Ibn Hūd alMutawakkil's kuttāb reestablish these citations to the point of saturation, as for example in taqdim 55. This contrast between the almost total absence of citations in the Almohad documents and their importance in the acts of other regimes (earlier, later, or contemporary but rival) bears witness to a different relationship with the Revelation.

These Koranic citations are not graphically different than the rest of the text, no particular care is given to their writing, the same ink and characters are used, there is no supplementary tashkīl. Nevertheless, though quotation marks are absent from medieval Arabic, certain words serve to announce Koranic citations: qāla Allā ta álá... wa qāla ... wa qāla: "God on High said:... and He said:... and He said...", and allow for a distinction between "profane" acts in the act and the "divine" from the Koran. ${ }^{638}$ This is absent from the Almohad taqāìm, where Koranic references underlie the whole and are not differentiated from the rest of the text, where the terms used are recomposed to echo the Book, without necessarily citing it explicitly.

Taqdim 6 offers a number of examples for this practice: the Koranic fragment $a-f a-l \bar{a}$ ya lama idha bu'thira mä fi l-qubur ("Does he not know that when the contents of the graves are scattered...") 639 is evoked in shortened form: idha bu thirat al-qubūru ("when the graves are scattered"). ${ }^{640}$ Elsewhere, the terms of a verse from the sūrat "The Constellations" (al-burūj) are inversed: Wa Llāhu min warā'i-him muhīṭ ${ }^{u n}$ ("For God, from behind, surrounds them") ${ }^{641}$ becomes wa Llāhu muḥ̂ț $t^{u n}$ min warā 'i-him (“[For] God surrounds them from behind”). ${ }^{642}$ This inversion probably is justified by the $s a j$ ', since the text continues with wa muhīq bi-him s $\bar{u}$ ' $\bar{a} r \bar{a}$ 'i-ihim ("and causes their maleficient ideas to fall upon them") with the double parallel muhịt tmuḥ̄q, warā'i-him/ārā'i-him, reinforced by the internal rhyme bi-him. This allows a semantic renewal of the Koranic phrase and reinforces the effectiveness of the Almohad saj .

Certain examples are repeated in a number of taqādìm. The call for mutual aid which appears often in the final protocol of Almohad acts echoes verse 2 of the sūrat al-Má'ida ("The

\footnotetext{
638 Numerous examples in taqdīm 55 , fo 37 r, p. 71 , I. $11-f^{\circ} 38 \mathrm{v}$, p. 74 , I. 3.

639 Koran 100:9.

640 Taqdīm 6, fo 7v, p. 12, I. 16.

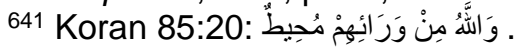

642 Taqdìm 6, fo 9v, p. 16, I. 11.
} 
Table"): ta 'âwanū 'alá l-bitti wa l-taqwá wa lā ta 'âwanū... ("help each other in righteousness and pious duty"). The secretaries do not hesitate, though, to create variations on this theme by replacing one term with another, for example al-birr ("goodness") with al-ṣabr ("patience") in taqdìm 26, adding ma 'a-hu ("with him [the judge]") between the verb and its complement or adding a maf'ul muțlaq (kull al-ta 'āwun). ${ }^{644}$ Taqdīm 72 offers an exemplary case of reworking the Koranic text to lend the weight of the Word to the caliphal order: li-dhalikum natakhayyaru li-ahkāmi-kum man yuqīmu wazna-hā bi-l-qiști ("this is why we will choose to judge your affairs someone who will weigh with precise weights") ${ }^{645}$ is the logical consequence of verse 42 of the sūrat al-Mà'ida: wa in hakamta fa-ḥkum bayna-hum bi-l-qisți inna Llāha yuhibbu almuqsițin ("If you judge, judge between them with equity. For God loves those who judge with equity") ${ }^{646}$ and verse 9 of the sūrat al-Raḥmān: wa aqūmū al-wazna bi-l-qisți wa lä tukhsirū lmizāna ("[Always] Give the exact weight and never fall short of the balance"). ${ }^{647}$ Another inversion appears in taqdìm 74, with a fragment of verse 57 of the sūrat Yünus: wa hujjatu-hu al-ladhì hiya hud ${ }^{a n}$ wa shafa "un li-mā fì l-șudūr ("as a sign that will be like guidance for him and healing in the breasts"), ${ }^{648}$ a variation on the Koranic phrase wa shafä ${ }^{\text {sun }} l i-m \bar{a}$ fi l-șuduri wa hud ${ }^{a n}$ wa rahmat ${ }^{u n}$ li-l-mu'minina ("a healing for that which is in the breasts, a guidance and a mercy for the believers"). ${ }^{649}$ We have noted each of these echoes, reworkings and modifications of Koranic expressions in the critical edition presented below. ${ }^{650}$

This reworking of Koranic text and literary and poetic echo contributes to the creation of a political language that commands the sacredness of the Koran without referencing it clearly. Caliphal decisions and Almohad administrative language thus form the basis of a law that enjoys the same aura as the Law of God. Using a Koranic verse is a form of functionalizing the religious original. This processes is perfectly visible in Almohad coinage and epigraphy, ${ }^{651}$ but strangely, this use of the Koranic word does not penetrate the chancellery, even though the $k u t t a \bar{b}$ were increasingly recruited from among the specialists of the Law. A detailed look at the

\footnotetext{
643 For example in taqdim $26, f^{\circ} 22 r$, p. $41,4$.

644 For example in taqdìm $57, f^{\circ} 39$ r, p. 75 , I. 19.

645 Taqdīm 72, fo 46 r, p. 89, l. 8.

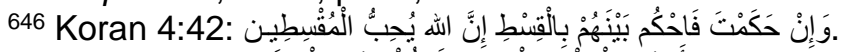

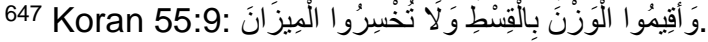

648 Taqdïm 74, f 47 r, p. 90, I. 19.

649 Koran 10:57.

650 Hassan Chahdi, specialist in the Koran, hadith and reading variants (qira'ât), doctoral candidate under François Déroche (EPHE), who has been efficiently responsible for this work of noting and referencing..

651 M. A. MARTINEZ NUÑEZ, "Epigrafía y propaganda almohades," 415-445.
} 
writing can help explain this paradox. The Word, for the Almohads was only a celestial pre-text on which the earthly language of power rested to shine light on its legitimacy, its faithfulness to divine precepts, to assure the addressees, readers and listeners that a political decision respected the commands of the Law, or to recognize the superiority of one order, the Prophecy, over another, the state. Before the Almohads, the Scholars ( 'ulamā') had collectively mediated between the Word of God and that of the ruler, between the Law and law, or between the Path of righteousness and concrete political decisions. Oscillating from interpreting the message of God, supporting the authorities, ensuring morality, backing political decisions, or on the contrary criticizing, contesting or rebelling, the specialists of the Law and their mystical variation, the "saints", were in a double position of mediation between God and the ruler, and between the faithful and authority.

\section{The creation of an Almohad writing of power}

The Almohad doctrine and the Mu'minid dynasty, in rejecting Mālikism and that school's works of jurisprudence and in promoting the imamate and the notion of the impeccability of the Mahdī, claimed for themselves alone the right to interpret. However, this reversal of authority was accompanied by a mutation in the discursive procedures of legitimation. The Almohad kuttāb used the Koranic lexicon and roots, but recomposed them, using more the evocative power of language and direct citation. In Ibn Hūd's acts, the Koranic citations form a kind of network that structures the text in two ways: they support the sense, playing their foundational role of auctoritates, while they also rhetorically form a tight armored weave of "strong points" that thus punctuate the text. The paradox is thus only surface deep: the elements used are all very well-known, but the ensemble is original and sets itself off within the production of the chancellery. ${ }^{652}$

The global composition of the Almohad taqādìm ensemble resembles a tapestry "à la Péguy", with each document not quite like the previous, but not entirely different. This work of infinitely recreating elements enriched by small touches constitutes the essence of administrative writing during this period. The stereotype is present everywhere, without there being a heap of insignificant or routine phrases. Common ground is consubstantial for such texts, but the way it is used is essential and must be taken into consideration. The acts are repellently repetitive, and seem at first fastidiously similar, but this should not hide the fact that

652 On the originality and the function of the citations, see S. BARRET, "'Ad captandam benevolentiam'," 331. 
none is exactly like another. The fact that taqâdim 35 and 44 are the same is probably explained by a compositional error, even if we cannot completely exclude the possibility of a double. Yahyá's collection is undoubtedly a selection of acts, and not an exhaustive reproduction of all the appointments between 1224 and 1269. This selection must have eliminated duplicates, while allowing acts 35 and 44 to slip through. Writing similarities between certain subgroups can be tied either to the activity of a kätib, to the organization of a chancellery office, or to the specific orders of respective reigns and so the context of production. As for the differences within a rather similar subgroup produced over a short amount of time, they are the exact expression of insh $\bar{a}$, creativity, variation on a theme, on the same structure.

The end of taqdim 1 provides an example of the styling work developed by the Almohad secretaries:

\begin{tabular}{|c|c|c|c|}
\hline$<-1-$ & $<-2-$ reading direction - & $<-3$ & $<-4$ \\
\hline و هُو المنجد والَمعين & و هو سبحانه يعرفكم اطََر اد الاسنحاد & ويمدكم في اعمال السَّداد & بالاعانة و الانجاد \\
\hline $\begin{array}{l}\text { It is He who brings } \\
\text { assistance and help, }\end{array}$ & $\begin{array}{l}\text { and } \mathrm{He}-\text { May He be glorified }-, \mathrm{He} \\
\text { will cause you to know unending aide }\end{array}$ & $\begin{array}{l}\text { and will bring you, for just } \\
\text { actions, }\end{array}$ & $\begin{array}{l}\text { His support and } \\
\text { His help. }\end{array}$ \\
\hline $\begin{array}{l}\text { Wa huwa }+ \\
\mathrm{A}(\text { munjid, } \mathrm{NJD})+ \\
\mathrm{B}(\text { mu 'īn, 'WN) }\end{array}$ & $\begin{array}{l}\text { Eulogy }+ \text { verb }\left(3^{\text {rd }} \text { pers. sing. }\right)+\text { pers. } \\
\text { pronoun }(-k u m) \text {, direct object (noun in } \\
\bar{a} d+i d \bar{a} f a \text { in rhyme } \bar{a} d)\end{array}$ & $\begin{array}{l}\text { verbe }\left(3^{\mathrm{e}} \text { pers. sing. }\right)+\text { pers. } \\
\text { pronom }(-k u m)+\mathrm{CC}(f \bar{\imath}+ \\
\text { noun }+i \underline{d} \bar{a} f a \text { in } \bar{a} d)\end{array}$ & $\begin{array}{l}\text { object } b i+ \\
\mathrm{B}^{\prime}\left(i^{\prime} \bar{a} n a, ' \mathrm{WN}\right)+ \\
\mathrm{A}^{\prime}(\text { injōad, NJD) }\end{array}$ \\
\hline
\end{tabular}

Table 10: example of the styling work developed by the Almohad secretaries

This passage condenses a certain number of rhetorical effects characteristic of chancellery saj ' in general, and the Almohad style in particular. Classically, the overall structure is a system of encased redundancies: the radical binomial 'WN-NJD, repeated at the beginning and the end, frames the structure; but the binomial is itself a semantic redundancy, anjanda being stronger than $a^{\prime} \bar{a} n a$; the second part $(3+4)$ echoes redundantly 2 , but the redundancy is updated by the surrounding chiasm NJD- 'WN (1) becoming 'WN-NJD (4), which allows in 4 the process of "inverse gradation" regularly observed in listings where the first term is semantically stronger than those following. The repletion of termes (wa huwa... wa huwa), of verbal constructions (yu'arrifu-kum/yamaddu-kum) or nominal constructions - with both annexing relations: itțirāda l-is ' $\bar{a} d$ / fì i 'māli l-sadād - , and the presence of rhymes - al-is ' $\bar{a} d$ (2) / al-injād (4), doubled by itṭirād (2) and al-sadād (3) - gives this passage a rhythm whose force would have come through during its proclamation in the great mosque. This analysis applies to each of the taqdim; some passages are more elaborate and successful than others, but they all reflect literary and poetic work, built around not only the constraints of oral "publication", of "recitation" in fact, and the combinative nature of the Arabic language built 
on the permanent reformulation of roots, but also the constraints of the Almohad ideology which impose the use of concepts and the Koranic vocabulary within a specific doctrinal context. This goldsmith's work was possible only for craftsmen of the language who had memorized not only a corpus of reference texts - mainly the Koran and hadìth - but also the rules of Arabic prosody and an ensemble of models of which Yahyá's collection belonged to one category.

A number of deletions and erasures throughout the text point to the principle of creation: in taqdìm 55, f. 38r, p. 73, 1. 18, a deletion on the theme of șala( $(t)$ is corrected with șalawāt: the scribe's mechanical memory took over his body during a loss of attention easily imagined in the work of the copier. In the chain of authors and copiers in Yahyá's collection, this error fits in the last segment: nevertheless, the machine-like character of writing this succession of words reveals quite well the work of composition. This is a fixed phrase (iqāmatu l-salā) that both the scribes hand and mind spontaneously chain together since they would have been fixed in his mind since childhood, for the copier as much for the various authors of the manuscript. The deletion and correction represent the share of interval and innovation within a ready-made phrase. Knowingly portioned on the scale of a document, this balance between recognizable elements, respect for an expected discursive structure, and subtle variations - inverted word order, use of a different form from the same root, bringing terms together through rhyme and $s a j$ ', plays on verb tense - allow an act to serve as a model, to honor it through memorization, and to thus enter it into the ever-growing thesaurus of phrases those who aspired to the insh $\bar{a}$, learned by heart. Yahyá's collection represents of course more a formulary than a collection of model-worthy letters, which are generally honored through citation in literary anthologies, biobibliographical and even geographical dictionaries. The chosen pieces of victory letters, or those of defeat, enjoy a much larger diffusion and audience than the taqādìm. Nevertheless, the practical character of Yaḥyá's manual is obvious, since it provides apprentice secretaries with a dossier of thematically consistent studies.

A long study of the archives throughout the Islamic world would be necessary to understand the diffusion of this type of manuscript. However, the existence of this type of note and document, preserved in a collection, indicates the share of peripheral regions in the development of Islamic chancellery standards, as they were formalized by al-Qalqashandī in the fourteenth century. 


\section{Governing the Empire}

\section{Conclusion}

A number of questions arise after this presentation of the structure and composition of Yahyá's collection: how and why did the author select each taqdīm? How useful was this work for the $k u t t a \bar{b}$ of the time and later periods. What relationships existed between the collection and this type of work in general with archival documents, as well as with textual production in the Islamic world? The usefulness of this formulary seems without a doubt, given the structure itself of manuscript 4752, a copy of two successive and connected collections - Yahyá's and the shaykh's. The collection may have aimed to be exhaustive, given the number of almost identical, though each different, taqādim, that the scribe brought together. However, a selection of the most representative pieces from the Almohad inshā', and even contemporary nonAlmohad, seems more likely. The survival of this "series" of taqāìm helps shed light on the specificity of chancellery style, which rests on the readjustment of recurring phrases and on the reformulation of Koranic terms and partial citations. These variations on segments from a referential corpus are favored by the structure the Arabic language, which is based on derivations from a limited number of roots, the process of writing/rewriting then relying on an almost unlimited number of combinations at the intersection of the axes of paradigm and idiom.

Yahyá's collection also illustrates the process of accumulation of texts at the basis of writing in medieval Islamic societies. Borrowings, glosses, successive copies, anonymity, the repetition of structures and variations in detail all contribute to creating a reality outside time. Michel Zimmerman has noted that this is not plagiarism or sterile mimesis: this borrowing is a revitalized inheritance, reuse and citation come from a strategy that associates respect for tradition and innovation, referring to authorities establishes the process of legitimation and reveals strategies specific to rival powers, such as the Almohads of Marrakesh, or Ibn Hūd of Murcia. $^{653}$

Rote memorization and the repeated copying of these acts constituted a thesaurus for the future $k u t t a \bar{b}$ who would be able to practice the mental gymnastics involved in composing chancellery texts. The mastery of internal rhymes, knowledge of a lexicon which the Arabic language allowed to be almost infinitely renewed, and sensitivity to the declamatory music specific to $s a j$ ' gave the secretaries the rhetorical tools that opened the way to social ascension. The competence that came from this apprenticeship of anonymous models and infinite

653 M. ZIMMERMANN, "Ouverture," 8. 
variations on the theme of election, appointment, and the exercise of power, as well as the adaption to contextual variations of the scriptural standards of a caliphate apart, made the kuttāb de facto practitioners of authority.

Yahyá's collection does of course remain within the tradition of compilation that characterized $a d a b$ works from the beginning. Copying a referential text then was not considered servile imitation or plagiarizing: to reproduce is to speak of authority. Medieval men granted as much worth to the imitation of consecrated words as to originality and innovation (bid'a), which were necessarily suspect. The last man whose textual innovations attracted no blame, or at least only from those unable to recognize the original One behind the originality, was obviously the prophet Muhammad, the carrier of the divine Word. Heidi Toelle thus notes that during the Middle Ages "the status of text and the notion of intellectual property were both vaguer and more subtle than in the modern period [...] Exchange from text to text through imitation or copying is constant, borrowing from erstwhile elders, or even contemporaries, was a common practice [...] It was not that the author was less important, for, just as in the hadith, the author plays, in the case of $a d a b$, the role of intermediary." 654

We should also wonder about the relation, within the literary, administrative, and political domains, between model letters extant in different anthologies and attributed to this or that famous writer, whose name had become, from Central Asia to al-Andalus, part of medieval Islam's universal heritage - like Ibn Khallikān or Ibn Abī l-Khiṣāl for the Almoravid period, alQāḍī al-Fāḍil and al-Isfahānī for Saladin's time, and Ibn 'Ațiyya, Ibn 'Amira, or Ibn al-Abbār for the Mu'minids - and these anonymous and anonymized texts transmitted by undated manuscripts. Does the difference in treatment reflect an internal specialization for the chancelleries, reserving the major texts (letters of allegiance, victory announcements, communiqués concerning the general policies of the state...) for the masters of insh $\bar{a}$ ' and routine matters for the unnamed or forgotten in the imperial administration? Or does the nature of the documents themselves determine their respective means of transmission?

The diversity of the kuttāb, the writers of the different appointment acts, must have contributed to the heterogeneity of the collection, in addition to the different addressees and interlocutors. Brought together in this collection, these different taqādìm exalt Almohad specificity, providing its letters of nobility. The production of these successive collections, the shaykh's, Yahyá's, and then the final stage in transmission, the later copy that is manuscript

${ }^{654}$ H. TOELLE, "L'expression littéraire," 459. 
4752, participates in establishing the Mu'minid dynasty's own tradition and posthumously consecrates the Almohad political creation. The formulary, which brings together in one collection a diversity of documents, without their differentiating more specific elements - dates, personal and place names - is an attempt to establish coherence and the sense of a specific history within the greater history of the peoples of Islam. It holds within one collection the concrete experiences of the essence of power - order, counsel, appointment, threat - and fills in part the void that exists between the chancellery document and its many embodiments.

The collection's composition also sheds light on the disappearance of archives in the medieval Islamic world. The original documents that served as the basis for this collection undoubtedly still existed at the end of the thirteenth century, probably within scholarly families. Yahyá thus belongs to a tradition of immortalizing administrative practice, and we can suppose that he got rid of any personal notes or the acts which, for the needs of his "work", he had brought together through a real labor of research. The acts themselves, as original documents, do not seem to have great importance for him, or for his descendants, only as the vehicle for an endangered text, a "power in acts" threatening to disappear. Through their collection, reproduction, and compilation, Yahyá integrated the content of these taqādìm into the body of referential texts, into the engorging belly of $a d a b$ swelling with any source of literary dimension. The fact that the collection carries for a name only the ism of his author (majmú Yahyá) can be seen as an expression of ownership for the work, even as the expression of an intimate tie between the author and his text. Nevertheless, it is more likely that the refusal to give the collection a name related to its content, as was customary, that the choice of affixing rather his own ism, noted only by its frequency and diffusion, reveals that this was meant less as a "book" in true form than it was Yahyá's creation of a dossier of diverse elements. It was a random act of history that honored this dossier, centuries after its composition, with becoming a "book" copied with care by a scribe who had understood its historical importance. This was Yahyá's almost anonymous contribution to the process of conserving and accumulating and of memory in the Islamic world. ${ }^{655}$

Somewhere between memory aid and manual, Yahyá's majmū' is a formulary collection, whose structure and organization were designed by their author. On a number of points, the manuscript is not a book written for publication. Borrowing the categories used by

${ }^{655}$ On the question of the author and the genesis of medieval writing, see M. ZIMMERMANN, "Ouverture," 10 
Gregor Schœler in his Écrire et transmettre dans les débuts de l'islam, manuscript 4752 is more a hypomnèma than a syngramma. The manuscript is an intermediary stage between personal notes meant as a memory aid in his work of "creation" (hypomnēmata) and works meant for a public audience (syngrammata). The taqādìm, as for the earliest Islamic periods, are located in the articulation of oral publication and the process of written memorization. ${ }^{656}$ Numerous indications in the manuscript for vocalization and assimilation (idghām) reveal the oral intention of the copied forms: memory of an original orality - for these taqāìm were meant to be pronounced in the great mosques - and indications for a future publication by other kuttāb. Schœler has noted a kind of intermediary literature between hypomnèmata and syngrammata: the mușannafät. "Neither course notebooks, nor literature", these writings are thoroughly and minutely produced, but "they were not destined for publication for a larger literary public of non-initiates." "These were written pieces (grammata), and they do belong to literature, but to a school literature, meant exclusively for that use, the publication of which was oral - the practical means of which were audition, dictation or recitation by a disciple." 657 Taxonomic attention is clear in Yahyyá's majmū', mentioned in the four extant intercalary commentaries presented above.

This compositional process has a number of consequences: it neutralizes the power contained in the taqāìm; they go from acts to references and memory. This neutralization attaches the temporal and textual ramifications of a specific, marginal, and peripheral power, characterized by an almost revolutionary birth, an original ideology, as well as by unique artistic, literary, architectural, and religious creations, to the trunk of the great dynasties of universal Islam. Whatever the religious and political theories that produced the Almohad caliphate, the work of compiling and transmitting the corpus of taqādim abolishes their heterodoxy and returns them to the heritage of Islam. The Almohads are no more Fatimid, Shiite, Khārij̄̄, Mu 'tazilī, Zāhirī, or Ash 'arī, heterodox or schismatic, but one among many of the political and religious realizations of Islam. This attachment to a textual tradition functions on a specular level, by way of a mirror game that places the text in a void. This process affects all the lexical aspects of administrative writing: if the sense of the phrases, titles, or functions necessarily evolves according to the constraints of literary reformulation and the ideological and political-religious imperatives of the ordering powers, it can only appear as a reminiscence

656 G. SCHOELER, Écrire et transmettre, 15.

657 G. SCHOELER, Écrire et transmettre, 83. 
in order to avoid entering the category of the muhadathāt ("new things") or bida ("innovations"). Until now, historians have relied on narrative sources in seeking to understand the nature of the titles and functions covered by these documents. However, though medieval Muslim chronicles sometimes took care to specify the meaning of certain terms - sayyid, talaba, or hăfiz during the Almohad period - they often forgot to trace the future evolution or disappearance in a memorial process of infinite accumulation. The Arabic language acts as a witness to this sedimentation, with the meaning of the words inflating with each innovation and the subtle game of literary creation; a meaning attributed one day then forgotten for years could be exhumed much later in a different context. This semantic revitalization gave an authority and poetic depth to the text, which thus always appeared to originate out of reminiscence, from the revelation of a meaning hidden and buried by time and use. The art of the secretary was thus to give the illusion that he was only reveling the signification present at the heart of the words, that he was imitating an unsurpassable earlier model, unveiling the sense hidden by unflagging variations, publicly exposing the eternal contents of the Arabic language as the Revelation had fixed it forever, even while he was reinventing its usage.

The other effect of neutralization was the disappearance of all performative effectiveness. From "order", the taqdim became text, it was no longer the "ex-pression" of political authority, but the manuscript "im-pression" of auctoritas, of a reference for future powers. Only this neutralization explains how a Maghribī author from the end of the thirteenth century could conceive of placing side by side texts produced by rulers as radically opposed as were the caliphs of Marrakesh and Ibn Hūd al-Mutawakkil, as al-Ma'mūn before and after the renunciation of the Almohad doctrine. The dynasties or polities who had given birth to them having disappeared, the acts lost all political utility and effectiveness. Because these texts had an authoritative value when they were written, and they were power in acts, their material destruction appears as the logical consequence of the disappearance of the sultann who have given them birth. Finally, once the Empire had disintegrated, once its officials had dispersed, only the text was left, which can then enter into the impersonal eternity of knowledge. The author intervenes only to disassociate the material vehicle from the text it carried.

Another important consequence of this process of composition is its decontextualisation, its extraction from time and uprooting which alone could enable its resuscitation. Through compiling and copying, these acts entered into the timelessness of patrimony and text. They lost all Maghribī character, which at other times betrayed Almohad 
ideology, to enter into the encompassing world of Islam. This disappropriation of the taqāìm translates into the suppression of proper names - replaced by Fulān, Abu Fulān, as in the juridical compilations to which the collection can be compared for its function and utility -, dates, and of anything that could root the acts in a particular space (Fulana) and time. This uniformization disassociates the appointments from anything that could relativize their belonging to the grand history of Islam. Beheaded and depersonalized, the assembled acts enrich the collective production of Arab-Muslim civilization and open the door to a future reappropriation, elsewhere and by others, in a rational of continuous and collective writing.

The original taqdim was thus the material and horizontal support of an act of power, the caliphal taqdìm. The articulation between "act" (of power) and "act" (document) came about when the text was read aloud in the mosque or on the public square: that was the vertical and immaterial aspect of authority that existed before the text. In its various forms, the recitation carried the expression of a simple authority by duplicating an original vocal presence, in this case the caliph immobilized in his capital. The production of this collection created the conditions for an inverse operation: henceforth the text laid to paper could, by the same process that had given it birth, could be brought back to life in future appointments for new temporal authorities textually and politically seated on their predecessors. The temporal and textual flattening caused by the compilation is thus the condition for the rehabilitation and renewal of the verb of power.

The last consequence of this process of compilation is in a way the canonization of the text. There exists a prime or first type of textual authority: "in the genealogy of texts, there is a first text, a sacred prototype, a writing which the readers always approach through the text before them." $" 658$ In the medieval Islamic world, that prototype was the Koran, the original standard. Any genealogy of authoritative texts in Islam thus traces back to the Koran, both the beginning and end of writing, the kitāb whose particular virtue initiates and delimits a discursive tradition. This specific religious logocentrism has widespread political, cultural, and institutional implications, many of which are related to the recitative character of referential texts. The operation of the Law was the matrix of a great number of scientific domains: the initial recitation by a master of a segment of the basic text, the matn, hadith, or Koran, is followed and completed by an explicative commentary, the sharh, the subordinated role of

${ }^{658}$ E.W. SAID, The World, the text, and the critic, 46. 
which is to facilitate the student's understanding of the principal educational object, the matn. ${ }^{659}$ This matn/sharh link, referential text/commentary, is the basis of all Islamic hermeneutics. It provides the key to reading and understanding the particular function of Yahyá's collection in regards to those chancellery manuals that came before and after. ${ }^{660}$

Meant for memorization, the taqādim function as the matn, as the referential text, at the origin of all other text, while chancellery manuals, through the citation of letters of reference, explain and establish the rules of writing and production and give order to the diversity of medieval creations. The complimentary quality of the matn/sharh is mirrored by that of the formularies, such as Yaḥyá's majmū', and the manuals, such as al-Kilā'î̀s Ihkām șan 'at alkalām or rather al-Qalqashandī's Șubh al-a 'shā'. This last author defines the rules of production for chancellery documents - address, phrases, order of sections, date and place clauses, etc. through the diversity of regional corpuses to which he had access, the conception of which he retrospectively explains by regrouping of all the texts produced, through comparison and deduction, calling on techniques perfected by centuries of commentaries. ${ }^{661}$ However, unlike the Official Closed Corpus (M. Arkoun) - the Koran, hadith, Sìra - the corpus of chancellery forms is not fixed, it is living material in perpetual renewal. In the process of transmission, of which manuscript 4752 is an example, the kuttāb, and Yahyá with them, took less care to preserve the textual exactness, or fidelity to the original, than for the preservation, even the improvement of the artistic and linguistic quality of the texts being transmitted. This conception of transmission is incompatible with the idea of a definitive recension that would make possible a normative publication of the texts.

The distinction between Yahyyá's formulary and later chancellery manuals offers strong similarities with the complimentary nature which Grévin describes in his Rhétorique du pouvoir médiéval between the summe dictaminis and the artes dictaminis. ${ }^{662}$ In regards to linguistic

${ }^{659}$ B. MEssick, The Calligraphic State, 30.

${ }^{660}$ Such as the Aḥkām șan 'at al-kalām by al-Kilā'î, 'Ațā' al-jazīl by al-Balawī (though this last text could be considered mixed) or the Șubh al-a 'shā' by al-Qalqashandī.

661 For a rapid presentation of the Subh al-a shā', see C. CAHEN, "Notes de diplomatique arabomusulmane."

662 "Les exemples inclus dans les artes dictaminis théoriques furent généralement des modèles de lettres fictives, créés par leurs auteurs pour les besoins de leurs démonstrations. Les "lettres" comprises dans les summe étaient généralement des documents qui avaient été réellement rédigés à fin d'expédition publique ou privée et dont une copie était ultérieurement incluse dans la collection formée soit par leur auteur de son vivant, soit par un des héritiers de son art. Les summe dictaminis sont donc des recueils de documents généralement produits dans un milieu restreint voire par un même rédacteur, ultérieurement rassemblés à des fins en partie mémorielles, puisqu'elles forment des matrices liées à des précédents administratifs ou juridiques pour la rédaction ultérieure de documents, et en partie didactiques, puisqu'elles facilitent l'apprentissage et la création de la rhétorique politique" (B. GREVIN, 
practices and textual rationales, Grévin lays out in a forthcoming work the bridges between medieval Latindom and the Arab-Muslim world:

"The scholarly apprentice thus accustomed himself through incessant mental gymnastics to jump from the infinitely big of memorizing the Book to the infinitely small of its reduction in a handful of verses, from the transposition in rhymed or simple prose to the pointing of corpuses fragmented by reading of collections, from the etymological decomposition of names to their assemblage through semantic constellations... The practice of medieval memory, benefiting from the enlarged capacities of an orality inflected and galvanized by the potentialities of the written form, prepared [students] for creation by multiplying experiences of a sacred and profane material they were first meant to transmit, eventually to comment, exceptionally to reformulate through its own recreation. And still, for that, the apprentice would need to pull together his energy for a last effort of concentration." ${ }^{663}$

Memorizing formularies allowed the scholar who had assimilated the rhetorical lines of $s a j$ ' to find in his memory the resources to create even more variations. "The arts of memory allowed for the metamorphosis of these accumulating sums of knowledge from the centuries into a mechanism of combinational tables." The chancellery language could thus oscillate between sacred hermeticism, fruit of the reformulation of the Koranic verb, and a necessary clarity of communication, for the needs of the administration, between the sources of linguistic legitimation of power and their vulgarization.

The edition, and facing translation, of Yahyá's collection will allow the reader to measure the degree of elaboration of the language of power and the virtuosity of the secretaries of the Almohad period. The translation's legitimacy can be questioned, given what we have written concerning the insh $\bar{a}^{\prime}$, concerning the tension between textual tradition and the unicity of each taqdim, between the hermeticism of power and minimal clarity. The choice made was meant to form a foundational basis of work, to create a reference for all those who work on chancellery documents in throughout the medieval Islamic world. It represents an impossible wager given that content was privileged over form. The proposed translation gives an impression of the level of meaning, but it is of course incapable of translating the poetic depth of the original text. It is a point of departure, not an arrival. It is open to the criticism of specialists of the Arabic language and literature, poetry or prose, of law, historical and

Rhétorique du pouvoir médiéval, 22-23). The historical importance of the summe depends on the conservation of the corresponding archives. Yet, orginals were rarely kept in the medieval Muslim world. The majority of the acts and letters contained in the summe are thus only known in that form.

${ }^{663}$ B. GRÉVIN, Le Moyen Âge du langage, chapter 3.4.1. Machina memorialis. I would like to thank Benoît Grévin for having provided me with a copy of his excellent work before its publication. 
geographical sources, as well as to comparison, and constitutes a prelude to the translation of the ensemble of Almohad chancellery documents. 
Governing the Empire

\section{Part Three}

Edition and translation of Yahyyā's formulary 


\section{Governing the Empire}

\section{Introductory remarks}

The critical edition and translation of Yahyá's collection follows below, manuscript 4752, from the Khizāna al-Hasaniyya of Rabat, systematically mentioning the variants present in Aḥmad 'Azzāwī's edition in his Nouvelles lettres almohades. We have tried to remain as faithful as possible to the text, as much for the written form Yahyá adopts for the lengthened horizontal line for certain letters, as for the vocalization (tashkil), placement of the hamza (s) - very rare over the alif -, the presence or not of diacritical points (under $y \bar{a}$ ' in terminal position in particular), the presence or not of the lengthened vowel 'a' (alif).

We thus took care to distinguish the two forms of $k \bar{a} f$ in terminal position: either with a hamza (S), or without (ك), the different forms of $y \bar{a}$ ' without a dot in terminal position or of alif maqsūra, either classically $s$, or in abbreviated form $\angle$. We likewise respected the writing of $t \bar{a}$ ' marbūta, often represented open, which 'Azzawī systematically corrected. We have also respected the writing of the wașla over alif, indicated either classically (i) for a number of internal plurals, though a number of current edition standards do not mention it, or noncontracted when fatha is elongated over hamza: $1_{s}$ and not $i$. Moreover, we have left breaks when they appear in the original since separated letters always end lines and a connected letter is never cut. Contrary to 'Azzāwī, we never impose punctuation, which is in itself an interpretation, and we have respected the punctuating symbols in the manuscript, $\square, \odot$, or $\square$. We have also tried to respect the manuscript's colors, essentially for the titles.

Nevertheless, a few interventions were made in the text. We have represented $f \bar{a}$ ' and $q \bar{a} f$ classically, because publishing programs in Arabic do not allow the "Maghribì style" of representation, with a dot under $f \bar{a}$,' and a dot over $q \bar{a} f$. Koranic citations are not absolutely distinguished from the rest of the manuscript text, either by a more developed tashkil or a particular graphic detail. Notes are included to indicate 'Azzāwī's version, specifying if he indicated the original version or not. We have provided the corrections he proposes, or suggestions made (these have moreover been taken into consideration for the translation). Brackets were added, either by ourselves or 'Azzāwī, specified in the note, where the scribe has obviously forgotten something. Finally, lines begin with line number (Arabic), folio number and the number written in blue on the manuscript.

Taqdīm 1: In response to a delegation carrying the allegiance of a region in al-Andalus, recognition, written after 1224, of already 
constituted authority with a delegation of the power to appoint (excerpt from the "collection of the shaykh"). ${ }^{664}$

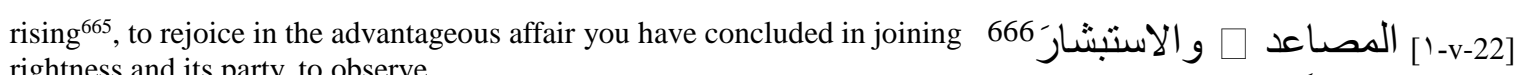
rightness and its party, to observe

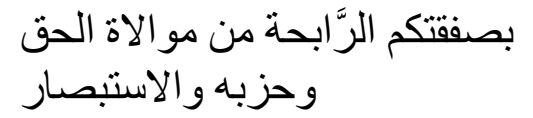

the correct beliefs and virtuous actions for which this Power has granted you the favor of being

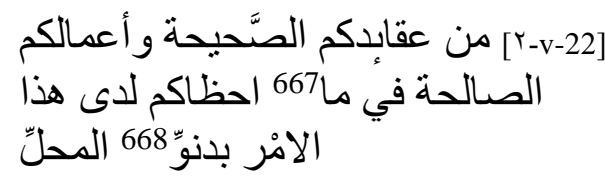

near to it and to lavish your clear and evident counsel, in order to multiply His offerings (li-inmā qisama-hu) and increase His benefactions (wa ihma suhuba-hu). Indeed,

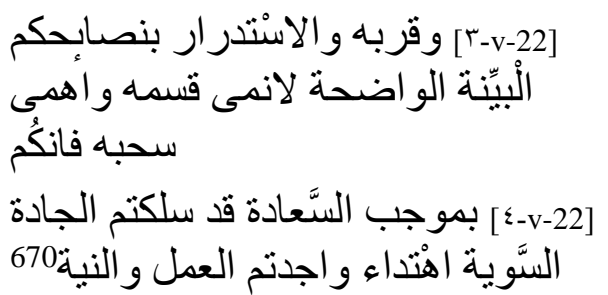

fortunately, you have taken the great road that will lead you directly to the goal. ${ }^{669}$

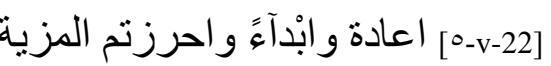

Your actions and intentions have always been excellent and you have been the first to acquire [such] sublime qualities. This is why we have lavished upon you

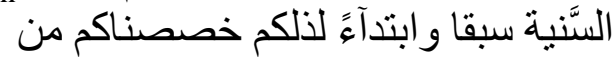

العنا

particular attention and we have set you apart to occupy the rank merited by your sincere [response] to the convocation $\left(d a a^{\prime} w a\right)$ of Unicity (tawhìd).

[?-v-22] بية بالمزيد و استخلصناكم للمكانة

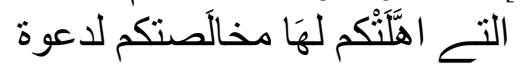
التو حيد

We have accorded you our confidence by virtue of the specificity of the sentence of duration and eternity rendered for your past noble actions

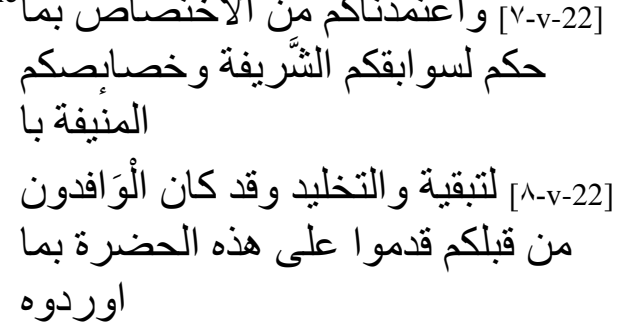

of bay'as from your land and laden with counsel emanating from your sincere من بيعات تلكم الْبلادِ وتحملوه-v-22] convictions.

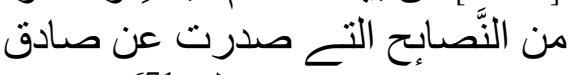
ذلكم 671 الاعتقاد

\footnotetext{
664 'Azzāwī, NLA, t. 1, 411-412.

665 "May God have written for you..."?

666 'Azzāwī places a d̦amma on the final rā', but it seems to be fatḥa, even if it is not quite clear in the manuscript.

667 'Azzāwī: فيما.

668 Shadda and kasra under wāw.

669 Echo and reformulation of the following hadīth reported by al-Bukhārī, Șahīhn, t. 1, 6, n 1: "works have worth but by intention" (inna-mā l-a 'māl bi-l-niyya).

670 Echo and reformulation of the following hadīth reported by al-Bukhārī, Șaḥịh, t. 1, 6, nº 1:

671 'Azzāwī: ذالكم. 
It has been learned by that which you reported how the inhabitants of Fulāna [1] and of its regions distinguished themselves, the people and the elite,

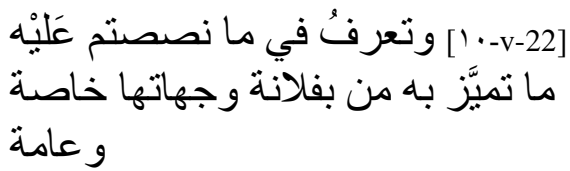

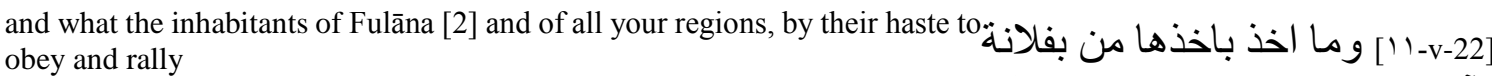

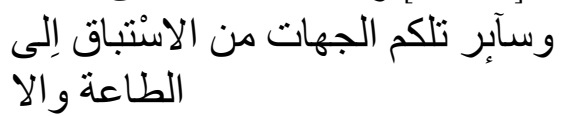

to the community ( $a l$-jama $\bar{a}^{\prime} a$ ), had obtained in taking [Fulāna 1] so that [its inhabitants] respond to your call to return (li-ihäbati-kum bi-him) [to a path that leads them] to happiness in this world and the next

[ [r-v-22] تساق في الجماعة تلبية

لاهابتكم بهم الى خير دنباهم و اخر اهم

وتوفية

and so that, the lights of friendship enlightening them and purifying their souls from the evils of dissidence, they fulfill all the favorable conditions [for their access]

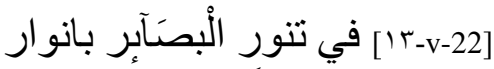

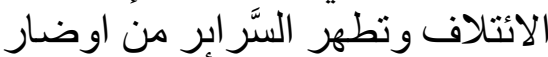

الخلاف لما بسَّر هم

to their happiness (li-yusrā-hum). This placed them in the forefront, giving them the same rank (sābiqa $)^{672}$ as the one that the Hijra had given to those who participated in it (ahla-hā), this gives them

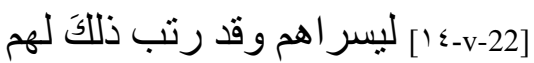

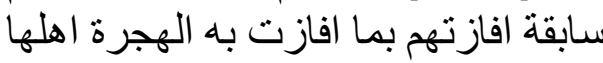

و انالتثه

honor such as they knew not before, and by which they deserve to be received under a protection that covers all their situations.

[10-v-22] الكر امة

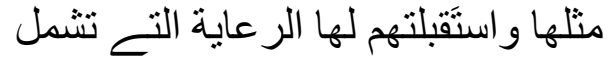

احو الثه

May God On High cause [us] to succeed in leading their interests towards that which is best and greatest and choose for us the clearest and

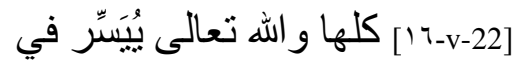

مصالحهم الى الاصلاح الاحُّن وياخذ

لنا في سبل النظر الانين

most evident path to govern them. And we, persuaded that you are excellent representatives and assured that you seek

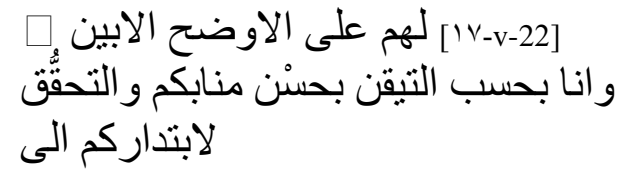

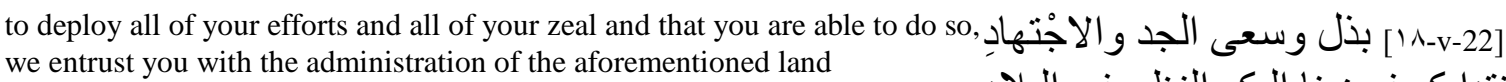

$$
\text { و انتدابكم فوضنا اليكم النظر فْي البلادِ }
$$

and all that has come under your responsibility, as well as with [the administration] of neighboring regions and places, both far and near, that come to you as a

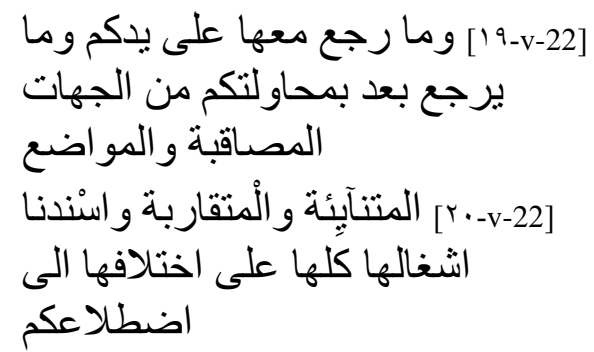

result of your [military] enterprises. We place under your competence all responsibility for finances in the region, whatever their nature.

672 See Dozy, Supplément, s.v. sābiqa, 628, for the meaning of maziyya al-sābiqati, or just al-sābiqa for ahl alsābiqa, the first to adopt Islam. For the Almohads, who preferred to model themselves on the first Muslims, going as far as to imitate their language, ahl al-sābiqa designated "those who sided with the Mahdi before his dominance was well-established, that is before he had taken the city of Marrakech." These tribes that had rallied early on to the Mahdī were said to possess maziyyat al-sābiqa, or simply al-sābiqa.

673 'Azzāwī: الكر امةُ الكر امةً 
We have full confidence in your guardianship (ishräfi-kum) and your vigilance (ițtila 'i-kum) for all [of the land's] affairs. Exercise this power through persons

that manifest noble competence and great care in the administration of interests and the permanent quality of counsel.

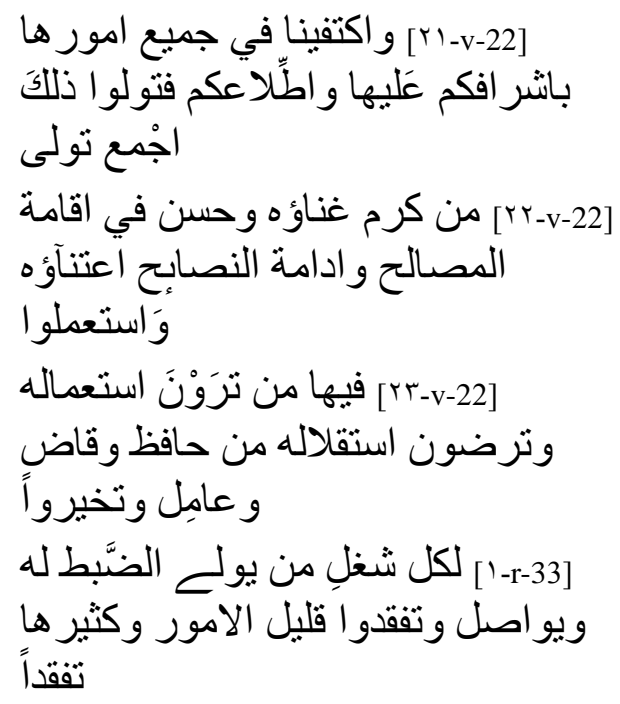

Appoint to the office of Guardian ( $h \bar{a} f i z)$, judge ( $q \bar{a} d \bar{l} \bar{l}$ ) or agent (' $\bar{a} m i l)$ those whom you judge [apt] and whose sense for responsibilities you appreciate. Choose

for each post someone who will steadfastly invest it with his authority. Control all affairs, both small and large,

in a way that respects, in this land and with its inhabitants (ra iyyati-hā), our beautiful project and our generous principles. In step with the bearing

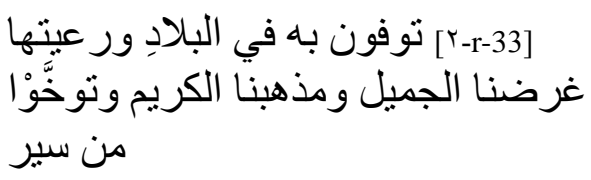

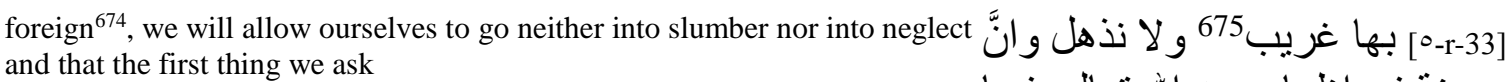

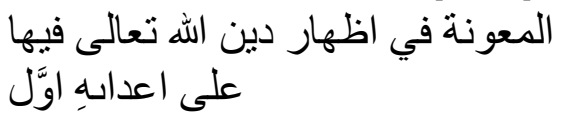

and demand of God - May He be glorified - is His aid so that the religion of God on High succeeds over His enemies. For we will not cease in watching over it to install amenities and places to live ${ }^{676}$,

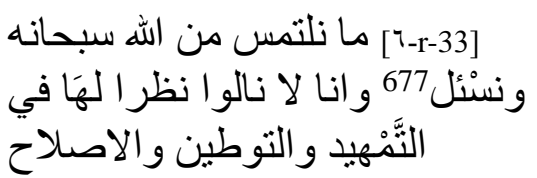

are near, peace accords that satisfy God and the Muslims and that allow to distance from their regions the aggressions of those who attack them and corrupt them. Our method

674 Reference to the hadith reported by al-Tirmidhī, Sunan, 593, n 2629 , by Ahmad Ibn Hanbal, Musnad, t. 13, 117, n 16 636, by Ibn Mājah, Sunan, 695, n 3987 and by al-Dārimī, Sanan, t. 2, 768, $\mathrm{n}^{\circ} 2653$

675 Hadïth: al-Tirmidhī, Sunan, 593, n² 629 ; Ahmad Ibn Hanbal, Musnad, t. 13, 117, n 16636 ; Ibn Mājah, Sunan, n 3 987, 695 ; al-Dārimī, Sanan, t. 2, 768, nº 2 653: إن الإسلام بدأ غريبا وسيعود غريبا كما بدأ فطوبى . للغرباء.

${ }^{676}$ See Dozy, tawțin: "establishment, action of establishing," Dozy, Supplément, t. 2, 820.

677 'Azzāwī: نسأل 
for reinforcing the call ( $d a w a)$ that is addressed to them and their security and for soothing their domain and their land is known to He who "embraces all things in His

$$
\begin{aligned}
& \text { [3-3-33-9 في تمكين دعْوتهم و امانهم }
\end{aligned}
$$

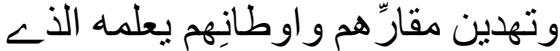

$$
\begin{aligned}
& \text { احاط بكل شیى }
\end{aligned}
$$

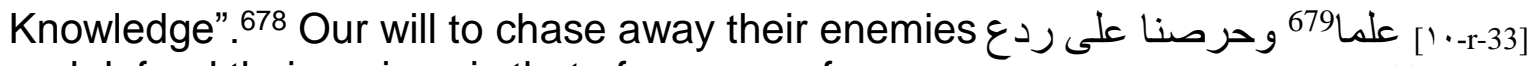
and defend their regions is that of someone for whom it has always been their

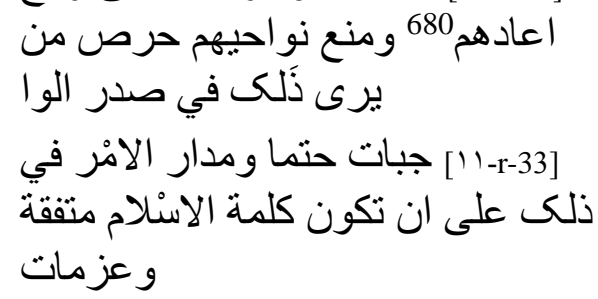

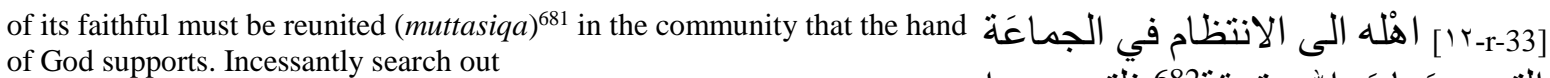

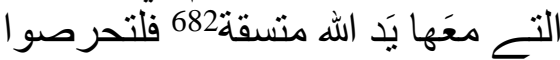

$$
\begin{aligned}
& \text { ابدًا على الاتحر الا }
\end{aligned}
$$

harmony, ${ }^{683}$ it is the axis upon which a perfect state rests; call on he who departs from its path to return to ensure

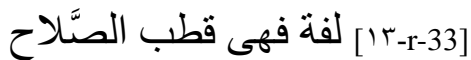

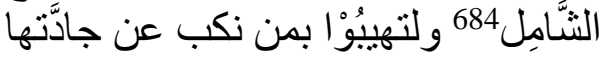

$$
\begin{aligned}
& \text { الى ما له في مر اجعتها }
\end{aligned}
$$

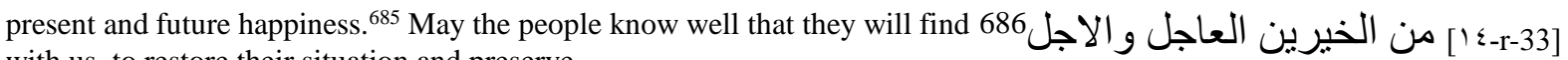
with us, to restore their situation and preserve

$$
\text { وليعلم الناس احق من } 687 \text { العلم انَّ لهم منا في الحافي }
$$

their land, all that the well-guarded flock (li-l-ra iyya al-makfüla) could hope [10-r-33] for from a responsible "shepherd" ( $r a$ ' $\bar{l}$ al-kâfil), that their protection is a concern from which

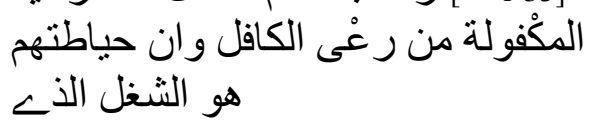

none may deter us, and a priority task that no event and no circumstance may prevent us from privileging and achieving.

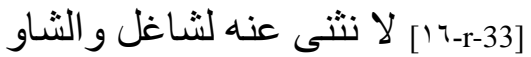

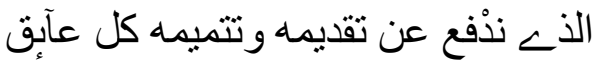

$$
\begin{aligned}
& \text { وحآبل وطا عان }
\end{aligned}
$$

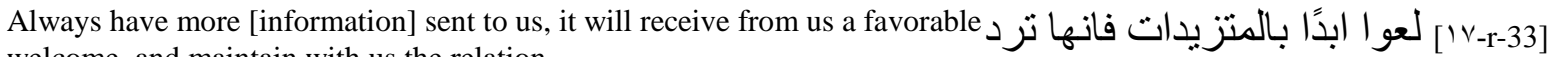
welcome, and maintain with us the relation

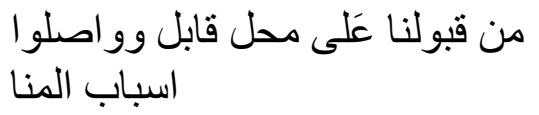

678 Koran 65:12: "God comprehends all things in (His) knowledge" (wa inna Llāha qad aḥātā bi-kulli shay' in 'ilm $\left.{ }^{a n}\right)$. Except where otherwise stated, we have used Abdullah Yusuf Ali's translation for Koranic citations.

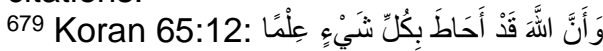

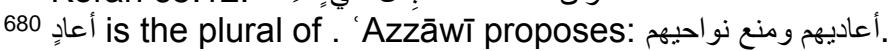

681 Reference to hadīth by al-Tirmidhī, Sunan, nº 2 167: yadu Llāhi ma ‘a al-jamā'a.

682 Reference to hadīth by al-Tirmidhī, Sunan, n² 167: عليكم بالجماعة فإن يد الله مع الجماعة 2 '

683 Koran 8:63: "And (moreover) He hath put affection between their hearts" (wa allafa bayna qulūbihim).

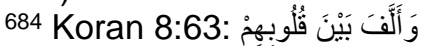

685 Koran 75:20-21: "No, (you men!) But you love the fleeting life, and leave alone the Hereafter" (kallā bal tuhibbūna l-ājilata wa tadharūna l-ākhirata).

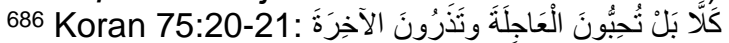

687 'Azzāwī: خيرَ. 
of your counsels, for we have great interest in all that they bring to us. Your delegation is on the verge of departing for your lands

carrying the best gift that a traveler ${ }^{688}$ could offer you. We continue to search out with care that which will have [positive] consequences for the affairs of the land,

which will make manifest and guarantee good administration of its interests

felicitous tomorrows, today and in the future, if God on High wills it. It is He who brings assistance and help. And $\mathrm{He}-$ May He be glorified - , He will cause you

to know unending aide and will bring you for just actions His support and His help. and the protection of its borders and which will fulfill with abundant benefits

[N-r-33 ] صحات فلدينا اهتمام بكل وارد

منْها وو اصِل وقد اخذ الان وفدكم في

الاباب النيم

[9-r-33-1 ] بايْمن ما يقدم بـه قادم عَلْيكم

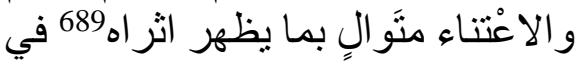

مصالح البلاد

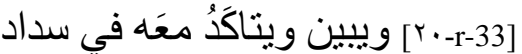

امور ها وسداد ثخور هَا اليقين ويفيض وينه بـانه

للخبر ات

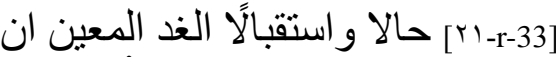

شناء لله تعالى و هْو المنجد

و هو سبحانه بعر فكم

[عr-r-33]

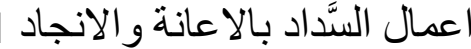

Taqdīm 2: Appointment (excerpt from the "collection of the shaykh") of an admiral of the fleet, probably in Ceuta, by the caliph alRashīd (629/1232-640/1242), with great military, fiscal, and monetary attributions. ${ }^{692}$

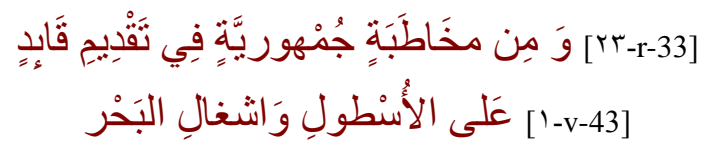

[Excerpt] from a public (jumhüriyya) allocution for the appointment of a commander ( $q \bar{a}$ ' $i d)$ at the head of the fleet $(\bar{u} s t \bar{u} l)$ and maritime affairs (ashghāl al-bahr)

which is called for by the links and ties [between us and] your district, [the merits] which are your own because of the manifest proofs

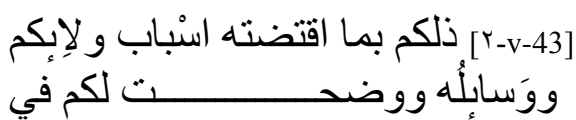<smiles></smiles>

and testimonies [that you have given] of your sincerity, and which is demanded by your land as care in the administration of its affairs and as measures to guarantee

\footnotetext{
688 Lit. "he who arrives".

689 'Azzāwī: اثره.

690 Al-munjid is not one of the recognized names of God (asmā'al-husná). It is a characteristic (șifa) that authors attribute to God, but is not a divine name. Attributes can be drawn from any divine name, but not the opposite..

691 One of the ninety-nine names of God.

692 'Azzāwī, NLA, t. 1, 413-414. A. 'Azzāwī suggests this appointment may concern Ceuta (Sabta). The Dìwān al-baḥr is the institution responsible for port affairs.
} 
its land and maritime protection for it is the most trusted lock for all of the hinterland, the capital from which

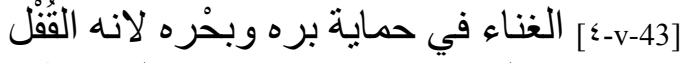
الاوثق لما ور اعَه من الاقطار و المصر 693

الذِي

all the capitals receive multiple and various benefits and the country that for us has all the advantages of

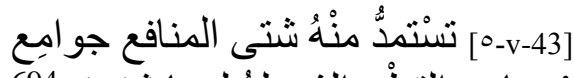

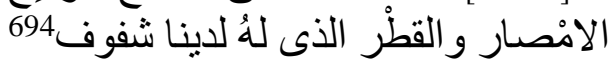

rank and the superiority of merit. May God - May He be glorified favor the best and most just administration to establish its interests and constantly protect

[ب-v-43] الرَّتبة و انافة المقدار و الله سبحانه يبسِّر في اقامة مصسالحه و ادامة الحياطة

he who comes and he who goes and may He orient [our] decisions in the most felicitous and profitable manner

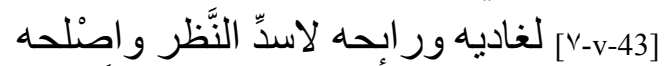

ويرشد في مأ بعتمد من تحسِين أَحْو اله اله

to reinforce its situation and fortify its inhabited places. In addition, the sea is for you the route

إنه-v-43]

و انجحِه و الى هذا فان البحر هناكم هُو جادة

ما بـجلب

taken by provisions, the source of all goods and the pillar from which you draw all manner

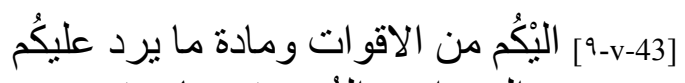

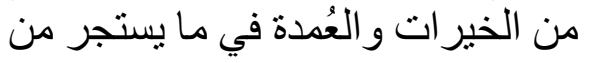

ضروب

of profits and which protects you from all harm. And in order to inscribe that in every mind and to assign the work

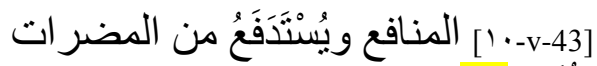

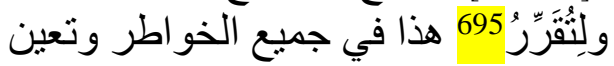

العمل ونعن

for that which we have entrusted you, for by the presence of your watch you replace he who is absent, we have distinguished you in appointing

[إن ['-v-43] بحسبه في ما نعتمدكم به و انتم بحال

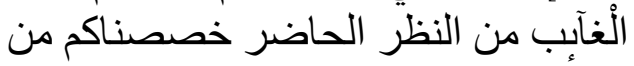

تقديم

Fulān from among you to lead the fleet and all maritime affairs, as well as all the responsibilities of

[اشغال البحر مع ملأن ملى الاسطول هنالكم وجميع

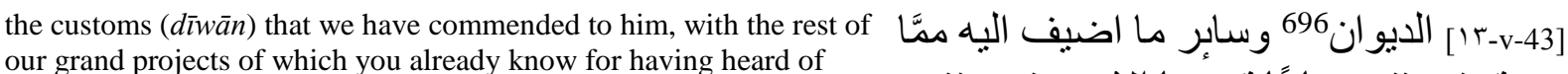
them; you will,

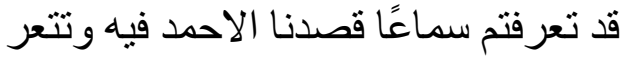

with God's help, note with your own eyes the felicitous consequences of all that he will undertake. He is the Almohad elite

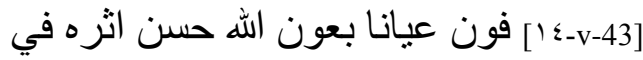

كل ما بنتحيه فهو خالصنة المو حدين الذي

whose pure radiance shines, the most loyal whose sincerity and fidelity are without equal. We wanted

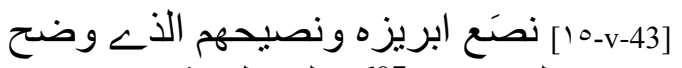

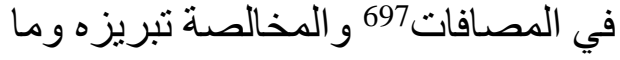

تو خينا

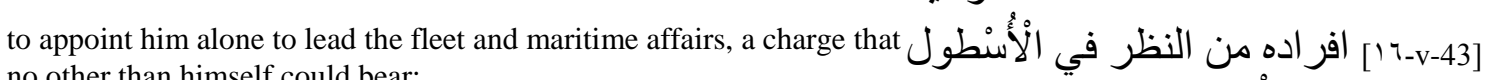
no other than himself could bear;

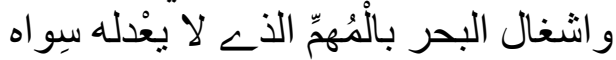

ون

\footnotetext{
693 'Azzāwī: النصر.

694 'Azzāwī: شرف:

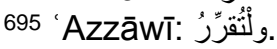

696 Compare with taqādīm 46, 48 and 50.

697 'Azzāwī: المصافاة.
} 
customs ( $d \bar{l} w \bar{a} n)$ fall under his responsibility, complemented by the mint (sikka), inheritances (mawärīth) and tithes (zakāt). We have chosen him to organize

those works destined to defend your lands and to protect your populations until the sea,

with the help of God, no longer fears its enemies and is totally protected, if God so wishes, in its ports (masbaha-hu) and harbors $($ mars $\bar{a}-h u)$. May

the traveler know morning and night permanent safety and protection aboard his ship. All of the surplus

from customs ( $d \bar{l} w \bar{a} n)$ and annex taxes will be spent in the interests of the fleet and for the pay of its [sailor-]combatants,

which will barely suffice to develop it and provide for the safety of its instruments. Small and large, [these taxes] will all serve

to pay for supplies and cover the costs of its missions (muhimmāti-hi). In doing so, we wanted to put aside vices and suppress the obstacles

for arming [the fleet]. We have commended to him alone the above mentioned charges to show you our plan to protect you and to shed light on $(\text { firās })^{700}$

existing complaints $(a l-d a w \bar{a} \mathfrak{\imath})$. You will know the various benefits that flow to you, the vast regions

from which come all manner ( $a n w \bar{a}{ }^{`} \ldots$ wa aṣnāfu-hā) of benediction for you, while the blind incursions of your enemies will be ceaselessly chased away

and pushed back into the sea. By this decision (nazar), you are ensured of attentive care that will accompany you in all

Circumstances and a firm volition will multiply for you, under the shadow of salvation, the reasons for you to rejoice. ${ }^{701}$ In trusting Fulān, we have simply

trusted one who fully merits it and who has shown this government the greatest loyalty. We hope that, thanks to his gravity and mettle,

we will continue to keep watch over and defend the sea

and to completely and radically eliminate the harm and damages provoked by the enemy. He has perfectly understood and grasped the remarks we have communicated to him to insist

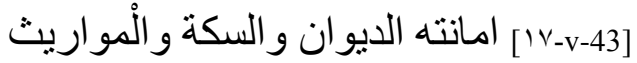
و الزكاة كماله تخيرناه الاك696 لينظم له بتقله 699

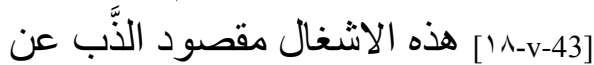

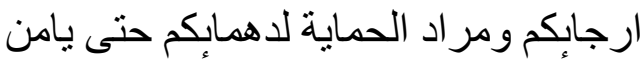
البحر

[9-v-433 ] بمعونة الله عداه وتعم الحر اسة ان

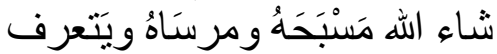

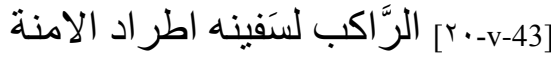

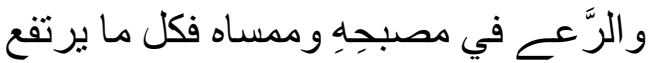

[ [بr-v-43] من مجبى الديوان وما اضيف اليّه

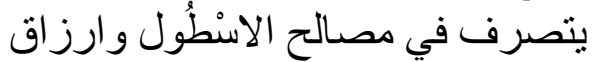

غز اته

[rr-v-43]

لملنته عالاته ويستعان بقليله و كثيره

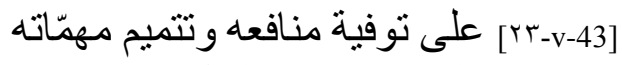

اردنا بذلكم ان تنز اح العلل في عمارته فيه فيه

وتر تفع

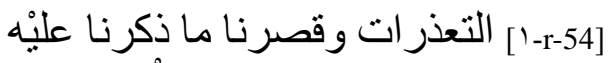

اظهارًا لما في النفس على الْعماية لكم

وفر اس

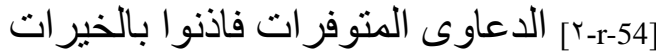

تدر عليكم اخلافها و الجهات النازحة

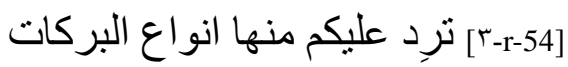

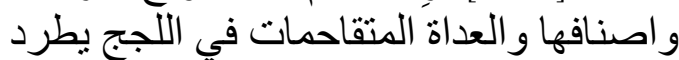

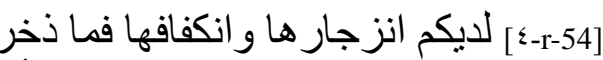

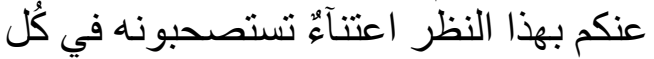

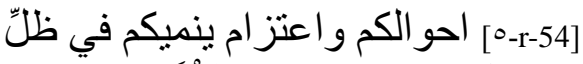

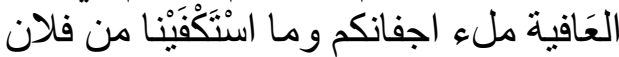

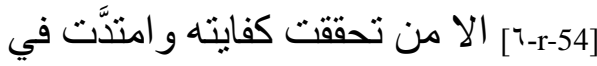
مناصحة الامْر غايته ورجى ان تستمر بجده

[V-r-54] وتشمبره حر اسة البحر وحمايته وتتدفعُ على اتم الْوجوه و اكُملِِ المقصود

مضرة

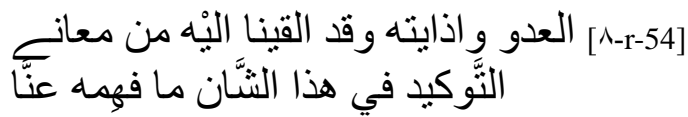

698 'Azzāwī corrects this with الآن.

$699 \mathrm{El}$ Aallaoui contributed to this reading.

700 Dozy, Supplément, t. 2, s. v. "FRS", firāsa: "sagacité, bon sens, jugement".

701 Lit. "the fullness of your eyelides". 
on this point. We have commended to him the multiple and various cares we have for your region and of which we inform you with a clear and limpid

$$
\begin{aligned}
& \text { [9-r-54] وو عاهُ وحملناه من ضروب عنايتنا }
\end{aligned}
$$

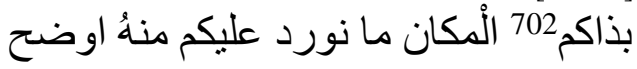

$$
\begin{aligned}
& \text { نص }
\end{aligned}
$$

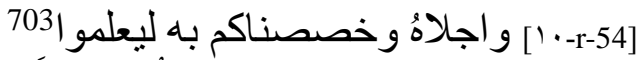

$$
\begin{aligned}
& \text { قدر ما نوثره من ايجاب المزية لكُم ونتوخَّاه } \\
& \text { [-r-54-1'] وور اء هذا النظر ما تحمد في الْحال } \\
& \text { و المنتظر بمن عقباه ونحن لانز ال دآببين }
\end{aligned}
$$

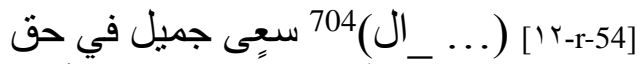

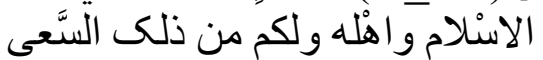

abundant part

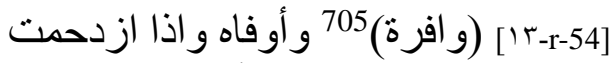

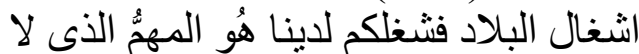

and no other (...), nor is as urgent. Be absolutely convinced of that and غير ه و لا يز حمه سو اه all the rest. Know

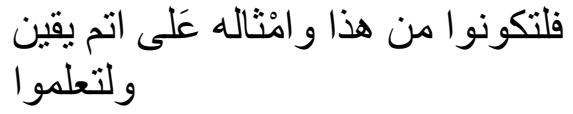

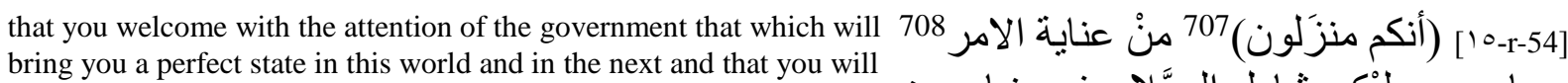
not

بما بعود علنيكم بشامل الصنَّلاح في دنيا ودين Yg

(...) the joys and the discovery of ever easier happiness If

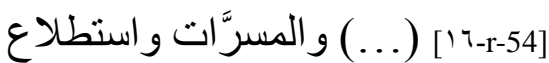

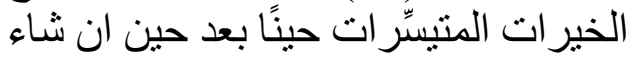

God on High wills it. And He - May He be glorified -, He will grant الله تعالى و هو سبحانه يخو لكم اوفر [1V-r-54] you the abundant parts of His grace and His favor and will always shelter you under the wing

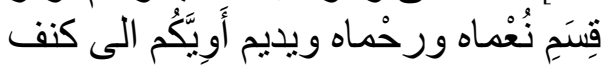
(...) its defense will never fail...

$$
\square \text { [1^-r-54] }
$$

\section{Taqdīm 3: appointment of an important governor}

\section{(excerpt from the "collection of the shaykh") ${ }^{709}$}

$$
\text { [19-r-54] }
$$

Another allocution concerning the appointment of a governor $\left(w \bar{a} l_{i n}\right)$. After the preamble:

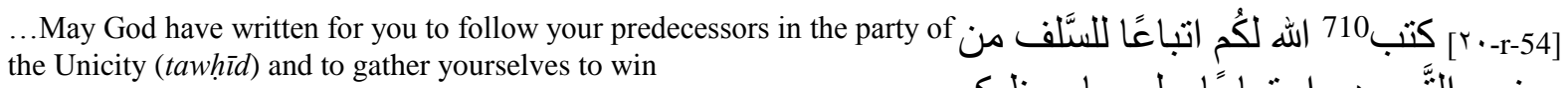

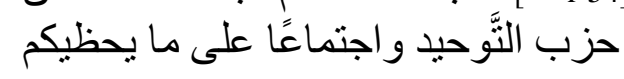

\footnotetext{
702 'Azzāwī: بذلكم.

703 'Azzāwī corrects this rightly with: لتعلموا.

704 About three words stained.

705 'Azzāwī proposes this to fill a blank.

706 One or two words erased, here and hereafter.

707 'Azzāwī proposes this to fill a blank.

708 'Azzāwī: من عناية هذا الأمر.

709 'Azzāwī, NLA, t. 1, 415-416.

710 'Azzāwī proposes ادام but most probably it is here كتب.
} 
even more religious and temporal (favors?). Know that the best thing to bring you an improvement in your situation

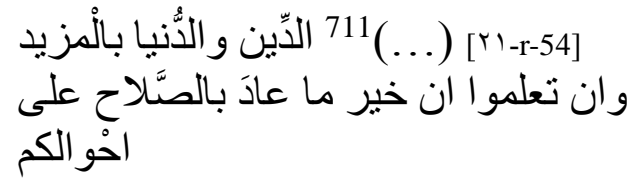

(...) in the present and future, is for you to follow the paths of this authority of which $(. .$.$) are evident,$

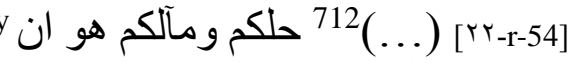

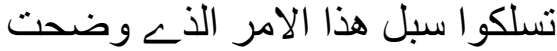

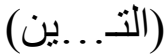

for you to agree to continue along the path opened by the first Almohads, and to devote yourselves to an attitude of perfect submission and

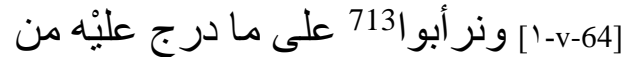

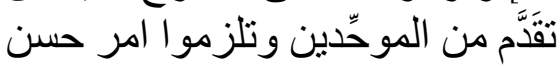

الائتمار و الان جوان

obedience that will allow the organization of your land and guarantee the security of your populations. Thus, we preserve the favors

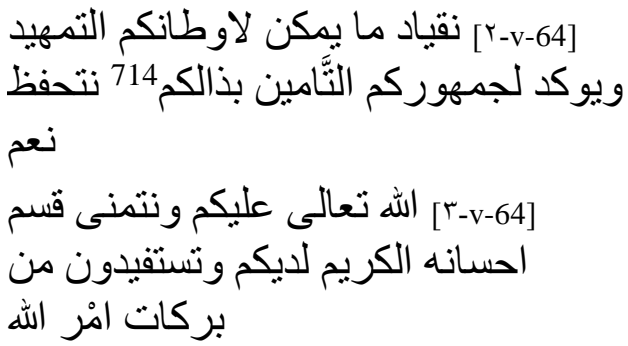

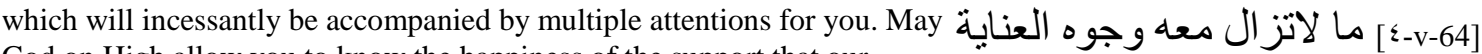
God on High allow you to know the happiness of the support that our

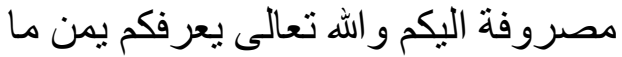
نعتمدكم

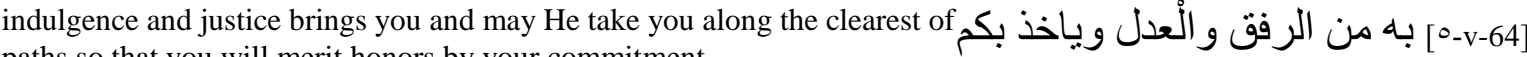
paths so that you will merit honors by your commitment

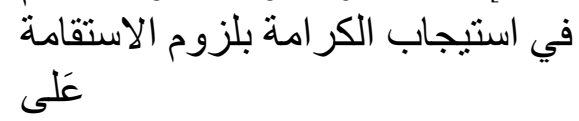

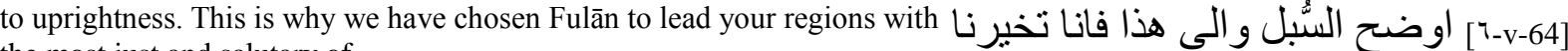
the most just and salutary of

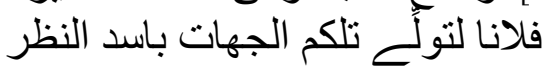

visions and to take care of their interests with the firmest and most

$$
\begin{aligned}
& \text { [V-v-64] و اصلحه و اجر اء العمل في } \\
& \text { مصالحه و اجر آء العمل في مصالها واهاء } \\
& \text { على أَحد مد مد }
\end{aligned}
$$

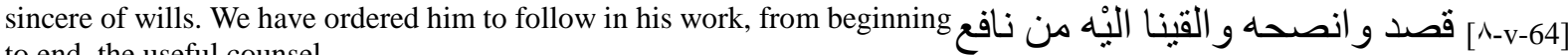
to end, the useful counsel

$$
\text { الوصايا في امور الخاصة و الجمْهور }
$$

we have given him for the affairs of the elite and the people. As for him, he has distinguished himself by his

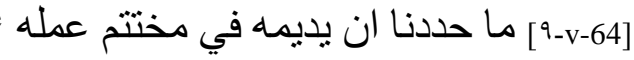

$$
\begin{aligned}
& \text { ومفتتحه و هو الموصوف في ما يسند }
\end{aligned}
$$

competence in the charges entrusted to him, he drew our service's attention to himself by the excellence of his intentions and we appreciated his sense for responsibilities and

711 One or two words are missing. Compared to the construction of the other taqādīm, it is probably من نعم or it is unlikely to be من خير because the term appears in the next sentence (khayr).

712 One or two words missing.

713 'Azzāwī justly corrects this to وتر أبوا which corresponds better.

714 'Azzāwī: بذلكم.

715 Repetition of the formula. 'Azzāwī chooses the second: مصالحها. 
his absolute loyalty in all that depended on him. May your worthy obedience in matters and your precious support in

accomplishing the undertakings we have ordered for him and on which depend, with the help of God, the existence ( qawām) of each of you, going

or coming, and the well-being of your lands, near or far, guarantee the value of your actions, the quality

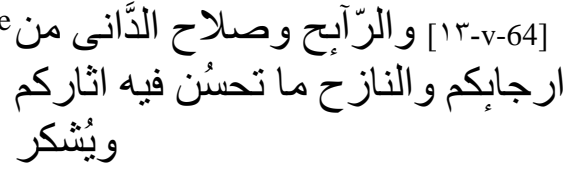

of your obedience, the security of your regions as well as the seriousness of work and the sincerity of intentions at work in your plans.

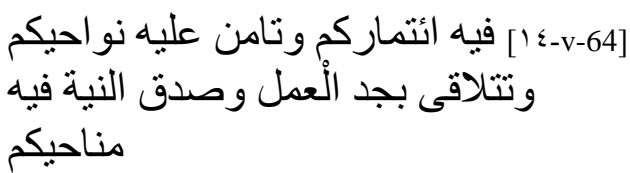

When he appears in your regions, designate from among your shaykhs and leaders those who will go out to meet him and present him

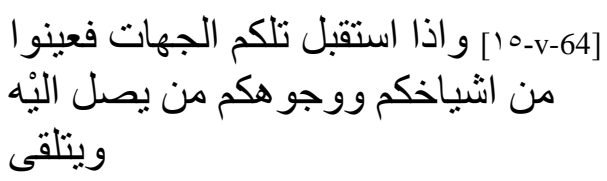

with the matters under his charge; we have already given him all those demanded by the benevolence of our manner with you and all

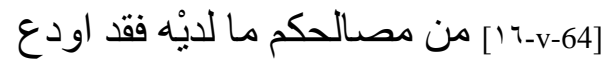

من ذلكم ما اقتضاه مذهبنا الجمبل لكم

ولكافة

your brothers and, because we choose justice and generosity $(i h s \bar{a} n)^{716}$, we have given him the charge of supporting you, if God on High wills it,

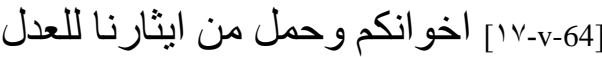

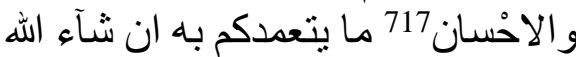<smiles>[AsH][AsH]</smiles>

in all circumstances. When your shaykhs and notables meet with him, they will recognize the well being we wish

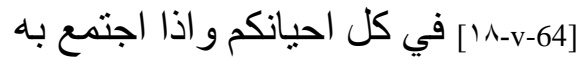
اشياخكم و اعيانكم عرفو ا الخير الذيـ

نوثره

and desire for all and they will see that, in our great solicitude for all of your matters, we seek to extend and expand

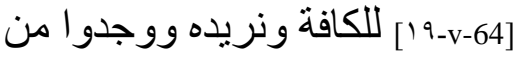
حسن 718 الاعتناء باموركم كلها ما نستديم عون الله

the help of God on High. Thus, do not forswear working fully together to accomplish good and fear [God] in all circumstances. ${ }^{719}$

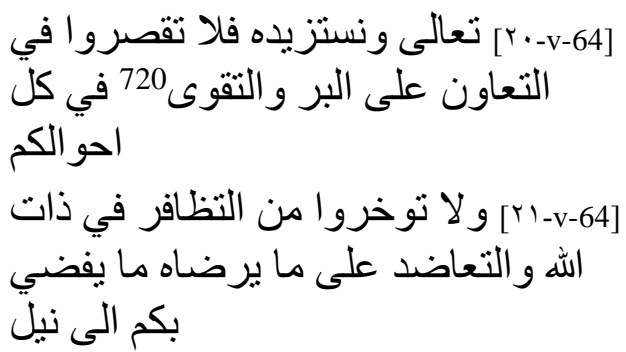

${ }^{716}$ Reference to Koran 16:90: "God commands justice, the doing of good” (inna Lläha ya'muru bi-l- 'adli wa-liḥsāni)

717 Reference to Koran 16:90: إنَّ الله بَأْمُرُ بِالْعَدْلِ وَالإحْسَسان

718 'Azzāwī: حس.

719 Reference to Koran 5:2: "Help ye one another in righteousness and piety" (wa ta 'āwanū 'alá I-birri wa-l-taqwá).

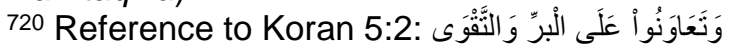


hopes may bloom. Proceed straightly on the road that, in none of your actions, will lead you astray of that

$$
\begin{aligned}
& \text { [rr-v-64] [مالكمو استقيمو ا على الجادَّة } \\
& \text { التخ لا تحيد بكم عن السَّداد في عمل من }
\end{aligned}
$$

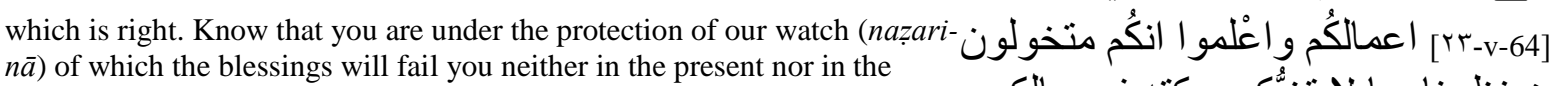
future,

if God on High wills it. And He — May He be glorified - , He will guide you towards the most beautiful [reward] (al-husná) $)^{721}$ and with steadfastness in that which is right, He will assure for

[-1-75-1 ان شاء الله تعالى وهو سبحانه

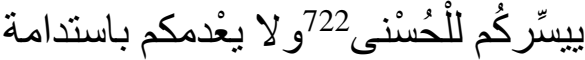
الاستقا

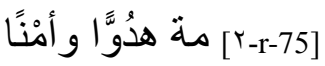

you calm and security...

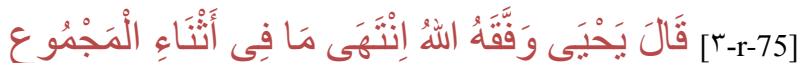

Yahyā - May God help him - said: "ends here in the compilation

the summary of appointments of governors (al-wūlāt) over the land or the confirmations of military leaders $(q u w w \bar{a} d)$ capable ${ }^{723}$ of closing the border zones

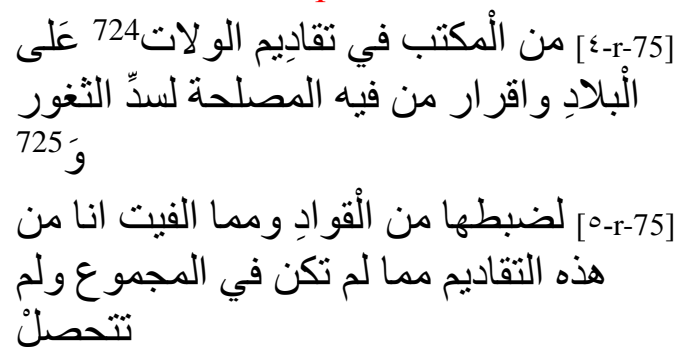

in this project; if God wills it, there are some that I will record with these, so that they will be tied to them and complete them,

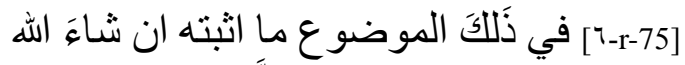

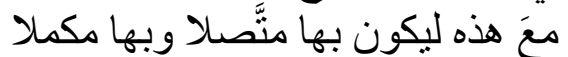

so that they will be found together in the presentation, to form a series and constitute a coherent and joined whole; thus these appointments will find

[Y-r-75] حتَّى ثتساوى انسياقا وترثنبط مساقا

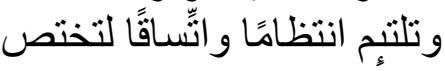

their proper place, they will be illuminated by way of their exposition and their resemblance will place them fully in the light. I will next add

the appointments of judges, whether they are in the compilation or whether I found them elsewhere, to define the titles (the laqabs)

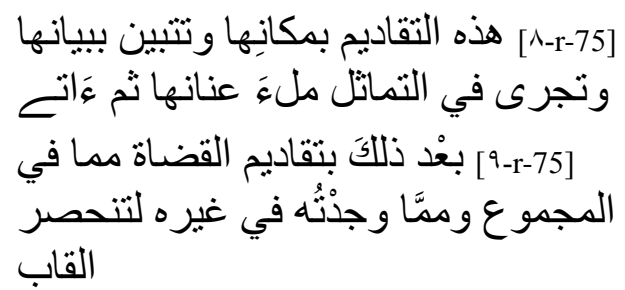

of what I wanted, and so that what I have set out may be useful. After which I will add the authentic acts, decrees, etc.,

$$
\begin{aligned}
& \text { [-7-75--1] ما اردته وتتحصل فابدة ما اوردته }
\end{aligned}
$$

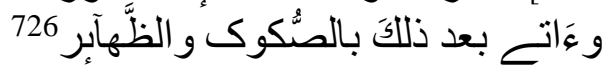

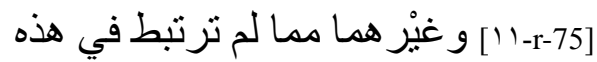

$$
\begin{aligned}
& \text { الفنون ولا تدخل في هذه العيون وتكون }
\end{aligned}
$$

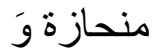

that do not belong in these chapters (funūn) and do not enter in these excerpts; they will be separated

${ }^{721}$ Reference to Koran 10:26: "To those who do right is a goodly (reward) - yea more (than in measure)!" (li-l-ladhīna ahssanū al-ḥusná wa ziyādatun) and Koran 92:5-7: "So he who gives (in charity) and fears (God), and (in all sincerity) testifies to the best-We will indeed make smooth for him the path to bliss" (fa-ammā man a țá wa ttaqá wa șadaqa bi-l-husná fa-sanuyassiru-hu li-l-yusrá).

722 Reference to Koran 10:26:

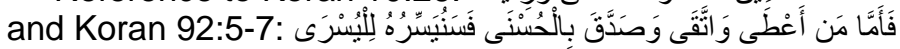

723 Or "useful for".

724 'Azzāwī: الو لاة.

725 'Azzāwī omits wāw.

726 'Azzāwī: الظواهر. 
and will provide their contents, so that there is no error in this book and that its different

[Yr-r-75] حدها و معطاةً مَا عندها حتى لا يقع في الكتاب غلط ويكون بغْضه

parts are linked. If, after having finished [my] project, I find something else related to these categories and that I am able

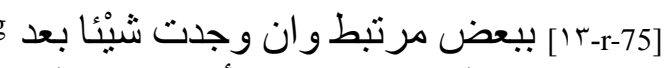

تمام هذا القصد من هذه الأنوع وحصلت

to acquire, then I will set it out in full if God wills it and I will publish it as a full moon.

[-r-75-1 ] على امتاع هذا المتاع فساءُورده ان

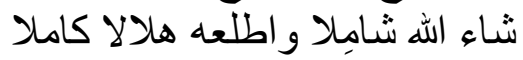

God is the One who helps in doing right and it is He who brings projects to fruition and responds to needs.

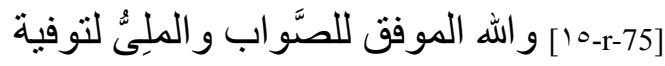

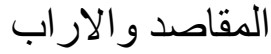

Taqdīm 4: From Cordova, the appointment of a governor with fiscal attributions (wālin) by Abū l-'Alá al-Ma'mūn before his ascension to the caliphate (summer 1226-September 1227) $)^{727}$

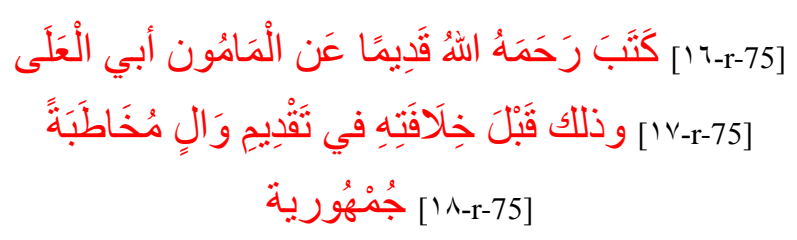

He wrote - May God have mercy on him - a long time ago, a public allocution for the appointment of a governor $\left(w \bar{a} l_{i n}\right)$, in the name of al-Ma'mūn Abū al- 'Alá, and this before he became caliph

To the population of Fulāna - May God gather them to do right and fear Him, and provide them with a just vision of what will

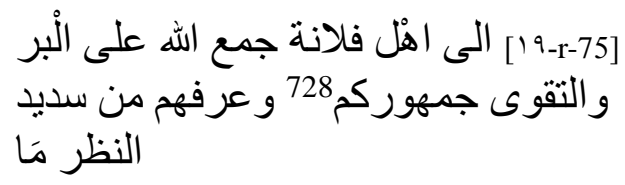

restore their situation and put their affairs back in order; salutations. This is what we write from Cordova - May God have written for you to assimilate counsel well

and to watch over your interests. The only thing that we know with the favor of God and the blessings of His highest plan, are the benefactions

that flow like rain in the springtime and the joys whose assistance renews without ceasing. We praise God grandly, that His favors always continue

to grow and increase.You know - May God treat you generously — that the most important advantage in your situation,

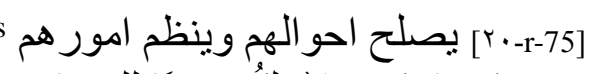

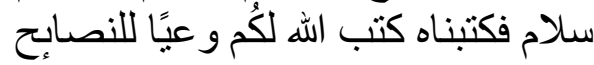

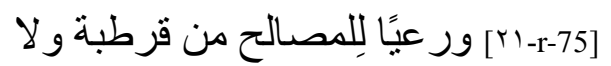

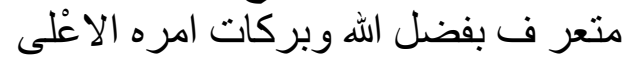

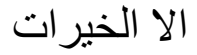

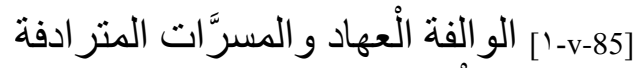

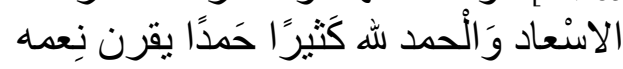

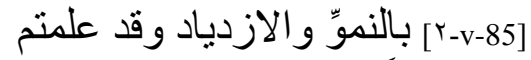

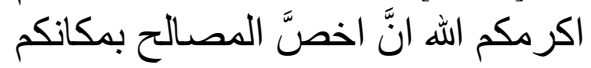
و اعودها بالامر بمر

727 'Azzawīi, NLA, t. 1, 417. 'Azzāwī suggests that this appointment took place while al-Ma'mūn was governor of Cordova for his brother al-' $\bar{A} d i l$, or of Cordova and Seville after he took these cities at the expense of al-Bayāsī. 728 'Azzāwī: جمهور هم. 
that which will bring you power and tranquility at any moment, is the choice of a governor who will take charge of your affairs (ashghāl) and take concern for your situation;

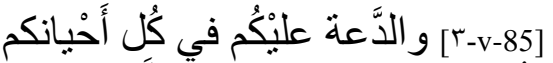
تخيُّر و ال بتقلد اشغالكم ويتفقِّ احْو الكم ويريكم من حسن

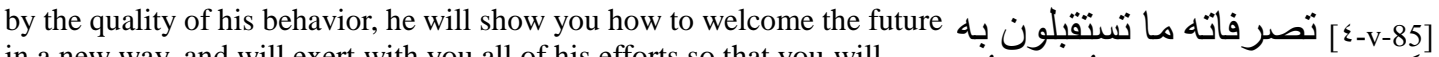

in a new way, and will exert with you all of his efforts so that you will

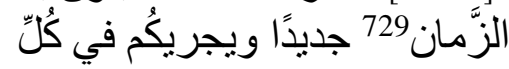

محاو لاته عَلى ما تعدمون

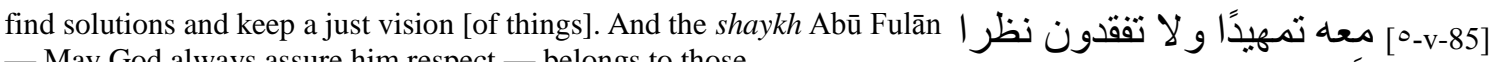

- May God always assure him respect — belongs to those

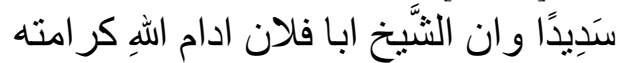

who have all the qualities of a responsible man and who evince the noblest of characters and the best nature. We trusted his

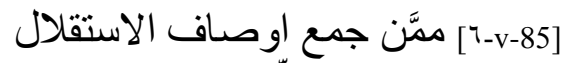

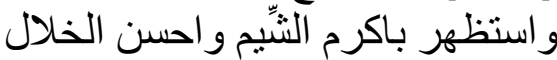

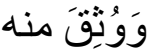

ability to assume the affairs (al-ashghāl) that were entrusted to him; that is why he was chosen to look after the interests (mașāliḥ) of your country

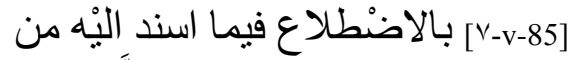

الاشغال ولذلى اختير (في) 730 النَّظر في في الخي

مصالح افقكم

and its districts. He was placed at the head of your affairs after having been tested and selected. We called on him to be alone in looking after them (biumūri-kum)

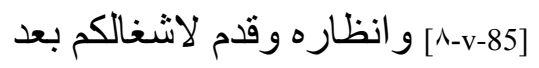

اختباره و اختيار و و انهض وف للاستبداد

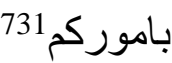

when we were sure of the excellence of his authority (bi-husni îrādi-hi wa $i s ̦ d \bar{a} r i-h i)^{732}$. We have counseled him to fear God on High for that which we have entrusted

[9-v-85] حين الثقة بحسن اير اده و اصداره

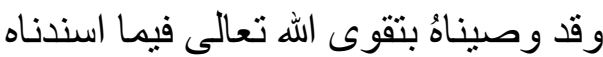

Him, we wanted to confide your important missions to him. To lead your regions well and chase from your lands

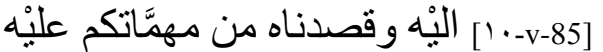

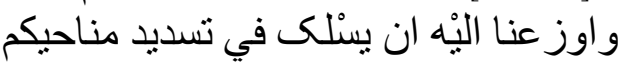

the camp of corruption, we have incited him to take the straight path; if he follows it, your situation will improve, your hopes,

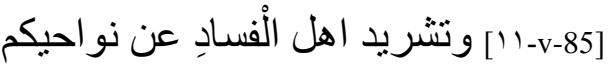

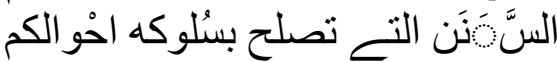

وتنبسط

under his command, will blossom and with him your words and your actions will progress along the great road. We have enjoined him

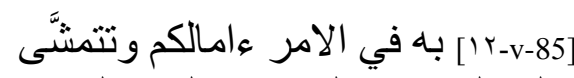

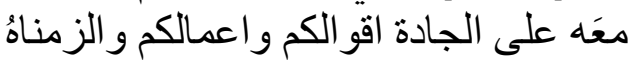

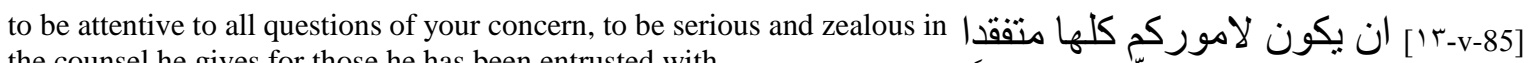
the counsel he gives for those he has been entrusted with,

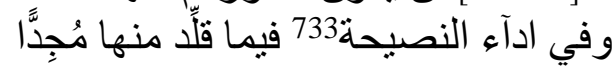

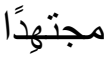

so that nothing important for you escapes from his attention, and his watch neglects none of your regions. You must

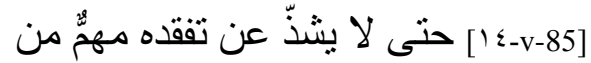

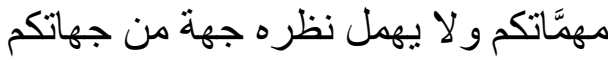
و وعليكم

aid him in executing and applying that which is righteous and lawful, and support him in fully retrieving and paying for the things that are due.

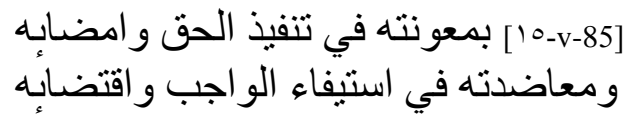

729 'Azzāwī: الزمان.

730 'Azzāwī: اختبر للنظر

731 'Azzāwī: ألأموركم.

732 Lit. "of his ìrād and ișdār".

733 This is probably an echo of the hadīth reported by Muslim, Șahīh, t. 1, 225, n' 194 and Tirmidhī, Sunan, 440, n 1 926: الدينُ النصيحة al-dīnu I-nașihha ("Religion is sincerity”). 
You must know that, before the Law, the famous man and the unknown are equal, and [belong] to the same category, and that religious

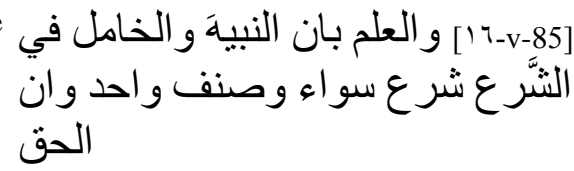

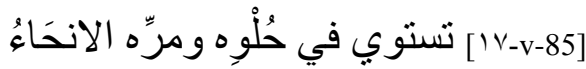

intentions and goals are equally present in the sweet and bitter [aspects] of the law. As long as efforts are exerted

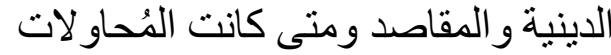

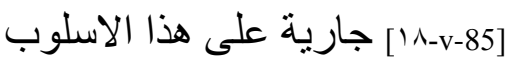

انتصف الضعيف من القوي وسار

الثريف

and the man of the people will take together the same straight path (sanan). Thus, when he arrives among you - If God on High wills it - acquit yourselves fully of what you (owe him?),

$$
\begin{aligned}
& \text { [19-v-85] و المشروف على السنن السَّبِى } \\
& \text { فاذا و افاكم ان شاء الله تَعالى فوفُوه } \\
& { }^{734}(\ldots)
\end{aligned}
$$

seek to satisfy him, follow him along the path of mutual aid for good and piety, and God on High

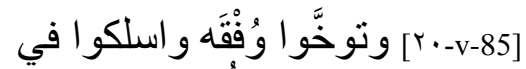

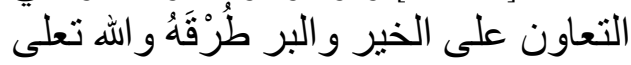

will bring you, to you and to him, His help to carry forward just causes (mașālih), and He will use you in a virtuous work. By His grace and His generosity. Peace.

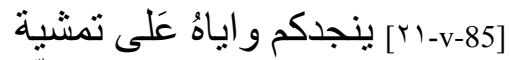

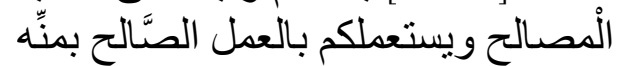

وكرَمها والسَّلام

Taqdīm 5: From Granada, Ibn Hūd al-

from Almería, and replaces him with the

vizier's son at the head of the region, ramaḍān

630/June 181233 (Act complete) $)^{735}$

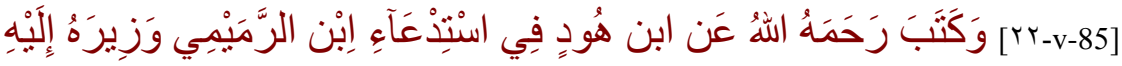

$$
\begin{aligned}
& \text { [rr-v-85] }
\end{aligned}
$$

This is what he wrote - May God have mercy on him - in the name of Ibn Hūd to recall Ibn al-Ramaymī his vizier to him, to name his son in Almería and its regions and to commend to him its administration ${ }^{737}$

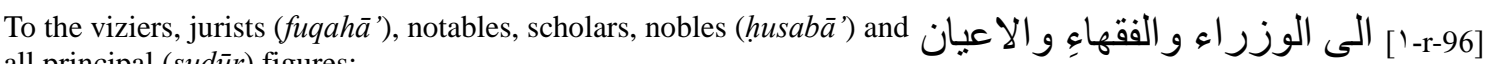
all principal (șựur) figures:

والاعلام و الحسباء و الصدور العلية النبهاء

\footnotetext{
734 Word erased, probably حقه.

735 'Azzāwī, NLA, t. 1, 419-421: this act corresponds to the zenith of Ibn Hūd's political power in the Sharq al-Andalus.

736 Hicham El Aallaoui deciphered the last two words

737 Literally "entrust him with the reigns."
} 


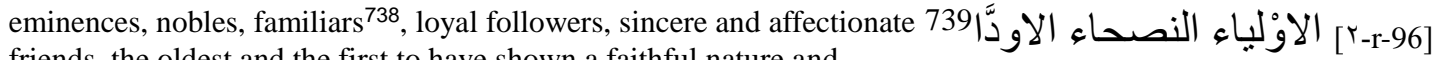

friends, the oldest and the first to have shown a faithful nature and qualities

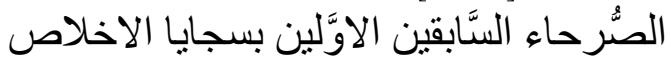

ومز ابا

of loyalty, truthful in the love and purity that clearly express their tongues according to their hearts;

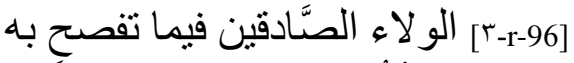
السنتهم عن صُدُور هم من الحب و الصَّفاء

to the elite of the population of our land, to our brothers in sincere affection, to our beloved among whom we have chosen

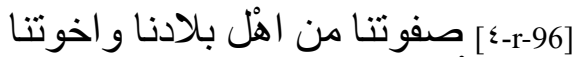

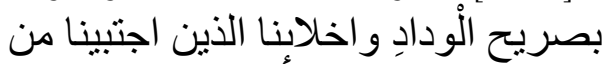

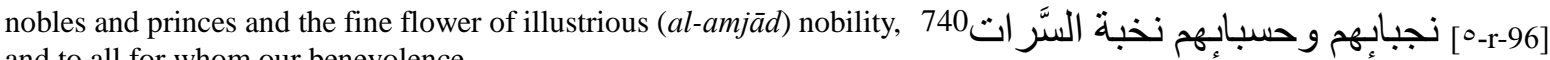
and to all for whom our benevolence

الامجادِ و الكافة الذين يتعهدهم نظرنا

cares to seek out the best situation in granting their hopes and fulfilling their desires - May God assure them always

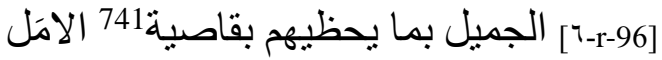

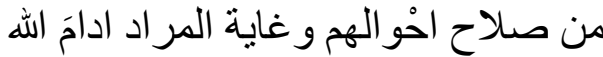

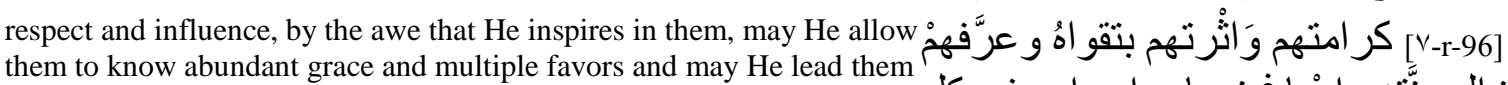

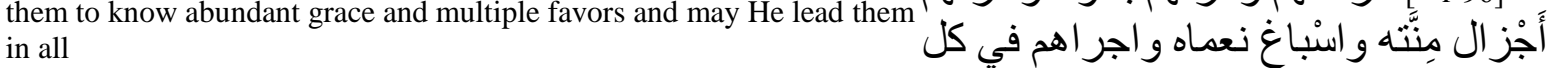
their affairs on the path that gives an easy access to His beneficence. Peace and honor on you, the honored familiars, affectionate

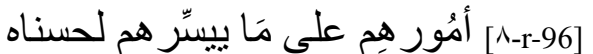

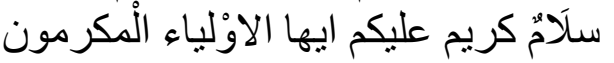

Friends who compete to occupy the first place in the hippodrome (miḍmār) of faithfulness (khulūss). After having praised God, who spreads

[9-r-96-9 و الاوداء الذين بسبقون في مضمار

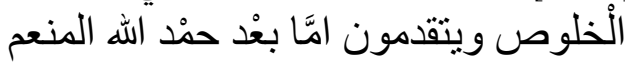

His blessings on those close to Him, of whom praises inspire the multiplication of the parts of His favor, of whom all favorable actions and

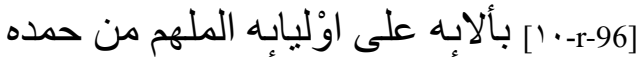

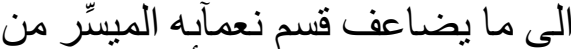

صنعه

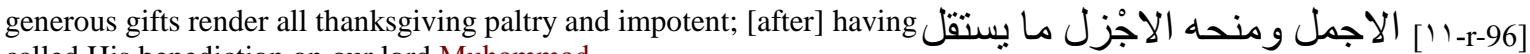
called His benediction on our lord Muhammad,

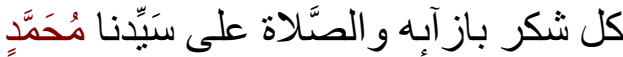

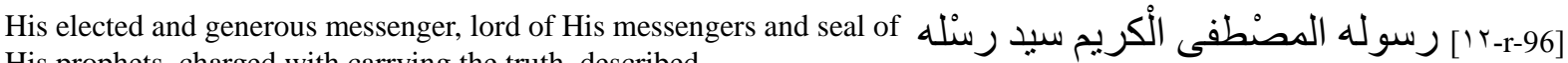
His prophets, charged with carrying the truth, described

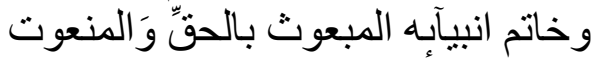

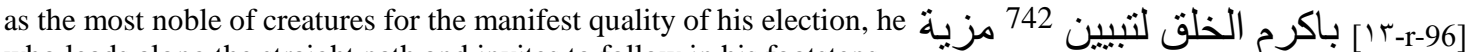
who leads along the straight path and invites to follow in his footsteps (iqtifä'i-hi),

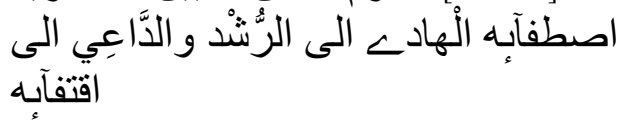

738 The translation "familiars" transmits only one aspect of this polyvalent word which signifies both protectors and patrons as well as clients, defenders, partisans, companions, friends, and, in Fatimid terms, also applies to missionaries ( $\left.d \bar{a} ' \bar{\imath}, \mathrm{pl} . d u^{\prime} \bar{a}\right)$. The word often has the vague meaning of soldiers or officers, officials in the entourage of a caliph or emir, his bodyguard and, by extension, simply troops or soldiers. Among the Fatimids, the awliyā' Allāh, the friends of God, are the imāms (Canard, Vie de l'ustadh Jaudhar..., 1958, 52).

739 'Azzāwī: الاودَاء.

740 'Azzāwī: السَّراه.

741 'Azzāwī: بقصية.

742 'Azzāwī: التبيّ. 
[as well as] to his family and his noble companions, banners of Islam and stars of his guidance, ${ }^{743}$ those who went to the end of

the road to spread and triumph the Abrahamic religion (al-dīn al-hanīfí), acting in the most just manner and never straying

from his straight path; [after] having asked Him to approve the imām the Abbasid caliph, prince of the believers, he of whom the purity

of lineage (sarīh intimā 'i-hi) confers illustrious nobility and glory without equal, ${ }^{745}$ he who defends the prophetic cause (al-da wa alnabawiyya)

as did the orthodox caliphs, his fathers, he [finally] who asked to drink from his ancestor - Salvation be upon him - , celestial cloud ${ }^{746}$ that granted

its water to him. This is what we write from the [palatial] residence ( hadra) Granada - May God keep it —; may God have written for you the knowledge of multiple and unending benefactions

and may He lavish on you His favor which will add without end new gifts to the old. And we

\section{$(\ldots)$}

... and make it grow. Our care for you, in large and small matters is constantly renewed, and the protection that we grant the interests of

you all, people and elite, is always growing. And that because God is your Lord of the important place you have acquired

in [our] mind, [because] of your past which warranted for you recognition without equal and [because] of your loyalty distinguishable

by the nobility of the qualifiers that corresponds among you to the nobility of those who are qualified. For you are the people (qawm) who cannot be contested in the hippodrome (midmār)

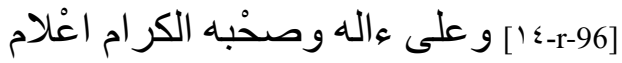
الاسنلام ونجوم اهتدآبه

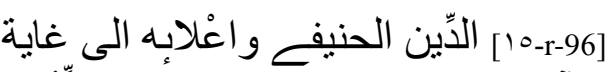
انتهآته العَامِلين على سنن السنن لا بِنكبِّون

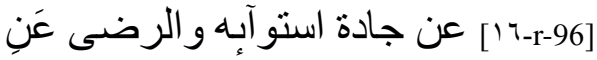

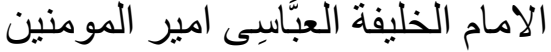
المحْتوى من لرن

[lv-r-96] على الثَّرف الباذخ و المجد الرَّاسِخ بصريح انتماءه القابح بالآَّعوة النبوية

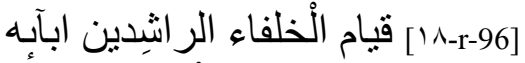

المسنتسقى بجده عليْه السَّلام مزْن 747 السَّمَاء آنَاء

وقد

[9-19-96-1 ] منّ بمابه فانا كتبناهُ كتب الله لكم تعرُّفًا لمتضاعف التف النعم ومثر ادفها ولقاكم

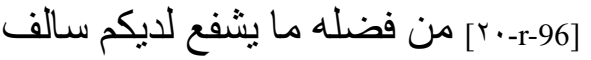
الْمنن بخالفها من حضرة غرناطة حَرَسـها الله ونحن جرن

748 (...) [r/-r-96]

[1-v-106] و انماهَا فان عنايتنا بالاقلَّ و الاكثر

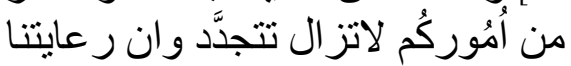

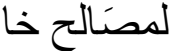

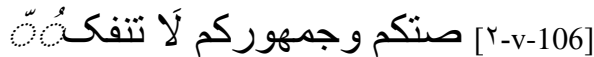

تثزيَّد ذلكُم اللهـهـبُّمم 749 لمكانتكم في النَّفس

التح أحظتكم با فيا

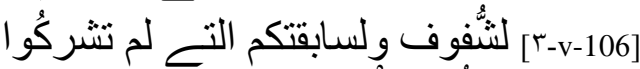

في تقدُمهـا الْمُروف وف ولمو الاتكم التح

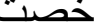

[ع-v-106 ] من شرف الصِّفات بما بناسب منكم شرف الموصنوف فانكم القوم لا بجارون في مضندار

743 Reference to a hadìth considered as weak (da 'îf): "My companions are the stars, follow any of them and you will go in the right direction"(așhābi ka-I-nujūm fa-bi-ayyi-him iqtadaytum ihtadaytum); see lbn 'Abd al-Barr al-Mālikī, Jāmi u bayān al- 'ilmi wa faụli-hi, t. 2, 898, n 1684.

${ }^{744}$ Reference to a hadìth considered as weak (ḍa 'îf) Ibn 'Abd al-Barr al-Mālikī, Jāmi u bayān al- 'ilmi wa faḍli-hi, t. 2, p. 898, n 1684: أصحابي كالنجوم فبأيهم اقتديتم اهتدينم

745 Lit. "firm, strong, rooted".

746 Koran 56:69: "Do ye bring it down (in rain) from the cloud or do we?" (a-antum anzaltumū-hu min almuzni am nahnu al-munzilūna).

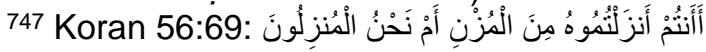

748 Three lines erased.

749 'Azzāwī does not mention this deletion by the copyist. 
of sincerity or purity, nor rivaled in the race of horses of zeal and faithfulness, people of the disciples of the truth who follow steadfastly

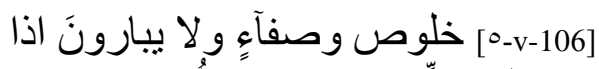

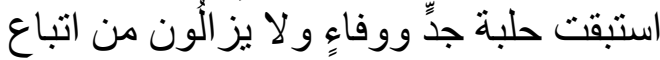

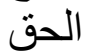

the straight paths and the right direction. An excellent administration to ensure the organization of your lands and the security of your regions is,

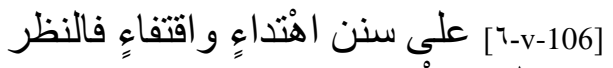

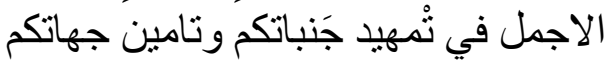

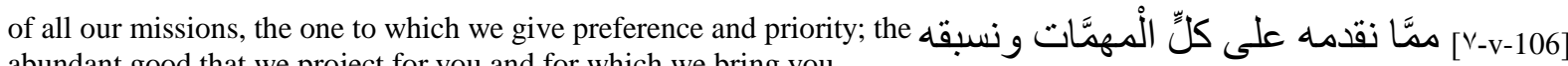
abundant good that we project for you and for which we bring you support is a permanent task

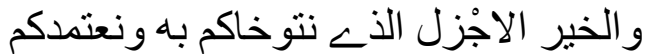

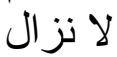

that we take on without end. It is in those terms that our most faithful companion, our most sincere friend,

an aid whose watch leads us and whose administration (tadbīr) saw illustrious actions shine, $D h \bar{u}$

l-wizäratayn ("the man with two vizierates") ${ }^{752}$ whose sublime rank distinguishes him at our side, and who is as intimate and close to us

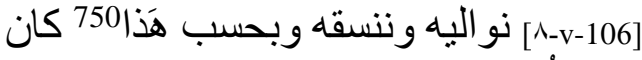

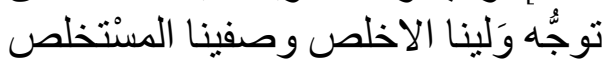

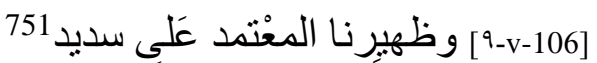

$$
\begin{aligned}
& \text { نظرهوخالصنتا الَّذَـ لاحَ في التَّدبير كريم } \\
& \text { أَثَره ذي كري }
\end{aligned}
$$

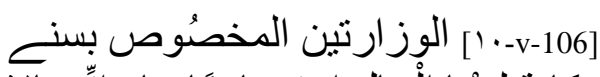

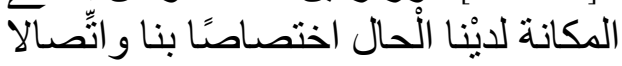

$$
\begin{aligned}
& \text { محل اليمنى الئل }
\end{aligned}
$$

as our right hand - May God allow his rise to continue and prolong his existence - is heading toward your country - May God protect it - to represent

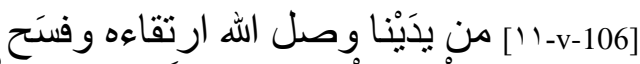

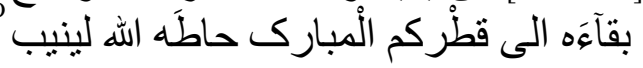
us in the administration of your affairs and fill our place to ease the success of your hopes. This was decided after we learned

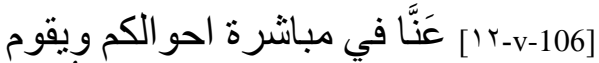

$$
\begin{aligned}
& \text { مقامنا في تيسير امالكم وقد كان من ذلكُم ما } \\
& \text { علمنا }
\end{aligned}
$$

that it corresponded with your choice. We have thus fulfilled our most important objective concerning organizing your regions

$$
\begin{aligned}
& \text { [r-v-106] انه يو افق اختياركم هنالكم وقضينا } \\
& \text { به الغرض الاهمَّ لدينّا من تمهيد ارجاءكم }
\end{aligned}
$$

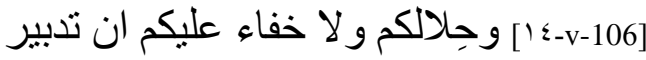

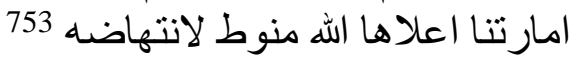

$$
\begin{aligned}
& \text { و غنابه }
\end{aligned}
$$
principality - May God raise it up — depends on his energy and aptitudes,

and that he settles the revenues (al-irāda $\bar{t}$ ) that circulate in our land with competence and efficiency. These are the reasons

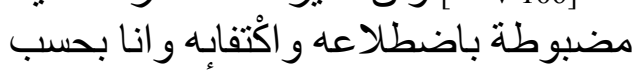

for which we require his presence among us; we call upon the accuracy of this watch and the weight of his judgment to

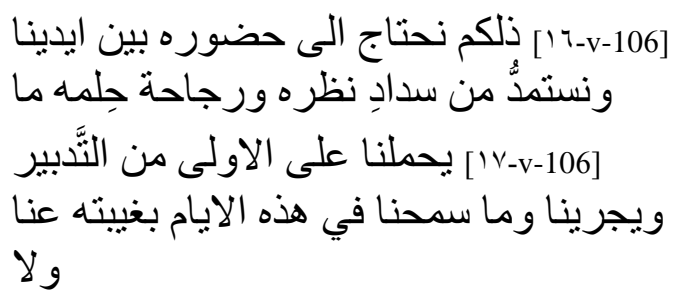
administration. We have tolerated his absence from among us these last days and endured

\footnotetext{
750 Alif inserted between the hā' and $d h \bar{a}$ '.

751 'Azzāwī: سَبيل.

752 This is Abū 'Abd Allāh Muhammad b. al-Ramaymī, who was named vizier of Murcia. On lbn Hūd's death, he became governor of Alméria before his son rebelled against him and the city fell into the hands of Ibn al-Aḥmar (al-Maqqarī, Naf̣ al-țīb, t. 4, 464).

753 'Azzāwī: بانتهاضي.
} 
the discomfort of his leaving solely because the care that we grant you requires that we choose for you he who is the most dear

to [our] hearts and that we generously give you he who is like the apple of [our] eye. Because the nobility of his vicariate shown

in the improvement of your entire situation and of all your measures as well as the quality of care he showed in protecting your domains and their borders ${ }^{754}$, our need [for him] opposed

yours (... [so much so that] we were solicitous with his person for you ${ }^{755} \ldots$...the favor...)

... of him in the presence? of which benefits will come to your regions and to others. Our watch over

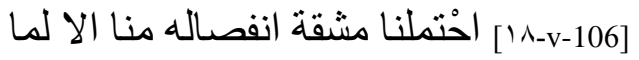

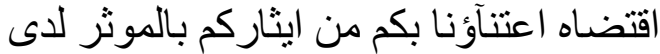

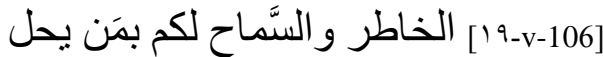
محل السَّو اد من الناظر ولما وضح كرم منابه في

[ب-v-106] تحسين احو الكم كلها و مذاهبكم وحسن عِنابه في تحصين خلالكم وجو انبكم وتعارض ونوان

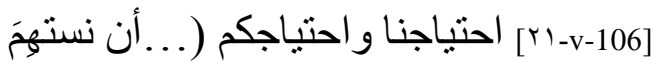

معكم عليه. ... النعمة. ....

[Yr-v-106] عنه في الحضور لما بعود نفعه على نو احي سو اكم ونو احيكم نظرنا في ذلكم نظر

(attempts to conciliate?) two goals: to not deprive you of this wealth and to have him present, with us in flesh

$$
\begin{aligned}
& \text { [1-117-1 [با؟ وقد جمع) } 757 \text { بين قصدين في } \\
& \text { ان لا نخلى منه } 758 \text { ذلكم المغنى وان يكون ليك }
\end{aligned}
$$

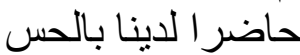

and blood, with you in mind. We thought for that of a plan that would be an excellent program and project and of a decision whose justice and rightfulness

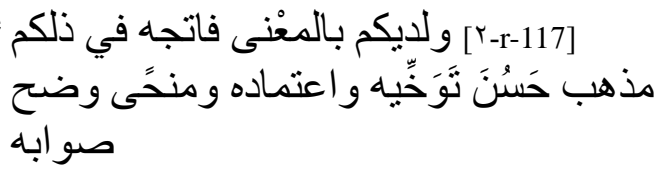

are obvious. It seemed to us that it would infringe on the desires and choice of neither of us. [This decision] is to put forward (qaddamnā), in

$$
\text { اختيار كل و احد منكم ومر اده وذاده وظر لنا انهَ لا بعدوه ان قدمنا }
$$

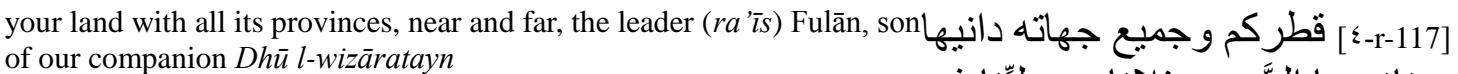

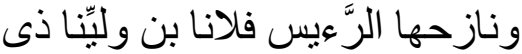

$$
\begin{aligned}
& \text { الوز ارَتين وصنَ }
\end{aligned}
$$

— May God always assure him His assistance and His aid and may He prolong his rise and his elevation on the stairs of glory. Previously, we noted his

$$
\text { [ـ-r-117] الله اسنعاده و انجاده و ادام ارقَّاَعَه في }
$$

Nobility and remarked his efficiency; witnessing for him before us were the incontestable antiquity of his family

and the merit of this rank; it is clear that he follows in the footsteps of this father and does not stray from his generous

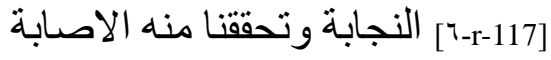

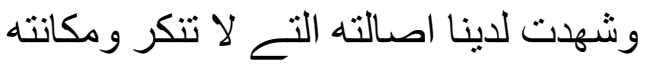

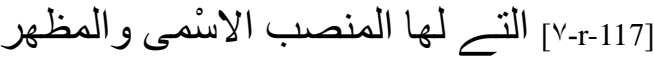
انه يحذو ا 759 حذو و الده و لا ينكب عن كَريم مقا

\footnotetext{
754 Lit. "your flanks".

755 With the eighth form of SHM (nastahimu). Another possibility with the tenth form of HMM (nastahimmu): "or we thought concernedly of him with you".

756 Two lines erased.

757 'Azzāwī propose: مبال لايجمع.

758 'Azzāwī: منكم.

759 'AzzāWī: يحذو.
} 
Plans. He is a nephew for us by affection and loyalty and for his father our companion, a pious son faithful to the nobility of his lineage. We watch over

him like a loving father over his beloved sons (nujaba 'al-abna '). $\mathrm{He}$ knows the fondness we have for him.

[to watch over] your interests and resources. We commended

to him the administration of your lands, the closest and the most far. In doing so, we count on you and on him to do well and act correctly

always and continuously. We have designated him as governor among you in entrusting him alone with the charge

of your affairs, thus protecting him from the attacks of associates and rivals. We know with certitude ${ }^{761}$ that, like his father, our eminent companion,

he constitutes a guarantee that will leave no room for negligence, and that, by his great personal qualities, he will not fail to rise to the rank

deserved by energy and a sense for responsibilities. This is a appointment whose choice and selection are specially meant for you. It is a gracious gift

that will eternally stay with you and your children. Rejoice in the abundant blessings you

will receive. Be happy in the profusion of benefactions the vision of which will fill your eyes and your hearts

with joy, if God on High wills it. And He — May He be glorified -, He will guarantee for you His protection and Salvation

and He will make you happy, now and in the future. Written the $8^{\text {th }}$ of the glorious month of ramadān of the year 630 .

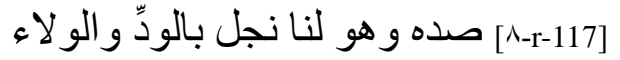
و لابيه ولينا المبرور بكرم الانتماء و اعتتاؤنا

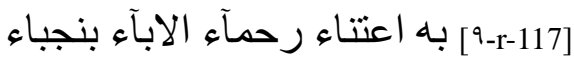

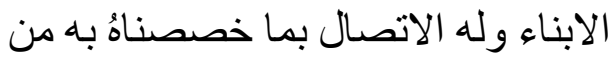

مزية الاحتبآء

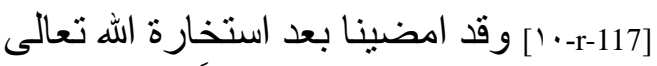

تقديمه على المصنْح 760 التح لَدَبْكم و المنافع و أسدنا

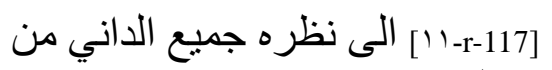
اقطار كم و الثـاسع و اعتمدناهُ و اعتمدناكم في جي ذلك بـالخير

[1/r-r-117] المتو الـخ و الاحسان المتتابع

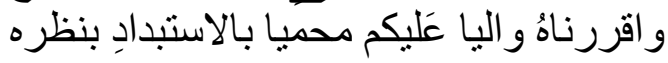

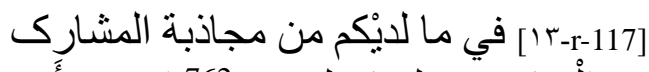
و الْمناز ع و علمنا علم يقين 762 انه من أَبيه وولينا الاعلى ملن النه

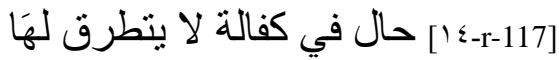

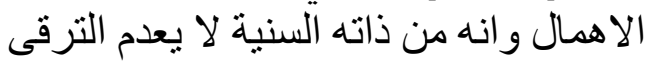
الى رثب الترى

[10-r-117] الانتهاض و الاستقلال وهذا نظر خصصناكم بمختاره و منتقاه و حبوْناكم منه وله بـ

[17-r-117-17 ] يخلد في الابآه منكم و البنين مؤبده ومبقاه فاستبشروا بما تستقبلون من البركات [IV-r-117] الجزيلة و ابتهجو ا بما بمالك عيونكم قرة ونفوسكم مسرة اجْتنلاء الموصولة النه و المنح للمبذ أموصوله

[1/N-r-117] المبذو لة ان شَآء الله تعلى و هو سُبحانه بصل اكتفالكم بـالْعَافية و اكتنَافكُم

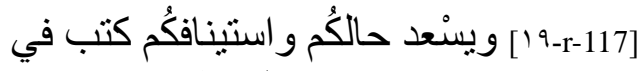

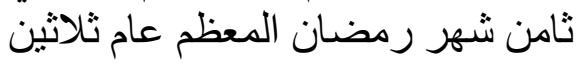
وستمائة

Taqdīm 6: Recognition, solicited by the population of Ceuta, of the appointment of Abū l-Qāsim al-'Azafī as governor by the

760 'Azzāwī: المصالح.

761 See Koran 12:5.

762 See Koran 12:5: كَلَّ لَوْ نَعْلَمُونَ عِلْمَ الْيَقِيَنِ 
caliph al-Murtaḍá on 14 rajab 648/12 October $1250^{763}$

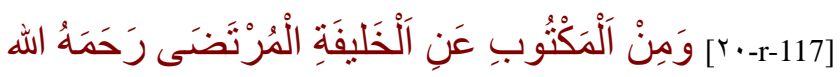

$$
\begin{aligned}
& \text { [r-r-117] }
\end{aligned}
$$

Among the writings in the name of the caliph al-Murtaḍa - May God have mercy on him - on this subject: public allocution (jumhūriyya) to the people of Ceuta

... requires care in managing their interests and constant preoccupation for what can bring happiness

to those who come and those who go. It contains the response that was addressed to them concerning their desire to see the illustrious legal expert (faqīh)

Abū l-Qāsim al- 'Azafĩ named over their land and to have their request approved, which was recognized as unanimous. Here,

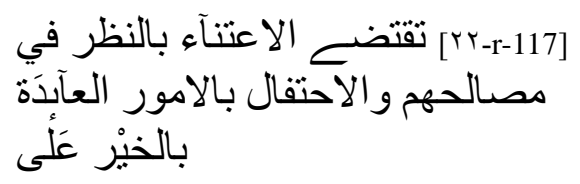

desire for them and all of their Muslim brothers. Peace. ${ }^{769}$ Next, we praise for you God - May He be exalted and magnified, there is

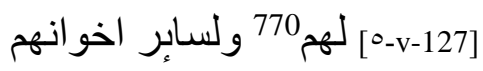

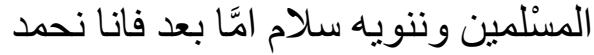

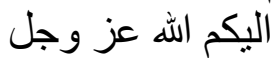

no other god but Him - and we give him thanks for His favors and His kindness. We pray for our lord Muhammad, the generous, the sympathetic $\left(r a^{\prime} \bar{u} f\right)$

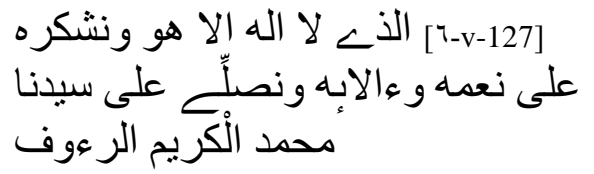

\footnotetext{
763 'Azzāwī, NLA, t. 1, 422-426.

764 'Azzāwī: فيما.

765 'Azzāwī: في ما:

766 Reference to Koran 5:2: "...help ye one another in righteousness and piety" (wa ta 'āwanū 'alá I-birri wa-l-taqwá).

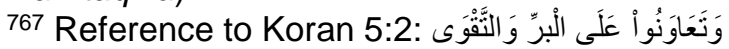

768 'Azzāwī justly corrects this with الخير' by adding a dot that had disappeared over yâ'.

769 It is not clear whether the passage beginning with bi-smi l-khalifa comes from the original document or if it was reconstituted by the manuscript's author. 'Azzāwī notes elsewhere that this introduction seems to be a sort of synthesis between the original taqdim and different preambles from the Almohad chancellery.

770 'Azzāwī: اليهه.
} 
and the merciful, ${ }^{771}$ the purest of His creatures, the seal of His prophets. Praise be to God who "knows of (the tricks) that deceive with the eyes, and al

that the hearts (of men) conceal;" 773 according to His will and His power, the

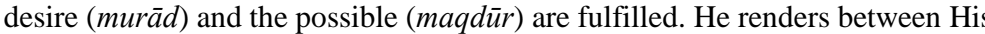
subjects

judgments to which submit the governors and the governed and "He doth guide whom He pleaseth to a Way that is Straight." 775 We can neither turn away

nor stray from "the way of God to Whom belongs whatever is in he heavens and whatever is on earth. Behold (how) all affairs tend towards God!"777

Constantly abundant and ceaselessly multiplied prayers on His prophet, he who is preferred to all the messengers and all

$$
\begin{aligned}
& \text { [V-v-127] الرحيم } 772 \text { صفوة خلقه وخاتم } \\
& \text { انبيابهـ و الحمْد لله الذَى يَعْلم خانـة } \\
& \text { الاعين وما جاه }
\end{aligned}
$$

$$
\begin{aligned}
& \text { [د-v-127] تخفى الصدور } 774 \text { وينفذ وفق } \\
& \text { ار ادته وقدرته المر اد و المقدور ويحكم } \\
& \text { بين عباده }
\end{aligned}
$$

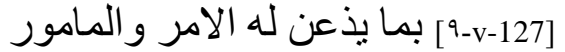

$$
\begin{aligned}
& \text { ويهدى من يشَآه الى صر اطِ مسنتقِيم } 776
\end{aligned}
$$

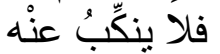

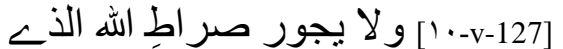

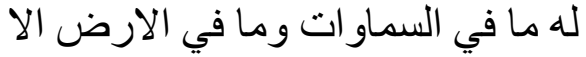

الىى الله تصير التهي الامور 778

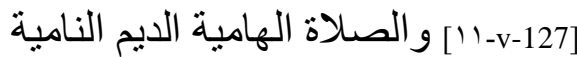

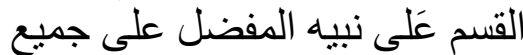

الارسال

Communities, messenger [to carry] the tolerant religion of Abraham ( $a l$ -

hanifiyya) to the Arabs and non-Arabs, our lord and master Muhammad whose

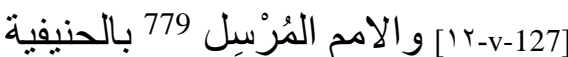

السَّمحة للعرب و العجم سيدنا ومو لانا

مُحَمَّدِ الأذى ونى

merit is worthy of glory and obvious superiority over the [other] prophets and by whose obvious and brilliant limpidity,

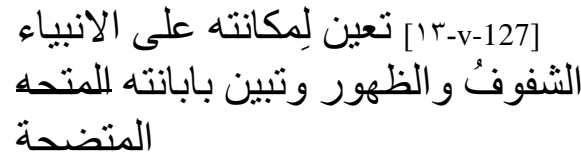

necessity and omnipresence were illuminated; his Lord supported him with the miracles of the Koran that remain new despite

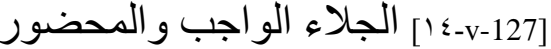

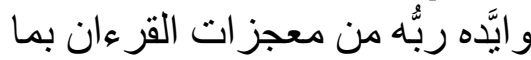

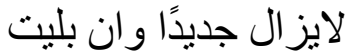

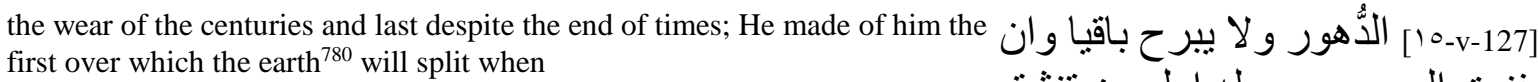

771 Koran 9:128: "Now hath come unto you an Apostle from amongst yourselves: it grieves him that ye perish: ardently anxious is he over you: to the believers is he most kind and merciful".

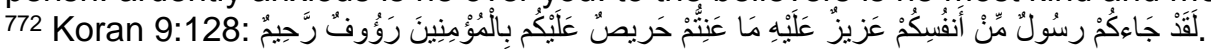

773 Koran 40:19.

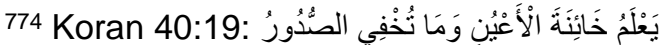

775 Koran 10:25: "The fools among the people will say" 'What hath turned them from the Qibla?' Say: 'To God belong both East and West: He guideth whom He will to a way that is straight."

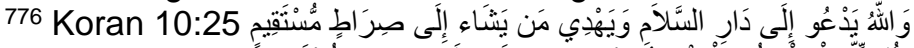

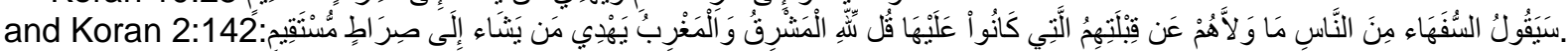
777 Koran 42:53.

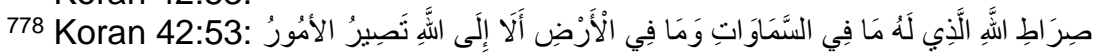

779 'Azzāwī: المرسنّ.

780 Reference to hadīth transmitted by Muslim in the Sharh d'al-Nawāwī, Kitāb al-faḍāil, bāb tafợil nabiyyinā 'alā jamī' al-khalq (Muslim, Șahịh, t. 15, p. 39, n 5899).

781 'Azzāwī: عليه.

782 Reference to hadīth transmitted by Muslim in the Sharḥ d'al-Nawāwī, Kitāb al-faḍā'il, bāb tafọ̄il nabiyyinā ‘alā jamī‘ al-khalq (Muslim, Șahīh, t. 15, p. 39, n 5899): أنا سيد ولد آدم يوم القيامة و أول من ينشق عنه القبر 
the tombs are scattered, ${ }^{783}$ the first intercessor whose intercession ${ }^{784}$ will be accepted when the people will be brought together on a single rug the day of the

universal resurrection; and on his family and companions, virtuous and generous, who made the moon shine, from the first to the last quarter,

in the sky of Islam and whose right hands received the keys to the vast countries and the metropolises,

near and far; they received in abundance the rewards and prizes for their struggle $(j i h \bar{a} d)$ on the path of God and the defense

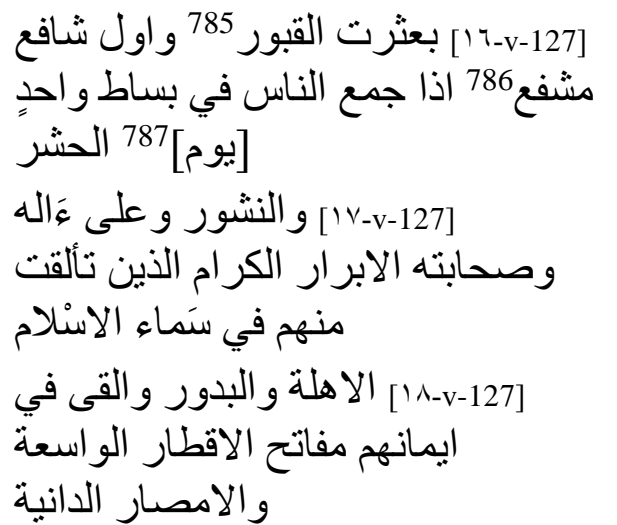

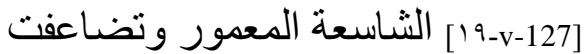
لهُم بالِجهادِ في سبيل الله و الذب عن ونه دينه

of His religion; the paths and fields lowered themselves to allow them to cross over to the enemies of the regions

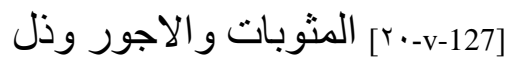

$$
\begin{aligned}
& \text { لاجتيابهم للاغداء من قو اصــ } \\
& \text { النو احه و الارجاء }
\end{aligned}
$$

and faraway lands. Thanks to their strength of will, neither the deserts nor the seas kept them from seizing

$$
\begin{aligned}
& \text { [ [الموطؤُ و المعبور فما عاقتهم } \\
& \text { عن الاخذ بناصيته } 788 \text { مر امهم و البرٍّ }
\end{aligned}
$$

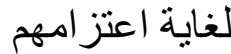

their desire and well-being. May the imām be approved who accomplishes the plan of God on High (al-qā'im bi-amri Llähi), who calls unto himself with a resolution

untroubled by tepidity, with a zeal that proceeds straight into the essence of God without turning back until the light shines,

such guidance! that straying be erased to avoid iniquity, that the lights of the truth rise [in the sky] to never disappear nor

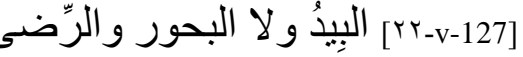

$$
\begin{aligned}
& \text { عن الامام القآحم بادْر الله تعلى و الداعِى لـى }
\end{aligned}
$$

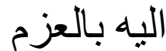

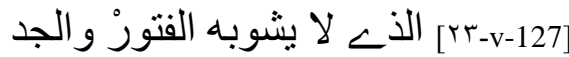

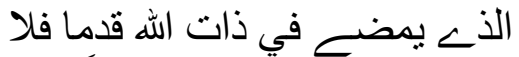

$$
\begin{aligned}
& \text { يَحْور حتى أَثرق }
\end{aligned}
$$

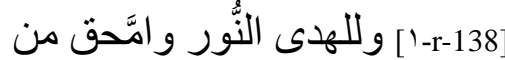

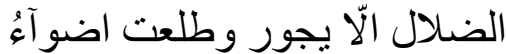

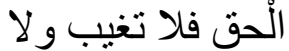

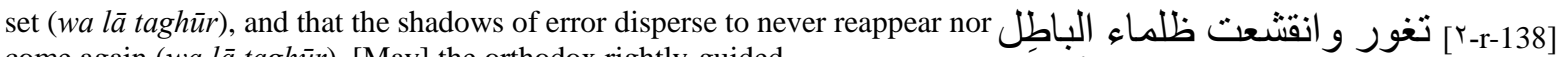
come again (wa la taghür). [May] the orthodox rightly-guided

783 See Koran 100:9: "when that which is in the graves is scattered abroad".

784 Hadīth by Muslim with al-Nawāwī's commentary, Kitāb al-faḍ̄àil, bāb tafợil nabiyyi-nā 'alā jamī' alkhalq (Muslim, Șahịḥ, t. 15, p. 39, n 5899): anna sayyidu waladi Ādāma yawma al-qiyāma wa awwalu man yunshaqqu 'an-hu al-qabru wa awwalu shāfi' in wa awalu mushaffa'

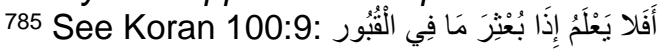

786 Hadīth by Muslim with al-Nawāwī's commentary, Kitāb al-faḍāil, bāb tafợil nabiyyi-nā 'alā jamī' alkhalq (Muslim, Șaḥịh, t. 15, p. 39, n 5899): أنا سيد ولد آدم يوم القيامة و أول من ينشق عنه القبر

787 Addition by 'Azzāwī.

788 'Azzāwī: بناصية.

من النجد و الغور و هما ضدّان 787. 
caliphs [be approved], whose victorious emblems and unfurled banners covered the East and the West. Security was assured

to [their] subjects by their justice and to the borders by their protection. They found in the exultation of the name of the faith and in the destruction of the worshipers

of the cross memorable satisfaction ( ghan $\bar{a}$ ') and immemorial praise. They protected the honor and well-being of Islam,

but not of the ravishers who stole the souls of the impious like birds of prey (al-șuqūr) with fish (banāt al-mā'). May He grant our lord

Prince al-Ṭāhir (“the Pure”) [Abū] Ibrāhīm ${ }^{790}$ double approval that will multiply visits to his pure (al-țāhir)

$$
\begin{aligned}
& \text { ["r-r-138] المهُتدين الذين طبق الخافقين } \\
& \text { شعار هم المنصور ولو اؤهم المنشور } \\
& \text { و امنت }
\end{aligned}
$$

[-r-138-re بعدالتهم الر عايا وبحمايتهم

الثغور وكان لهم في اعلاء كلمة

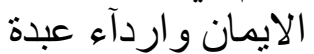

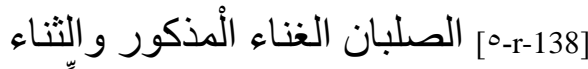
الماثور وحاطو ا ما للاسلام من الأِّمَار المداء

بالْحُماة

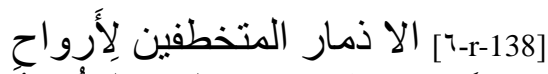

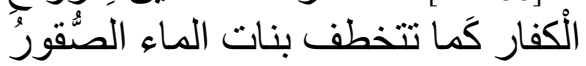

و عن سَبدنا

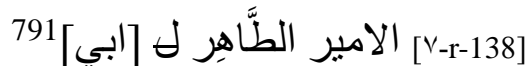

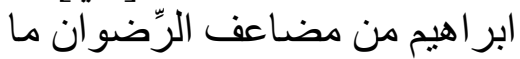

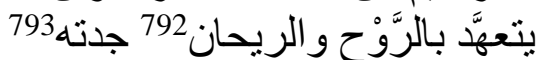

tomb bringing rest and satisfaction ${ }^{794}$ and will allow increasing shares of grace الطاهر ويزور ويتجدَّد لديْه بـانه and pardon to be abundantly renewed in his presence; and he will

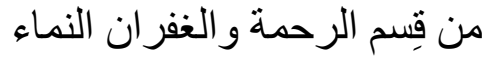

و الوفور ويكون

deserve this generous reward by his blessed and laudable efforts to bind himself to knowledge and work, That [That which is agreeable] will manifest

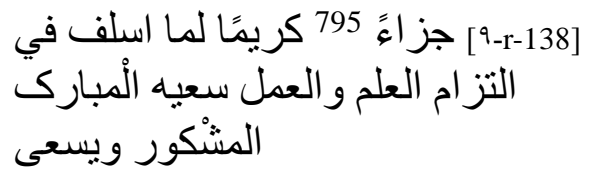

790 This is the father of the caliph al-Murtaḍá, the uterine brother of Ya qūb al-Manșūr. He was the governor of Granada, then Seville under al-Nāșir, the he received the government of Fez in 610/12131214 and was defeated by the Banū Marīn during one of their earliest attacks.

791 Addition by 'Azzāwī.

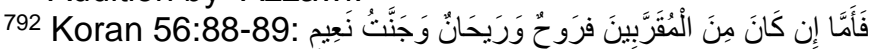

793 T prononciation of th: jadatha-hu: "his grave".

${ }^{794}$ Koran 56:88-89: "Thus, then, if he be of those Nearest to God, [there is for him] rest and satisfaction, and a garden of delights." The term rayhān, sweet-smelling plants, is used as an indication in the verse of satisfaction and delight. The use of both terms in the taqdim, of rawh et rayhān, assimilates the tomb in question with Paradise through a phonetic and graphic play on jadatha-hu or jadata-hu, written and pronounced almost like the Koranic jannatu (Paradise) coranique: وجنة and وجنت

795 'Azzāwī: $\mid$ s 1 ج. 
itself like light between his hands, the day his prevalent book is placed in his right hand ${ }^{796}$ and when the angels ${ }^{797}$ will welcome him, if God

on High wills it, with gifts of great reward foreseen at God's side for he who has prepared himself and has lain up those treasures.

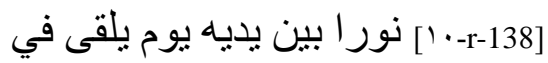
يمناهما798 كتابه المنشور 799 و تتنلقاه

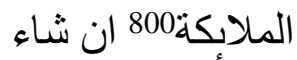

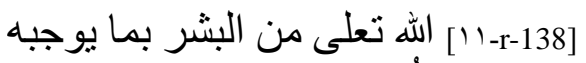

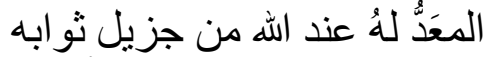
و المذْخور

[Y-r-138]

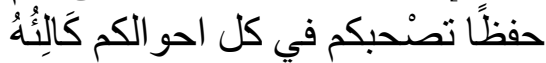
و كَاقله

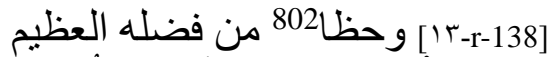

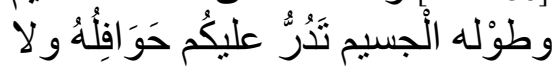

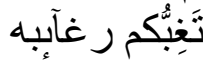

and a well-being that, by His illustrious favor and His immense power, spills over you in abundant streams, and never deprives you

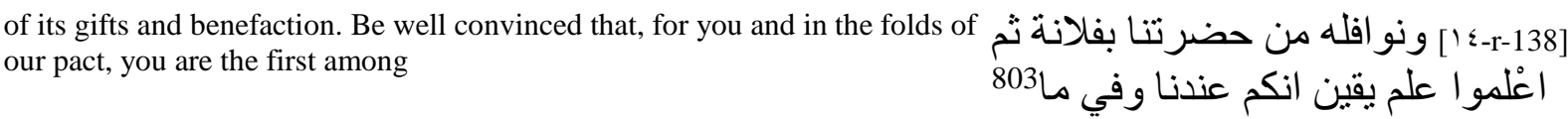

طوينا عقدنا

the faithful familiars, ranked among the loyal and sincere and marked by the sign

$$
\begin{aligned}
& \text { [10-r-138- في الاوليآه الخلصـاء }
\end{aligned}
$$

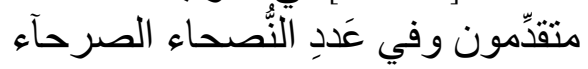

$$
\begin{aligned}
& \text { منتظمون وبشيم }
\end{aligned}
$$

of frankness and faithfulness. You have distinguished yourselves in welcoming our cause with the greatest of haste (bi-maziyyat al-sabaq), in answering it you have taken

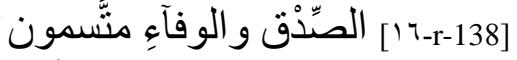

$$
\begin{aligned}
& \text { تميزتم في تلبية دعوتنا بَمزية السَّبق } \\
& \text { وسَلْكتم }
\end{aligned}
$$

the straightest road and your sincere feelings for it were pure of all vice and fault. This is why

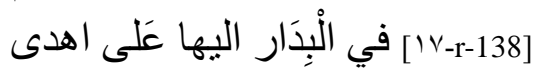

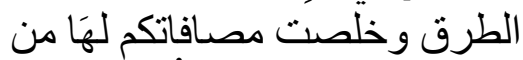

$$
\begin{aligned}
& \text { الثُوِّب8048 و المذْق لذلكم } 805
\end{aligned}
$$

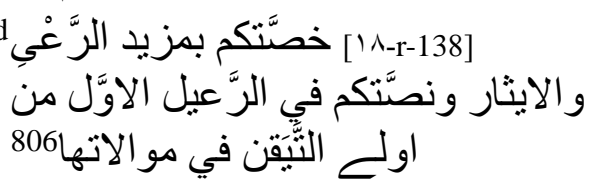

he has granted you a special supplement of care and predilection, he has placed you in the first division of those who are assured, in the deepest part of themselves, of his protecting

796 Koranic reformulation with bi-aymāni-him (their right) which becomes bi-yumnā-huma (their right hand [of them both]), see Koran 57:12: "One day shalt thou see the believing men and the believing women-how their light runs forward before them and by their right hands" and Koran 66:8: "Their light will run forward before them and by their right hands".

797 Koran 21:103: "The great terror will bring them no grief: but the angels will meet them [with mutual greetings]: 'This is you day-(the day) that ye were promised".

798 Koranic reformulation with bi-aymāni-him (their right) which becomes bi-yumnā-huma (their right

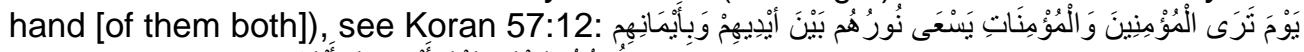

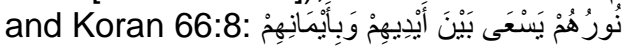

799 'Azzāwī: المنثور.

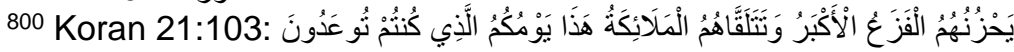

801 'Azzāwī proposes Marrakesh.

802 'Azzāwī: وحفظا.

803 'Azzāwī: فيما.

804 'Azzāwī: الثَّون.

805 'Azzāwī: لذالكو.

806 'Azzāwī: موالاتنا. 
alliance (muwālāti-hā), he has judged you to be close despite the distance $\mathrm{e}^{807}$ and length of the journey, he has not strayed from

this point of view in taking care for your flanks and watching over your paths and, in helping you to accomplish

your hopes and satisfy your needs, he has not distanced himself from the choices (al-ikhtyār) and the rewards (al-baqiyya) owed to you (mäla-kum). May God on High give you easy access to [19-r-138]

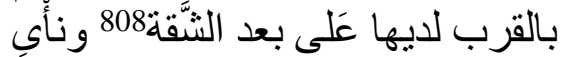
المز ار ولم تعدل في

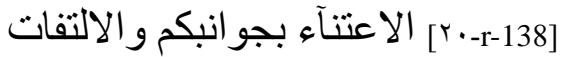

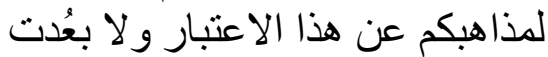
لكم في الاسعاف

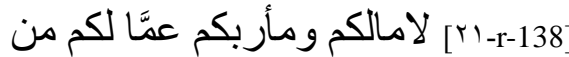

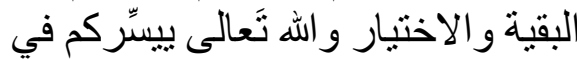

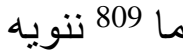

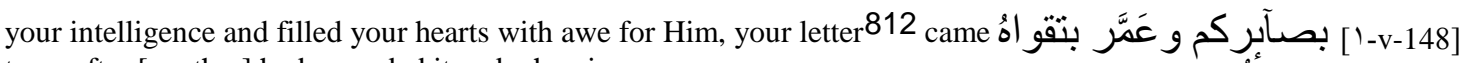
to us after [another] had preceded it and wherein you

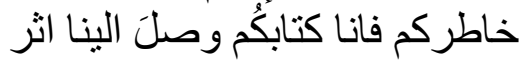

كتاب منكم تقدَّمه تذكرون

evoke what you have undertaken to integrate and come together on the path of community (silk al-jamā'a), and wherein you confirm having been the first to hasten

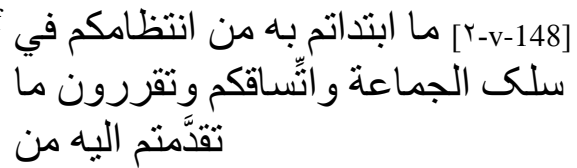

God on High to be the ally

of this cause. All that - May God on High exalt your worth - is an$$
\text { imperishable (la yulă ) treasure (mar i } 816 \text {, supported as much as possible }
$$

$$
\begin{aligned}
& \text { bliss (al-yusrá) through our intentions for you and the great care }{ }^{810} \text { we extend } \\
& \text { on your behalf, and may He cause you to know His grace by the priority that } \\
& \text { we accord }
\end{aligned}
$$


through practice, protection and watchfulness. God on High did not want to turn you away from our nature (...)

to keep the pacts of those concerned, to ignore a primacy that none would contest you. On the contrary,

with us you rejoice in all that God - May He be exalted and magnified requires us to provide for his faithful whose care he has charged us with, and you receive

from us all the solicitude possible with its instructions. Did we neglect, when, on meeting the messenger who invited you

to the gathering (al-tawfiq), you responded favorably, and when you did not weaken when he asked you to walk on the exemplary road, to eliminate injustices

that still blocked your ears and the innovations your land was unable to exorcize

during the previous period? 818 We have ordered that the traces of those unjust decrees be rubbed out and erased and we have distinguished and determined the texts that do

not tolerate the interpretation $\left(t a^{\prime} w \bar{l} l\right)$ to remove their ambiguity. Today, we have wiped out through justice that which [0-v-148] و الرَّعْي و اللَّحظظ بما بسنتطاع

ابى الله تعلى ان بعدل فيكم عن سجيتنا

817 (...)

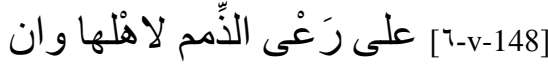

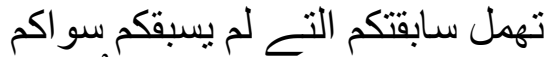

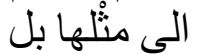

[ انتم موفون لدينا اتم ما لله عز ع-v-148] وجل علينا ان نوفيه لمن استر عانا من لن انس عباده و منلقون

[^-v-148] منا بكُل ما في الامكان من

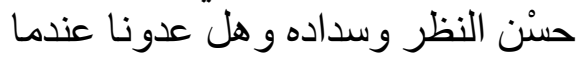

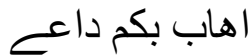

[9-v-148]

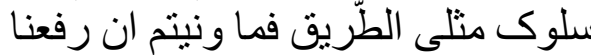
عنكم المظالم

[-1-v-148] التخ لم تزل الاذان منها تستك و المحدثات التح كانت البلاد في المدة السَّالفة

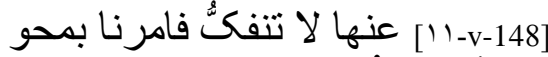
تلكَ الرُّسوم الْجآرِرة وطمْسها وصدعْنا

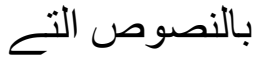

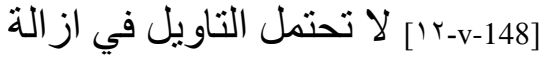
لبسها و اعدمنا بالعدل في البوزم مـا كان موجوداً في 819 الجور مالي

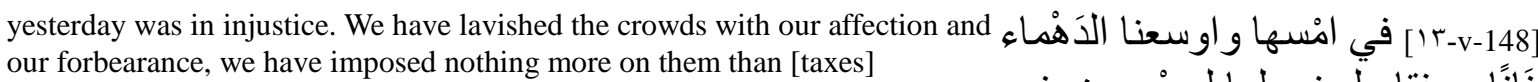

$$
\text { حَنَانًا ورفقا ولم نحملها لعبْْ من غير الْ الْ اجبات }
$$

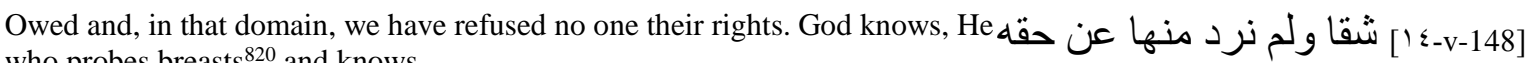
who probes breasts ${ }^{820}$ and knows

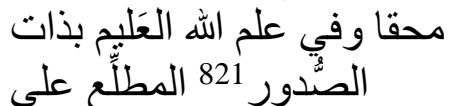

what conscience hides in its folds and what it lays out, that we thus wanted, with the virtuous plans and measures

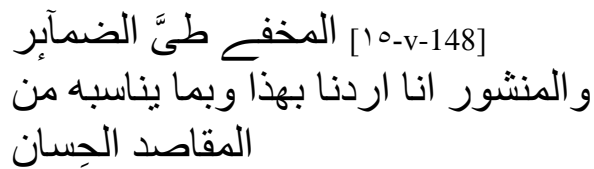

817 Word erased.

818 Reference to the time when Ceuta was under Hafsid rule, before al- 'Azafi's revolt.

819 'Azzāwī: من.

820 Koran 3:119: "God knoweth well all the secrets of the heart."

821 Koran 3:119: إنَّ الله عَلِيمُ بَذَاتِ الصنُُّورِ 
based on justice and benevolence ${ }^{822}$ it implies, to render unto Him that to which $\mathrm{He}$ is entitled in Creation - May His face be exalted -

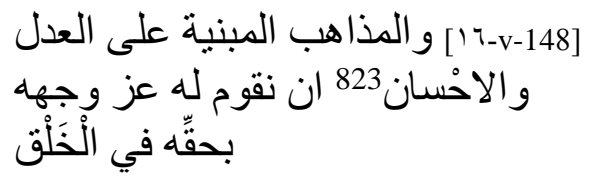

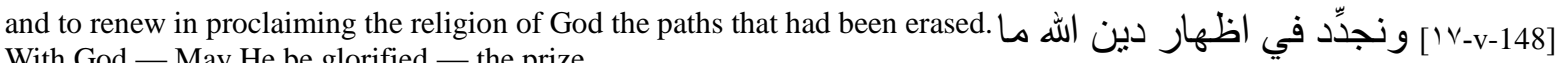
With God - May He be glorified — the prize عفا من الطرق و عند الله سبحانه في ذللكَ الْجز آَّاء

and the reward [are found]. To Him — May His face be exalted — we come back and return, and in His help and His orders rightful bearing bears its fruits.

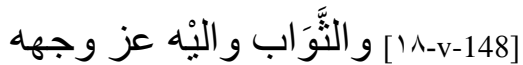

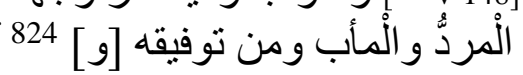

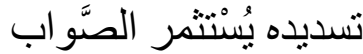

There is no master but Him. As for your remarks concerning the person we named as governor among you and what happened (...),

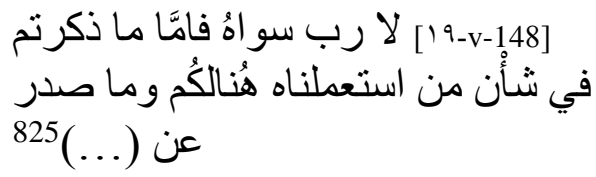

first of all, you know that we never name a governor among you without your having expressed your wishes on many occasions

[ب.-v-148]

و البا لثخل عِندكم حتى تكررث في

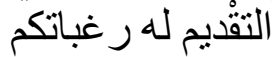

and without your demands following on each other to hasten it. Your two emissaries $^{826}$, with the missives they brought us, pushed

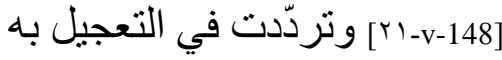

طلباتكم واستحثنا في ذلك خطيباكم

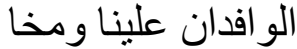

us to this, we have thus designated, ceding to your insistent request (is ' $a f^{a n} l a-$ kum), someone who we are sure has the qualities needed for that which we judged him worthy, someone whom we have judged competent for the charge we have

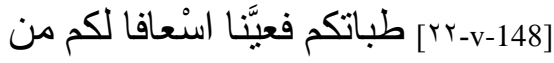

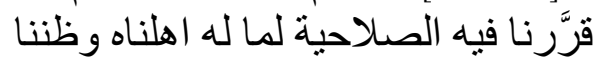
به الاضطنلاه

commended to him. We have impelled him to cling to justice and to privilege the law in all for which we have named him governor;

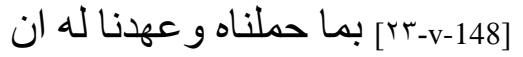

يلتزم العدل ويوثر الحق في كلّ ما فيه

استعملناه و الذى كان

[the duty] that we owed to you to make the best choice and the best selection, we have acquitted ourselves of it. And in our efforts for you

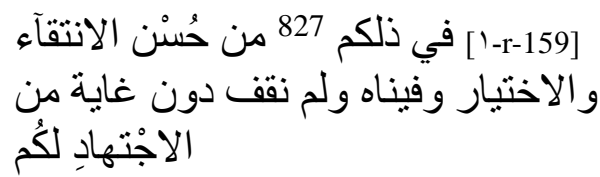

and your land we did not stop until we achieved the impossible for what we had planned and desired. We do not know ${ }^{828}$ that which is intimate (damá 'ir) and hidden (bawātin).

[r-159-r-r] و لقطر كم في ما829 اعتمدناه

من ذاللكَ830 وتوخيناهُ ولبس البيا

علم 831 البو اطن و الضمآدر

822 Reference to Koran 16:90: "God commands justice, the doing of good..." (inna Llāha ya'muru bi-I'adli wa-l-ihsāni).

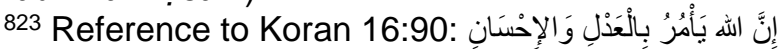

824 Addition by 'Azzāwī.

825 Two words erased.

${ }^{826}$ Detail taken from the letter from al- 'Azafī (al-Ghāfiqī al-Qabtūrī, Rasāill dīwāniyya min Sabta, 111).

827 'Azzāwī: ذالك..

${ }^{828}$ Evocation of Koran 12:81: "We bear witness only to what we know."

829 'Azzāwī: فيما.

830 'Azzāwī: ذلك.

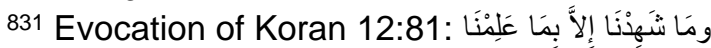




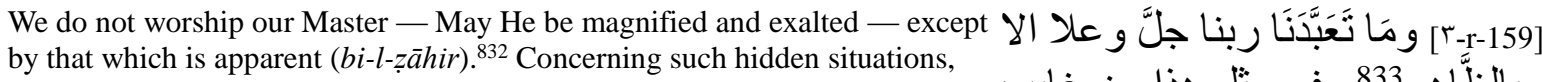
our prophet

— Peace be upon him — said: "I was not sent to penetrate the hearts of men." ${ }^{834}$ We do not admonish you ${ }^{835}$ for the remarks you made about

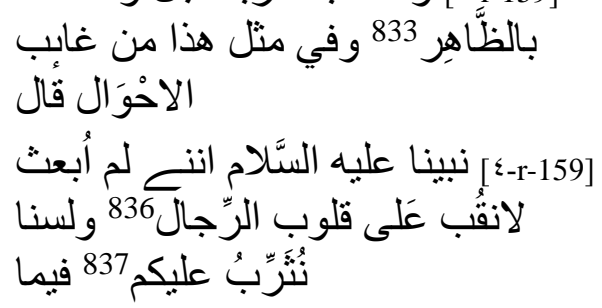

matters you noticed among them, nor do we reproach you your praise for their inefficiency in

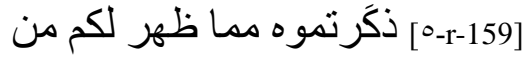

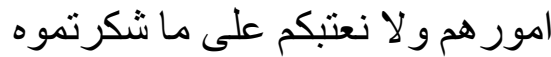

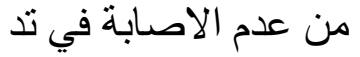

administration, for name him in we name governor over you and over our other subjects - May God defend them -

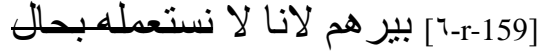

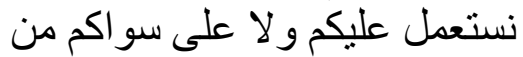

الر عايا حاطهم الله

only those [persons] whose behavior they agree with and whose excellent intentions they follow. He who the subjects detested,

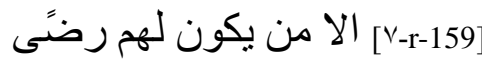

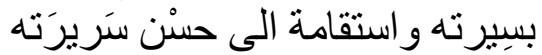

و من كر هته الرَّعية

we would never name governor among them and we prohibit him access among them by not confirming [his charge] thus acting according

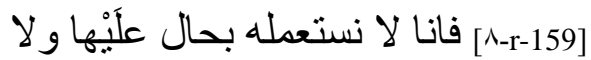
نوجده بالاقر ار فيهم سبيلاً اليها عملا علان في ذَللكَ

to the law that God - May He be exalted and magnified — imposed on the shepherds of [the flock] for which they were responsible and taking the paths of justice

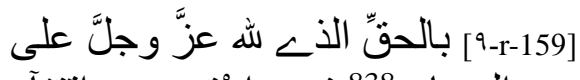

الر عات838 فيمن اسْتر عوه ور اقتفآه

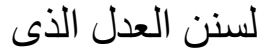

followed and taken by the orthodox caliphs. As for the words attributed to the people

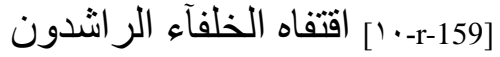

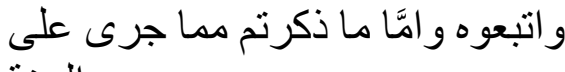

السنة

of the governors' house of which you spoke, [we know] no sane man who could repeat them and no one knows who pronounced them; it would have been so much better had you neither

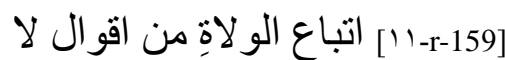

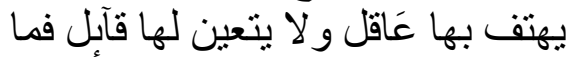

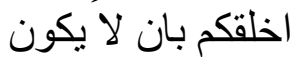

832 Evocation of an athar mu 'allaq attributed to 'Umar and reported by Bukhārī, Sahịhh, t. 3, 169, n 2 641: ma ta'abadda-nā rabbu-nā illā bi-l-zawāhir.

${ }^{833}$ Evocation of an athar mu 'allaq attributed to 'Umar and reported by Bukhārī, Șaḥīh, t. 3, 169, n 2 641:

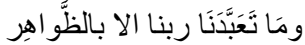

834 Hadīth: Ibn Hanbal, Musnad, t. 10, 14, n 10950 ; Muslim, Șaḥịn, t. 7, 162, n² 449, Kitāb al-zakāt, bāb dhikr al-khawārij ; al-Bukhārī, Șaḥịh, n 3344.

835 Evocation of Koran 12:92: "This day let no reproach be (cast) on you."

836 Hadīth: Ibn Hanbal, Musnad, t. 10, 14, n 10950 ; Muslim, Șaḥịn, t. 7, 162, n² 449, Kitāb al-zakāt, bāb dhikr al-khawārij ; al-Bukhārī, Șahīh, nº 3 344:

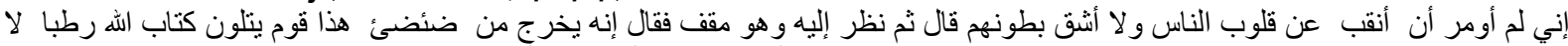

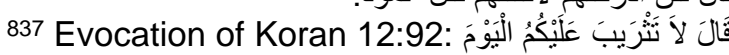

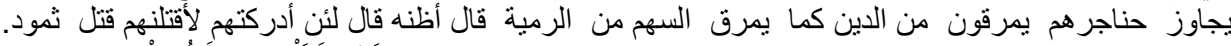

838 'Azzāwī: الر عاة. 
let them influence your minds nor produce any change whatsoever in your souls, since such words

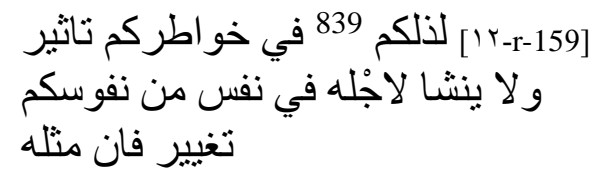

should not be heard. Such things are far from you! That does not correspond to what we know of your excellent intentions in regards to obedience. How [is that possible?]

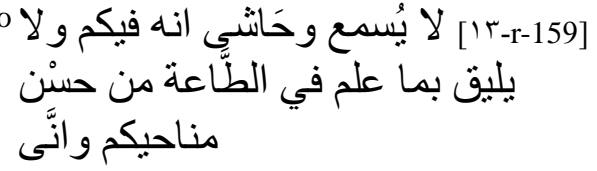

considering that you distinguished yourselves with real and sincere friendship that led to the signature of pacts, that your

[2-r-159-2]

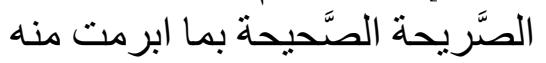

المعاقد وتتز هنم

loyalty for our cause kept you far from all accusations and all critiques, and that the demands

[10-159-10 في المناصحة لدعْوتنا عن كُل ما بنقمه النَّاقم وينقده النَّاقد ونأَيتم

عن مو اقف و

of your intuitions and of your profound convictions placed you above all suspicion. The words of whoever says

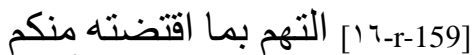

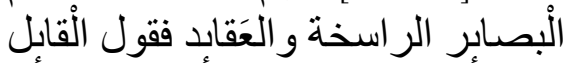

فيكم لما عدَا

otherwise about you are refused and the door for receiving them is absolutely closed; no matter who he may be,

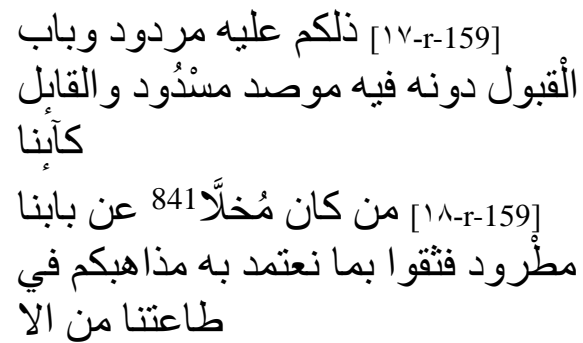

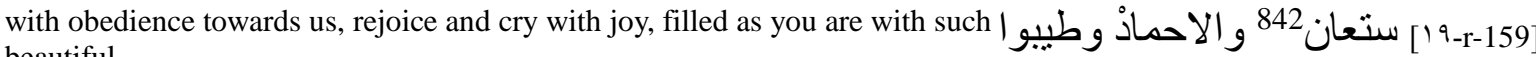
beautiful

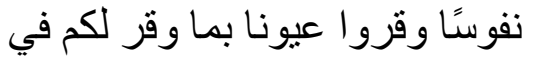
النفس من جميل

Conviction. Busy yourselves with matters useful to you in a way that will benefit you in this life and the next.

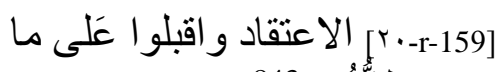
يعينكم من الشَُُّونُ 843 اقبالا ينفعكم في

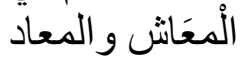

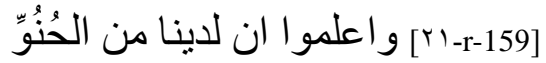

Know that we have affection for you, the desire to obtain happiness for you and to distance from you all harm and that we will never renounce

عليكم وار ادة الخير لكم ودفع المضار

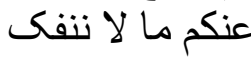

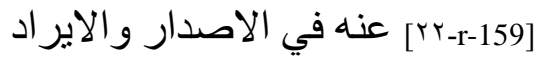

وما نتخو لكم منه باوفى ما نتخول بـ الاهيه

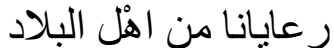

839 'Azzāwī: لذالكم.

840 'Azzāwī: المو الاة:

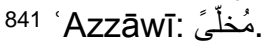

842 'Azzāwī proposes الاستخارة.

843 'Azzāwī: الثؤون. 
God is the one who favors virtue and righteousness and He is the one who offers us support and help in exercising our powers.

As for that which you recalled concerning the declaration of the two

"(religious) brothers" (ifrayriyyān $)^{844}$, whom you reported as having arrived in your land

— May God protect it - from Seville — May God return it [to Islam] — to join with the Christians who are there

with you, concerning matters about which they were interviewed in Our presence - May God watch over it - how could such a hideous and reprehensible lie

penetrate the ears of Muslims as reasonable as yourselves? What a marvel to hear the remarks of impious enemies

who "will not fail to corrupt you. They only desire your ruin: rank hatred has already appeared from

their mouths: what their hearts conceal is far worse!" ${ }^{\prime 847}$ We should have silenced this pure lie (safh $\left.h^{a n}\right)$

for it has no place in our letter and does not deserve to be there, and the mind should not take heed nor worry about the fact that the hate of the impious (alkafara) appears clearly therein,

but we decided to refute it according to what has been learned and confirmed

of your spirits; [so] we thought

844 This term also appears in official documents. The term refers to brethren in military orders or, as in the present case, monastic orders (probably Franciscans).

845 Illegible; 'Azzāwī also proposes الثغر: "border".

846 'Azzāwī:

847 Koran 3:118.

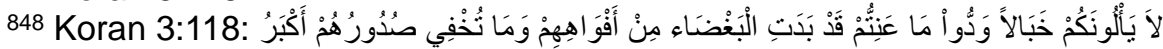

849 The last two letters are illegible. Proposal by 'Azzāwī.

850 'Azzāwī: لكن.

${ }^{851}$ Absent from 'Azzāwī.

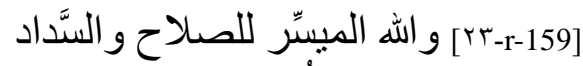

و المان علينا في كُل ما تولينا بالاعرانة و والانجاد

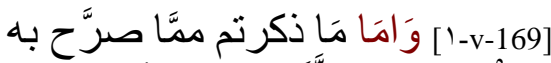

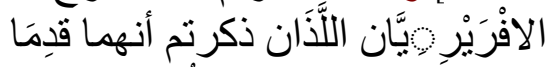

على ذلكُم القطر 845

[r-v-169] حماه الله من اشبيلية اعَادهَا الله

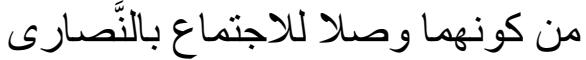
الذين

[\%-v-169] هنالكم في امور خوطبو ا بها

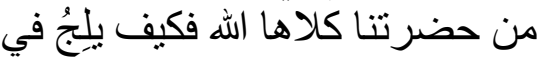
اسنْماع امثنالكم فئمي

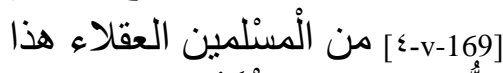

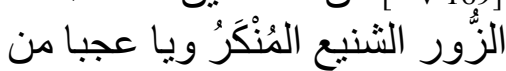

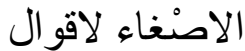

[0-v-169] كفرة الاعْدايَ الذّين لا يالونكم

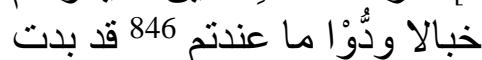
الْبغضآه من

[-7-169-7 افو اهم وما تخفح صدور هم أَكبر 848 وقد كُنَّا نضرب وهن عن هذا البهت الْبحت صفحا

فلا يورد في كتابنا وَلا يُذْكر

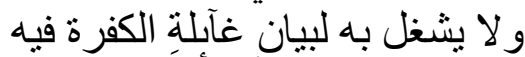

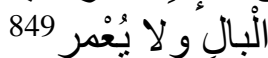

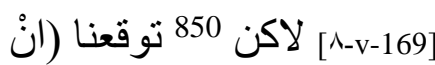

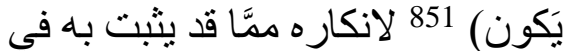
خو اطركم ويتقرَّر ور أَيْنا أَن

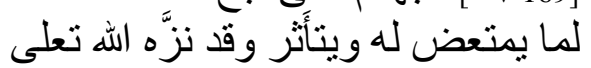
حضرة 


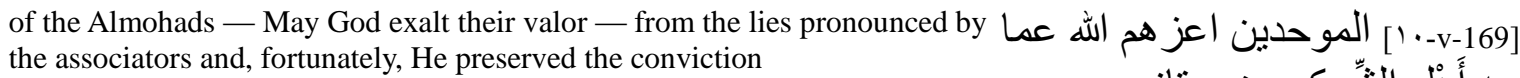

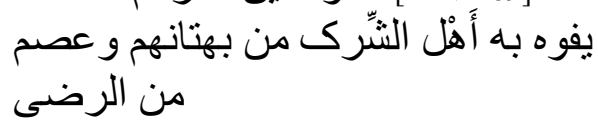

of their faith (= of the Almohads) from the lies [the associators] threw at them [For] God, behind them ${ }^{852}$, circles them from all parts and makes their evil ideas fall

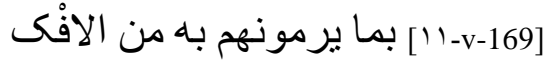

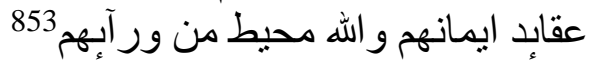

ومحيق بِّهم سور

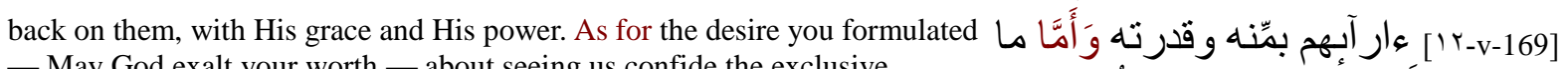
— May God exalt your worth — about seeing us confide the exclusive management of your interests and your taxes to Fulān

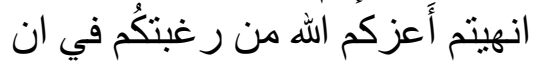
تفرد

— May God assure him radiancy and respect and may He continue to grant him his help in virtuous actions -

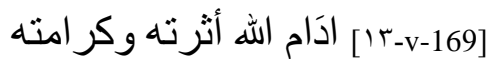
ووصل على الاعمال الصنّالحات اعانته النهاته

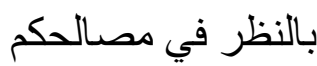

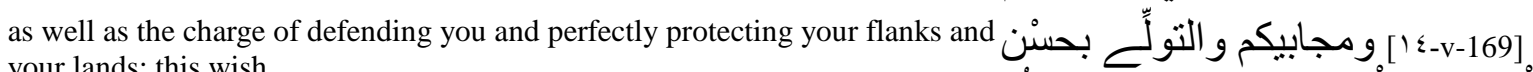
your lands; this wish

الْحياطة و الْحماية لجو انبكم ونو التيكُ

فقد و افقت

agrees with our choice and in no way contradicts — God on High knows it - غيتكم في ذلكى اختيارنا the high esteem we have for the nobility of the particular tie

ولم تعد علم الله تعالى ايثارنا لما له فئنا قديمًا وحديثاً 855

he has long had with us, for the sincere loyalty that distinguishes him in our friendship, and for the manner for which he, his ancestors,

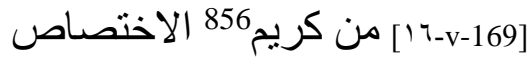

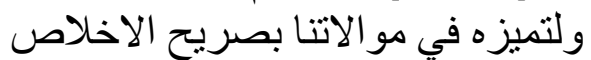
ولكونه بذاته وسلفه

his religion and his knowledge deserve pure and sincere affection. And had he not initially shown

reticence for this position, we would not have discarded [the idea] of commending [to him] the governorship of your land whose importance is crucial for us.

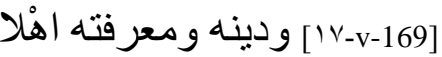

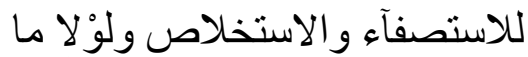

صدرر عنه أَََّلا

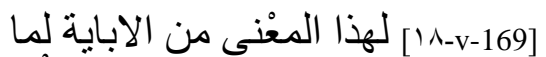
عدلنا عنه في ذلكم الْقطر المهم شأْنه لدينا بالو لاية

We have decided to entrust him completely with this position and we have placed in his hands that which before fell only under his watch

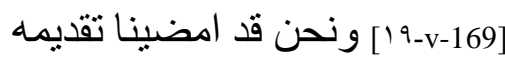

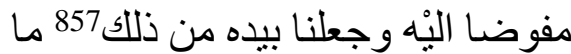

كان نظره قبل فيه

of [only] supervisory power. Indeed, those governors whom we named before were used to seeing

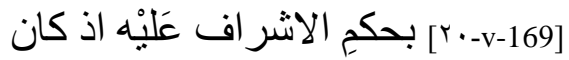

الو لاة المقدمون من قبلنا قبل مُهردًا

لهم ان لا يقطع معتود

852 Inversion from Koran 85:20: "But God doth encompass them from behind".

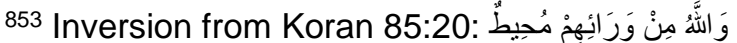

854 'Azzāwī corrects with أن ينفرد, but it is simpler to read أن نفرد. We thank Abdallah Cheikh-Moussa for this proposal.

855 Last three letters illegible, completed by 'Azzāwī.

856 'Azzāwī: كَر.

857 'Azzāwī: ذلكم. 
no matter decided without him and to consulting him for the decisions they made and carried out. From now on, we have placed

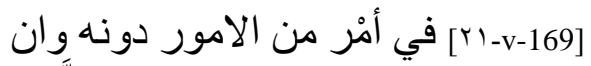

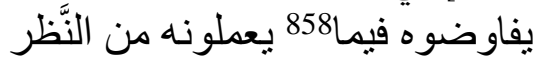

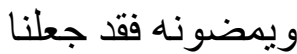

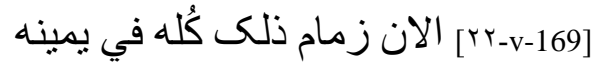

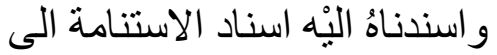

نصحه و الثقة860

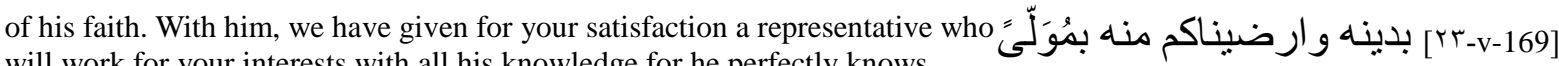
will work for your interests with all his knowledge for he perfectly knows - May God exalt his worth -

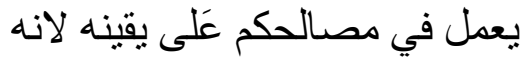
اعزه الله بحفظ

the details of your situation and of your affairs. He adds to his superior qualities (istiqlāli-hi) for which we are attached to him the argument that he grew up

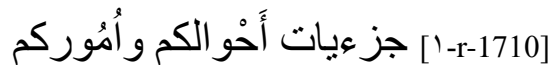

ويزيد الى استتقلاله بما نطنا بـه بصيرة

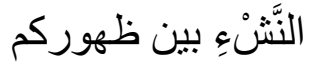

among you (...) the elite or the people. Welcome him with perfect submission, bring him pure and sincere affection,

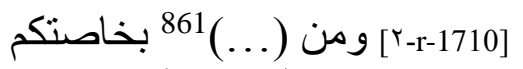

وجمهوركم فتلقوه بحسن ون انقبادكم

و امحضوه خالص ود دادكم

and help him in your affairs with your loyalty, your efforts and your zeal. It is right to take advantage in the exereise of his atthority (ireded)

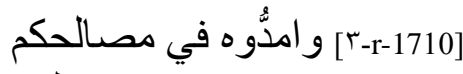

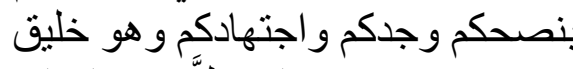

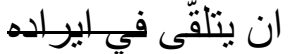

of the counsel we gave him to fear God on High with total submission and obedience, making it the target

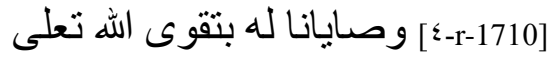

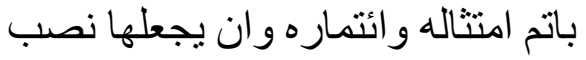

عن료

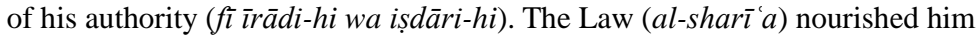
with its milk and raised him on its breast.

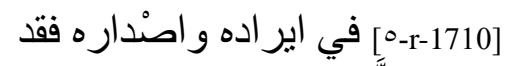

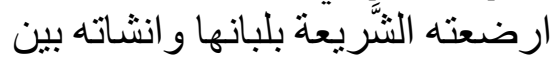
سحر ها ولبانها

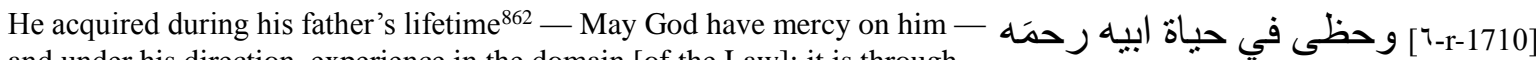
and under his direction, experience in the domain [of the Law]; it is through his power that he judges ${ }^{863}$

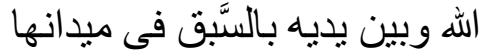

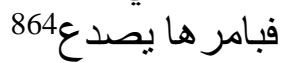

[V-r-1710]

تعالى وبدع و عهودنا برفع المظالم

واز الة المحدثات

and according to his decrees that he takes or leaves - If God on High wills it - and our promises to eliminate abuses and to cease innovations,

858 'Azzāwī: في ما.

859 Lit. "the bridal in his right [hand]".

860 Word unread by 'Azzāwī, deciphered by H. El Aallaoui.

861 Two words erased.

862 On the faqīh Abū l- 'Abbās al- 'Azafī, see the introduction by al-Ghāfiqī al-Qabtūrī, Rasā'il dīwāniyya

min Sabta, 15-17 and J. D. Latham, "al- 'Azafî", EI², t. 12, Supplement, 110-112.

863 Reversed evocation of Koran 15:94: "Therefore expound openly what thou art commanded".

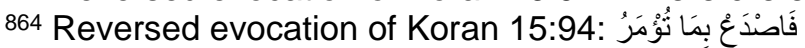


he knows them well (having seen and heard them) and all that we have explained to him concerning this, he perfectly understood. When our letter

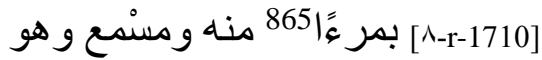

$$
\begin{aligned}
& \text { لما اوردناهُ منها قبلُ اوعى مسندع فاذا } \\
& \text { و افاكم كتا }
\end{aligned}
$$

comes to you, hasten to support him and help him in all that will improve your actions. Be

$$
\begin{aligned}
& \text { المعاضدة له و المسنَاعدة لما تحسن فيه }
\end{aligned}
$$

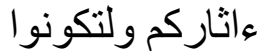

$$
\begin{aligned}
& \text { [م-1710-r-17 معه بذًا و احدة فيما } 866 \text { تامن } \\
& \text { عليْه ارجآؤكم و اقطار كم و لتعلمو ا انه وله } \\
& \text { لا بعنيكم من نظرنا }
\end{aligned}
$$

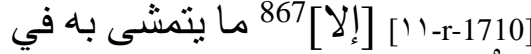

$$
\begin{aligned}
& \text { الْمصنالح اختيار كم ويصسان بتو البيه } \\
& \text { وتتاليه حماكم وذماركم ان شاء } \\
& \text { [ I Y-r-1710] الله تعلى و هو سبحانه يعلق } \\
& \text { بالتقوى ايمانكم ويصل عافيتكم ودعتكم } \\
& \text { و امانكم ولدم }
\end{aligned}
$$

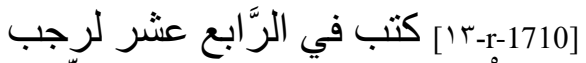

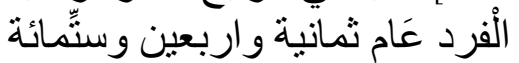

Taqdīm 7: Gubernatorial appointment ('āmil), with fiscal and military attributions ${ }^{868}$

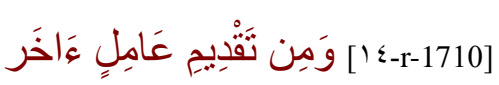

[Excerpt] from another appointment of a governor ( 'āmil)

This is what we have written you - May God have written for you a situation that improves, and actions, from beginning to end, that are based

$$
\begin{aligned}
& \text { [10-r-1710 ] موانا كتبناه كتب الله لكم }
\end{aligned}
$$

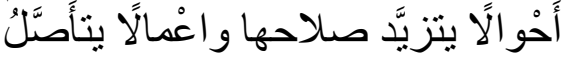

$$
\begin{aligned}
& \text { على التقوى ختمها }
\end{aligned}
$$

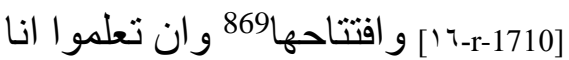

$$
\begin{aligned}
& \text { نتعَهدكم بالنظر الجميل ونستعمل فيكم } \\
& \text { من يجري مصالحكم }
\end{aligned}
$$

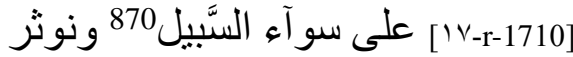

$$
\begin{aligned}
& \text { العمل بالعدل و الرفق في الكثير من }
\end{aligned}
$$

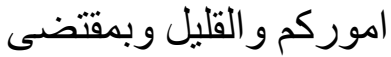

along the straight path. ${ }^{871}$ We prefer to call on justice ( $a d l$ ) and forbearance $($ rifq) in your affairs, large and small. As a result of

on the fear [of God] Know that we watch over you with benevolence, we appoint as governor over you people who lead your interests

\footnotetext{
865 'Azzāwī: بمرأى.

866 'Azzāwī: فيما:.

${ }^{867}$ Added by 'Azzāwī.

868 'Azzawī, NLA, t. 1, 427.

869 Evocation of a hadīth reported by Ibn Mājah, Sunan, 697, n 4199 and by Ibn Hibbān, Șahīh, t. 2, 51, n 339 and 340: إنما الأعمال بالخو اتيم (inna-mā l-a 'māl bi-l-khawātim).

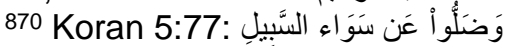

871 Koran 5:77: "strayed from the even Way" (sawā' al-sabīl).
} 
which, we have appointed ('ayyannā) Fulān - May God cause his radiance (athrata-hu) and generosity to endure (wașala) and may He continue (wālá) to help him (injāda-hu) and aid him (wa i'ānata-hu) - to watch over

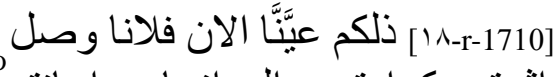
الله اثرته وكر امته وو الى انجاده و اعانته للنظر في

the economic matters (ashghāli-kum al-mașlahiyya) and tax questions (a māla-kum al-makhzaniyya) that concern you and to assure for you an administration true to straight paths. Among

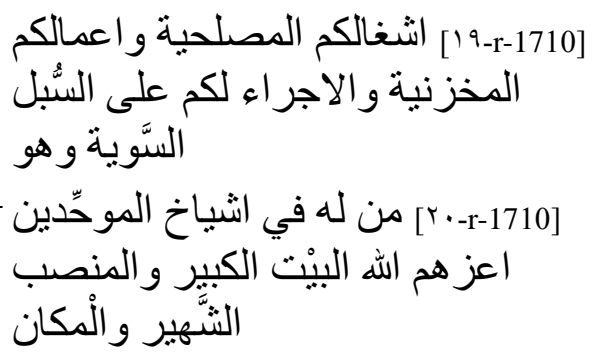

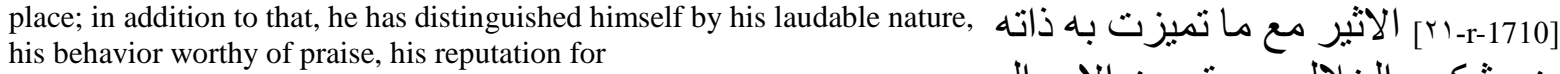

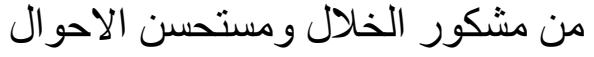

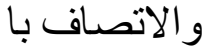

righteousness and temperance, and for having acquitted himself of all for which he has been named governor with competence and a sense for responsibility. Moreover,

we have counseled him to fear God, to carefully respect His plan and to commit himself to fear Him secretly and openly.

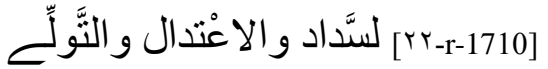

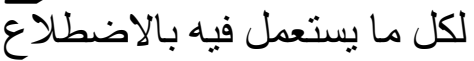

$$
\begin{aligned}
& \text { و الاستقلال وقد } \\
& \text { [ [-v-1810] اوصيناه مع ذللك بتقوى الله } \\
& \text { ومر اقبة امره و التز ام خثيته في سره } \\
& \text { وجهر }
\end{aligned}
$$

We have ordered him to take charge of your interests with great care and thoroughness, to manage the improvement of all your affairs

[r-v-1810] و امرناه ان بياثر مصالحكم

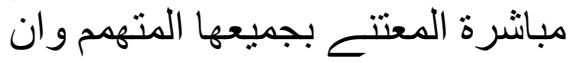
يتولى صلاح شُؤونكم

as a far-sighted man (al-mubirr), who excels in the arena ( $f i$ miḍmār) in leading the effort $(i j t i h \bar{a} d)^{872}$ and taking the lead, of gathering and conserving the surplus of your taxes,

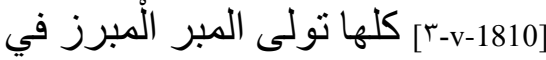

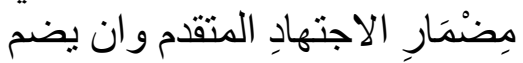

$$
\begin{aligned}
& \text { مر تفع مجباكم ويضبطه }
\end{aligned}
$$

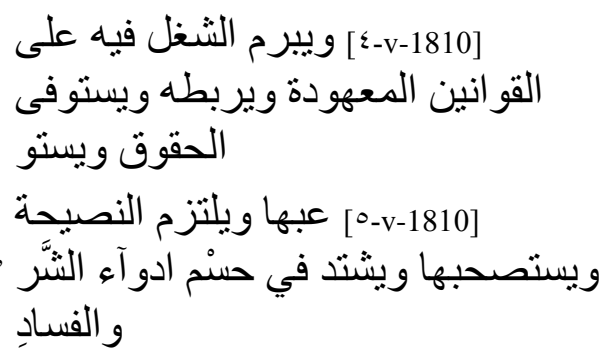

of exerting (yubrim) and consecrating (yarbut) his activity (al-shaghl) to that in accord with traditional rules (al-qawānìm al-ma 'hüda), of collecting and taking duties

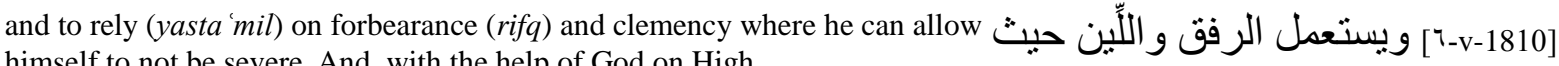
himself to not be severe. And, with the help of God on High,

he will attain these handsome objectives and will take the path of justice and well-doing in the charge we have commended to him in your

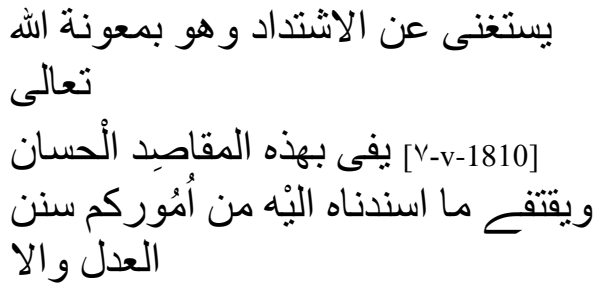

872 Equestrian comparison: mubarraz (who surpasses because he is put in front), or mubarriz (who is shown on the ring), miḍmār (arena, place where horses are trained). Therefore: "He leads men like horses." 
affairs. Thus, when he arrives among you, by the will of God on High, submi to him as you should, obey

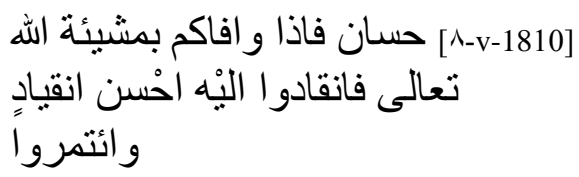

his desires for you by means of his authority (min iṣdār wa îra $\bar{a} d_{i n}$ ), completely trust in the duties he will

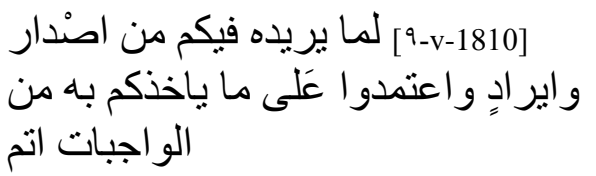

demand of you, and know that we honor you through the behavior of he who, with the grace of God, will rejoice you; you will find happiness (yumn) in this appointment at your head

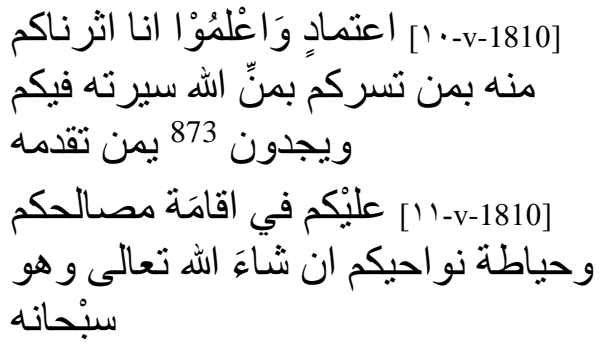

He will give well-being through this decision that we hope will restore your situation, and He will decide that which is best for you, in the

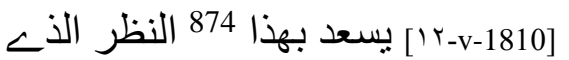

$$
\begin{aligned}
& \text { توخينا به تسديد احو الكم ويقضـــ لكم } \\
& \text { بالخيرة في عَا }
\end{aligned}
$$

immediate and in the future ( $f \grave{\imath}$ 'ăjili-kum wa ma'āli-kum). By His grace..

$$
\text { ['r-v-1810] جلكم ومآلكم بمنّه }
$$

Taqdīm 8: Gubernatorial appointment ('āmil), with fiscal and military attributions and the ḥisba $^{875}$

$$
\text { وَمِنْ عَاخَرْ فِي سَنَ }
$$

[Excerpt] from another that is similar
...May God have written for you the righteousness of which you will harvest the fruits now and in the future, and [His] uninterrupted protection
[1 [1-v-1810] كتب الله لكم استقامة تجنون ثمرتها في حالكم

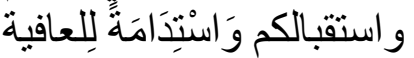
for the correct actions you will undertake with zeal.
Know that our benevolent watch extends over the

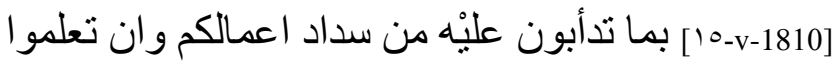 interests
ان النظر الجميل منا يتعهد مصالح

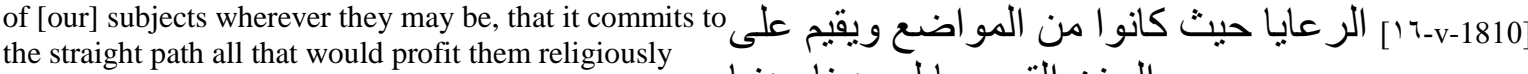$$
\text { السنن القويم ما لهم دينا ودنيا }
$$
and secularly and that it welcomes them with justice and the favor of this power under the expanse of its shadow and its extended

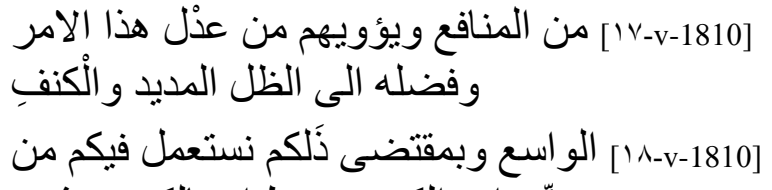

873 'Azzāwī corrects with تجدون.

874 Alif inserted between hā' and dhāl.

875 'Azzāwī, NLA, t. 1, 428. 'Azzāwī suggests this may be Sijilmāssa at the beginning of al-Mu'taḍid's, then under d'al-Murtadá (655-656/1257-1258), because the region does seem to be in rebellion against the Almohads, or perhaps Salé in 649/1251, with this appointment finalizing the city's return to the Almohad orbit.

876 Fi: among 


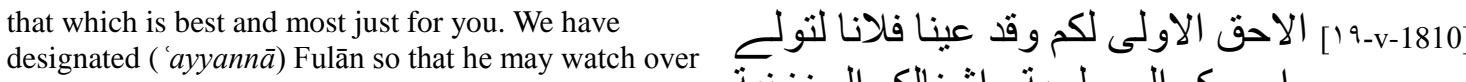
your economic problems (umūra-kum al-maṣlahiyya) and اموركم المصلحية و اشغالكم المخزنية

your tax matters (ashghāla-kum al-makhzaniyya)

after his seriousness and zeal manifested themselves in allor-1810] his actions and his exercise of the authority (ișāru-hu wa $\bar{i} r \bar{a} d u-h u)$ was in accordance with the straight path.

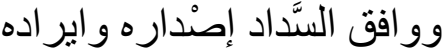

Moreover, we have advised him to fear God on High, to carefully respect His plan and to commit himself to fearing His (wrath) in secret

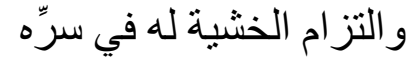

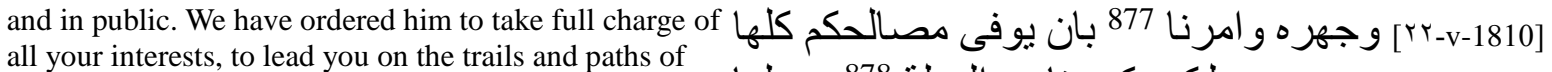
equity ( $m a$ 'dala),

to be severe in removing the plagues that are evil and corruption, to stop those who allow themselves to be seduced by distraction and those who compete

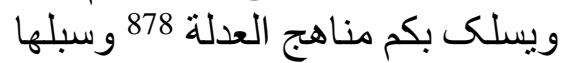

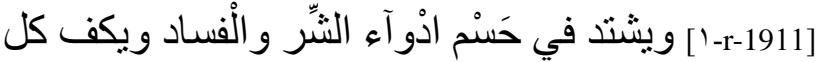
مسترسل في الغـ و مستشرف وست

[r-r-1911] الى العناد ويعامل باللين و الرفق كل من بادر

الى الانقياد ويلقى ما يطلب بـ به باله regarding all those who hasten to obey and to respond favorably

with assistant to what we ask of him in the name of the law. We have insisted that he collect and have discharged the taxes of the Treasury (wäjibāt

al-makhzaniyya), and that he demand payment of whomever owes it and extend all his efforts ${ }^{879}$

in their complete collection; [we have likewise insisted] that he act against injustice and that he abolish innovations (muhdathāt) by fully following

the orders we give to all those we employ. That he devote himself to rightful evidence in what he says and does, and distance himself

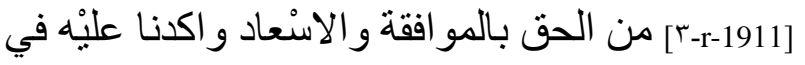

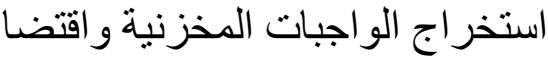

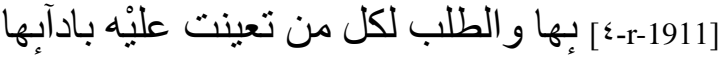

و التشمير عن ساعد الانتهاض في

[0-r-1911] استبعابها و استيفابها وان بجري في رفع المظالم

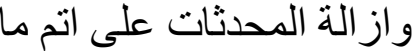

[7-r-1911] نامر بـه كل من نستُعله ويقف مع الحق

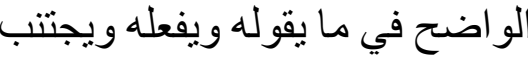

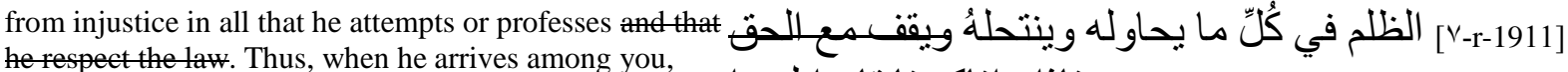
obey him and follow

his orders, hasten and hurry yourselves to collaborate with him, be [with him] like one hand united in the administration

of matters; as a result of which you will have only to praise and congratulate yourselves. Behind that, our watch will remain permanent in all

فاذا و افاكم فانقادو اله ورح

[^-r-1911] ئتمروا و استبقو الى التعاون معه وابتدروزا

وكونو ا بدا و احدة في تمشية

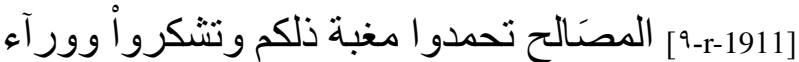

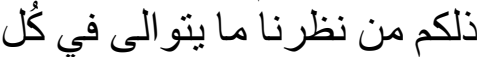

Circumstances and thanks to it you will discover the face of justice revealed to all, if God on High wills it. And He - May He be glorified (subhāna-hu) -

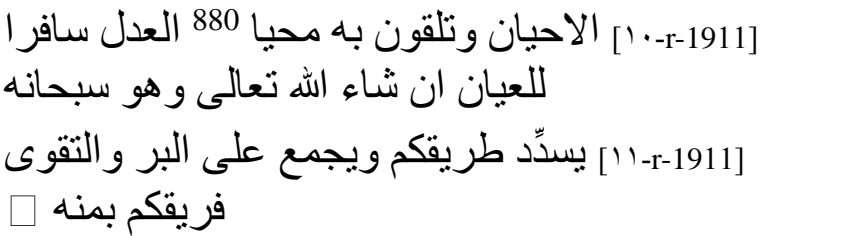

Taqdīm 9: Gubernatorial appointment (wālī or 'āmil), with fiscal and military attributions and

877 'Azzāwī corrects with ورامرناه.

878 'Azzāwī: المعدلة.

879 Lit. "roll up his sleeves".

880 'Azzāwī: مُحَيَّ.

881 Translation of farīqa-kum by "you" because the word is too vague to have precise meaning and it is used for the rhyme with tarīqa-kum. 


\section{the hisba. Revenue from taxes is destined for the defense of the Muslims ${ }^{882}$}

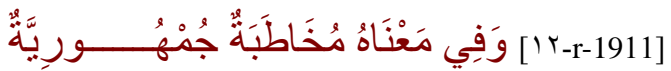

In the same sense, a public allocution

May God always assure them respect in the awe that He inspires in them and may He spread over them His favor and His mercy in abundance. May God have written for you

a healthy and just situation, and the hopes that ceaselessly accompany success. Know that we always extend

our watch over your land and its inhabitants so that the plains of their abodes be made smooth, their situation improved, their regions secure

and so that their desire to obtain Salvation be made possible. We thus seek to completely fulfill our duty to them to watch over them

and protect them, to do everything to eliminate and destroy dangerous places (makhāwif) to deliver our subjects from all worries so that they may pursue

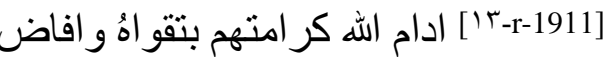

عَلْيْهم سو ابخ نعماه ور حماه كتب الله لكم

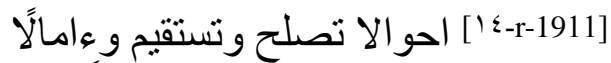

يصحبها النجح فلا تريم وان تعلمو النَّا نديم

[19-1911-10 النظر للبلادِ و اهُلها بما بمهد

حلالها ويحسِّن احْو الها ويؤمن ارجاََّها

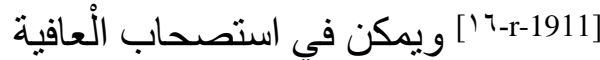

رجآءها قصدنا بذلكم أن نوفى حق كفالتها

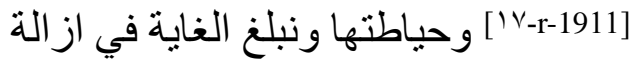

المخاوف عنها و اماطتها ونفرغ الر عابيا

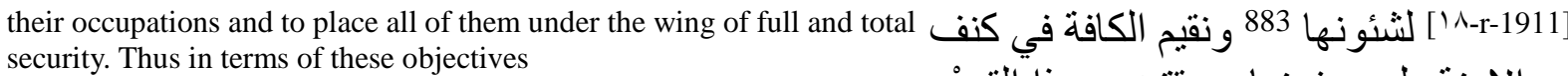

الامنة مله جفونها وبمقتضى هذا القصند

and the efforts we make for them, as well as the resources and riches that we spend,

[19-r-1911]

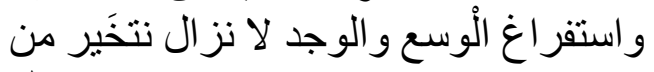

نستعمله

that we always choose the one we appoint as governor to organize and defend the land, the one that we judge worthy of assuring his watch and protection so that matters there

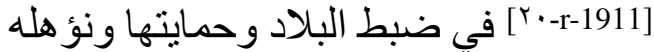

لحفظها ور عايتها لتجر هـ الامور فيها

are managed in accordance with the rules of its villages and that the important fortresses receive all they need to close all entries (bi-sidādi-

$h \bar{a})$. We implore His help in what we do - with the protection of God on High, by Whom alone is any action just [...]

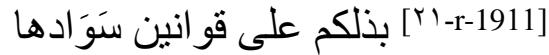

وتتتهى في المعاقل المههَّة الى انَمِّ ما يفي

بسدا

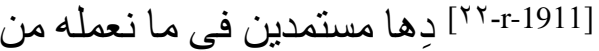

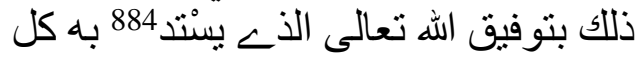

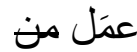

and opinion - we implore His assistance in accomplishing a great effort and feat in what we intend [to accomplish]. May God on High be,

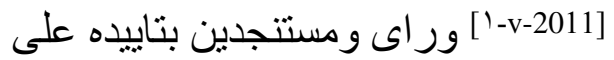

اجمل اثر في ما نعتمده و احسَن سعي وراله ولني

تعلى

for our administration, the Guarantor of help and assistance, the One we

[r-v-2011] الكفيل لادار تتا بالاعانة و الانجاد ask to guide us in undertaking and and exercising authority $(f i-l-i s d \bar{a} r$

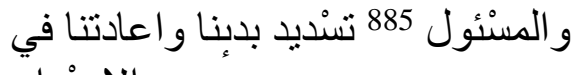

الاصندار

\footnotetext{
882 'Azzāwī, NLA, t. 1, 429-430.

883 'Azzāwī: لشؤونها.

884 In the sense of استقام:

885 'Azzāwī: المسؤول.
} 


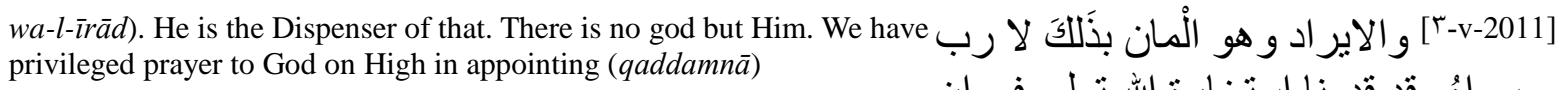

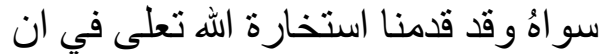
قدمنا

Fulān to take lead of all your economic affairs (ashghāli-kum almașlahiyya) and all of your tax matters (a'māli-kum al-makhzaniyya). $\mathrm{He}$ is held in high esteem

[ع-2011 ] لجميع اشغالكم المصلحية وكافة اعمالكم المخزنية فلانا و هو الجليل في المو by the Almohads. His spirit, judgment and opinion ${ }^{886}$ are sure. He was chosen to govern you because of his experience.

[0-v-2011 حِّدين مقداره و الاصبيل عقله ورايه و اعتباره المختار لتوليكم بما الَّى البه

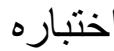

We have advised him to fear God on High, which is God's general recommendation to his servants, ${ }^{887}$ the useful treasure

[7-v-2011] [ قد وصيناهُ بتقوى الله تعلى وهىى وصية الله الجامعة للعباد 888 و الذخيرة

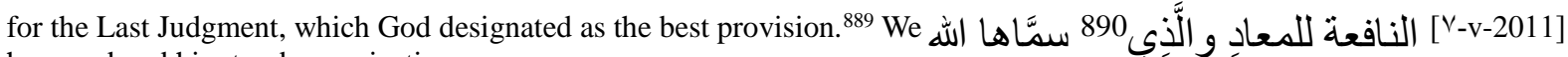
have ordered him to observe justice,

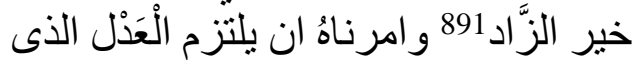
أمر

as God on High ordered, to employ all his will in totally collecting that which is due, to levy

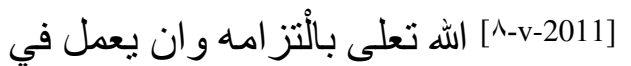

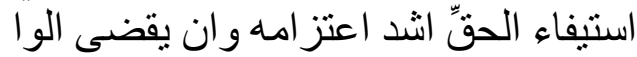

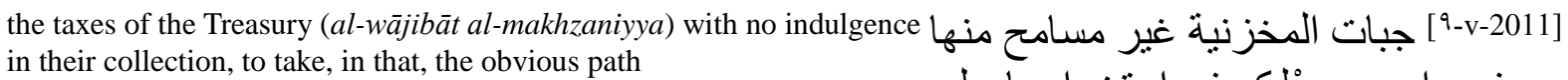

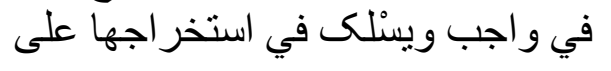
سنن

of zeal and effort. For they are destined to finance the interests and defense of Muslims, and will

$$
\begin{aligned}
& \text { [1-v-2011] من الجد و الاجتهادِ لاحب فانها } \\
& \text { لمصسالح الْمنلمين و الحماية لهم مرصدة } \\
& \text { وفي ما مات }
\end{aligned}
$$

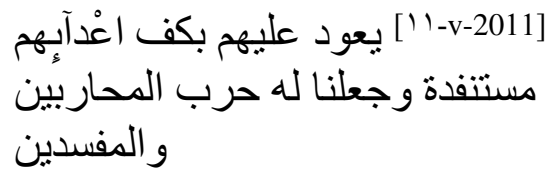

serve to pay to make their enemies disappear. We have enjoined him to combat enemies and troublemakers,

to punish rebels and outlaws, and to personally address whosoever strays from the clear and

[ [r-v-2011

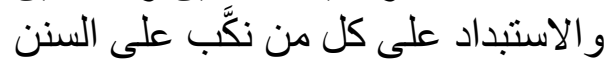

الو اضح

obvious path, and to be the champion of the necessary respect for the duties imposed by religion. We insisted that he

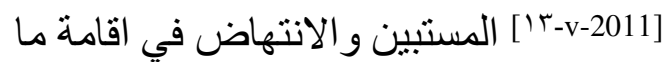

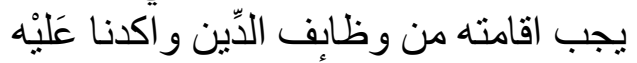

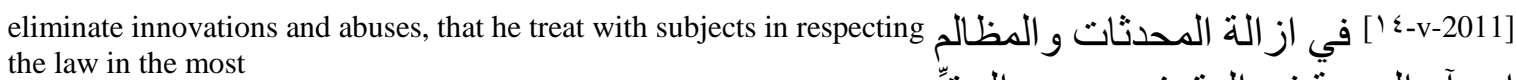

$$
\text { و اجر آء الر عيةة في الوقوف بهم مع الحقِّ الهُ أوضح }
$$

\footnotetext{
886 Inverse order.

${ }^{887}$ The wișāya refers to Koran 4:131: "Verily we have directed the People of the Book before you, and you (O Muslims) to fear God."

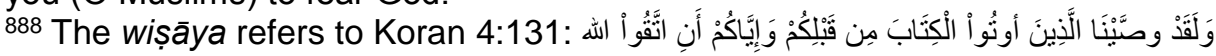

889 Koran 2:197: "The best of provisions is right conduct. So fear Me, o ye that are wise."

890 'Azzāwī: والتي.

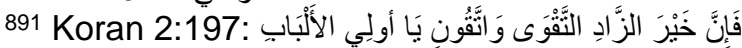


obvious way, that he eliminate any abuse brought before him, that he erase any blamable act ${ }^{892}$ when he discovers it,

in accordance with our intention to make definitively disappear all trace of injustice and its partisans, and to decide with ${ }^{894}$ an impartiality that knows no path

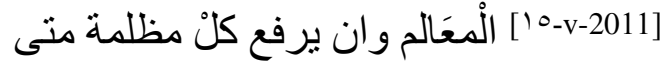

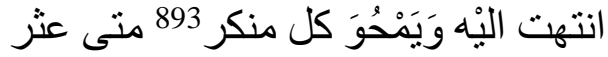

علَّبه

[17-v-2011]

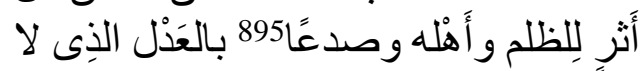
معدل

['V-v-2011] عن و اضحات سبله فاذا و افاكم بمشيئة الله تعلى فانقادو ا البّه احسَن انقياد

that strays from the obvious paths. Thus, when he arrives among you, by the will of God on High, submit to him as you should,

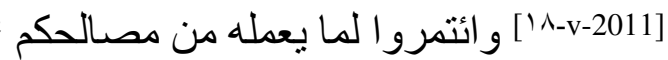

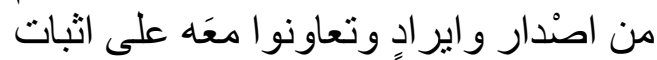

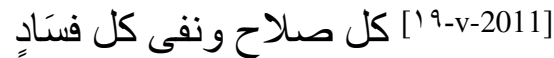
و اعْلمو ا انا مع ذلكم نتعهدكم من نظرنا بما لا بخليكم

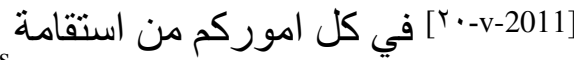
وسدَادٍ ويجريكم في تمهيد بلادكم على اجمل من من

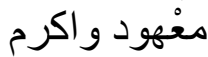

in any of your affairs, neither direction nor righteousness and that in the organization of your land you will be treated according to beautiful habit and generous

customs, if God on High wills it. And He - May He be glorified - He wil bring you to know the happiness of this appointment and He will guide you, in your life

and in your religion, on the obvious and solid path...

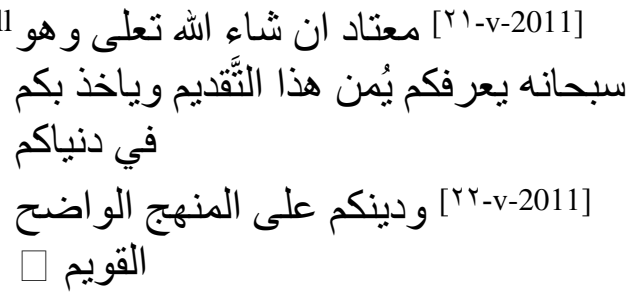

Taqdīm 10: Appointment of a Guardian (ḥāfiz) as governor (wālī), with military attributions and the hisba ${ }^{896}$

[rr-v-2011]

In a similar allocution (?)

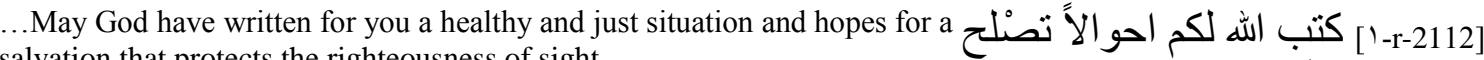
salvation that protects the righteousness of sight.

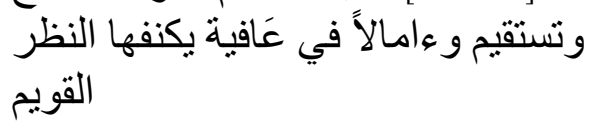

892 Allusion to hadīth transmitted by Tirmidhī, Sunan, $491 n^{\circ} 2172$, by Ibn Mājah, Sunan, 227, $n^{\circ} 1275$, by Aḥmad Ibn Hanbal, Musnad, t. 10, 154, n 11398 and by Muslim, Șaḥịn, Kitāb al-īmān, t. 2, 211, n 175: man rā'á min-kum munkaran fa-l-yughayyiru-hu bi-yadi-hi.

${ }^{893}$ Allusion to hadīth transmitted by Tirmidhī, Sunan, $491 n^{\circ} 2172$, by lbn Mājah, Sunan, 227, $n^{\circ} 1275$, by Aḥmad Ibn Ḥanbal, Musnad, t. 10, 154, n 11398 and by Muslim, Șaḥịn, Kitāb al-īmān, t. 2, 211, $n^{\circ} 175$ :

من رأى منكم هنكرًا فاليغيره بييه

${ }^{894}$ Allusion to Koran 15:94: "Therefore expound openly what thou art commanded, and turn away from those who join false gods with God."

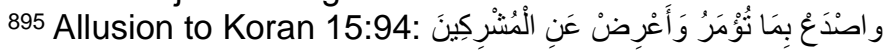

896 'Azzāwī, NLA, t. 1, 431. 
Know that you can count on our full attention and repose on our protection at any moment. That is why

we choose for you one whom we esteem capable of putting to work among you our principles of justice and benevolence; ${ }^{897}$ we have committed him

to spread the shadow of security over your regions. Considering this, we have appointed (qaddamnā) Fulān to watch

over your economic problems (ashghāli-kum al-mașlahiyya) and the tax matters (a'māli-kum al-makhzaniyya) that concern you and to lead you, in the administration of your affairs, on the straightest

Path; [and this] after having confirmed his great competence and noted the righteousness in all his plans. We have advised him

to fear God, which is the solid foundation of all actions; we have ordered him to follow

with you the paths of forbearance and restraint and to perfectly assure the total protection that that implies. We have insisted

that he organize and secure your regions, that he defend and fortify your lands, that he be severe in pushing back

the partisans of evil and corruption, that he take with you, in all situations, the straight and just path

and that he stray with you neither from tradition nor custom. Thus, when, with the help of God on High, he arrives among you, show him perfect obedience

in all the matters he will administer for you, collaborate with him in his exercise of authority (īrād wa ișdār),

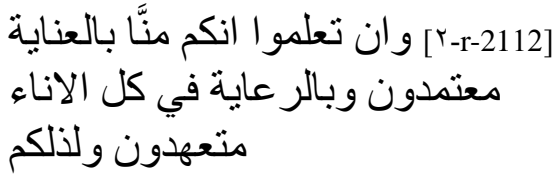

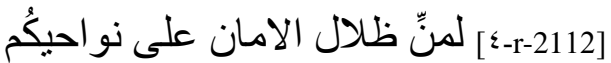

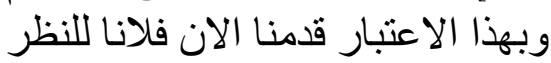

[0-r-2112] في اشغالكم المصلحية و اعمالكم

المخزنبة و السئلوك بكم في امور كم كلها

على السَّبيل

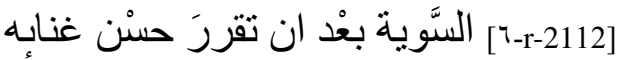

وذكر بالسيَّاد في كل انحابه وقد وصيناه

[?-r-2112] بتقوى الله تعلى و هـى الْقاعدة

التح ثبتت 901 علْيْها جميع الاعمال

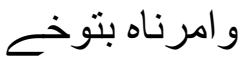

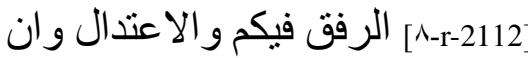

يستوفى الحماية عند وجوبها على الكمال

و اكدنا

[9-2112] عليْه في تمهيد جهاتكم وتامينها

وحماية ارجانكم وتحصينها وان يشتد في

عد

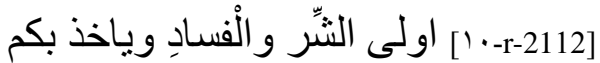
في احو الكم على سبيل الاستقامة و السَّداد

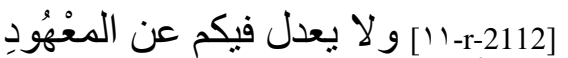

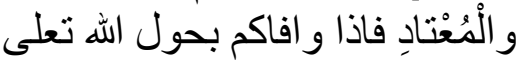

فائتمروا لله في لهون

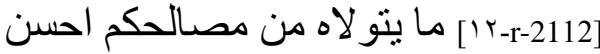

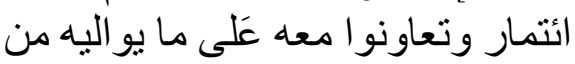

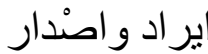

897 Reference to Koran 16:90: “God commands justice, the doing of good” (inna Llāha ya'muru bi-I- 'adli wa-l-ihsāni).

898 Perhaps نقرر.

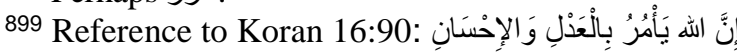

900 'Azzāwī corrects with نستنهُ

901 'Azzāwī proposes تثبت as a correction. 
ardently seek with the most sincere intention and best volition (athār) perfect attention and obedience. ${ }^{902}$ Moreover,

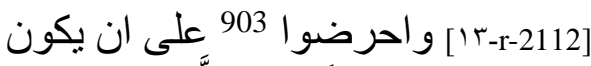

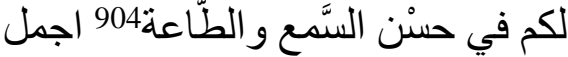

$$
\begin{aligned}
& \text { مساع و اكرم اثار ثنَّمَ }
\end{aligned}
$$

our benevolent watch will then be over you in all times and will ceaselessly renew in improving your situation and protecting

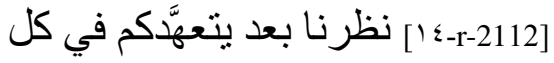

احيانكم ويتردد عليكم بتحسين احو الكم

$$
\text { وتحصنين أحو }
$$

your domains and your lands, if God on High wills it. May He found your passions in the piety and awe [He inspires] and may He spread

[10-r-2112] حلالكم و اوطانكم ان شاء الله تعلى وهو يجمع على البر و التَّقوى أنى

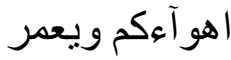

security and protection in your regions. Among the orders we have given your Guardian (hăfiz) and on which we have insisted, there is the obligation

of eliminating innovations with zeal, of erasing all trace of reprehensible things, of eliminating taxes that are not authorized by

$$
\begin{aligned}
& \text { [و-r-2112 [17- بالامنة و العافية ارجآءكم } \\
& \text { [و] } 905 \text { ممَّا امرنا بـه حافظكم وو وكّدنا } \\
& \text { عليْه فيه الاجتهاد }
\end{aligned}
$$

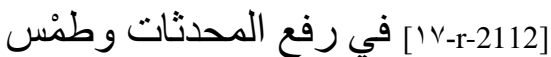

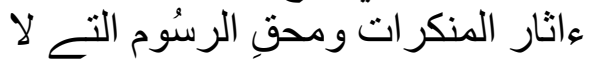$$
\text { بيبحها }
$$

the Law in the markets and at the gates [of the cities], and to end all that Tradition and the Book do not clearly authorize,

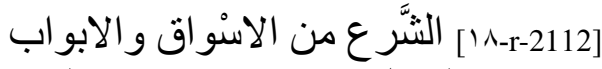

$$
\begin{aligned}
& \text { واز الة كل ما لا يجيزه مُحكم السنة التهو } \\
& \text { و الكتاب }
\end{aligned}
$$

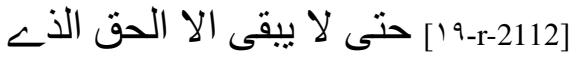

$$
\begin{aligned}
& \text { درج سلف هذا الامر عليْه ويذهب الباطل الاطن } \\
& \text { ذهابا } \\
& \text { [الأr-2112-r.r كُليا برغم من انتمى اليه فهذه }
\end{aligned}
$$

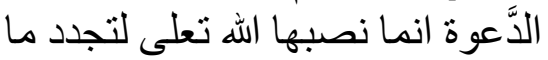

$$
\begin{aligned}
& \text { للانسنام }
\end{aligned}
$$

in spite of those committed to it. For the [Almohad] cause was only proclaimed by God on High to renew the signs

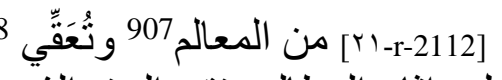

that distinguish Islam, ${ }^{906}$ to erase, through justice,
establish the sole law that God on High accepts,

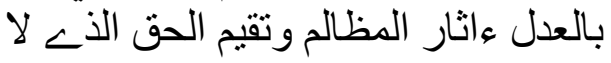

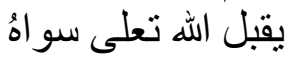

902 Reference to a hadīth cited by Muslim, Șahịh, t. 12, 428, n4 731, 4 732, 4 735, 4 736: "you must listend and oben, even if an Abyssinian slave commands you" ( 'alay-ka bi-l-sam 'i wa-l-țā 'ati... wa law ustu 'mila 'alay-kum 'abdun habashì).

903 Probably: واحرصوا.

904 Reference to a hadìth cited by Muslim, Șahīh, t. 12, 428, n 4 731, 4 732, 4 735, 4 736:

905 Added by 'Azzāwī.

عليك بالسمع و الطاعة.... ولو استعمل عليكم عبدٌ حبشي

${ }^{906}$ Reference to a hadīth transmitted by Abū Dāwūd, Sunan, ch. al-malāḥim, bāb mā yudhkaru fi qarn almi'a, 639, n 4291: "God on High sends this Community every 100 years someone who renews its religion" (inna Llāha ta 'ālá yab 'athu li-hadhi-hi l-ummati 'alá ra'si kulli mi'ati sanati man yujaddidu la-hā dīna-hā).

907 Reference to a hadīth transmitted by Abū Dāwūd, Sunan, ch. al-malāḥim, bāb mā yudhkaru fi qarn al-

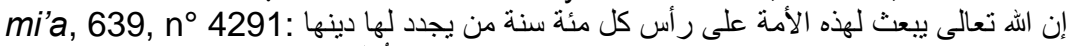

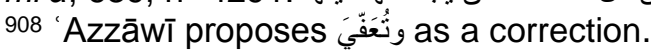


to reveal the Law, ${ }^{909}$ by which the subjects devoted their worship to God, and to distance all those who oppose it. This is our pact:

we require that all those we name as governor in the affairs (ashghāl) of the land respect it rigorously. This is the proof

that we raise against those who watched over this domain and when the witnesses are brought forth. ${ }^{912}$ Be persuaded of that in all

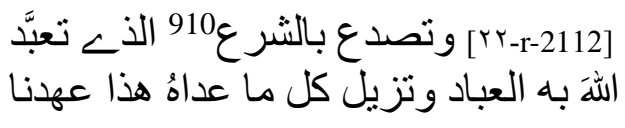

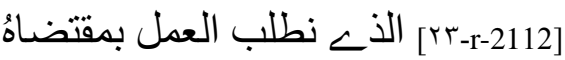
من كل ما911 نستعمله في اشغال البلادِ و هو حجنتا

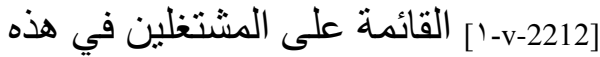

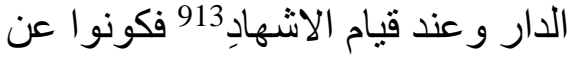

ذلك على اتم

certainty.Collaborate with your governors: in return you will doubly benefit, مانقين وتعاونو ا محَ و لاتكم على-v-2212] in this world and in the next, with the help of God on High...

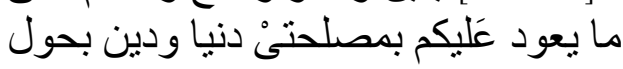
الله تعالى

Taqdīm 11: Irrevocable or absolute appointment (muṭlaq) of a governor ('àmil) in a frontier zone, with fiscal and military attributions ${ }^{914}$

○ـــ-v-2212]

Another appointment

...May God on High have written for you and your lands happiness and security and through the person we are appointing to lead you, may He allow you to know the justice

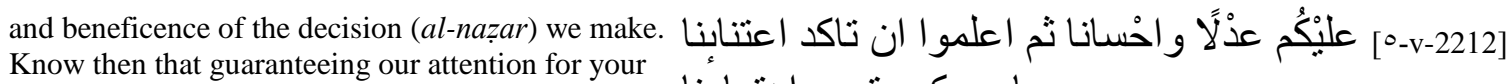
affairs, ceaselessly renewing our care for the interests باموركم وتجدد اهتمامنا

of all of you, the elite and the masses, and assiduously casting our careful watch on you, to fill your eyes with tears of joy and swell your breasts,

[all that] is part of what is necessary in choosing the person we will appoint as governor to manage your affairs, to protect your lands, and to assign

[־-v-2212] بمصالح خاصتكم وجمهوركم وتعهد نظرنا لكُم بما

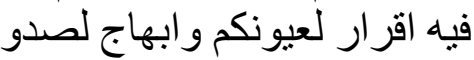

[V-v-2212] رِكم مما بوجبه تخير من نستعمله في اقامة

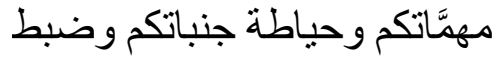

your taxes by adopting with you the most just

behavior. Indeed, our spirit is concerned by all that security brings to your domains, how

[^-v-2212 [جابيكم و السَّير باعْدل السيّير فيكُم ذلكُم لان

الْخاطر مغْدور بكل ما بؤمن حلاعلكم

it improves your situation and allows forbearance and justice in regards to your duties and rights. May God on High cause you to adopt

the best habits now and in the future and may $\mathrm{He}$ ceaselessly renew the signs of His favor that will

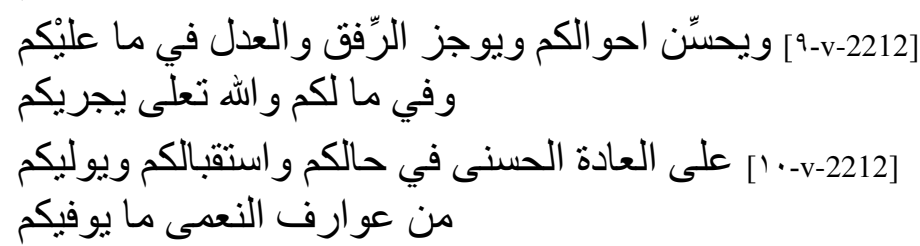

${ }^{909}$ Allusion to Koran 15:94: "Therefore expound openly what thou art commanded, and turn away from those who join false gods with God."

910 Allusion to Koran 15:94: واصندَعْ بِمَا ثُؤمَرُ وَأَعْرِنْ عَنِ الْمُشُشْرِكِينَ

911 More likely: مَ.

912 Reference to Koran 40:51: "on the Day when the Witnesses will stand forth." This passage holds a double connotation: juridical in its allusion to tribunals, witnesses, and legal acts, and eschatological with the allusion to the Last Judgment.

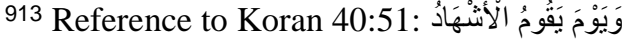

914 'Azzāwī, NLA, t. 1, 432-433.

915 Omitted by 'Azzāwī. 
Fulfill all your hopes, by His grace. We requested the help of God on High before irrevocably appointing (qaddamnā) Fulān to take charge

of your economic affairs and fiscal matters, to hold this border region

and to protect its inhabitants (man fihi min alra iyya) and those of the surrounding areas. You already know his upright conduct [since] he has already led you; you are familiar with his laudable directives that have assured you security and peace. According to what has been reported to us, you still desire

him to manage your affairs, and to watch over your interests, large and small, because of the qualities that have distinguished him

in all his activities: integrity, purity, energy, competence, and disgust for

[1'-v-2212 ] جميع عامالكم بمنّهه وقد استخرنا الله تعالى في أَن

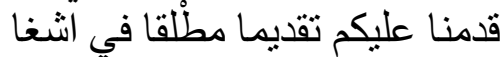

[Y-v-2212] الثَّغر وحماية من فيه وبنو احيه

[r-v-2212] من الر عية فلانا وهو الإِى عرفتم سيره الحسنة

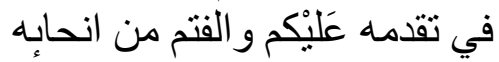

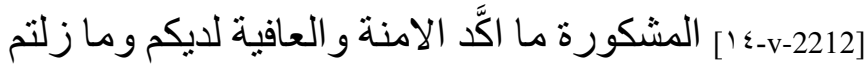

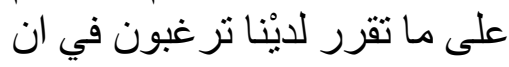

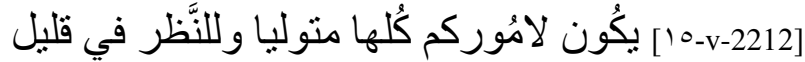

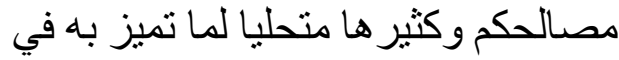

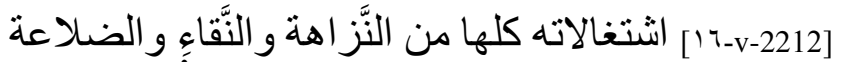

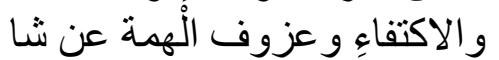

all turpitude, not to mention his solid loyalty, which are his most beautiful finery and most handsome garments. This is why

we have charged him alone with your affairs and your interests. For many years, we have tested in these two areas the justice of his views

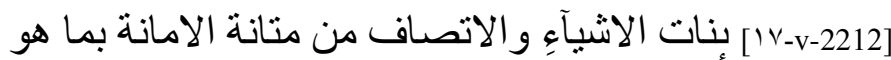

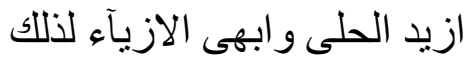

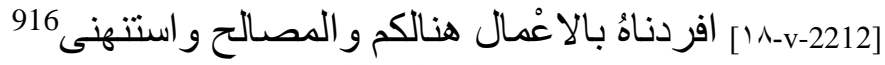

في الثظلين للمخبور عنده من النظر

and the weight of his opinions. In addition, we have advised him to fear God on High in all circumstances and to devote himself to respecting

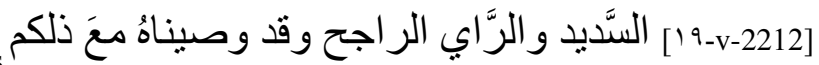

بتقوى الله تعالى في كل حالاته و التز ام

justice in all he undertakes. We have ordered him to completely collect from you all Treasury duties

( huqūq al-makhzan) - May God on High make it flourish - according to

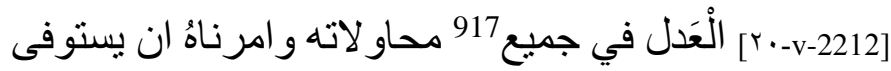

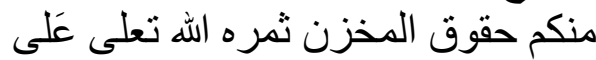

the known rules [of that institution], to not stray with you from its usual practices, to eliminate abusive novelties with

[r-v-2212] قو انينهَا المغْروفة وان لا بعدل فيكم عن رسُومها المالوفة وان بزيل المحدثات الجوريَّة

titles [that they give themselves], to punish those who give themselves over to them and to keep only the Law, the only thing we ask of anyone.

[Yr-v-2212]

يبقى الا الحق الذـ لا نطلأب بسو اه احدًا

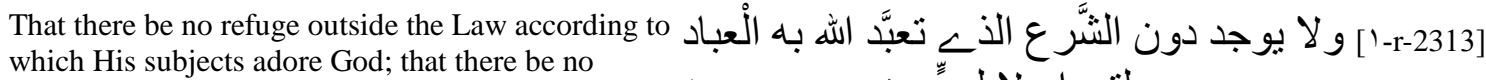
escape, in any way,

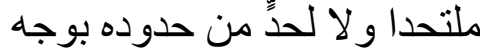

from any of these rules (hudūdi-hi). [We have ordered] That he, with the help of God on High, lead you in all that we have commanded of him along

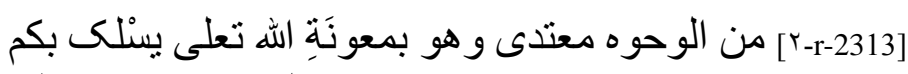

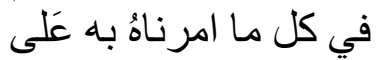

luminous paths, that he choose preferably what is useful and profitable for you, that he struggle severely

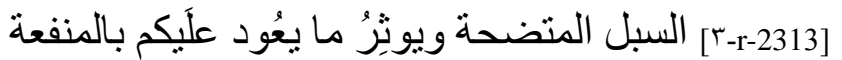

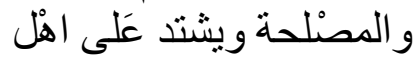

with enemies and the partisans of corruption and inflict upon them destructive punishments thus liberating the regions of the land.

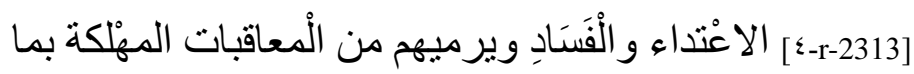
يريح منهم اكناف البانلد مئه

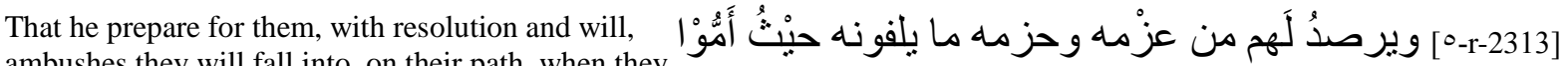
ambushes they will fall into, on their path, when they instigate a plan

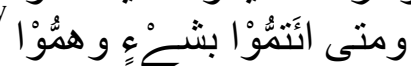

916 'Azzāwī: استَنْْنا or مرت علينا السنون.

917 'Azzāwī: كل. 
or conspiracy. He is supported in this by the armies with you and by the aid we will send him. Thus, when,

by the will of God on High, he arrives among you, entrust him with your affairs, trust the orders we give asks of you in the interest of your regions.

At no time should you deprive him of your obedience, nor of your assistance. You will know,

by the grace of God, the beautiful consequences of what we have charged him with and you will find the well-being of his authority (wirdi-hi wa șadri-hi) in that with which we have entrusted him.

In addition, our benevolent watch will take care of you at all times, it will improve the conditions of life

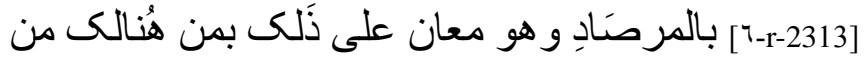

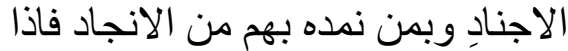

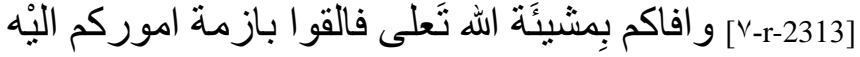
واعتمدوزا في ما نتهيه أموريه

[^-r-2313] اليكم من او امرنا علنيه و ابذلو ا بداركم و ائتماركم في ماي

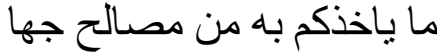

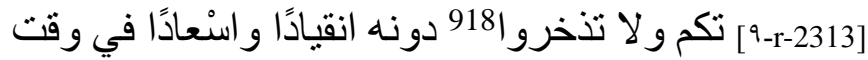
من اوقاتكم وستعرفون

[-r-2313-• 1] بمن الله حسن اثره في ما (البّه) 919 اسندناهُ

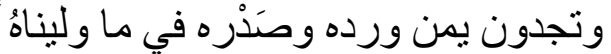

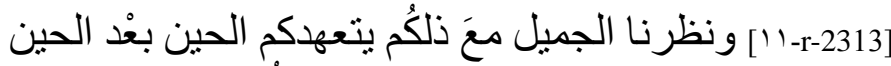

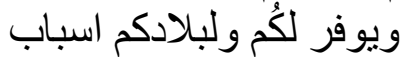

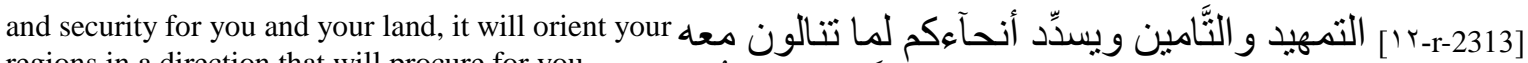
regions in a direction that will procure for you absolute peace in this world الصصلاح الثَّامل في الأُّنيا

and the next, if God on High wills it. And He - May He be glorified - He will grant you the entire protection of Salvation and He will make

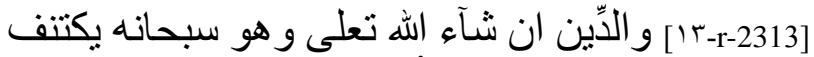
بالْعافية الو افية اكنافكم ويجعل فئل

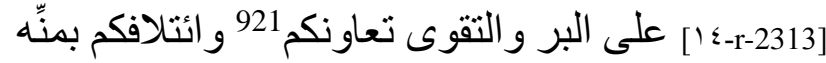
your collaboration and union true to good and to the awe that He inspires. ${ }^{920}$ By His grace.
Taqdīm 12: "Complete" appointment (taqdīm tāmm) in favor of a member of the local elite to defend a frontier zone, with fiscal and military attributions $^{922}$

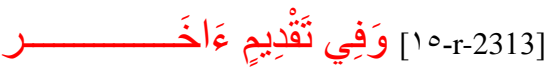

Another appointment

... May God have written for you a healthy and just situation and hopes that neither leave nor abandon success.

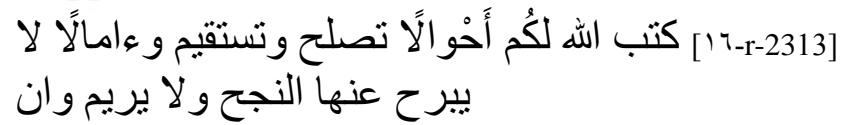

Know that God - May He be exalted and magnified - by تعلمو ا ان الله عز وجل بما قلدنا من القيام بحقّه charging us to institute His law in all the lands of Islam and in entrusting us

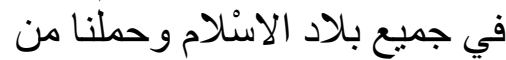

with the responsibility of watching over what brings peace (bi-l-șalăh) among the Muslims and order to your affairs,

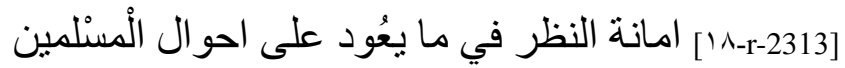

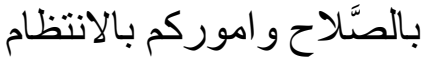

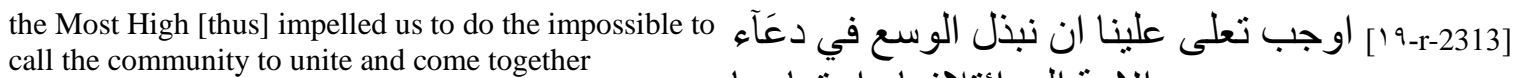

918 'Azzāwī: تََّخروا.

919 Omitted by 'Azzāwī.

920 Reference to Koran, v, 2.

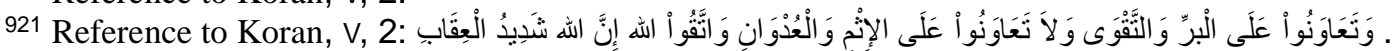

922 'Azzāwī, NLA, t. 1, 443-444. 
and to apply our administration (al-nazar) to anything that would spread the shadow of security over its regions and lands. This is why we care

for our subjects, be they near or far, and their lands, we devote our habitual efforts to prolong

peace there and implant security and we appoint to rule them someone that we believe capable of defending their flanks

and of assuring the correct state of their affairs. May God on High help and assist us always in the management of

their religious and secular interests of His Muslim subjects and may He grant them, wherever they may be,

the benediction of what we desire for them and the good and just decisions we make for them. This is why - May God watch over you and may He help you to fear Him we,

because of what we have learned of the refuge you have taken under this Cause of Unicity (al-da'wa altawhìdiyya), in submitting yourselves perfectly to his authority,

and of the appeal to law you have sought in adhering to his community $\left(j a m \bar{a}^{\prime} a t i-h \bar{a}\right),{ }^{925}$ we have decided that affairs in your land (hunālikum) would depend on

someone who rigorously takes in hand the frontier zone and closes it, who will manage your affairs according to the most just and correct of paths, and whose opinions,

favorable or unfavorable, would hold steady and maintain you in the requirements of the Law, so much so that you may not deviate

from your religious obligations under any circumstance, nor stray from fiscal rules in any of your affairs (alqawānin al-mașlahiyya bi-shaghl in min ashghālikum). this decree, we name

Fulān over you because he is the most known of your notables, because he has distinguished himself by the justice of this views (bi-sadādi l-nazar) in the defense of your territory (makāni-kum),

because he has endeavored to protect your interests and your affairs and he has been vigilant in pushing aside from you the attacks

of your enemies. Previously, it was confirmed for us that you were satisfied (mughtabițūn... bi-) by his conduct among you and that you were attached (murtabițūn... to his manner

of exercising authority ( $m \bar{a}$ yūridu-hu wa yușdiru-hu) in your affairs. Also we have granted him full power (al-

[Yr-v-2413] في اموركم مرتبطون 928 فامضينا له التقديم

$$
\text { التام في بلادكم وما يرجع اليْهِ من انظاره }
$$

[ [-r-2313-r-r وان نعمل النظر في كل ما يمد ظلال الامان

على اكنافها واصقاعها فنحن لذلكم نتعهر

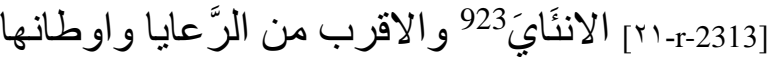

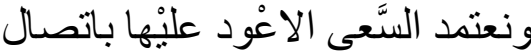

[rr-r-2313]

نعتقد منه الغنآه في حياطة جَانبها
لعباده المسنْمين من مَصدالح

[r-v-2413] دينهم ودنياهم بنصره وتاييده ويوجد هم حيث

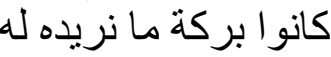

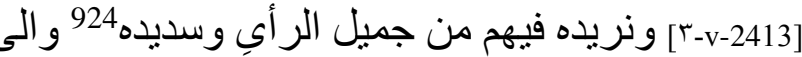

هذا كلاكم الله و اعانكم على تلى تقو اهُ فانا

[ـ-v-2413] لما تعرفناهُ من اويكم الى هذه الدعوة التوحيدية

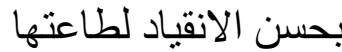

[0-v-2413] و الاعتماد على الحق في اتباع جماعتها راينا

ان تكون ايُوركم هُنالكم مسندة أنهاع

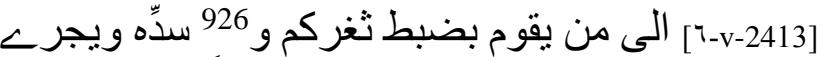

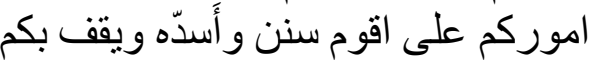

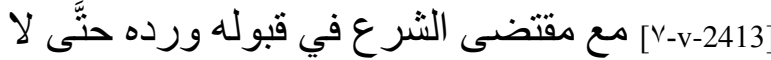

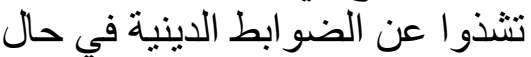

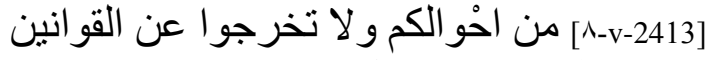

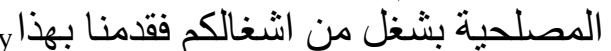

[9-v-2413] الرَّسم علبكم فلانا لتقدُّمه الثهير في اعيانكم

وتمبزه بسَداد النظر في حماية مكانكم

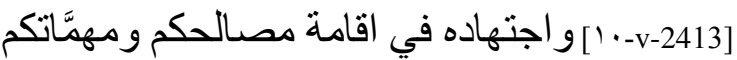

و احتياطه في كل ما يكف عنكم عادية

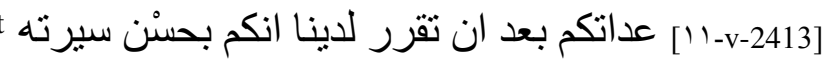

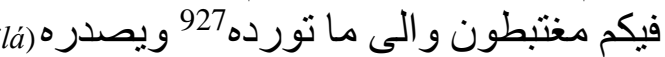

923 'Azzāwī: الأنْأَى.

924 'Azzāwī: وسداده.

925 'Azzāwī suggests that this may refer to Seville's return to the Almohad flock under al-Rashīd, in particular because of the use of the term jihād.

926 'Azzāwī: أو.

927 'Azzāwī corrects with يوردم:

928 'Azzāwī: مغتبطون. 
taqdìm al-tāmm) in your land and in the districts that are under it;

and we appreciated for you the rendered accounts that came to us on the quality of his effort among you and the nobility of his actions. We have decided that your economic

affairs and fiscal matters would depend entirely on his management and his control. We have entrusted this activity

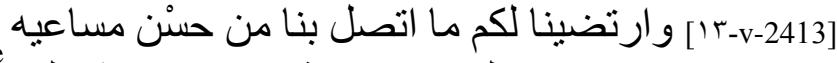

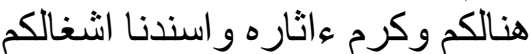

[ [-v-2413- المصلحية و اعمالكم المخزنية الى نظره

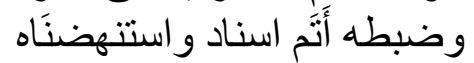

to his sole responsibility and he will accomplish it all, if God wishes, by deploying all of his efforts and all of his zeal.

[10-v-2413] من القيام بذلك كُله و الاستقلال بـ لما ينهض

بـه ان شَآَء الله نهوض الأه جد و اجتهاد

He will adopt for that the path of volition and righteousness. We have advised him to fear God on $\mathrm{High}^{929}$ in all

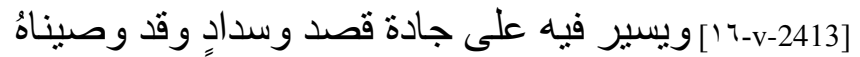
بتقوى الله تعلى 930 في كلّ ونّل

that he undertakes, and to fear Him in all his orientations محاو لاته و مر اقبته في جميع انتحاءاته [1V-v-2413] and adhesions, to bind himself to justice ${ }^{931}$ and forbearance in all

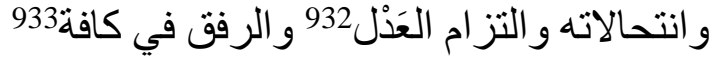

Situations, ${ }^{934}$ to eliminate abuses that deserve to be abolished and eliminated, and to confirm only what has been confirmed by the Law

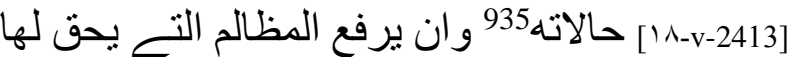

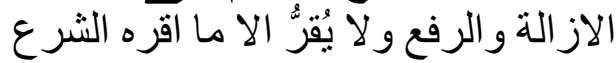

[19-v-2413] يكون للحزم ملتزمًا وللاحتيط ولهي

and whose utility contributes to the common good. We have insisted that he endeavor to be firm and always

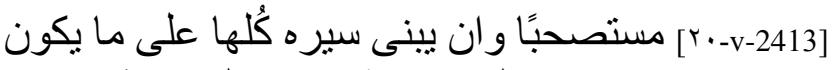

Vigilant, that he base all his conduct on what is necessary to satisfy God - May He be exalted and magnified - that he

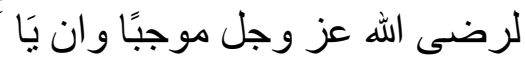

lead you, the masses or the elite, to accomplish your religious duties, to assiduously follow the

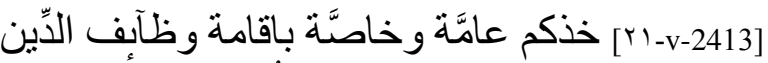

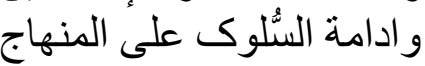

bright and luminous paths, to correct blameworthy conduct (al-manākir) that merits it, to revitalize the decrees

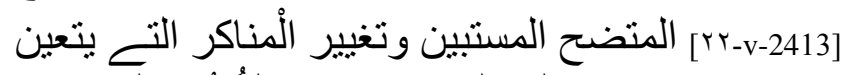

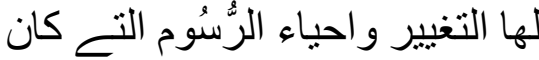

whose pious ancestors followed the right path, to collaborate in doing good and in fearing $\mathrm{Him}^{936}$ in what

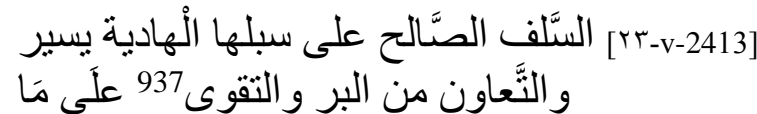

brightens and illuminates hearts, to hear you to privilege matters useful for religion and

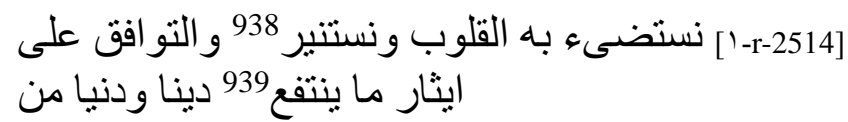

929 The wișāya refers to Koran 4:131: "Verily we have directed the People of the Book before you, and you (o Muslims) to fear God."

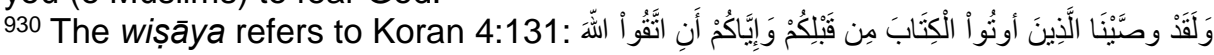

${ }^{931}$ Reference to Koran 16:90: "God commands justice, the doing of good" (inna Llāha ya'muru bi-l-'adli wa-l-iḥsāni).

932 Reference to Koran 16:90:

933 'Azzāwī: Sل.

${ }^{934}$ Reference to a hadīth reported by Ibn Ḥibbān, Șahịḥ, t. 2, 312, n 551, by 'Abd al-Razzāq, Mușannaf, t. 11, 141-142, n 20 145, by Tirmidhī, Sunan, 449, n 1 974, by Ibn Mājah, Sunan, 695, n 4185.

${ }^{935}$ Reference to a hadìth reported by Ibn Hibbān, Sahịh, t. 2, 312, n' 551 , by 'Abd al-Razzāq, Mușannaf, t. 11, 141-142, n 20 145, by Tirmidhī, Sunan, 449, n 1 974, by Ibn Mājah, Sunan, 6995, n 4 185:

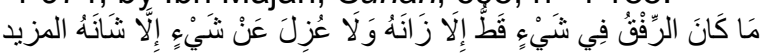

${ }^{936}$ Reference to Koran 5:2: "Help ye one another in righteousness and piety, but help ye not one another in sin and rancour: fear God: for God is strict in punishment."

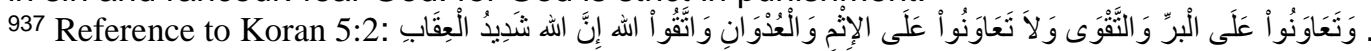

938 'Azzāwī: وتستضيى.... وتستير:

939 'Azzāwī: ينفع. 
the world and to avoid all that lead to incorrect deeds. Thus, when our letter comes to you, rejoice in the favor that our

benevolence gives you in the person we are appointing to govern you. Accomplish with perfect obedience to him all that we have proposed to you. Thank

God on High for the generous solicitude and attention that this Cause $\left(d a^{i} w a\right)$ reserved for you, for the just resolution he taught

you in asking after your situation and in managing it so well that you will praise his visits in the present

and future. Look with the same gaze as God on High on that which will render their blows to His enemies and that will accomplish the

true Promise of proclaiming and raising high His

religion. Congratulate yourselves for what the calls of the Almohads (dawā '̀ al-muwahhidìn) - May

God exalt their worth - lavished on this land: coming together, uniting and mobilizing to be dedicated exclusively to the duty of jihād,

in working with zeal and seriousness, in showing force and making an effort, and in seeking out victory while also asking of

God - May He be exalted and magnified - His aid and His help. The aid of God on High for the faithful in His religion, stands on the great road and the souls

of His servants, the believers, are certain that $\mathrm{He}$ will carry out [His promises] before the [appointed] hour. Be sure - May God on High honor you -

of the good you are going to receive and the conquests you hope for over the enemies of the faith. Insist to obtain

this in obeying God, His messenger and the governors $(\bar{u} l \bar{l} l \text {-amri })^{941}$ in all that you say and do, if God [r-r-2514] الامور و اجتناب ما يضبر فاذا و افاكم كتابنا هذا

فاغتبطوه بما اثرنا(ه؟) لكم من جميل

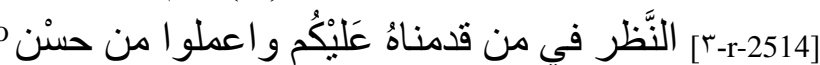

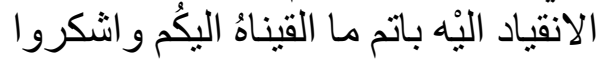

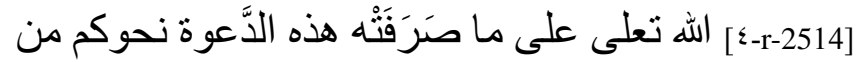

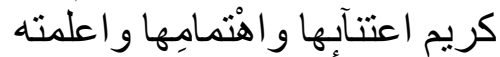

[0-r-2514] في تفقد احو الكم و اجر آبها على ما تحمدون

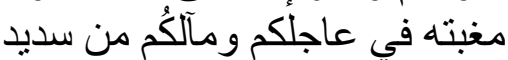

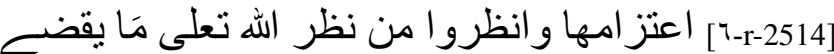

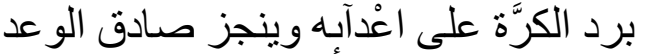

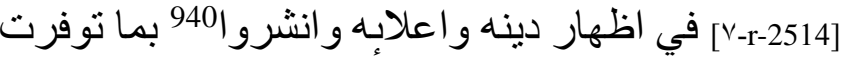

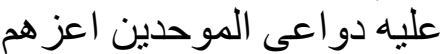

[^-r-2514] الله بـذه البلادِ من الاجتماع و الاحتشـاد و التجرُّد

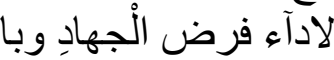

[9-r-2514] عمال الجد و الاجتهادِ و اظهار القوة و الْعتاد

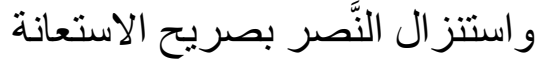

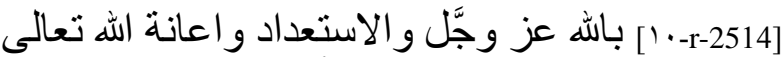

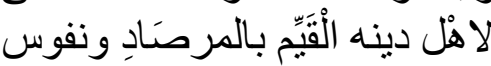

[-2514-r-1'] عباده المومنين على ثقة من انجازه لسابق

المبعَاد فكونو ا اكرمكم الله على يقين

[M-r-2514] من الخير الذى تستقبلون و الفتح الذِى في عدو

الايمان تؤملون وتَوصلو النيل

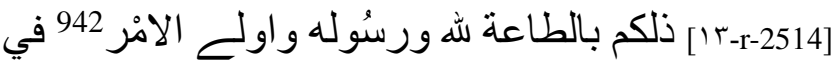

كل ما تقولون وتفعلون ان شآه الهاء الهُ

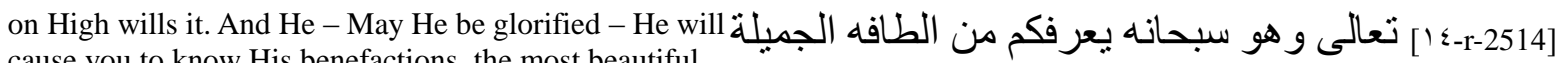
cause you to know His benefactions, the most beautiful you may await from heaven (tatashawwafün), He will never cease

in granting you in all circumstances His abundant favors which you already know, and, now and in what you undertake,

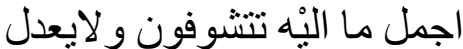

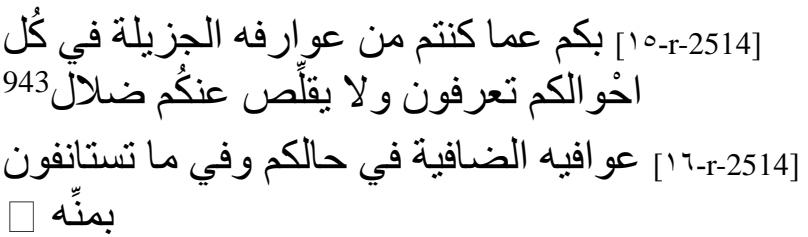

Taqdīm 13: Appointment of a "Scholar" (țalaba)

who had already served as governor (wālī) in

940 'Azzāwī: وابشروا.

941Echo of Koran 4:59: "O ye who believe! Obey God, and obey the Messenger, and those charged with authority among you". The omission of the final min-kum accentuates the distance between he, or those, who governs (the caliph) and the subjects from whom, in the Koran, he, or they, is supposed to come.

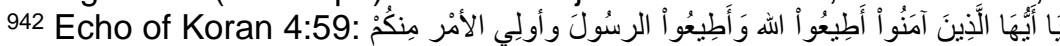

943 'Azzāwī proposes ظلال as a correction. 
...May God have written for you a situation characterized by virtue and righteousness and hopes crowned with success

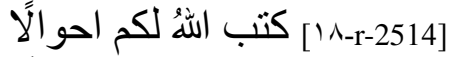

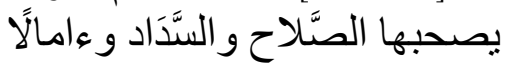

$$
\begin{aligned}
& \text { يقترن بها الانجاح }
\end{aligned}
$$

and happiness. Know that our benevolent watch its center and periphery over your land will smoothen

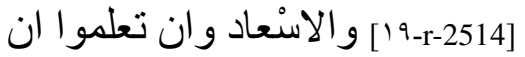

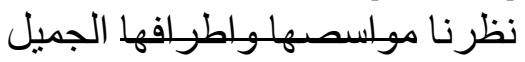
لبلادكم945 موذن بتمهيد

its regions and lands and spread the shadow of Salvation ( 'a $\bar{f}$ iya ) and security in the center as much as the periphery.

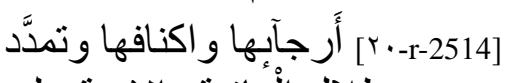

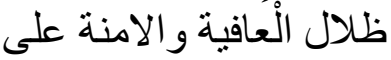

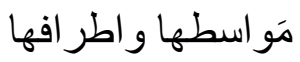

We will spare neither effort nor zeal to guarantee the means of its protection and defense,

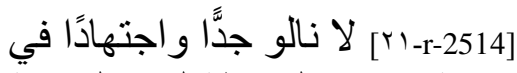

$$
\begin{aligned}
& \text { توفية اسباب الحياطة لها و الحماية }
\end{aligned}
$$

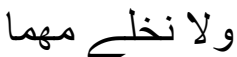

we will neglect none of the important matters for its provinces and districts, we will even grant them absolute attention and care. That $[\ldots]$ the subjects

and lands for which God charged us to establish their interests, to assure the security of those who come and go

$$
\begin{aligned}
& \text { وجهاتها و التهمُّم التَّام بهانه و العناية } \\
& \text { ذلكم (....946 الرَّعايا }
\end{aligned}
$$

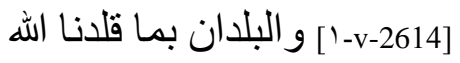

$$
\begin{aligned}
& \text { تعلى من الاقامة لمصالحها لمانيا }
\end{aligned}
$$

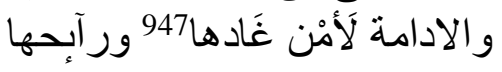

$$
\begin{aligned}
& \text { [r-v-2614] و الاخذ في امُور ها }
\end{aligned}
$$

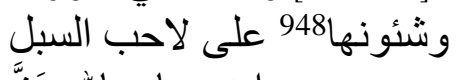

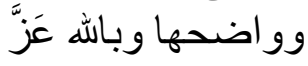

$$
\begin{aligned}
& \text { [r-v-2614] وجل نستعين } 949 \text { في } \\
& \text { جميع ما نوثره لبلادكم من تمكين } \\
& \text { موجبات الهدنة و الامان ونعت لهند }
\end{aligned}
$$

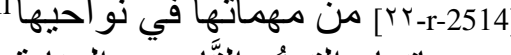

and magnified -, we ask His help in all that we will decide for your land, to guarantee conditions of security and immunity (amān),

and for the clemency, justice and benevolence our support will bring you. ${ }^{950} \mathrm{We}$ will always choose, to govern your affairs and apply our doctrine (madhhab)

944 'Azzāwī, 436.

945 'Azzāwī: ببلادكم.

946 Word erased.

947 'Azzāwī corrects with غَاديها.

948 'Azzāwī: وشؤونها.

949 Omitted by 'Azzāwī.

${ }^{950}$ Reference to Koran 16:90: “God commands justice, the doing of good” (inna Llāha ya'muru bi-l- 'adli wal-ihsāni).

951 Reference to Koran 16:90: إِنَّ الله يَاْْرُ بِالْعَلْلِ وَالإحْسَنَانِ 
in your organization, for the elite and the masses, the best of our lieutenants for all of that, someone who will make your domains more agreeable

and redress the situation, making decisions that follow the straightest and brightest paths. By [this act]

and after having best chosen as we have just informed you, we now appoint Fulān - May God perpetuate his influence and his obedience and protect his rank and his honor. He is a man that is very close to us, known in all that he undertakes for this righteousness and

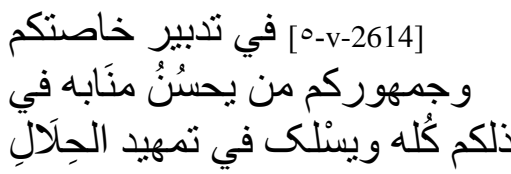

[7-v-2614]

اقوم طرق النَّظر و اجلى سبله الآنه

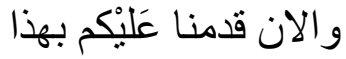

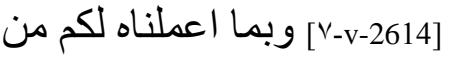

حسن الاختيار فلانا وصل الله

اثرته و مبرَّته و حفظ مكانه

[^-v-2614 [ حظوته و هو منا القريب

القر ابة و الْمغروف في محاو لاته

كلها بالسيَّداد و الا

Efficiency. He has been charged numerous times with governing the great cities [of صابة قد ترددت و لايتهابه

the Empire]. All his administrative acts have been distinguished through noble

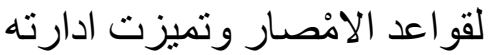

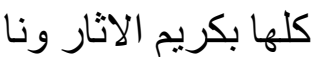

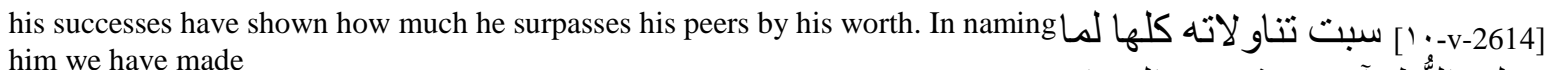

له على النَّظر آه من شفو فت المقدار

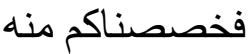

a generous choice for you, because of the merits that set him apart: his age, prestige and personal quality. By this

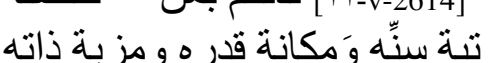

$$
\begin{aligned}
& \text { بكريم الاختصساص و اوجينا }
\end{aligned}
$$

appointment we have granted you the best share, because your land and population thus acquire preference and exclusivity.

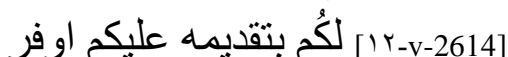

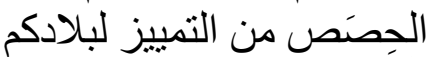

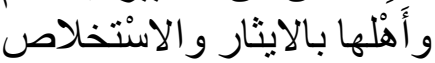

And, by the force given him by the excellence of his character, the rectitude of his opinions, the nobility of his intentions, and the firmness of

[r-v-2614]

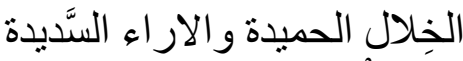

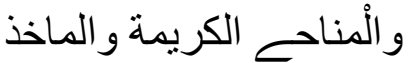

his decisions, he will protect all that serves and is useful (manāfi $\left.{ }^{\prime}\right)$ to you with a benevolent watch and, to defend your province

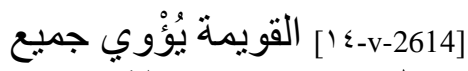

مصالحكم و منافعكم نظرًا جميلا

ويقتف في حماية جنباتكم

and manage your affairs, he will follow the paths and trails of rectitude; large or small, he will distance from you harm, caused or suffered,

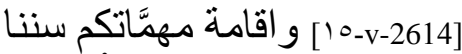

سويَّا وسبيلًا و يدفع عنكم الْمضنار

و المعَارِّ جملة و تفصيلا

and he will teach the recommendations we have imparted to him, those that God on High addressed to his subject in His Word:

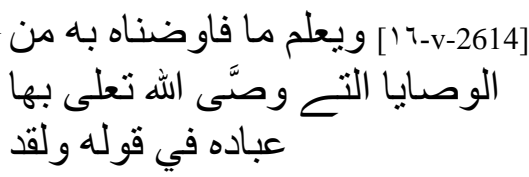

952 ‘Azzāwī: بما. 
"Verily we have directed the People of the Book before you, and you (o Muslims) to fear God"953, thus will he make the fear of God on High..

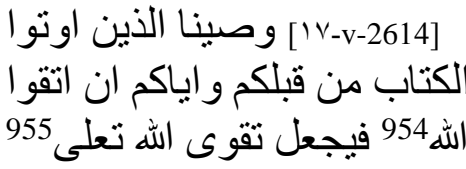

Welcome his arrival with all possible joy and show perfect obedience to the orders he will

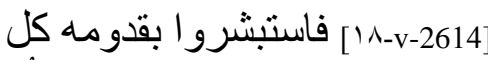

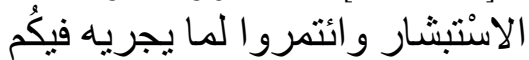

من الاوَامر اتمريه

give, be for him, to implement the law and apply justice, helpers and auxiliaries. Know

to recognize the honor granted to you by the Presence of the Almohads, your brothers, in appointing the most illustrious of its grand notables

and in choosing he whose place in its administration and whose counsel is known. By the force of God on High...

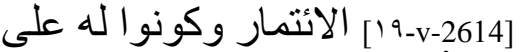

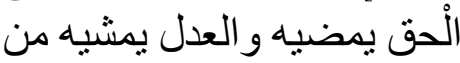

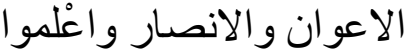

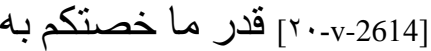

$$
\begin{aligned}
& \text { حضرة الموحدين اخو انكم من تقدم } \\
& \text { المقدَّم في الجلَّة من كُبَرَ آبها آنهام }
\end{aligned}
$$

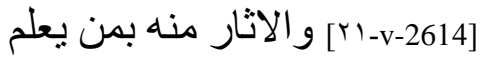

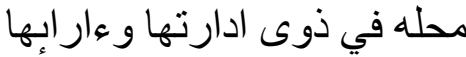

بحول الله تَعلى الهى

Taqdīm 14: Gubernatorial appointment with fiscal and military attributions ${ }^{956}$

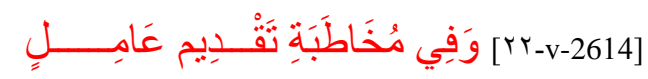

Allocution for the appointment of a governor ('ämil)

May God always assure them respect through the fear He inspires in them and help them to follow a path $\mathrm{He}$ accepts and approves. This is what we write

- May God have written for you to recognize the best and most just situations, to find refuge in the vastly spread shadow of security and

in observing the duties of your religion that will bring you closer to Him. Know that our watch over

the land and its population sets its edges straight, protects it in the center and on the periphery, establishes security

and expels reasons for fear. And that is because God - May He be exalted and magnified entrusted us with guarding its affairs and the protection of its elites

and masses. We also devote to it all the care and attention we can, our concern

$$
\begin{aligned}
& \text { [ [rr-v-2614] ادام الله كر امتهم بتقوَاه و اعانهم على العمل بما } \\
& \text { يَتقبله و برضر اهنَاه و انا كتبناه }
\end{aligned}
$$$$
\text { ['-2715-r-2 كتب الله لكم تعر فا لاصحلاح } 957 \text { الاحو ال و اسدِّها }
$$$$
\text { و اويا الى اورفن ظلادل الامنة وَ }
$$

[r-r-2715] أَمدِّها و المحافظة من وظابف دينكم على ما يحظيكم

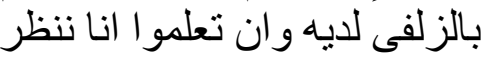

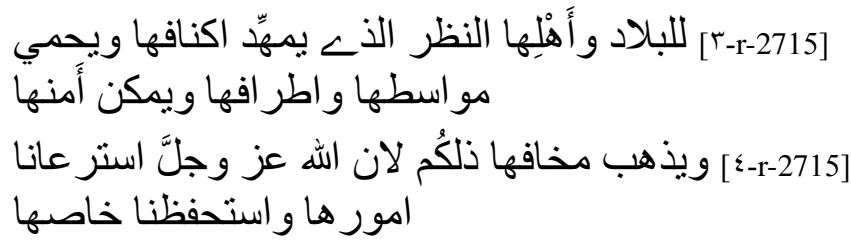

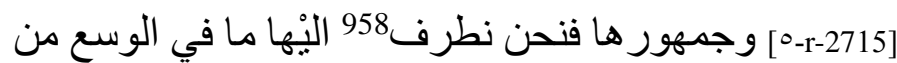

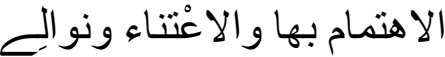

953 The wișāya refers to Koran 4:131 (excerpt): "Verily we have directed the People of the Book before you, and you (o Muslims) to fear God."

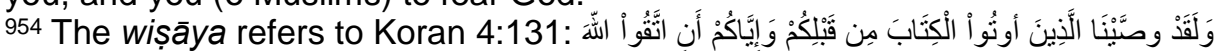

955 'Azzāwī notes that the following passage should indicate the addition of a word such as sabilla-hu or amāma-hu.

956 'Azzāwī, NLA, t. 1, 437.

957 'Azzāwī proposes لأصلح as a correction, matching with wa asaddi-hā.

958 'Azzāwī corrects with نصرف. 
for it continues at all hours and moments. We choose for its affairs (li-ashghāli-hā) competent and efficient people

so that its interests might advance along the path righteousness and that it might receive a protection

that pushes aside the attacks of evil and corruption. May God on High grant us the continuation of that with His aid and

His support and may His assistance accompany us in the exercise of authority ( $f \hat{\imath} l-i s ̦ d \bar{a} r w a-l-\bar{r} r \bar{a} d)$. In terms of what we have just evoked

of our intentions to improve the lot of the subjects (li-l-ra 'iyya) and their land, and of [our] desire to grant them security in green sweetness of its opulent

Plains, we have named Fulān to lead your regions - May God on High protect them - to take charge of their interests

and their resources, to spread complete security to all places and all localities, to guarantee for all regions,

near and far, regular visits, to lead all districts, in improving easy paths and removing

Obstacles. He is known for his wisdom and reputed for his firmness, following the path of his predecessors

in courage and bravery. We have advised him to fear God on High ${ }^{959}$ and to submit to Him in private and in public,

to adorn himself with the best and most handsome character traits, to take in all situations the paths and trails

of truth. We have ordered him to be severe in crushing corruption and corrupters, to chase away rebels

and aggressors, and to ceaselessly assure order and security for your lands. We have insisted that he collect taxes due to

the Treasury (makhzan) - May God cause it to flourish - , that he completely collect taxes on all the [population], that he deduct

what remains due by the subjects ( $m \bar{a}$ baqiya $f \bar{i}$ dhimam al-ra iyya) and is specific to them, and that he have them pay the rest of what

they normally must pay using an authority that unites both clemency and the demands of truth,

in assembling the [landed?] revenues from which general interests (al-mașälih) draw and in thus protecting that
[-7-2715-3 التعهد لهَا في كل الاوقات و الانآه ونتخير لاشغالها

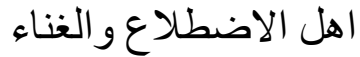

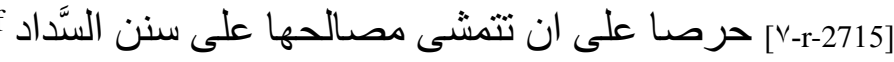

وتوفى من الاحتياط عَلْيْها

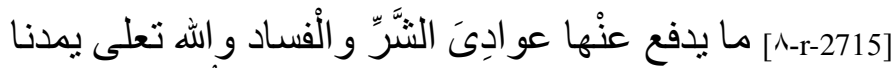

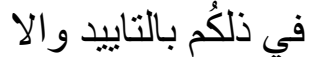

[9-r-2715] نجاد ويجعل توفيقه لنا رفيقًا في الاصدار و الاير اد وبمقتضى ما ذكر ناهُ

[-2715-r-1] في توخِّ الصَّلاح للر عية وبلادها وقصد الامانة

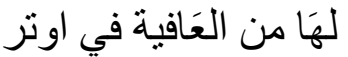

[1'-r-2715] مهادها قدمنا الان فلانا على جهاتكم حاطها الله تعلى ليقوم بمصالحها

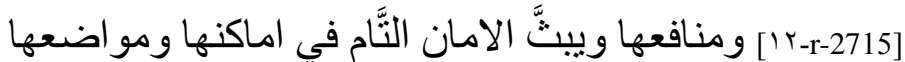

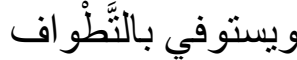

[r-r-2715 ] جميع دانيها وشاسعها وينظر في الاعمال كُلها بما فيه تدليل مهآبعها ورفع في الآن

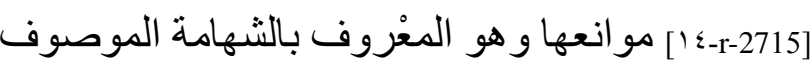

بالحز امة السَّالكى سبيل سلفه

[10-r-2715] في النجدة و الصَّر امة وقد وصبيناهُ بتقوى الله

تعلى 960 و التز امه في سره وه وه و علنه

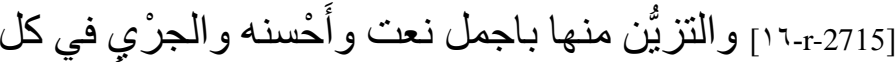

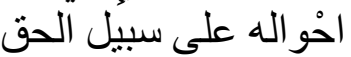

[Y-r-2715] وسننه و امر ناهُ ان يشتد في محق الفسادِ و المفسدين

وتشريد الباغين

[1/r-r-2715]

و اكدنا عَليه ان يقضى الحقوق

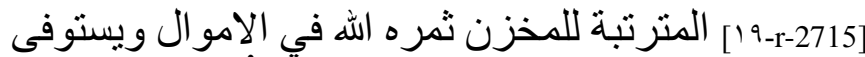

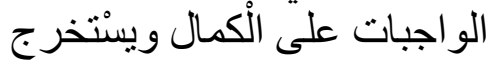

[r-r-2715-r] من ذللكَ ما بقى في ذمم الر عية وتعيَّن عَلْيْها

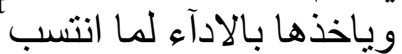

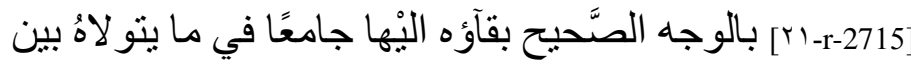

ملاحظة الرِّفق و المطا لئن

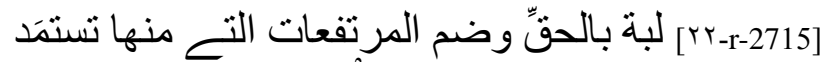

الْمصالح و الاحتياط منهات

959 Reference to Koran 5:2: "Help ye one another in righteousness and piety, but help ye not one another in sin and rancour: fear God: for God is strict in punishment."

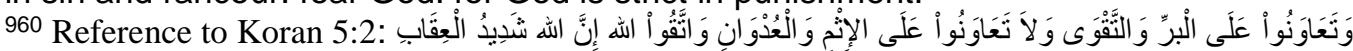


on which repose, for Muslims, sincere efforts.

Thus, when he arrives among you, with the help of God - May He be glorified -

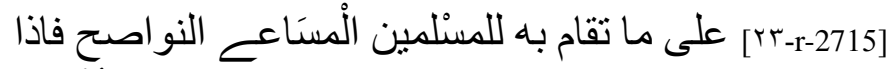
و افاكم بمعونه الله سُبْحانها

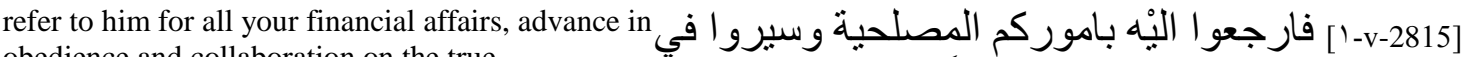
obedience and collaboration on the true الائتمار له و التَّعاؤن على الليّيّر 961

paths, be with him as one hand united to ordain good and prohibit evil. ${ }^{962}$ Much success

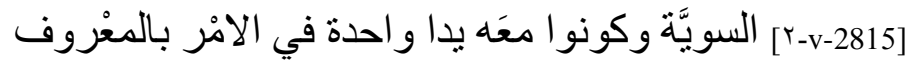
و النهُه عن المنكر 963 و المو افقة

to your interests, small and large, if God on High wills it..

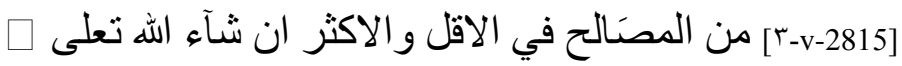

Taqdìm 15: Gubernatorial appointment (wālī), with fiscal and military attributions, in collaboration with Abū Fulän for the affairs of the Treasury ${ }^{964}$

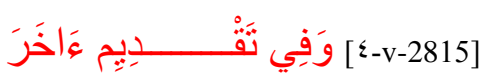

Another appointment

...We have appointed Fulān - May God on High continue to favor him and guide him on the path his righteous authority (ișdāra-hu

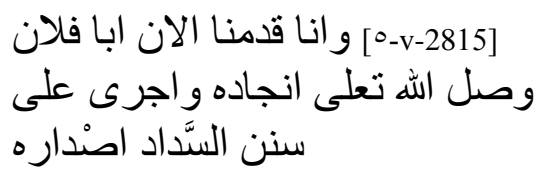

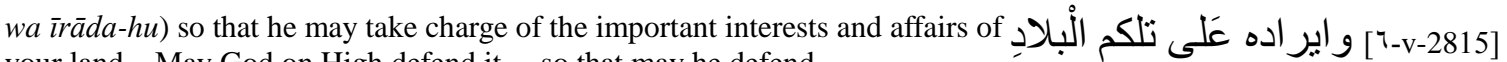
your land - May God on High defend it -, so that may he defend

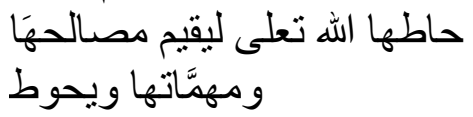

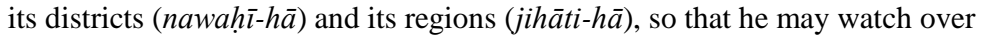
the taxes and over all Treasury matters (a'māli-hā al-makhzaniyya wa majābi$h \bar{a})$, so that he may have power over revenues, to manage them

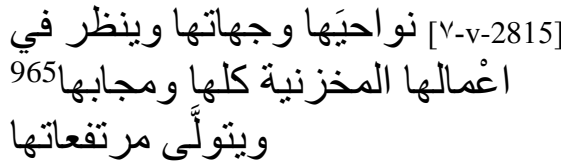

and cause them to flourish in such a way that they increase and develop. He is known for his aptitudes (iktifā') and competence (wa-l-ghanā'). We have been satisfied

[^-v-2815] من الضَّبط و التثمير بها

يوفر ها وبنمبها و هو معْلوم بالاكثفاءِ

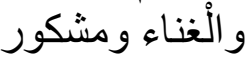

with all he has undertaken in the different fields ( $a n h \bar{a} \bar{a}$ '). He is reputed (mawșūf) for being faithful (bi-l-wuqūf ma'a) to religion (dīn) in creating

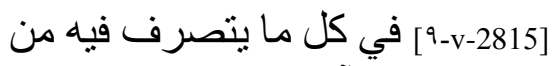

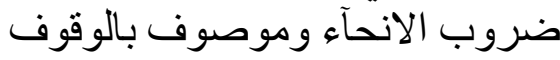
مع الادِّين في الاعودادة

961 Omitted by 'Azzāwī.

962 Reference to Koran 3:110: "Ye are the best of peoples, evolved for mankind, enjoining what is right, forbidding what is wrong and believing in God."

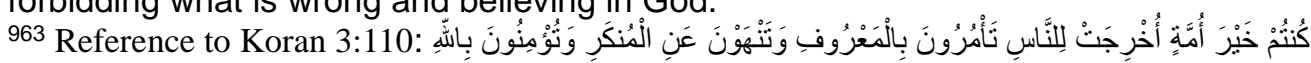

964 'Azzāwī, NLA, t.1, 438.

965 'Azzāwī corrects with ومجابيها, without changing the meaning. 
and pursuing his projects ( fi l-i 'âdati mim muhāawalāti-hi wa libdā'). We have advised him to fear God on High, ${ }^{966}$ [that is] what orders (tusaddid) remarks

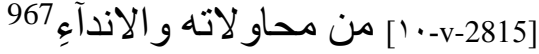

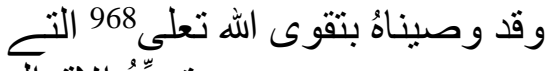

$$
\begin{aligned}
& \text { تسدِّدُ الاقو الَ تعل }
\end{aligned}
$$

and acts and guides affairs and situations on the royal paths of truth (haqq) and justice. We have ordered him to double efforts

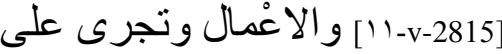

$$
\begin{aligned}
& \text { جادة الحقِّ و العدل الثُئون } 969
\end{aligned}
$$

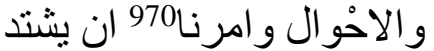

to stop corruption (fasa $\bar{a} d)$ and malfeasance (al-dirar), and, to sever the scourges 971 they are, to use the zeal

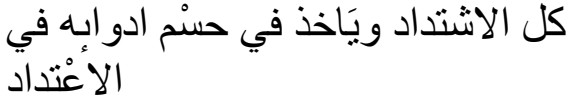

demanded by the [duty] of "personal interpretation" (ijtihād). ${ }^{972}$ We have insisted that he collect and obtain in full all duties due the Treasury (makhzan) - May God cause it to flourish -

$$
\begin{aligned}
& \text { [r-v-2815 ] [1 ] بمقتضى الاجتهادِ و اكدنا } \\
& \text { عليْه في اقتضآء كل حق بجب } \\
& \text { للمخزن ثمره الله }
\end{aligned}
$$

and that he force whosever owes a tax to pay it as quickly as possible. We have placed

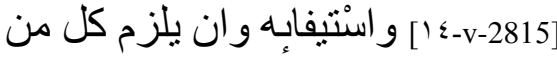

$$
\begin{aligned}
& \text { عليْه من واجب من المجبى بتعجيل } \\
& \text { ادآبه وجعلنا }
\end{aligned}
$$

Abū Fulān with him to assist in Treasury (makhzan) matters (ashghāl), and in that his discernment is joined to [Fulān's].

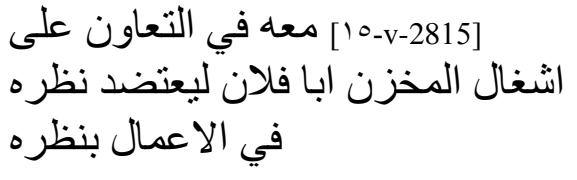

Understanding and collaboration will be so much better for Treasury (makhzan) tasks, large and small. Thus, when this

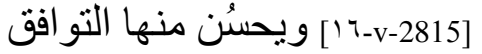

$$
\begin{aligned}
& \text { و التر افق في اقل الشغل المخزنيى دني } \\
& \text { و اكثره فاذا و افَاكم المَ }
\end{aligned}
$$

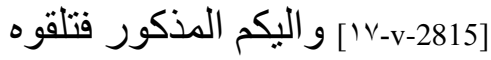

$$
\begin{aligned}
& \text { بالامتثال والائتمار في كل ما بلقيه } \\
& \text { وتعاونو ا كَعها }
\end{aligned}
$$

governor, yours, arrives among you, welcome him with submission and by obeying all his decrees, and collaborate with him

in all that his just authority (nazar) demands and requires. Submit to him in all that he carries out

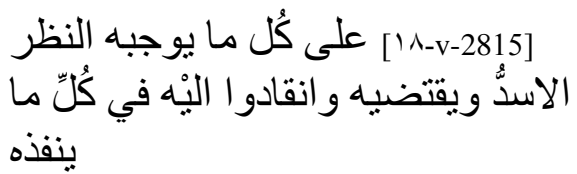

\footnotetext{
966 The wișāya refers to Koran 4:131: "Verily we have directed the People of the Book before you, and you (o Muslims) to fear God."

967 'Azzāwī corrects with والإبداء, which fits with the context since the term forms a logical and flowing pair with $f f_{l} l-i$ 'ädati... (wa-l-ibdā'i), since there seems to have been a simple error of a dot placed above the consonantic ductus instead of below and since al-andā' would not make sense here.

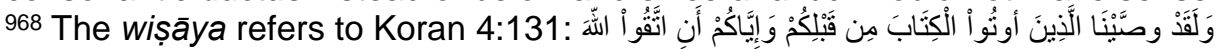

969 'Azzāwī: الشؤونَ.

970 'Azzāwī corrects with امرناه.

${ }^{971}$ Allusion to hadîth لا ضرر ولا ضراد (lā ḍarar wa lā ḍirār) reported by Mālik, Muwațta', t. 2 290, n² 2 171, "no trouble and no competition."

972 "Effort of juridical interpretation."
} 
and accomplishes for your interests, if God on High will it. And $\mathrm{He}-\mathrm{May} \mathrm{He}$ be glorified - He will render you happy with this appointment and He will renew for you

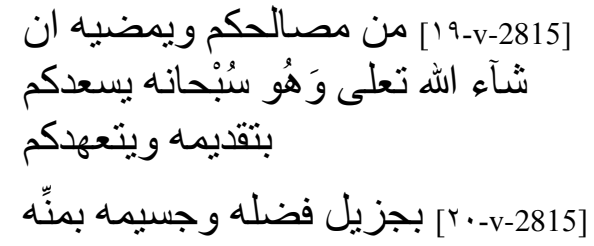

His many and abundant favors. ${ }^{973}$ By His grace...

Taqdīm 16: Appointment of a shaykh as governor ('āmil?) with fiscal and military attributions and

\title{
the hisba ${ }^{974}$
}

\author{
[rir-v-2815] \\ Appointment of another governor ( 'âmil)
} ...May God treat them generously by the fear that He inspires and may He
watch over them; may He bring them together for what merits them His
favor and may He receive them under

His protection and mercy. This is what we have written - May God have written for you a situation well-ordered and harmonious and may He have spread over you

the shadow and stage of justice and beneficence. ${ }^{975}$ Know that our benevolent watch will not fail you and that in the best choice we will make

for you on a brilliant path, we will not stray. We seek for your regions nothing but what we seek for all

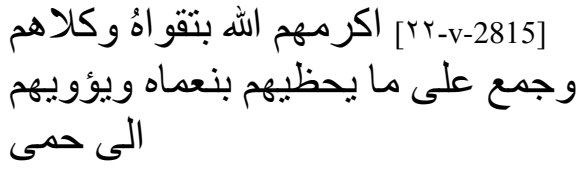

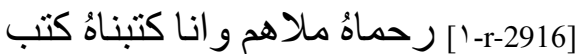

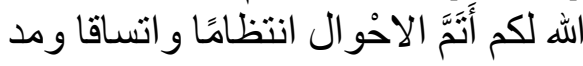
عليكم

[r-r-2916] للاعَذْل و الاحسان 976 ظعلا ورو اقًَا وان تعلمو ا انا لا نغبُّكم بنظر جميل ولان نعدل

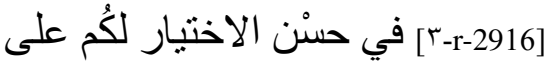

اجلى سبيل ولا نعتمد في جو انبكم الا ما

ن تمتمده لكل

God's subjects with whose charge he has entrusted us in matters concerning security and fulfilling expectations. As a result,

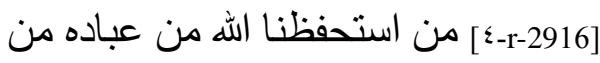
توفية تامين وتبليغ تاميل وبهذا الاعتبار we have named Fulān - May God assure him respect and always lavish on him His aid by assisting and leading him - so that he would have sole charge

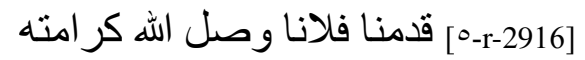
و ادَام بِتوف فِقه وتسْديده اعانته للاسْتبداد

of your economic problems (umūri-kum al-mașlahiyya) and your financial affairs (a'mālikum al-makhzaniyya), and so that in your land he would devote to these two functions the most serious

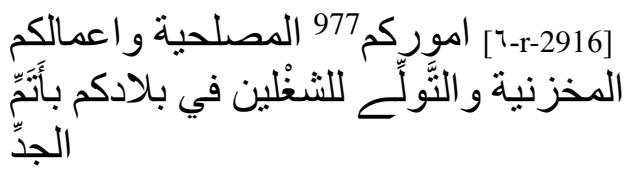

work and most upright intentions. He is one of the Almohad shaykhs with a rank known for its superiority;

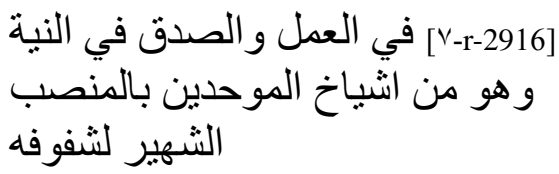

973 Other possible translation: "may He take care of you by the abundance and number of his merits" depending on whether it is the favors of God or the merits of the governor.

974 'Azzāwī, NLA, t. 1, 439.

975 Reference to Koran 16:90: "God commands justice, the doing of good" (inna Llāha ya'muru bi-l-'adli wa-l-ị̂sāni).

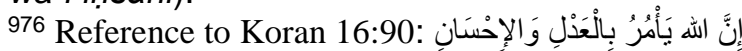

977 ‘Azzāwī corrects with بأمورَ 
among them he is at the forefront, which can be neither ignored nor disdained. We have witnessed

his sense of moderation in all circumstances and we have verified how much he surpasses his peers and equals [ـ-r-2916] وله من الْكان الاثير فيهم ما لا يدفع معُلومه و لا ينكر معروفهُ وقد خبرنا من

[عن-2916-r-3 اعتداله في كل احو اله وتحققتا

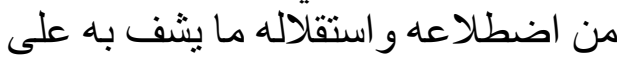

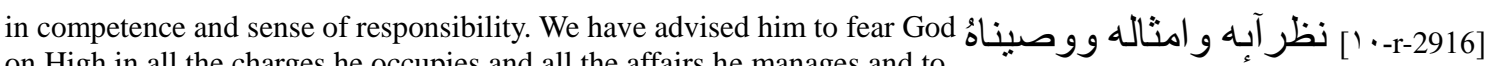
on High in all the charges he occupies and all the affairs he manages and to carefully

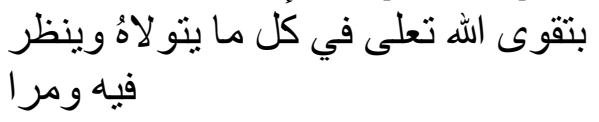

respect His plan and His prohibitions in all that he directs or supervises he leaves or undertakes. We have ordered him to collect in full

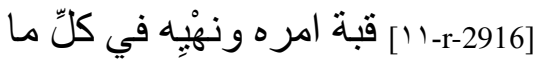

يتولاهُوينظر فيه بذره وياتيه و امرناهُ انه وئه

بسنتوفى أمرن

taxes due (al-huqūq al-wājiba) on property and to expend all his zeal in collecting them completely as well

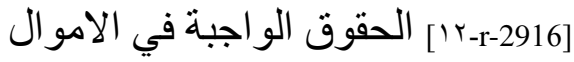

ويوفى الاجتهاد في الاستخر اج لها لها

و الْجباية

as [other] taxes, to also take care of the interests on which repose your recovery as well as the entire situation,

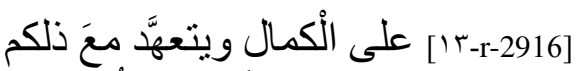

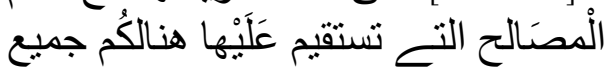
الاحو الن

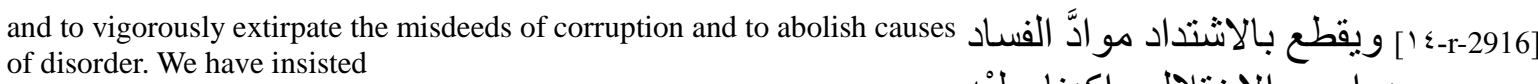

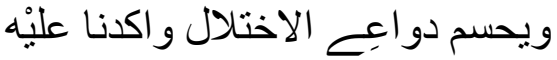

that justice be the basis for all his efforts and undertakings, the axis of his power at all times and in

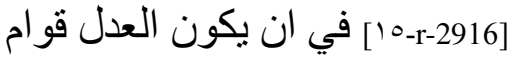

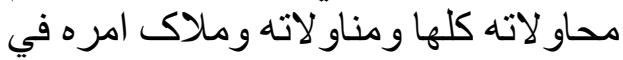

جميع انحآنه

all places, that he prohibit innovations (al-muhdathāt) condemned by the Law, that he put a stop (yada') to exactions (al-mazālim)

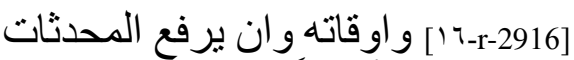

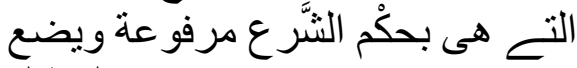

المظالم

concerning [His] creatures, that he maintain only what the law obligatorily states should be conserved and confirmed,

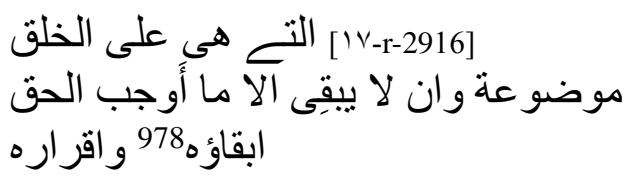

and that he not adopt an attitude whose mark is not clemency and on which justice leaves handsome traces.

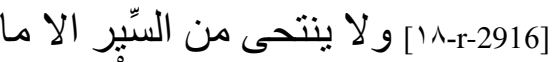 يكون الرفق شعاره وما يحسّن الْعدل فيه لإنه عاثاره

This is the firm order we have addressed to him, to him and to all whom we employ, and this is the objective that we will never forget nor neglect.

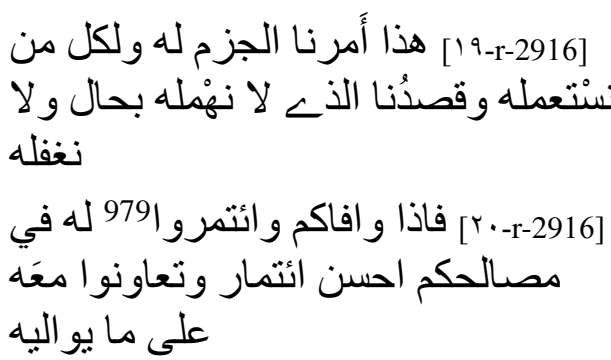

978 'Azzāwī corrects with ابقاءه.

979 'Azzāwī corrects with فائتمروا. 
his relevant authority (min ìrādi-hi fi-hā wa isḍarri-hi). Pay him in full that which you owe in advance

and with alacrity. Be certain that you will know the well-being of God. And $\mathrm{He}$ - May He be glorified - He will assure you a situation

that is always better than normal. We will not stray with you from the luminous path, when we are collaborating for the common good (mașālih)

and exchanging counsel for beneficial work, ${ }^{981}$ if God on High wills it...

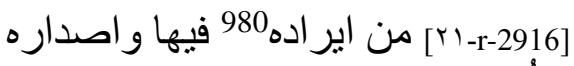

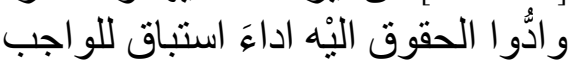

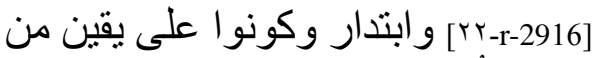
انكُم تثعرَّفون ونَّن بمن الله و هو سبحانه

يجريكم من احو الكم

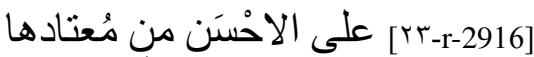

فالاحسن و لا نعدل بكم في التَّظافر مرني

المصالح

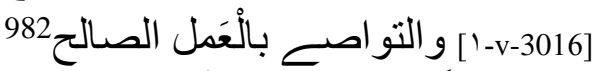

على السَّنن الابين ان شَآََّ الله تعلى

Taqdīm 17: Joint appointment of a shaykh as governor ('āmil ?) of Sijilmāssa and its region, with fiscal and military attributions, and of an official responsible for taxes (nāẓir fī lmajbá) $)^{983}$

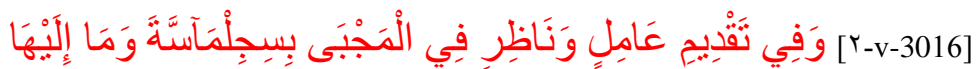

Appointment of a governor ( 'àmil) and a person responsible for taxes in Sijilmāssa and dependant [regions]

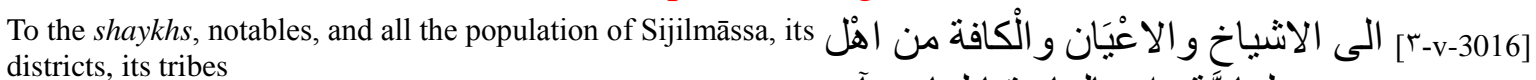

and those under them. May God always assure them respect through the fear $\mathrm{He}$ inspires, and may He give their eyes rest (anāma 'uyūna-hum qarīra) in a refuge and

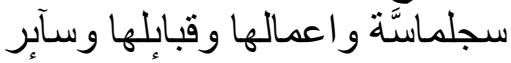

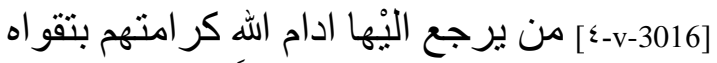

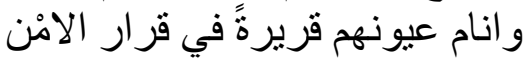

shelter of security. This is what we write - May God have و مثو اهُ و انـا كتبناهُ كثب الله تعلى لكم اقبالا written for you to accept what will cause your actions to flourish

على الثان الذى بصلح اعمالكم

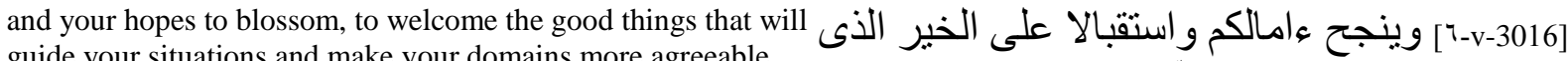
guide your situations and make your domains more agreeable,

and to observe the duties of your religion to bring you closer to Him. Know that the most important matter we take care of

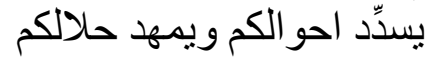

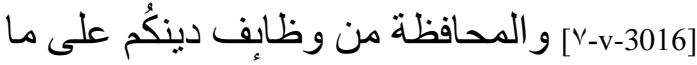

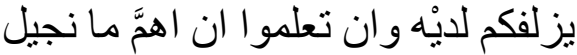

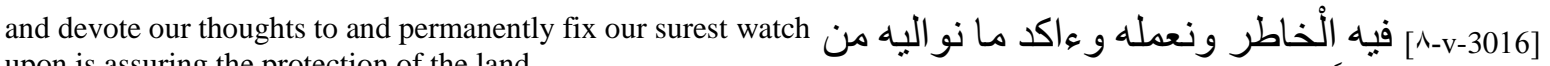
upon is assuring the protection of the land

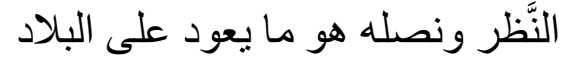

and its inhabitants and guaranteeing the support of its interests. We devote our great attention

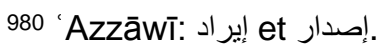

981 Reference to Koran 103:3: "Except such as have Faith, and do righteous deeds, and (join together) in the mutual teaching of Truth, and of Patience and Constancy."

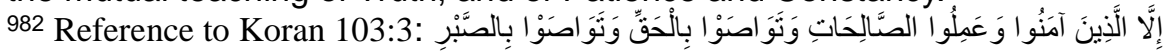

983 'Azzāwī, NLA, t. 1, 440-441.

984 'Azzāwī corrects with يو فيها. 
and care to its affairs. If all the lands have their share with us in this process and if we never

stray from this generous path to take charge of their affairs and care of their population, both the elite and the masses,

your land receives at all times a large share of this care and interest and we plan to organize

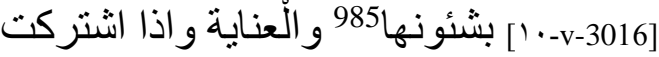

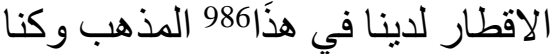

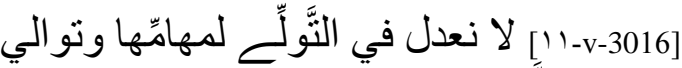

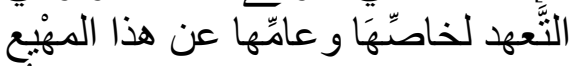

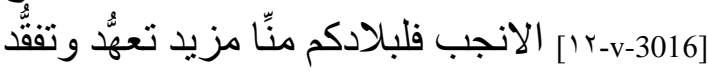

في كلّ الانآء ولنا في تمهيد

your districts and assure the security of your population and [this desire] will never loosen. As this plan

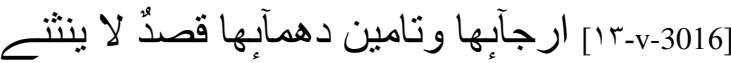
عنها بحال عنان الاعْتناء وبموجب وهب

[hat we favor for your regions demands, and since you enjoy the هذا القصند الذى في جو انبكم اعتمدناه best [treatment] we reserve for

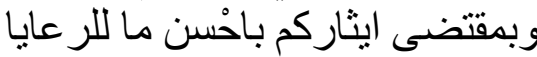

our subjects, we have entrusted your affairs for the good of you all, the masses and the elite,

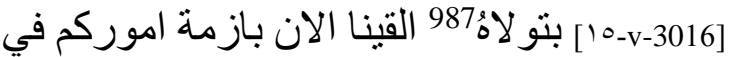

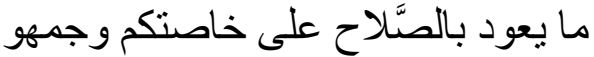

[17-v-3016]

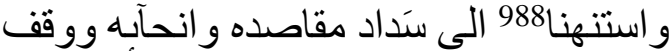

repose entirely on the uprightness of his goals and intentions.

Our choice is fixed

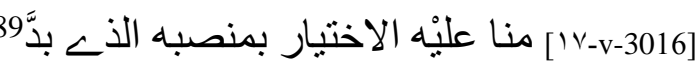

on him because of his rank,
Fulān - May God conserve

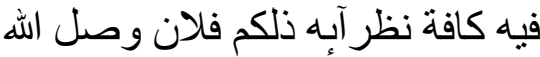

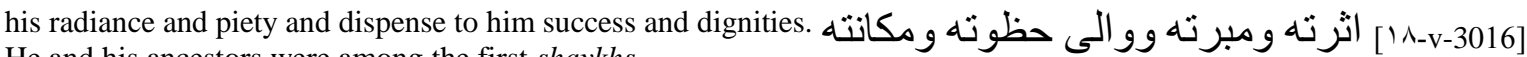

$\mathrm{He}$ and his ancestors were among the first shaykhs

$$
\text { وهو السَّابق بذاته وسلفه في اشنياخ }
$$

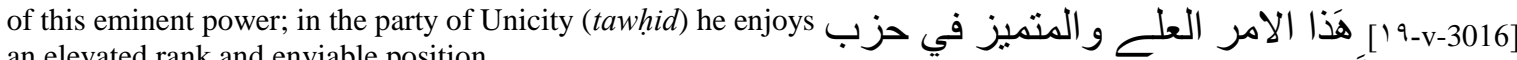
an elevated rank and enviable position,

and, in our service, he has not ceased to follow the straight and luminous paths. He has warmly welcomed our

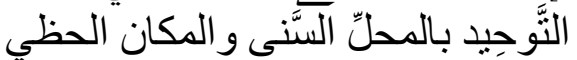

[ب-v-3016] و الذى لم يزل في خدمتنا سالكًا على فئى

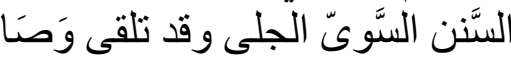

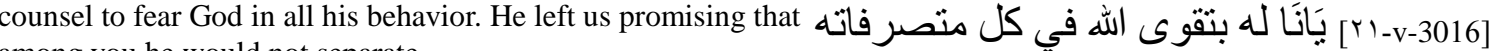
among you he would not separate

اجمل تلق وو ادعنا على ان [لآ]

from justice and forbearance, and he would guide all your interests lawfully and with the Law for his horizon. We have ordered him

to make your land agreeable in being resolute to cut it off from all its evils, to use severity to extinguish

rebellion and aggression and to frighten all those who would defraud justice and equity, so much so

that those who have taken on the habit of corruption would be turned away and those intent on following and respecting [our] pact $(a l-a m \bar{a} n)$ rejoice in tranquility

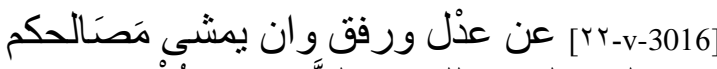

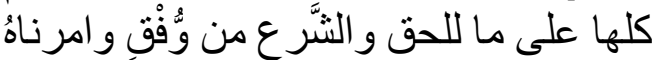

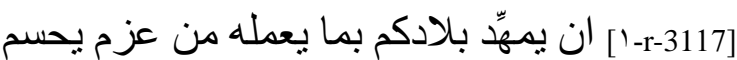

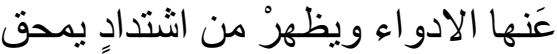

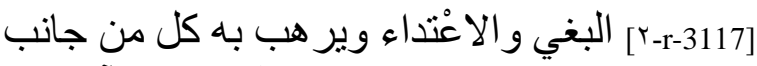

الا عتدال و الاستو آء حتى هن

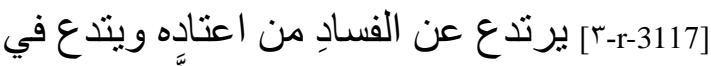

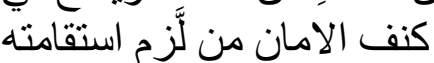

85 'Azzāwī: بشؤونها.

986 Alif inserted between hā' and dhāl.

987 'Azzāwī corrects with نَّ لنَّ

988 'Azzāwī corrects with وراستنمناه

989 'Azzāwī corrects with بزّ.

990 Added by 'Azzāwī. 
under its wing. As for those who persist in following their passions, who obey the demon who inspires them

and head strongly commit shameful acts with stubbornness of those [the Devil] has lost and led astray, the sword

is ready for them and the Law permits the shedding of their blood. For severity against the wicked improves and purifies the situation

[-r-3117-؛] وسداده ومن لجَّ في ارتكاب هَو اهُ و اطاع

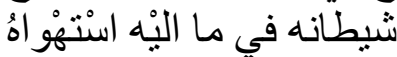

[0-3117-3 وتمادى في الاصنر ار على قبيح الاثار تمادِىَ من اضلَّله و اشقاهُ فالسيَّيف

[7-r-3117] منه مريح و الثرر ع لسفك دمِه مُبيحِّح

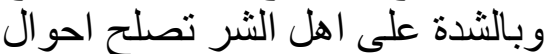

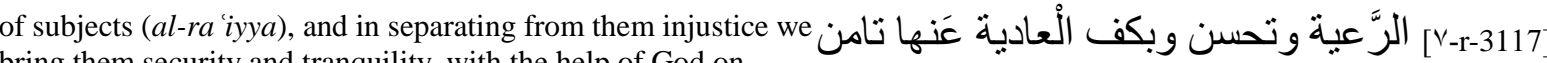
bring them security and tranquility, with the help of God on High. We have charged him

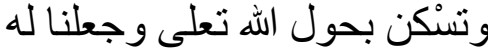

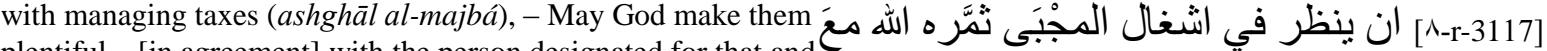
plentiful - [in agreement] with the person designated for that and in strictly setting their sum,

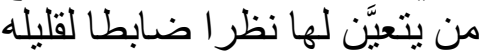

low or high, in order to make them increase and flourish. In this area, he should let no one decide alone without him on carrying out or stopping

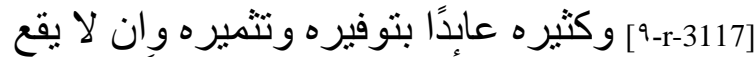
دونه انفر ادُ فيه بتتفير 991 أَّر او تو تون

an order, no sum should go out without him being informed and apprised, not without his having authorized the delivery

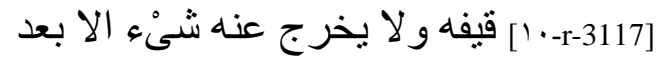

مطالعته وتعريفه و الاذن منه في اخر اجه

and expenditure needed for the common good. Thus, when, with the help of God on High, he arrives among you, submit

[1'-r-3117] بمقتضى المصلحة وتصريفه فاذا و افاكم بمعونة الله تعالى فانقادو اليْه ولهي

entirely to him, collaborate with him in the decisions he makes on his authority ( $\min$ al-isdâr wa-l-īrad) for the interests and resources of your

Land and in all the measures he takes to protect it against the part of corruption and violence, and to defend it against all

rebels and enemies, and to guarantee the security of its inhabitants, be they coming or going. Gage what privilege we grant you in him

who will have for you only just decisions and noble intentions. All his undertakings for you

will receive from us approval and praise, if God on High will it...

[r-r-3117] كل الانقباد وتعاونو ا معه على ما يتو لاه

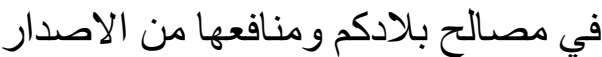

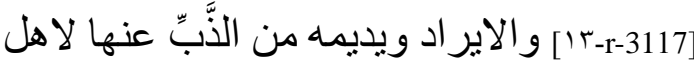

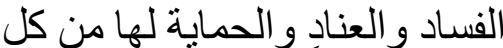

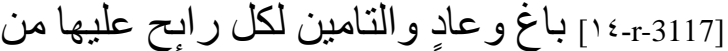

اهلهاو غَادٍ و اقدروا قدر ايثارنا عائا

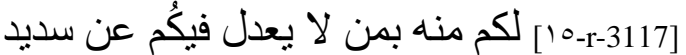

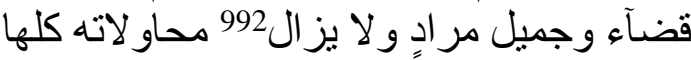

[17-r-3117 ] فيكم و اقعة منا موقع استتحسان و واحماد

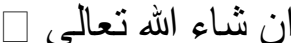

Taqdīm 18: Gubernatorial appointment (wālī), with fiscal and military attributions, along with an official responsible for the Treasury ${ }^{993}$

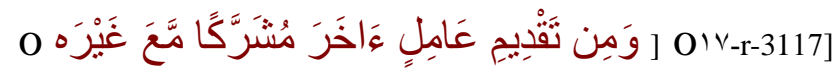

Excerpt from the appointment of another governor ( $' \bar{a} m i l)$ in association with a second

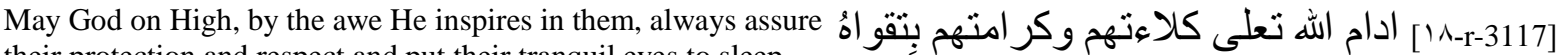
their protection and respect and put their tranquil eyes to sleep under the wing$$
\text { و انام عيونهم قريرة في كنف كنف }
$$

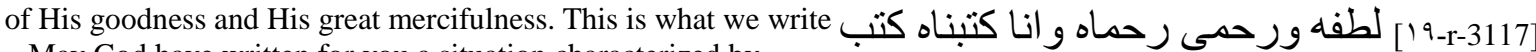

- May God have written for you a situation characterized by righteousness

991 'Azzāwī corrects with بتنفيذ.

992 'Azzāwī corrects with ول لا نز ال.

993 'Azzawī, NLA, t. 1, 442. 
and virtue, as well as the bestowal of His favor of the best of what is possible and permitted and the observation of

$$
\begin{aligned}
& \text { [ب-r-3117] لصَّلاح و استقبالا من فضله لاحسَن ما } \\
& \text { ييسر ويتاحُ } \square \text { و المحافظة من }
\end{aligned}
$$

the duties of your religion that will bring you closer to Him.

Know that the interests of your land come before others in the care

and attention (nazar) [that we grant], and that you can count on us to have in all circumstances the most widespread and complete

Protection. We also choose for you the governor who will purify your affair when he will take care of them. As a result,

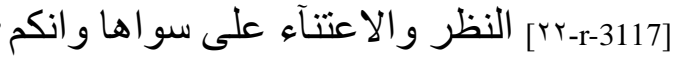

مُتمدون منا في كل احيانكم باتم الحياطة

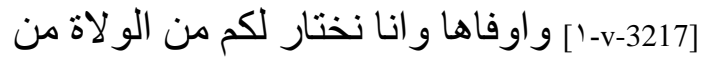

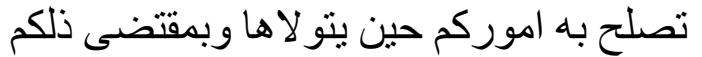

given the consideration [we have] for him, of the desire for absolute good [we have] for you and of the preference [we grant him], we have appointed Abū Fulān - May God continue

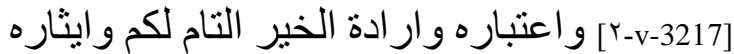

قدمنا الان لذلكم ابا فلان وصل

to grant him His aid and His assistance and assure him always respect and authority. He occupies a high rank among

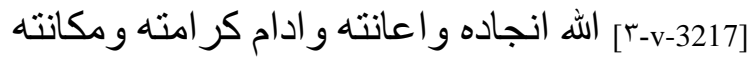

وهو المعلوم مكانه في وكي

those who work under our orders and who grew in our most prestigious services, those distinguished by

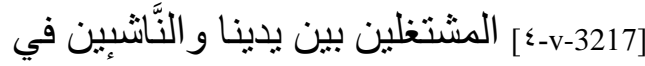

انبة-994 الخدم لدينا و المتميزين بمشكور

competence and aptitudes and characterized by their attachment to الاضطلا ع و الغناء و الموصوفين [0-v-3217]

religion in all their undertakings

بالوقوف مع اللّين في كل التحاو لات و

and plans. This is why we have entrusted him with the

responsibility for your land's interests and important affairs,

[-r-v-3217] و الانحآء ولذلكم اسندنا اليْه القيام

بمصالح تلكم البلاد ومهمَّاتِها و الانه الان

with the responsibility for the defense of its regions and districts, the management (nazar) of fiscal questions and

[Vت-v-3217]

و النظر في اعْمالها المخزنية ومر المرانية

revenues, taking care in managing all this, of the whole and its parts. We have advised him

[^-v-3217]

كلياتها وجز عياتها وو صنيناه

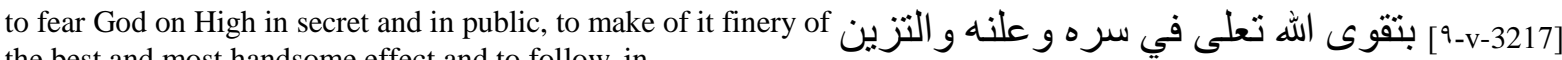
the best and most handsome effect and to follow, in

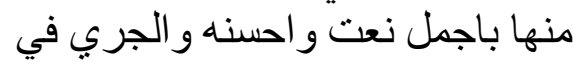

all circumstances, the path and road of the law. We have ordered him to be severe in eliminating corruption

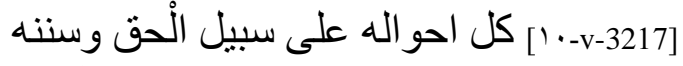
و امرناهُ ان يشتد في محقِي الفساد

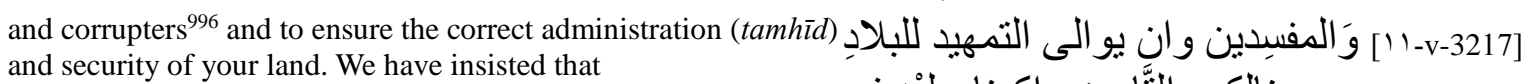

هنالكم و التَّامين و اكدنا عليْه في

he collect in full all duties due the Treasury (makhzan) - May God اقتضآء كل حق بجب r-v-3217] on high cause it to flourish - and that he demand of all those who owe

تعلى

و استيفابه و اخذ كل من ترثب

to pay in full. We have placed with him Abū Fulān to assist him in Treasury (makhzan) matters,

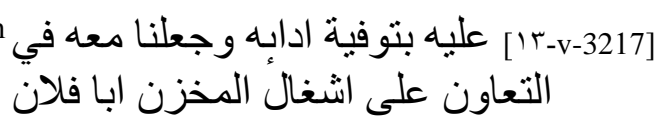

994 'Azzāwī corrects with أنبه.

995 'Azzāwī: المحاو لات.

996 Rather than the modern sense of "corruption", this refers to a more general meaning, at once moral, political, and religious. 
and, in order to do so, he should contribute his own counsel. The accord and collaboration between them will be a benefit to the Treasury (al-shaghl

al-makhzanī), no matter what the significance of the matter. Thus, when this governor, yours, arrives among you, welcome him with obedience and submission.

Give evidence of the willingness and haste that we will appreciate in paying all he is charged to collect. Act in accord with him

as one hand united, collaborating and helping him with all your will. Give thanks to God - May He be magnified and exalted -

for the means He has granted him to exercise just authority in your name (min sadìd al-īrādi wa-l-iș̣ârr). Have an ardent desire to set yourselves apart, in

all circumstances, with praiseworthy acts and good deeds, if God on High will it. And $\mathrm{He}$ - May $\mathrm{He}$ be glorified - He will give you happiness

through the bond of piety and awe [He inspires], ${ }^{998}$ and He will fasten your faith in the submission [you show] for Him, with a solid and strong rope. By His grace.

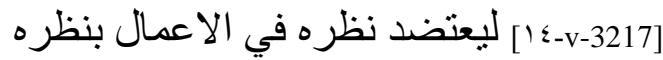
ويحسُن منها997 التو افق والتر افق في اقل الثخل

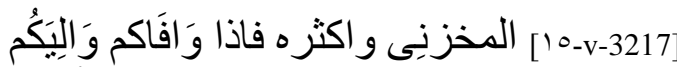
المذكور فتلقوه بالانقياد و الائْتمار

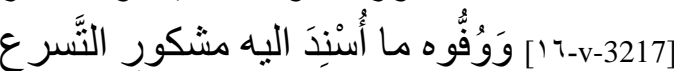
والابتدار واجروا في الكون معَه

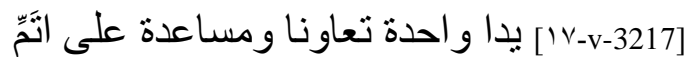

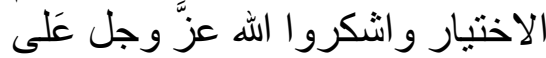

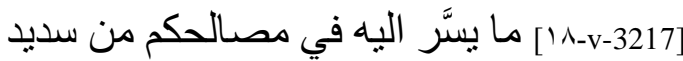

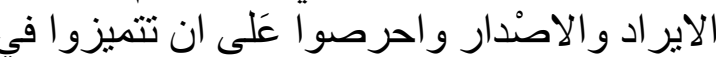

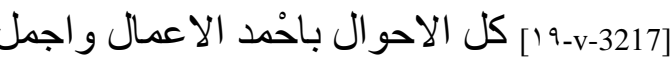

الاثار ان شاء الله تعلى وهو سبحانه بسعدكم

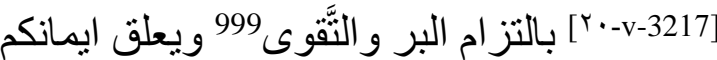

في طاعته بالسَّبب الامتن الاقوى بمنِّه

Taqdīm 19: Appointment of a governor with

fiscal and military attributions, and collaboration with the official (mushtaghil) of

\section{Fulāna $^{1000}$}

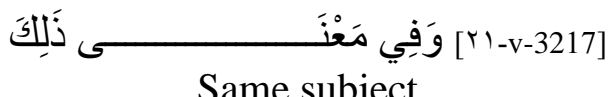

Same subject

...May God have written for you a better state that is to come (and accompanies your affairs) and a success that fulfills your hopes $(\ldots)$

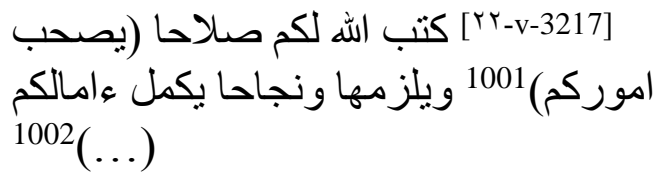

Know that our benevolent watch is one of the elements of the care we take for your lands at any moment, and the bearing we adopt on

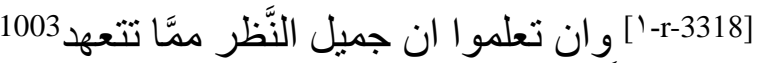

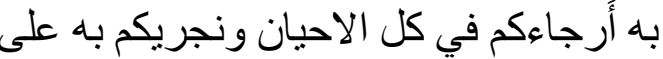

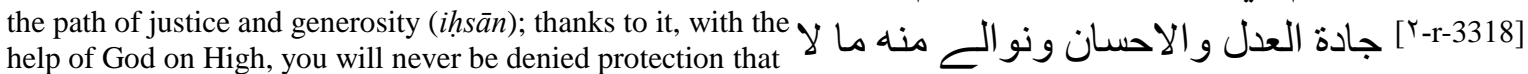

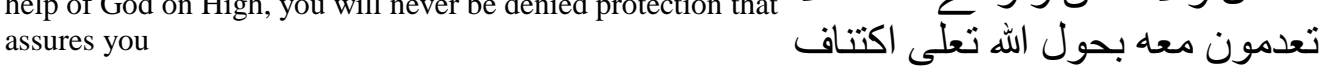

salvation and security. As demand our solicitude for you and the preference we have for advancing good and useful measures

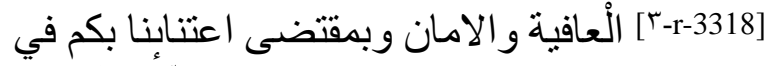

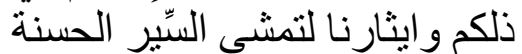

[- [-3318- هنالكم نختار لكم من يتولَّى اموركم ويحوط

خاصنكم وجمهوركم ويكف عنم لموري affairs, to defend you, the elite and the masses, to end your fears
997 'Azzāwī corrects with منهُ.

998 Reference to Koran 5:2: "Help ye one another in righteousness and piety, but help ye not one another in sin and rancour: fear God: for God is strict in punishment."

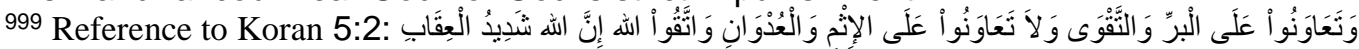

1000 'Azzāwī, NLA, t. 1, 443-444.

1001 Two unclear words, suggestion in brackets.

1002 Missing word.

1003 'Azzāwī corrects with نتعهـ. 
with the energy he will put to work. May God on High cause you to know the happiness of our decision for you, and may He bring together your deeds

and words in what is pleasing to Him. By His Grace. We have appointed Abū Fulān to take charge of your interests and important affairs, to totally protect

your regions, and to lead you in all time on the paths and road of righteousness. We praise

his behavior and his services. He is famous in the party of Unicity (tawhid) for the age of this worth. His radiance

and alliances with those close to this eminent power are remarkable. We have already experienced the quality of his initiatives in the [functions] entrusted

to him. He is known for his aptitudes and his competence in the projects he had under his responsibility. He will have

the management of affairs under his responsibility among you with the official of Fulāna, may he make

decision concerning them only with him. We already advised him to fear God on High in all his deeds and to fear

Him in secret and in public; to endeavor to manage your interests and to always protect your regions,

near and far. We have firmly ordered him to use the greatest severity to submit the partisans

of evil and corruption, to cut off the evils who led them astray off the paths of righteousness, to

disperse them, after having punished those who deserve it, far from your country which is a land of the faithful

in religion and virtue ${ }^{1006}$, to take measures against those who lead astray with their vile actions, and, if they

do not enter back into the path of righteousness, to take them into exile, into wandering, far from your country, so that it will be completely

delivered from their evil deeds and protected from their nefarious actions. May he bring together all his forces ${ }^{1007}$ with zeal

to carry out our orders, and proceed along the clearest and most luminous path in what he is charged with and may he scrupulously respect

our advice in all that he undertakes. We have insisted that in the management [0-r-3318] بما بعمله من الانهاض محذوركم و الله تعلى في

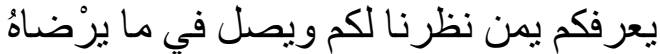

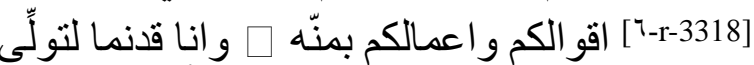

مصالحكم ومهمَّاتكم و الْحياطة الْهم التامة

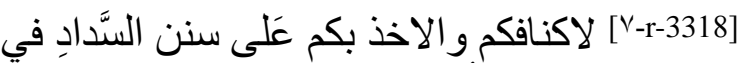

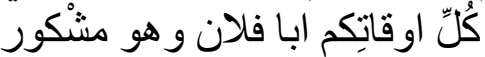

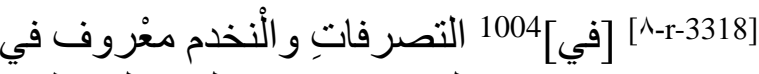

حزب التوحبد برسوخ القدم ملحوظ الا

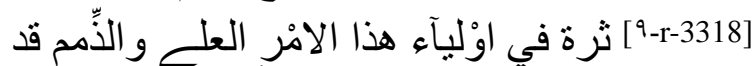

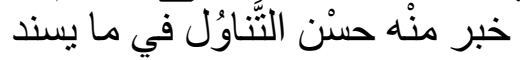

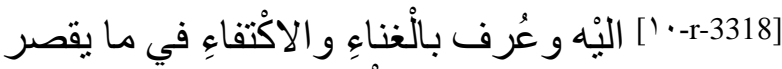

من الْمحاو لات عليه وجعلنا لاعله ماعله

[-r-3318-' النَّظر مع مشتخل فلانَة في الاشغال الته

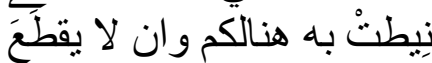

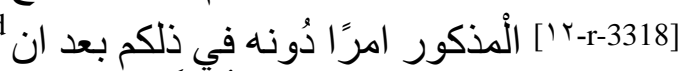

وصنَّنْاهُ بتقوى الله تَعلى في كُلّ أَمره و المرا

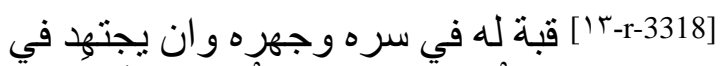

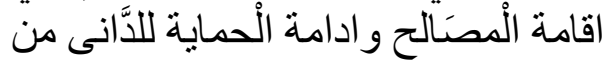

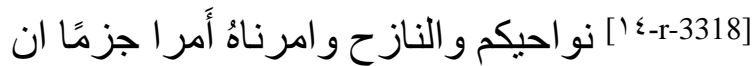

يعمل اتم الاشتداد في قمع اهْل آنراه

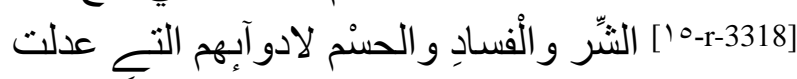

بهم عن طرق السَّداد وان

[17-r-3318] بَثَرْدَدهُهْ بعد عقاب من بستحق ذللكَ منْهم

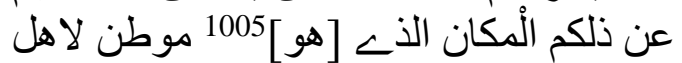

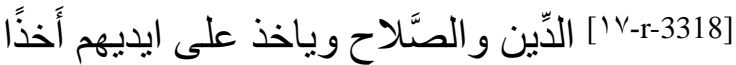

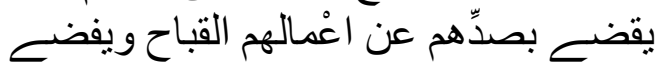

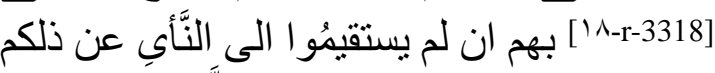

القطر و الانتز اح حنَّى ينقِى بالكلية

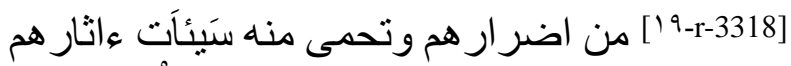

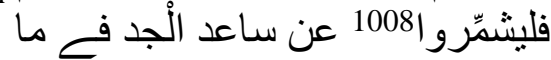

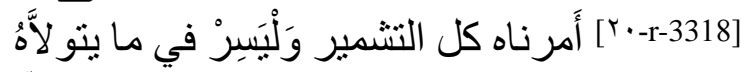

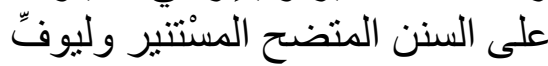

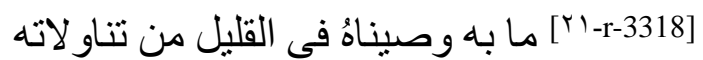

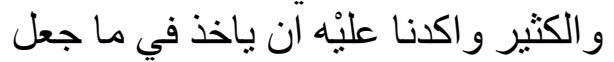

1004 Addition by 'Azzāwī.

1005 Correction by 'Azzāwī.

1006 'Azzāwī suggests this could be Fez, since al-Marrākushī refers to it this way (Mu jib, 357-358).

1007 Lit. "that he roll up his clothing completely."

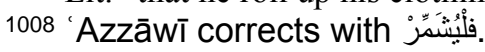


whose responsibility he shares, he act with a rigor that tolerate no slackening, and the collaboration with the assistant

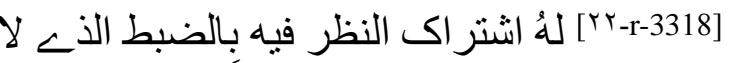

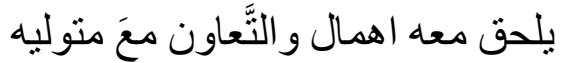

he is associated with, so that the measures he takes not be in excess $(. . .)^{1009}$ Thus, when, with the help of God on High, he arrives

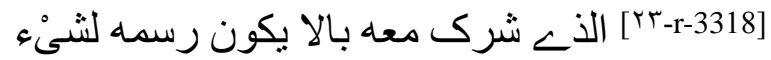

among you, submit to him perfectly, obey the reason and righteousness towards which he will take you and be

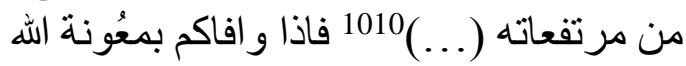

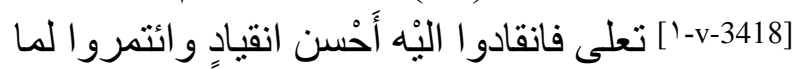

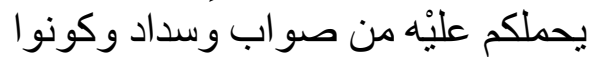

like one hand united with the authority ( $m i n$ ișdar wa $\overline{\text { r }} \bar{a} d_{\text {in }}$ ) that he will carry out in your interest, if God on High wills it. And $\mathrm{He}$

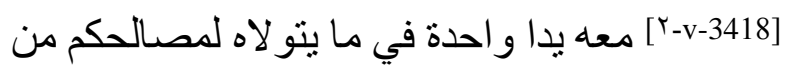

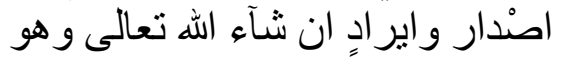

- May He be glorified - He will bring together your requests in the awe He inspires in you and He will cause... [agree] with what He loves and approves... By His grace.

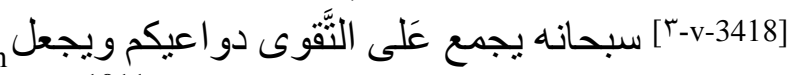
في ما يحب ويرضى (. . . 1011 بمنه

Taqdīm 20: Delegation decree to maintain

Fulān (mushtaghil or 'āmil ?) in his post, with

military attributions. Fulān, an Almohad

notable, is to serve alongside him, to work with

\section{him in repairing the walls ${ }^{1012}$}

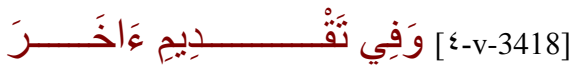

Another appointment

...May God always assure them respect through the awe He inspired in them, and may He spread over them the shadows of His favor and mercifulness. May God have enrolled you among the first whom His will guides and assists, and for whom he redoubles His grace and

Gifts. May He grant you His abundant benefactions and His kind favors, that you will never see cease to increase, nor cease

to multiply. Know that we take care of your affairs, in particular and in general, that we always give

your interests more room in our concerns and that we welcome you at all times with total and

absolute benevolence. Indeed, we want for your land and all of you the uninterrupted improvement of your situation, we

prefer to treat you according to the paths of forbearance and moderation and we give those responsible for

your taxes and finances explicit advise to manage your affairs well and to perfectly defend your regions. May God on High guarantee you [0-v-3418] ادام الله كر امتهم بتقو اهُ و أَفاض عليهم ظلانل نعماهُ ور حْمَاهُ كتبكُم الله من الهُ الذين

[?-v-3418 سبقت بتوفيقهم وارشادهم ار ادته و تضاعفت

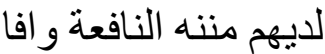

[V-v-3418 دته و انالكم من خير اته الْجزيلة و الطافه منه

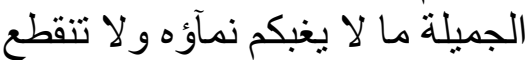

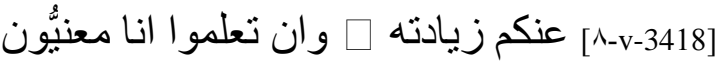

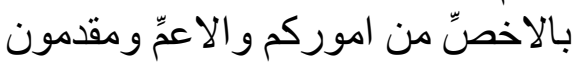

[9-v-3418] من مصالحكم للاهمّ فالا هم و مستقبلون لكم

في كل الاحْبِن من جمبل النظر

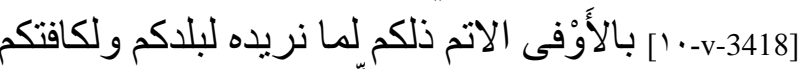

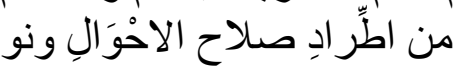

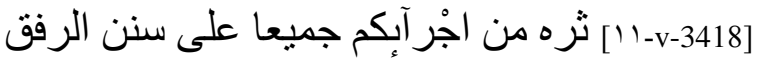

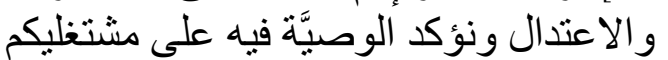

[Yr-v-3418] و عمالكم من تمشية مهمَّاتكم وحياطة

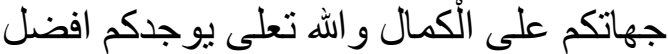

1009 Or possibly: "so that none of the measure he takes regarding his surplus be..."

1010 One or two illegible words.

1011 Two words erased.

1012 'Azzāwī, NLA, t. 1, 445-446. 
the security and tranquility that we desire for you, the best there is, and may $\mathrm{He}$ aid us in assuring your lands well-being and profits,

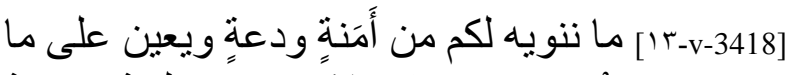

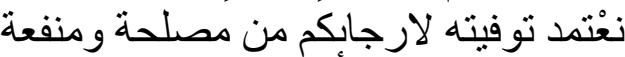

by His grace. This is why - May God honor you by the awe $\mathrm{He}$ inspires in you and may He fasten your faith to His guidance with the strongest of ties -,

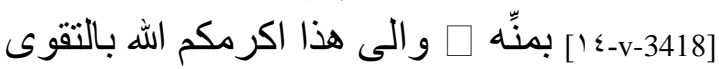

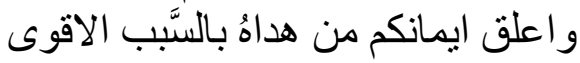

we have issued a delegation decree (rasm al-niyāba $)^{1013}$ to

keep Fulān in his post among you, thus choosing the

qualification [given him by] (tanāwulāt)

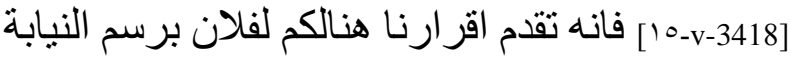

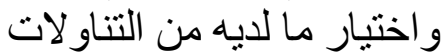

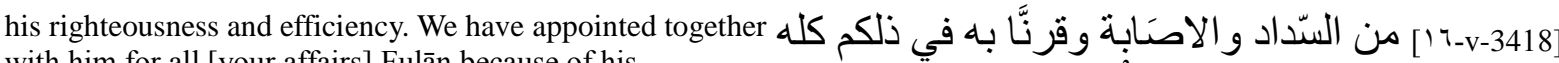
with him for all [your affairs] Fulān because of his prestigious rank in the community (tô 'ifa) of Unicity فلانا لمكانه المكين في طآنفة التوحيد (tawhid)

and his faithfulness on his ancestors' just and righteous path. Our choice is confirmed by what both have produced together

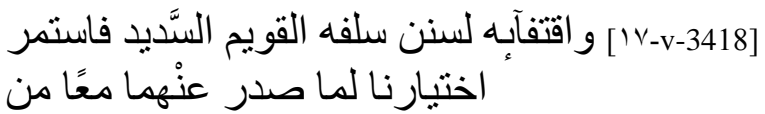

in their just undertakings and righteous administration, while ll1-v-3418] their sense of responsibilities

in these [financial] matters and their competence (ghanā'uhumā) in making your regions pleasing and correctly managing your situations are manifest.

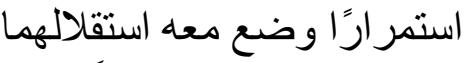

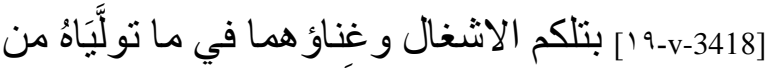

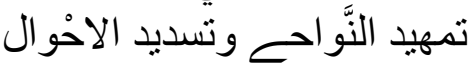

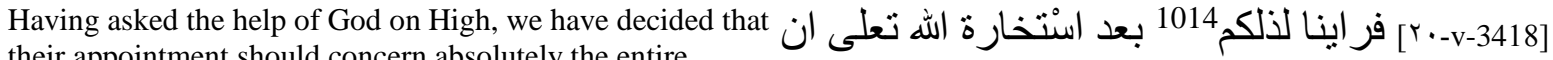
their appointment should concern absolutely the entire

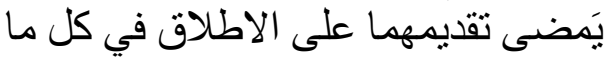

management of your affairs and interests with which they had previously been entrusted. We publicly declare that they have

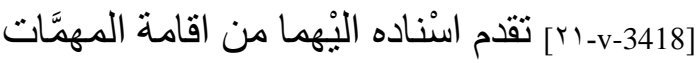

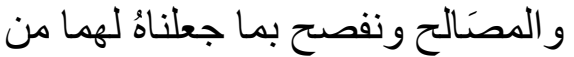

full liberty in defending your land [and its regions] near and far, and in protecting its populations, be they coming

[rr-v-3418] الاستبداد في حياطة الذَّانى من تلكم الْبلاد

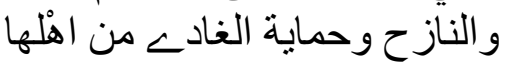

or going, with the clause that they must be united and not disagree, that they should consult each other and work together on what your [land's] interests

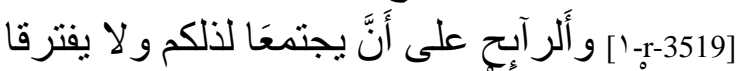

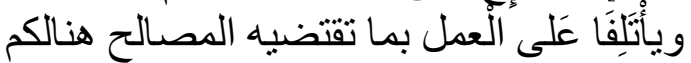

[2519-r-35] ويتفقا ويديما من الْخدمة و النصيحة ما يكون Demand and their services and counsel constantly assure you coherent order.

We have communicated this to them, to them and you, so they know we expect them to defend and protect your districts,

and we have enrolled them to do all that is necessary to watch over and guard them. We have ordered them to be good

in their seriousness and efforts, to accomplish in full [our] plans and [our] goals for the security and tranquility of

the population, and to have absolute care for all that will make your situations pure and just. We have advised them

to fear God in exercising authority ( $f \grave{i}$ ișdār wa-l-īrad), to devote themselves without ceasing day and night (yașilā...

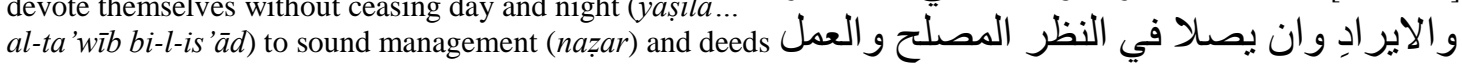

به نظام الامور لديكم مثَّقا

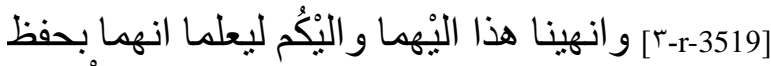

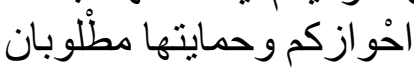

[-3519-3 ـ الى بلوغ الغاية في حر استها ور عايتها

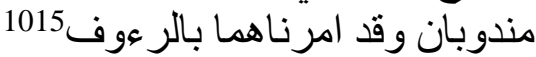

[o-r-3519] عَلى الجد و الاجتهادِ و الوفآَ في تامين

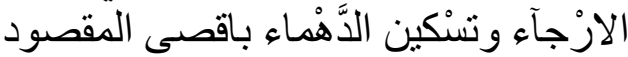

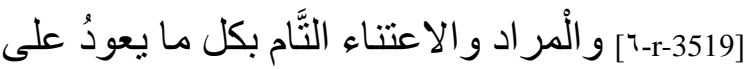

احو الكم بالصَّلاح و السَّداد وو صنينا

[ هما باستشعار تقوى الله في الاصندار

1013 Sole occurrence of the term niyāba, with the unfinished form of taqdīm 26: وينوب احمد مناب.

1014 'Azzāwī: بذإنك.

1015 'Azzāwī: بالرؤوف. 

of clear and evident success. We have insisted that they build 1016 البيّن نجاحه المتضح التاويب بالاسئادئم-r-3519]
the missing parts of your

$$
\text { و اكدنا عليهما في بنآه ما بحتاج الى }
$$

city (baladi-kum) walls, which surround its palm groves and protect its inhabitants from attack on its borders, that they take responsibility

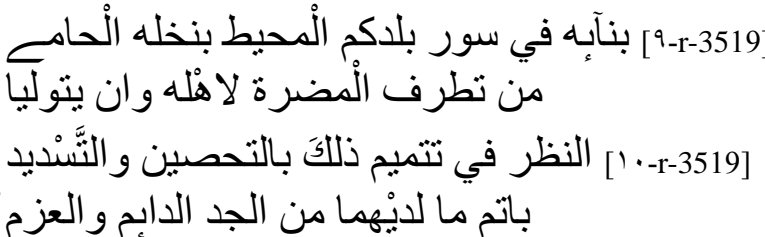

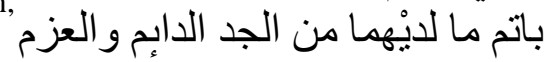

for watching over the final completion of these fortifications and defenses, with all the fierceness and persistence they can,

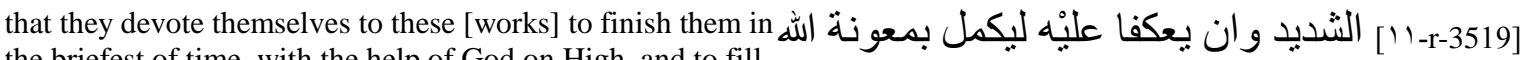
the briefest of time, with the help of God on High, and to fill in

تعالى في الاهْر 1017 القريب وينحم

the fortifications' breaches by raising and barricading them. Our explicit order on this has been communicated to the governor ( 'àmil)

[r-r-3519] امرنا الجزم في ذللكَ للْعَامل

- May God assist him - so that he hasten the works, with the help of God, and immediately carry out [our] instructions.

For that and the rest, collaborate with your two leaders in a way that benefits you.

Act with them as one hand united in all that brings about felicitous results

and whose success will echo back handsomely. Enter into these works for this world and the next with security and serenity. Carry out for your leaders (wulāti-kum)

all that will bring praises upon you for your obedience and submission. Be certain that our guarantee, with the grace of

God on High, places you in the bed of justice and benevolence and grants you abundant shares and favors.

We spread over you a thick shadow ${ }^{1020}$ to [assure you] salvation and security. The demands of these our intentions will produce shining work,

with the force and strength of God, and our will as our affection for you imposes and demands. We ask of God

- May He be exalted and magnified - to ease the accomplishment of these projects we consider, and to always help and assist us

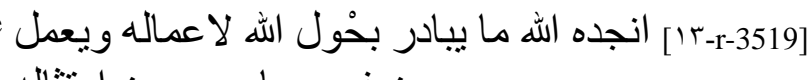
من فوره ما بججب من امنثاله

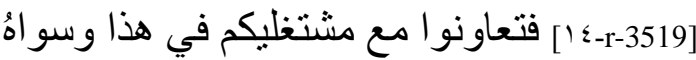

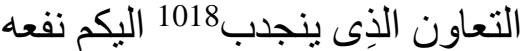

[10-r-3519] وكونو ا معهم يدا و احدة على كل ما بجمل

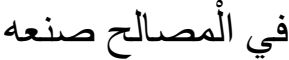

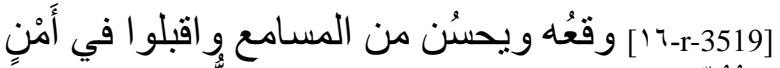

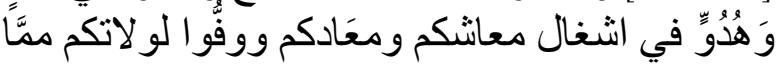

[IV-r-3519] تشكرون عليْه من ائتمار كم و انقيادكم

وكونُوْا على يقين من ان كفالتنا لكُم بمن

[1/N-r-3519] الله تعلى تبونئكم مهاد الْعَدل و الاحسان

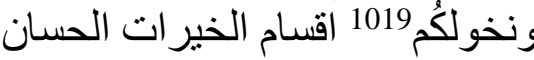

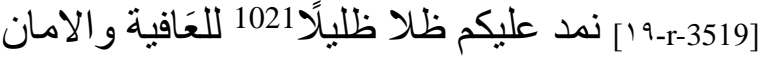

هذه نيتنا التخ بَيَرز العدل بحول الله

[r-3519-r-r] وقوته في مقتضـاها وار ادتتا الته اوجبها

حنانتا عليكم و اقتضاها ونسئل 1022

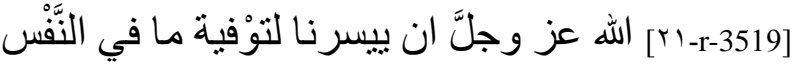

من ذلكم وان يمدنا بتاييده و انجاده

in accomplishing what will cause you to know peace (alsalāh) now and in the future and to assign us on His behalf an assistant

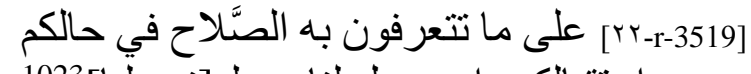

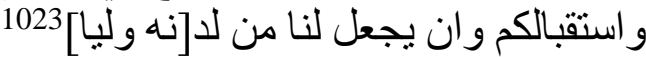

1016 ‘Azzāwī بالاسناد

1017 'Azzāwī corrects with الأمد 'Azzầ.

1018 'Azzāwī corrects with ينجذب

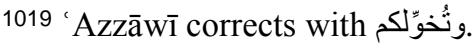

1020 Reference to Koran 4:57: "We shall admit them to shades, cool and ever deepening."

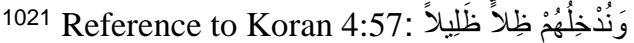

1022 'Azzāwī: ونسأل

${ }^{1023}$ A corner of the manuscript is torn. 'Azzāwī probably completed it using the Koranic citation without mentioning it. 
and protector ${ }^{1024}$ to defend you with justice and to be your bondsman for the goodness, will and assistance of God.

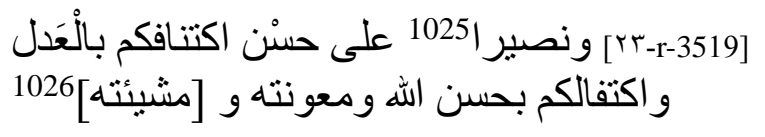

[-v-3619- فهو القادر على ذلكم لا رب سواهُ و هو

سبحانه يبسط باتصال العافية

[r-v-3619] عامالكم ويجعل ما يقربكم اليْه اقو الكم

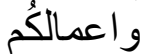

Taqdīm 21: Appointment of a military governor (qâ'’id) in a border zone, with fiscal and military attributions ${ }^{1027}$

Appointment of a military governor

...May God have written for you help and union for the well-being of your interests, haste for that which will lead you to

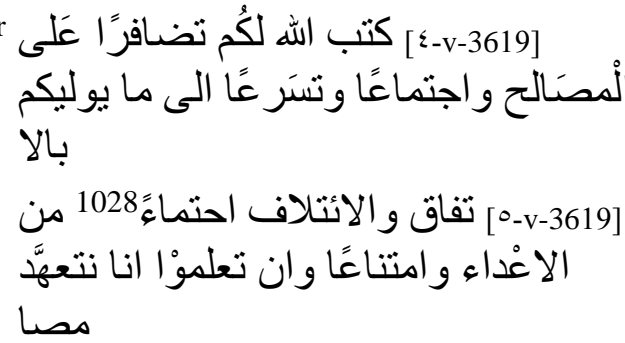

(mașālih) of your land (bilād). We look after the things that improve what is apparent and what is hidden. We take great care in

[7-v-3619 ] لح بلادكم الاونة ونعتنى بما

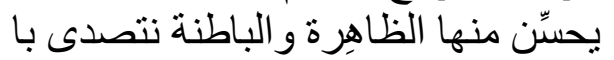

consolidating its fragile situation. This is why we have chosen the most courageous and

[V-v-3619] قصنَى النظر لما يقوى احو الها

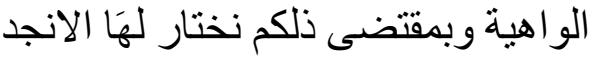

[^-v-3619] و الامجد من خدمآنائا ونعطيها

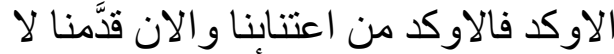

have appointed

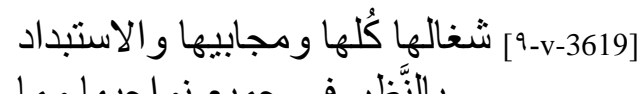

Fulān to take charge of its taxes (majābi-hā) and all its finances (ashghāli$h \bar{a})$, and to lead alone all its regions, with

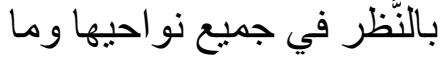

their dependencies, near or far. In the party of Unicity (tawhīd), he enjoys

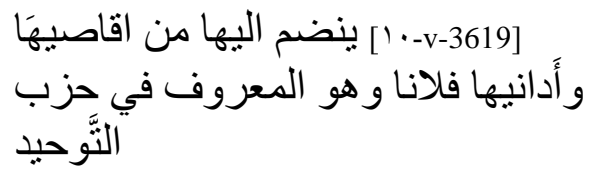

a reputable rank and lineage; he occupies the first place and highest dignity $\left(\right.$ rutbat $\left.^{a n}\right)$ among familiars (al-awliya $\left.\bar{a}^{\prime}\right)$ and protectors (zahīr, pl. zuharā'). We are thankful

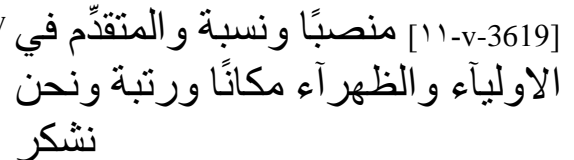

\footnotetext{
1024 Reference to Koran 4:75: "and raise for us from thee one who will protect; and raise for us from thee one who will help."

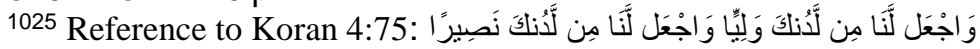

1026 Lower lefty corner ripped. 'Azzāwī's proposal is either a hypothesis or a sign that the manuscript has deteriorated since he consulted it.

1027 'Azzāwī, NLA, t. 1, 447.

1028 'Azzāwī: احتماءl.
} 
for the commendable competence ( ghana ') he has shown in many contexts, as well as the justice of opinions he has given in [diverse] endeavors ( $f$ imuhāâwalāt)

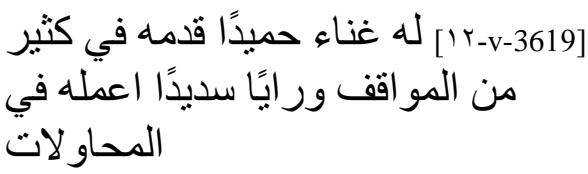

like a seasoned expert. This is why we have chosen him to lead the armies and flush out the perfidious enemy, ${ }^{1029}$

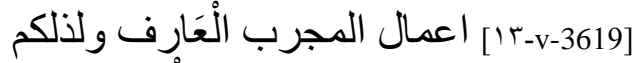
اخترناهُ لقودِ العسَاكِر وطلب الْعدو الغادر

and we have entrusted him with the responsibility for your land: [we have chosen him] to reassure those who are scared, to eliminate dangerous places (makhäwif), to lock down

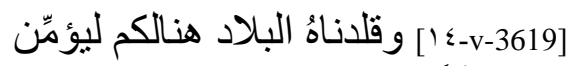

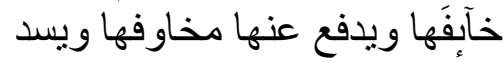

the borders, calm those who tremble, cut away evil with the sword, to root out rebels

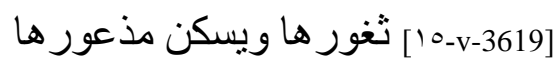

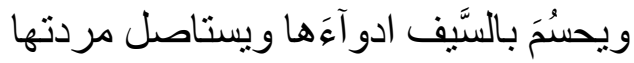

and enemies, and thus, with the help and strength of God, bring it back to security and tranquility (hudūni-ha). With

[ [ته-v-3619

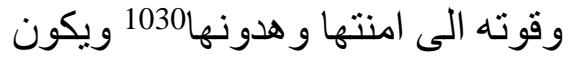

God on High's will and His help, he will be a veil (hijāb) that protects it. This is all in agreement with God on High's plans

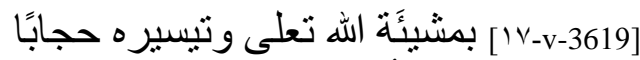

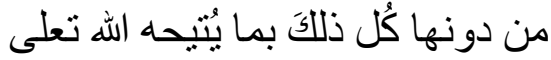

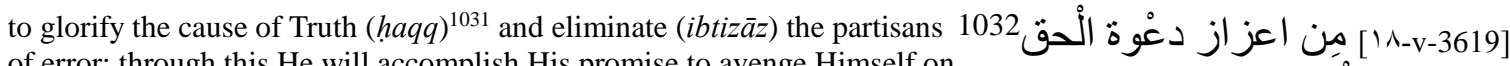
of error; through this He will accomplish His promise to avenge Himself on the impious

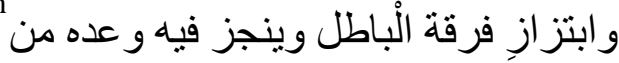

انتقامه بكفرة عده من

who deny His power that leads in the most just of directions.Thus, when you receive our letter, be with your venerated governor

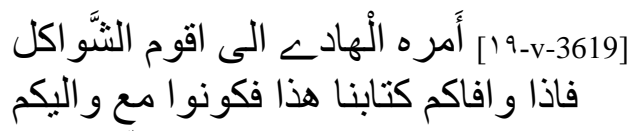

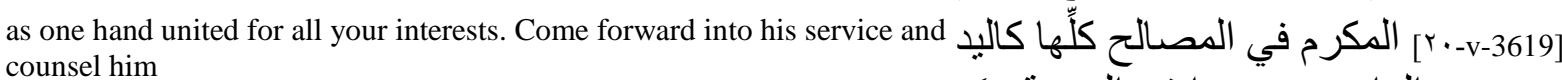

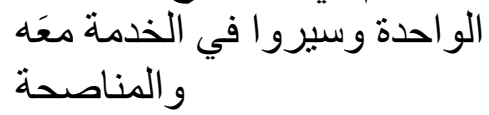

according to the path of mutual and reciprocal harmony. Believe in a victory that will annihilate the corruptors and destroy

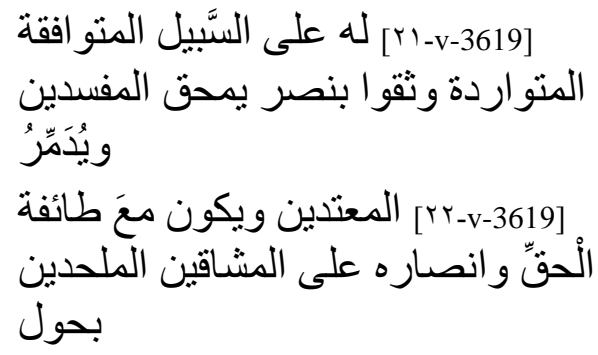

the aggressors; [a victory] that will be with the party of Truth and its helpers over dissident deviants (mushāqqīn) by the strength of

God on High. Our watch (nazaru-nā) stays with you, continuous despite the distance, and our help for your land stretches out

$$
\begin{aligned}
& \text { [-3720-3 ] الله تعلى ونظرنا مع ذلكم مثتابع } \\
& \text { معَ الاناء و امدادنا للبلاد مو افت لها لها }
\end{aligned}
$$

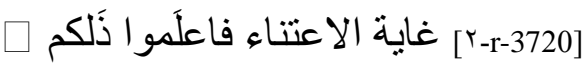

to it with extreme care. Know that...

1029 A. 'Azzāwī suggests this may refer to the Marinids, but it is not clear which region they would have threatened. Perhaps, Salé, one of the tribes, or Sijilmāssa?

1030 Probably a confusion between hudūì-hā ("calm", "security", cf 20r, 37, I. 9) and hudna, pl. hudunihā ("truce"). Abdallah Cheikh-Moussa generously contributed to this reading.

1031 Koran 13:14 : "For Him (alone) is prayer in Truth: any others that they call upon besides Him hear them no more than if they were to stretch forth their hands for water to reach their mouths but it reaches them not: for the prayer of those without Faith is nothing but (futile) wandering (in the mind)." 1032 Koran 13:14:

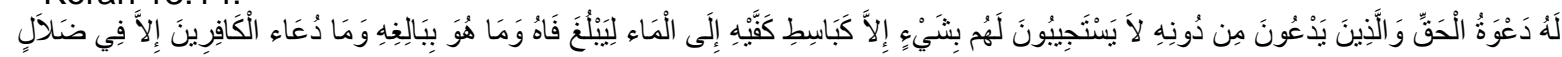


Taqdīm 22: Appointment of a governor (wālī) with fiscal and military attributions. An army accompanies the governor to bring order back to this southern region ${ }^{1033}$<smiles>[14CH3][14CH2][14CH2][14CH2][14CH2][14CH2][14CH]=O</smiles>

\section{Another appointment}

May God have written for you to know righteous and just situations and to find the familiar and usual

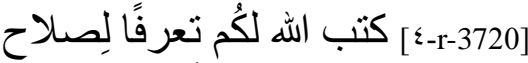

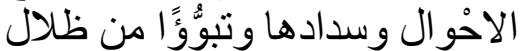

$$
\begin{aligned}
& \text { الْعافية }
\end{aligned}
$$

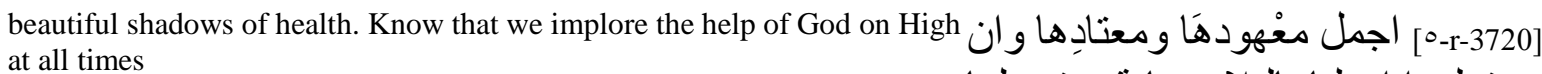

تعلمو ا ان لنا بالبلاد عناية نستمد لهانيا

for the care we bring to the land, [care] that allows us to obtain rapid success for all the efforts we dispense;

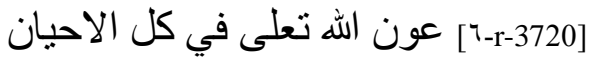

ونستنجز 1034 منها ما نبذل فيها في فيه غاية الاحية الامكان

we act in its defense and for its protection against rebels and aggressors, and we choose from among brave

and capable men those who will defend it by striking with the sword and severity and will gently lead its subjects

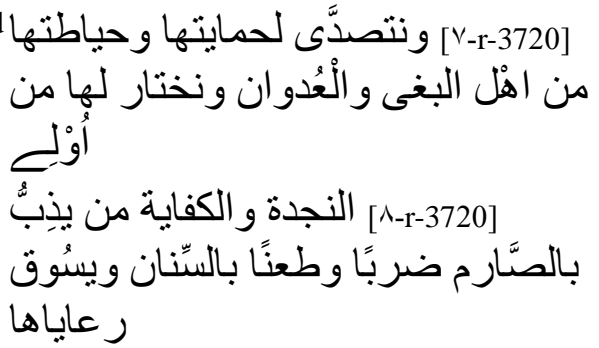

towards the peace and security they have known at the side of this eminent power. As a result,

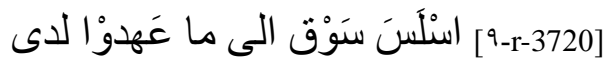

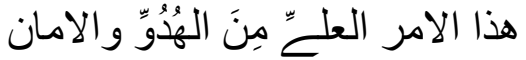
وبمقتضى و والمني

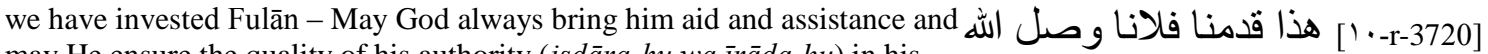
may He ensure the quality of his authority (ișdâra-hu wa îrāda-hu) in his endeavors (muhāwalāt). اعانته و انجاده وحسَّن في المحاو لات أنات

اصداره

He is someone whose competence was manifest in the important functions [he carried out] and whose initiatives have produced actions

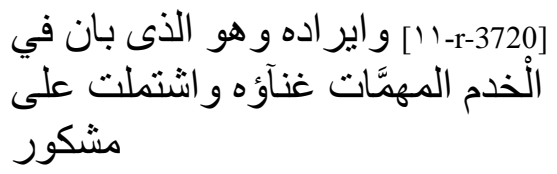

worthy of praise. We have entrusted him with the reins of this southern land ${ }^{1035}$ and the complete management

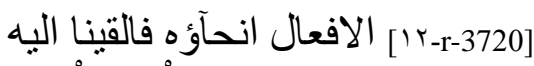

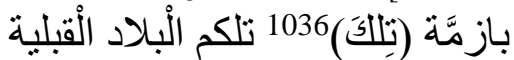

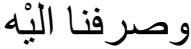

1033 'Azzāwī, NLA, t. 1, 448.

1034 'Azzāwī: ونستنتئ.

1035 'Azzāwī suggests Dar'a or Sijilmāssa.

1036 Removed by 'Azzāwī because of the repetition. 
of its finances (ashghāla-hā), its taxes (majābi-hā), its interests (mașālihi$h \bar{a})$, and its important affairs (muhimmati-hā). Despite the distance, he can count on the help our watch

will bring him to place him, with the aid of God on High, on the clear and obvious path.

For all of this, we have advised him to fear God on High, oh what perfect counsel! We have ordered him to

bring the population of your land back to the obedience ${ }^{1038}$ that gave happiness to the believers

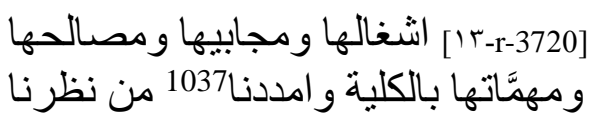
الذن ن ن ن

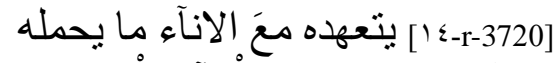

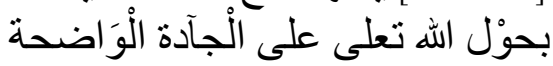
الجلية

[10-r-3720]

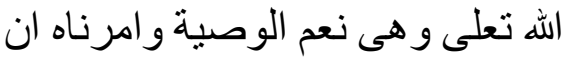

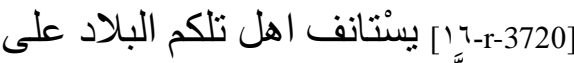

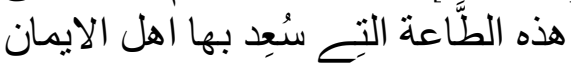

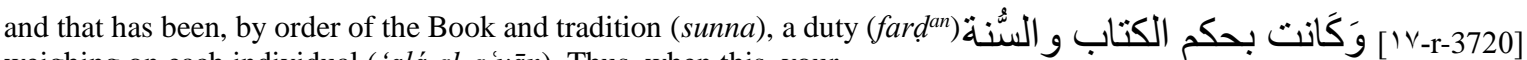
weighing on each individual ( 'alá al-a'yān). Thus, when this, your respected governor, arrives

فرضنًا على الاعْيان فاذا و افاكم وَرالَّيكم

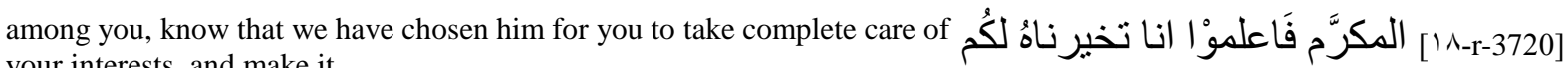
your interests, and make it

ليقيم مصالحكم على الاطلاق وياخذكم فئم

so that you would hasten to run to us. Be with him as one hand united to chase the rebels

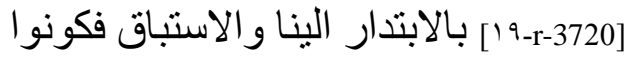
يدًا و احدة على ما بذود عن البلادِ البد

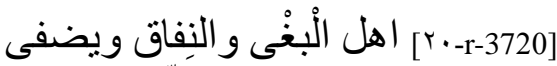

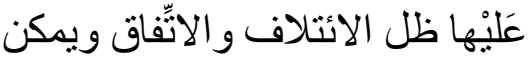

and hypocrites from the land, so that the shadow of union and accord will spread over it and to strengthen

the ties of attachment and friendship. On our orders, he will be accompanied by a mighty army with which he will tread

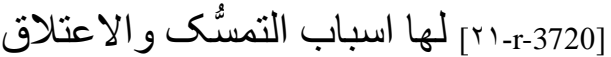

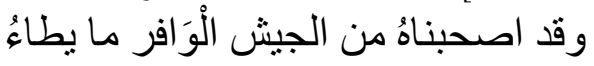

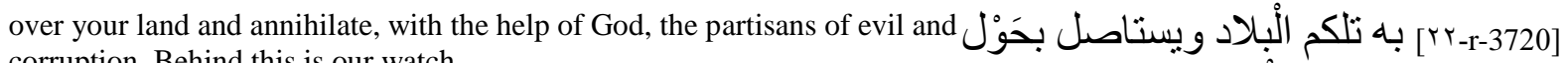
corruption. Behind this is our watch

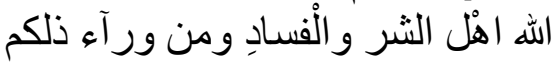
نظر نا

that we spread over your countries to ensure them security, tranquility and permanent peace:

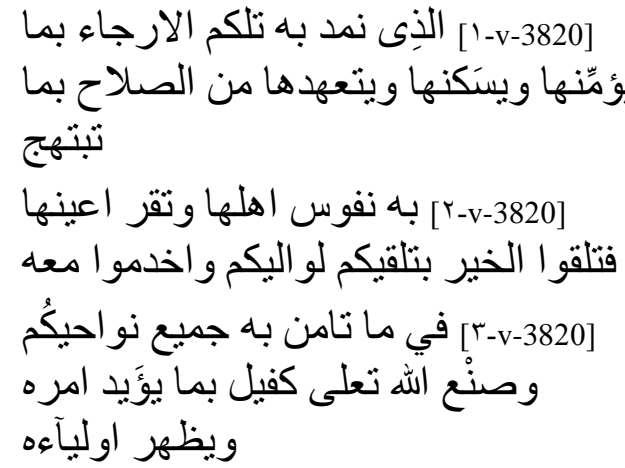

$$
\text { ويظهر اولبآهه }
$$

the inhabitants will then be gleeful and their eyes will rejoice. Thus, you welcome happiness in welcoming your governor. Work with him

for all that will bring security to your regions. The action of God on High guarantees that which will strengthen His power and give victory to His familiars,

1037 'Azzāwī corrects with و أمدناه.

1038 'Azzāwī suggests this refers to one of the many revolts in Sijilmāssa during the reigns of al-Rashīd, al-Sa'îd or al-Murtaḍa (sic!). He evokes in particular the revolt of 632-634/1234-1237, as well as the secession of the Ma 'qil and Yayghaz Arabs near the region of Dar ${ }^{\circ}$ a on the occasion of al-Sa ' $\overline{1} d$ 's rise to power. That revolt led to the caliph's personal intervention. The last revolt was led by Muḥammad al-Qațrānī allied with the Ma 'qil Arabs in $655-656 / 1257-1258$. 
and His aid - May He be glorified - is the help we beseech to raise His word and increase His glory. ${ }^{1039} \mathrm{Be}$

certain of that and take the straightest path in your speech and actions, if God on High wills it...

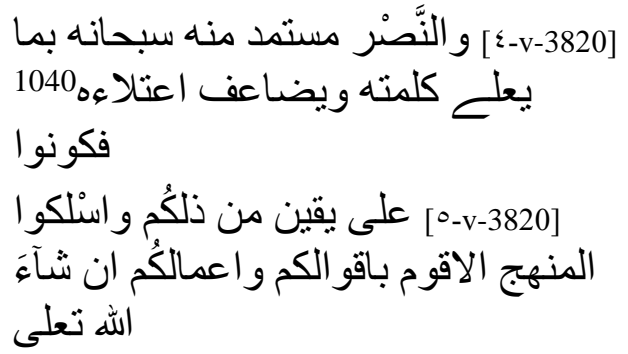

Taqdīm 23: Appointment of Fulān as governor, with military attributes. ${ }^{1041}$

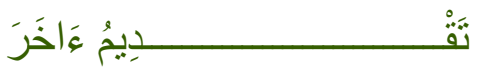

Another appointment

May God on High have written for you efforts that carry you to sublime actions and roots that reach down with you into a friendship

worthy of praise. Know that the first thing the well-content hastened to and that confirmed the direction of salvation

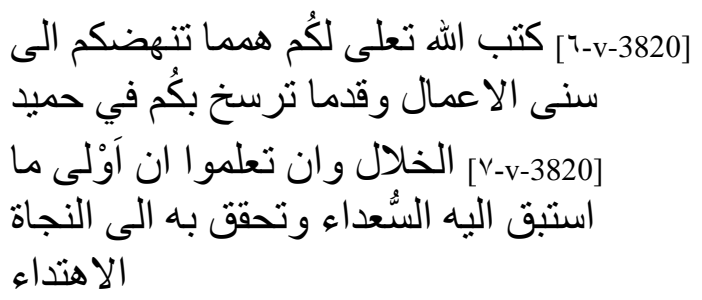

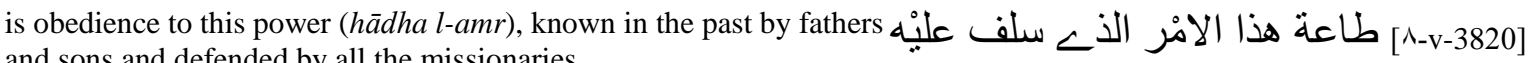
and sons and defended by all the missionaries

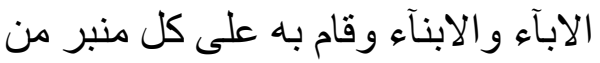

and preachers from the tops of the pulpits of Islam. We have been informed of your services and your faithfulness to the familiars [of this power],

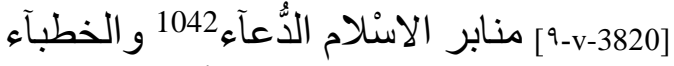
وقد اتصل من خدمتكم لاوليآنه وملاز منتكم

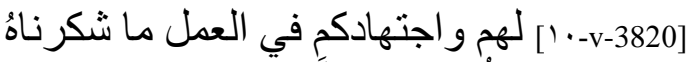

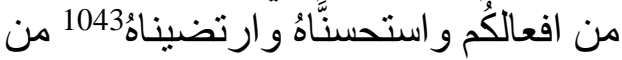
that we deeply recognize

and appreciate. Persevere in that and you will obtain from this power (hädha l-amr) abundant kindness

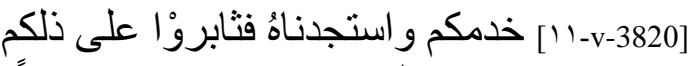

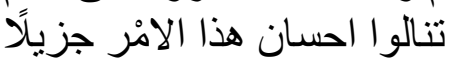

and you will find at its sides benevolent $\left(j a m \bar{l}^{a n}\right)$ attention. We have decided to appoint Fulān - May God continue to grant him His strength

[ r-v-3820] اقتضى نظرنا تقديم فلان وصل الله عزته

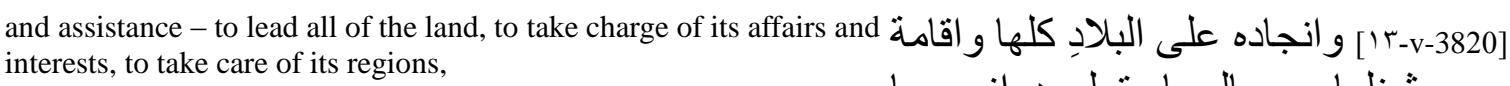

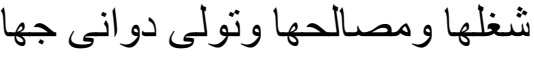

near and far, and do all that is necessary for the security [of travelers] who come and go there. Be with him and all

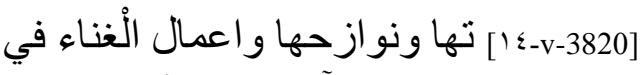

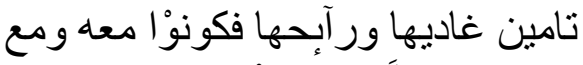

of his troops as one hand united to push back the party of revolt and rebellion and to exterminate

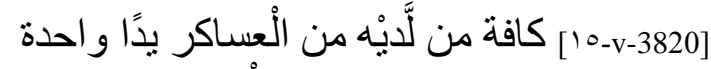

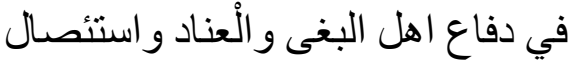

1039 Reference to Koran 9:40: "But the word of God is exalted to the heights: for God is Exalted in might, Wise."

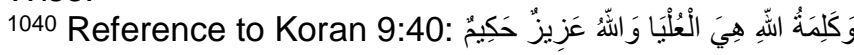

1041 'Azzāwī, NLA, t. 1, 449.

1042 Probably an error on the part of the copyist for الذُّناة, the final tā' marbūṭa being replaced with hamza.

1043 'Azzāwī: وارتضياه. 
the partisans of evil and corruption. We count on your seriousness, your efforts and the useful counsel [that you will be able to give], [the tidings]

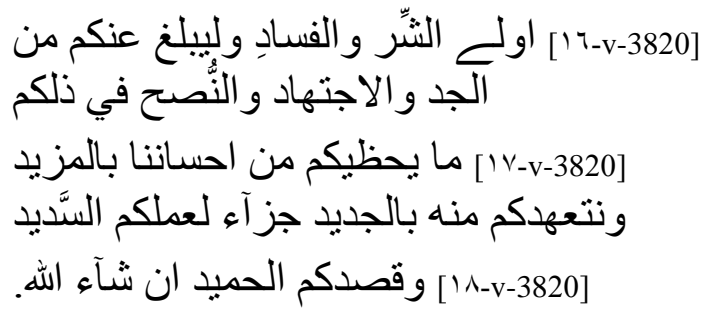

Taqdīm 24: Appointment of a governor, probably in Tinmā $1^{1044}$

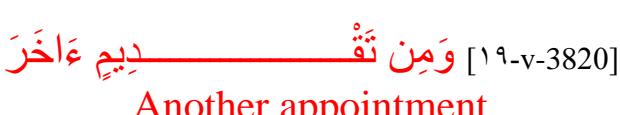

Another appointment

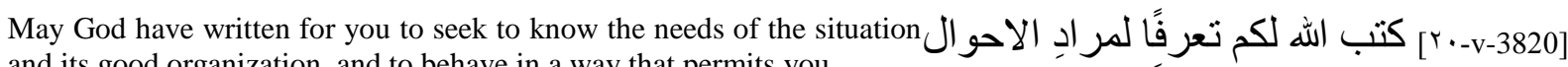
and its good organization, and to behave in a way that permits you

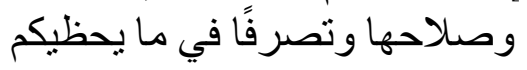

to easily realize [your] hopes. Know that of this city (...)

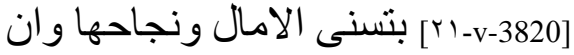

$$
\begin{aligned}
& \text { تعلمو ا ان تلكم المدينة (. . 1045) }
\end{aligned}
$$

we must take care, passing its interests before those of the rest of the districts $\left(\operatorname{arj} \bar{a}^{\prime}\right)$ and

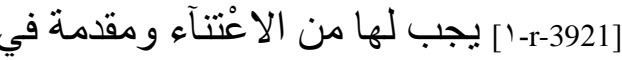

$$
\begin{aligned}
& \text { تمشية مصالحها على سَآدر الاقطار }
\end{aligned}
$$

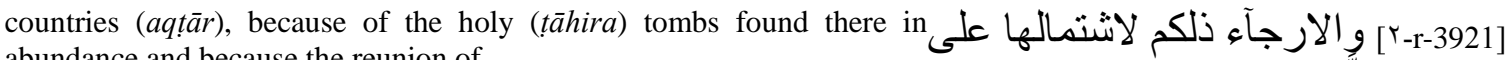
abundance and because the reunion of

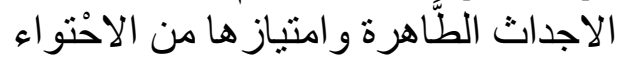

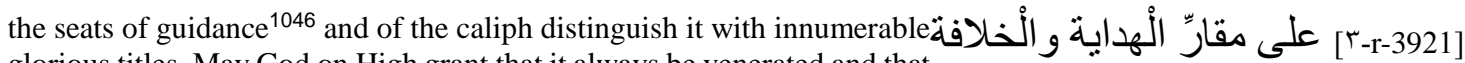
glorious titles. May God on High grant that it always be venerated and that it bring

$$
\begin{aligned}
& \text { بالمفاخر المكاثرة وصل الله تعلى لنا } 1047
\end{aligned}
$$

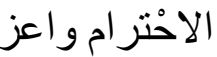

honor to His assistance to he who settled there before Islam. This is why بنصر من حلها قبل الاسلام و الى we have chosen Abū Fulān, so that by this act

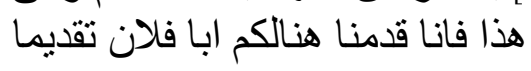

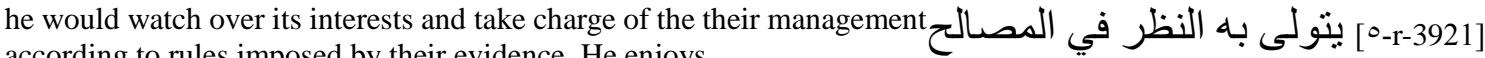
according to rules imposed by their evidence. He enjoys,

$$
\text { و الجرى في اقامتها على السنن الؤاضح وليه }
$$

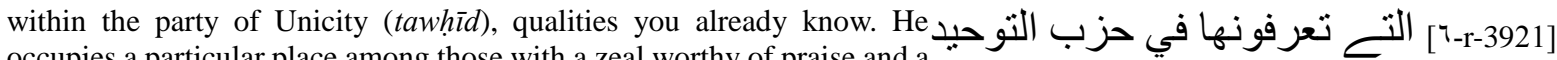
occupies a particular place among those with a zeal worthy of praise and a straight

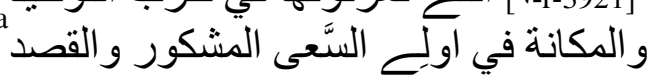

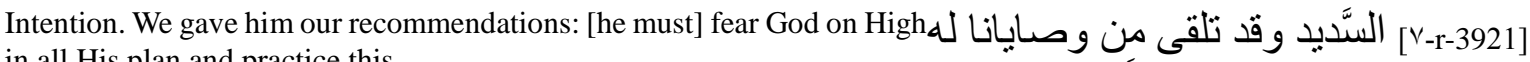
in all His plan and practice this

$$
\text { بتقوى الله تعلى في كل أَمرهو ومر اقبته }
$$

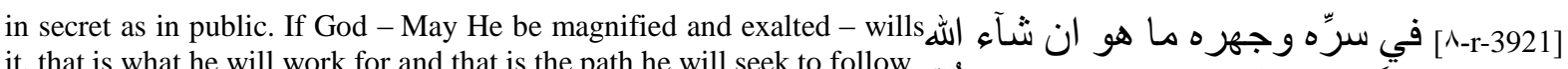

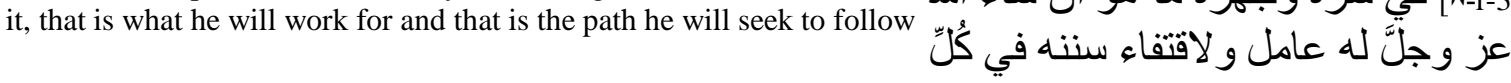

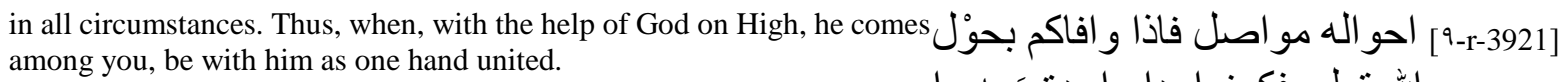

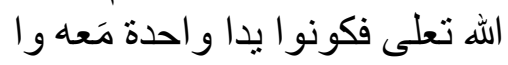

1044 'Azzāwī, NLA, t. 1, 450.

1045 Two words hidden by humidity.

1046 These all indicate that we can consider with certitude this to be Tinmāl: the term hidāya (maqām al-hidāya) evokes the mission of the Mahdi, who must be the guide.

1047 'Azzāwī: لها. 
Support him in all that will help him to take the rightful path and enlarge it for him. Dispense in all your affairs

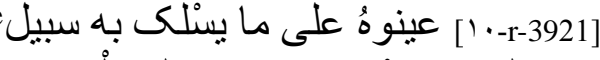

$$
\begin{aligned}
& \text { الحق و مهزيعه و اجرو ا على الْعهرد }
\end{aligned}
$$

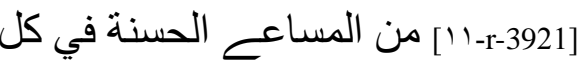

$$
\begin{aligned}
& \text { شئونكم } 1048 \text { و انشرو ا بابهاج نفوسكم بما }
\end{aligned}
$$

and joyful eyes, of the goodness you have learned, if God on High wills it. تقعرفون من الخير و اقرار

$$
\text { عيونكم ان شاء الله تعلى }
$$

\section{Taqdīm 25: Appointment of Abū Fulān as governor with fiscal and military attributions $^{1049}$}

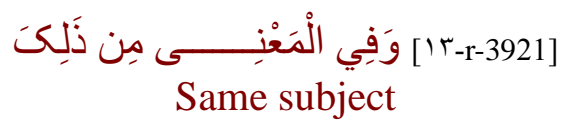

May God always assure them respect through the fear He inspires in them and grant them a large part of His favor and His mercy. This is what we write

- May God have written for you a decision that will improve your situation and crown your hopes with success and may He have sheltered you

under a wing spread for the coming salvation and entire security. Know that the care we take

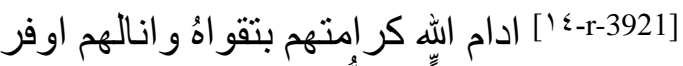

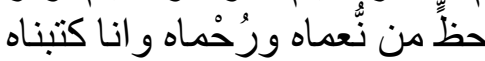

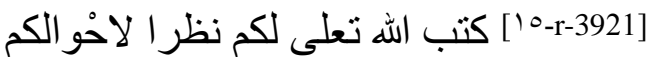

مصلحًا و لامالكم منجحًا وبو اكم للعافية

[17-r-3921] المتحصلة و الامانة المشتملة كنفا

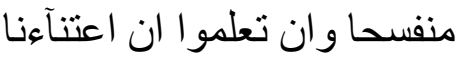

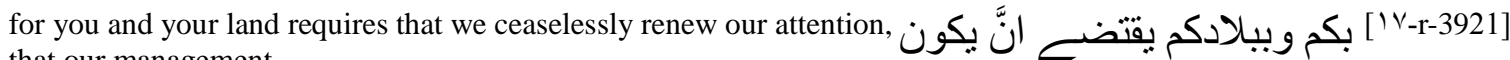
that our management

تعهدنا لها معَ الاحْبِان منتابعًا ونظرنا

of economic matters (muhāwalāt al-mașlahiyya) be sure and global, and that we administer everything that brings happiness

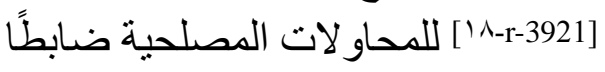

جامعًا وتدبيرنا لكل ما فبه جلب الخير ات لت الت

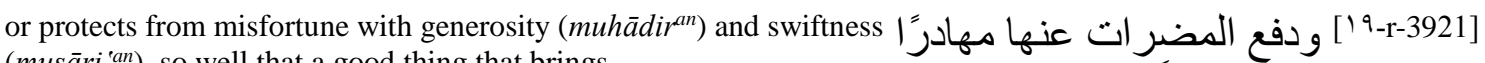
$\left(\right.$ musāri $\left.{ }^{\text {'an }}\right)$, so well that a good thing that brings

another does not arrive too late and that not one of your regions, near

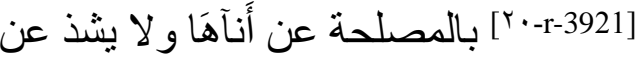
or far, be denied protection

الحماية و الحياطة اقصى جهة من جهن جهاتهم

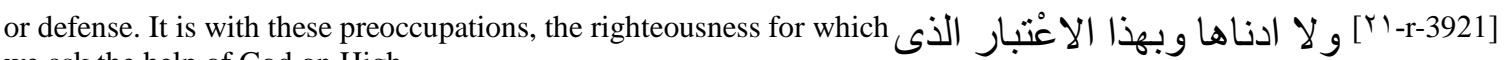
we ask the help of God on High

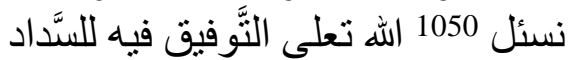

(...) His gift: the divine guidance (tasdīd) necessary to exercise authority ( $f \grave{l} l$-ișdār wa l-īrād), We have appointed Abū Fulān

1051 تمنحُهـ1052 [... [بr-r-3921]

يصحب في الاصندار و الاير ادفقدمنا الان ابَا لماهد فلان

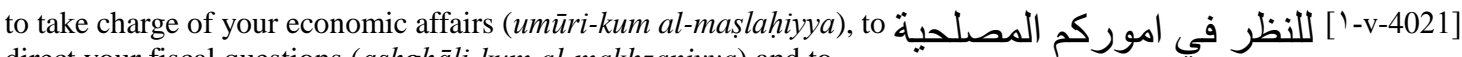
direct your fiscal questions (ashghāli-kum al-makhzaniyya) and to keep your land

\footnotetext{
1048 'Azzāwī: شؤونكم.

1049 'Azzāwī, NLA, t. 1, 451.

1050 'Azzāwī: نسأل.

1051 One word erased.

1052 mașdar fifth form: tamannuhu-hu.
} 
from evildoers and criminals. We give thanks for his competence; he is known for his aptitudes and his

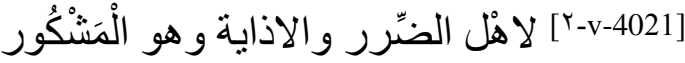

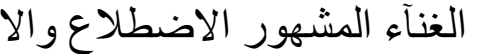

Efficiency. He has distinguished himself through the rightness of his projects in the offices he occupied. We have counseled him to fear

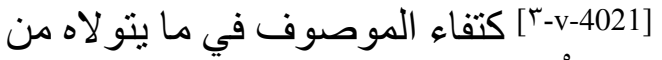

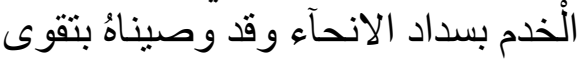

God on High, as God [himself] - May He be exalted and magnified counseled His subjects. ${ }^{1053}$ On that subject, we have insisted on the best

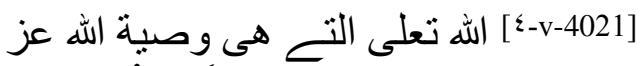

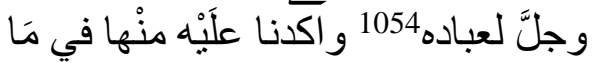

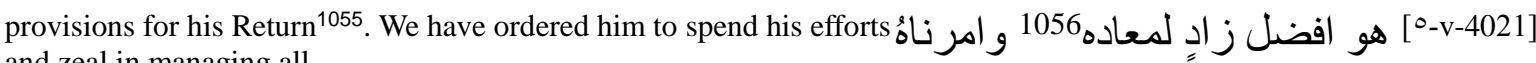
and zeal in managing all

your interests, to be extremely severe towards anyone who gives himself over to evil and corruption and to

ان بَّصنرف لاقامة مصالحكم كلها وجه جدها

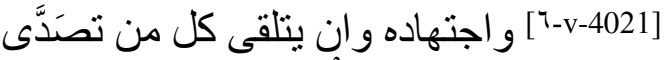

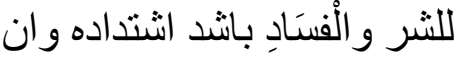

spread security throughout the region, through the examinations and inspections he will perform. We have incited him

[ي-v-4021]

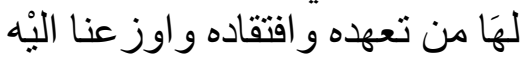

to completely collect all the taxes when they are determined and due, to manage finances in this area according to the

[^-v-4021]

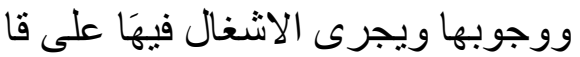

law and usual custom, and to consecrate all his energy to that, to recover

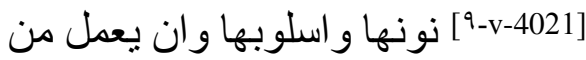

الانتهاض في ذللكَ ما يجمع فيه بين اقتضآه

what is due, while also acting with gentility and according to the clearest path. Thus, when he arrives among you, with the help

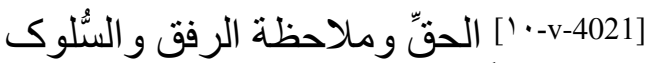

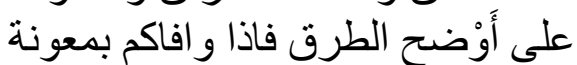

of God on High, work in concert with him for your interests in a spirit of submission and obedience. Be

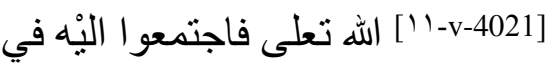

مصالحكم اجتماع الانقيادِ و الائتمار وكونوا

with him las one hand united, which will bring you tranquility and stability. Know that, in this appointment, we have sought to

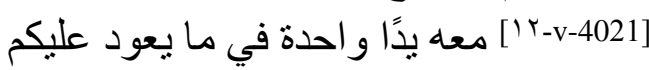

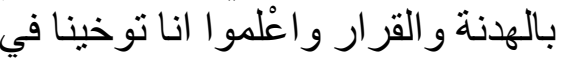

make a good decision and the right choice for you, with the strength of

God on High. And He - May He be glorified -

و الاختيار بحول الله تعلى وهو سبْحانه

will smoothen your regions and guide your behavior towards mutual aid in obedience. By His grace.

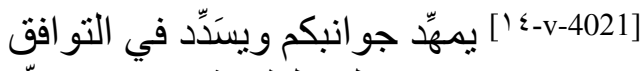
على الطاعةِ مذا هبكم بمنّه

Taqdīm 26: Appointment of Fulān as governor, with fiscal and military attributions ${ }^{1057}$

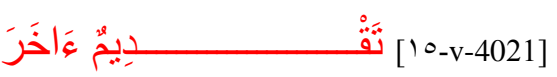

Another appointment

...Know that we will not deny you consideration that brings order to

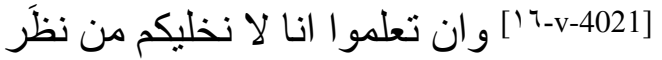
your affairs, that leads your people along a wide and clear way,

يضبط اموركم ويحمل على الجادة الو اضحة

1053 The wișāya refers to Koran 4:131: "Verily we have directed the People of the Book before you, and you (o Muslims) to fear God."

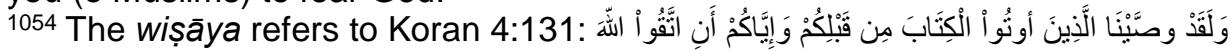

1055 In the future, on the day of judgement. Koran 2:197: "The best of provisions is right conduct. So fear Me, o ye that are wise."

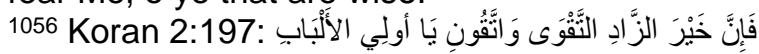

1057 'Azzāwī, NLA, t. 1, 452. 
that leads your interests according to the straightest and most obvious path and that takes for important questions measures that offer the most chances

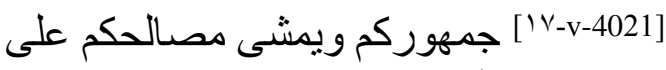

اقوم سبلها واوضحها وياخذ في مهمَّاتِكم

for success and achievement. As a result, we have appointed Fulān to supervise your taxes (a māli-kum), ${ }^{1058}$

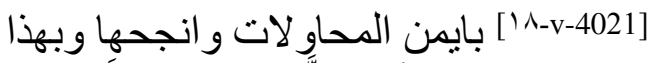

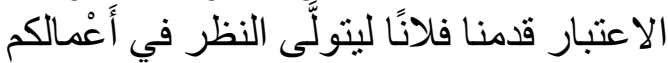

to be the best possible lieutenant in organizing your finances

(ashghāli-kum), ${ }^{1059}$ and seek a justice that will lead your countries and improve

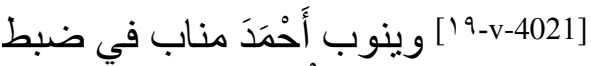

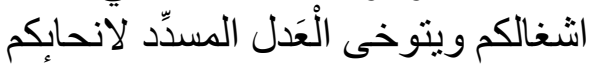

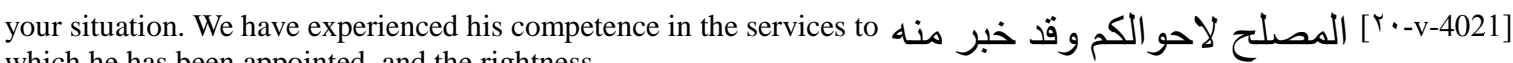

which he has been appointed, and the rightness

غنآًَ 1060 في الخدم التخ استعمل فبها وسدادًا

بـجر

of his vision in managing and leading interests, as was needed. We have counseled him to fear God on High,

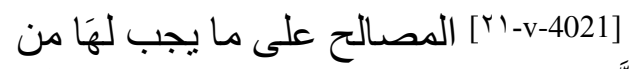

النَّظر ويمشيها وقد وصيناهُ بتقوى الله تعلى

which is the basis for good actions: the order to commit to those is found [in the Koran] at the end as at the beginning (al-fätiha).

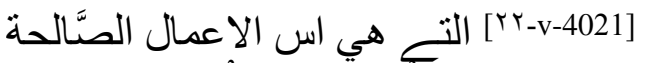

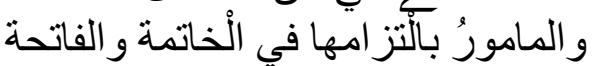

We have ordered him to collect duties when they are due, to not stray from correct methods in fiscal affairs (ashghāl al-makhzaniyya),

to be firm in stopping corruptors and corruption and deploy permanently praiseworthy zeal and effort

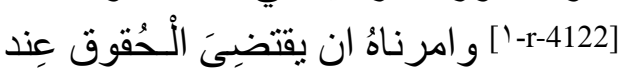

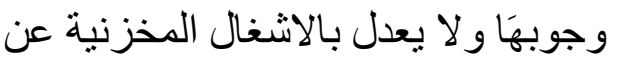

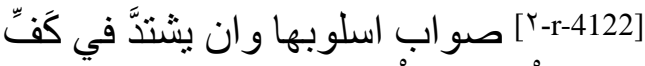

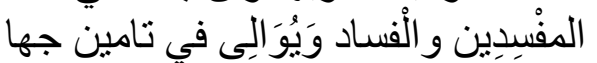

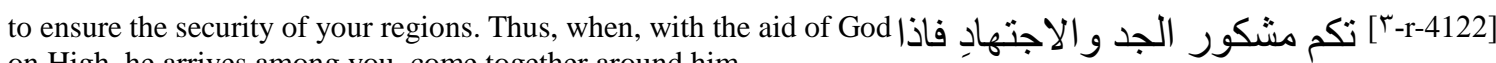

on High, he arrives among you, come together around him,

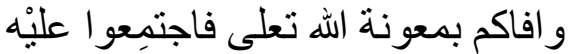

confide yourselves to him for your affairs, help each other in the endurance and fear of God, ${ }^{1061}$ walk along an exemplary

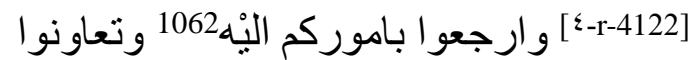

على الصبر و التقوى 1063 وسيروا على على الئى

الطر بقة

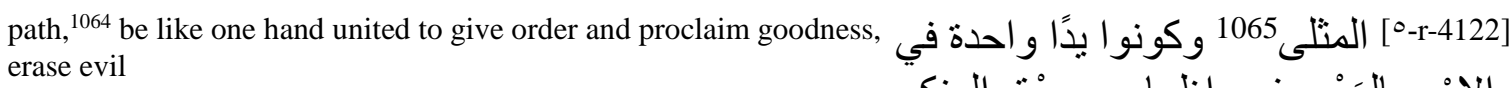

and make all traces of it disappear. This will bring you much, both now and in the future, and will cause you happiness

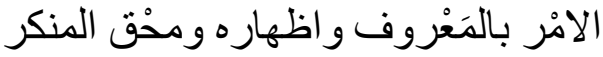

in all circumstances, with the strength of God on High.

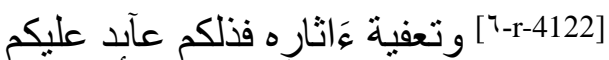

بالنفع في حالكم و استقبالكم وجالب

[N-r-4122] اليكم الخير في كل احْو الكم بحول الله

تعلى

1058 The following section suggests this particularly precise translation.

1059 "Finances" is suggested here because of the precision of makhzaniyya which accompanies this term a few lines below.

1060 'Azzāwī corrects with غناءٌ...

1061 Fusion of two references: - Koran 103:3: "Except such as have Faith, and do righteous deeds, and (join together) in the mutual teaching of Truth, and of Patience and Constancy" - Koran 5:2: "Help ye one another in righteousness and piety, but help ye not one another in sin and rancour: fear God: for God is strict in punishment."

1062 'Azzāwī: عليه.

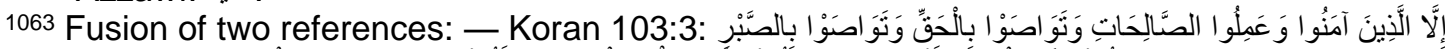

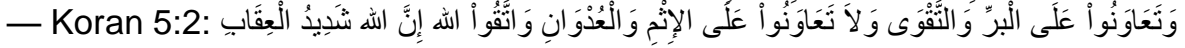

1064 Reference to Koran 20:63: "They said: These two are certainly (expert) magicians: their object is to drive you out from your land with their magic, and to do away with your most cherished institutions."

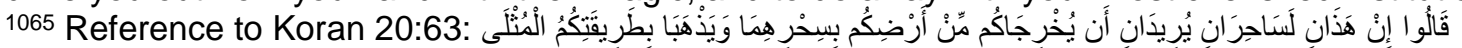




\section{Taqdīm 27: Appointment of Abū Fulān as governor with military attributions ${ }^{1066}$}

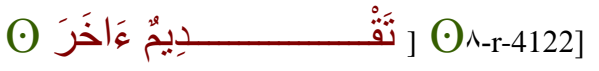

Another appointment

...And know that over the land and its inhabitants we extend a watch whose rightness will envelop [you] all, by the strength of God. To take

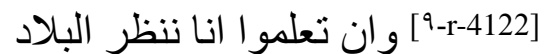

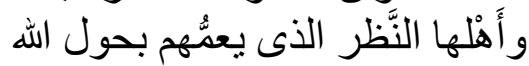

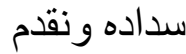

charge of its interests (mașālih) and assure the security of those who come and go there, we are naming someone whose seriousness and zeal in the service [of the state]

[آ-4122-r-1 [- لتولّى مصسالحها وتامين

غاديها ور آبحها من بان جده في الخدمة الخونة

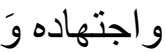

have clearly shown themselves and whose authority (ișdāru-hu wa īrādu-hu)( has been excellent. As a result, we have appointed Abū Fulān to govern and defend your regions,

وبمقتضى ذلكُم عينا ابا فلان ليضبط نو احيكم

to assure there all conditions necessary for total protection, to manage with competence

[1r-r-4122]

التامة لهَا ويُوفى شروطها ويتولى باليى

بالْغناء

and satisfactorily the great interests given and confided to him, this once it was established that his sense for responsibilities justified our

[بr-r-4122]

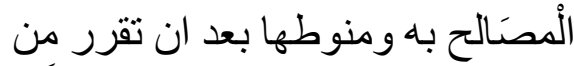

استقلاله ما ادَّى تصن

employing him, and his obvious capacity (iktifä $\left.{ }^{\prime}\right)$ led us to depend on him (istikf $\bar{a}^{\prime}$ ). We have advised him to fear God

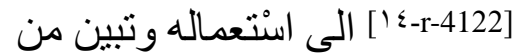

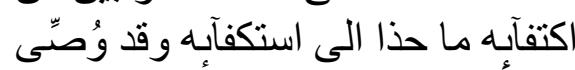

بتقوى الله

on High, which is the surest of travel provisions (al-'udda al-wathīqa). We have ordered him to carry himself well and to follow the straight path by committing to give good counsel

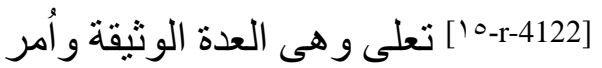

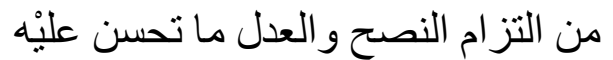
السيّيرة

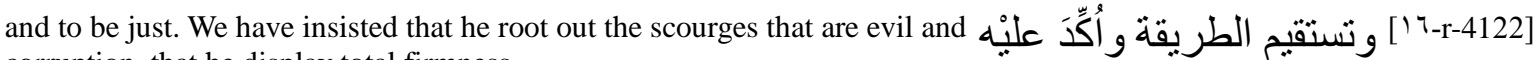
corruption, that he display total firmness

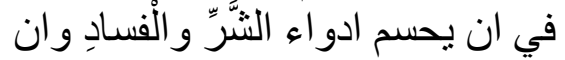
يعمل

in subjugating aggressors and rebels, so that the shadow of security

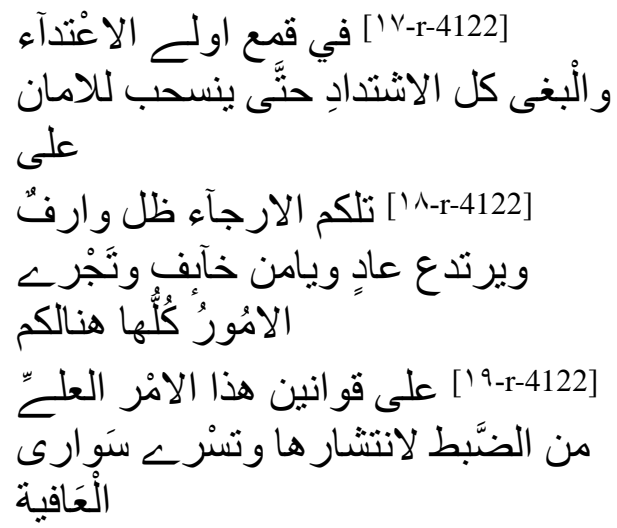

spreads over your lands, that the enemy be pushed away and fearful men reassured, that all your affairs be managed

according to the statutes (qawānin) of this supreme Power, by maintaining their fulfillment, that the defenders of salvation 
and security (tasrī sawārī al- 'âfiya wa-l-amāna) progress across the plains and valleys of your regions, to suppress from your major thoroughfares

whatever may dissuade the flocks of travelers from taking to the road and to prevent brigands from carrying out their

exactions and usual evil deeds. Thus, when he arrives among you, with the help of God on High, submit to him as you should to the authority (li-ma

yūridu-hu... wa yușdiru-hu) he will exercise in all your important affairs. Be like one hand united in all that he decides and chooses for the protection

of your regions. Come together and help each other in all that will be useful for you and will keep

evil away from you. Behind this is our constant and permanent watch over you, the best and most beautiful of care dedicated to your situation,

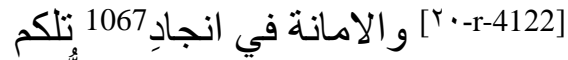

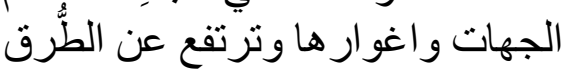
المسنْو كَة المَّة

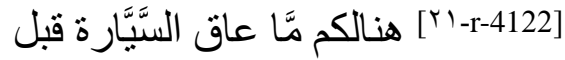

تسبار ها وترتدع الثر ار عما اعتادت

من

[فr-r-4122] شر ها و اضر ار ها فاذا و افاكم بمعونة الله تعلى فانقادو ا احْسن انقبادٍ لما

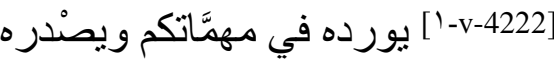

وكونو ا معه بدًا و احدة في ما بعتمده من

حمابِة

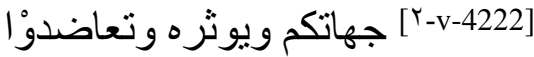

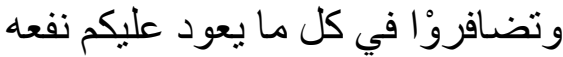

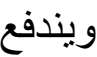

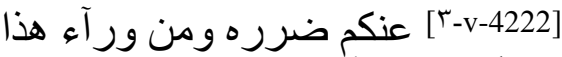
نظر منّاّ نو اليه لكُم ونصله و اعتنآ يتعهد احو الكم

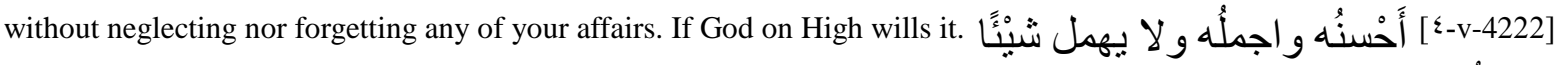
من أمُوركم و لا بغفله ان شُاء الله تعَلى و هو

And He - May He be glorified - He will smoothen your land and countries and will grant you generous salvation now and in the future. By His grace.

Taqdīm 28: Appointment of Abū Fulān as

governor with fiscal and military

attributions $^{1068}$

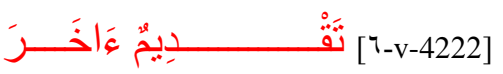

Another appointment

...May God assure them always respect through the fear He inspires in them and ease a cooperation between them that pleases Him. This is what we write - May

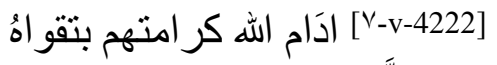

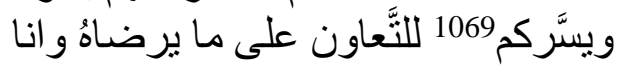

$$
\begin{aligned}
& \text { كتبناه كتب }
\end{aligned}
$$

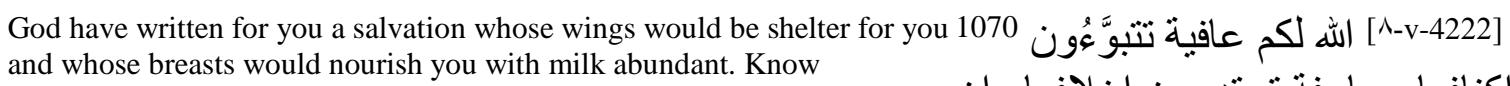


that we reserve a benevolent watch over you that will improve your situation, will make your domains more pleasant and will lead all your interests, [9-v-4222]

يصلح احو الكم ويمهِّ حِلالكم ويجرِ

مصالحكم كلها

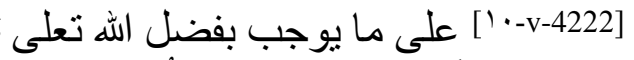

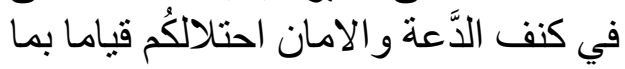

له

- May He be exalted and magnified - impelled us to do to protect [our] subjects, to bring an end to complaints, to assure the security of the land as well as

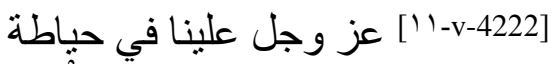

الرَّ عايا و اماطة الثكايا وتامين الْبلادِ

وتمكين

the possibility of virtue and righteousness. May God on High give us the time for this, supporting [us] and guiding [us], and may He assist us in the beautiful

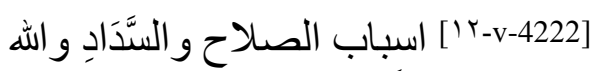

تعلى يمدَّنا في ذلكم بتاييده وتسنديده

[ [ب-v-4222]

للمسنلمين من جمبل السَّْى و حميده وقد

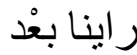

the aid of God on High, and solicited His assistance and His help to guide us on the roads

[ [استخارة الله تعلى و اسْتمداد

توفيقه و الاستنجاد به على سلوك سنن

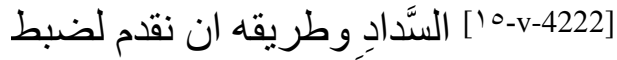

and paths of righteousness, we have decided to appoint Abū Fulān - May

God assure him always respect and continue to grant him His aid and assistance - to organize ( $d a b t)$ your

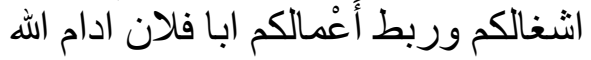

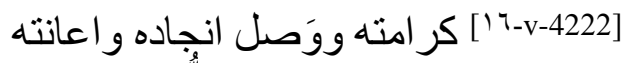

و هو الذــ شكرث تصر فاته كلّها وتتاو لاته

( $\left.a^{\prime} m \bar{a} l\right) .1071$ As for him, we have appreciated his conduct and all his

initiatives,

[IV-v-4222]

ومنتحياته وجرت على وتيرة قويمة

وسبرة

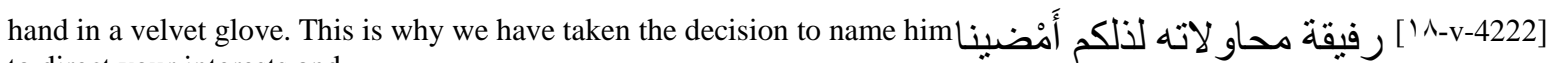
to direct your interests and

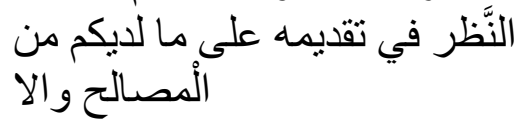

your taxes and to entrust him alone with these functions for which he will bear witness, with the strength of God, to a perfect competence and a great

sensitivity for responsibilities. We have advised him to devote himself to fearing God on High, which is the best of assurances for the present

[9-v-4222]

بما بيذل في القيام بـه بحول الله اتم الْغناء

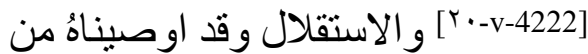

التز ام تقوى الله تعلى بما هو انفع عدة

للحال

and the future, and, for that which concerns you, to walk the clearest paths of equity and moderation. We have ordered him

1071 The mention of duties and taxes in the following lines of this taqdìm seems to justify associating the binomial a'māl and ashghāl with fiscal matters. 
to protect you by taking very firm measures to keep distant the party of corruption, to defend you so that

enemy forces cannot reach and dominate you, to exert zeal and

extreme efforts in all that may contribute to giving you a good and just state. We have insisted that he take in

and collect completely all taxes due, and that he treat you most fairly

by conciliating the demands of the law and the use of clemency. We have enjoined him, to put an end to innovations,

to combat abuse and to respect the limits and signs of the Law by which His subjects worship God

on High, which is what we insist on for all those whom we appoint as governor and what we advise each to respect in his language

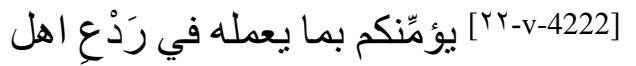

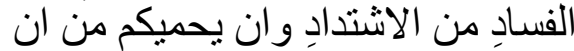

تصنل

[-1323-r-1 [إلبْكم الايدي المعتدية بالاسْتطالة

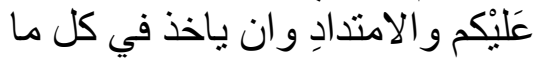

[-r-4323-r-r فيه استقامتكم وصلاحكم بغاية

الجد و الاجتهادِ و اكدنا عليه في استيفاء

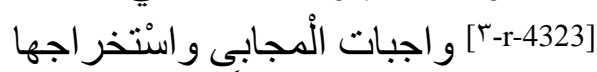

و اجر آبكم من المعدلة على أَْْضح منْهاجها

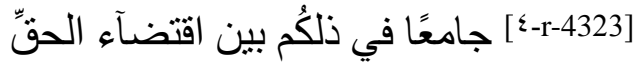

وتمثية الرِّفق وجددنا 1072 له في از الن الة

المحدثات

[-1323-r-0 ورفع المظالم و الوقوف مع مَا

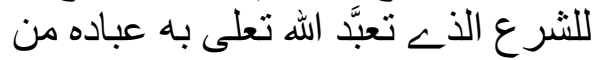

الحدود

[3-4-4323-[ و الْمعالم ما لا نز ال نحده لكل من

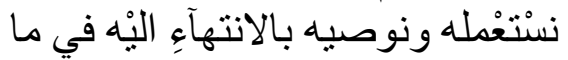

يقو له

and actions. Thus, when he arrives among you with the help of God - May ويفعله فاذا و افاكم بمعونة الله He be glorified - show him perfect obedience, hasten

سبْحانه فائتمرو اله احسن ائتمار و ابتدروا واله الهواه

to cooperate with him in the best possible way for your interests. Do not stray from the path of submission, you will receive

[^-r-4323] للتعاون معه على مصنى مصالحكم

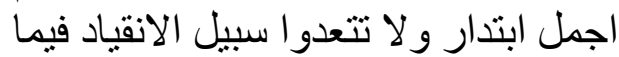

ه

in return goodness which will bear witness to your perfect obedience and exemplary [conduct]. If God on High wills it.

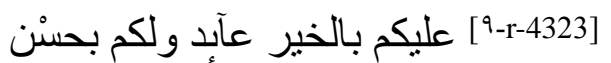

الطاعة و الامثنال شاهد ان شاء الله تعلى

And $\mathrm{He}$ - May He be glorified - He will spread over your regions the shadow of security in granting success and achievement to your hopes and desires. By His grace.

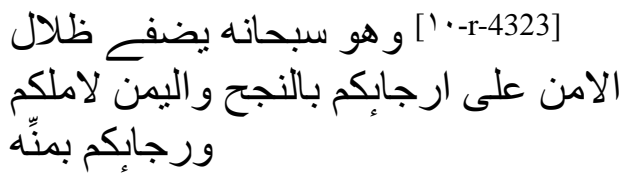

Taqdīm 29: Appointment of Fulān as governor with fiscal and military attributions ${ }^{1073}$

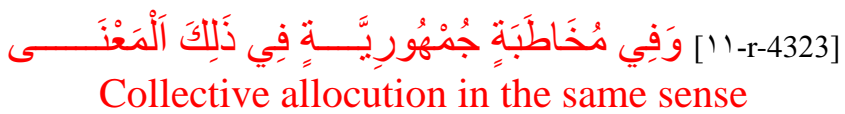

...Know that we welcome your land with a gaze that will smoothen all its regions and renew for it the best

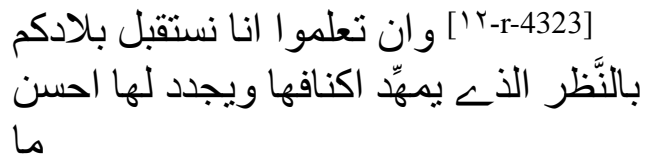

1072 'Azzāwī corrects with وحدنا.

1073 'Azzāwī, NLA, t. 1, 455. 
rest, tranquility, security and calm it has known, and with care for its protection,

for its defense and the complete management of its interests, in all its affairs and any situation. As a result of the

benevolent interest we grant your lands, of the protection whose shadow we extend over you, present and absent, and the defense we never cease to assure you,

we have chosen Fulān - May God perpetuate his devotion (mabarra) and maintain his rank and merit - to take charge of

all your financial affairs, to bring order to your fiscal ${ }^{1075}$ matters according to the straightest path

and to liberally manage your interests, small and great. As for him,

we have seen his fine actions in all his deeds. He has distinguished himself with laudable competence and the best of qualities in

his assignments (tanāwulāt). His personality, functions, methods, and alliances in the past have equaled those that

merited for his predecessors in the party of Unity (tawhīd) noble privileges. He will pursue with you the engagements of the one whose leadership you have known,

and which has shown itself to be excellent, the one to whom you were grateful for his laudable behavior (mithāl) in governing your countries,

and the pleasant conduct in collecting your taxes to which you have become accustomed. We have reminded him of

God's counsel to His subjects to devote themselves to fearing Him, and to prefer that which is lawful and to avoid the rest. He has

listened to this with attention and approved of it. We have enjoined him to adopt the best possible conduct to assure the security of the land

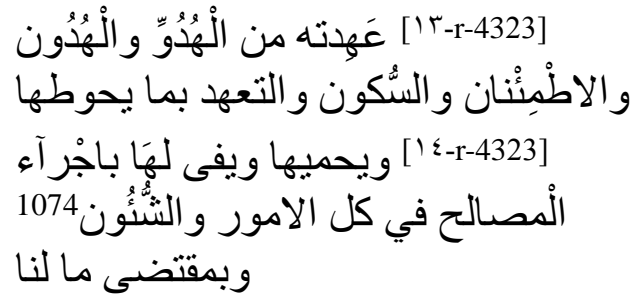

[10-r-4323 بكم من جميل الْعناية الته

نستتصحبها في جو انبكم و الر عاية التح

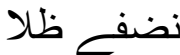

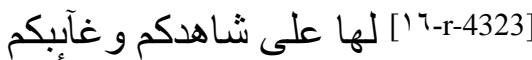

و الحياطة التخ لانز ال ننوطها بكم اخترنا

لتولـ

['V-r-4323 اشغالكم كلها و التقديم على اجراء

اعمالكم على اقوم سُبْلهاب1076 و النظر اجنر

المطلق 1077

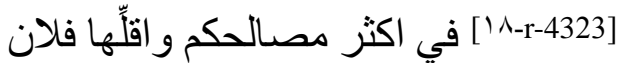

وصل الله مبَرَّتهنه وو الَى مكانته و حظوته و هو

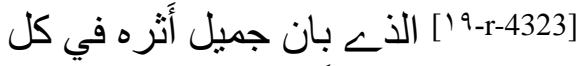

التصر فات وتميَّزَ من حميد الغناء في جمي لري

التناو لات باحْنَنِ

[r-r-4323-re الصفات و تتاسبت ذاته وخدمه

ووسابله وذذمَمه في السو ابق الته

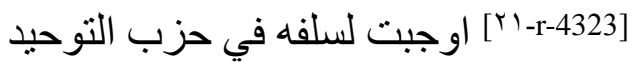

كريم المزيات و انه ليو افيكم منه من عرفتم

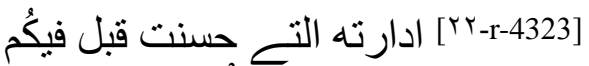

وشكرتم متا. ... 1078 الْحميدَ في ضنبط فيط

نو احيكم

[1-v-4423- ] و الفتم سياسته المشكورة في

استخر اج مجابيكم وقد القينا له من الوصايا

الت

[ب-v-4423] وصى الله بها عباده من التز ام

تقو اهُ وايثار الحقِّ واجتناب سو اه ما هو لهو

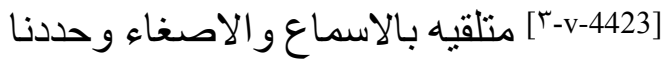

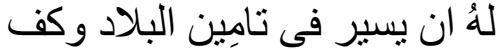

1074 'Azzāwī: والثؤون.

${ }^{1075}$ As in the preceding taqdìm, the mention of duties and taxes seems to justify associating $a$ ' $m \bar{a} l$ and $a s h g h \bar{a} l$ with fiscal and financial matters.

1076 'Azzāwī: سُبْ

1077 Partially erased word. 'Azzāwĩ proposes المطلوب, but a dot over the line negates this hypothesis. El Aallaoui contributed generously to this reading.

1078 Word erased. 
and to stop the party of evil and corruption, to be he who carries out good, with clearsightedness, in his words

and deeds; that he not close his eyes before the criminal, and that, with eagerness, he not stray from good by giving himself over,

publicly or privately, to corruption, so that virtue will be desirable and the masses most firmly taxes on goods and not postpone beyond the appointed deadline

the payment of duties owed to God, no matter what they may be. He will proceed with Obey him in a way that clemency though without letting it be forgo
collect taxes in full. Thus, when he arrives

clemency though without letting it be forgotten that his objective is to

among you, rejoice that we have chosen and named him to lead you.

[ـ-v-4423] اهل الثر و الْفسادِ احسن سبرة

وان يكون من بجرى الاصلح قو لا و عملاً

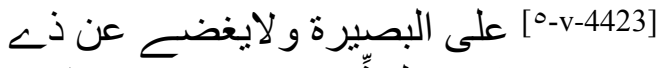

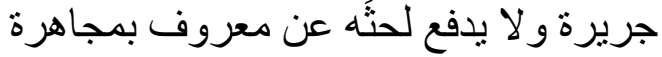

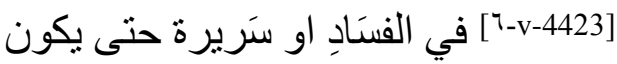

الصلاح محبا للقلوب ويسلك الجماهير

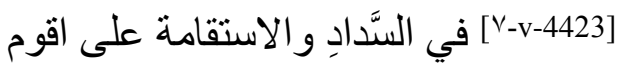

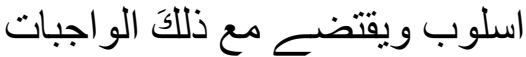

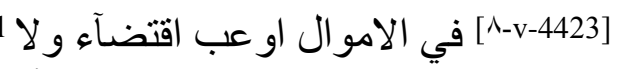

يوخر حقا من حقوق الله عن محل ادآ آل

وبتولى ملى

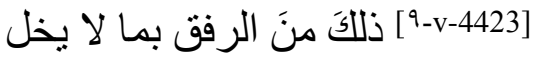

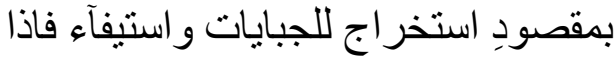

و افاكم

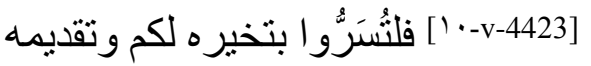

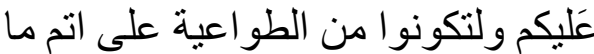

allows him to fully receive what you owe. Submit yourselves absolutely to what he says in

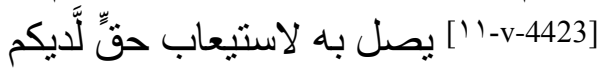

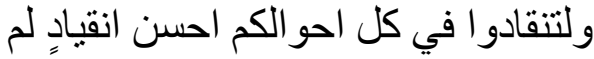

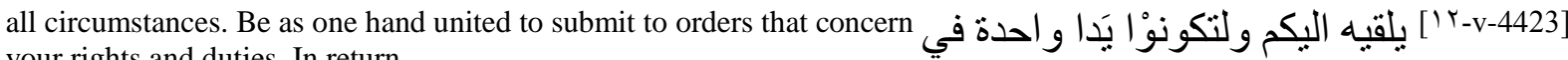
your rights and duties. In return,

الائتمار في ما لكم و علبنكم فذلكم

you will all be collectively rewarded, and this will fulfill your desires by bringing peace to your souls

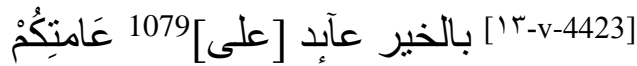

وجمهوركم وسآّق لكل ما تحبون من ابتهاج

نفوسكم

and tranquility to your hearts and will strengthen the improvement of all your affairs. If God on High wills it...

Taqdīm 30: Appointment written in Fulāna, end

of ramaḍān 635 / May 1238, of a governor

(wālī) in Algésiras by Ibn Hūd al-Mutawakkil

$(\text { Complete act })^{1080}$

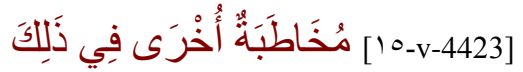

Another allocution on the subject

To the shaykhs, jurisconsults, viziers, notables, nobles ( $\left.a l-h u s a b \bar{a}^{\prime}\right)$,

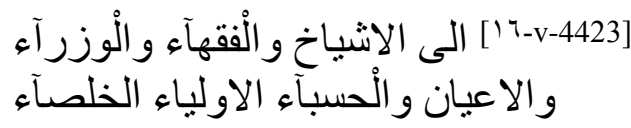

familiars, those who are faithful,

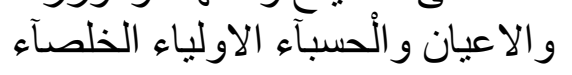

1079 Correct addition by 'Azzāwī. The scribe seems to have made and error and written 'alay-kum, because it is added between the lām and kāf, mīm and tā' to form 'āmmati-kum.

1080 'Azzāwī, NLA, t. 1, 456-457. Ibn Hūd was assassinated at the end of jumādā I 635/December-January 1237 1238 by Ibn al-Ramaymī, master of Almería. Ibn al-Aḥmar had sworn allegiance to Ibn Hūd before joining the Almohads and entering into conflict with Ibn Hūd in 635, when he took Granada. 
sincere, wise, known for the rightness of their doctrine and the nobility of their intentions,

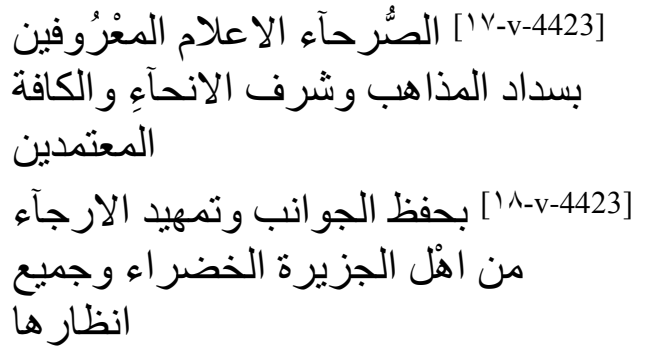

and to all those in the population of Algeciras and all its districts who are charged with protecting its flanks and making its lands pleasant.

May God assure them always a healthy situation and the accomplishment of their hopes and may He allow them to know matters in good order and

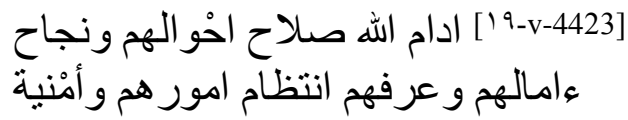

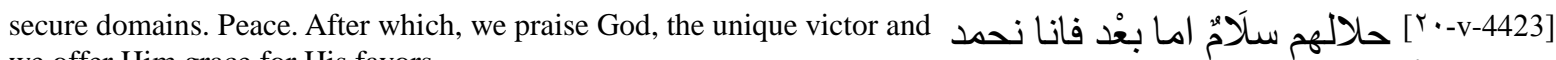
we offer Him grace for His favors

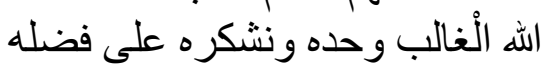

whose numbers nor limits we will never know. ${ }^{1081}$ We call for his benediction of our lord Muhammad, His elected messenger who

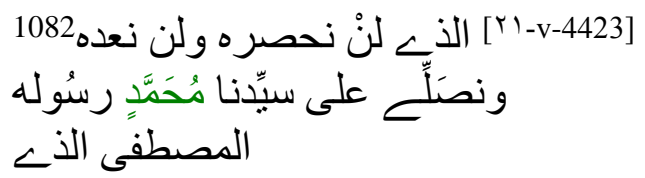

transmitted His warnings and promises, on his family and his generous companions who, in the proclamation of the religion of Islam, carried out his plan by proclaiming the religion

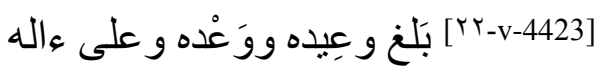

وصحبه الكر ام الأِين وَفو ا في اظهار دين ؤهن الاسارن

of Islam. We ask Him to grant the Abbasid imām,1083 prince of the believers who received the sword, staff and mantel of

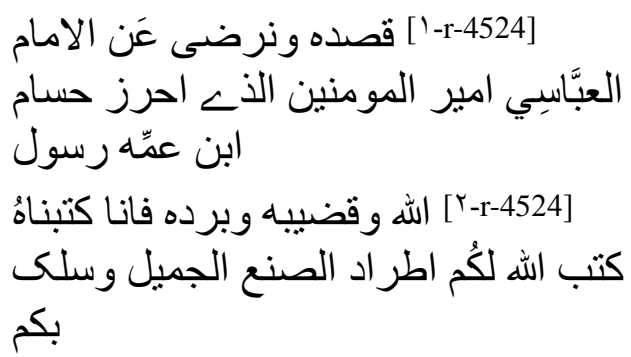

on the obvious path that will allow you to know happiness and grace. And we are victorious, thanks to God on High, over the enemies of His religion

God's messenger, his (paternal) cousin. This is what we write about Fulāna1084 - May God have written for you the successions of this lovely favors and He places you

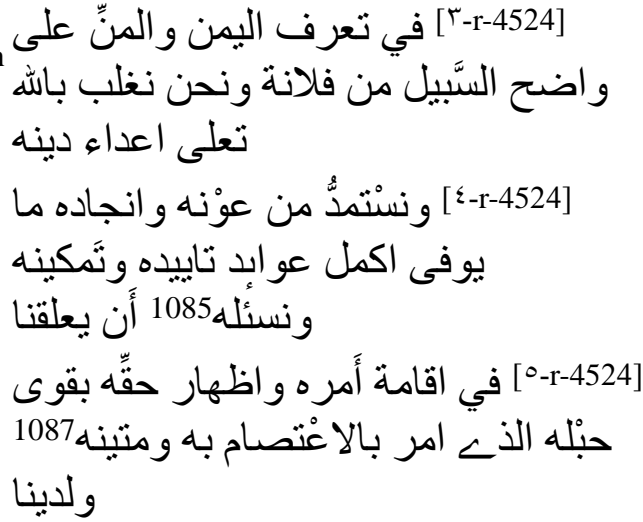

His plan and proclaiming His Truth to fix us to His strong and solid cord which he ordered us to grasp. ${ }^{1086}$

and we ask His aid and His help to complete what His power and force [bring us]. We beseech Him in carrying out

1081 Reference to Koran 14:34: "And He giveth you of all that ye ask for. But if ye count the favors of God, never will ye be able to number them. Verily, man is given up to injustice and ingratitude".

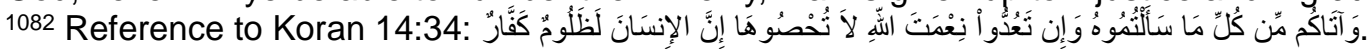
${ }^{1083}$ Abū Ja far al-Manșūr al-Mustanșir bi-Llāh (623-640/1226-1242).

1084 'Azzāwī suggests Murcia, Ibn Hūd's capital.

1085 'Azzāwī: ونسأله.

1086 Reference to Koran 3:103: "And hold fast, all together, by the rope which God (stretches out for you), and be not divided among yourselves; and remember with gratitude God's favour on you; for ye were enemies..."

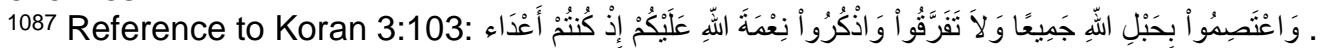


In the rightness of the watch we maintain continuously over your affairs and in the meditation over what will bring you all, the

elite and the masses, immediate or delayed happiness, we hope there is something that will bring you a new era, that will shelter you

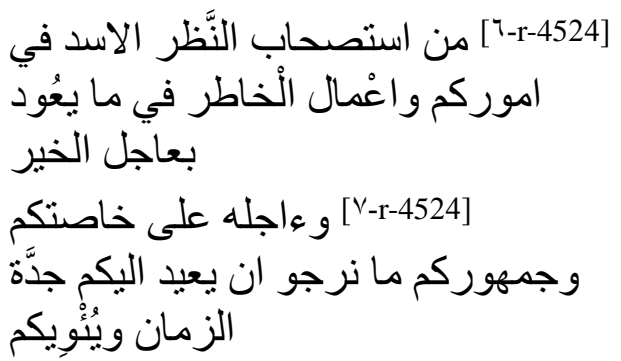

someone whom we could not have not chosen and of whom we know only noble efforts and lovely achievements.

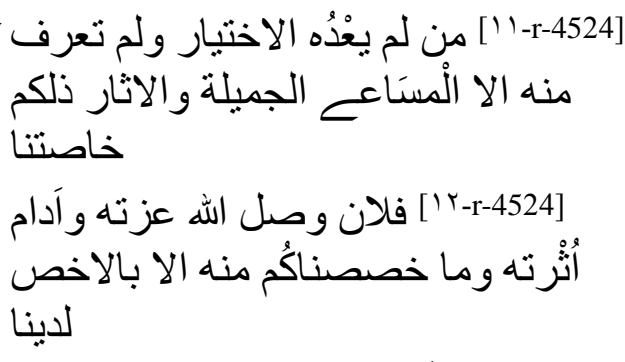

and who deserves to be our closest friend. He and his devoted father were among the first to join (sābiqa al-sawābiq)

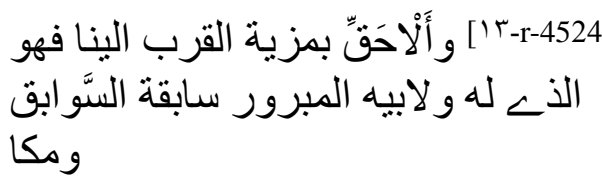

and they have a rank worthy of pure loyalty and sincere belief. We have communicated to him advice that he will respect

to assure well-being for all your regions and to make them pleasant. We have enjoined him to manage your affairs so that you will always enjoy

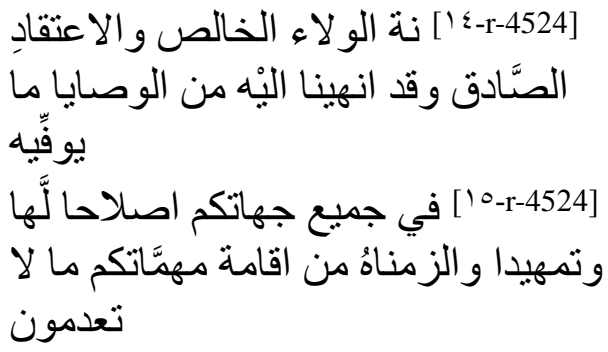

1088 Reference to Koran 16:90: "God commands justice, the doing of good" (inna Llāha ya'muru bi-l-'adli wa-l-ihssāni).

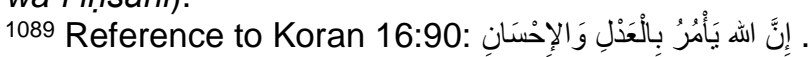

1090 'Azzāwī corrects with بصميم. 
for you. The choice among our illustrious familiars and our appointment [of Fulān] to lead you fall on one with noble ancestors

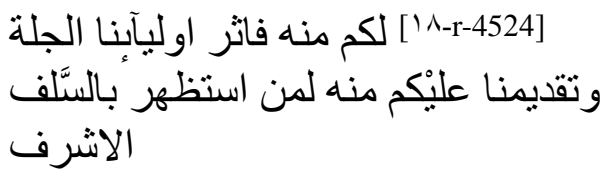

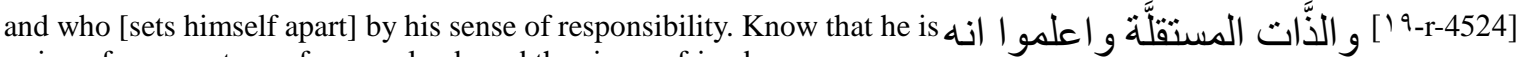
a sign of our great care for your lands and the sincere friend

$$
\text { عنو ان عنايتنا الحافلة لجو انبكم و الخلصان }
$$

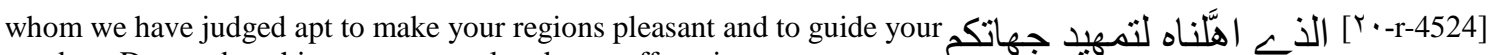
conduct. Do not deny him your counsel and your efforts in any

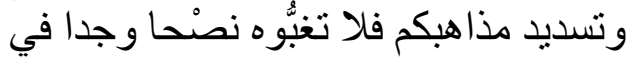

Circumstance. Be satisfied with his government which will assure you a regular

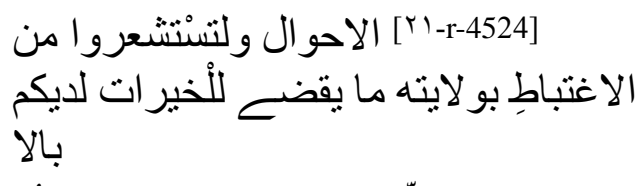

flow of kindness and bring for you from us measures that will allow you to know

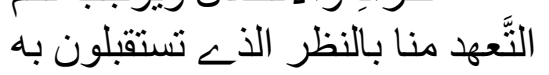

$$
\begin{aligned}
& \text { الصنّلاحن }
\end{aligned}
$$

complete and absolute peace, if God on High wills it. And He - May He be glorified - He will allow you to find happiness in this appointment

and He will multiply for you abundant shares of His favors and kindness. By His grace. May peace and honor be upon you,

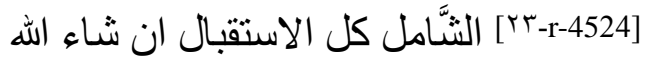
تعلى وهو سبحانه يسنعدكم بهذا التَّقديم

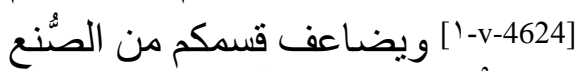
الجميل و الْمنح الجسيم بمنّه و السَّلام الكريم عليكم

as well and God's mercy and His benedictions. Written at the end of the glorious month ramadān, the year 635 .

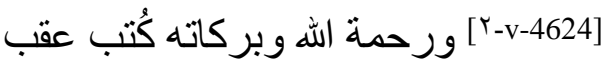

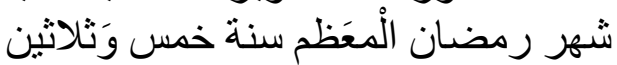 وستمائة

Taqdīm 31: Appointment of a governor with military attributions ${ }^{1091}$

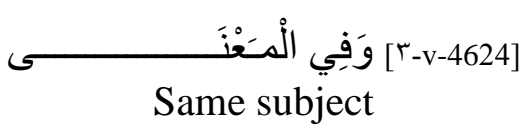

Same subject

...This is what we write - May God have written for you and your situation uniform order and reconciliation and may he grant you abundant shares of the kindness ('awārif)

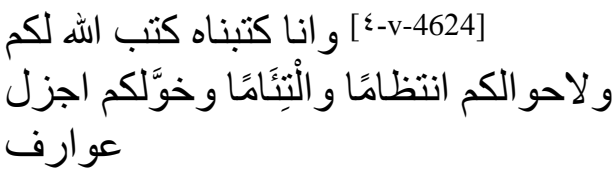

of His assistance (tawfiq ) and His guidance (tasdìd). Know that we watch over you, the masses and the elite $\left(k h \overline{a s s a t}{ }^{a n}\right.$ wa jumhür $\left.^{a n}\right)$,

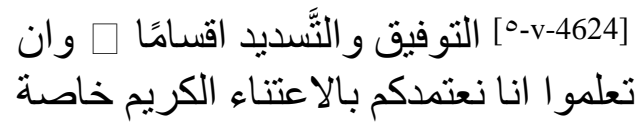

with generous attention. Our benevolent watch over you rejoices your eyes and expands your chests. 
As a result, we have appointed Fulān to take charge of your affairs as well as possible with the most just decisions, to put to work

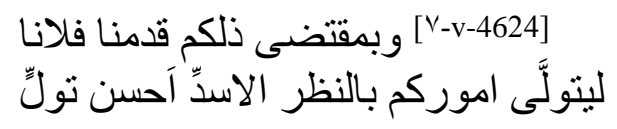

arbitration that follows the best opinions in managing your interests, to lead you in the service

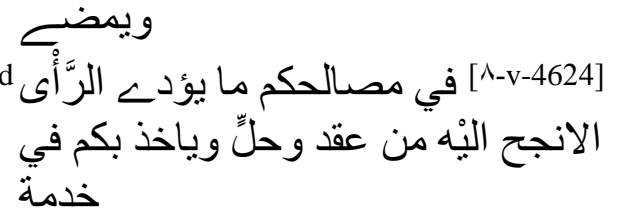

of this Power along paths that will give you rapid access to its familiars (awliy $\left.\bar{a}{ }^{\prime}\right)$, that will guarantee you a sure protection

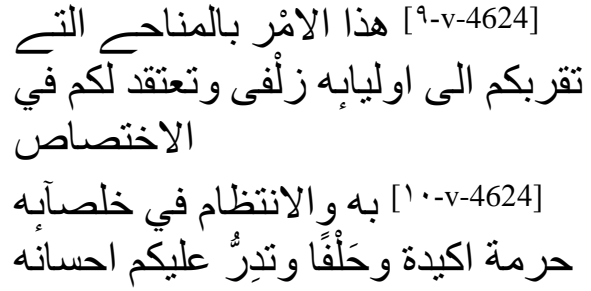

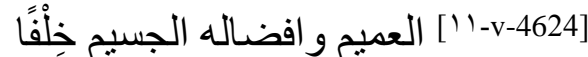
فَخِلْفاً و هو اعز كم الله من بان غناؤه في كل

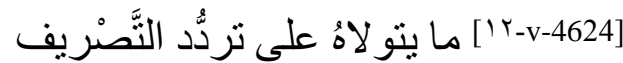

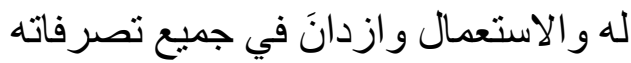

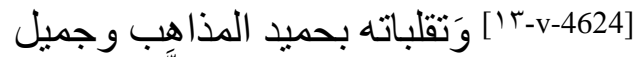

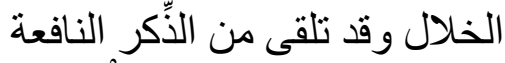
و الْوصنابا

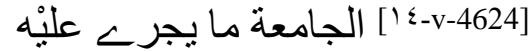
محاو لاته كلها و اعماله ويبذل في العَمل به

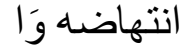

Responsibilities. Thus, place yourselves at his service in this land to drive away enemies and the party

[10-v-4624] ستقلاله فاخدمو ا معه في تلكم

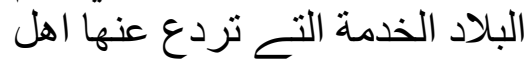

الا عتدآء

of corruption, to bring it back to a situation of normal righteousness and justice. Show him

perfect obedience in all that he entrusts to you. Be as one hand united to help and

$$
\begin{aligned}
& \text { [ [ [17-v-4624 } \\
& \text { منْهود الاستقامة و السَّداد و انقادو ا النْه }
\end{aligned}
$$

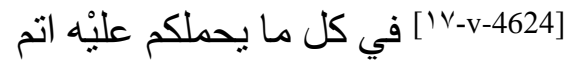

$$
\begin{aligned}
& \text { الانقياد وكونو ا يدًا و احدة في الاعانة لله } \\
& \text { عَلى }
\end{aligned}
$$

assist him in all matters. Continue thus so that the esteem you enjoy from us

[1^-v-4624] جميع الْمصالح و الانجاد

$$
\text { و اسْتمرو ا من ذلكم على ما يقضحم منح }
$$

will grow, so that your hopes may count on our help and assistance,

1092 'Azzāwī corrects with وتوفي. 
so that we will count your actions among those that will receive praise and approval, and so that we may confirm recognition

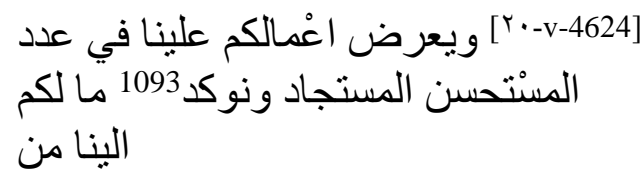

of serious and zealous pacts in our service. If God on High wills it. And $\mathrm{He}$ - May He be glorified -

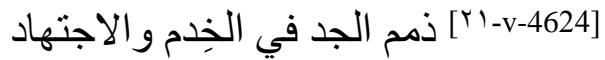

ان شـاء الله تعلى و هو سبحانه بستعملكم

He will use you to collaborate in the best deeds and will grant you happiness, now and in the future, through the fear He inspires in you.

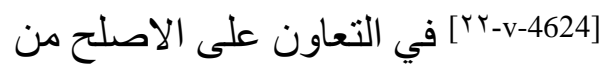

الاعمال ويمنحكم بتقو اهُ سعادة الحال

و المـــآل

By His grace. $\odot$ بمنِّن

\section{Taqdīm 32: Appointment of a governor to reestablish order ${ }^{1094}$}

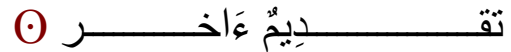 \\ Another appointment}

...May God have written for you fortuitous understanding for all of your interests and hastened searching for all that may give you

[ب-r-4725] كتب الله لكم اتفاقا على مصسالحكم

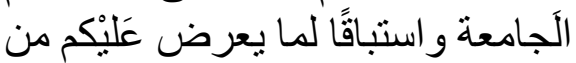

useful indications. Know that we generously grant you our greatest attention and that we cast

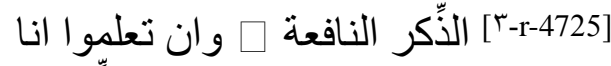

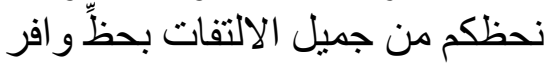

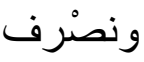

a beneficial watch over your situation, one that rejoices your soul and causes you all to shed tears of joy. Despite our

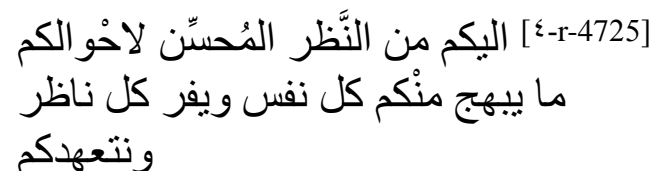

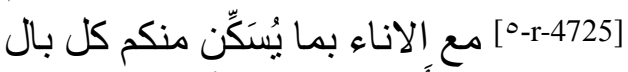

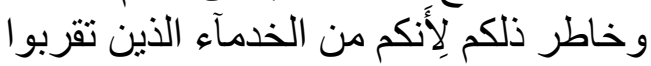

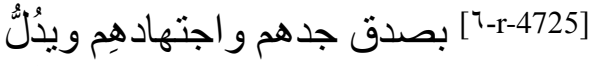

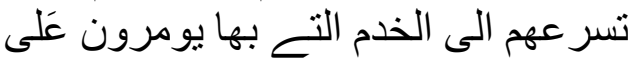

distance, we take care in obtaining for you whatever appeases the hearts and minds of each of you, because you are a part of those servants who came near

through the truth of their effort and zeal and whose haste to accomplish the service we command of them bespeaks

the sincere attachment and faith they have for this eminent Power. May God on High guide you along

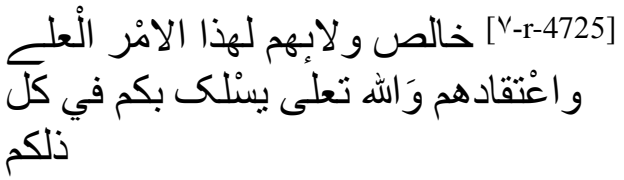

the paths of the lawful path and shelter you under cool shade by lavishing [on you] His favor and mercy, by his Grace.

Thus, after having asked the help of God on High, we have appointed Fulān to [lead] you. He is among those who have distinguished themselves with great competence 
and just orientations. We have chosen him to manage your important affairs and to adopt at all times the best measures

to take care of you. We have advised him to fear God, which is the foundation of any virtuous action, and, as a result, to take

the obvious lawful path in all his endeavors. We have insisted that he manage your affairs [by conciliating] the law

and clemency, that he not stray from the lawful path with you, that he be severe enough with evil ones to prevent them from

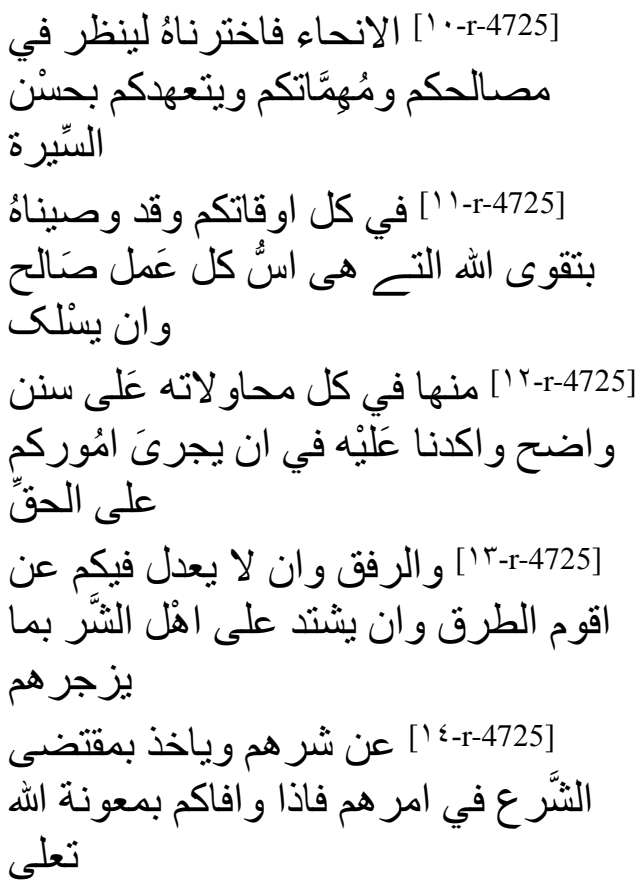

doing evil and act with them in conformity with the Law. Thus, when he arrives among you with the help of God on High,

bring him all possible support to carry out this advice, be with him as one فأَعينوه على اعْمال هذه الْوصنايا hand united in all

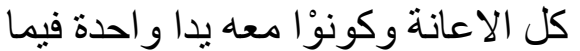

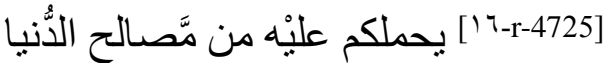

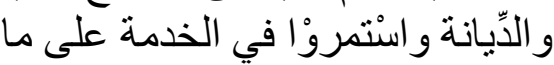$$
\text { يزيدكم منا }
$$

he asks of you, whether for secular or religious affairs. Persevere in serving what will increase our attention and

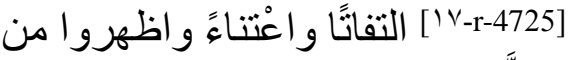

$$
\begin{aligned}
& \text { حُسْن الطَّاعَةِ ما يوجب لقسم الخير ات لديكم }
\end{aligned}
$$

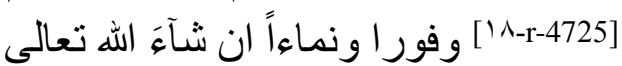

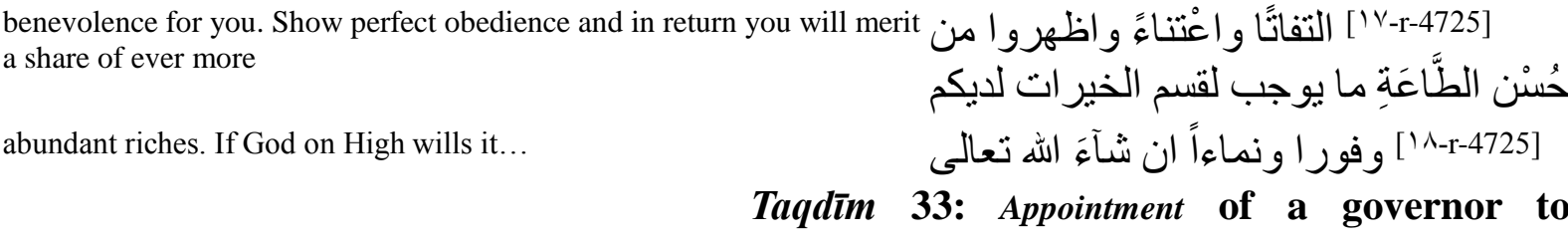
reestablish order in a region ${ }^{1095}$

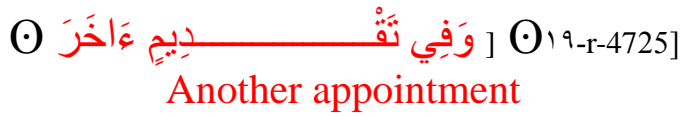

[We know only]... those good things that spread like clouds and the well-being that flows like a long tranquil river. Because of the privileged attention we pay you

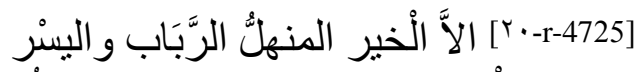

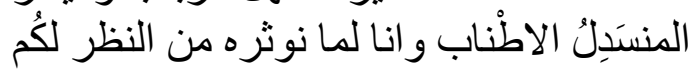

$$
\begin{aligned}
& \text { ونتو } \\
& \text { [r-r-4725] خاهُ من تخيُّر من نقلِّده شغلكم قدمنا }
\end{aligned}
$$

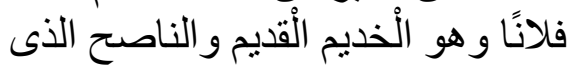

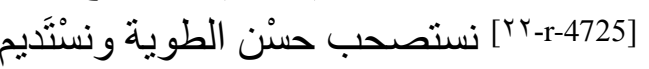

$$
\begin{aligned}
& \text { ومن (ربَّته الحضرة) } 1096 \text { في حجر كفالتها } \\
& \text { وضرََّّته المهذَّب }
\end{aligned}
$$

and the fact that we must choose someone who will invest it with your affairs, we have appointed Fulān, who has long been a servan we have sought out and whose company we have kept because of his excellent nature, someone who His Presence has raised in the lap of his guardianship,

1095 'Azzāwī, NLA, t. 1, 460.

1096 Hole in the manuscript the equivalent of two words. 'Azzāwī's proposal for the first word is plausible, but not the second (presence of sukūn two dots twice at the end). 
that was cast into the shadow of his power, refined of all suspicion. He has ancestors who were faithful in the service [of the state], deserving of praise and favors,

spending all of their energy and possible deeds in the service of this power. We have advised him, and he is one to follow

Advice, to do everything necessary to establish peace, to fly once again the banners of the world and those of religion, and to bring you back

to the rules of divine law and the custom of pastoral care. Reserve a joyful and warm welcome for him, and act with him

with respect and loyalty. May you feel the improvement that his government will bring, for he has a just religion and noble character.

We have reserved him for you and no other. Give thanks to God on High for this favor. May God carry him, and you with him,

along the straightest path, and may He not deny you, neither you nor him, enduring goodness and eternal comfort...

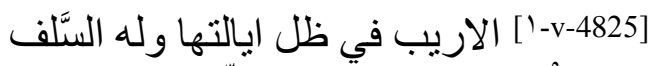

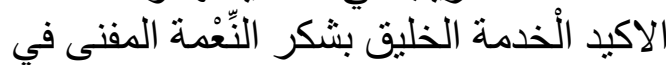

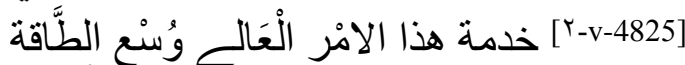

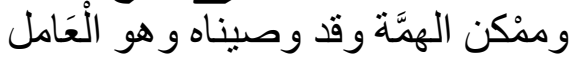

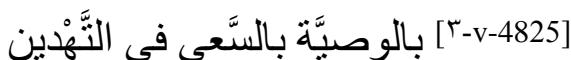

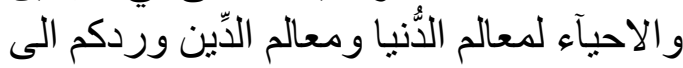

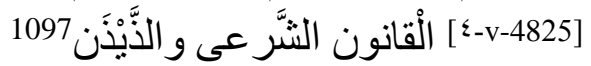
المرعى فتلقوْه تلقي جَزلٍٍ ومسرة و عَامِلوه معاملة وعلم

[0-v-4825] اكر ام و مبرة و اسْتشتعروْا الصَّلاح بتوليته فله الدِّين الصحيح و الثيمة الحرة

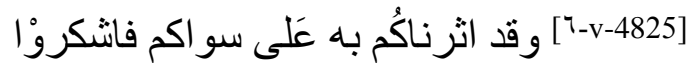
الله تعَلى على هذه الاثرة و الله يحمله و اياكم

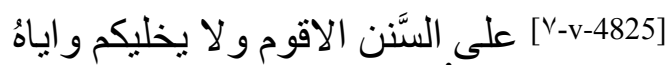

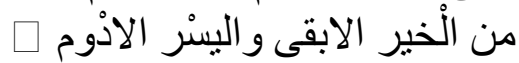

Taqdīm 34: Appointment of Fulān to lead the temporal affairs of a region and practice hisba there $^{1098}$

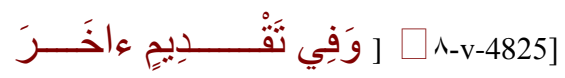

Another appointment

After the preamble (sadr) ...This is what we write - May God have written for you a decision whose choice suits you and matches [your situation] through the preference he gives [you] and the affection he

brings [you]. We have appointed Fulān to govern you and therefore manage your temporal affairs (masā'ila-kum al-dunyawiyya) ${ }^{1099}$ as well as possible,

that he may follow the most rightful approach to your disagreements, that he bring justice to the weak from the strong when matters are obvious

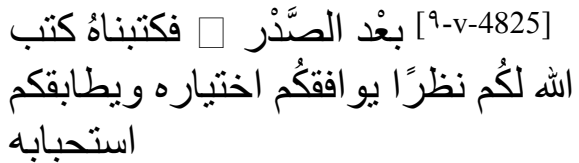

and that he never stray from the straight path in all that he undertakes $(f i$ mutanāwalāti-hi).

1097 'Azzāwī corrects with والديدن.

1098 'Azzāwī, NLA, t. 1, 461.

1099 Affairs "of the world", that is civil, secular matters, with the military domain, everything that is not religious. 
a sure travel provision and laudable behavior in public assemblies ( $f$ l $l$-andiya).

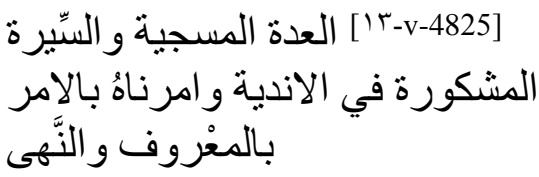

We have ordered him to advocate good, to prohibit evil and annihilate the traces of corruptors and corruption to the point of erasing all memory and recollection of them. Thus, when he arrives among you - If

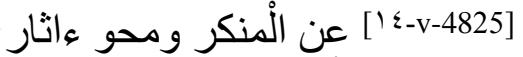

المفسدين و الْفساد حتى لا لا تذكر و لانا

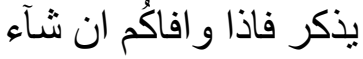

God will it - help him to accomplish these virtuous objectives, be with him in the affairs he undertakes

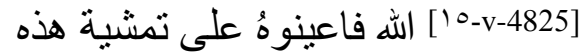

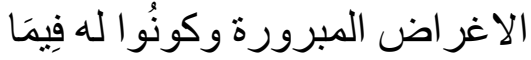

يمضيه من المصنَالح ورون

like the spirit [breathed] into the form. Be united, for in union resides all

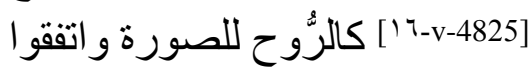
benediction, avoid discord, for in discord is the source of all

ففي الاتفاق كل بركة و لا تختلفؤا فمع لاهو التهو الاختلاف كل

Perdition, and we will closely follow your situation and his and we will reward accordingly the favorable welcome both you and he will reserve

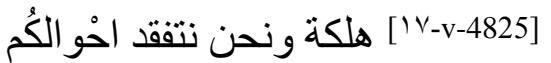

و احْو اله ونكافئُ بالو اجب اقبالكم على هن هذا الرَّنْم

for this intangible decree. If God on High wills it...

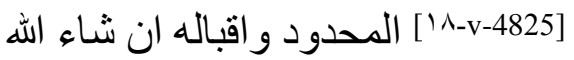

$\square$ تعلى

Taqdīm 35: Appointment of Fulān as governor (identical to taqdīm $\left.n^{\circ} 44\right)^{1100}$

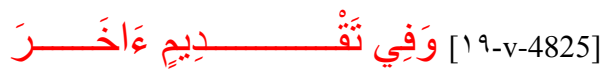

Another appointment

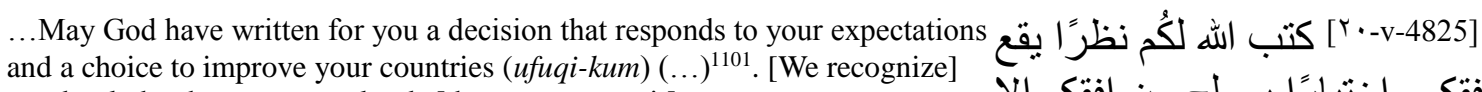
good only by the generous clouds [that accompany it]

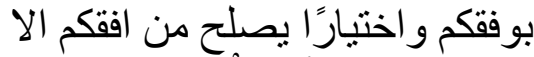

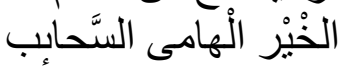

and well-being by the swords that protect it. Praise be to God: may that assure [us] [His] uninterrupted grace and [His] renewed favors.

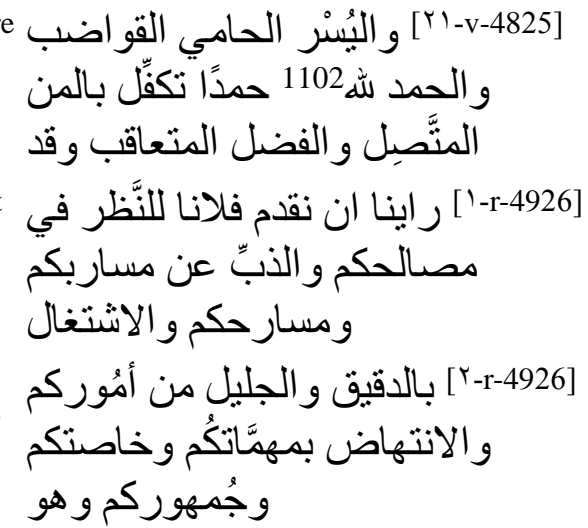

of your affairs, important and insignificant, to move forward with all your problems, with your elites and your masses (bi-muhimmāti-kum wa khāșșatīkum).

We have decided to name Fulān to direct your interests (mașāliḥ) and protect your routes and pastures, to take care

1100 'Azzāwī, NLA, t. 1, 462. Text identical to letter 44

${ }^{1101}$ Completed with taqdīm 44 by wa lā muta arraf illā.

1102 Both words are illegible. 

confirmed through experience. We have had only praise for this work
His effectiveness and aptitudes have been proven, his zeal and competence

[بr-r-4926] المجرَّب اضطلآعُهه و اكتفآؤه

و المختبر انتهاضهه و غنآؤهُ الْمشكورة

قدبيمًا

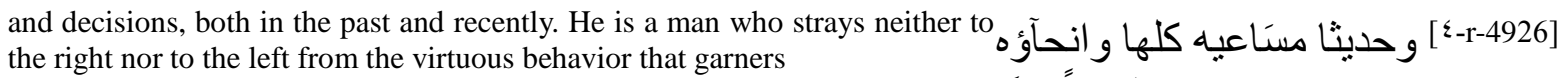

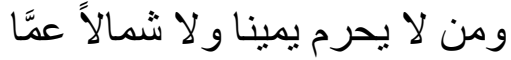

نوثره من السيرة

our favors and preference. His high deeds and what we know of him, present and absent, have always received our approval.

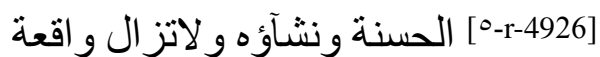

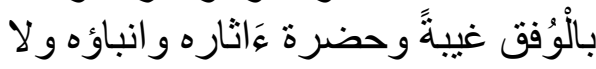

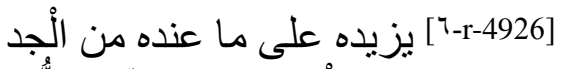

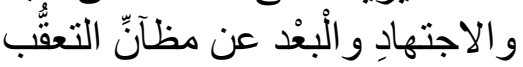
و الانتقاد مهن

His counsel and remarks are hardly necessary [to know] his seriousness, his zeal and the fact that he is above any suspicion (bu'd 'an mazānnn) of prevarication (al-ta'aqqub) or corruption (wal-intiqād).

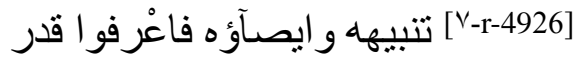

Recognize the privilege we are granting you with his [appointment]! Through your excellent behavior towards him, help him in

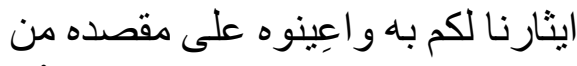

حسنْ

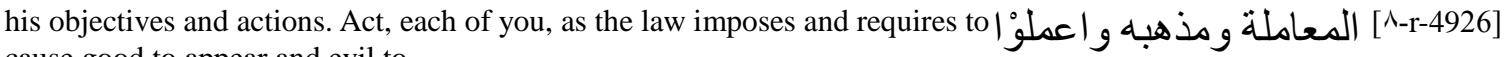
cause good to appear and evil to

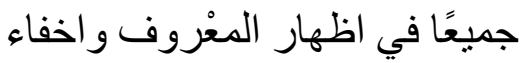
المنكر بالزم حق مقو

Disappear. And God will help you, both you and him, and will prolong your life through the respect and fear [He inspires in you] in all circumstances...
[قكائ

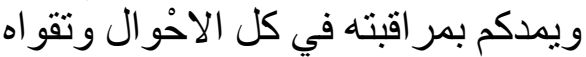

Taqdīm 36: Confirmation of a governor (wālī)

after a complaint probably concerning his management of the Treasury (makhzan) ${ }^{1103}$

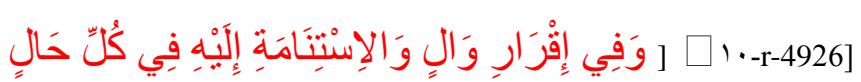

Confirmation of a governor and of the confidence placed in him in all circumstances

...May God on High assure always with security and health the organization of their land and may at all times and in all circumstances He lavish on them the signs

of His favor and the kindness of His mercy. This is the letter (kitābu-nā) we address to you - May God on High have enrolled you

among those whose public or hidden actions converge on good and the fear [of God] ${ }^{1104}$ and whose searching and conviction come together to prefer

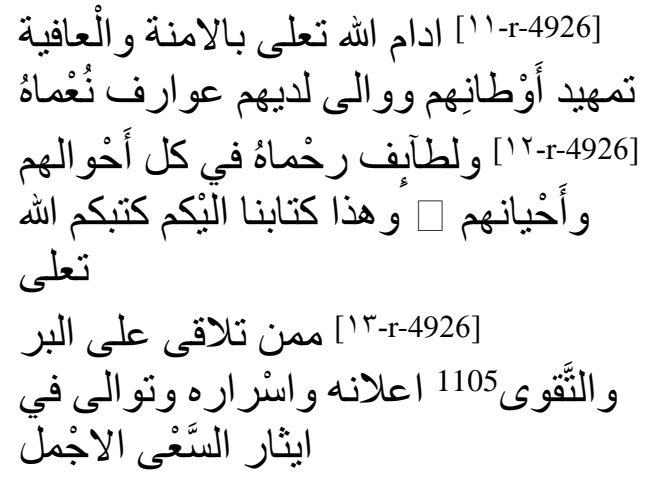

1103 'Azzāwī, NLA, t. 1, 463-464.

1104 Reference to Koran 5:2: "Help ye one another in righteousness and piety" (wa ta 'āwanū 'alá I-birri wa-l-taqwá).

1105 Reference to Koran 5:2: 
the most beautiful and pleasing efforts. Know well that we take great care of your land's interests - May God on High

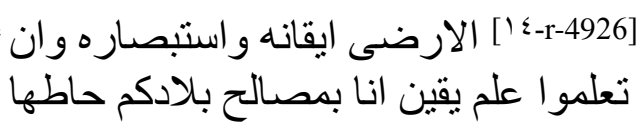

defend it - that we favor everything that improves your situation and causes your hopes to blossom, that you are the first [to

[10-r-4926] تعلى معتنون ولكل ما فيه صالاح احو الكم ونجاح عامالكم منثنون نقدمكم في معان

benefit] from all our benevolent actions, that we start with you in the measures we ceaselessly and permanently take to defend the land and its inhabitants,

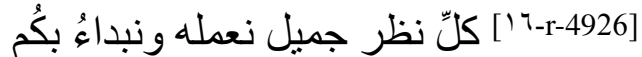

في ما نو اليه من الحياطة للبلادِ و أَهلها نهاء

ونصله

and that we remember your haste to obey and join the community $\left(j a m \bar{a}{ }^{\prime} a\right)$ so much so that we are neither ignorant

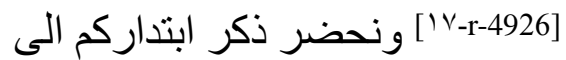

الطاعة و الانتظام في الجماعة فلا نهمل

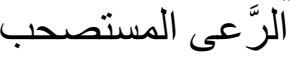

nor negligent of the duty it imposes on us to protect you at all times. As a result, we ceaselessly seek to know exactly your affairs

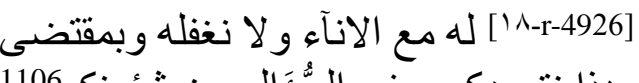

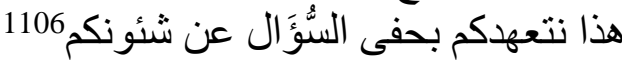

and bring you at all times the support of our generous attention that will shower you with happiness and will cause you to shed

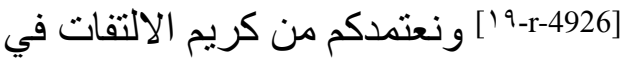

كل الاوقات بما بحسبكم ابهاجا لنفوسكم

و اقر ار الموان

tears of joy. By the glory of God, your affairs and the situation of your elite and masses will know

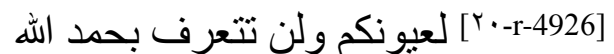

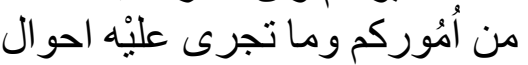

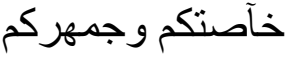

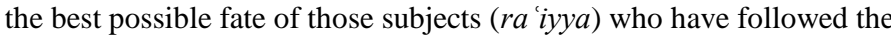
exemplary path and who have behaved themselves

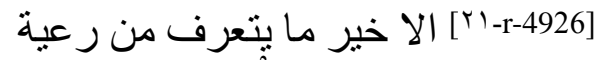

استقامت على الطريقة الْمثلى و اقبلت من من فين

مهرَّات

in a most decent and just manner in their secular and religious activities and who have willingly obeyed their government in helping

$$
\begin{aligned}
& \text { [ [بr-r-4926] }
\end{aligned}
$$

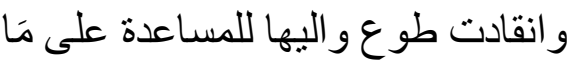

to manage their interests. This is why we judge your actions laudable and excellent, and to fulfill your wishes

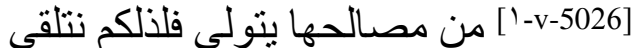

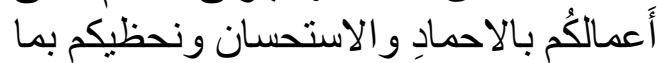

بتقا

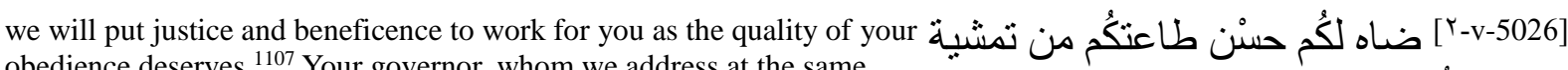
obedience deserves. ${ }^{1107}$ Your governor, whom we address at the same time

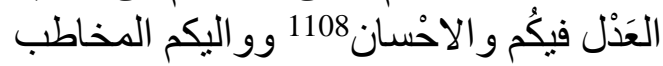
الان

as we address you, the shaykh Abū 'Abd Allāh - May God on High support and assist him through the fear He inspires in him, and guide his aims

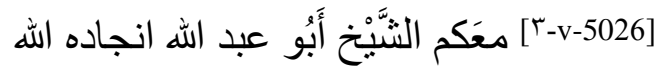

تعلى على تقو اه و اعانه وسدد قصده إن

in all his endeavors, and favor his affairs - is, as you know, the first to have proclaimed our cause ( $d a^{\prime}$ wati-nāa) among you;

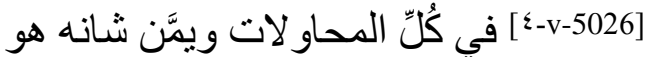

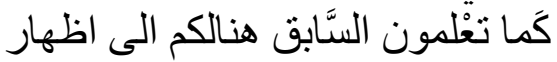

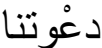

1106 'Azzāwī: شؤونكم.

1107 Reference to Koran 16:90: "God commands justice, the doing of good” (inna Llāha ya'muru bi-l- 'adli wa-l-ihsāni).

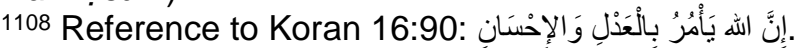


and he spent all his efforts and zeal in the multiple services he rendered us by the sincerity of his intentions and the purity of his convictions. This is why we chose him as the sole person to

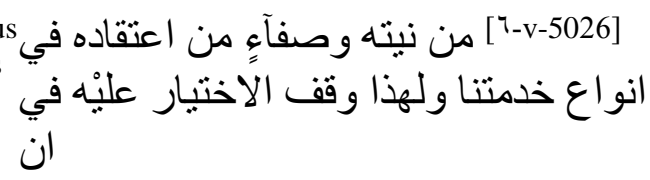

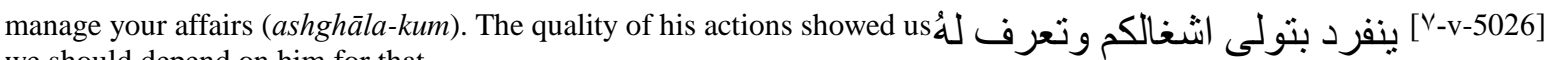
we should depend on him for that

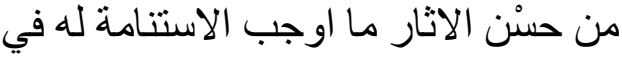

at all levels. We never cease to learn lessons from his initiatives and the whole of his conduct that allow us to increase

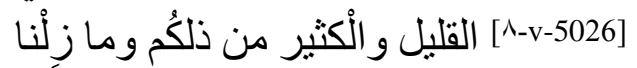

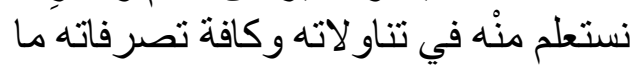
نزداد

our happiness, and we discover in the righteousness of his methods and intentions a rampart that protects at all times his religion and

مذأه

مذا هبه ومناحيه ما لا يز ال على داطيه دينه و اما

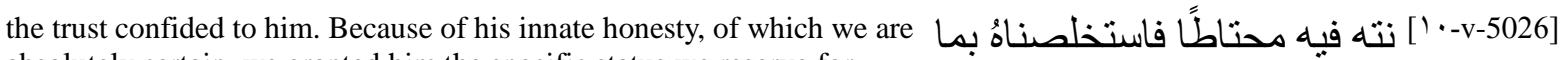
absolutely certain, we granted him the specific status we reserve for

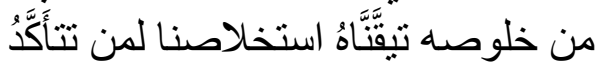

servants confirmed in our cares and we accorded him the preference we accord only the most faithful of the faithful

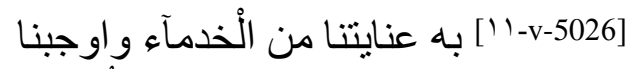

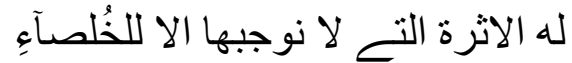

الاصفياء

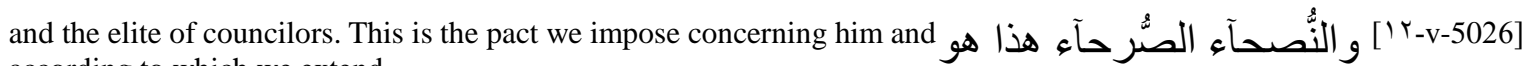
according to which we extend

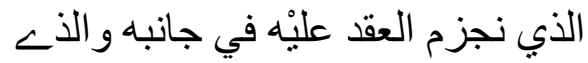

نوالـ

him our benevolence and generous attention. If a troublemaker said otherwise,

إع-v-5026]

الاعتنآء به فان ارجف بغير ذلكم مرجف

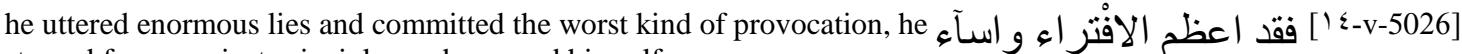
strayed from our just principles and exposed himself

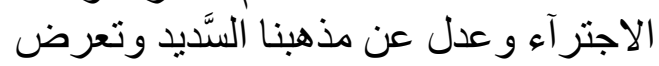

to a most severe punishment. We will be merciless to he who opens his mouth to slander the actions of our servants

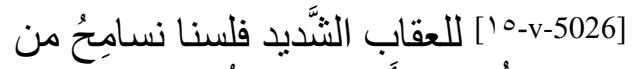

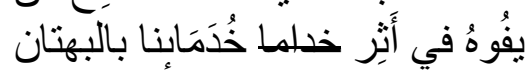

and we will pardon no false steps that bring him to contempt and infamy; we will make of him an example for whomever makes a habit of spouting

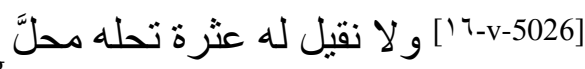

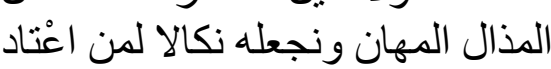

بالافتيات الاطنلاق نون الاعن 1109

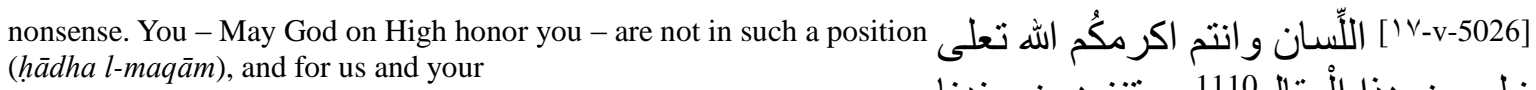

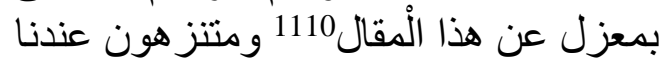

و وعند

governor you are in a garden far from all wickedness, great or small. Your alliance with this power and its partisans,

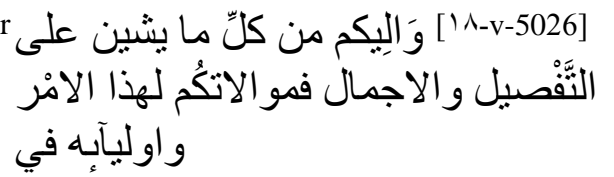

1109 'Azzāwī corrects with لإططلاق.

1110 'Azzāwī corrects with ألمقام 
in the past as in the present, is well known. Your flanks receive surveillance from us that covers

them permanently. Your communities are reputed among us for their magnificent friendship (al-khiläl) in the just actions you compel yourselves

to carry out. And we address these severe threats only to those who turn from the obvious straight path

and who approve the scandalous rumors about the Treasury (makhzan). Continue to walk along the path of faithful obedience to

your above-mentioned governor, be with him as one hand united in important matters and help him with sincere

intentions and pure hearts. Know that for us that is the most beautiful thing authorized and ordered for you;

it is part of the virtuous works and laudable efforts we prefer to see you accomplish, if God on High wills it. And $\mathrm{He}-$ May He be glorified - $\mathrm{He}$ will bring

together under His obedience your union and understanding and He will assure you profusely and permanently His guard and His protection. By His grace...

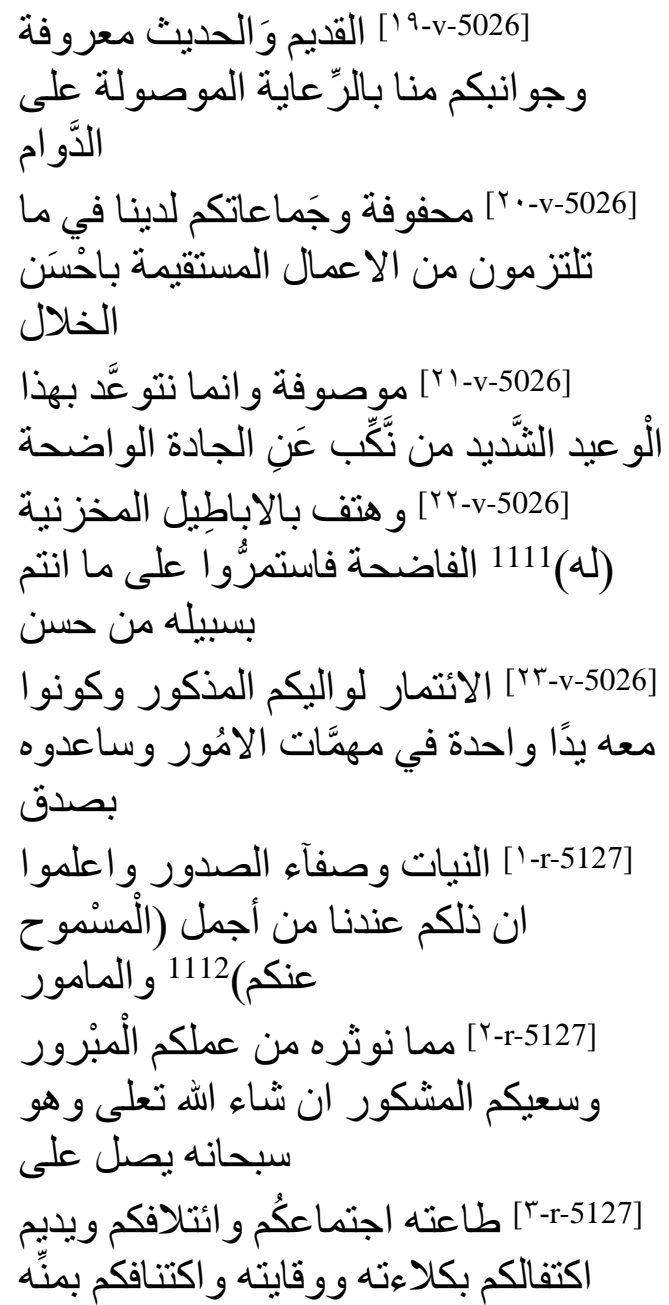

Taqdīm 37: Renewal of Abū Fulān as governor, with fiscal attributions ${ }^{1113}$

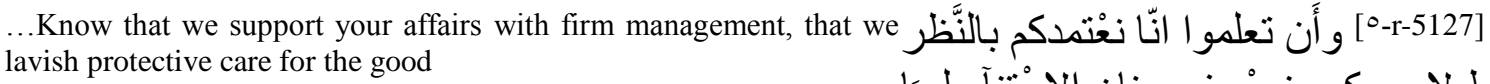

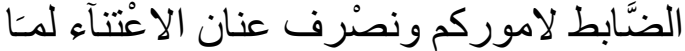

of you all, the masses and the elite (khāsșati-hi wa jumhüri-kum), that we watch over you with a benevolent watch that allows you to fulfill your desires and

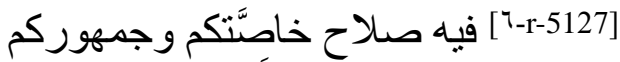

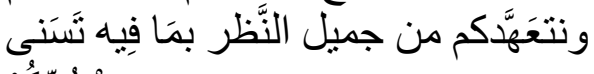

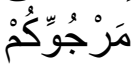

dissipates your fears, in granting you the most generous possible protection we offer the land and its inhabitants,

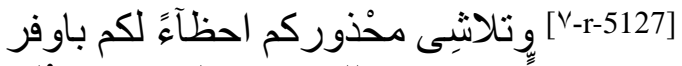

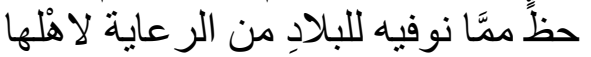

and the defense that allows them to proceed in security and health along the straightest of paths. May God on High thus carry you

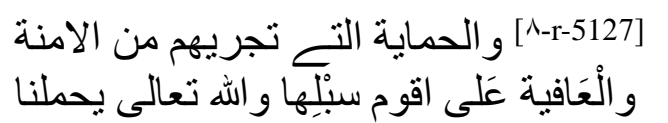


towards [an action] from which good will spread and become widespread. May He complete and consummate the protection that [we] seek for all of our subjects. و[9-r-5127]

ويعم ويكمل مقصود الحياطة لجميع الرَّ عايا

ويتم

By His grace. We have decided - May God on High guide the decision that we make and allow our plans to know success -

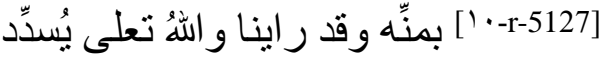

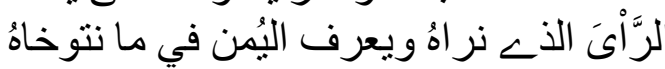

to renew Abū Fulān to lead, as before, your economic and fiscal affairs (fi umūri-kum al-mașlahiyya wa-l-makhzaniyya),

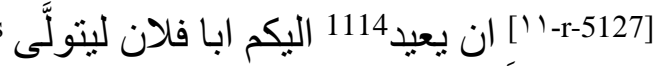

النَّظر على ما كان عليْه في اموركم

المصلحية و المخزنية في امورية

and to lead you in all circumstances along the large and straight path. $\mathrm{He}$ is one whom you already are familiar with and you know

[1'r-r-5127]

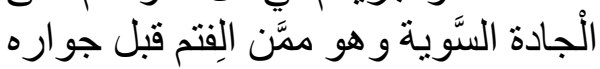

وعرفتم

his authority (irāda-hu wa ișdāra-hu) over you. He has distinguished himself before us with laudable competence and just orientations. We have recommended that he

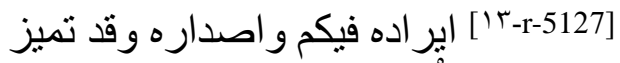

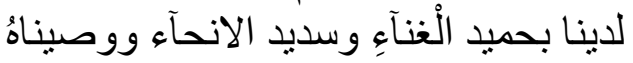

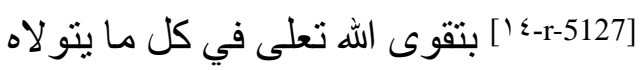

وان ير اقبه سبحانه في سره ونجْو اه و امرنـاه

أَن

- May He be glorified - in secret and in his heart of hearts. We have ordered him

to be severe with the agents of corruption until their evil deeds end, or until they improve their behavior by returning to

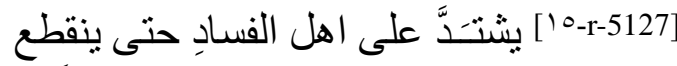

اضر ار هم او تحسن بمر اجعة السنَّداد

Righteousness. All his decisions must be made according to the paths of obvious law and his undertakings

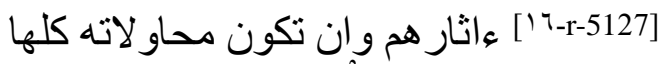

جارية على سنن الْحق المستبين وتناو لاتها

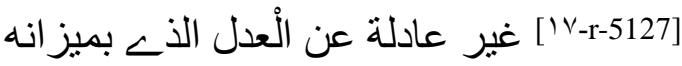

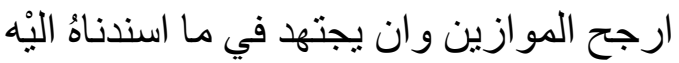

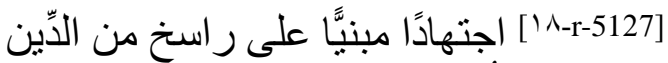

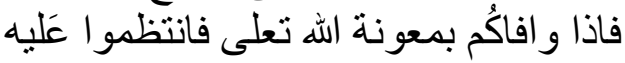

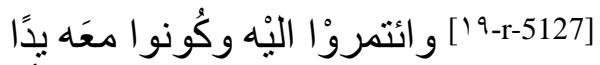

واحدة في كلّ ما يصلحكم ويحمى جهاتكُم

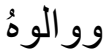

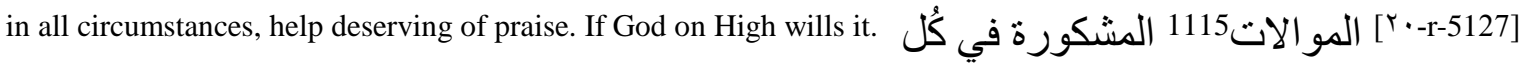

اوقاتكم ان شاء الله تعلى

Taqdīm 38: Appointment or confirmation of a

shaykh from an Arab tribe 1116

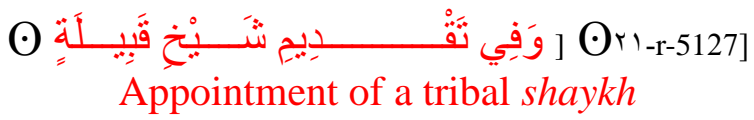

...May God have written for you to rejoice at the news of the benevolent

[بr-r-5127] كتب الله لكم استبشارًا بجمبيل

watch that cares for you

النظر الذى يتعهدكم واستشعار ا للخيْر الذى الذى الني

1114 'Azzāwī corrects with نعيد and later with ونجريكم.

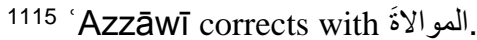

1116 'Azzāwī, NLA, t. 1, 466. 
and to be aware of the good that happens to you and touches you. Know that we have not ceased to take care to spread security over all the land

and to root the scourge of corruption from the cities and countryside ( $f^{2} l$ hădiri wa $l-b \bar{a} d$ ). Presently, praise be to God for the

aid and help He has always granted us, and [also] for having eased our exercise of authority (min i māli l-ișdāri... wa l-īrādi) in managing affairs.

We have caused the blessed army - May God grant it His support and victory ${ }^{1117}$ - in the company of Almohads

whom we have chosen, with Abū Fulān whom we have entrusted with the affairs (ashghāl) of the Arabs, considering that the sincerity of his counsel has made him worthy of the noblest

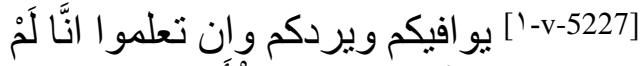

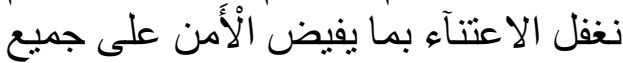
البلاد

[ب-v-5227] و بحسم أَدو اء القساد في الحاضر

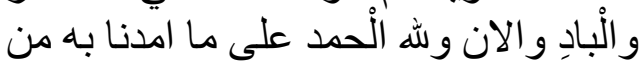

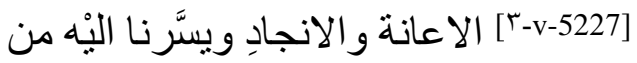
اعْمال الاصدار في تمشية المصالح و الاير اد قد المداست

[- [-5-5227]

الله تعلى و انجده صحبة من تخيرناهُ من

الموحدين

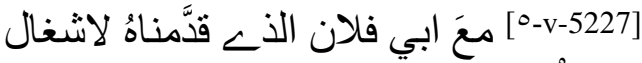

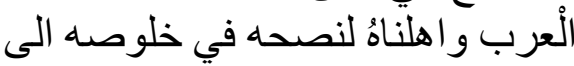
اكرم المب

of functions. [That,] after the Arabs arrived en masse before our door, after they rushed to the good they were used to from

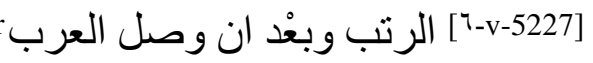

بجمو عهم الى بابنا وبادروزا للخير 1118

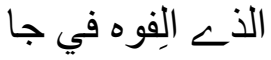

us, after they committed themselves to listen and obey, and to expend all of their resources to serve and aid [us],

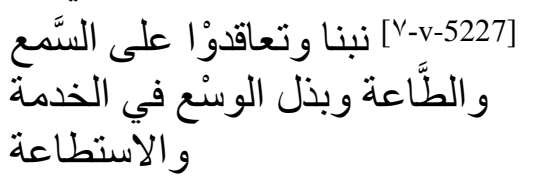

after their affairs found with us the best organization and they took their leave committing to always offer good

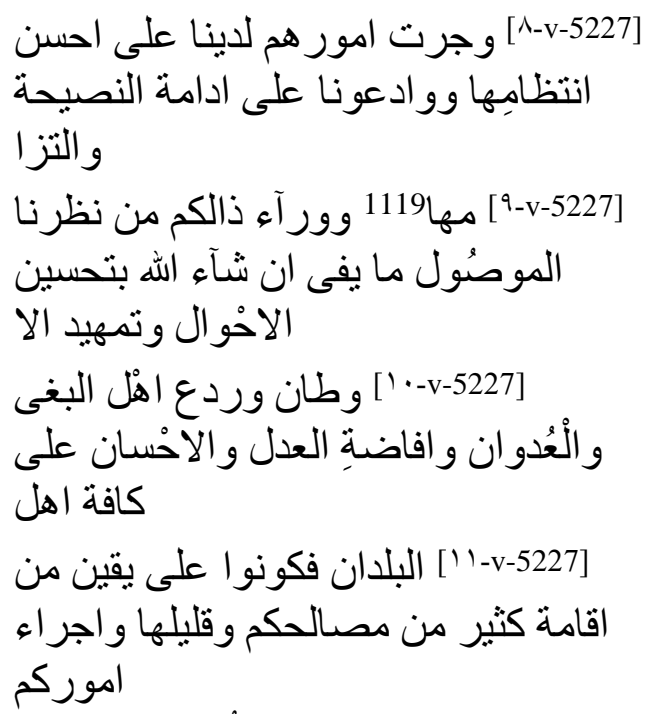

clearest path, thanks to perfect attention and control. Dedicate yourselves to your affairs, adopt

of the provinces. Be sure that your interests, small or large, will be maintained and that your affairs will be led according to the

\footnotetext{
1117 Reverse order.

1118 'Azzāwī: إلى الخير.

1119 Not read by 'Azzāwī.
} 
words and acts that benefit you, and truly believe that we will deny you no consideration that may improve

Taqdīm 39: Appointment or confirmation of an

Arab shaykh, dismissal of the deceased predecessor's son for his brother ${ }^{1120}$

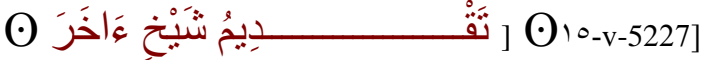 \\ Appointment of another shaykh}

...Know that the Arabs are known within our cause ( $\left.d a^{i} w a\right)$ by the abundance of our favors and the profusion

of kindness that their ancestors knew. But among them all, we praise your services and distinguish your pact of

alliance (dhimma). We accordingly write you so that you will have the same haste as your Arab brothers

in rendering us the services that will garner you esteem and praise, and so that you will arrange yourselves at their sides and at the side of the armed and

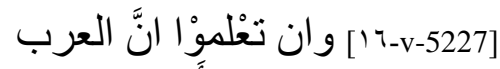

مخصنوصون من دعوتنا بما نشاً فيه اسلافهم من افاضة اسلة

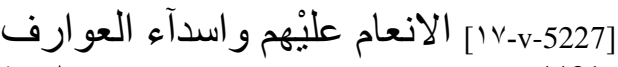

اليْهم 1121 وانتم فيهم ممن تشكر خدمته وتلحظ

[ A-v-5227 ] ذمته وبمقتضى ذلكم خاطبناكُم

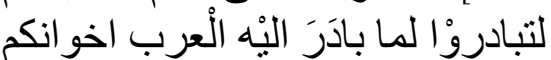

[19-v-5227] من الخدم الذى 1122 نستحسن منكم

وتستجادُ وتصلو ا الى الانتظام معهم ومع

...)

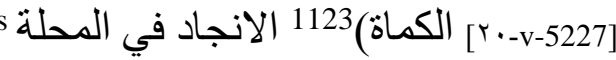

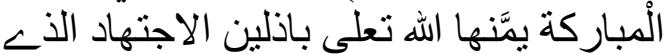

[1124) الاعتنآ

ويفيدكم افضل ما عُوِّدتم من الاثتار و الاحْتفاء

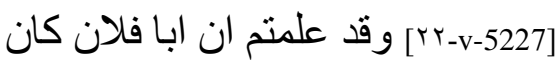

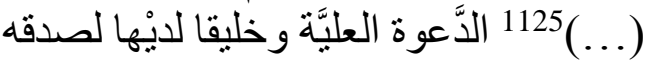

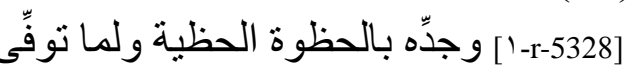

ابقينا ولده في مكانه ونو هنا بتقديمه على به وهي

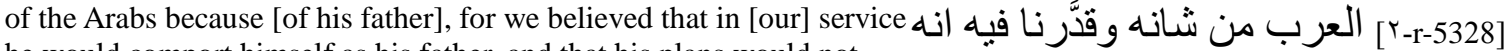
he would comport himself as his father, and that his plans would not stray

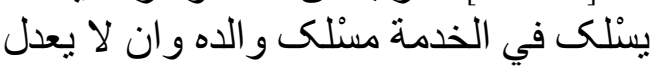

from the praiseworthy paths his father had followed. Nevertheless, he delayed not in renouncing [that] favor and in calling misfortune on himself through his

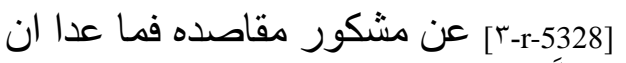

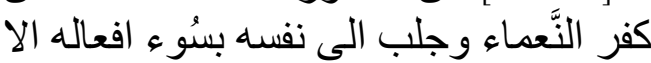

1120 'Azzāwī, NLA, t. 1, 467.

1121 'Azzāwī: عليهi.

1122 'Azzāwī corrects with التي

1123 Two unclear words, the second is probably الكماة.

1124 One illegible word.

1125 Space for two illegible words. 
Misdeeds. We have dismissed him and [in his place] have named his [paternal] uncle, Fulān, at the head of the Arabs, to manage their affairs and govern

[-r-5328-؛ سو آء و اخرناه وقدمنا عمَّه فلانا

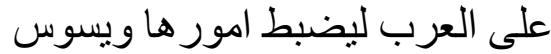

them as well as possible. We are informing you of this so that you will hasten to act with him as did

[0-r-5328] احسن سباسة جمهور ها فاعلمناكُم

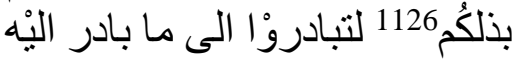

your brothers, and so that you will plunge headlong into our service,

with the certitude that you will know [our] care and generosity,

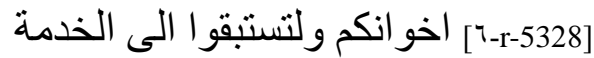

مرسلا فبها عنانكم على ثقة من تجدد

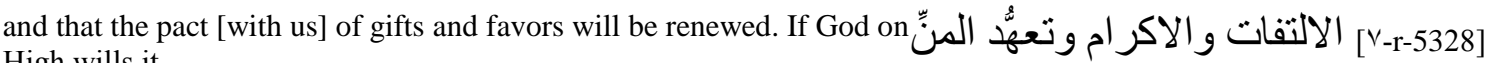
High wills it..

و الانعام ان شاء الله تعلى الخد

Taqdīm 40: Appointment or confirmation of an

Arab shaykh at the head of two armies to be united under his command ${ }^{1127}$

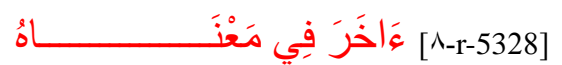

Another [note] on the same subject

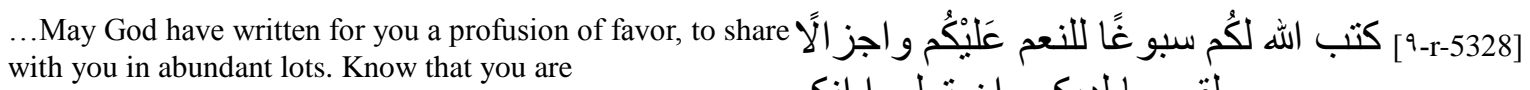

لقسمها لديكم وان تعلمو ا انكم

the faithful (al-mukhlișūn) devotees (ardiy $\bar{a}^{\prime}$ ) of our cause (da'wati-na) , its supportive good counsel. That is why we support you with all

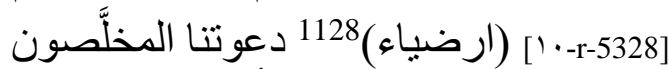

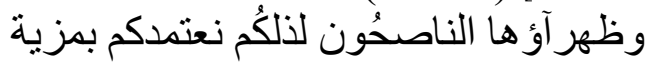

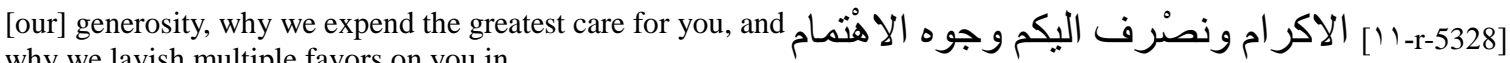

why we lavish multiple favors on you in

ونحظيكم في كل الاحو ال بمز الانمان

all circumstances. May God on High grant you a profusion of kindness for eternity. By His grace. That is why

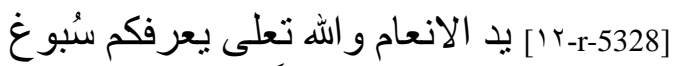

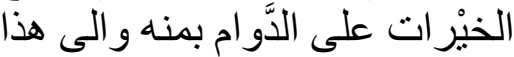

we have named Fulān at the head of the army we have sent you. We have also decided

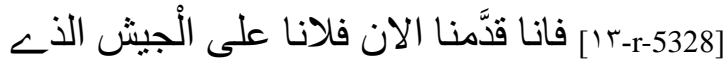

اشخْصناه الان فانيان اليكم ور اينا

to appoint him at the head of the first army, so that both armies fall under his command. His talent will show itself

in his deeds with them both. He is known for this ability and for the rightness of this decisions. We have ordered him

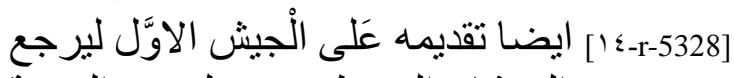

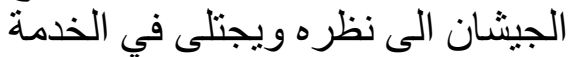

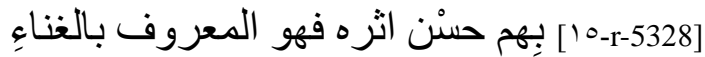

و المعروف بسدادِ الانحاء وامرناه بـناه

that all should act with you as one hand united to push back enemies and so that in return

[7-r-5328]

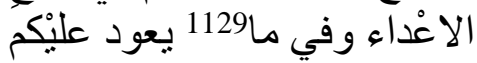

the regions and countries you receive will know peace. ${ }^{1130}$

[We have also ordered him] that you expend continuous

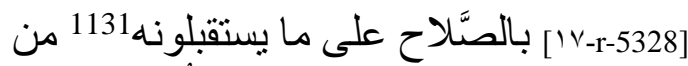

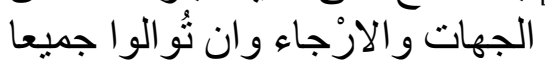

1126 'Azzāwī: بذلك.

1127 'Azzāwī, NLA, t. 1, 468.

1128 Beginning of the word erased.

1129 'Azzāwī: وفيما.

1130 Or "that they will receive".

1131 'Azzāwī corrects with تستقبلونه". 
effort to push back hypocrites and to show praiseworthy accord in all

your tasks. We also advise you to assemble all your groups and to sound the call for those who are late among the Arabs

(...[your brothers]). May they be bound together in the seriousness and quality of counsel, agreeing on a [sincere]

service (șarịha) [and to give counsel] until the enemy - May God break them - fears your place

(........ handsome, continue... many)

efforts great and small. Know that... [1/1-r-5328] الاجتهاد في كُل ما يُرْدِى اهل النفاق

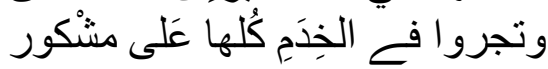

[19-r-5328] الاتفاق 1132 ونحن نزيدكم الوصية في ضم مئم

جمو عكم كلها و استدعاء من تاخر من الترب وند

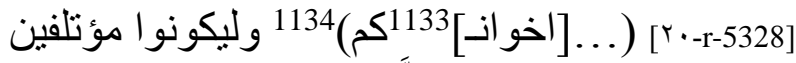

على الجد و النَّصيحة متفقين على الخدمة

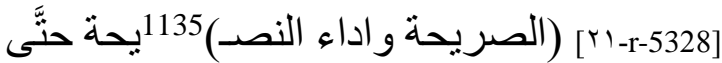

ير هَبَ العدو قصده الله مكانكم (...

[rr-r-5328] و اضـاقته و احْيانكُم ........ الجميل وو اصلو ا.

1136 (الكثير

[ [ -v-5428 من المحاو لات و القليل فَاعْلمو ا ذلكم

Taqdīm 41: Appointment of the son of an Arab

shaykh at the head of the Sufyān Arabs, with

authority over the Anfā territory (modern

Casablanca) ${ }^{1137}$

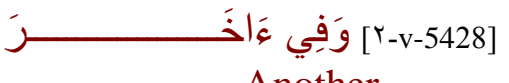

Another

...May God, by the fear He inspires in him, make his virtue and generosity endure and may He confirm through the esteem he enjoys at our side his joy and happiness.

[بr-v-5428] ادام الله أثر ته و كر امته بثقو اهُ و اكد

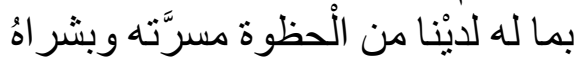

This is what we have written - May God have written for you that you should receive abundant shares of bountiful favors

$(\ldots=$ to see? $)$, in the honors and dignities to which we have raised you, the most beautiful gifts as marks of distinction. Know...

[ـ-v-5428]

لاجزل حظوظ النعم قسْمًا و (...)

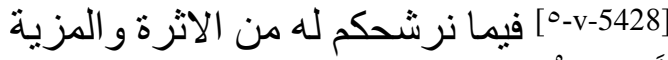

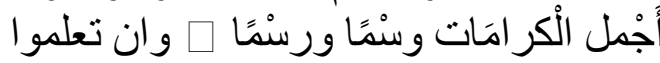

1139 (...)

what we have granted you by privileging, raising and demanding for you

[ب-v-5428] ما استانفناه لكُم من الاحْظاء لرُتبتكم

و الارققاء و الاستخلاص لمس الذه لكم

a rank like the most beautiful finery for the faithful servants you are, and keeping with you the same demeanor as with your father regarding...

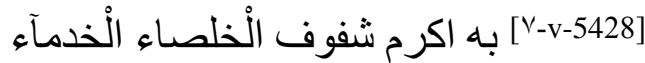

و الاجر آء لكم مجرى و الدكم في كل مرام 1140 (...)

1132 Hole at the beginning of the word.

1133 Suggestion.

1134 Space for two words erased.

1135 Suggestion for three words erased at the beginning of the line based on the saj and the other taqādīm.

1136 Partially or completely erased words along an entire line.

1137 'Azzāwī, NLA, t. 1, 469.

1138 One or two words erased.

1139 One or two words erased.

1140 One or two words erased. 
this power, for the appointment, honors, benefices, retributions (ashäm), and the favor you have received

by being, in our service, the first in seriousness, good counsel, and purity, and in keeping ([the responsibility ?]...)

exercised by your father, transmitting it among yourselves to the noblest sons. Accordingly - May God assure you always respect through the fear He inspires in you -,

we have appointed you irrevocably at the head of all your brothers, the Sufyān Arabs (...),

to take charge of all their affairs, fiscal and otherwise, and to lead them, both the masses and the elite

(...) in addition [we] [grant] you the direction of Anfāa ${ }^{1145}$, as with your father before, we place all its affairs (ashghāl)

under your excellent administration. We grant you full power for that, as with your father before,

(...[we have granted you]) the same favors and benefits, the same rank and illustrious dignity as were his; [we] have treated you in all regards

as we did him ${ }^{1151}$. You enjoy the same high esteem from us as did your father during his lifetime. Know that, and lend your ear (...)

confidence in the favorable welcome we reserve for all your hopes. Set out to find us and present yourselves to us,

you will see (...) all [your] hopes and desires brighten and blossom to enjoy abundant and (...)

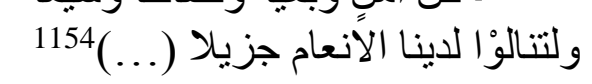

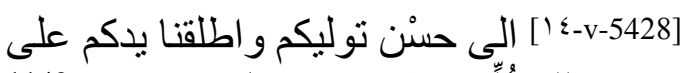

ذللكَ كُلِّه كاطلاق بده فبل فيما (. . . 1149

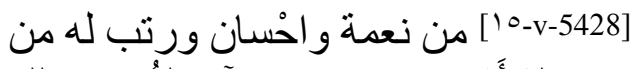

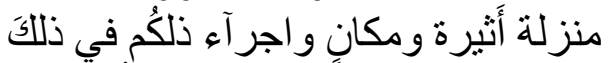

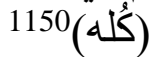

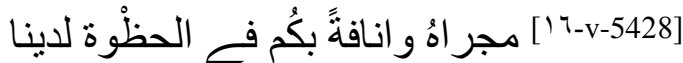

على مداهُ فاعلمو ا ذلكُم وتنسَّطو ال (. . . 1152

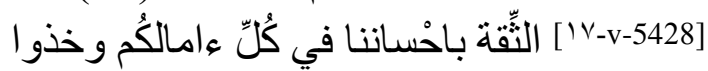

في الوصنول الينا و القدوم علينا

1153 (تجدون....

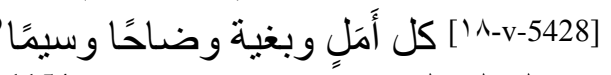

\footnotetext{
1141 One or two words erased.

1142 Plausible completion.

1143 One or two words erased.

1144 One or two words erased.

${ }^{1145}$ Former name of Casablanca (al-Idrīsi, Description de l'Afrique septentrionale et de l'Espagne, éd. et trad. R. Dozy and de Goeje, 1866, p. 48 and A. Adam, s.v. "Ānfā", $E I^{2}$, t. 1, 521-522).

1146 'Azzāwī: آنفا.

1147 'Azzāwī: حسب ما: حسا.

1148 Suggestion by 'Azzāwī.

1149 One or two words erased.

1150 Suggestion by 'Azzāwī.

1151 It is possible that the idea of d'ijrā' majrá refers to the continuation of appointments as suggested by Kazimirski.

1152 One or two words erased.

1153 One or two words erased. Suggestion by 'Azzāwī.

1154 One or two words erased.
} 
immense favors and to occupy at our side the unique place reserved for you..

...which will cause favors to increase and grow for you...

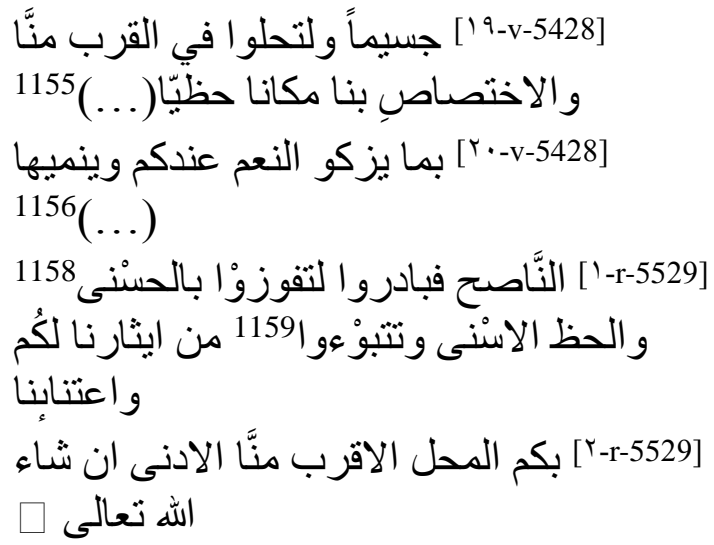

Taqdīm 42: Appointment of a tax collector ${ }^{1160}$

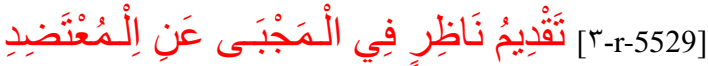

Appointment of a tax agent in the name of al-Mu'tadid

...This is what we write to you - May God have written for you consensus for [your] interests. Know that [our] benevolent watch

guides your regions, organizes your provinces and grants you riches in harmony with your hopes

and wishes. Rejoice in that the generous care granted your situation gives order to your affairs, concerns both the elite

and the masses, fills your eyes with tears of joys, and swells your breasts. We ask the support of God on High to assure, [-r-5529-ء ] و انا كتبناهُ كتب الهه لكُم تو افقا عَلى

$$
\text { المصنَالح وان تعلموا ان النَّظر الجْميل }
$$

[0-r-5529] بسدِّد انحاَّكُم ويمهد ارجاءكم ويطلع عليكم من الخيرات ما بطابق املكم

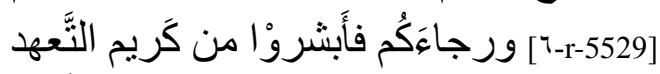
لاحْو الكم بما ينظم امور جم ويشمل خاصَّنكم

[V-r-5529] و جمهوركم ويقر عيونكم ويبهج صدوركم وبالله تعلى نعتضد على ما نتو لاه

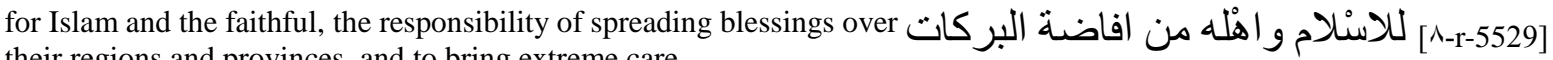

their regions and provinces, and to bring extreme care

على جو انبهم وجهاتهم و اجادة العنا مناه

to their interests (bi-mașālihi-him) and their affairs (muhimmāti-him). For it is He who dispenses His support and whose Will guides along the

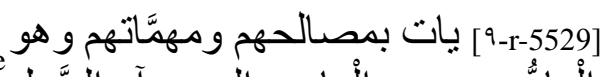

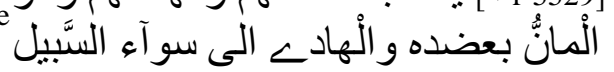

straight path. There is no master but Him. In accordance with this, we have named Fulān to efficiently watch (al-nazar al-asadd) over your interests

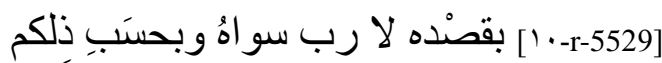

قذَّمَنا فلانا لينظر في مصنَالحكم النَّظر

and to exert the greatest gravity in collecting Treasury (makhzan) and Domain (mukhtaș) taxes - May God make them productive.

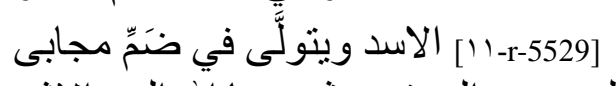

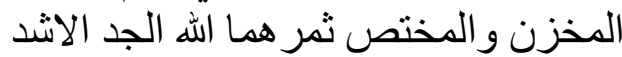

1155 One or two words erased.
1156 The ends of this and the next two lines are hidden by the affixation of the pages.
1157 Reference to Koran 10:26: "To those who do right is a goodly (reward)- Yea, more (than in
measure)!") and to Koran 92:5-7: "So he who gives (in charity) and fears (God) / And (in all sincerity)
testifies to the best / We will indeed make smooth for him the path to Bliss".
1158 Reference to Koran 10:26: and to Koran 92:5-7: 
This is why we have counseled him to fear God on High in carrying out his functions. We have ordered him to the royal path of

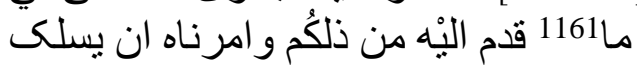

$$
\begin{aligned}
& \text { جآدة }
\end{aligned}
$$

righteousness in all circumstances with you; we have enjoined him to be paid completely and in full all Treasury (makhzan) and Domain (mukhțașs

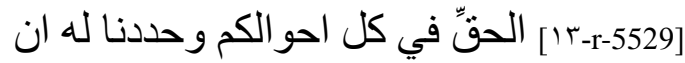

يستوفى حقوق المخزن و المختص هن هن احنا

duties in your [province], to be as selfless and upright as possible in mastering their collection

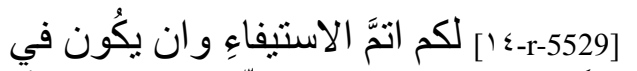

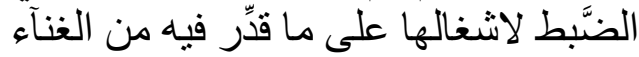

and to accomplish this task with care and diligence. Thus, when he arrives among you,

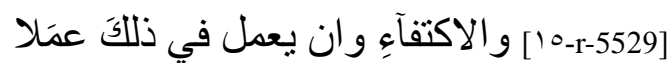

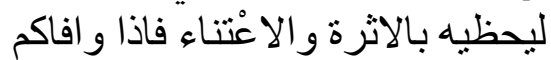

with the help of God, refer to him for all your fiscal questions, help him in all that we have entrusted exclusively

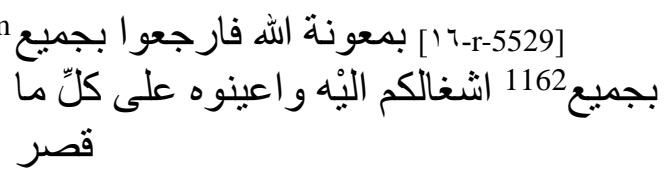

to him, collaborate with him to merit praise now and in the future and to manifest

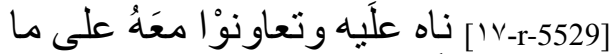
تحمدون أَثره في حالكم ومآلكُم ويظهر مئه

the worthy choice of your actions, if God on High wills it. It is He that helps you in that which is pleasing to Him

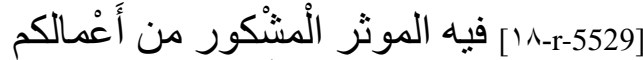

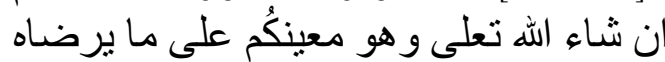
and eases for you the straightest and most just path.

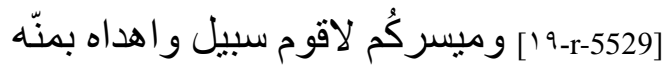
By His grace.

Taqdīm 43: Appointment of shaykh Abū Fulān as governor ('āmil), with fiscal, military, and perhaps judicial attributions, in the name of the caliph al-Murtaḍā from Fulāna in Jumāda I 657/may 12591163

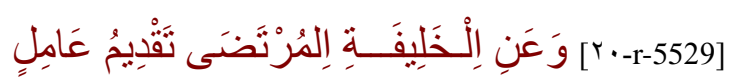

Appointment of a governor ( 'ámil) in the name of Caliph al-Murtaḍā ...This is what we write from Fulāna ${ }^{1164}$ - May God have written for
you to know that which is best and preferable and to conduct
yourselves in a manner that assures you

happiness in this world and the other. This is what we advise you, etc. Know that we lavish

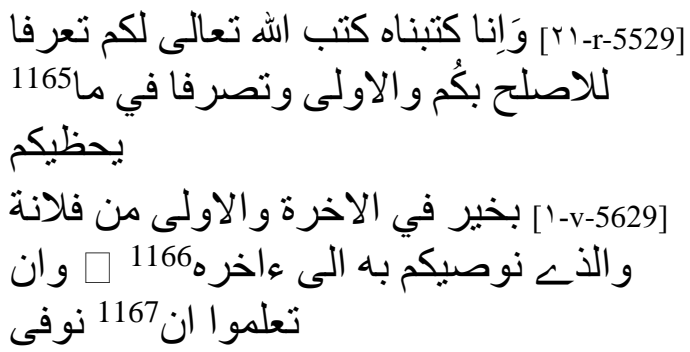

\footnotetext{
1161 'Azzāwī: فيما.

1162 Repetition omitted by 'Azzāwī.

1163 'Azzāwī, NLA, t. 1, 471-472.

1164 Perhaps Marrakesh.

1165 'Azzāwī: فيما.

1166 That is the tawșiya bi-taqwá Allāh wa-l- 'amal bi-țā ati-hi.

1167 'Azzāwī corrects with أنّا.
} 
over your region - May God protect them - their share of benevolent attention, that we choose for them someone who will take responsibility for protecting and

overseeing them, and that we will always spread and cause security to reign, near and far. This

in accordance with the requirements of the authority (nazar) we have been invested with over you and your peers, and with the duty of protecting you all, near

and far. Accordingly, we have chosen shaykh Abū Fulān ${ }^{1168}$ to take charge of your economic affairs and fiscal matters (makhzaniyya)

and to govern you in all circumstances according to correct and equitable methods (al-manāhij).

In the part of Unicity (tawhìd), he is famous $\left(a t h \bar{i} r^{u n}\right)$ and influential (makin); he deserves this rank for sure and solid reasons.

The services he has rendered by way of his counsel and zeal are manifest and evident. We have advised him to fear God and remain in awe of Him,

and to apprehend [His wrath] in secret and in public, that is the most solid and firm foundation for salvation and the first and true

support for people of the faith. We have ordered him to put nothing before the law, whenever he applies or

pronounces it, to cling to justice for his direction and methods and to take charge of your interests

and affairs with laudable competence and efficiency. We have insisted that he collect in full fiscal

fees and duties - May God cause them to grow. He should use all means to develop and make [them] blossom

and that he dedicate the most of his time to taking care of this task and collecting [the sums due], large and small. Surplus must be

spent in the general interest of Muslims and reserved for treating affairs that concern them all.

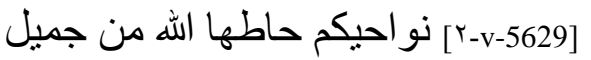

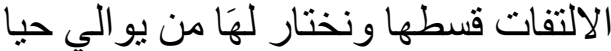

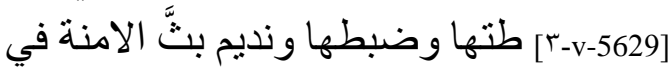

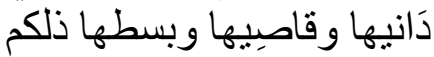

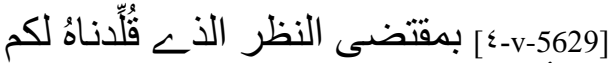

ولسو اكُم وموجب كُ الر عَاية التح تعم انز حكم

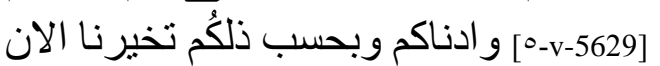

لتولــ اموركم المصلحية و اعْمالكم المخزنية ونية

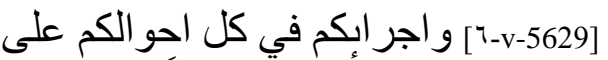

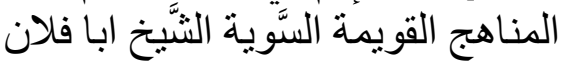

[V-v-5629] و هو في حزب التوحيد أَثير مكين

وسببه في استحقاق الْمكانة وثيق متين

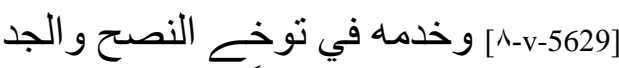

تتضح وتبين وقد وصنَّنياه من تقوى الله

وخشنيته

[9-v-5629] و مر اقبته في سرِّه و علانيته بما هو

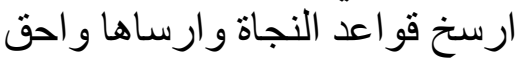

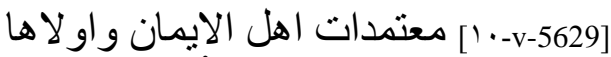

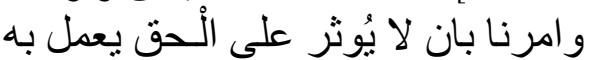

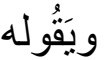

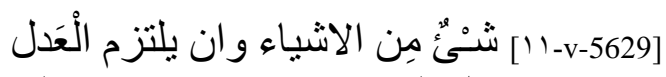

في كل المذاهب و الانحاء وان بنتولى

مصالحكم

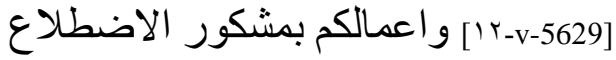

و الغناءِ و اكدنا عليْه في ان بستوفى حقوق اعتى

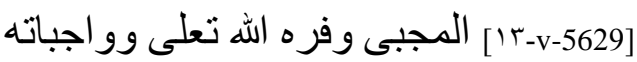

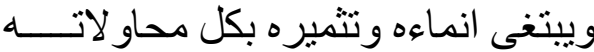

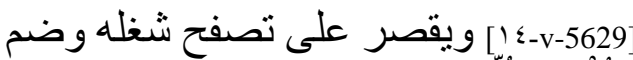

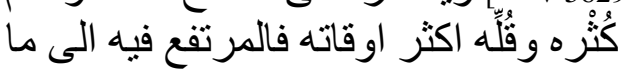

[10-v-5629] بعم المسنلمبن نفعه مصروف

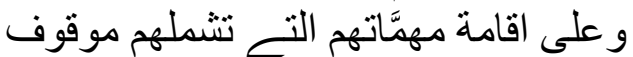

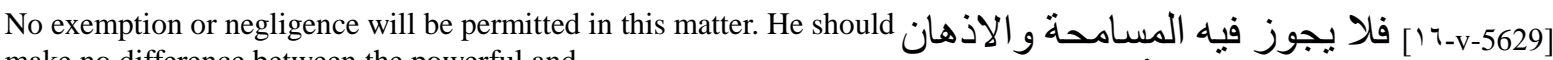
make no difference between the powerful and

و لا يميز في استخر اج الْحق و استقصنَآنه

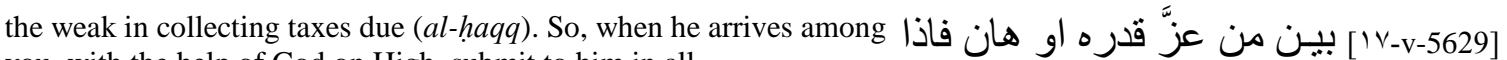
you, with the help of God on High, submit to him in all

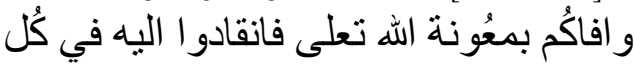

1168 lbn 'Idhārī mentions for this period the appointment by al-Murtaḍá, from Marrakesh, of the qāọ̄ Abū 'Amr b. Hajjāj over Sijilmāssa. He had already appointed him when al-Qițrānī returned to caliphal obedience. The qāọī had organized the execution to calm the situation (Bayān, 419). 
Things. Be as one hand united [with him] to accomplish what will bring good to all, to the elite and the masses.

Among other things, we have prescribed him to consecrate his efforts and zeal to eliminating the traces of rebellion and corruption

and to confront them with brutality and severity. ${ }^{1169}$ Offer him for that and the rest of your interests

all the help you can. Collaborate fully with him to advance the law with your counsel and loyalty (diyāna).

If God on High wills it. And He - May He be glorified -, He will assure you always respect by the fear $\mathrm{He}$ inspires in you and $\mathrm{He}$ will ease for you that which pleases Him.

By His grace. Date: middle of Jumāda I in the year 657.

$$
\begin{aligned}
& \text { [1/l-v-5629] }
\end{aligned}
$$

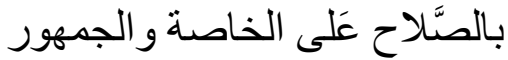

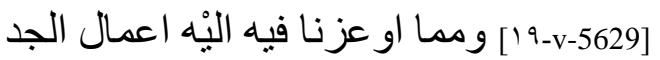

$$
\begin{aligned}
& \text { و الاجتهاد في محق ءاثار البغى و الفساد }
\end{aligned}
$$

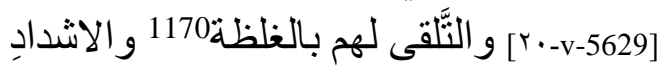

$$
\begin{aligned}
& \text { فاعينوه على ذلكم وسو اه من مصالحكم }
\end{aligned}
$$

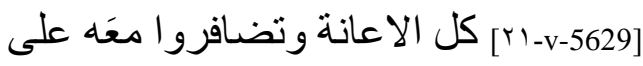

$$
\begin{aligned}
& \text { تمشية الحق تضافر ا وفي النصح و الديانة }
\end{aligned}
$$

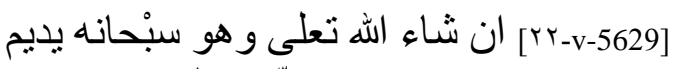

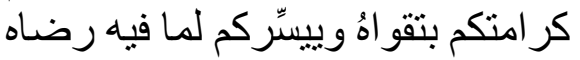

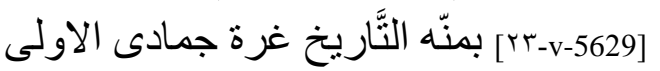

$$
\begin{aligned}
& \text { سنة سبعة وخمسين وستمانة }
\end{aligned}
$$

\section{Taqdīm 44: Appointment of Fulān as governor}

\section{(identical to taqdīm 35) $)^{1171}$}

In the name of the same... May God have written for you a decision that responds to your expectations

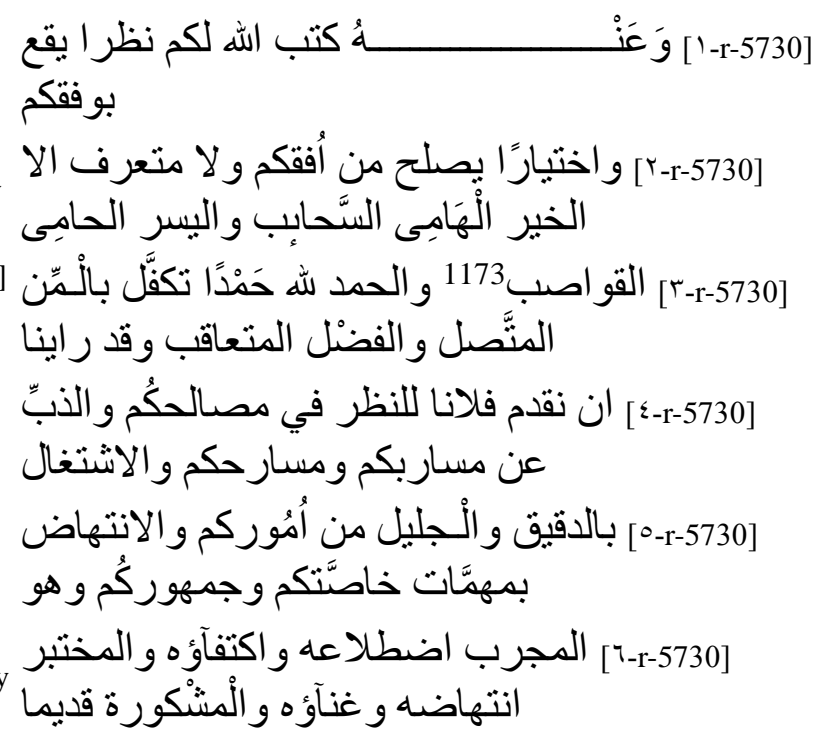

of your affairs, important and insignificant, to move forward with all your problems, with your elites and your masses ( $b i$ muhimmāti-kum wa khāṣsatī-kum). His

effectiveness and aptitudes have been proven, his zeal and competence confirmed through experience. We have had only praise for

[V-r-5730] وحديثا مسناعيه كلها و انحأؤه ومن لا يحيد

his work and decisions, both in the past and recently. He is man who strays neither to the right nor to the left from the virtuous behavior that garners our

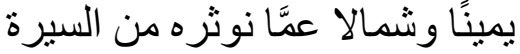

favors and preference. His high deeds and what we know of him, present and absent, have always received our approval.

His counsel and remarks are hardly necessary [to know] his seriousness, his zeal and the fact that he is above any suspicion (bu'd 'an mazānnn) of prevarication (al-ta'aqqub)

1169 Reference to Koran 9:123: "O ye who believe! fight the unbelievers who gird you about, and let them find firmness in you: and know that God is with those who fear Him."

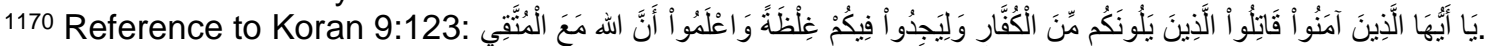

1171 'Azzāwī, NLA, t. 1, 473. Text identical to taqdīm $\mathrm{n}^{\circ} 35$.

1172 It sounds like a threat.

1173 Corrected with القو اضب thanks to the identical taqdīm n³5. 
or corruption (wa l-intiqād). Recognize the privilege we are granting you with his [appointment]! Through your excellent

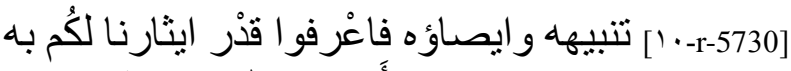
behavior towards him,

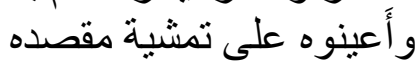

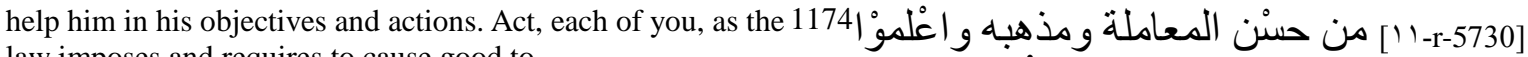
law imposes and requires to cause good to

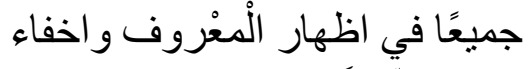

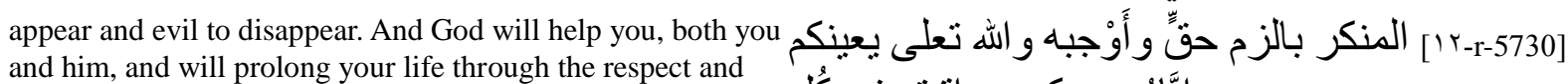
fear [He inspires in you]

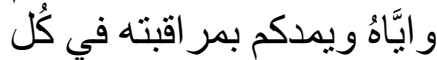
in all circumstances..

$\square$ [بr-r-5730]

\section{Taqdīm 45: Incomplete appointment ${ }^{1175}$}

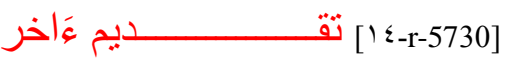

Another appointment

This is what we write - May God have written for you that you should agree with each other for [your] interests and compete in acting with virtue. Know that

[our] benevolent watch guides your provinces and organizes your countries..

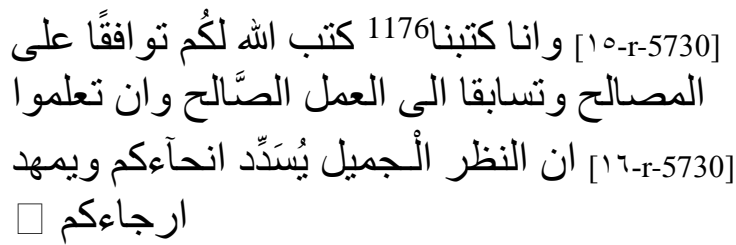

Taqdīm 46: Appointment of Fulān as governor responsible for the Domain (mukhtașṣ) and hisba, with fiscal and military attributions ${ }^{1177}$
May God have written for you lasting healthy conditions and hopes crowned with success. Know

that our care to dedicate our watch over those whom God has entrusted to us concerns all regions, near

and far, and that our action uses forbearance and justice at all times. It is in consideration of this that we chose those person

whom we take as governors to manage interests and matters and that we name those in whom we distinguish the righteousness of their intentions

and the rectitude of their enterprises. This is in order that matters progress along the clearest and straightest of paths and that [our]

subjects (al-ra iyya) be lead under the protection (...)

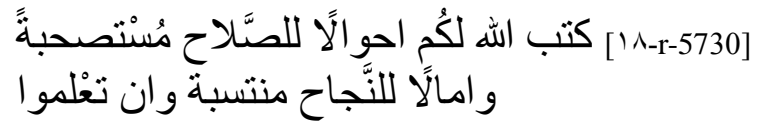

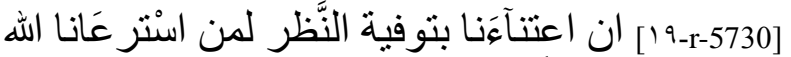

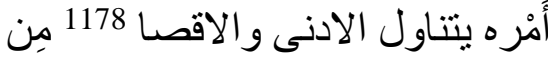

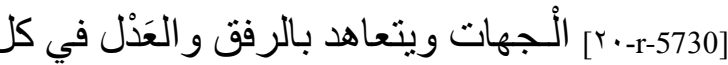
الاوقات وبهذا الاعنتبار نختار فئرل ونقدّمّم من نتوسَّم فيه سداد الانحاء الهم

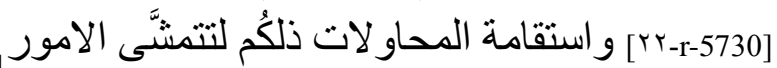

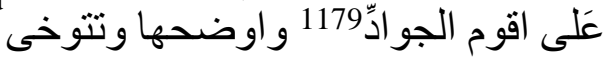

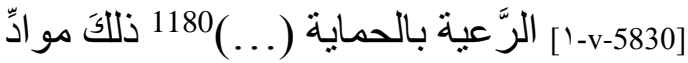

1174 Should probably be corrected with 1 واعملو, according to taqdim 35 and the meaning.

1175 'Azzāwī, NLA, t. 1, 473.

1176 'Azzāwī corrects with كتبناه

1177 'Azzāwī, NLA, t. 1, 474-475.

1178 'Azzāwī: والاقصى.

1179 Plural of جادي.

1180 The paper has been damaged here, and so part of the line is missing. 
... the means of His aid and His direction and that He cause us to know in the protection of Islam (...) and His
[Y-v-5830] توفيقه وتسنديده ويعر فنا في حياطة الاسنلام 1181(..)

assistance. This is why, after having asked the help of God on High, we have appointed Fulān over you, to manage

economic affairs and tax questions pertaining to the Domain (mukhtașiyya), ${ }^{182}$ to take care of all that by adopting just conduct

and correct methods. We know him because we have chosen him numerous times and observed on a number of occasions

his behavior in the different positions he held: he answered the expectations [we had] on naming him to lead you and completely fulfilled [our]

magnificent plans in governing you and your regions. We have advised him to fear God on High in both small

and large affairs. We have insisted that he take the paths and ways of justice. We have categorically ordered him

to do all that is possible to redress your affairs, to display competence and a sense of responsibility for [managing] the interests

entrusted to him for you, both the elite and the masses, to use severity in the fight against the partisans of evil

and corruption, to remain impartial between the city dweller and the Bedouin, to scrupulously conserve with you the surplus

resources of the Domain (mukhtaș) with the interest, to direct finances according to the law $(\ldots)^{1183}$

and with precision (iqsāt $)$, and to demand all sums due with no deductions and without abuse.

Among the most important tasks we care about and for which we spend as much as necessary are the suppression of diverse abuses,

the elimination of innovations, the prohibition of inebriating drinks, the correction of reprehensible actions, and, addressed to your peoples,

the incitement to accomplish virtuous actions useful during their lifetime and after death. Thus, when he arrives among you,

with the help of God, obey perfectly the [directives] he gives you concerning the [tasks] for which we have named him. B

as hand united with him in the decisions he makes, by his authority, for your finances ( fì mā yuwālì-hi fì tilkum alashghāl min ìrād wa ișdār). Above all else, in collaborating

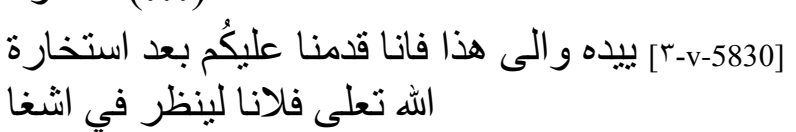

[-v-5830] [كُم المصلحية واعمال مجابيكم المختصبِية ويتولى ذللكَ كله بالسيّير القويمة

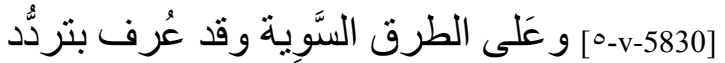

الاختيار لاحْو اله وتكرر الملاحظة

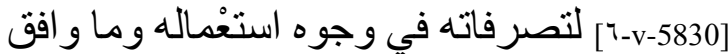

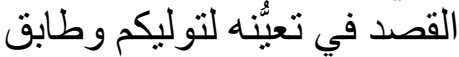

[الْغرض الْجميل في النظر لكُم ولنو احيكم

وقد اوصى بتقوى الله تعلى في كثير

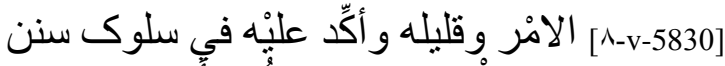

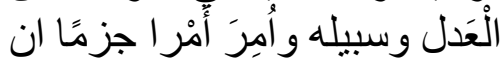

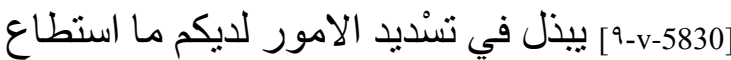

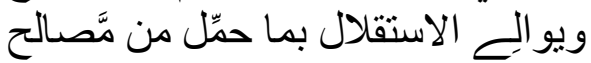

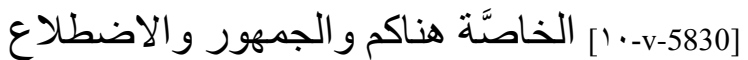

ويعمل الثدة في ردع اؤلى الثر الشر

[ ['-v-5830] و الْفسادِ ويقيم المعدلة بيـن حاضر منكم

وَبَادٍ ويحتاط على مرتفعات

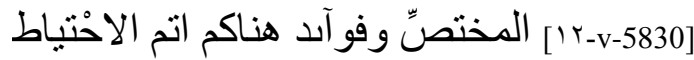

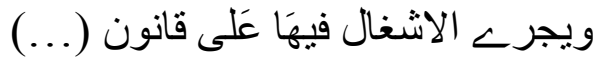

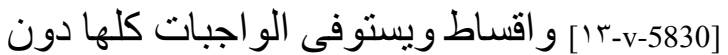

تقصير فيها ولا اشتطاط

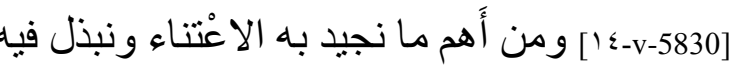

الغنآء رفع المظالم على اختلافها

[10-v-5830] و از الة المحدثات وقطع الْمسنكر ات وتغيير

الْمنكر ات و اخذ الناس هنالكم التهر

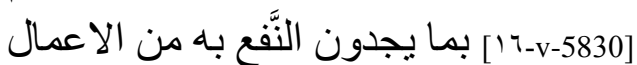

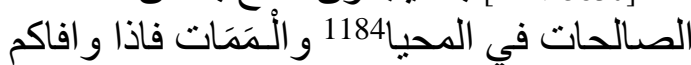

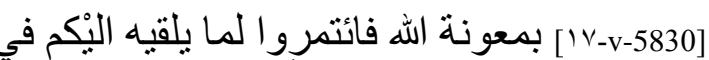

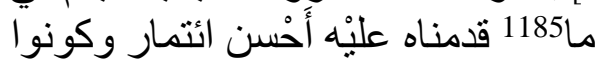

[1/N-v-5830] معَه يدا و احدة في ما يو اليه في تلكم

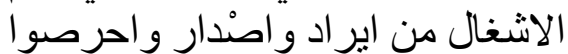

1181 About three words are missing.

1182 See note 'Azzāwī, 6, 474. Commentary on these functions.

1183 One or two words, almost illegible.

1184 'Azzāwī: المحيَى.

1185 'Azzāwī: فئما. 
to do good and fear God, ${ }^{1186}$ you should patently carry out the most beautiful efforts and noblest actions there are.

[9-v-5830] و التَّقَى 1187 و اجمل مسنَاع و أكرم أَثنار

Know that behind this and at all times, we keep over your situations the best watch,

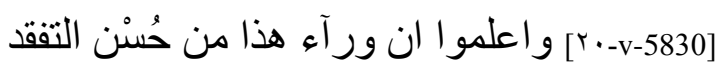

لاحو الكم ما نو اليه لكم مع الاعنيان

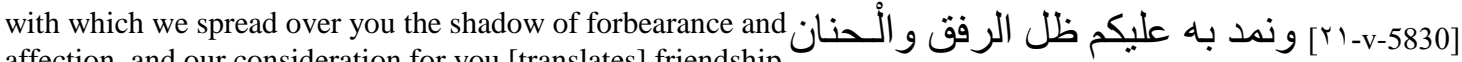

affection, and our consideration for you [translates] friendship and good wishes in which you

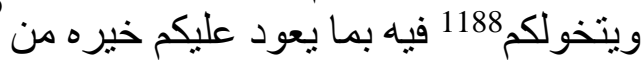

will find happiness. And $\mathrm{He}$ - May He be glorified -, He will make your lands pleasant in health and security and He will grant

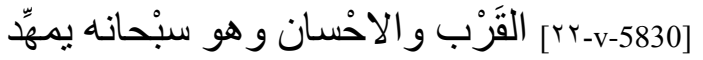

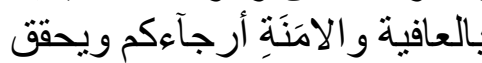

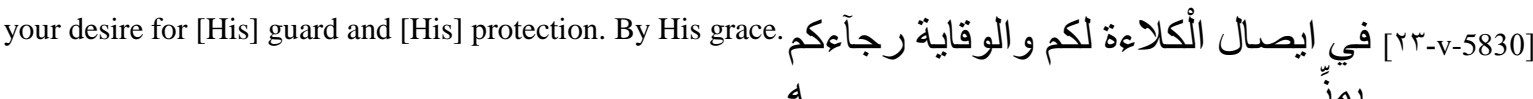

Taqdīm 47: Appointment from Fulāna, just after the conquest of the city, of a governor by the caliph al-Murtaḍa (649/1251-650/1252) $)^{1189}$

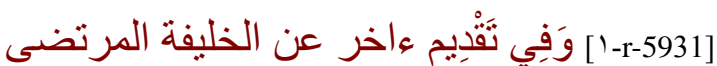

Another appointment in the name of Caliph al-Murtaḍā

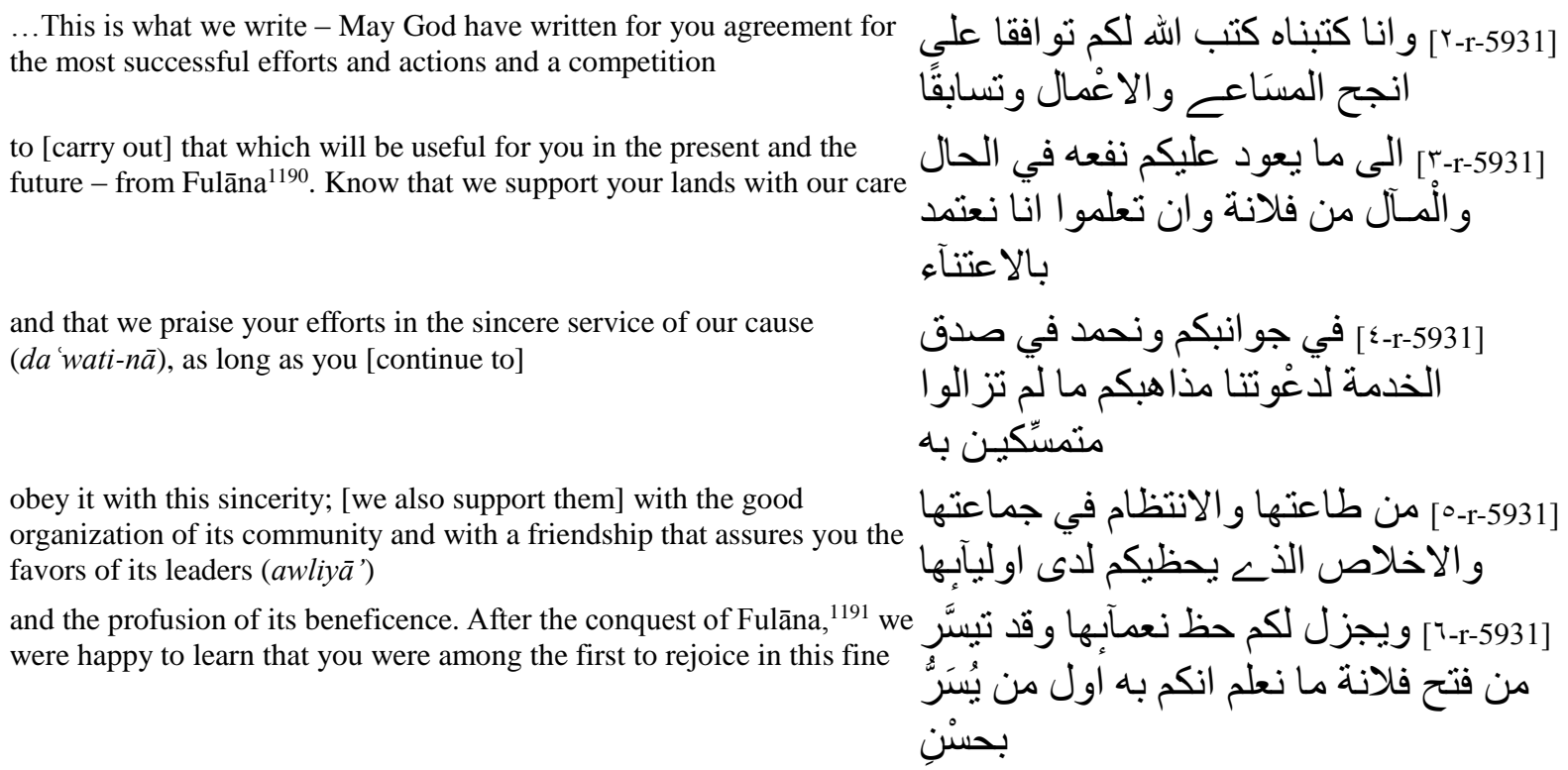

1186 Koran 5:2: "Help ye one another in righteousness and piety, but help ye not one another in sin and rancour: fear God: for God is strict in punishment."

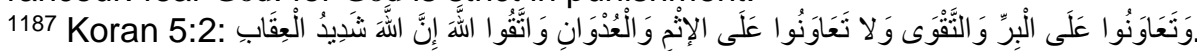

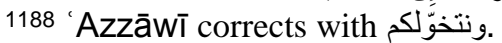

1189 'Azzāwī, NLA, t. 1, 476.

1190 'Azzāwī suggests Marrakesh.

1191 Al-Murtaḍa conquered Siljilmāssa when al-Qațānī swore the bay'a to the caliph in 656-7/1258-9 (Bayān, 415ff.), the Sūs was beyond his control since 651/1253 and he failed in conquering it (Bayān, 405, 406, and 415), Fez fell during the beginning of his reign and did not come back under his power, and Salé, the most likely here, was taken by the Marinids in 649/1251 (al-Qirțās, 296). The Bayān mentions its return and its Almohad governor, Ibn Abī Ya lá when the Marinids took it again in 658/1260 (Bayān, 421-422). We can thus conclude that the letter dates from 649/1251 or 650/1252 and was meant for the Sufyān Arabs living in Tāmesnā. 
action and to glorify God - May He be magnified and exalted - because it will reunite the land, chase away

the evil caused by the agents of rebellion and corruption, and to spread the shadow of security and equity over

its cities and countryside. Praise be to God who grants and dispenses gentle favors, and who frightens

and ruins the squadron rebellious against Islam. Our [generous] leadership - for which we ask

God on High to lastingly lead us along the straight path, and to thus bring us to that which assures a healthy and virtuous (bi-l-șalāh condition

to the land (li-l-bilādi wa-l- ibādi) and [its] subjects - has decreed that we appoint Fulān ${ }^{1194}$ to administer the interests and important affairs of your land,

to study the situation of each one of its regions and provinces and to gently impose on its subjects (al-ra iyya) an accompaniment

at all times, if God on High wills it. And he will travel throughout your regions and bring them all

the attention and care their affairs deserve, with the competence and desire to do well that we know in him.

$\mathrm{Be}$ as one hand united with him each time he needs you. Appreciate all the care we bring to you

in appointing him to [govern] you. We have advised him to fear God on High, which is the foundation of all that is good ${ }^{1197}$

and the condition for success in settling any affair. We have ordered him to be a factor of order and peace, to manage

interests according to the most righteous of rules, to be severe with corruptors and aggressors, and to

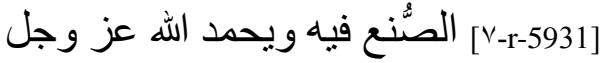
على تسنيه لما في ذلكم من اتصسال البلاد

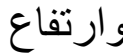

[^-r-5931] شر اهل البغيى عنها و القسادِ

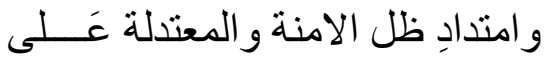

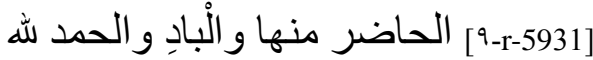

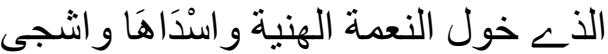

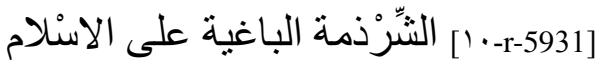

وأَرداهَا وقد اقتضى النظر [الكريم]1192

الذ نــ نسئل 1193

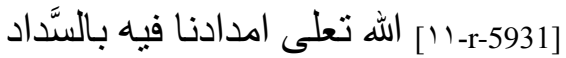

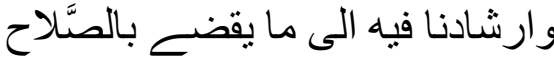

[r-r-5931 ] للبلاد و الْعباد ان قدمنا فلانًا

لتولــ النظر في مصسالح تلكم البلاد

و مهوَّاتها

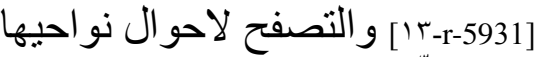

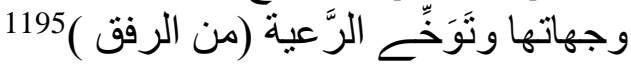

بما بصحبها

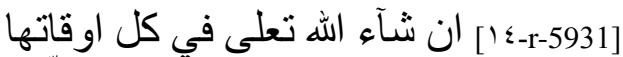

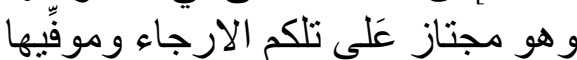

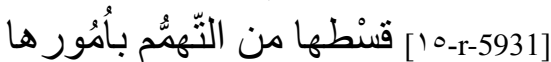
و الاعتنآء بما عرف له1196 من الغنآء وحسن من الانحاًء

[7-5931-r-7 ] فكونو ا معه بدا و احدة فيما بحتاج

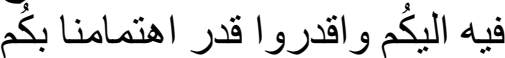

[IV-r-5931] في تقديمه عليْكم وقد وصيناهُ بتِقوى الله تعلى التّم هـَ اس الخير كله

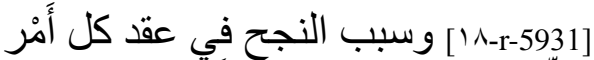

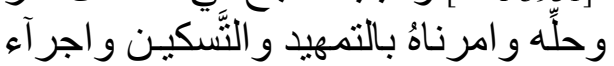

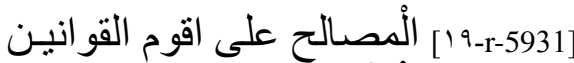
و الاشتدادِ على الْمفْدين و المعتدين وان بالا

\footnotetext{
1192 Addition by 'Azzāwī.

1193 'Azzāwī: نسأل.

1194 If the previous hypothesis is correct, this is the governor of Salé, Abū 'Abd Allāh Muḥammad b. Abī Ya' lá al-Kūmī.

1195 Omitted by 'Azzāwī.

1196 'Azzāwī: عis.

1197 The wișāya refers to Koran 4:131: "Verily we have directed the People of the Book before you, and you (o Muslims) to fear God."

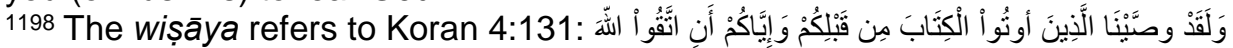




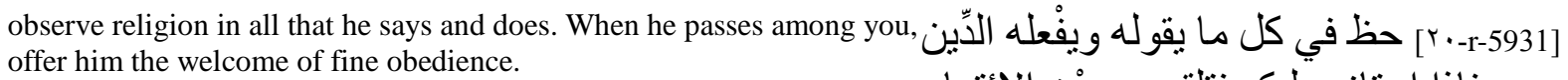

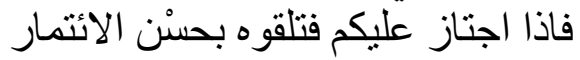

Help him to put into place excellent projects and fine actions. While, by the will (șun') of God on High, ${ }^{1199}$

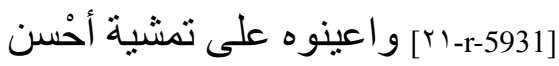

المقاصد و اجمل الاثثار وارتقبو اعن من صنع الهّ

تعلى 1200

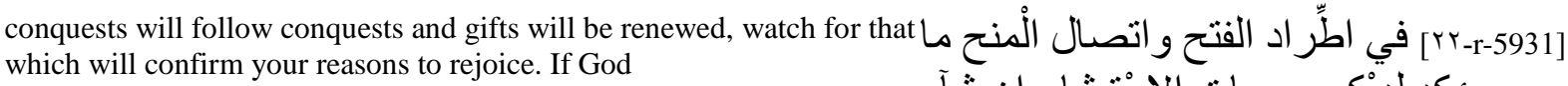

on High wills it...

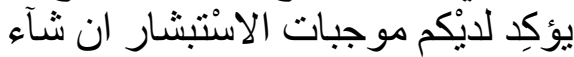

[rr-r-5931]

Taqdīm 48: Appointment of a governor with

fiscal attributions ${ }^{1201}$

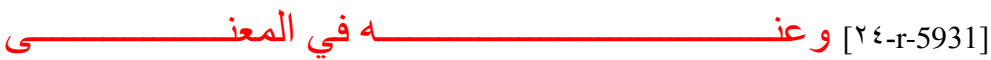

In the same name, on the same subject

This is what we write - May God have written for you to ascribe

(takayyuf) $)^{1202}$ a good situation and to know the success of your hopes. Know that

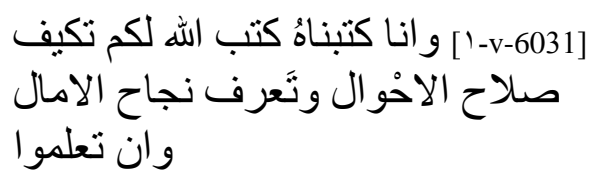

we care about your affairs, that we take you, both the people and the elite, under the protection of our benevolent watch, that we prefer that you continue

$$
\begin{aligned}
& \text { [ب-v-6031] [نا نتفقد اموركم ونتعهَّ } \\
& \text { بالنَّظر الجميل خاصتكم وجمهور انّم } \\
& \text { ونوثر ان تشنتمروا }
\end{aligned}
$$

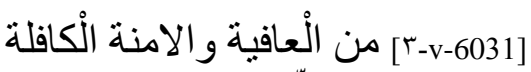

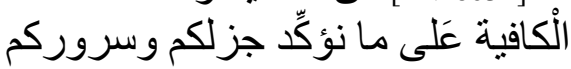

$$
\begin{aligned}
& \text { قياما بما }
\end{aligned}
$$

to rejoice in beneficent and complete security and health, to see us confirm your prosperity and your joy by the virtue

of God on High having entrusted us with guarding the affairs of His subjects and His lands and that, for that, we are devoted to working correctly

$$
\begin{aligned}
& \text { [ع-v-6031 [استر عانا الله تعلى من امور } \\
& \text { عباده وبلاده و التز اما في ذللكَّ لصو اب الصن } \\
& \text { العمل }
\end{aligned}
$$

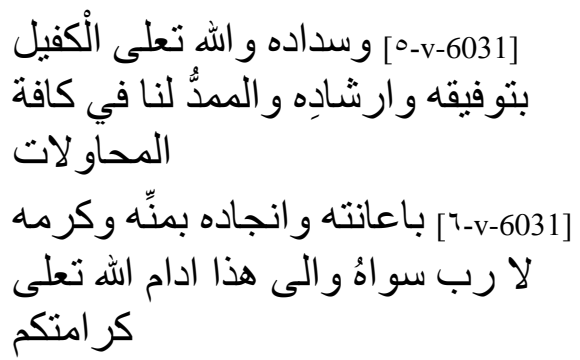

in the right direction. For God on High is the One who guarantees His assistance and the right direction, and Who perpetuates

His aid and His support for us in all our enterprises, by His grace and His generosity; there is no lord but Him.

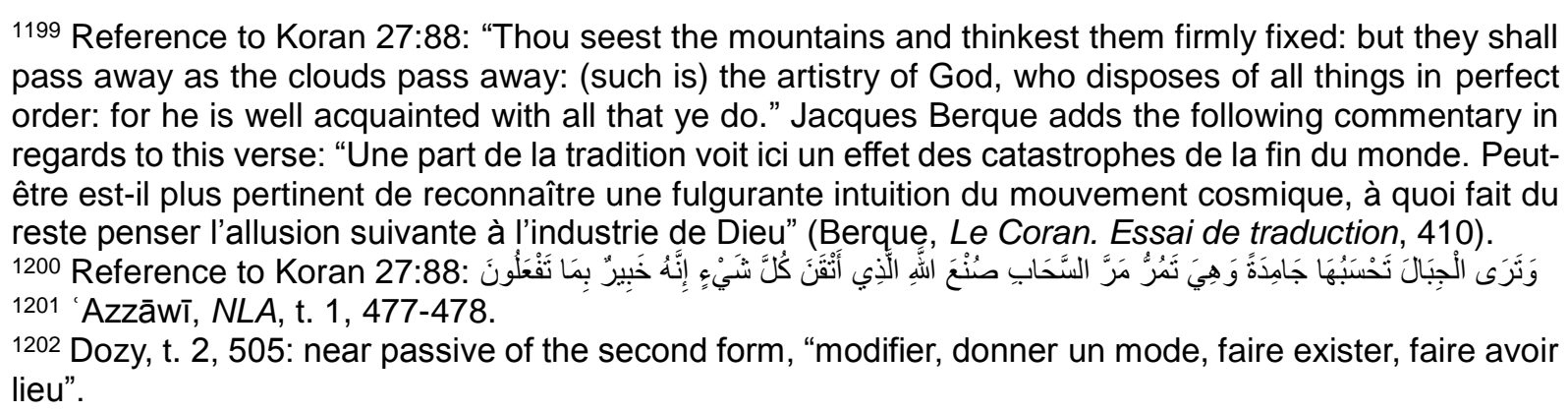


This is why - May God on High assure you always respect through the fear He inspires in you - we have decided, after having asked the help of God on High, to name Fulān to [manage] your fiscal matters.

He is among those who deserve to be chosen and who acquired training through experience in successive jobs.

We have advised him to fear God on High $^{1203}$ in [all] that he undertakes or leaves, to always fear Him - May He be exalted and magnified -

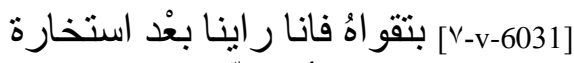

الله تعلى على أن نقدّم على اعمالكم المخزنية

[م-v-6031] ورشحه الاستعمال المردد و الاختبار

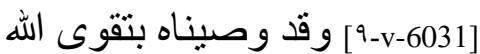

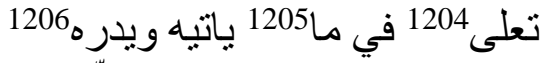

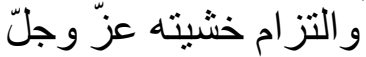

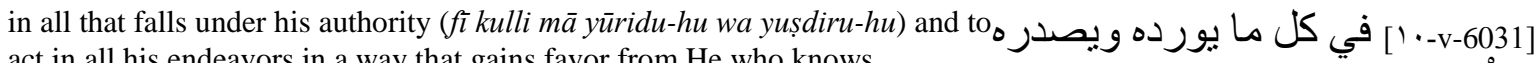
act in all his endeavors in a way that gains favor from He who knows

what he shows and what he hides. We have ordered him to establish mandatory duties for you most justly

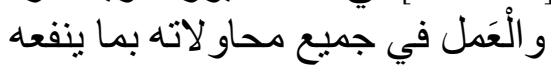

عند من بعلم ما باه

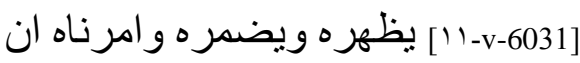

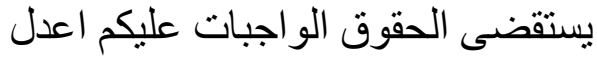

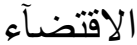

and to collect them in full, to take the greatest care in safeguarding them, whether they

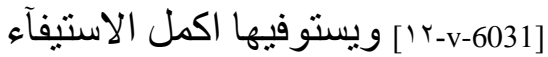

وبعتنى في الاحتباط على قليلها

وكثير ها

be few or substantial. We have insisted that he treat you according rules of benevolent and generous ('áfiya) conduct,

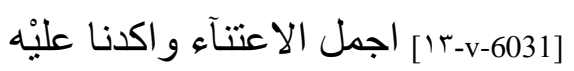

في ان بجريكم على قانون السبرة

الجمبلة و الْعافية النونة

that he never lead you astray from the paths of justice while carrying out the pursuit [of his actions], that he resort to clemency

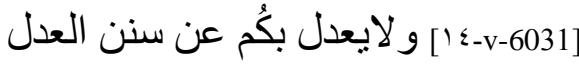

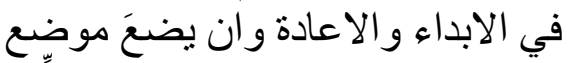
اللَّنّن

when he should and to severity when necessary, bringing to all of that the seriousness and competence he has already proven,

[10-v-6031] لبنه وموضع الثدة اشتداده

متوليا ذلك كله بما قدِّر فيه من الجد فيد

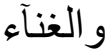

showing in all the affairs he treats the righteousness of his principles and intentions and accomplishing his work in a way

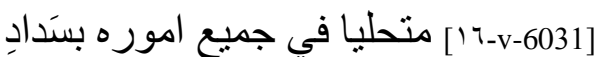

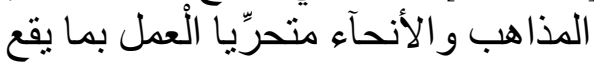

deserving of praise and approval. Thus, when he arrives among you, thanks to the help of God on High, submit your

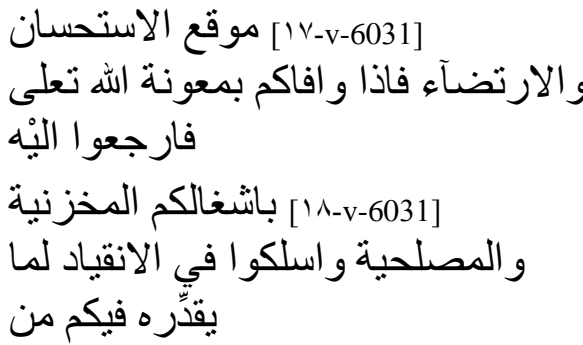

يقدره فيكم من

economic and fiscal affairs to him. Follow the clear sublime path in complying with the decisions

\footnotetext{
1203 The wișāya refers to Koran 4:131: "Verily we have directed the People of the Book before you, and you (o Muslims) to fear God."

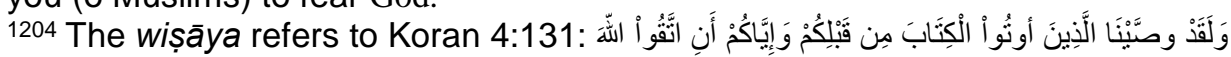

1205 'Azzāwī: فيَّا.

1206 'Azzāwī: ويذره.
} 


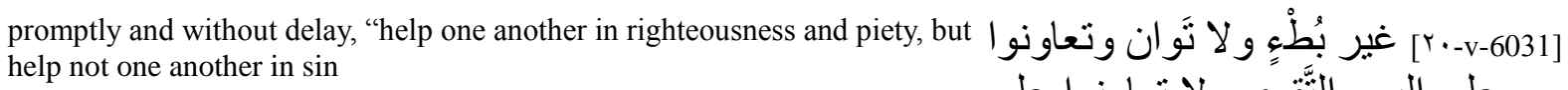

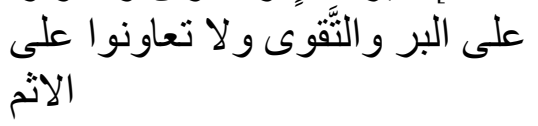

and rancor." ${ }^{207}$ Be united in exemplary obedience, devote yourselves to works that will bring

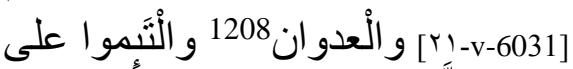

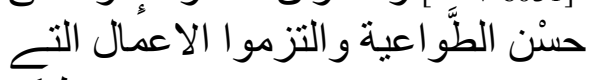$$
\text { تحظيكم }
$$

you uncountable favors. Know that in our benevolent watch over you there is one who watches without striking and thought [interested]

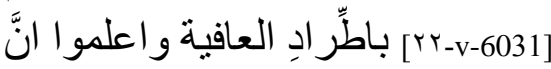

$$
\begin{aligned}
& \text { ور آعكم من نظرنا الجمبل ناظر ال الا يهدِّم }
\end{aligned}
$$

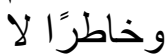

and caring only for the interests of the Muslims, if God on High wills it. And $\mathrm{He}$ - May He be glorified - He will cause you to know

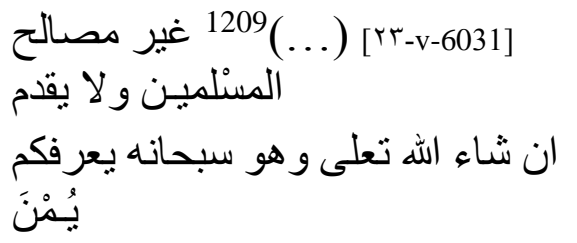

the privilege of this appointment and He will fulfill you with His general and universal favors. By His grace. ${ }^{1210}$ Yahyā said

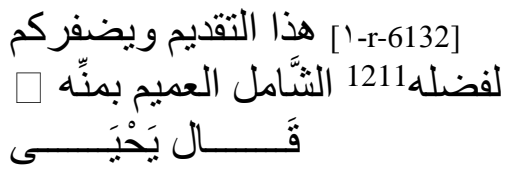

- May God assist him: here end the writings concerning the

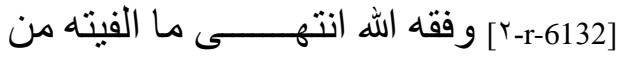

$$
\begin{aligned}
& \text { المكتــوب في تقادِيم الو لات الته }
\end{aligned}
$$

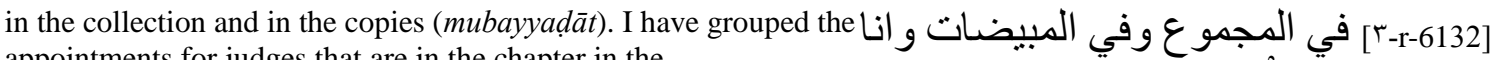
appointments for judges that are in the chapter in the

Collection, and I have added the contracts and writings that are inside and outside of the collection/

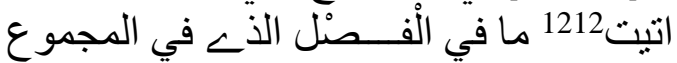

$$
\begin{aligned}
& \text { من تقاديم }
\end{aligned}
$$

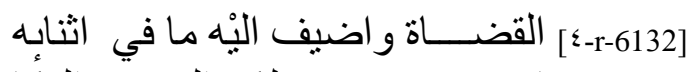

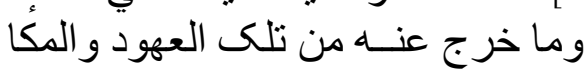

1207 Koran 5:2: "O ye who believe! Violate not the sanctity of the symbols of God, nor of the sacred month, nor of the animals brought for sacrifice, nor the garlands that mark out such animals, nor the people resorting to the sacred house, seeking of the bounty and good pleasure of their Lord. But when ye are clear of the sacred precincts and of pilgrim garb, ye may hunt and let not the hatred of some people in (once) shutting you out of the Sacred Mosque lead you to transgression (and hostility on your part). Help ye one another in righteousness and piety, but help ye not one another in sin and rancour: fear God: for God is strict in punishment."

1208 Koran 5:2:

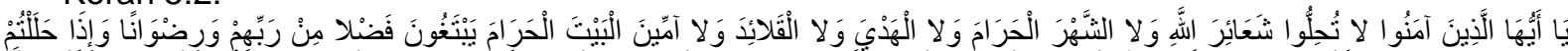

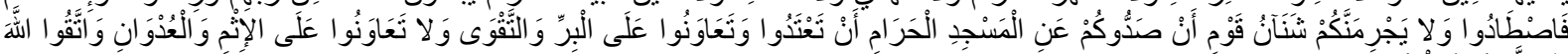
1209 Missing word.

1210 This is the last taqdīm concerning governors, 'ummāl and qā'id. Taqādīm concerning judges follow next, as in the manuscript.

1211 'Azzāwī corrects with بفضله.

1212 'Azzāwī corrects with آتيلك. 
Chapter. $[\mathrm{X}]$ wrote - May God's mercy be upon him - the the preamble appointment of a judge in the name of the imām al-Ma'mūn After

$$
\begin{aligned}
& \text { [o-r-6132] تبات كتب رحْمة الله عَليه عن الامام } \\
& \text { المامون تقديم قاض بعْد التَّصدير }
\end{aligned}
$$

Taqdīm 49: Appointment of a judge,

responsible for choosing instrumentary

witnesses and secondary judges, in the name of

the caliph al-Ma'mūn, before the renunciation

of the Almohad doctrine (2 shawwāl 624/1227-

626/1229). The bases of the law are the Koran and Tradition ${ }^{1213}$

This is what we write - May God have written for you a watch whose favor concerns you and brings you all together and care that promises and destines

you for happiness. Know that your land - May God make it a plain enjoys in our heart exclusive and constantly

renewed attention. For your place with us, by the seniority of your friendship, is protected by the generous solicitude

of its shepherds (al-ra $y i)$. This is why we continually distinguish you by watching over your situation, why we enquire

$$
\begin{aligned}
& \text { [-r-6132-r-3 و انا كتبناهُ كتب اله لكُم نظر ا بعمكم } \\
& \text { منُّه و بشثملكم و اعتناءً } 1214 \text { يَؤمكم }
\end{aligned}
$$

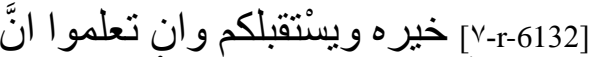

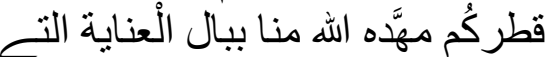$$
\text { [^-r-6132] نتعهده و نتخو له و انكم لديْنا بقديم }
$$$$
\text { اختصاصكم بالمحل الذــ بحدق به احفى ونى }
$$

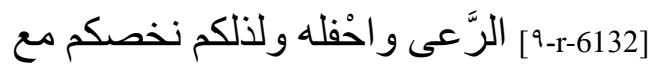

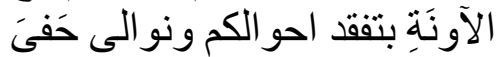

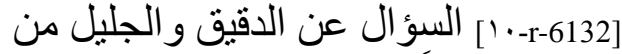
اشغالكم ونتوخَّى اجر اءكم في الامون المور كلها

ceaselessly about the state of your affairs, small and large, and why we propose to act on all that concerns you

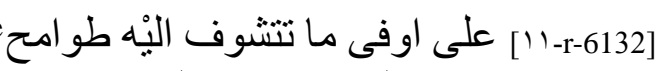

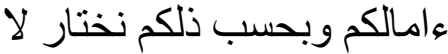

your judgments one who will fully satisfy our objectives for you, and who will advance our fine doctrine in all your lands.

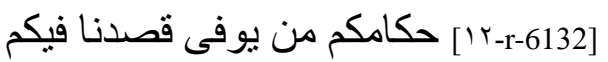$$
\text { ويمشى مذهبنا الجميل في كَافة نو احيكم }
$$

We ask the help of God on High to spread [His] grace and security and to install the order of justice and good behavior. ${ }^{1215}$

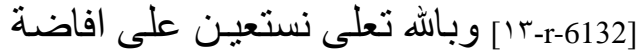

$$
\begin{aligned}
& \text { المنّ و الامان و اقامة رسم العدل } \\
& \text { و الاحسان } 1216
\end{aligned}
$$

We have judged it a good thing, after having asked the help of God on High, to name Fulān to judge your affairs related to the Law

$$
\begin{aligned}
& \text { [ [اينا بعد استخارة الله تعلى أن أن }
\end{aligned}
$$

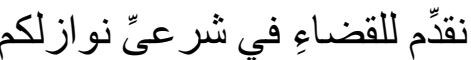

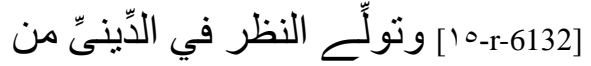

$$
\begin{aligned}
& \text { مسآيلكم فلانا وله المنصب الثهير و المحل } \\
& \text { [17-6132-r-1 في الدين الاثير و على زكاءه } \\
& \text { و اتقابه تثفق الجماهير بعد ان وصبيناهُ بتقوى التي }
\end{aligned}
$$

and to take charge of the religious aspects of your problems; he enjoys a celebrated rank and place of choice

in our religion, and everyone agrees on his purity and devotion. We advised him before to fear

1213 'Azzāwī, NLA, t. 1, 479. Azzāwī claims that this taqdīm and the following two were written between 2 šawwāl 624/September 151227 and the end of 626/November 1229.

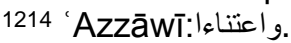

1215 Reference to Koran 16:90: "God commands justice, the doing of good” (inna Llāha ya'muru bi-l- 'adli wa-l-ihssāni).

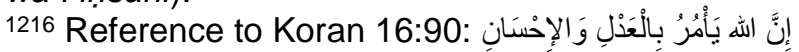


God on High, that is the foundation of all good, the pillar on which the believer rests when he knots and unknots.

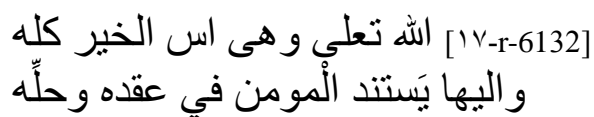

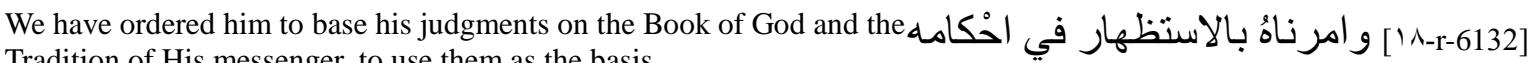
Tradition of His messenger, to use them as the basis

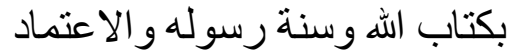

of his words and actions, and to choose well his instrumentary witness and secondary judges (musaddidin) ${ }^{1217}$ indeed, they are the cornerstone on which

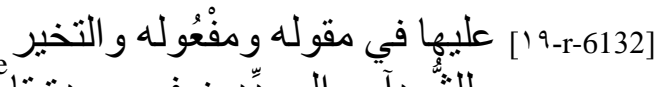

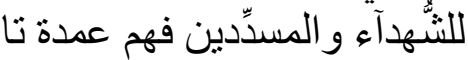

he founds and authenticates his judgments. We have prescribed that he grant everyone their place, as long as

[r-r-6132-r-r سيسه للقضآه وتاصيله و او عزنا

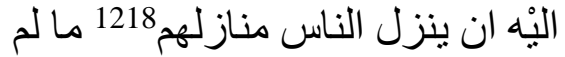

it does not conflict with the Law; indeed, he must take this under consideration, see and hear only it;

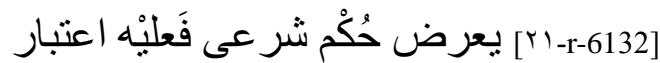

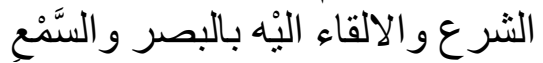

and no one should have more than another in regards to the imperatives of the law, there is no exception for rank in the pronouncement or execution of a sentence.

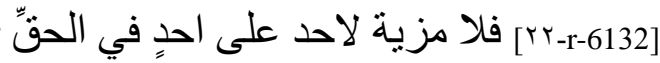

Once our letter has been read before you, submit your decisions

(ahkām) to him, [come together]

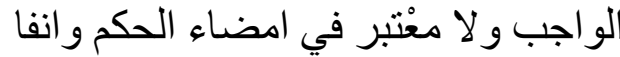

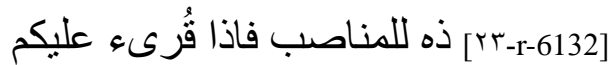

كتابنا هذا فارجعوا اليه باحْكامكم (....

behind him so that he may arbitrate among you in case of disagreements. Be in agreement, rather than opposition, you will find the blessing that offer concord and

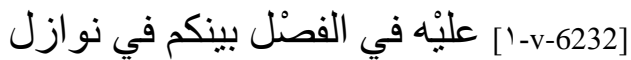

خصامكم و اتفقو ا و لا تختلفو ا تجدو الفئ فركة

اتفاقاكم و التئيا

Union. Know that we have chosen him from those among you with the most perfect valor, education, and religious practice. By our benevolence for you

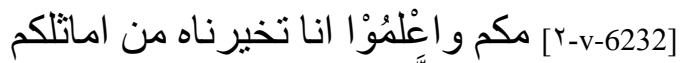
في الحسب و الطَّلب و الديانة و انهضناه بحُكم

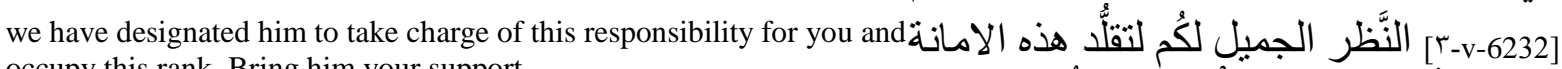
occupy this rank. Bring him your support,

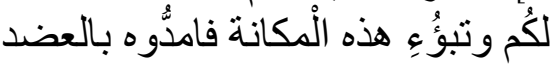

your aid, and your assistance, if God on High wills it. And He - May

He be glorified -, He will keep you always under the wing

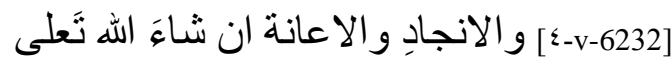

و هو سبحانه يصل استقر اركم في كنف والأه

of salvation and His solicitude will never deny you abundant favors and efficient protection ( ișam).

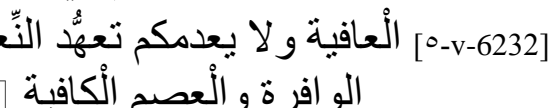

Taqdīm 50: Appointment of a judge, responsible for the choice of instrumentary witnesses. The bases for law are the Koran and Tradition $^{1220}$

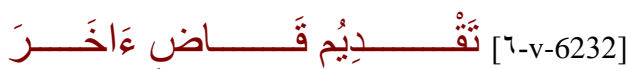

Appointment of another judge

1217 See al-Maqqarī, Naf̣̣ al-țīb, ed. I. 'Abbās, Beirut, Dār șādir, 1968, t. 1, 218 on the musaddidīn who were judges in small places and in the coutry.

1218 Reference to a hadīth whose authenticity is contested; attributed to 'Ā'isha, reported by Abū Dāwūd, Sunan, $726, n^{\circ} 4842$ :

1219 Word erased.

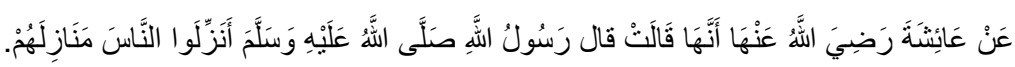

1220 'Azzāwī, NLA, t. 1, 480. 'Azzāwī claims this and the previous taqdīm were written between 2 shawwāl 624 and the end of 626 (between September 151227 and November 1229). 
May God assure them always respect through the fear He inspires in them and cause them to know the happiness that we desire and propose in the decisions we make.

This is what we write - May God have written for you a manifestly excellent condition and actions whose first-fruits announce

fortuitous ends. Know that care for the interests of the faithfut of [your] land is our first concern

and an objective for which we accept no delay or slowness. For we work without ceasing

to advance the best and most correct solutions, we lead affairs along the most clear and evident path

and we have always in mind the worries (muhimmāt) of the Muslims, morning and night. We ask of God assistance for the good

for which we braid and reinforce ties, and we place ourselves in His hands for the administration we envisage

and plan to achieve it. Since the judgment of affairs pertaining to the Law deserves more than anything to be treated as a priority

and to see its organization protected with benevolent attention, because it is the axis on which the interests of the Community

rests and the refuge for grave matters, we choose always [to take responsibility for it] one in whom we reckon a sense of responsibility and whose intentions and friendship we
the best choice by granting preference

and whose intentions and friendship we praise fulfilling our efforts to make

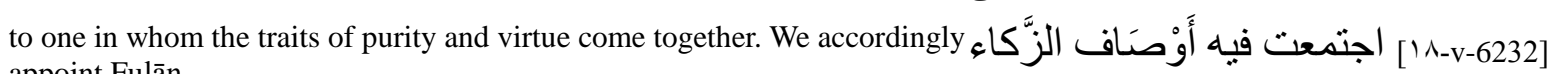
appoint Fulān

to arbitrate and judge your disputes, to pronounce and apply the law in the questions you pose, [that] after

having verified that we was worthy, that he possessed the best and finest qualities, and that his words and actions were known
[V-v-6232]

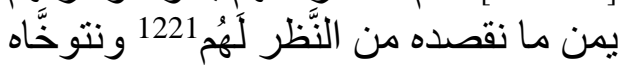
[^-v-6232]

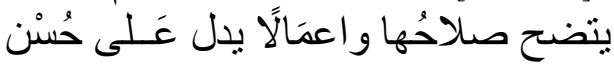

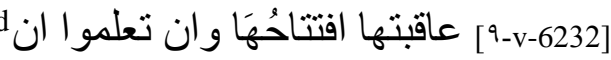
العنابة بمصالح للعبلدِ البلاد هو تهمُّمنا

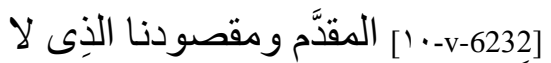

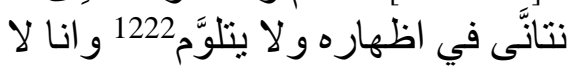
نز ال نعمل

['-v-6232] [النَّظر في تمشية الاوفق الاصلح ونجرى الامور على السَّنن الابين الاوضح

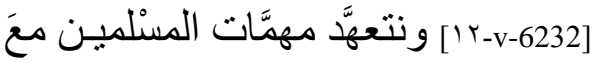

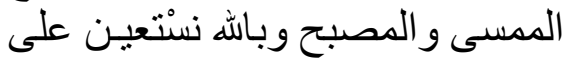

الصَََّحَّن

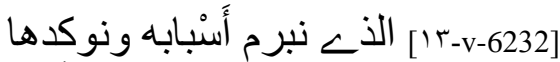

و البْه نفوِّض في الادار ات التح نتوخَّاها في

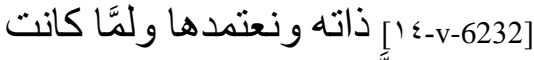

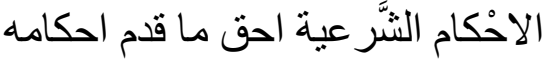

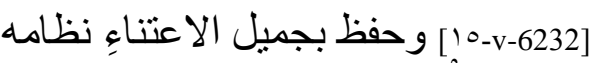

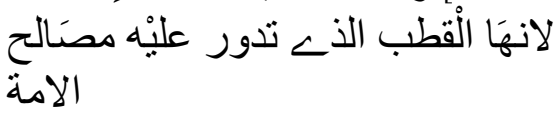

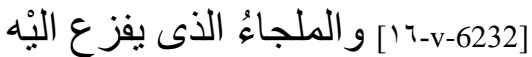

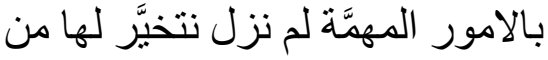

نظن به الاستقلال نمان

[IV-v-6232]

باذلين اقصى الوسع في الانتقاء موثرين

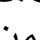

و النقاء وبحسب هذا النظر قدمنا فلانا

[19-v-6232] للفصل في نواز ازلكم و القضاء

و الانفاذِ للحق في مساءلكم و الامضاء بعد

نان

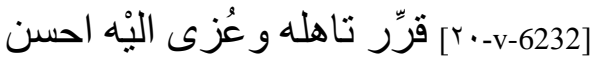

الوصف و اجمله وذكر باستقامةٍ وسدادٍ

1221 'Azzāwī: له.

1222 'Azzāwī corrects with.نتوَّ 'Azzāi. 
for their righteousness and accuracy; we appreciated that he follows the footprints of his father. We likewise appreciated that he made the best decisions in matters entrusted to him

or for which he was responsible. In addition, we have ordered him to make the fear of God - May He be glorified - the first among his motivations

and conformity with the Book and Tradition the surest rule of his acts; to fear "He who knows the seen and the unseen"1223

in that which he makes or unmakes. ${ }^{1224}$ We have ordered him to stray in no way from the path of the pious ancestors

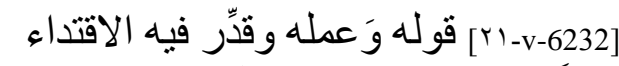

بأَبِيه و هو المشكور تحرِّيه في ما يقلده

[rr-v-6232] و بحمله ومع ذلكع فقد عهدنا

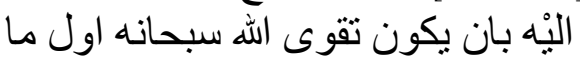

يقدمه

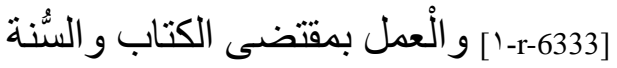

عاكد ما يلتز مه وان ير اقعمب إنب عالم الغيب

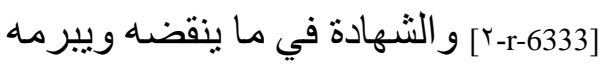

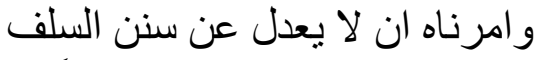

الصنَّالح

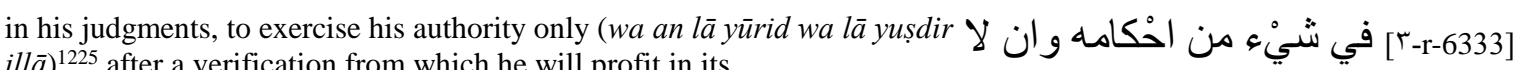
$i l l \bar{a})^{1225}$ after a verification from which he will profit in its

constancy and by the interrogations he will multiply. For in [juridical] affairs, there is both the clear and the ambiguous, and cases for which

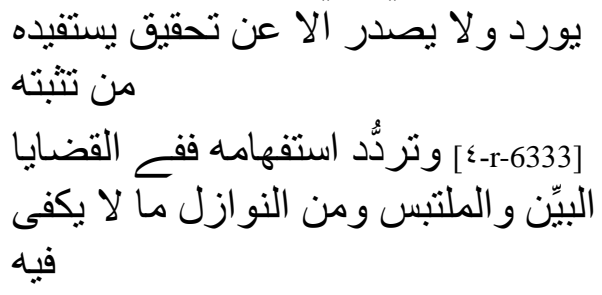

a quick glance does not suffice. May he then consider thoroughly to escape from the flaw of haste and may he prolong examinations,

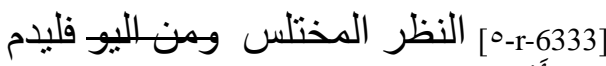
التأَُْلْ ليسلم من ز لل الاستعجال وليطل التصفح

for that is the best means to lift away uncertainty. We have insisted that he name only those people in whose religion and knowledge he has faith

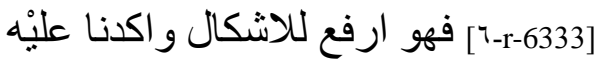
في ان لا يقدم الا من وثق بدينه ومعرفته

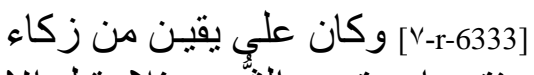
and of whom he is sure of their virtue, that he choose instrumentary witnesses (thus he will allow no justice

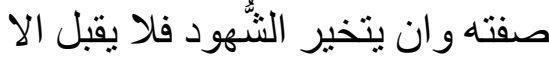
العَدْل المنتفق

that is not recognized by all and will use only irrefutable witnesses), and that he ceaselessly seek

]_-r-6333]

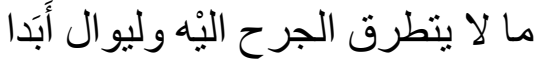

information about them, for in regards to a witness certain elements come out which appear clearly in the next instant and an attentive

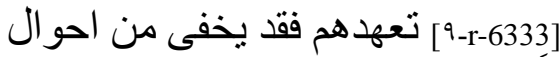

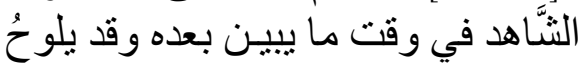

cos

examination can reveal facts that impose recusal after verification. We have warned him to avoid any shadow of suspicion,

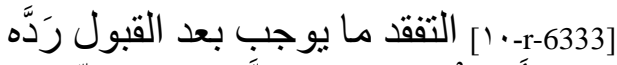

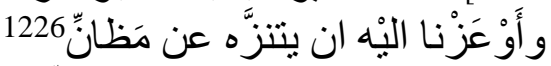
الاتِّهام

to take care [for the blows] that could bring him the arrows of blame, to treat equally all opposing parties in the place,

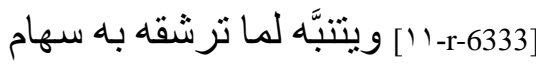

الملام ويُسَوِيَ بيـن المتحاكميـن في

المجْلس

1223 Name of God appearing often in the Koran (6:73, 9:94, 9:105, 13:9, 23:92, 32:6, 34:46, 54:22, 62:8, $64: 18)$.

1224 Other possible translation: "In [the decrees] he confirms or nullifies".

1225 "To not receive and not transmit".

1226 'Azzāwī: مَضَانِ (in this case, a Maghribī form by 'Azzāwī, and not the manuscript). 
attention, and words [he grants them]; to take care that in the judgments [he gives], the weak and the strong, the near

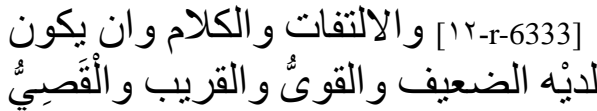

and the far have before him equal rights. So, when he arrives among you, support him in advancing these

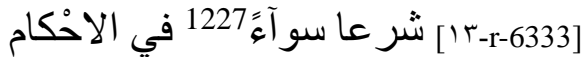

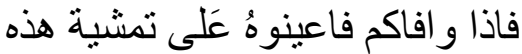

magnificent objectives, bring him your firm support and your manifest help.

If God on High wills it...

بالمعاضدة المتمكنّة و المساعدة البينة اندان

شنآء الله تعلى الهـ

Taqdīm 51: Appointment of a judge responsible for choosing instrumentary witnesses and secondary judges, after the abandonment of the Almohad doctrine. The person appointed follows in the footsteps of his father and his uncle. The foundations of the law are the Koran, Tradition, community consensus and juridical consultations of the imāms ${ }^{1228}$

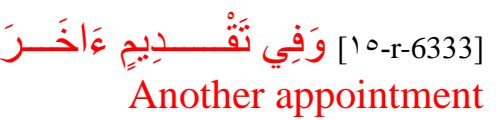

This is what we write - May God have written for you an administration the happiness of which you will recognize in all situations and the best choice in all

[7-r-6333 [ [ ] انا كتبناه كتب الله لكم نظر ا تتعرفون

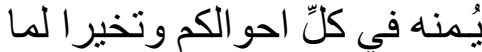

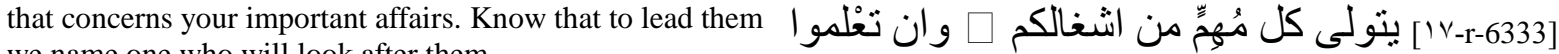

we name one who will look after them

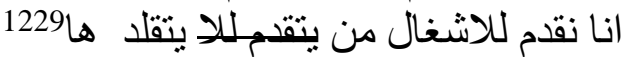

with most perfect competence, that we watch over the land and its problems with full solicitude

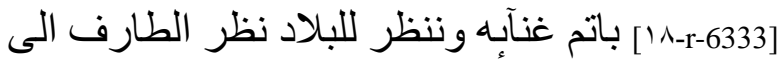
مهمَّاتها وجه اعتنابه ه ه هن

and that because of its noble rank we designate projects for it 19-r-6333 crafted with continuous and renewed care for نقصده من تتابع التهمهّم بمصالحها

its interests. Since your land holds a place of choice with us and we have always

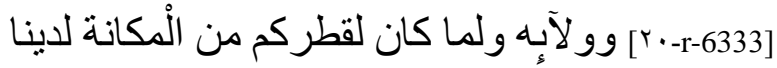
ما يز حم عليه و كانت خو اطر مانم

held it in great esteem, we have judged that only one who has acquired merit

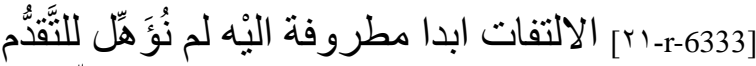

through his numerous prior deeds would be worthy of directing the least of its affairs, one whose independent personality and illustrious ranks designates him as such.

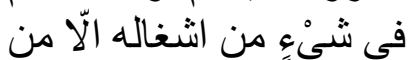

[rr-r-6333]

المستتقلة ورتبته الاثيرة

1227 'Azzāwī: سواءl.

1228 'Azzāwī, NLA, t. 1, 481-482.

1229 Added in the margin. 
We have tested him many times, and each time he has revealed his excellent nature (...)

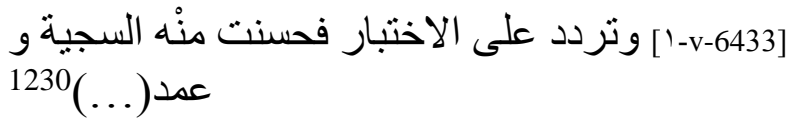

he has acquitted himself as a judge the benefits of whom will ما تعنى بـ القضاءُ الذي بنال منفعته [r-v-6433] benefit you all, the elite and the masses (...)

خاصنكم وجمهوركم (... 1231)

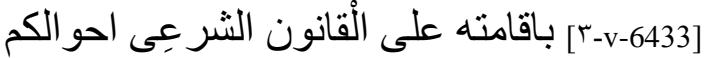

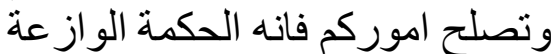
situations (...) and your affairs will become sound. He is wisdom that spouts

[ـ-v-6433] عن استرسال و العصنمة للذِّماعِ الا بحقِّها

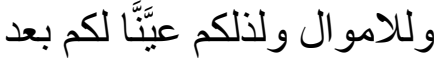

[-o-v-6433] التخير و الانتقاء و التامُّل و الارثياء فلانا

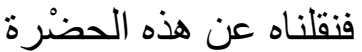

This is why, after selection, election, meditation, and
consideration, we have designated Fulān for you. We have sent him to you from our (hädhi-hi) Presence ${ }^{1232}$

[?-v-6433 [اليكم و اثرناكم بتقديمه عليكُم فانه معَ تمكُّن

اختصساصِه وتاكده وتمبزه

[V-v-6433] من احر از الوسـائل المرْ عية بما لا خفاء

بتعدده الْقديم الانحآء التعديم

[^-v-6433] النظر آيِ في المعرفة و الزكآيٍ المتردِّد بيـن

ابيه و عمّّه بالاقتداء و الاقتهفآه

footsteps of his father and his (paternal) uncle. ${ }^{123}$

In addition, we have counseled him to fear God, which is the surest support, and (...)

[9-v-6433] ومع ذلك فهو موصنَّى بتقوى الله التح هى الته المستند الاعْصَمَ (و ال....

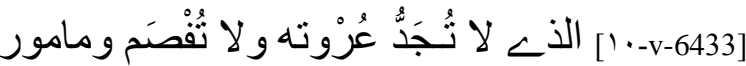
بالر جوع الى كتاب الله وسنة

of His messenger - Peace be upon him - in all his judgments, to rely on the consensus of the community (ijma ' $i$ l-ummati)

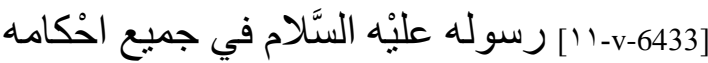

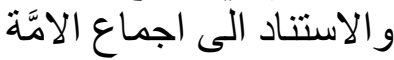

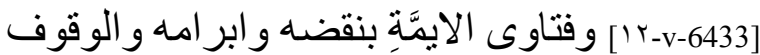

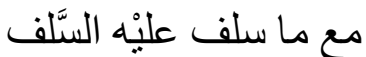

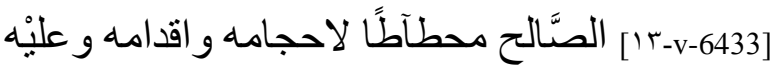

ان بنتقى المسدِّدين الذين وديه

confirms or nullifies [a decree], and to conform to the pas conduct of his virtuous predecessors

when he undertakes something or abstains. He must select secondary judges (musaddidìn) to

[1 [-v-6433- يستعملهم في الجهات و لا يقدم الا

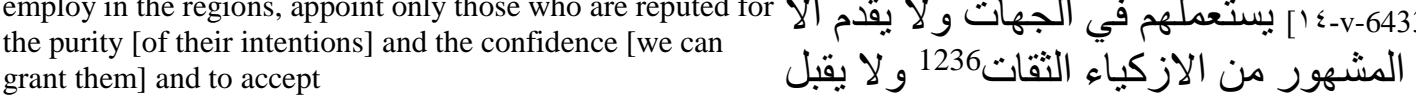
grant them] and to accept

\footnotetext{
1230 End of the line covered by a piece of glued paper, one or two illegible words.

1231 Idem.

1232 He seems to have been qāọīin the court of al-Ma'mūn in Seville, as shown by al-Ma'mūn's presence in the city (taqdīm 53). 'Azzāwī notes that the date of this taqdīm and the next two comes between the caliphal proclamation of al-Ma'mūn, 2 shawwāl 624/September 15 1227, in al-Andalus and his crossing to the Maghrib at the end of 626 (November 1229).

1233 The appointee seems close to the qāọi appointed in the following taqdīm.

1234 Word erased.

1235 Unread by 'Azzāwī.

1236 'Azzāwī corrects with الثقاة specifying that this version is perhaps due to the necessities of saj', for the rhyme with jihāt, shahādāt.
} 
as witnesses only those who fulfill completely the conditions necessary for this position. And, with the help of God, may

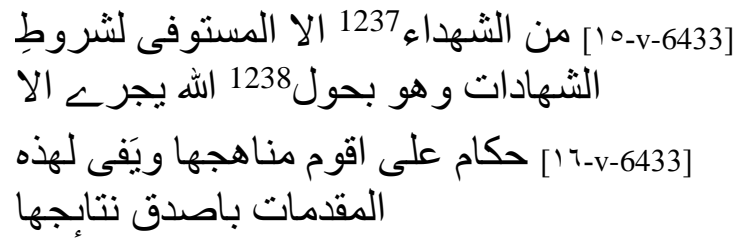

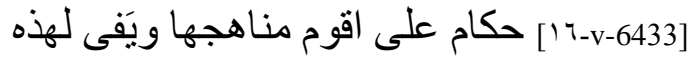

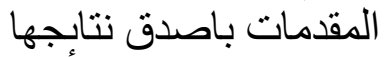

he judge according to the most just rules, may he crown this preamble with real results,

may he approach complicated juridical questions presented to ويتلقى بما بعرض ضع-1V-6433]

him with the [means] of openness and decision [given him by] reflection

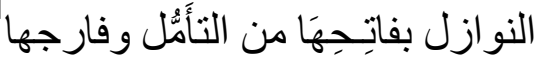

and may he always follow the path traced by his father

— May God show him mercy — by privileging justice, taking

[1/N-v-6433] وبستمر على الوتيرة التخ كان ابوه رحمه

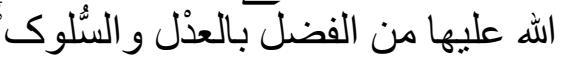

the clearest paths, and resolutely applying the law caring neither for blame nor critics

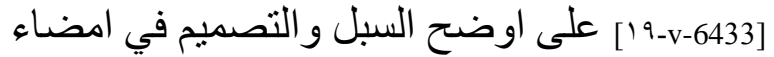

الحق غير مبال باللإم و العَذل التصاء

and pronouncing the same judgment for the man of the people as for the noble, without showing preference for the people of the nobility. We have taught him

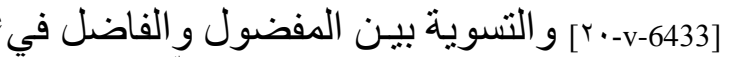

to give each the place he deserves: may a noble come before an unknown, as long as it is not against a right that needs

الحكم غير موثر فيه لذوى الفضل (ولقيّنّاه ان)

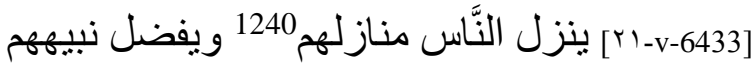

خاملهم ما لم يعرض حق ئن يتعين

to be considered and that determines a judgment that imposes privileging him. Thus, when he arrives among you, receive him with joy

و افاكم فتلقوه تلقى الجذل به هـ

and respect and seek to help him for the authority we have conferred on him (min al-ìrād wa-l-iṣdar). Be

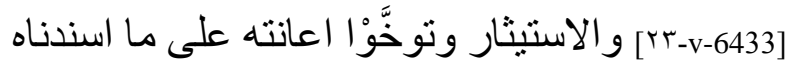

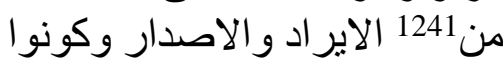

his auxiliaries and (...) in all that he does for your interests. Cultivate always agreement and confidence (al-iqtiläf) ${ }^{1242}$

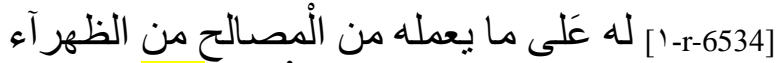

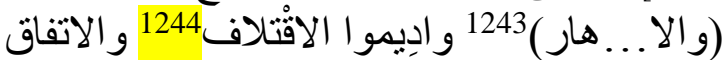

and you will find the benediction of God in this domain and the domain of deliverance.

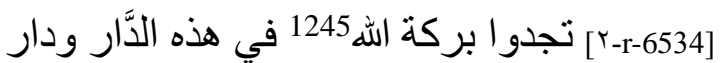

القرار

Taqdīm 52: Appointment of the jurist Abū

Muḥammad as judge of Jérez by the Caliph al-

Ma'mūn, middle of the month of shawwāl

$626 / b e g i n n i n g$ of September 1229 . The judge is

responsible for choosing instrumentary

witnesses and assistants or secondary judges.

The foundations of the law are the Koran,

\footnotetext{
1237 'Azzāwī: الشهود.

1238 'Azzāwī: بحبل.

1239 Words unclear. Proposal by 'Azzāwī.

1240 Reference to a hadīth whose authenticity is contested; attributed to 'A' isha, reported by Abū Dāwūd, Sunan, 726, $n^{\circ} 4$ 842:

1241 Three words unread by 'Azzāwī.

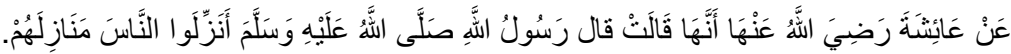

1242 Lit. "to deduct without weighing".

1243 Suggestion الانصار.

1244 'Azzāwī gives ختخار الانصار, but this is clearly incorrect.

1245 'Azzāwī: هذا الامر.
} 


\section{Tradition and the consensus of the Community ${ }^{1246}$}

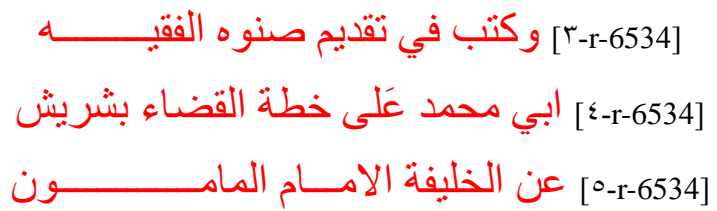

[X] wrote for the appointment of his relative (șanū-hu) the jurist Abū Muhammad ${ }^{1247}$ as judge of Jérez in the name of the caliph Imām al-Ma'mūn

May God assure them always respect by the fear he inspires in them and may he lavish them with the benefits of His grace and His abundant favors.

This is what we write - May God have written for you a vision whose happiness you will know in your lands and thanks to which you will be sure

to enjoy a calm situation and civilized domains. Know that the care taken for you means

that your affairs (ashghāli-kum) are counted as priorities and that you are treated like those on whom we lavish the greatest consideration.

We keep this in mind when choosing officials for you and making the best possible selection for the one that we appoint to lead your provinces. May God

on High help in assuring the interests [of all] and protecting everlastingly those regions near and far.

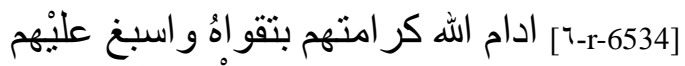
عو ارف منته الْجزيلة ونعماه

[ب-r-6534]

تتعرفون يُمنه في اقطاركم و لا تعدمون

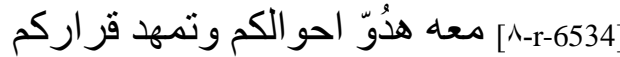

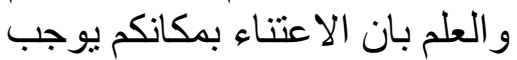

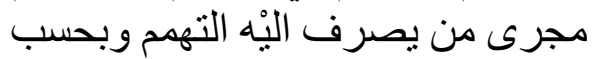

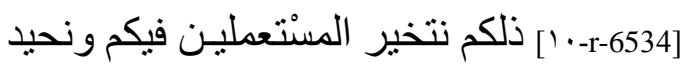

الانتقاء لمن نقدمه في نو احيكم و الله

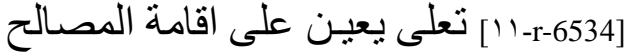

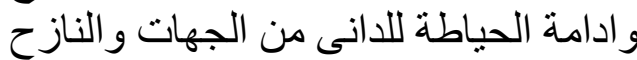

We appoint Fulān alone to manage your affairs regarding the Law and to make an effort

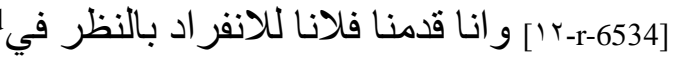

احكامكم الثر عية و الاجتهاد في

to arbitrate your religious disputes. This comes after he has already occupied numerous jobs and we have been able to verify

[1r-r-6534] الفصل بينكم في النوازل الدينية بعد ان تكرَّر مرار ا استعماله وتحقق

his competence and sense of responsibility. We have tested him and he has shown fine qualities and a praiseworthy character.

[r-6534-ـ 1 ] غناؤه و استقلاله وخبر فكانت جميلة

اوصافه ومشكورة خلانله

We have advised him to fear God on High, which is the obvious path and the promise of success.

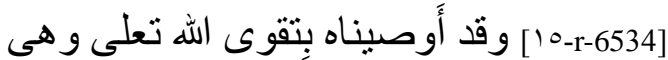

الجآدة الو اضحة و الوسيلة الناجحة

We have ordered him to seek help in the Book of God, in the Tradition of His messenger, and in the consensus of the Community (ijmā 'i l-ummati)

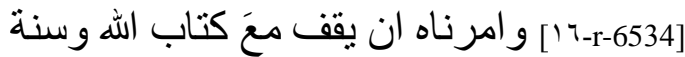

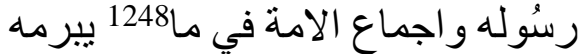

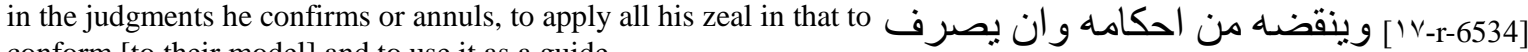

conform [to their model] and to use it as a guide,

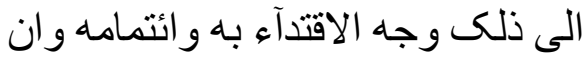

to attentively observe our orders to devote himself to justice and forbearance and to insist

[1/N-r-6534] يحافظ على الوصـايا التخ نامر بها

من التز ام الْعَدل و الرفق والتُ التصميم في كل

1246 'Azzāwī, NLA, t. 1, 483-484.

1247 'Azzāwī remarks that he was appointed judge in Algeciras, as shown in the next taqdīm, which means that this appointment happened before the other.

1248 'Azzāwī: فيما. 
on the law in all new matters. We have enjoined him to exercise as well as possible the judgeship

we have entrusted exclusively to him, to appoint as assistants only those people who demonstrate remarkable qualities for that and who are reputed for

their equity $(a l-' u d \bar{u} l),{ }^{1250}$ to accept as [instrumentary] witnesses only those who are known for their sense of justice

and honesty, famous for their vigilance and sagacity, as well as for their purity and virtue, for testimony (shahāda)

is the judge's pillar and support (by which he issues or receives... that he refuses)

and it is the source of what he binds or unbinds in his judgments. Thus, to that must he dedicate all his efforts and

recognize or refuse [witnesses] as he should. In his judgments, he must treat equally those who are famous or unknown,

the man of the people or the noble, for the eyes of the Law do not take status into consideration; there is no care for [social] rank

before the Law, observing only what is right, beyond which there are only partisan views. Thus, when, with the help of

[19-r-6534] ناز لة تشثاءُ على 1249 الحق وحددنا

له ان يضبط شغل القضآَ الذــ اسند

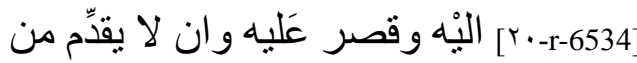

المسددِّين الا من يتميز بالقبول ويَرَتسم في وني

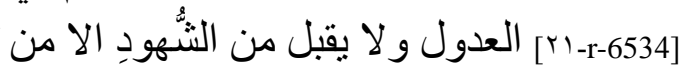

عرف بللثـهلدة بالعدالة وسدادِ

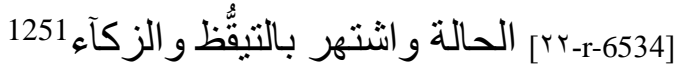

و اتصف بالنز اهة و الز كاء فالثهادة ولئه

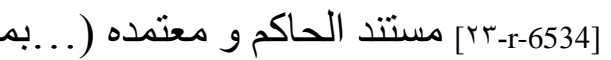

يصدره وبها يورد....ورده)

[1-v-6634- ] وهى اصل ما بحله من قضاياه

ويعتقده فعليه ان يحتاط1253 لذلكم جهده ويضع

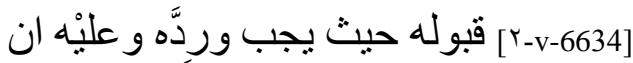

يسوِّى في الحكم بيْن النَّبيه و الخامل

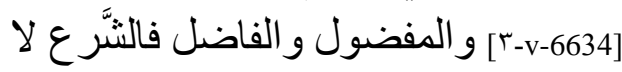

تعتبر فيه المناصب ولا تلحظ في تنفيده المرا

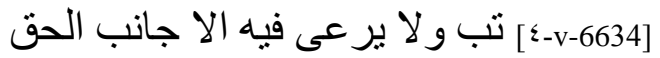

الذى دونه الجو انب فاذا و افاكم بمعونة الانة

God on High he arrives among you, rejoice in his arrival in your land, help him ceaselessly and in all circumstances,

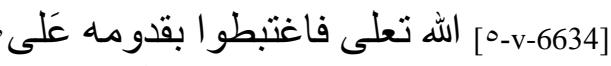

مكانكم وو اصلو ا انجاده في كل احيانكم

offer him constant collaboration to do good and to fear [God], ${ }^{1254}$ be as one hand united for the good we desire

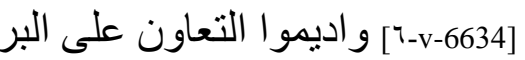

و التَّقوى 1255 وكونو ا بدًا و احدة في ما بر ادئو بكم

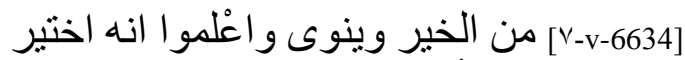

and that we want for you, know that he was chosen for you after having been tested and once we had appreciated

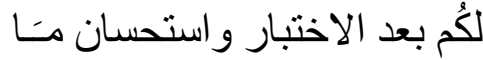

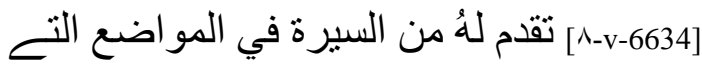

قدم عليها و الاثار و التقدير فيه

previously appointed; we had esteem

[9-v-6634] للوفاء بمر تضدى الاير ادِ و الاصندار

for his faithfulness towards the demands of authority (bi-murtadá al irādi wa-l-ișdāri). If God on High wills it. And $\mathrm{He}$ - May He be glorified - He will bring

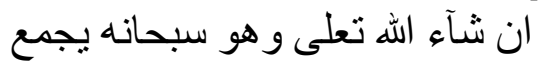

\footnotetext{
1249 'Azzāwī: عن.

1250 In the sense of 'adāla, rather than 'udūl.

1251 'Azzāwī justly proposes to correct with الذكاء which agrees much better with tayaqquz..

1252 The page bottom is worn, seven or eight words are half missing.

1253 'Azzāwī: يحطاط.

1254 Koran 5:2: "Help ye one another in righteousness and piety, but help ye not one another in sin and rancour: fear God: for God is strict in punishment."

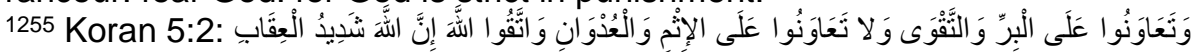


your passions together under His obedience ${ }^{1256}$ and He will guide your goals and your intentions towards what pleases Him By His grace. Peace.

Date, middle of the blessed month of shawwāl, the year 626 .

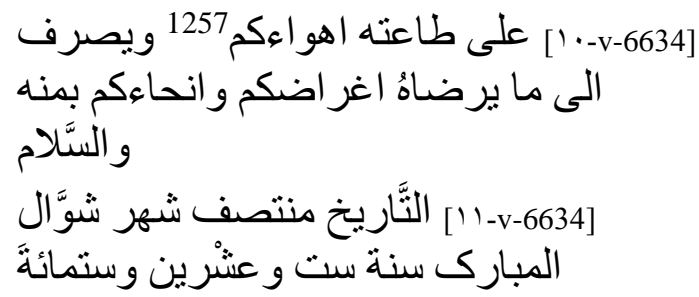

Taqdīm 53: Appointment from Seville of the jurist Abū Muḥammad as judge in Algeciras by the Caliph al-Ma'mūn (șafar 626/January 1229). The judge is responsible for choosing instrumentary witnesses. The foundations of the law are the Koran, Tradition, and the consensus of the Community ${ }^{1258}$

$$
\text { [ I r-v-6634] }
$$

In the same name, in an appointment by the above-mentioned in Algeciras
...May God assure them always respect through the fear $\mathrm{He}$ inspires in them and tie their faith to the strongest and most solid ropes of goodness.

This is what we write from Seville - May God have written for you a choice that protects the organization of your affairs, and options that improve

your population's condition. Welcome that which helps you in at your religious

and secular affairs, and know that because of the guarantee of [our] benevolent watch you enjoy protection that extends to you all, near

and far. This is why we take care to select those whom we name for you and neither you nor with anyone in the provinces [of the Empire],

do we spare our effort to help and protect you. We ask the help of God on High

to obtain the general happiness that we desire for all and we beg him to guide us in our plan

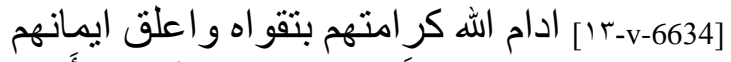

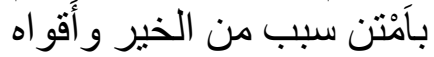

[ [-v-6634- ـ و انا كتبناهُ كتب الله لكم اختبارًا بحفظ نظام

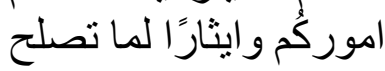

[10-v-6634] عليْه احو ال جمهوركم من اشبيلية

و الاقبال على ما بعينكم من شئون 1259 دينكم

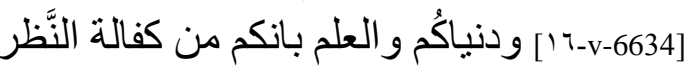

الجميل في مـ1260 يقضـــ بحياطة ادناكم

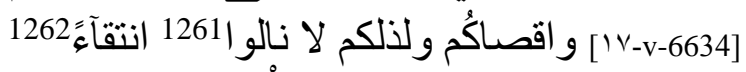

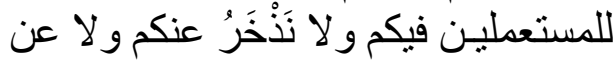

[1^-v-6634] غيْركم من أَهل الافاق اعتناءًَ 1263 بكنفكم

ويحميكم وبالله تعلى 1264 نستعيـن على ما ها اهنى

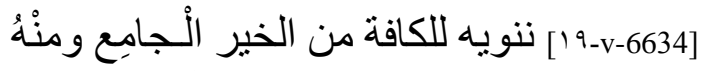

نلتمس الانحاء على ما نتوخاهُ لته

1256 Reference to a hadith reported by al-Baghawī, Sharh al-sunna, t. 1, 212-213: "None of you will believe as long as his passion does not agree with what has been revealed to me."

1257 Reference to a hadith reported by al-Baghawī, Sharḥ al-sunna, t. 1, 212-213: لا يؤمن احدكم حتى يكون هو اه تبعا لما جئت بـ

1258 'Azzāwī, NLA, t. 1, 485-486.

1259 'Azzāwī: شُؤون.

1260 'Azzāwī: فيمان.

1261 'Azzāwī corrects with ونألواء.

1262 'Azzāwī: انتقاءl.

1263 'Azzāwī: اعتناءاً.

1264 'Azzāwī: تعالى. 
to establish sound (mașālih) foundations and to manage resources. We appoint Fulān to take charge of affairs pertaining to the Law

in your district and its surrounding area and to satisfactorily advance your problems while maintaining

constant effort, [and this] after his sense of responsibility was revealed and confirmed in repeated and renewed positions,

and after long reflection in choosing who would be named as judge among you, he was chosen. We have counseled him to fear

God the Great, to weigh with just scales the decisions made with his authority ( $m \bar{a}$ yüridu-hu wa yușdiru-hu), that which he takes care of and that which he leaves to the side

and to fear He who surrounds him in the deepest and most intimates places of his being (madmar), He who knows his movements and stops, whether He favors

or humiliates him. We have ordered him to refer to the Book of God, the Tradition (sunna) of His messenger - Peace be upon him -

and the consensus of the Community (ijma $\bar{a}$ ' $\mathrm{l}$-ummati) in his judgments, to build on these three foundations the judgments he confirms

or annuls, and to choose [well] instrumentary witnesses; they are the keystone of the opinions he issues, and he calls on them to exercise his authority (fi wirdi-hi wa șadri-hi);

he should accept only those whose sense of justice is obvious and whose religious and secular behavior (hālatu-hu) is without fault. We have encouraged him

to dedicate himself completely to his work, and that his

to take as secretary or substitute only those persons of words and deeds worthy of confidence, to treat the unknown and well-known man equally

in his judgments, and equity that will allow him to assure the injured party full reparation of its rights, to render his proclamations according

to the most just method and to find balance ${ }^{1268}$ between firmness and forbearance. Thus, when arbitration rest on [a base that is] sure and exempt of all vice,

[قr-v-6634] من اقامة الْمصنَالح و اجر اء المنافع وانا

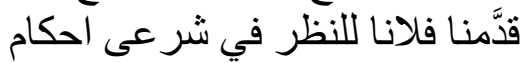

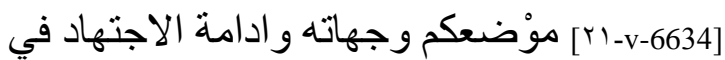

تمشية قضاياكم على السيرة

[rr-v-6634] المر ضنية ومو الاتهه بعد ان تردَّد استعْماله

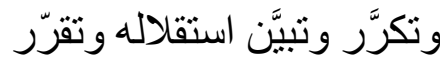

[-6735- ' ] و اجيل النظر في تخير من بقدَّم لقضابكم

فكان المتخير وقد اوصيناهُ بتقوى

[r-r-6735] الله الْغَظيم ووزن ما بور ده ويصدر ويهاتيه

وبذره بالقسنطاسِ المسنتقِيم

[r-r-6735] و مر اقبة من يحيطه بمضمر ه و مخفاهُ ويعلم

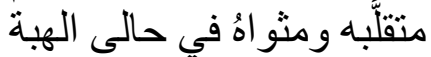

[-r-6735-؛ و التهريم و امرناه ان يستتند الى كتاب الله

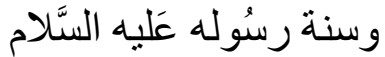

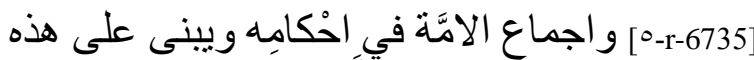

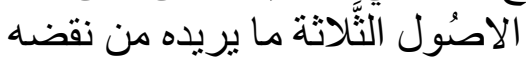

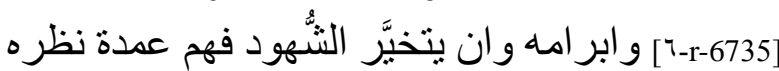

و اليهم يزْجع في ورده وصدره

[V-r-6735 فلا بقبل الا من تبيَّنت عدالته وحسنت دينًا

ودنبا حالته و اوزعزنا هنان

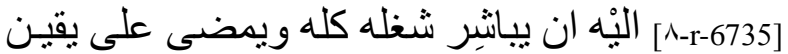

و استبر اء عقده وحله وله وله و لاه

[9-r-6735] يستكتب ويستتبب الا من يَتِّق 1266 قوْْله

وفعله وان بسوِّىَ بين الخَامل و النبيه

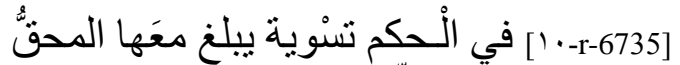

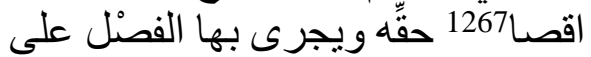

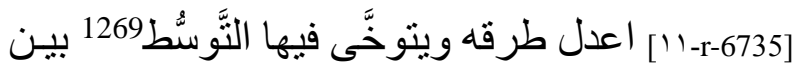

حالّى شدته ورفقه فاذا

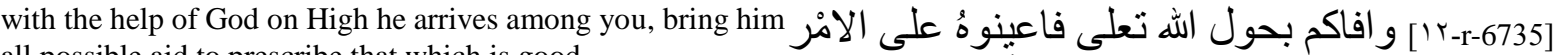
all possible aid to prescribe that which is good

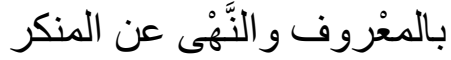

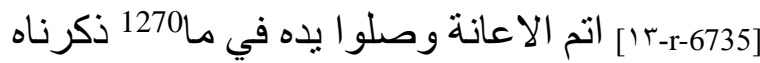

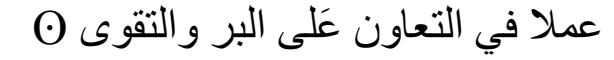

and forbid evil; stay at his side to carry out what we have ordered him contributing to good and the fear of [God]

\footnotetext{
1265 Error by 'Azzāwī who adds an incorrect tashkīl : حُّل instead of istibrā'u 'aqdi-hi wa halli-hi.

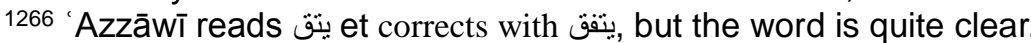

1267 'Azzāwī: أقصى.

${ }^{1268}$ Reference to Koran 2:143: "Thus, have We made of you an Umma justly balanced..."

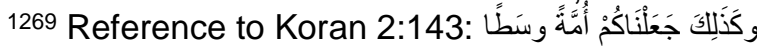

1270 'Azzāwī: فيما.
} 
in accord with religious practice. If God on High wills it. And $\mathrm{He}$ - May He be glorified - He will bring your hopes together towards that which is pleasing to him

[ [-6735-r-1 ] بمقتضى الديانة ان شآء الله تعلى وهو

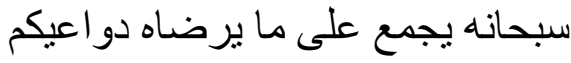
and will guide your efforts towards that which will bring [you] closer to Him. By His grace. Peace. The month of safar in the year و السَّلام في شهر صفر سنة ست و عثر 626.

Taqdīm 54: Appointment by Ibn Hūd alMutawakkil of a judge in Malaga ( $\operatorname{rabi}^{-}$II 634/December 1237). The judge is responsible for the market police and choosing assistants, or secondary judges, and instrumentary witnesses. The foundations of the law are the Koran, Tradition, the consensus of the Community, and the juridical consultations of the imāms ${ }^{1271}$

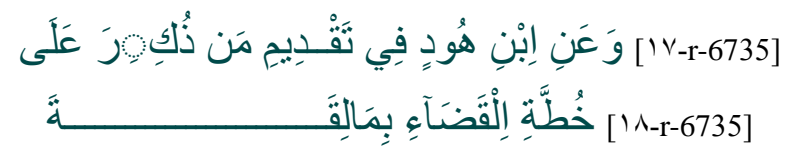

In the name of Ibn Hūd, appointment of the above-mentioned to the post of judge in Malaga

To the people of Fulāna - May God cause them to know the well-being of the protection and watch we constantly assure their flanks and may He lead them,

in all the plans for forbearance and justice we have for them, to the perfect accomplishment of their hopes.

After having praised God who established the laws to found and proclaim religion

and whom humans adore in devoting themselves to the Truth and following its path, after having called for His blessing on our lord Muhammad (...His messenger?)

whose lights dispersed the shadows and who saved the full moon of justice (badr al-'adl), whose last night (sarāri-hi)

saw the skies and lands emerge, as well as on his family and its noble companions, the banners and auxiliaries of Islam,

thanks to whom the religion of God appeared in full light and spread in all its fullness. We have [also] asked Him to recognize the imām, "vicar of God"

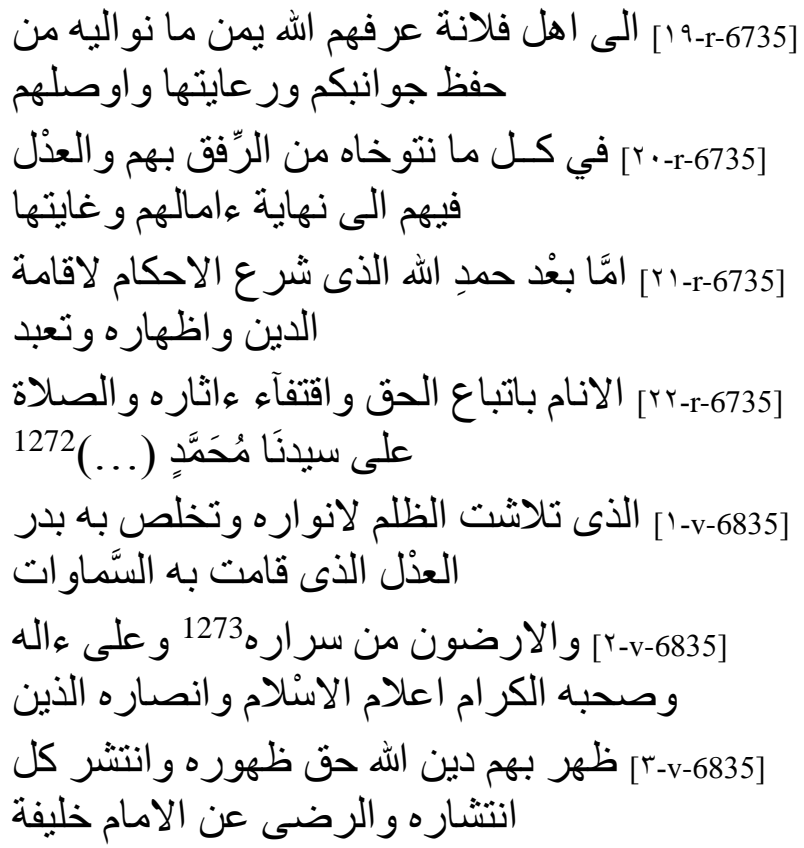
the lunar month"), compared with al-badr (the "full moon"). 
over His creatures and the receiver of His of power in His lands and His cities, who carries out the order of God on High, as must execute it

one who shares with His prophet - Peace be upon him his noble origin. ${ }^{1274}$ This is what we write - May God have written for you

the finest support and best direction to protect your organization and may he treat you with such great benevolence

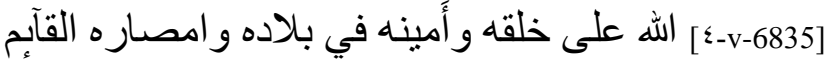

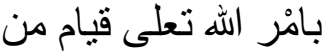

[0-v-6835] اضحى قسيم رسوله علبّه السَّلام في كريم

نجاره فانا كتبناه كثب الله

[7-v-6835] لكم اجمل معنتمد في حفظ نظامكم و احسَن من اكم

منتحى و اجر اكم من جمبل همديل النظر

that the person in charge of your affairs act from beginning على ما بكون به متولى احكامكم مختنما

to end with justice. And we, we place ourselves in the hand of God

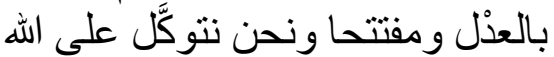

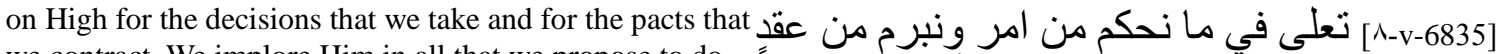

we contract. We implore Him in all that we propose to do

as praiseworthy efforts and fine projects. We ask Him to guide us in the exercise and practice of the authority ( $\mathrm{min}$ şadr

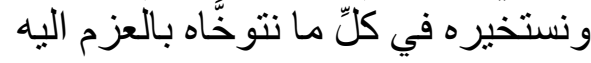

[9-v-6835] من حمبد سنْى وجمبل قصند ونسئله1275

الهداية في ما نحاولهُ ونز اوله من صدئل صدر

wa wird $_{\text {in }}$ ) that we practice and exercise. We welcome His abundant favors and His continuous mercies with the profusion of thanks

[-v-6835- [1 من صدر 1276 ووردٍ ونتلقى نعمه الجزيلة

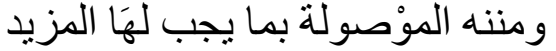

and praise they are owed. This is why your land, with its districts, is among those to which we ceaselessly dedicate part

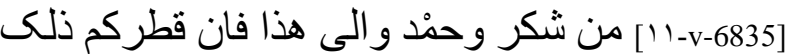

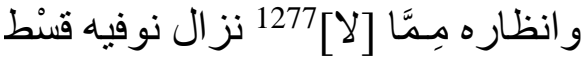

of our sustained attention and we choose for it officials whom we have verified work according to our fine

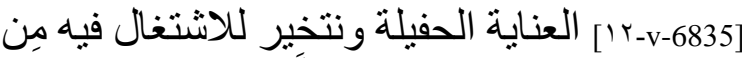

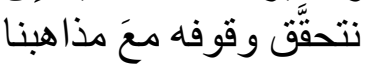

principles. We called to arbitrate disputes among its inhabitants someone whose good reputation, purity of intentions,

[1r-v-6835] الجميلة وننهض لتقلد الفصنل في الاحكام

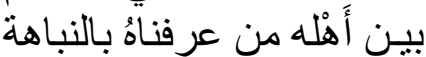

equity, and merit we know well. Taking into account these just considerations and the sincere

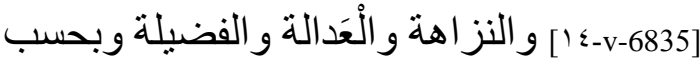

الصَّحيح مِنَ هذا الاعتبار و الصنّرِيح

plans we form for you and your regions with an abundance of friendship and preference, we have taken the greatest precaution

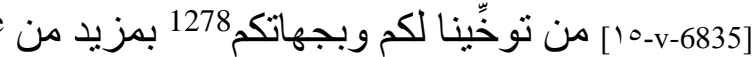

التقديم و الايثار بَالَخْنَا في الانتقاء

in the selection and choice of a judge for you, and we have designated for this post someone whom we have tested and who came out

[17-v-6835]

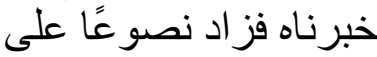

Stronger. We have appointed him as governor ( 'āmil) a number of times, in the most well-known of lands, and always and everywhere

[IV-v-6835] الاختبار و استعُملناهُ في نبيهات البلادِ المرة

بعد المرة فحمدناهُ

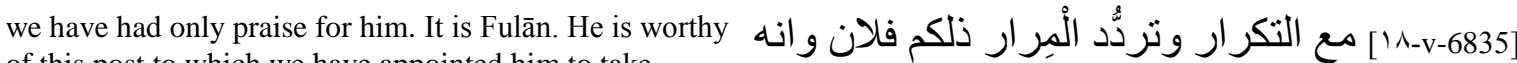

of this post to which we have appointed him to take responsibility

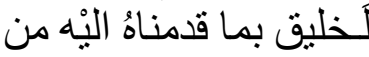

for your judgments and he is capable of arbitrating alone your disputes and differences, for he has marked himself

by his qualities of justice and uprightness, he brings together all that could be desired in politics and

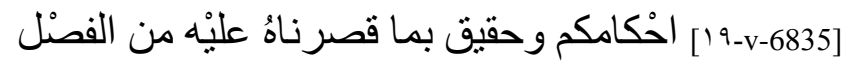

في نو ازل خصامكم لاستظهاره

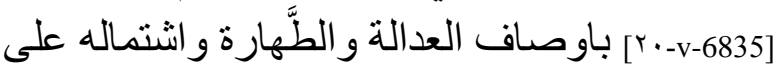

كلِّ موثر مشكور من السِّيا

1274 This is the Abbassid caliph al-Mustanșir bi-Llāh (623/1226-640/1242).

1275 'Azzāwī: ونسأله.

1276 Repetition.

1277 Addition by 'Azzāwī.

1278 'Azzāwī: ولجهاتكم. 
Administration, he innately has an excellent character and

exceptional nature. Over the numerous years we have employed him as governor, these qualities have always

been clear and obvious, his intentions in [the decrees] he annuls (naqdi-hi) or confirms (ibrämi-hi), that the has carried out (imḍ̄ $i$-hi)

or that he suspends (irtiyābi-hi), never lack uprightness and never fault in religion. He has understood quite well the general directives

we have given him: we have enjoined him to base all his judgments on the demands of the book of God,

the Tradition of His messenger, to follow in deeds and words the consensus of the Community (ijma ' $i$ l-ummati) and the juridical consultations of the imamss (wa fatāwá al-a 'immati), we have insisted that he choose and select with care the assistants for all regions, that

he employ only pious and virtuous people, that he keep watch over them in all circumstances and that he confirm

or replace in certain ones that which his judgment dictates. That he act in the same way with the instrumentary

witnesses who help in validating or annulling rights and on whose witness the detestable is rejected and the comely is accepted.

We have ordered him to protect the market police (hisba) who support the resources and framework of life and to give responsibility for these,

no matter where, only to one known for the purity of his initiatives and the uprightness of his methods;

[and also] to manage judgments concerning the Law according to the applicable rules, to follow the path

of equitable judges in the establishment of the law and the proclamation $\left(i s h \bar{a}^{\prime} a\right)$ of justice and to act in accordance with required

behavior in the accomplishment of [our] praiseworthy principles. Thus, when with the help

of God on High he arrives among you, know well that we honor you by appointing him as governor over your lands; it was a satisfaction for us to give you his neighborship (mahmūd)

and him yours; we chose him for you and you for him as his merits and

yours required. Thus, be with him as one hand united to take on the charge of judging your affairs for which [r-v-6835] سة و الادارة وكونه مجبو لا على الثيم

المسنتحسنة و السَّجايا

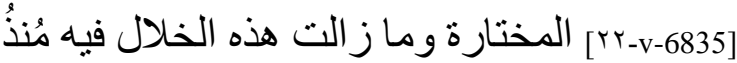

استعملناهُ على مرِّ السِّنينْ

[r-v-6835] تتضح وتستبين و مناز عه في نقضسه و ابر امه

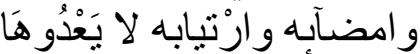

[-r-6936- السَّداد و لا يريمها الدِّين وقد القينا اليْهِ من and

الو صنايا الجامعة ما تلقاهُ

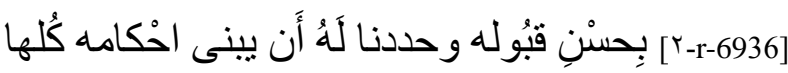

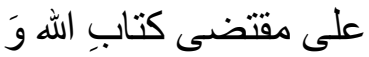

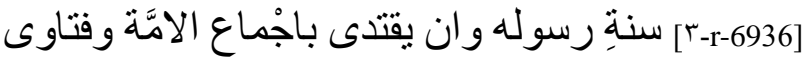

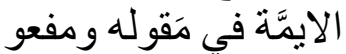

[ [أَكدنا عليْه في ان بختار المسَدِدين للجهات

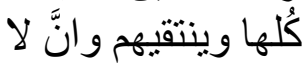

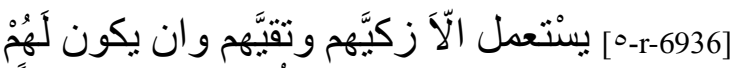

متعَهِّدا في كُلِّ الاحْو ال و وعاخذًا

[r-r-6936] فيهم بما يقتضيه نظره من الاقرار و الاستبدال

وكذلك فليكن عمله في الثهود

[V-r-6936] الذين تصح الْحقوق بهم وتبطل وبشهادتهم

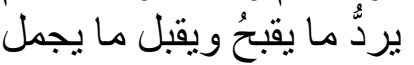

[N-r-6936] و امرنا1279 ان يحتاط للحسبة التخ هـى قو ام

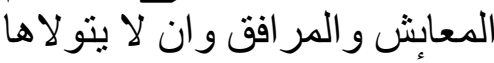

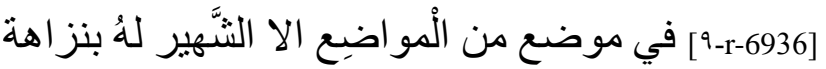

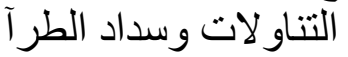

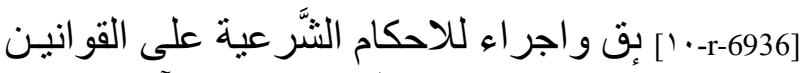

المرتضاة و اقتفاء في اقامة اقهية

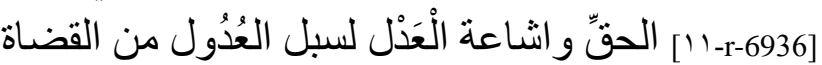

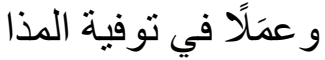

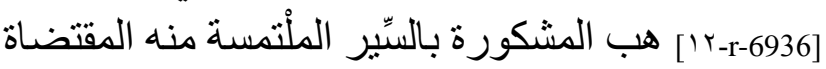

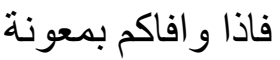

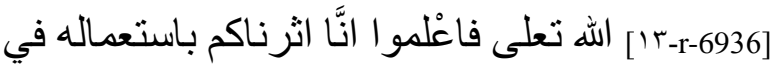

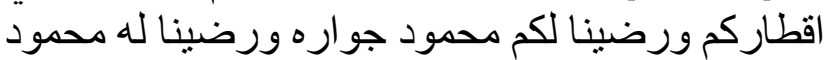

[1-6936-r-1 ] جو اركم و اخترناهُ لكم و اخترناكم له عملاً بموجب

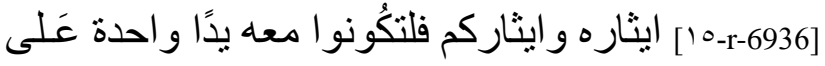
ما انهضناهُ اليّهـ من

1279 'Azzāwī: و وامرناه. 
he has been invested; help him with all your strength and determination if God wills it. know the happiness of his arrival and He will bring you the blessing of his employment and the joy of

his leadership. By the grace and generosity of God on High. Peace. Date, first day of $r a b \bar{\imath}^{`}$ II,

in the year 634 .
And He - May He be glorified - He will cause you to

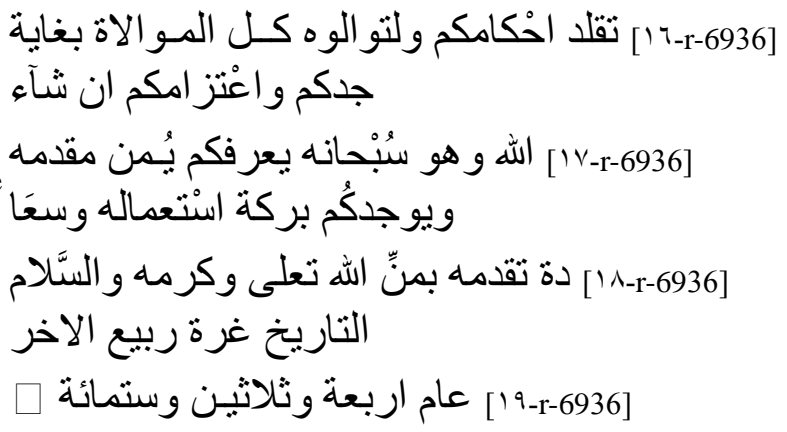

Taqdīm 55: Appointment by Ibn Hūd alMutawakkil of a judge responsible for choosing instrumentary witnesses. The foundations of the law are the Koran, Tradition, the consensus, and the words of the imāms. Many Koranic quotations (12281238) $)^{1280}$

$$
\text { [r-r-6936-r.r و عنْه مخاطبة جمهورية في تقديم قاض عاخر }
$$

In the name of the same, collective allocution for the appointment of another judge

May God assure them always better conditions and well-ordered affairs and cause them to recognize the benevolence that will

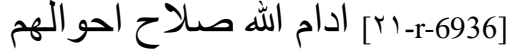

$$
\begin{aligned}
& \text { و انتظلام امور هم و عر فهم من جميل }
\end{aligned}
$$

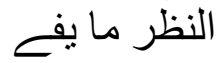

$$
\begin{aligned}
& \text { [بr-r-6936] باقر ار عيونهم و ابهاج }
\end{aligned}
$$

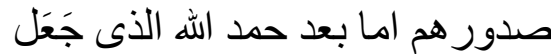

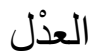

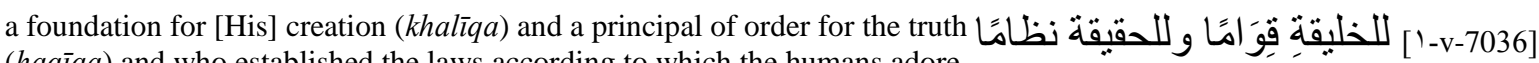
(haqiqa) and who established the laws according to which the humans adore Him,

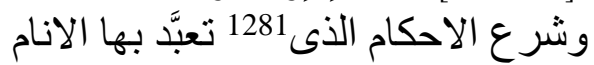

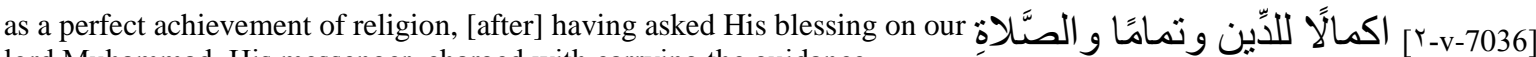
lord Muhammad, His messenger, charged with carrying the guidance

of the true religion to terrorize and crush the deceitful misled, and who spread light and justice (al-qist)

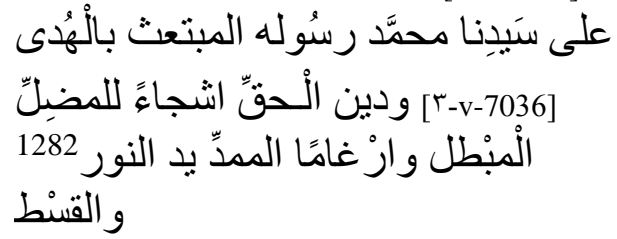

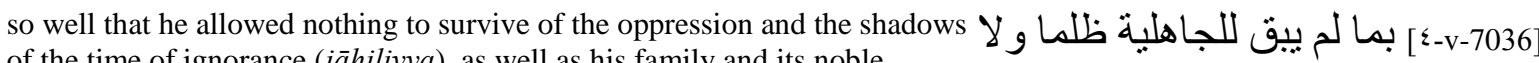
of the time of ignorance (jähiliyya), as well as his family and its noble companions who

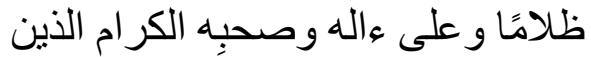
were stars and banners for Islam, who followed his example — Peace be upon him -

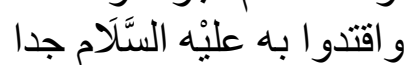

1280 'Azzāwī, NLA, t. 1, 489-492.

1281 'Azzāwī corrects with التئ.

1282 The manuscript clearly indicates المدِّين, but 'Azzāwī is correct in proposing: الممّدِ يد النور والقسنط. imposed by the syntax and sense of the sentence. 
in proclaiming the Truth with zeal and determination; [after having asked God] to recognize the imām who exercises the vicariate (khiläfa) of the prophecy, ${ }^{1283}$

who is chosen for that, and who brings together all the required merits, which, according to

the consensus $(i j m \bar{a})$ and the unanimous opinion (isfa $\bar{a} q)$, requires that he be joined (ilmāman) and followed. This is what we write for you - May God have written for you

the most righteous and just actions and cause you to know hopes that are generously and lastingly fulfilled.

We deliver ourselves into the hands of God on High for all that we undertake or forsake, and we implore the help of His assistance

and His direction so that our opinions might be just and our decisions correct, we ask Him to guide us

towards that which will make us pleasant in his eyes, for it is He who hold fate and destiny; we address our thanks and infinite praise to Him. For to praise Him

and thank Him are the first desire we have in all circumstances. This is why - May God fasten you to the ties

of His favors and may He spread over you the shadows of innocence (ișam) - we grant you as is proper for you and your rank,

the noble solicitude and universal protection required by your past, and that made you deserving

of your faithful loyalty and sincere affection. You will recognize in return that which is suitable and in accord

with your wager. With this in mind, we choose with the greatest care the person we will appoint as governor among you and whom we will order

to lead you. We make him responsible for assuring a task in your regions, more specifically the function of judge on which

depend judgments, [as well as] the protection of individuals (al-dimā'), moveable goods (al-amwāl) and families (al-ahrām), and for which the laws

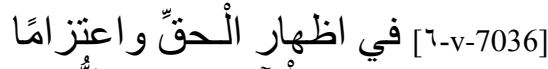

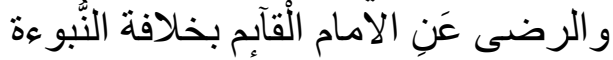

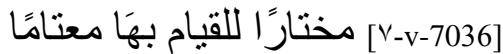
الْجامع من شُروط الاسْتحقاق ما اوجب

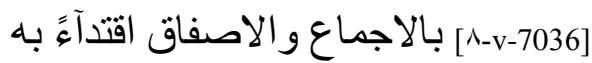
و المامًا فُفانا كتبناه كتب الاهب اله لكم [9-v-7036] اوضح الاعْمال سدادًا وصو ابًا و عرَّفكُم أَسْمح الامَّال انقيادًا و اصحال

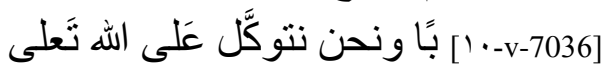
في كُل ما ناتــ ونذر ونستو ونستمد من

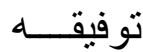

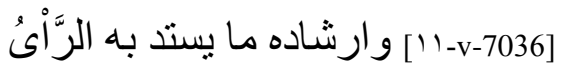

وبستقيم النظر ونستئله 1284 ان بـديَّنا

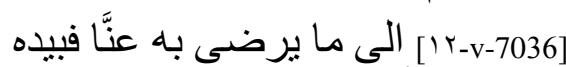

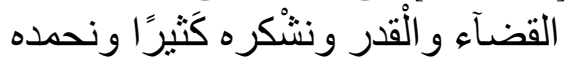

وحمده

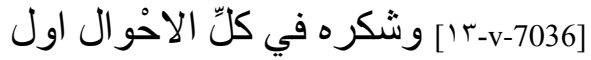

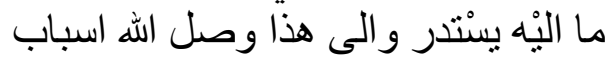

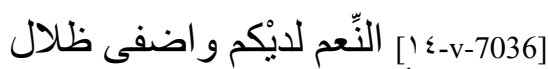

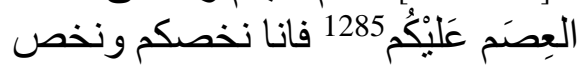
مكانكم

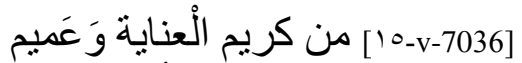

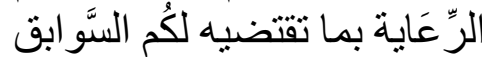
وبحظيكم

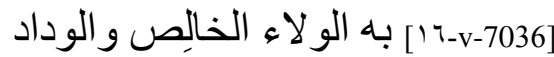
الصنّادق وتتعرفون منه ما بناسب سبقكم

[ IV-v-7036] ويطابق 1286 وبهذا الاعتبار

نجد الاختبار لمن نستتعمله فيكم

ونستتهونه

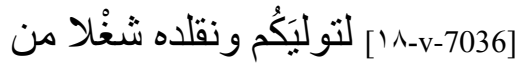

اشغال نو احيكم وبخاصنَّة خطة القضآ لئ

التح

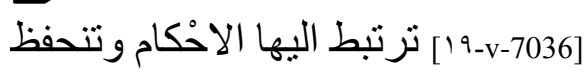

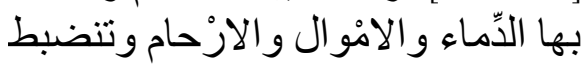

1283 This is the Abbassid caliph al-Mustanșir.

1284 'Azzāwī: ونسأله.

1285 'Azzāwī: لديكال

1286 Most likely the city under Ibn Hūd's power, Murcia or Malaga. 
define the fundamental principles that permit distinguishing between the licit and illicit. For that, we

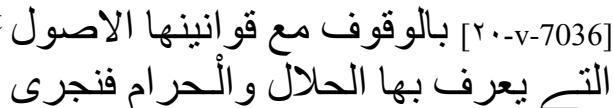

choose a person with exemplary method and upright character. To fill that place, we wish only

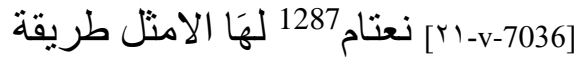

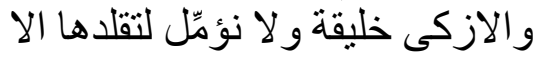

for someone in whom we have recognized correct behavior and strong aptitudes (munna). With this decree, we have appointed

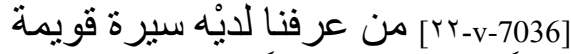

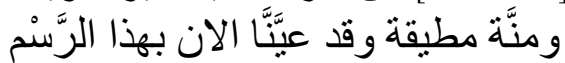

Fulān, because his renewed experience has corrected his faults and because he has many works and [because of] the excellence of his character

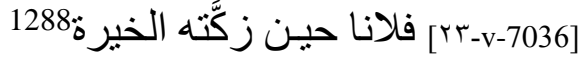

المتردِّدَة وكانت لله الاثر 1289 المتتعَدِدة

وحسن:ت

and his sincerity (hadhabu-hu). His efforts and decisions in all that he has been charged with have received nothing but praise. The surety of his judgments and his firmness have shown brilliantly,

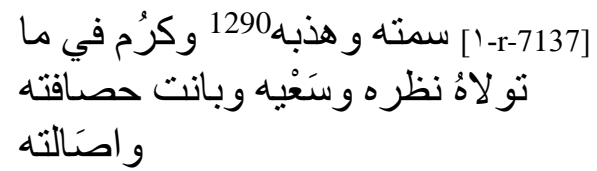

his calm and his superiority have been manifest. We have asked the help of God on High in appointing and designating him and we

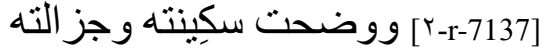

فاستخرنا الله تعلى في تقديمه وو انهاضهـ

وَرَ

hope he lives up to our [good] opinion of him in all his directives and projects, without straying from the path

[r-r-7137] جونا ان بكون عند الظَّنِّ به في

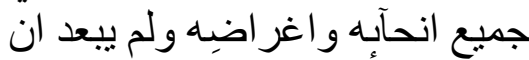

يكون

traced by illustrious judges who preceded him, nor the direction opened by the jurists of reference, his

$$
\begin{aligned}
& \text { [ـ-r-7137] بالقضـاة الاعْلام من سلفه } \\
& \text { مقتديا وبالفقهاء المشاورين من آََابله }
\end{aligned}
$$

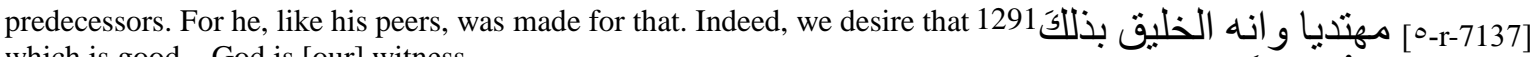
which is good - God is [our] witness -

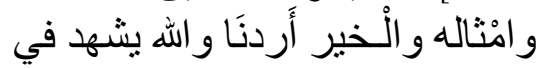

in employing him: "my success can only come from God. In Him I trust, and unto Him I look..." 1292 We

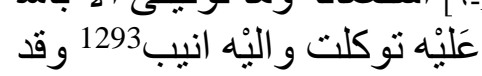

have given him advice, insisting that he follow it by the letter and we are exempt of any faults

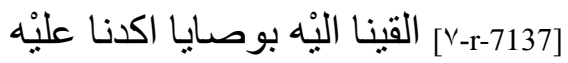

$$
\begin{aligned}
& \text { في امتثالهَا وبرئنا عيه لليه من }
\end{aligned}
$$

for the responsibilities that we have entrusted to him [in this advice]; and in our excuses and [our] warnings, we have left him

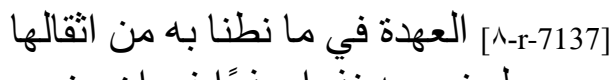

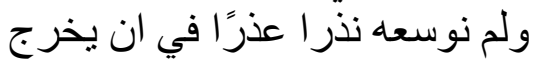

فنجرى فنجر 1287 فنجرى العتام, word unclear at the end of the line. 'Azzāwī reads first word of the next line is clearly نتعتام.

1288 Should be corrected with khibra, الخبرة.

1289 'Azzāwī: الآثار.

1290 'Azzāwī: وهديه.

1291 'Azzāwī: لذأل

1292 Koran 11:88: "He said: "O my people! see ye whether I have a Clear (Sign) from my Lord, and He hath given me sustenance (pure and) good as from Himself? I wish not, in opposition to you, to do that which I forbid you to do. I only desire (your) betterment to the best of my power; and my success (in my task) can only come from God. In Him I trust, and unto Him I look".

1293 Koran 11:88:

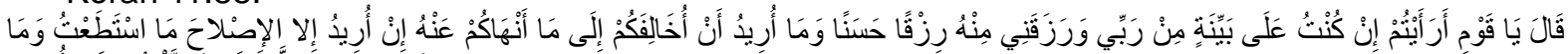

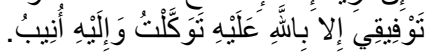


no freedom to leave in word or deed from the obvious path [of this advice] and the ideal example [that it gives]; in particular, we have ordered him to take inspiration before all else from the fear of God

on High that serves as the center of all intentions and acts, for it is the best provision for the hereafter. Benefits

abound with it and happiness is reached. God on High said: "O ye who believe! if ye fear God, He will grant

you a criterion (to judge between right and wrong), remove from you (all) evil (that may afflict) you, and forgive you: for God is the Lord of grace unbounded." ${ }^{295} \mathrm{He}$ [also] said:

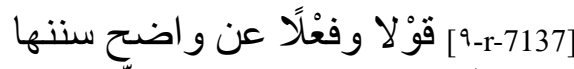
وقويم مثنالها منها انا امرناهُ ان بقدّمّم تقوى وعى لَّا

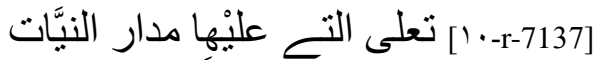

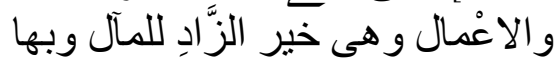

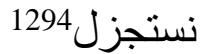

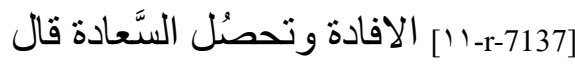

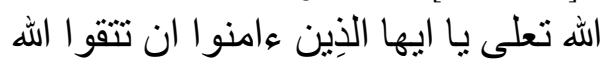
يجنل

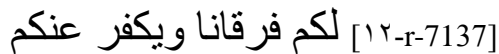

سيئاتكم وبغفر لكم و الله ذو الفضل فئل

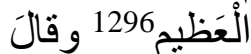

"For God is with those who restrain themselves, and those who do good."1297 We have required of him to refer to the Book of God

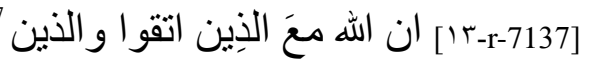

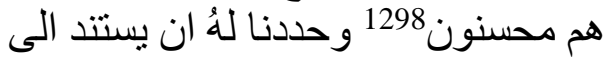
كتاب الله

the Mighty so that "no falsehood can approach it from before or behind it," 1299 to hold himself to its solid

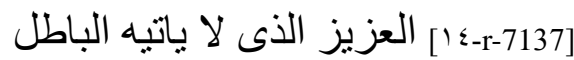
من بين يديه و لا من خلفه مع عاباته

Verses with a solid heart, an attentive ear and a penetrating gaze. It is the light that

[10-r-7137] المحكمات بو عي قلبه فيه

و اصغاء سَمْعه و ابصار طرفه فهو النور

الذي

dispels shadows when it rises and diffuses, and the rope of God, and he who hastens

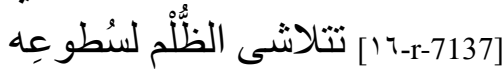
و اشر اقه وحبل الله الإِى قد سعد من بادَرَ

to seize it and fasten himself to it is happy. God on High said: "And this is a Book which We have revealed as a blessing: so

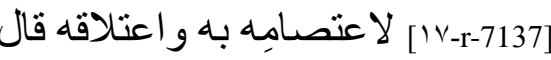

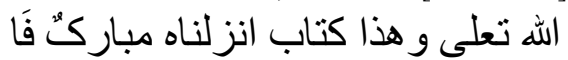

follow it and be righteous, that ye may receive mercy." ${ }^{1301} \mathrm{He}$ [also] said: "Verily this Koran doth guide to that which is most right (or stable),

[1^-r-7137] تبعوه و اتقو العلكم ترحمون 1302 وقال ان هذا القر عان بـهدى

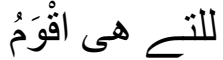

and giveth the Glad Tidings to the Believers who work deeds of righteousness, that they shall have a magnificent reward." ${ }^{303}$ May he take into account the Tradition (sunna)

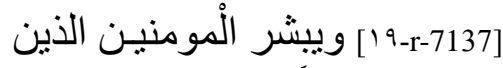

يعملون الصنّالحاث ان لهم اجرًا

كَبير ا1304 وان باخذ بسنَّة

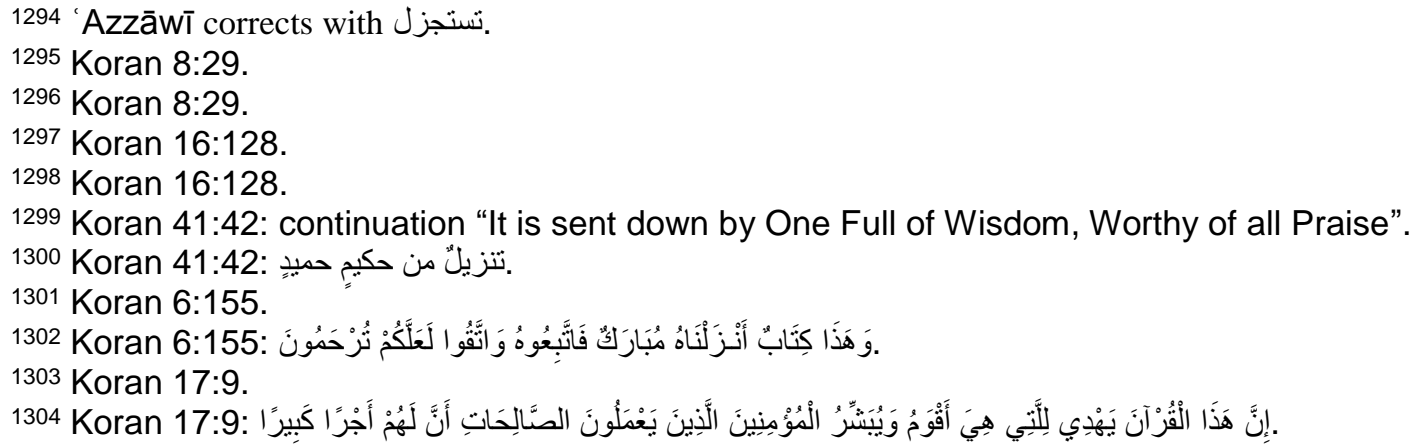



of the messenger of God - Peace and the blessing of God upon him - as does
the saint who seeks to follow his footprints and enlightens himself

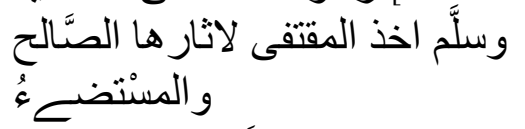

with his sparkling lights, for that is the path of guidance and the discourse of he who "says aught of desire." 1305 God on High said:

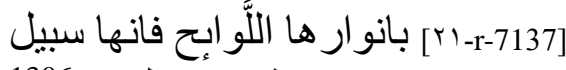
الْهُدَى وكلام من لا بنطق عن الهوى 1306 قال الله

"Obey God, and obey the Messenger, and beware (of evil): if ye do turn back, know ye that it is Our Messenger's duty to proclaim (the message)

in the clearest manner." ${ }^{1307} \mathrm{He}$ [also] said: "So take what the Messenger assigns to you, and deny yourselves that which he withholds from you."1308

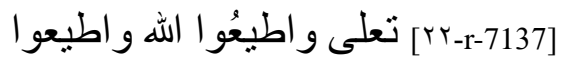

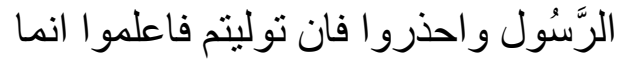
على

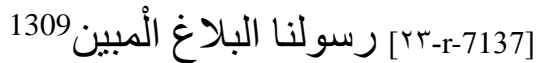

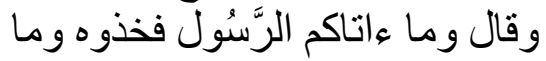

نهاكم عنه فانتهو 1310

He said - Peace be upon him: "I left you two things [such that] you will never stray as long as you remain devoted to them: the book of God and the Tradition (sunna)

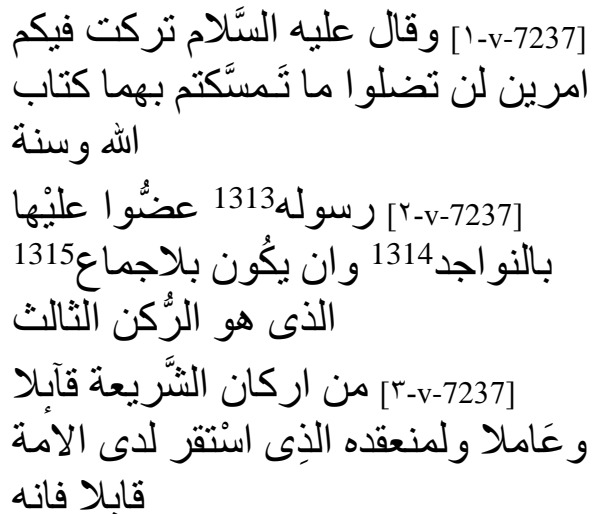

قابالك فانه

pillar of the Law, and that he accept its pact which is implanted in the community (umma). With this

of His messenger." 1311 Hang on with your teeth ${ }^{1312}$ that his words and acts conform to the $i j m \bar{a}^{\prime}$ which is the third

\footnotetext{
1305 Koran 53:3.

1306 Koran 53:3: وَمَا يَنِطِقُ عَن الْهَوَى

1307 Koran 5:92.
}

1308 Koran 59:7: "What God has bestowed on His Messenger (and taken away) from the people of the townships,- belongs to God,- to His Messenger and to kindred and orphans, the needy and the wayfarer; In order that it may not (merely) make a circuit between the wealthy among you. So take what the Messenger assigns to you, and deny yourselves that which he withholds from you. And fear God; for God is strict in Punishment"

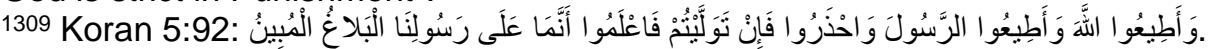

1310 Koran 59:7:

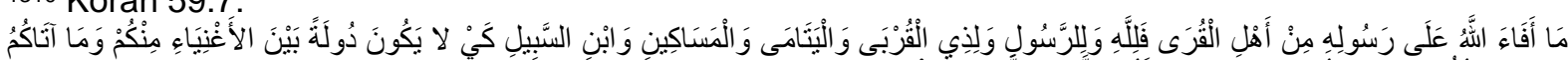

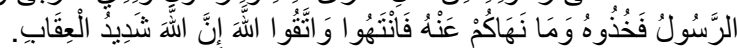

1311 In the muwatța’ Mālik there are three types of reported stories.: prophetic hadīths , āthārs (companions and their disciples) and balāghāt. The latter are hadīths cited by Mālik, but introduced with the expression balagha-nī, ("I heard said that... The Messanger of God is said to have said..."), indicating that the authenticity of the hadīth or isnād is doubtful. These are called the balāghāt muwațta' Mālik. In this case, allusion to the balāgha in Muwatțā', t. 2, 480, n² 2618.

1312 Lit. «bite it with your molars». Reference to ḥadīth al-sam 'wa-l-țā 'a, reported by Abū Dāwūd, Sunan, 691, n 4607 and Tirmidhī, Sunan, 603, n² 676.

1313 Allusion to balāgha in Malik b. Anās, Muwațțā', t. 2, 480, n² 618: تركت فيكم أمرين لن تضلوا ما تمسكتم بهما كتاب الله وسنة نبيه.

1314 'Azzāwī corrects with بالنواجذ. Reference to hadīth al-sam 'wa-l-țā'a, reported by Abū Dāwūd, Sunan, 691, n 4607 and Tirmidhī, Sunan, 603, n² 2 676:

أوصيكم بتقوى الله... و إياكم و محدثات الأمور فمن أدرك ذلك منكم فعليه بسنتي و سنة الخلفاء الر اشدين المهديين عضوا عليها بالنواجذ.

1315 'Azzāwī: الإِجماع. 
pact God showed His law, He forbade transgressing it and He imposed it as worship on His creatures. God on High said:

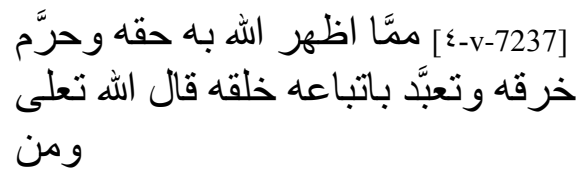

"If anyone contends with the Messenger even after guidance has been plainly conveyed to him, and follows a path other than that becoming to men of Faith,

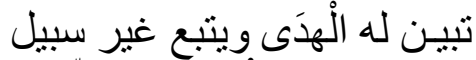

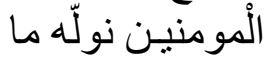

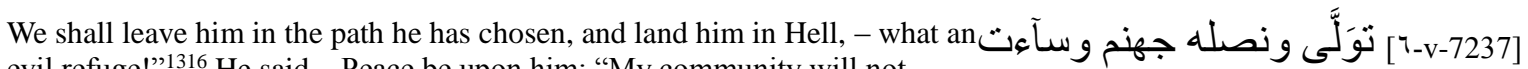
evil refuge!" 1316 He said - Peace be upon him: "My community will not agree on error." 1317

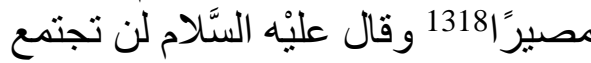

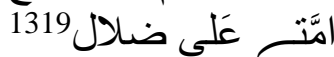

In addition, he must consult the words of the imāms, preferring those which the law (al-haqq) has corroborated,

rely on the counsel of men of knowledge in examining the arguments they present, and tie himself to the wisdom of God

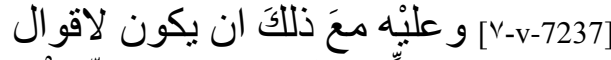

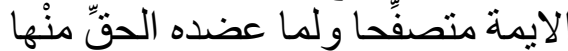

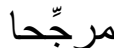

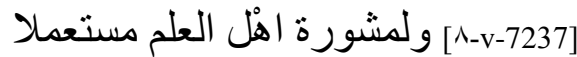
ولما يوردونه من الحجاج متامِّلا ولحكم مديم

الله

in referring to the prophet and to those who hold authority ( $\bar{u} l \bar{l} l$-amr). God on High said: "But who, for a people whose faith is assured,

can give better judgment than God?"1320 Ordering His prophet to follow Him, he said: "Consult them in affairs (of moment). Then, when thou hast Taken a decision

put thy trust in God. For God loves those who put their trust (in Him)." ${ }^{1322}$ May he devote himself to the justice that God ordained in

his decisions and may he manifest the greatest efforts and greatest possible zeal when he draws up his scales. That is

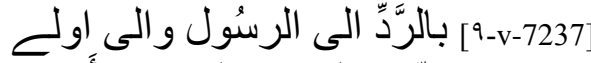

$$
\begin{aligned}
& \text { الامْر متوصِّلا قال الله تعلى ومن أَحْسن لَّن } \\
& \text { من الله حكُما من احن } \\
& \text { [1-v-7237- لقوم يوقنون } 1321 \text { وقال عامرا } \\
& \text { لنبيه ليقتدي به وشاور هم في الاهزر فاذا } \\
& \text { عز مرث }
\end{aligned}
$$

[11-v-7237 فتوكل على الله ان الله يحب

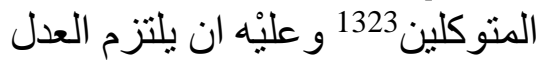

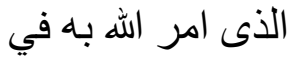

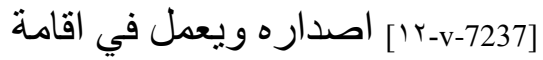

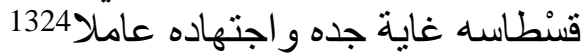

1325 (...) انه (. I

1316 Koran 4:115.

1317 Hadīth reported by Tirmidhī, Sunan, 490, n² 2167.

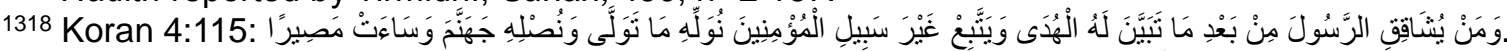

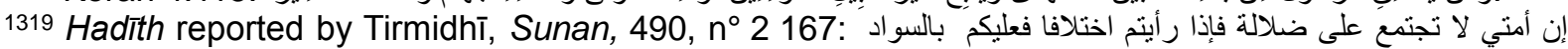

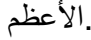

1320 Koran 5:50.

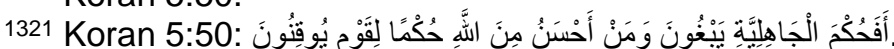

1322 Koran 3:159: "It is part of the Mercy of God that thou dost deal gently with them Wert thou severe or harsh-hearted, they would have broken away from about thee: so pass over (Their faults), and ask for (God's) forgiveness for them; and consult them in affairs (of moment). Then, when thou hast Taken a decision put thy trust in God. For God loves those who put their trust (in Him)."

1323 Koran 3:159:

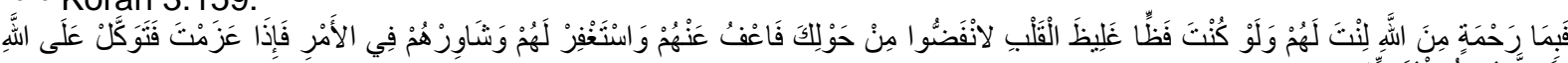

1324 'Azzāwī proposes عالما.

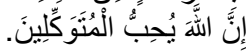

1325 One illegible word. 
the surest commitment for it is what God demands of all leaders (hukkām). God on High said: "God

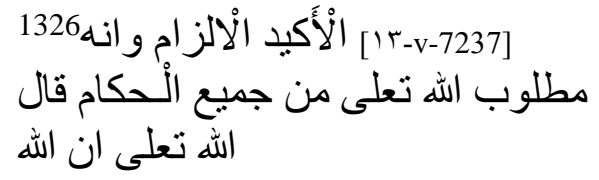

doth command you to render back your trusts to those to whom they are due; and when ye judge between man and man, that ye judge with justice," 1327

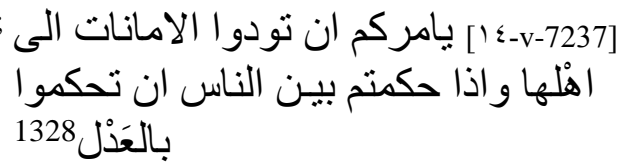

and $\mathrm{He}$ [also] said: "O ye who believe! stand out firmly for justice, as witnesses to God, even as against yourselves,

[10-v-7237] كونوا قو امبن بالقسنط شهداء لله ولو عَلى انفسكُ كو

or your parents, or your kin, and whether it be (against) rich or poor: for God can best protect both." 1330 The function of judgeship has rules (qawāninn)

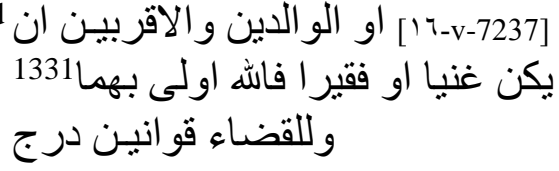

that have been respected by the most illustrious of judges, as shown through their satisfying behavior. Among others, what is known of their firm actions (al-tawathuq) [such as]:

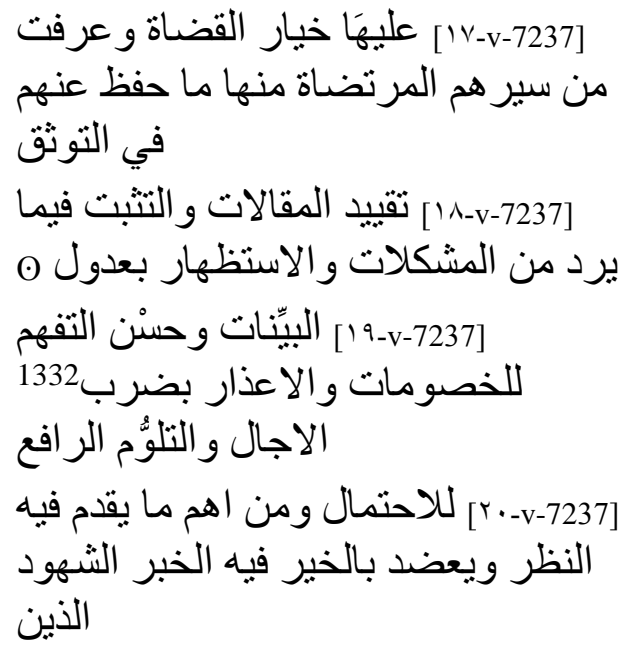

the execution of judgments rests and who are consulted to annul or confirm them. It is said

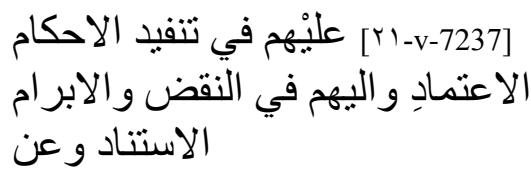

Doubts. One of the principle points that needs to be seen and the right direction of which needs to be verified is the instrumentary witnesses on whom

transcribe depositions (maqālät), verify the problems that appear, rely on evident

proof, have a good understanding of disputes, fix terms with equity, and act with a slowness that raises

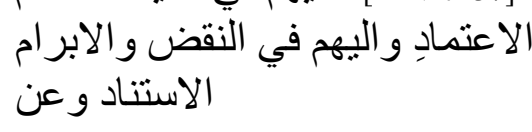

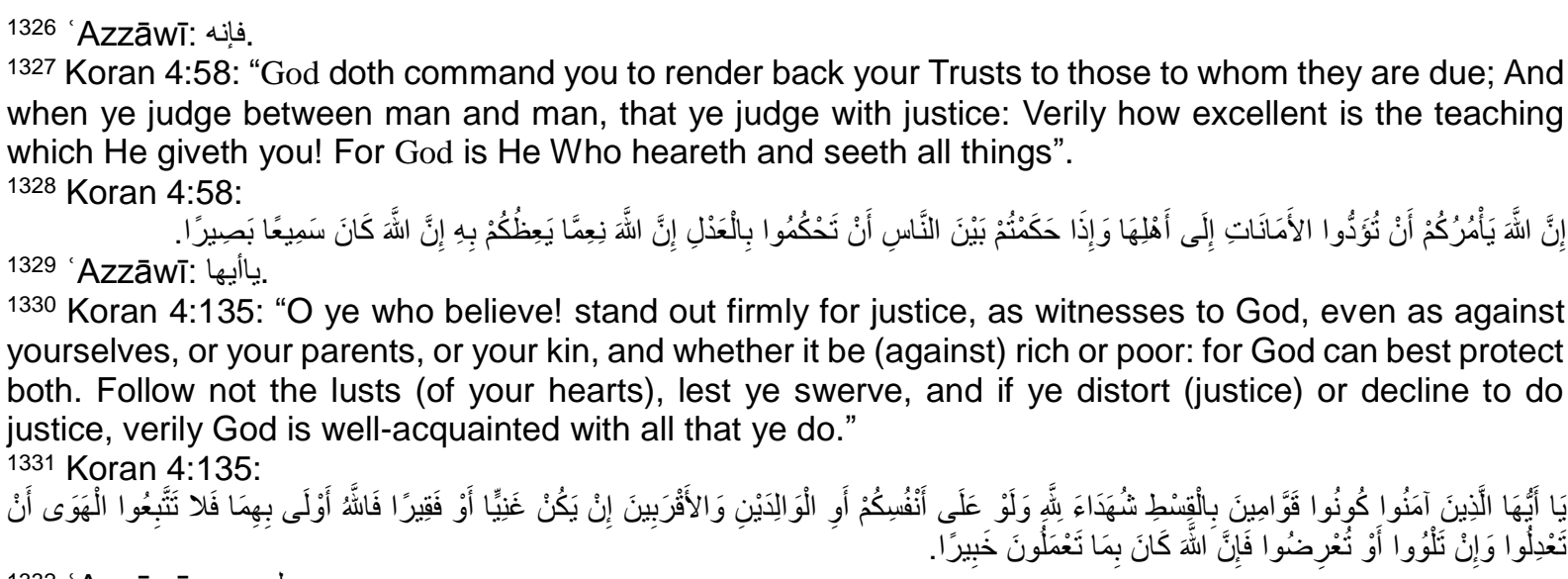
1332 'Azzāwī: لضرب. 
that a judge once said to some witnesses: "You are the judges and I am but the executor." God on High

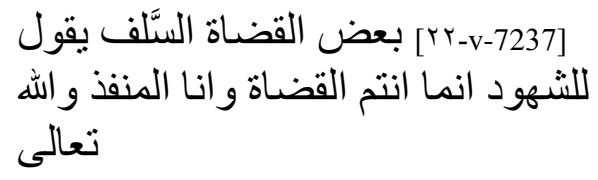

said in His book: "Their evidence will be recorded, and they will be called to account." 1333 (He has been ordered) to choose them scrupulously

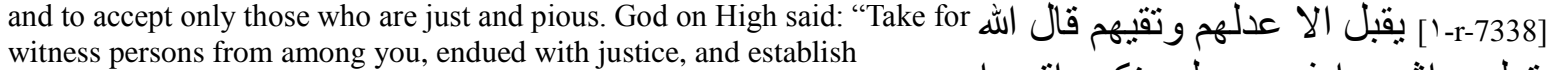

the evidence (as) before God." 1335 And among the remarks quoted from the prophet - Peace be upon him: Testimonies from the opposing party,

the quick-tempered, and the concerned man are dismissed." ${ }^{1337}$ He should verify their conditions at all times, and nothing should stop his vigilance

in monitoring them. When with experience he has noted the virtue [of a witness] and verified his equity many times, may he accept and ratify his

Testimony, and when he discovers a lie, may he refute and invalidate the testimony [of its author] in order to be sure of the foundations

on which the judgment is based, and certain of that on which he bases his preference. He must apply the penalties (hudūd Allāh)
تعلى و اشهدو ا ذوى عدل منكم و اقيموا

[r-r-7338] الثهادة لله 1336 وفي الاثر

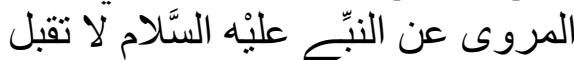

شهادة خصم

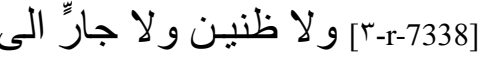

نفسه1338 فليكن باحثا عن احو الهم في كل

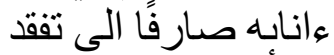

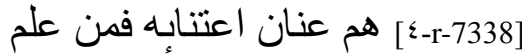

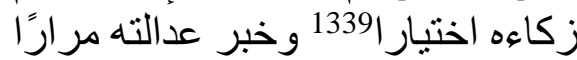

امضنى شهـادته

[0-r-7338] وقبلها ومن عثر له على جرحة

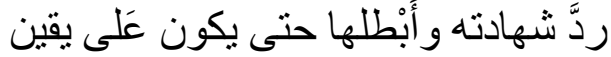

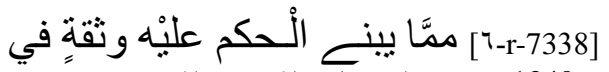

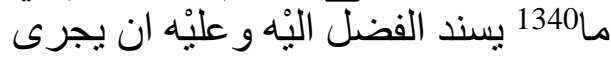

حدود الله

1333 Koran 43:19: "And they make into females angels who themselves serve God. Did they witness their creation? Their evidence will be recorded, and they will be called to account!"

1334 'Azzāwī: ويسألون. Koran 43:19:

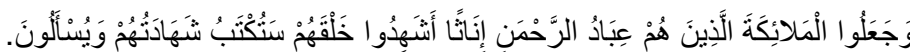
1335 Koran 65:2: "Thus when they fulfil their term appointed, either take them back on equitable terms or part with them on equitable terms; and take for witness two persons from among you, endued with justice, and establish the evidence (as) before God. Such is the admonition given to him who believes in God and the Last Day. And for those who fear God, He (ever) prepares a way out."

1336 Koran 65:2:

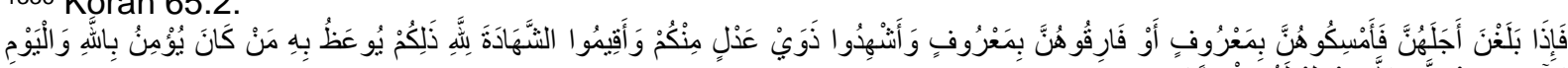

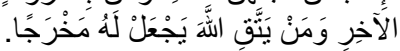
1337 Hadīth reported by Abū Dāwūd, al-marāsil, 202, n² 2, al-Bayhaqī, al-Sunan al-kubrā, t. 10, 260, n' 21159 and by Mālik, Muwațta', t. 2, 462, nº 2 107, Kitāb al-aqựiya, bāb al-shahādāt, as balāgha.

1338 Hadīth reported by Abū Dāwūd, al-marāsil, 202, n² 2, al-Bayḥaqī, al-Sunan al-kubrā, t. 10, 260, n' 21159 and by Mālik, Muwațta', t. 2, 462, nº 2 107, Kitāb al-aqựiya, bāb al-shahādāt, as balāgha:

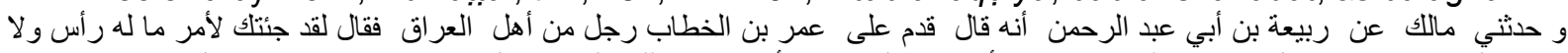

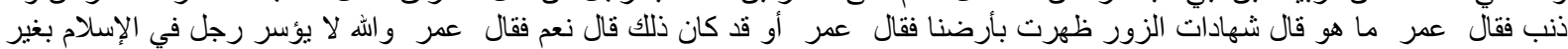

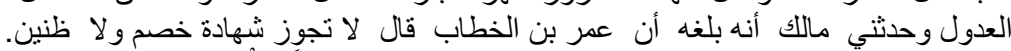

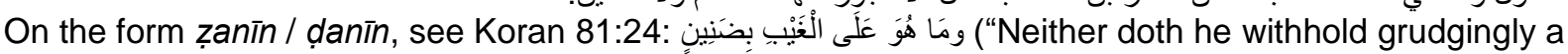
knowledge of the Unseen") and the commentary by Jacques Berque: "Avare': traduction de danin, avec ḍād: c'est la lecture de Médine. D'autres lectures présument un zā̄', ce qui donnerait zanīn, 'suspect' ou 'qui conjecture' (appliqué au Prophète)" (Berque, Le Coran. Essai de traduction, 665).

1339 Should this not be ikhtibār?

1340 'Azzāwī: فيما. 
according to the clearest paths and have them carried out without tyranny

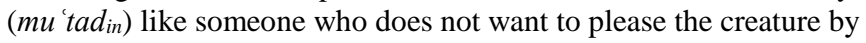
irritating

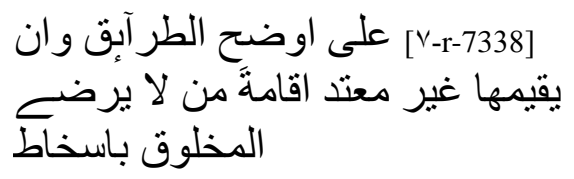

the Creator. God on High said: "These are the limits ordained by God. So do not transgress them if any do transgress the limits ordained by God, such

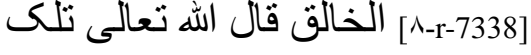

حدود الله فلا تعندو ها ومن يتعد حدود الله فا

persons wrong (Themselves as well as others)." ${ }^{1341}$ When opposing parties hold forth before him, may he fear the anger of God - May He be glorified

[9-r-7338] ولبك هم الظالمون 1342 ومنى

مثل الخصوم بيـن يديْه فلير اقب الله

سبحانه في

if he does not give to each the share he deserves in the manner that he listens (majlas), speaks or watches. May he likewise grant to each

[-r-7338-1 [ن توخه التَّنْوية بينهوا في

المجْلس و اللفظ و اللَّحظ وليعط كل و احدً

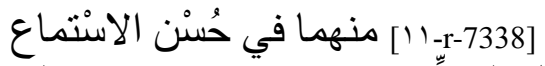

great attention (istim $\bar{a}$ ) without taking into account the superiority of the noble over the man of the people,

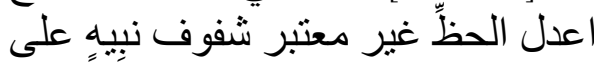

خاملٍ

nor favoring close (mulāșiq) kin (qarīb) or an old friend. God on High said: "whenever ye speak, speak justly,

هوبr-r-7338]

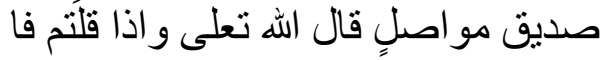

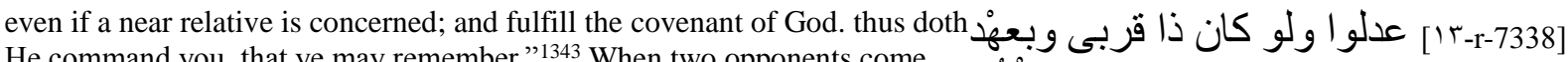
He command you, that ye may remember." ${ }^{1343}$ When two opponents come before

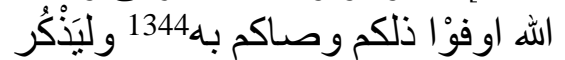

متى حضر

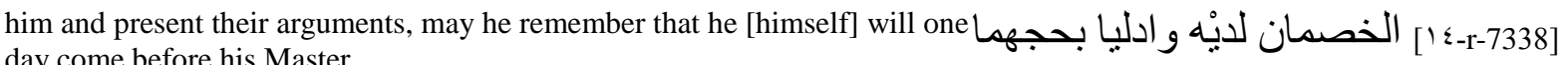
day come before his Master

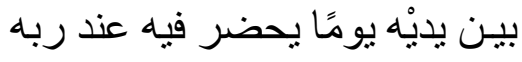
وتعرض

and that the contents of his pages and his writings will be spread ( $t u$ ' $r a d$ ) before him. Then will his injustice cause his loss or his justice assure his salvation. [10-r-7338] [عليْه مُودعات صحانفه وكتبه

فهزاك بوبقه جوره او بطلقه عَذْله

ويُنْصَى

1341 Koran 2:229: "A divorce is only permissible twice: after that, the parties should either hold Together on equitable terms, or separate with kindness. It is not lawful for you, (Men), to take back any of your gifts (from your wives), except when both parties fear that they would be unable to keep the limits ordained by God. If ye (judges) do indeed fear that they would be unable to keep the limits ordained by God, there is no blame on either of them if she give something for her freedom. These are the limits ordained by God; so do not transgress them if any do transgress the limits ordained by God, such persons wrong (Themselves as well as others)."

1342 Koran 2:229:

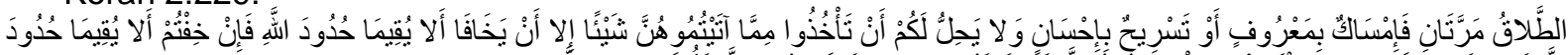

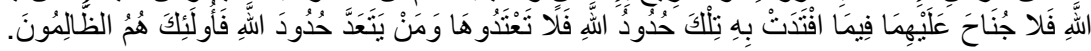

${ }^{1343}$ Koran 6:152: "And come not nigh to the orphan's property, except to improve it, until he attain the age of full strength; give measure and weight with (full) justice;- no burden do We place on any soul, but that which it can bear;- whenever ye speak, speak justly, even if a near relative is concerned; and fulfil the covenant of God: thus doth He command you, that ye may remember."

1344 Koran 6:152:

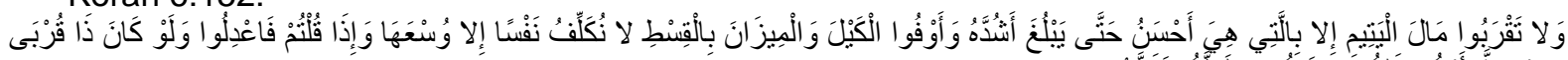

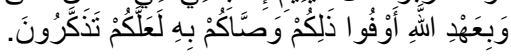


All that he will have done will be counted for or against him. God on High said: "That Day shall ye be brought to Judgment: not an act of yours that ye hide will be hidden." ${ }^{345} \mathrm{He}$ must

order good and forbid evil, [confident] in God, without fear of blame; ${ }^{1347}$ he must not open

a path in the law for the oppressor against the oppressed; he must accomplish prayer-prayers and impose them

on those in the communities who do not acquit themselves of them. God on High said: "(They are) those who, if We establish them in the land, establish

regular prayer and give regular charity, enjoin the right and forbid wrong: with God rests the end (and decision) of (all) affairs." 1349

This is the advice we have given him and we have given as much evidence [which can plead] for or against him; we have ordered

him to encourage the inhabitants of your province and its regions to follow them and to require that they be held to in all circumstances.

Thus, when with the help of God he arrives among you, be as one hand united for that which we have ordered him (...) action (...)

goals (...) obvious directions in all your situations. Seek in helping each other in this to work like

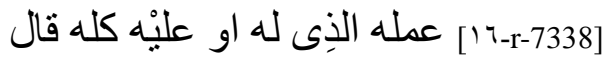

الله تعلى بوميذ تعرضون لا تخفى منكم

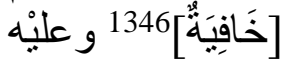

[IV-r-7338]

عن المنكر لا بخاف في الله لومة لامد

لاءم 1348 وان لا يجعل في الحق لحن

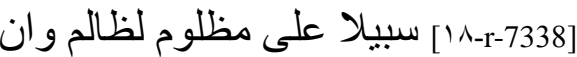

باخذ باقامة للصدلاة الصلو ات و الملاز مة

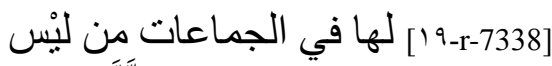

بملازم قال الله تعلى الذين ان مكنََّّاهم في

الارنض اقناموز

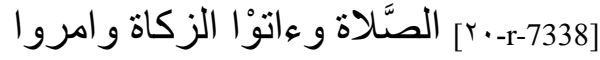

بالمغروف ونهو ا عن المنكر ولله عاقبة أنة

الامور 1350

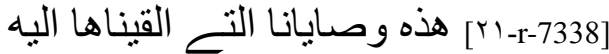

و اقرر ناها لديه حجة له و وعليْه

و امرناه

[rr-r-7338] ان بحمل عليها من في نظركم

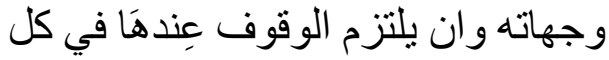

اوقاته

[مr-r-7338] فاذا و افاكم بمعونة الله فكونوا

معه بدا و احدة في ما امرنا بـه من

1352 عمل لمن (...)

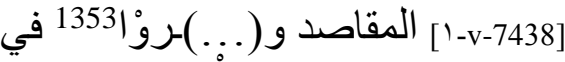

جميع احو الكم اوضح الْر اثْد واسنعوا

في التعاون

1345 lit. «you will be exposed». Koran 69:18.

1346 Koran 69:18. The copyist forgot this word from the verse.

1347 Reference to Koran 5:54: "O ye who believe! if any from among you turn back from his Faith, soon will God produce a people whom He will love as they will love Him,- lowly with the believers, mighty against the rejecters, fighting in the way of God, and never afraid of the reproaches of such as find fault. That is the grace of God, which He will bestow on whom He pleaseth. And God encompasseth all, and He knoweth all things."

1348 Reference to Koran 5:54:

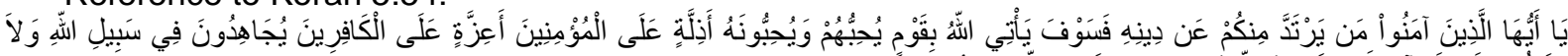

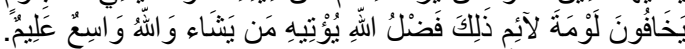
1349 Koran 22:41: "(They are) those who, if We establish them in the land, establish regular prayer and give regular charity, enjoin the right and forbid wrong: with God rests the end (and decision) of (all) affairs."

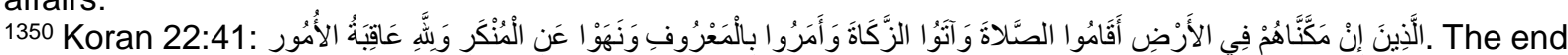
of the verse (ولله عاقبة الامور) was omitted by 'Azzāwī.

1351 'Azzāwī proposes وامرناه

1352 Hardly legible word: حميد?

1353 Two or three illegible words. 
those who act according to the law (al-haqq) and support it. God on High said: "Help ye one another in righteousness and piety,

but help ye not one another in sin and rancor: fear God for God is strict in punishment." 1354 We ask God for us and for you

to help us to follow the law, by leading us so that we might reach and hear the finest words

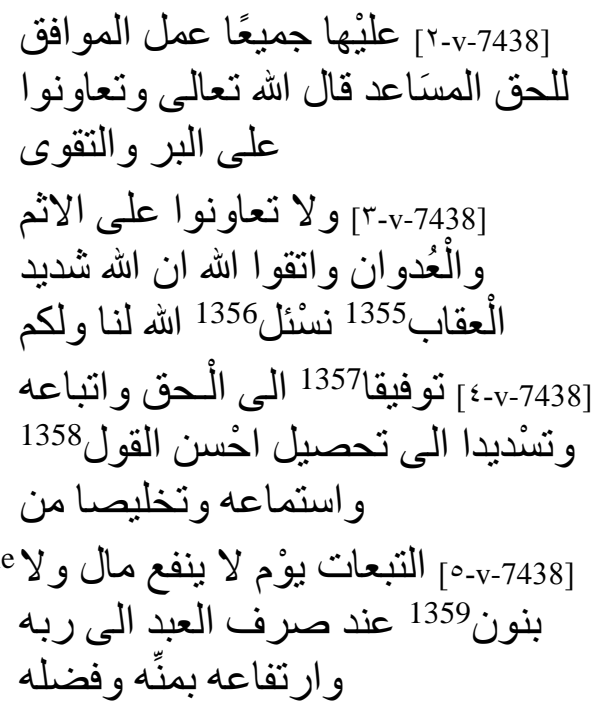

Taqdīm 56: Appointment of a judge, responsible or choosing assistants or secondary judges and instrumentary witnesses. The foundations of the Law are the Koran, Tradition, the consensus of the Community and the sayings of the greatest scholars ${ }^{1360}$<smiles>CC(C)[Al]C#[As][As][As][As]</smiles>

Another Appointment

...since your affairs are among the most important cares that constantly haunt our mind in your favor (al-khiṣamm), and the responsibility (al-nazar) for judgments

that come between you requires more than anything the choice of an agent who will be charged with rendering them and, on our part, full

1354 Koran 5:2: "O ye who believe! Violate not the sanctity of the symbols of God, nor of the sacred month, nor of the animals brought for sacrifice, nor the garlands that mark out such animals, nor the people resorting to the sacred house, seeking of the bounty and good pleasure of their Lord. But when ye are clear of the sacred precincts and of pilgrim garb, ye may hunt and let not the hatred of some people in (once) shutting you out of the Sacred Mosque lead you to transgression (and hostility on your part). Help ye one another in righteousness and piety, but help ye not one another in sin and rancour: fear God: for God is strict in punishment."

1355 Koran 5:2:

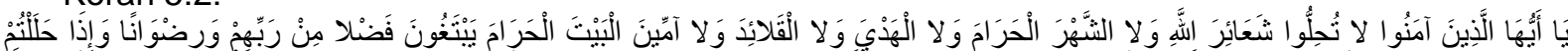

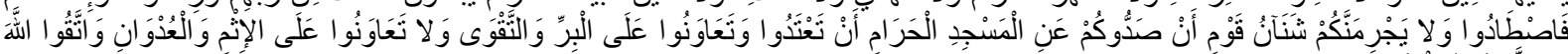

1356 'Azzāwī: نسأل

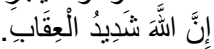

1357 'Azzāwī: التوفيق. التوفيق.

1358 'Azzāwī: الاقو ال:

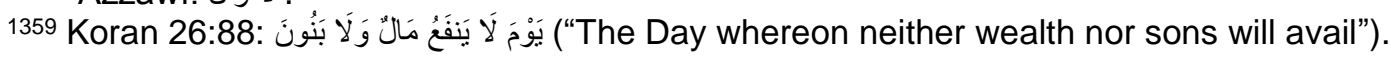

1360 'Azzāwī, NLA, t. 1, 493. 
and complete vigilance which we assume, we have long considered to know to whom we were going to confide the judgeship in your regions.

We have chosen someone whose religion and reason inspire confidence for that. After a long search, an examination with the best methods and just conduct

and an inquiry to find one whose repeated testing and series of good deeds had proven his integrity, Fulān was designated. He is known recommend him for this responsibility. This is why we have appointed him for your affairs

which have to do with the Law and have given him license to treat your problems according to the appropriate rules. We had ordered him beforehand to fear

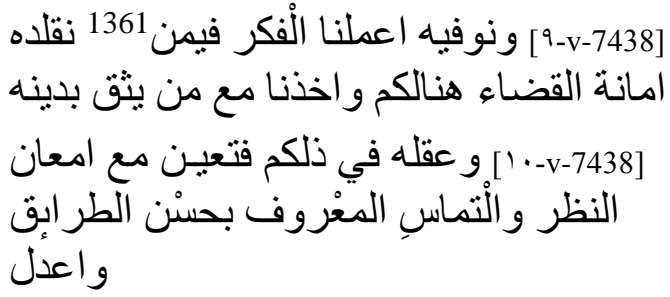

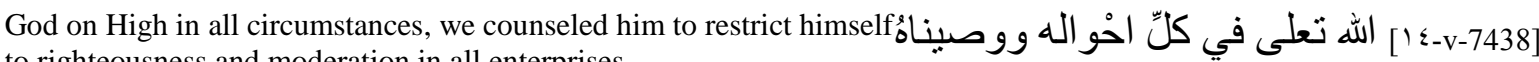
to righteousness and moderation in all enterprises,

and we required him to make the Book of God, the Tradition of His prophet - Peace be upon him - and the consensus of the Community (ijmá 'a l-ummati) the foundations

بالتز ام سداده في كل المحاو لات الت و اعتداله

[10-v-7438]

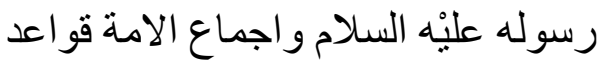

[17-v-7438] [حكامه وان يستند في ما لم برد فيه

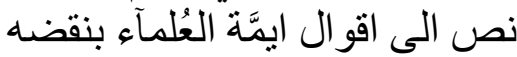

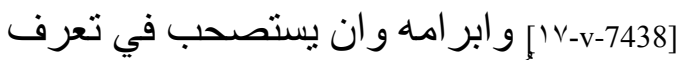

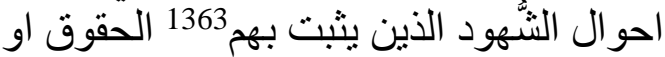

بنفيها

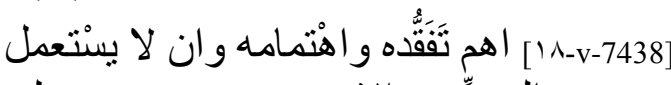

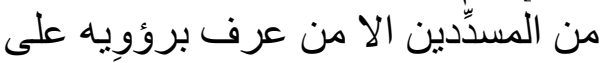

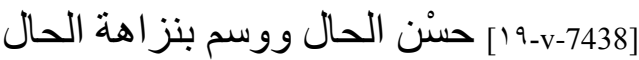
ونقاء الانتحال واو عزنا الينا اليه ان بامر

بالمعروف

and forbid evil; ${ }^{1364}$ that he establish the law with all his strength and all his zeal,

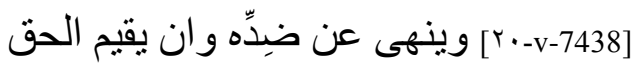

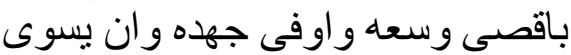

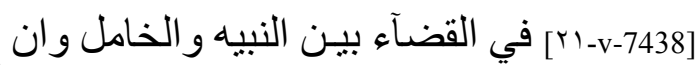

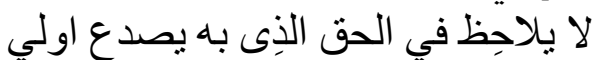

المناصب أديب

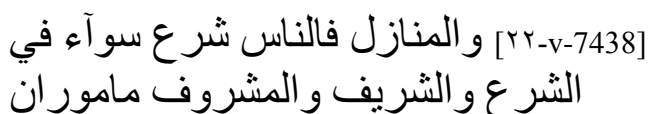

or dignity, for, before the law, people are equal and [belong] to the same category, the noble and the man of the people both received the order

that in his judgments he treat equally the famous and the unknown, when he arbitrates according to the law, may he observe no preference for those who have a function

\footnotetext{
1361 'Azzāwī: في من.

1362 Probably as corrected by 'Azzāwī: الخير.

1363 'Azzāwī: بـ.

1364 Lit. "its opposite".
} 
to obey and submit. Thus, when he arrives among you, collaborate with him in what we have entrusted to him and be with him as

one hand united in the law... Yahyá - May God help him - said: Thus ends the appointments that I found in the chapter

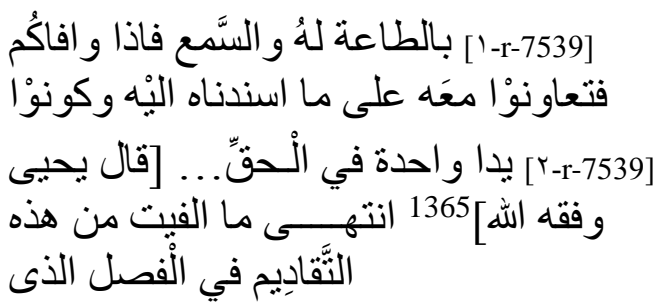

that contains the collection of the shaykh - God's mercy upon him. Within the collection, among these appointments, I found what was written in the name

of the caliph al- Rashīd for the appointment of his kin Abū Muhammad to the post of judge in Jérez (Sharish)

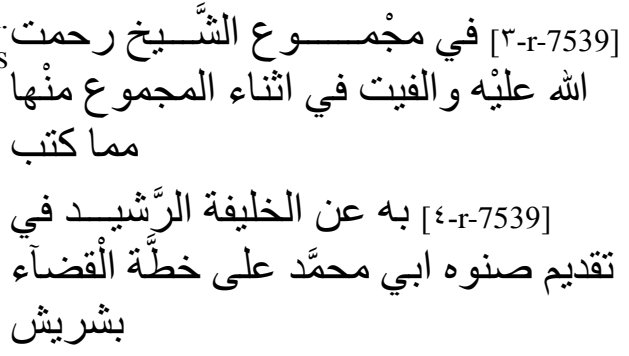

Taqdīm 57: Appointment of Abū Muḥammad as judge of Jérez by the caliph al-Rashīd on the first of $d h \bar{u}$ l-qa 'da 636/June 5, 1239. The judge is responsible for choosing substitutes and instrumentary witnesses. The foundations of the law are the Koran, Tradition, consensus of the Community and the "path of the imāms of religion and the scholars of Islam."1366

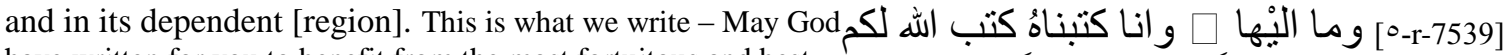
have written for you to benefit from the most fortuitous and best watch

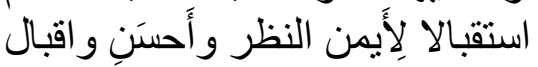

and for you to progress in the clearest and most obvious manner that will improve your situation and fulfill your hopes.

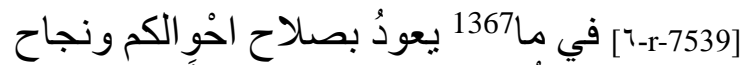

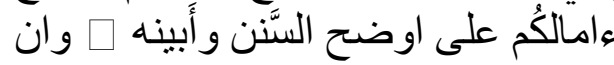

[ع-r-7539]

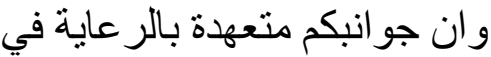

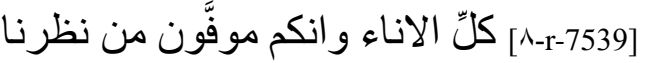

لاجمل ما لا يغبكم منه نظام الأمور وسداد وناد

[9-1-7539]

من يعيّنه الارتضاء ونوثر بتقلد

1365 Addition by 'Azzāwī in comparison with similar passages.

1366 'Azzāwī, NLA, t. 1, 494. 'Azzāwī suggests this is the Abū Muhammad appointed as qāọī by alMa'mūn in Algésiras (Jazīrat al-khaḍrā') in taqdīm 53, then in Jérez (Sharīsh). Title added by 'Azzāwī: "In the name of the caliph al-Rashīd, appointment of Abū Muhammad to the judgeship of Jérez and its dependent regions."

[و عن الخليفة الرشيد في تقديم أبي محمد على خطة القضاء بشريش وما إليهاء :

1367 'Azzāwī: فيماء 
of your affairs (ashghāli-kum), our preference goes to someone whose virtue is known and for whom competence is a habit. We have just appointed Fulān to

judge and mediate among you, to treat your disputes having to do with the Law according to the rules of equity and justice.

Each time he was employed among you his competence and sense of responsibility were confirmed, his character was noteworthy

for its virtue and his fine reputation. He has been counseled to respect God with awe, to fear Him and His wrath ceaselessly,

in public and secretly, to seek help in the Book of God, in the Tradition of His messenger — Peace be upon him -

and in the consensus of the Community (wa ijmā' $i$ l-ummati) in the judgments he pronounces,

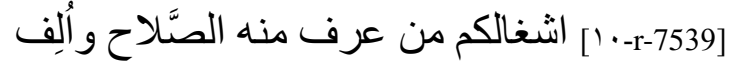

لديه الغناء و اءلان قدمنا فلانا لخطة مرنة

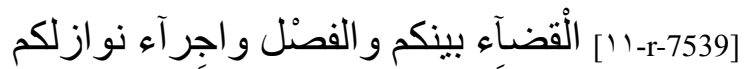

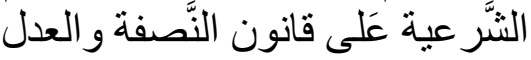

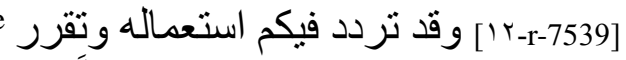

اضطلا عه و استقلاله وتميزت بـالنَّباهة

[1r-r-7539-1 ] و النَّز اهَة خلاله و هو موصنَّى بتقوى الله ومر اقبة أُمره و التز ام الخيفة

[1-7539-1 ] لله في سرِّه و جهزه و ان بعمل بكتاب الله وسنة رسئو لله عليْه السَّلام

[10-r-7539] و اجماع الامة فيما بمضبيه من الاحْكام

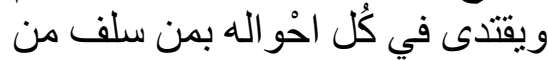

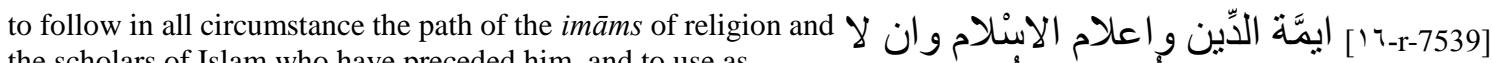
the scholars of Islam who have preceded him, and to use as substitutes or instrumentary witnesses

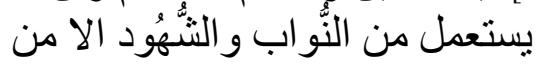

only men who are exempt of all suspicion and accusation and who, in the testimonies rendered to judges will have presented the qualities necessary

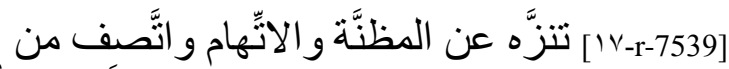

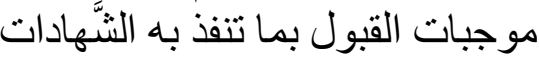

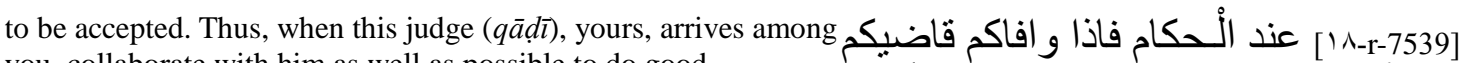
you, collaborate with him as well as possible to do good

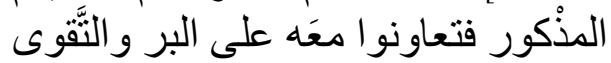

and fear [God]. ${ }^{1368}$ To enjoin good and forbid evil, ${ }^{1369}$ conform in your worship to that

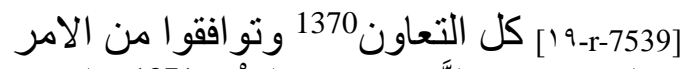

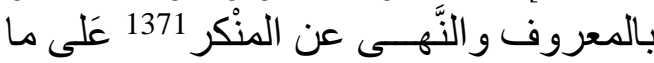

يقتضـ

which will tip the scales to the right side, and God will cause him to act, and you with him, with the purest of deeds

[r-r-7539-r] في ديانكم 1372 بالرَّجحان عند التوازن و الله بسنتعمله و اياكم بازكى المسنَاعـ

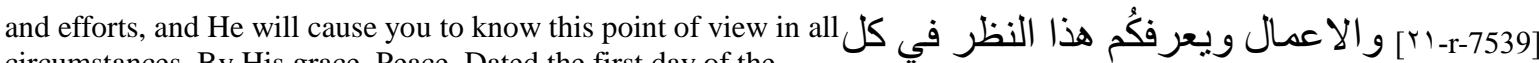
circumstances. By His grace. Peace. Dated the first day of the moon

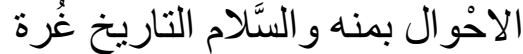

of $d h \bar{u} l-q a^{\prime} d a$ in the year 636.

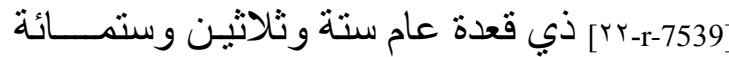

Taqdīm 58: Appointment by the caliph alRashīd of a judge responsible for choosing instrumentary judges. The foundations of the

law are the Koran, Tradition, consensus and

${ }^{1368}$ Reference to Koran 5:2.

1369 Reference to Koran 3:110: "Ye are the best of peoples, evolved for mankind, enjoining what is right, forbidding what is wrong, and believing in God."

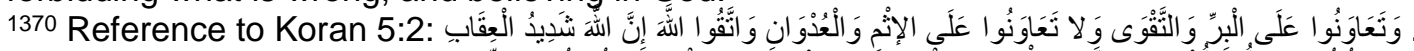

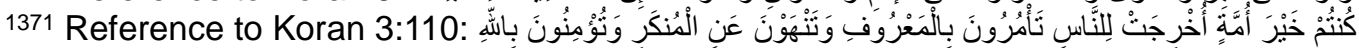

1372 'Azzāwī: ديانتكم. 


\section{the words of the scholars based on reflection and personal interpretation ${ }^{1373}$}

○ وَّrr-r-7539]

Another appointment in the same name

...May God always assure them respect through the awe He inspires in them, and grant them the best and most deserved benevolent watch. May God have written for you

to know prodigious kindness through the conditions, because of the improvement of your situation and dedicate you to the works

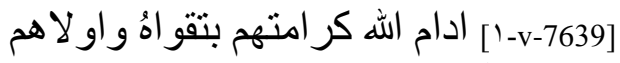
من جميل النظر احقه واوْلاه $\square$ كتب الله اله ل)

[r-v-7639]

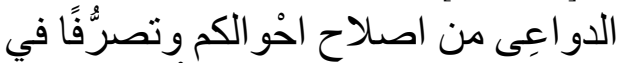

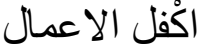

and deeds that guarantee your hopes full success. Know that we keep over the land and its inhabitants a watch

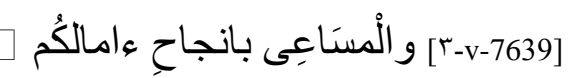
وان تعلمو ا انا ننظر للبلادِ ور عُاياها النظر

that grants them always greater importance to their affairs, that takes in their interests, public and private, the elite

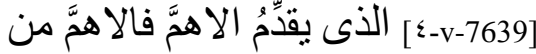

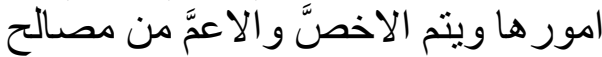

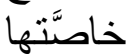

and the people, and that establishes the rules of what is required or forbidden by the Law this community follows

in its devotion. And this so that the care we have for it may pursue the clearest objectives, so that [our] protection

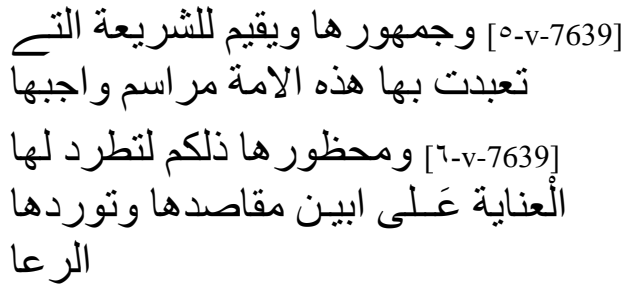

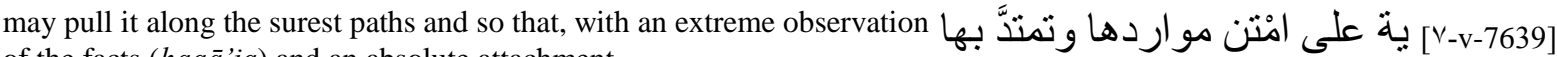
of the facts (haq $\left.\bar{a}^{\prime} i q\right)$ and an absolute attachment

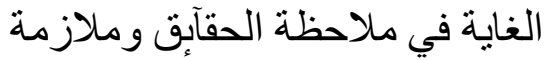

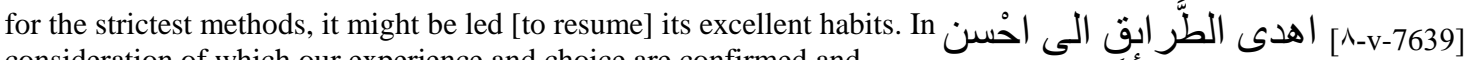
consideration of which our experience and choice are confirmed and renewed

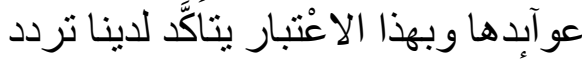

for he who surpasses in the satisfaction that he gives and who presents the qualities required

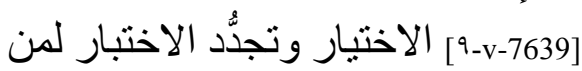

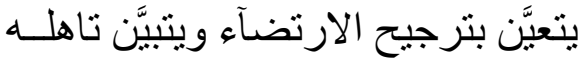

for a judgeship, he whose activity in the field of law has been confirmed by his application of it,

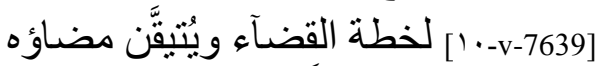

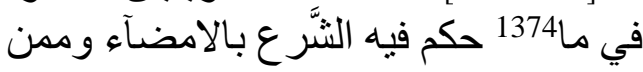

وفى ونى

someone who [for this position] has proven himself on all topics and has paid knowledge all it is due in verification and learning, and who has chosen

[11-v-7639] لهذه الْجُملة بتفصيلهَا ووفَّى

المعارف حقَّ تحقيقها وتحصِيلها و اقته

the obvious path in the services required of this sublime responsibility. [It is] Fulān. We have thus appointed him to take charge

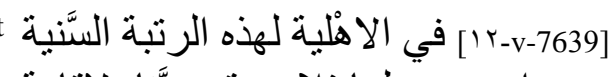

و اضح سبيلها فلان وقد عينَّاه لاقامة النتة

1373 'Azzāwī, NLA, t. 1, 495-496.

1374 'Azzāwī: فيما. 


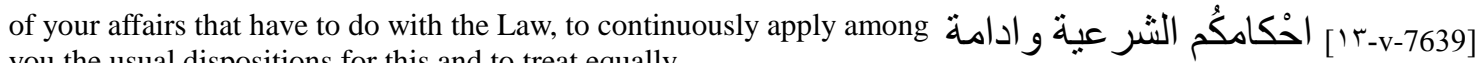
you the usual dispositions for this and to treat equally

according to justice ( $f i$ l-haqq) all [our[ subjects (al-ra iyya) in our provinces; we ordered him beforehand to take his inspiration first of all from the fear of God

on High, a fear that acts as a North Star to righteousness and, for the believer, as traveling supplies to the hereafter, to refer to the Book and

Tradition which are the two fundamental sources, and [then] to the consensus ( wa ila l-ijmā') which is the third pillar for seeking just instruction and correct

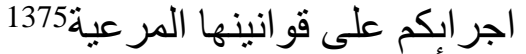

و المساو ات

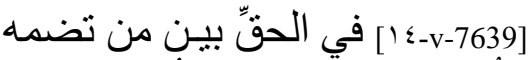

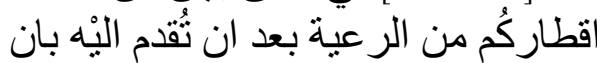

يقدم تقوى الله

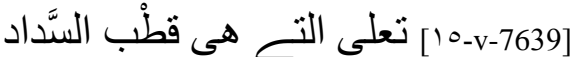

وحسب المومن للمعاد ويستند الى الكتاب و

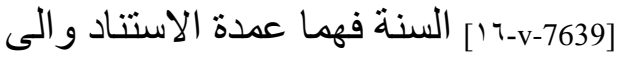

الاجماع الذـ ثالث قواعد الاستدلال والا

Directions, and [finally], in cases without a text, to call on that which the words of the scholars

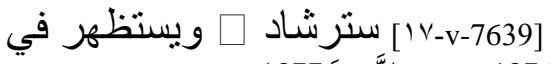

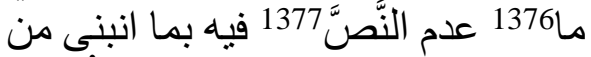

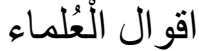

have built on the two foundations which are reflection (nazar) ${ }^{1378}$ and personal effort $(i j t i h \bar{a} d)$. Thus is the path which admits no departure for just

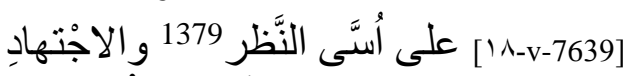

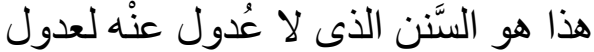

judges, and the road indicated by the verification of valid conduct (almurtaḍat), and his opinions

[19-v-7639] القضاة و الطريق الأِى ادَّى اليْهِ

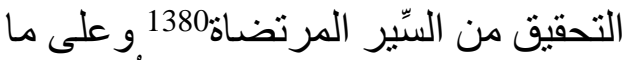
أُصِّل منْه منا

and analogous acts will rest on these, and this will be the instrument to plumb judgment when analogies are ambiguous and to pronounce a sentence

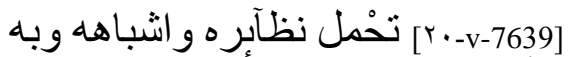

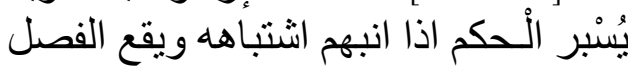

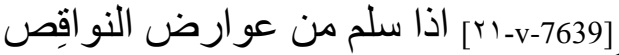

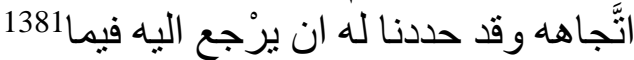
يثبته

negative [decrees] and make of them the path he will follow painstakingly. We have ordered him

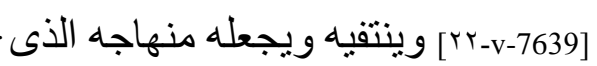

when it follows a sense without apparent fault. We have enjoined him to refer to these in his positive or

يسْلكه دابمًا ويقتفيه و امرناهُ ان (يكثر

من:21382

to regularly examine the condition of instrumentary witnesses, to make the difference between those to accept and those to dismiss, to... the most important $(\ldots)$
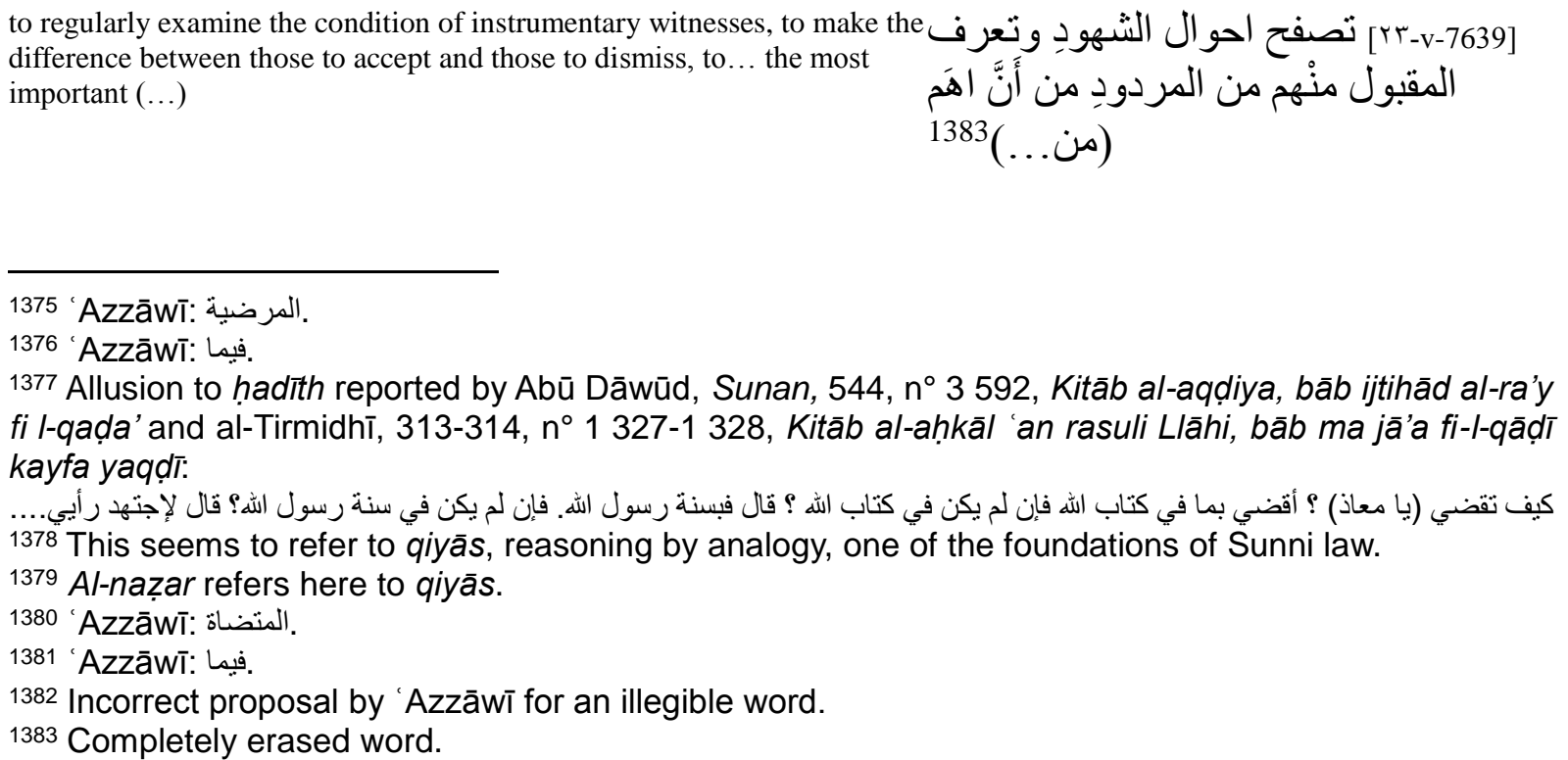
to seek piety and loyalty in those whom he delegates [power] or entrusts.

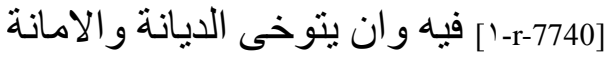

فيمن يستعْمله من النواب عنه وئه ويستكفيه

Thus, when he arrives among you, may your submission to his authority (li-iṣdāri-hi wa ìrādi-hi) be irreproachable, may your conduct towards him be excellent in the collaboration

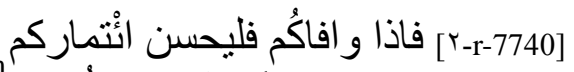

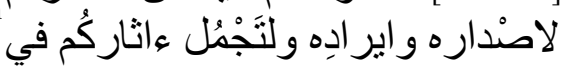

التعاون

[you bring him] for the responsibility and the exclusive command he has over your jurisdiction. Know how we honor you

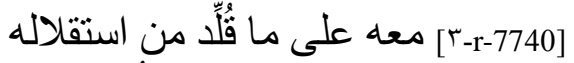

$$
\begin{aligned}
& \text { باحْكامكم و اسْتبداده ولتعلمو ا انكُم اوثرنم }
\end{aligned}
$$

through the person who will guide legal decisions for you according to the trajectory of this righteousness, if God on High wills it...

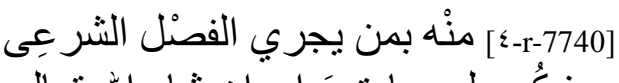

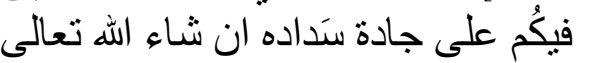

Taqdīm 59: Appointment by al-Rashīd, before the reestablishment of the Almohad doctrine, of a judge responsible for choosing instrumentary witnesses. The foundations of the law are the Koran, Tradition, consensus and the juridical consultations of the scholars of the Community and the most learned imāms ${ }^{1384}$

○ هـ-r-7740]

Another appointment

May God have written for you to agree on fine deeds, to seek who can best find the straight path,

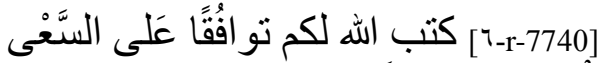

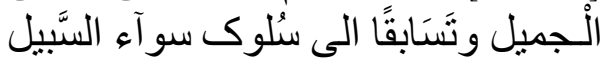

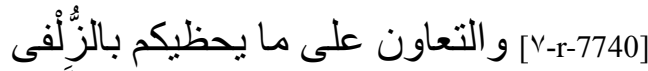

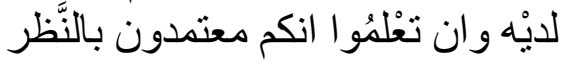

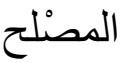

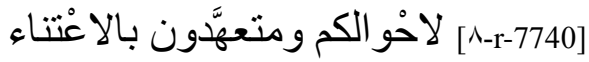$$
\text { الميسَّر لامالكم و اولى مهمَّاتكم بالتقديم }
$$

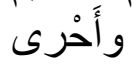

and collaborate on [deeds] that will allow you to be near to Him. Know that you have the support of a beneficent watch over

your situation and the backing of a solicitude that favors your hopes; [know also] that the most important function, the first to consider,

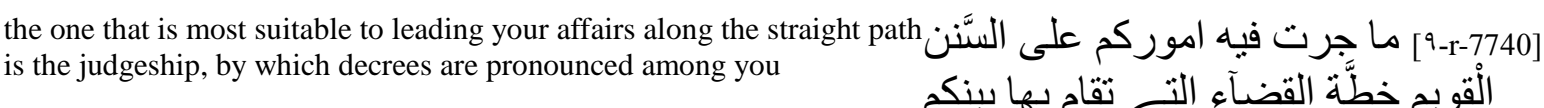
الإمكام

and which assures order if it is carried out according to religious rules in all disputes. Fulān has been appointed

to judge and mediate among you and has been put forward to answer your needs concerning the promulgation and execution

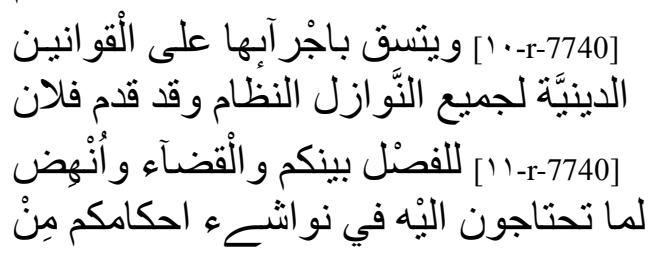


of sentences in your trials. Previously, we entrusted him with jobs on many occasions and were able to judge that he followed the paths of his predecessors/ancestors in the situations

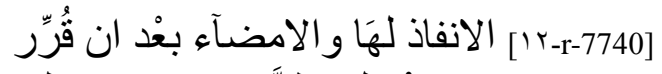

تردده في الاستعُمال فظنَّ به الاقتداء بـاء بسلفه

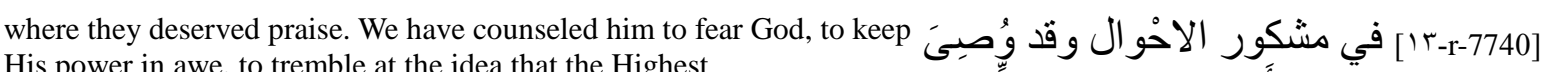

His power in awe, to tremble at the idea that the Highest

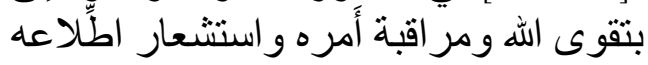

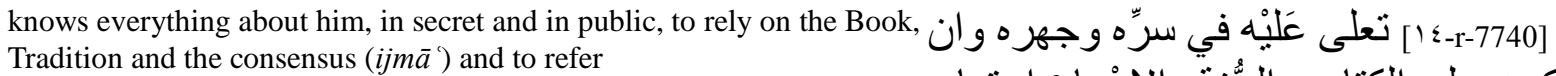

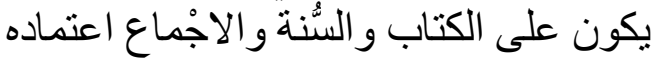

$\odot$

to the juridical consultations of the scholars of the Community (fatāwa 'ulamā' 'i l-ummati) and the most learned imāms. We have ordered him to treat equally in [his] judgments

[10-r-7740]

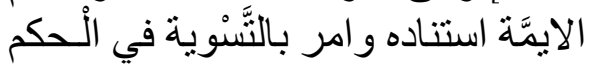

the man of the people and the noble and to force the strong to render justice to the weak. We have insisted

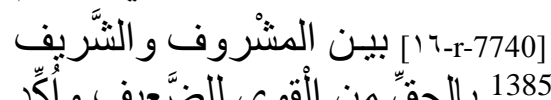

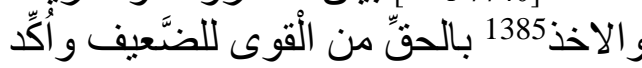

عَلَّبه في في أني

concerning instrumentary witnesses, that he select them and accept

among them only just and pious people, for on [their] testimony

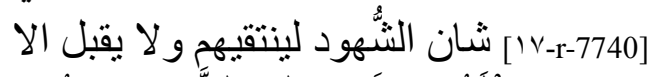

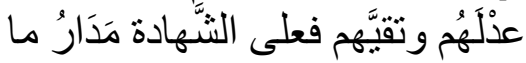

rests the suspension or execution of the judgments he pronounces on matters, and to pay attention to that is the most important [conduct] for improving,

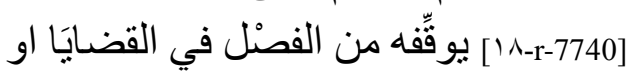

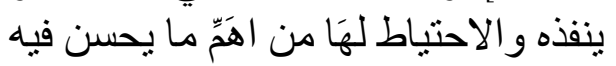

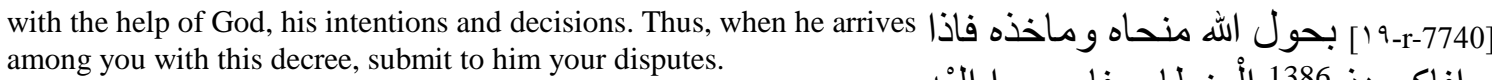

و افاكم هذه1386 الْخطاب فارجعو الْيْه

باحكامكم

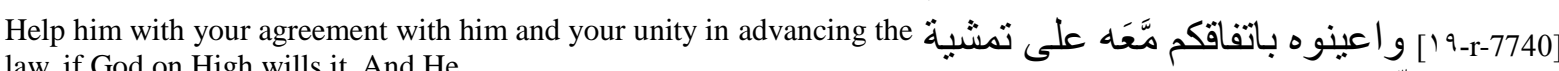
law, if God on High wills it. And He

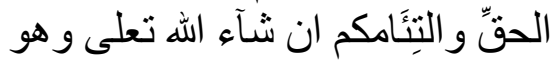

- May He be glorified - He will cause you to know the happiness of the benevolent watch that covers you and its solicitude and He will lead you along His obvious path through the collaboration

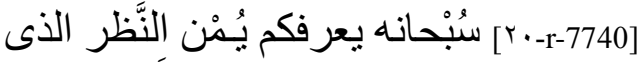
for $(\ldots)^{1387}$ and through agreement in good deeds...

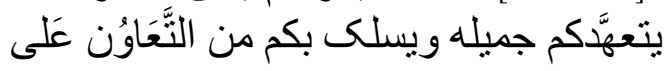

[1388 و التو افق في اعمال

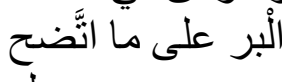

d

['-v-7840] قال بحيى و فقه الله تعلى انتهى ما في المجموع

Yahyā — May God on High assist him — said:

Thus ends that which was in the collection

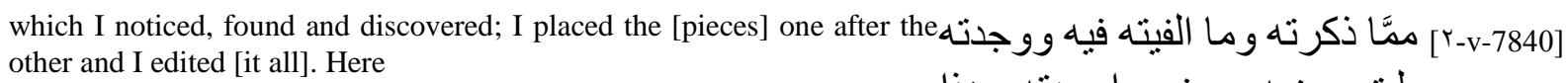

begins the appointments which I found elsewhere, those whose fruits I picked,

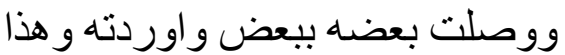

$$
\begin{aligned}
& \text { [ب-v-7840] ابتدآء ما وجدته من هذه التَّقاديم }
\end{aligned}
$$

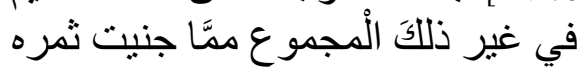

\footnotetext{
1385 'Azzāwī: والآخذ.

1386 'Azzāwī: بهذا:

1387 Proposals: "good", "that which He approves", "fear", "patience".

1388 Illegible word missing. Proposals: الصبر، التقوى، ما يرضاه، الخير" "
} 
whose rivers I flowed and the perfume of whose flowers I smelled; I organized their pearls for the masters of $a d a b$ and intelligence

so that it would end with the finest and [one] takes consolation in that which humanity scatters during its nights. Among others... Appointment of a judge

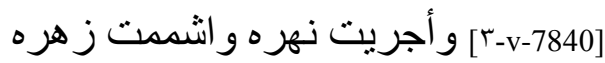

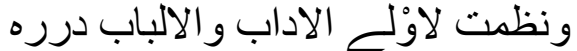

لينتهي

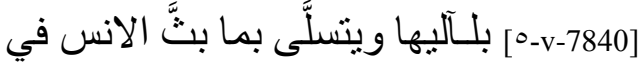

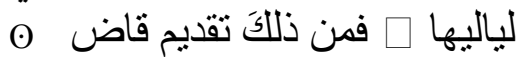

Taqdīm 60: Appointment of a judge responsible

\section{for choosing instrumentary witnesses ${ }^{1389}$}

...This is what we write, May God have written for you a decision that advances your interests and the consequences of which guarantee the safety of your

paths and fields. We have decided - and we ask God on High to make [this] decree just and to correctly lead [this] matter -

to appoint Fulān — May God treat him generously by the awe $\mathrm{He}$ inspires in him and may he guide his plans and intentions to pronounce and apply the Law -

to judge your affairs that have to do with the Law and to watch over your religious interests. We previously counseled him to fear

God, which is the foundation of good deeds and the sign of favorable conditions. We have ordered him to exercise

the charge of judgeship and to take the time to ensure judgments before having them carried out ${ }^{1393}$,

to arbitrate according to the law between opposing parties without exception for rank or wealth. We have prescribed him to accept among the instrumentary witnesses

only those whose method (tarīqatu-hu) has been praised and to use only acts whose authenticity has been recognized. We have insisted that he

respect scrupulously these rules which we have defined and that he take as support our desires and plans.

Thus, when he arrives among you, if God wills it, help in the work that pertains to him. Be at his side to make the law

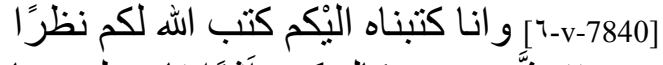

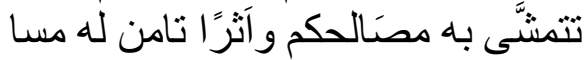

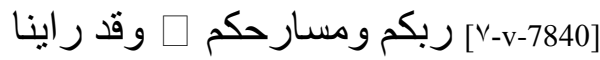

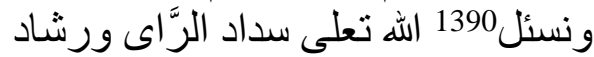

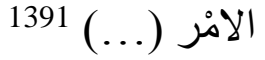

^^-v-7840] وان بقدم 1392 للاشتغال باحكامكم

الثرر عيَّة و النظر في مصالحكم الدِّينيَّة فلانا

اكر مـه

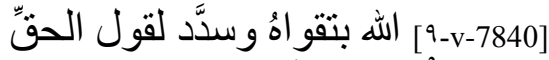

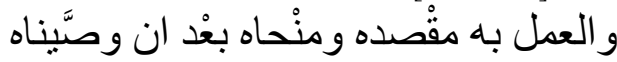

بتقوى

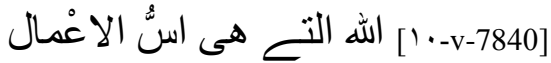

الصَّالحة و عنو ان الاحو ال الناجحة و امرناه

بالقبام

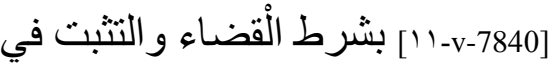

الاحْكام قبل الامضناء و التسوية بين

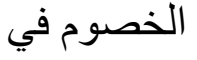

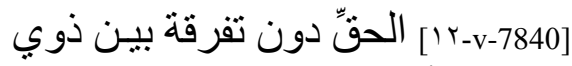

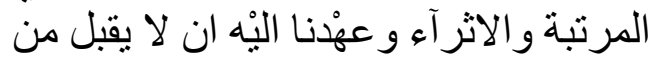

الثهداء

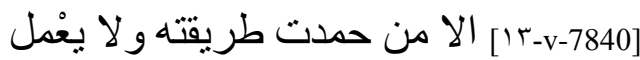

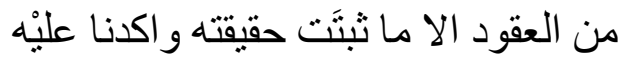

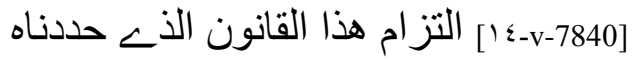
و الاعتماد على الذى نويناه و قصدناه

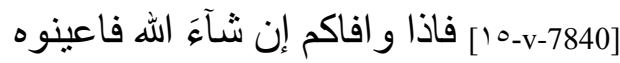
على الثخل المنوط بـه وشار كوه في اظهار

1389 'Azzāwī, NLA, t. 1, 498.

1390 'Azzāwī: ونسأل.

1391 Word erased.

1392 'Azzāwī corrects with نقدم.

1393 To sign? In signing them? 
reign: we have appointed him for that ${ }^{1394}$. Collaborate with him when he orders good

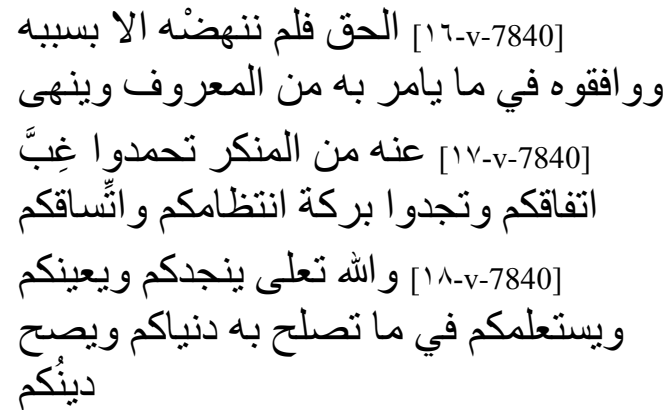

Taqdīm 61: Appointment of a judge responsible for selecting instrumentary witnesses $^{1395}$

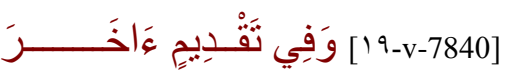

Another appointment

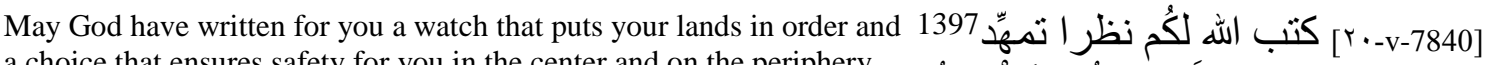
a choice that ensures safety for you in the center and on the periphery. [We know] ${ }^{1396}$ only the

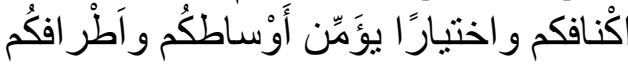
الا الخير

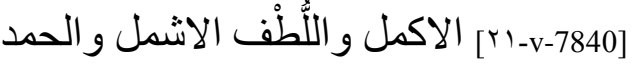
لله حمدًا تستدام بـه الالاءُ وتستجزل والان وقد راينا perpetuate and multiply kindness. We have decided

— and we ask God to make our opinions just and to favor all [our] projects and [our] choices — to appoint [Fulān] to judge

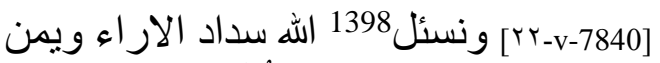
المقاصد كلها و الانحآء ان نُقدِّم عليكم للقضناء 1399 (في)

your affairs that have to do with the Law, to take care of your religious activities, to arbitrate among you according to the scales of justice and equity,

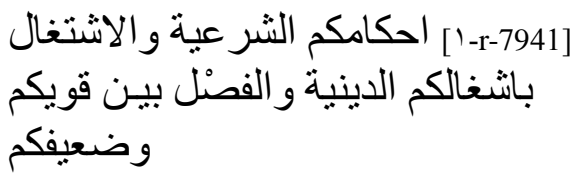

be it for the strong or the weak, for the noble or the man of the people. We have counseled him to fear God everywhere he casts

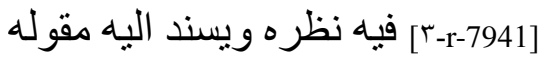

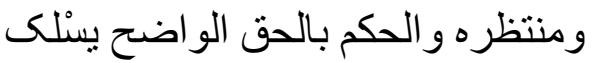

his gaze and for the references on which his words and expectations are based, and to judge according to the incontestable law whose

$$
\text { ومنتظره و الحكم بالحق الو اضح بسنح }
$$

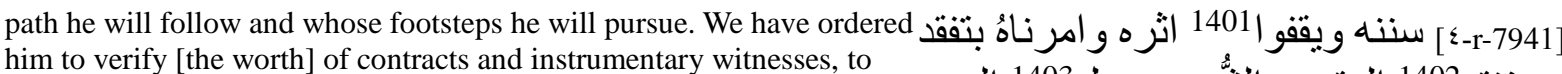
devote himself

\footnotetext{
1394 Lit.: "only for that."

1395 'Azzāwī, NLA, t. 1, 499.

1396 See taqādīm 33, 35, 44, 62, and 64.

1397 'Azzāwī corrects with يمهّة

1398 'Azzāwī: ونسأل

1399 Paper torn at the end of the line, completed by 'Azzāwī.

1400 'Azzāwī: في ما.

1401 'Azzāwī corrects with يقو.

1402 Repeated in the original.

1403 'Azzāwī: وبذل.
} 
to discerning which can be approved and which should be dismissed and to respect the legal clauses for

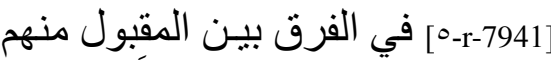

$$
\begin{aligned}
& \text { و المرْدودِ و الوقوف عند الحدود الثَّر عية في }
\end{aligned}
$$

punishments and penalties. Help him for the instructions we have given him to enjoin that which is good

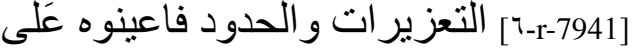

$$
\begin{aligned}
& \text { ما وجهناه اليْه من الامر بالمعروف }
\end{aligned}
$$

and forbid evil. So that the Truth will appear and error disappear, bring him a firm support that will be counted in your favor

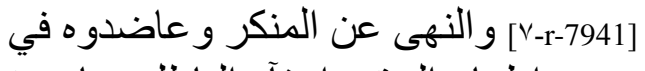

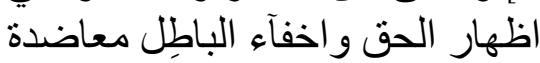
and will earn you praise.

[^-r-7941]

Taqdīm 62: Appointment of a judge responsible for selecting instrumentary witnesses. The foundations of the law are the Koran and Tradition $^{1404}$

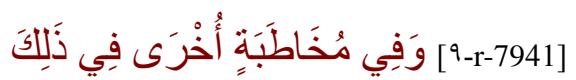

Another allocution on the same subject

...May God assure them always respect by the awe he inspires in them, may He ease and favor for them their spiritual and temporal happiness. Thi is what we write - May

God have written for you quality of choice and the happiness of authority (yumna l-īrādi wa-l-iṣdāri). [We know...] only welfare in abundant parts and well-being

of triumphant fragrances and scents (adfar). We have decided - and we ask God to guide [our] views and to orient [our] intentions -

to appoint Fulān to judge your affairs that have to do with the Law, to treat the religious aspects of annulled or

confirmed judgments and to decide by imposing the law in your budding disputes and your unexpected conflicts. This was after

having verified his education (talabi-hi) and his virtue and assured ourselves of the uprightness of his plans and his intentions. We have counseled him to fear

God on High, to take the royal and exemplary path of the Law and to follow the footsteps of the Book

and Tradition, to draw up all his zeal and all his will to enjoin that which is good and

forbid evil, to settle problems with prudence and in awe [of God]. What fine armor, what

1404 'Azzāwī, NLA, t. 1, 500.

1405 'Azzāwī: ونسأل

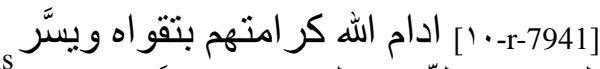

لهم خير الدَّين و الدنيا وسناه كَتبناه كتب الثب اله

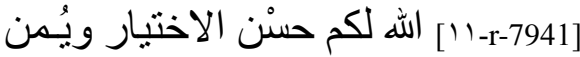

الاير اد والاصدار الا الخير الاوفر نصيبا لإنيا

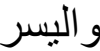

[ [Y-r-7941] الادفر عبقا وطيبًا وقد راينا

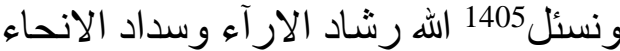

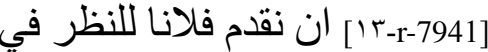

الثر عى من احْكامكم و الاشتنغال بالأِّينى

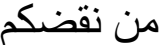

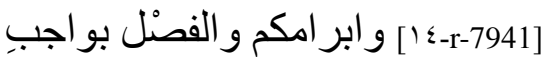

الحق في نو اشى نز اعكُم وطوارى ولمى

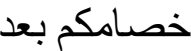

[10-r-7941] تقرر طلبه وز كابه و الثّقة بسداد

مقاصده و انحاءه وقد وصيناه بتقوى

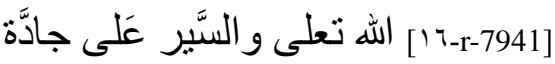

الثر ع المثلى و الاقتدآء بآثار الكتاب آلثاب

[1/v-r-7941] و السنة و الانتهاض في في الامر بالمعروف والنَّهى عن الْمنكر ببذل الجهُ النها

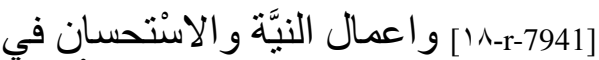

المشكلات بالحذر و التوقى ونعمت الْوقاية 
excellent cuirasses! We have ordered him to choose and select instrumentary witnesses and stay close to the law

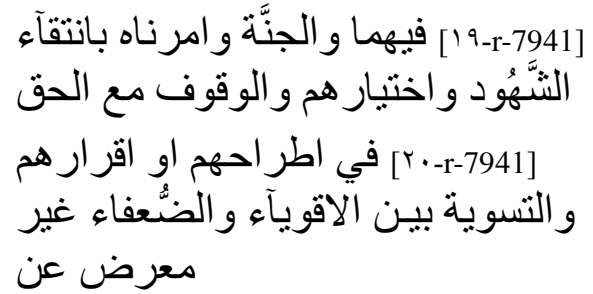

in dismissing or confirming them, to treat equally the strong and the weak without pushing

some away for their misery or welcoming others for their opulence. Thus, when he arrives among you, bring

him powerful support and effective aid, and God will grant you always His assistance, and will guide your steps towards happiness.

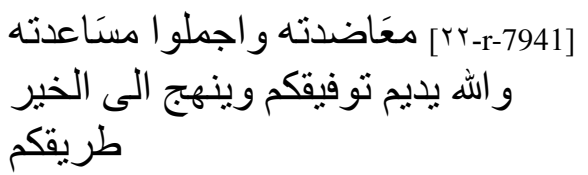

Taqdīm 63: Incomplete excerpt of a judicial appointment $^{1407}$

\section{[rr-r-7941]}

Paragraph from another on the same subject

...we write you - May God have written for you excellent administration (husn al-nazar) and happiness [that will bring you] the competence and attention [of he] whom we send you.

We have decided, and we ask God to make [this] view just and to guide [this] decision, [to appoint Fulān] to take charge of your religious affairs and to decide

according to the law in your problems that have to do with the Law...

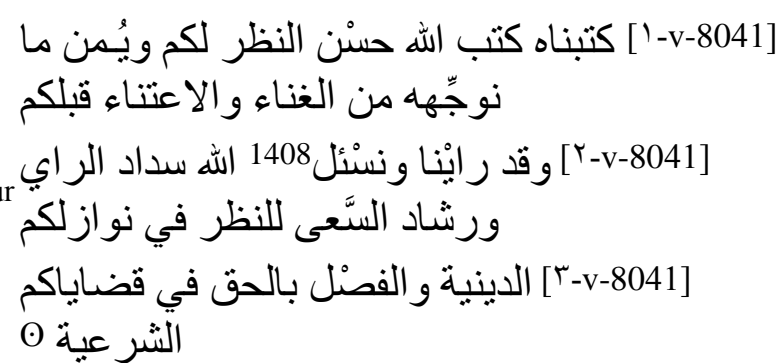

Taqdīm 64: Appointment of a judge responsible

\section{e s-v-8041]}

[Excerpt] from a collective allocution on the same subject

May God assure them always respect through the awe He inspires in them, may He spread their shares in His mercy and His favor. [We know] only

abundant graces and fortuitous conditions! Because your region is at the center of our cares, because it is at the forefront of

our watch and attention, because the choice of judges deserves to be treated as a priority, $[\ldots]^{1410}$ [we $]$ have dedicated all

\footnotetext{
[0-v-8041] ادام الله كر امتهم بتقو اه ووفَّر حظوظهم

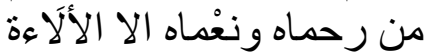

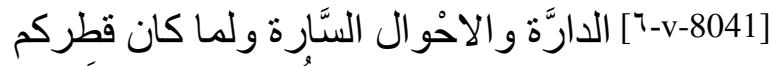

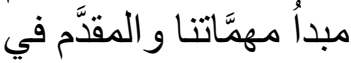

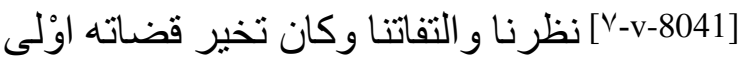

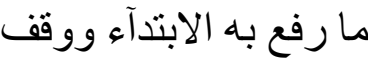

\footnotetext{
1406 'Azzāwī corrects with و لا مُقبل.

1407 'Azzāwī, NLA, t. 1, 500.

1408 'Azzāwī: ونسأل

1409 'Azzāwī, NLA, t. 1, 501.

1410 Missing judicial appointment?
} 


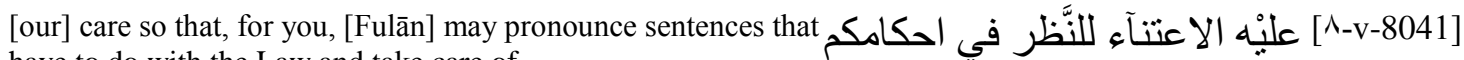

have to do with the Law and take care of

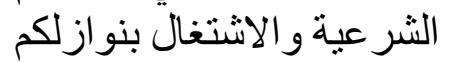

[eligious affairs. He is known for his merit, his education and his الدينية وهو المشهور حسبه وطلبه-V-8041]

piety. We know that he does not

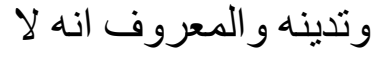

quit until he has completely committed himself, and that he is one in whom, each time we put him to the test and that

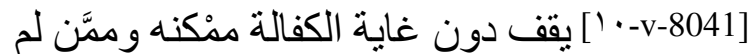

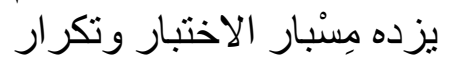

we observed him conduct, we discovered new qualities and

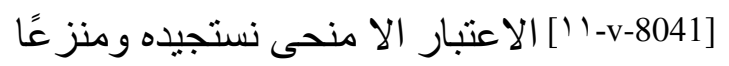

meritorious practices. We have recommended

نستحسنه وقد وصنَّيناهُ

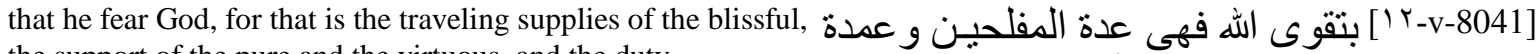
the support of the pure and the virtuous, and the duty

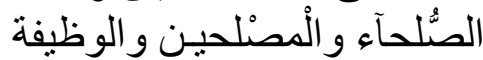

that must terrorize without end the proud $(a b b \bar{a})$. We have ordered him to listen

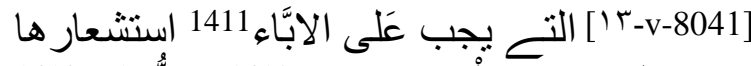

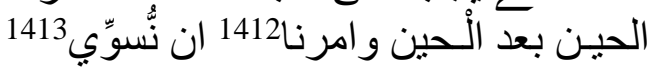

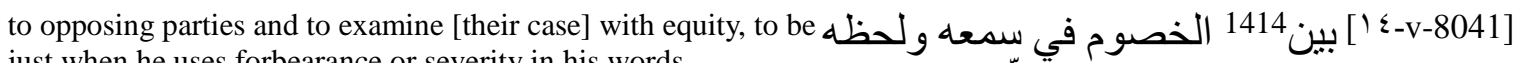

just when he uses forbearance or severity in his words,

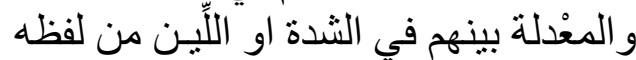

to not fear blame when he applies the law, to not stray from the
path of forbearance as long as it does

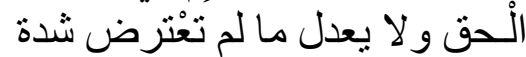

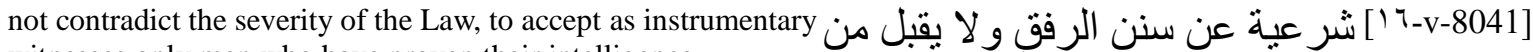

witnesses only men who have proven their intelligence,

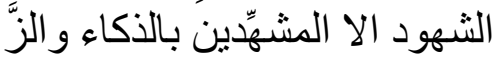

virtue and sincerity; for his judgments depend on witnesses. He relies on them to confirm or annul [a sentence];

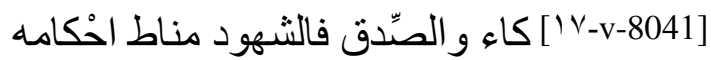

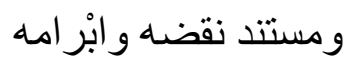

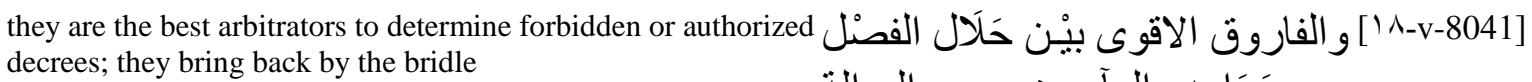

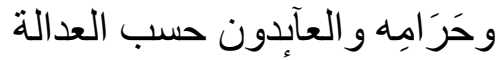

whoever goes to the right or left, according to justice or against it. As for him, he must hold himself to that,

[ [9-v-8041 ] او ضددّها ذات اليمبن او ذات الثمال

بزمامه و هو يقف عند هذا الوقف

conform to this pact in his actions and put to work the correct objectives for which without end we give him instructions and explanations.

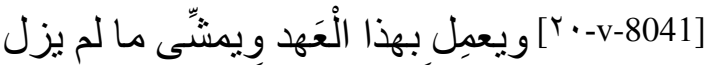

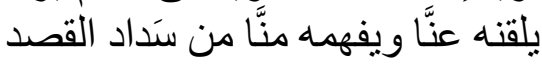

Thus, when he arrives among you cooperate with him to advance the interests of religion, give him the possibility

of [your] will, [your] support and [your] aid...

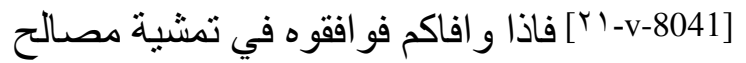

الديانة و اولوه مُمكنه فئح

[ [بr-v-8041] في ذللكَ من الانحاء وَالعضد

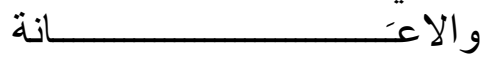

Taqdīm 65: Renewal by al-Mu taḍid of a judge

responsible for choosing delegates and

instrumentary witnesses. The foundations of

the law are the Koran, Tradition, and the

1411 From the verb 'BY, abá, ya'bī.

1412 'Azzāwī corrects with وأمرناه

1413 'Azzāwī corrects with يسريناه.

1414 'Azzāwī: بينهم. 


\title{
consensus of the Community (mid shawwāl 640/beginning of April 1242) ${ }^{1415}$
}

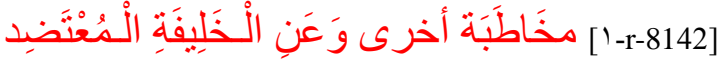

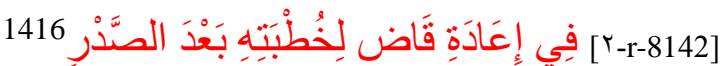

Another allocution in the name of the caliph al-Mu'tadid to renew a judge in his appointment. After the preamble

May God have written for you a watch which hastens the improvement of your situation and accompanies you along the royal path

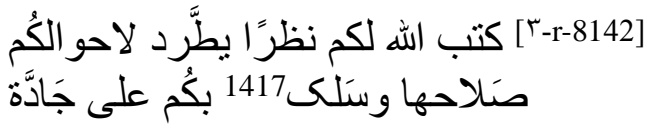

of His assistance (tawfiqi-hi), a path so obvious and clear that it cannot be missed. Know that the care we have for you

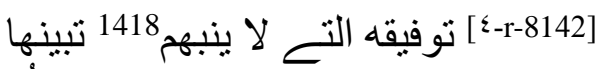

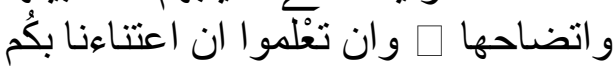

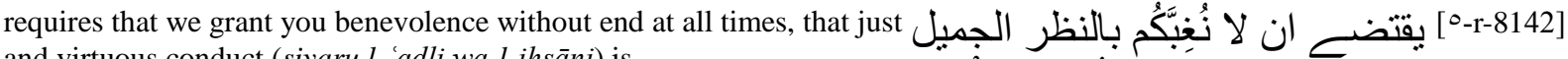
and virtuous conduct (siyaru l- 'adli wa-l-ihsānni) is

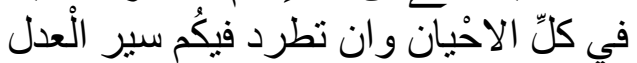

required with you, and that we must appoint for your interests and finances someone whose worth we have recognized for that by putting them to multiple

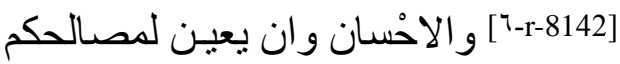

و اشغالكم من عرفنا تاهله لدلكم 1419 بتردد

tests and repeated examinations. Taking this into account, we have appointed again Fulān to settle your affairs that have to do with

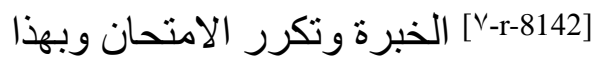

الاعتبار اعدنا الان الى تولى الألى احكامكم

the Law and to manage your religious questions; from now on we entrust him alone to arbitrate

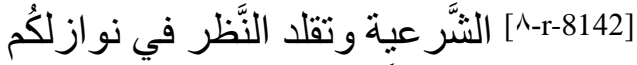

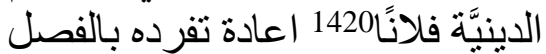

and judge for you, and this speaks to the fact that for us he certainly has بينكم و القضآء وتشهد بما تاكَّد له [9-8142] the qualities necessary for this [appointment]

لايْنا من موجبات التَّاهيل لذلكم

and to please us and it [also] show how much he has acquired merit in our eyes by [his] care ( $i^{\prime}$ tin $\left.\bar{a}\right)$ and [his] application $(\bar{i} t h \bar{a} r)$. He is someone

who has distinguished himself in our service, recently and in the past, and whose behavior each time we have employed him

in this responsibility followed the clear roads and straight paths. He has been given the firm

advice to make the fear of God on High the pivotal point of his actions, to not allow his authority $(\bar{i} r \bar{a} d u-h u$ wa ișdāru-hu) to stray from the Book of God

on High, the Tradition of His messenger, and the consensus of the Community (ijma $\bar{i}$ l l-ummati), to employ as delegates

1415 'Azzāwī, NLA, t. 1, 502-503.

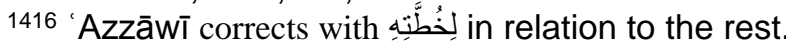

1417 'Azzāwī corrects with يسلـ

1418 B-H-M, seventh form, absent from Kazimirski (pres. 2, 4, 5, et 10 $)$. Sense adopted from fifth and tenth forms.

1419 'Azzāwī: لذلكم.

1420 'Azzāwī: فلان. 
only the most virtuous [men] whom he will have carefully selected. As for instrumentary witnesses, they are offer support

when he decides to execute or postpone [a decree]; may he strive to choose them without fault and to accept them only after having

verified their sense of justice. May his greatest care be to judge in putting on the same plane the noble and the man of the people,

[10-r-8142] عنه الا الازكبآه الإِين بحسن لهم

اختيار هو الثهود هم مستند الحكم في

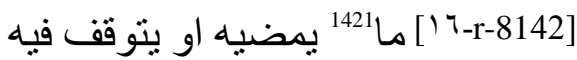

فليقدِّم انتقاءَهم جهده و لا يقبل منهم الا من هن

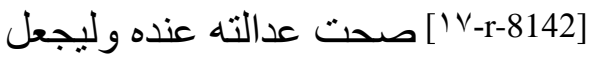

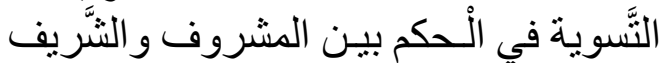

the strong and the weak. In making decisions managing disagreements, may he adopt the point of view (al-nazar)

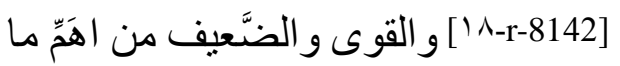

يصرف البيه قصده وليتول النظر في تمشية

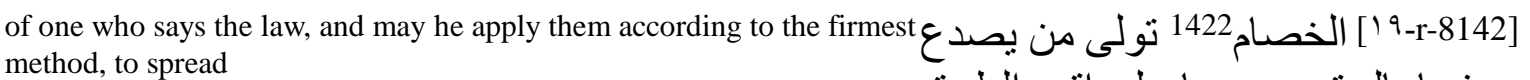

فيها بالحق ويجريها على اقوم الطرق اظهار المذ المز

our doctrine in justice and forbearance and to support ( $i$ 'timädan) the good condition that we desire for the situation

[r-8142-r-r-3 هبنا في العدل و الرفق و اعتمادًا

عَلى ما نوثره من استقامة الاحْو ال لكافة إنة

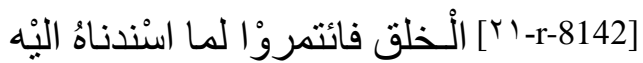

of all [our] people (al-khalq). Show him perfect obedience in the appointment with which we have entrusted him, show him the finest perseverance

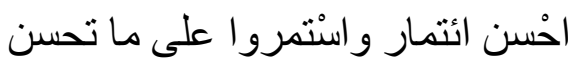

عاثار كم

with aid that will increase the worth of your deeds and know that in him we honor you through an excellent decision and choice for you.

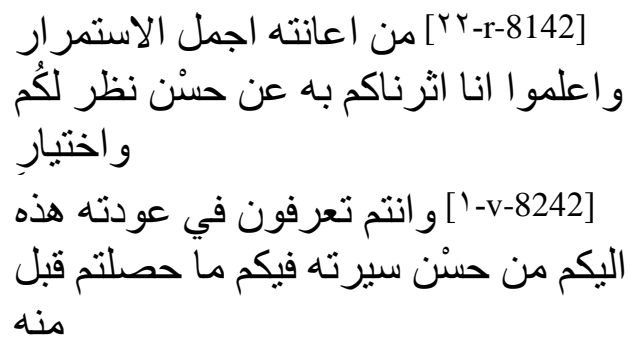

to know and appreciate ('alā ma 'rifat wa ikhtibār), if God on High wills على معر فة و اختبار ان شآء الله ب-v-8242] it. And $\mathrm{He}$ - May He be glorified - He will spread the welfare of our decision

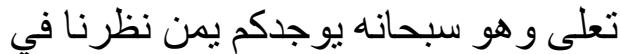

to all of your affairs, and cause all of you, the elite and the masses, to know the full reward of His kindness. By His grace.

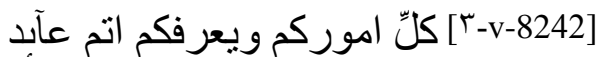

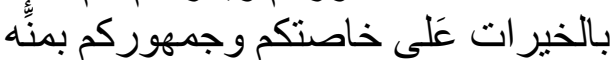

Peace. Dated the middle of the month of shawwāl in year 640 .

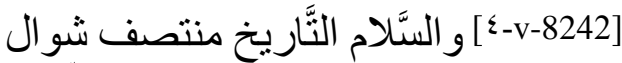

عام اربعيـن وستِّمائة

Taqdīm 66: Appointment of a judge to a post where he had already served. The foundations of the law are the Koran, Tradition, and the consensus of the Community ${ }^{1423}$

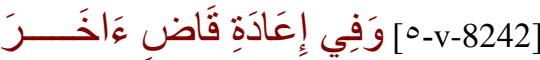

Renewal of another judge

1421 'Azzāwī: فيما.

1422 'Azzāwī: الاحكام.

1423 'Azzāwī, NLA, t. 1, 504. 
...May God on High assure them respect always by the awe He inspires in them, may He lead their situation in religion and in life on earth, as $\mathrm{He}$

approves of it. This is what we write - May God have written for you that the shadows of salvation will pass and flow slowly

over you, that security will be a companion for you that is always present and renewed, and that you will have confidence

in His magnificent kindness, which will ease the hopes you place in Him. Know that our attention for you extends to all your

affairs and [aims for] that which will be good for your elite and your masses; this attention will put your land in order, will comfort

your righteousness, will direct you to the best paths and will bring you,

God on High. This is why, when we ordered

your judge Fulān, as our generous solicitude for you and for him required, to betake himself to his appointment as judge

and to exert himself for you in the offices with which he had already been entrusted with you, we saw fit to strengthen his arm

with this allocution so that he might establish the law and justice in the affairs pertaining to him in his legal appointment (khuțtatti-hi alshar 'iyya),

and in arbitrating among you, which is incumbent on him alone for your religious disputes; may he apply the law without fear

of blame, and may he, in putting it to work, draw himself up as an obstacle to any oppressor. We have given him counsel

to fear God - May He be exalted and magnified - in public and in private, to rely on the Book of God the Powerful and on the Tradition brought by the

messenger of God - Peace and the blessing of God upon him - and on the consensus of the Community (wa 'alá ijmã i l-ummati) which

leads not astray he who follows the lights of its path. And he, with the help of God on High, may he firmly direct

your trials $(a h k \bar{a} m)$ and suppress the wrongs of your conflicts in the way you are accustomed to, may he adopt for you the attitude you are used to,

in delivering among you perfect sentences according to the law that grants no superiority to those who are known over those who are unknown

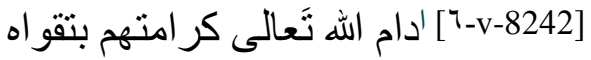

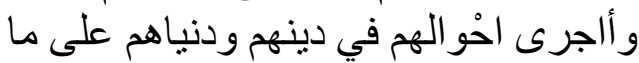

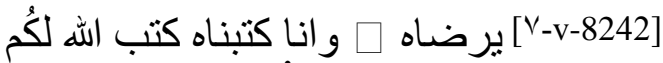

انسحاب ظلال الْعافية علئكم و انسدا

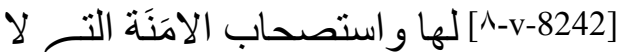

تعدمون اطرّ ادها و اتِّصـالها و الثقةتة

[9-v-8242] من الطافه1424 الجميلة بما بيَيَسِر

عَامالكم لديْه و أان تعلمو ا ان نظرنا لكم في كُلِّ

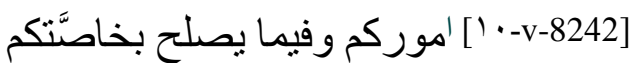

وجمهوركم النظر الذى يمهد بلادكم ويوكد

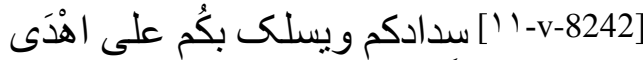

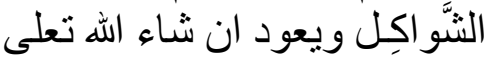

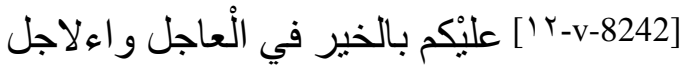

بمن الله تعلى و الى هذا فانا لما امرنا

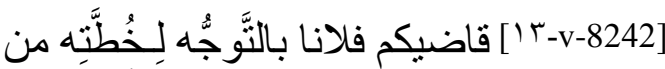

القضاءِ الذـ كان هنالكُم بسبيله

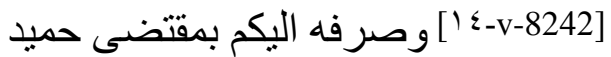

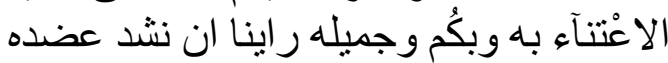

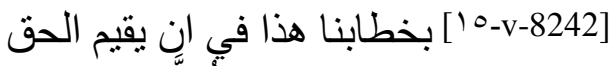

و العدل في ما برجع البّه من خُّنَّنه الثر عية

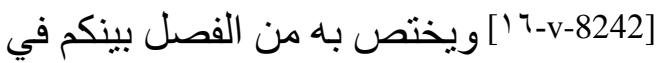

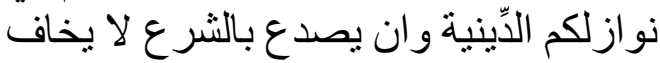

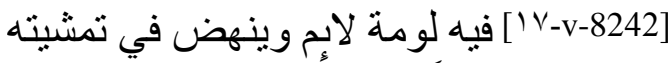

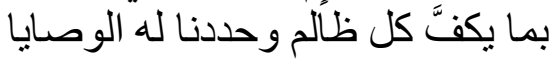

[1 N-v-8242] باتقاء الله عز وجل في سره

و علنه و الاعتماد على ما جآء بـه رسول الله

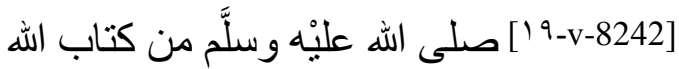

العزيز وسنته و عَلى اجماع الامهة الذي لاهي لانه

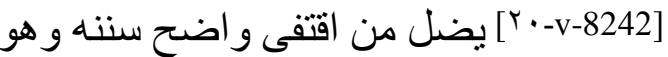

بمعونة الله تعلى بجريكم على ما عهن من لمن

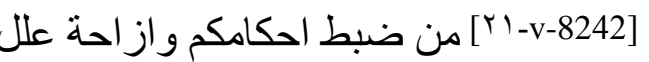

خصامكم ويسير فيكم السيرة التم الفتمو

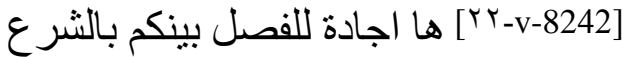

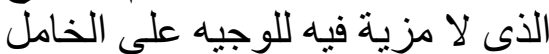

1424 'Azzāwī: ألطافة. 
and in establishing the law in the eyes of which the ranks of the most humble are equal to the most elevated. He is the one designated

by neighbors for this appointment among you, he had excellent deeds carrying it out along the straightest

paths during his long stay among you, so much so that over the years he has come to know you all, great and small, and the quality of

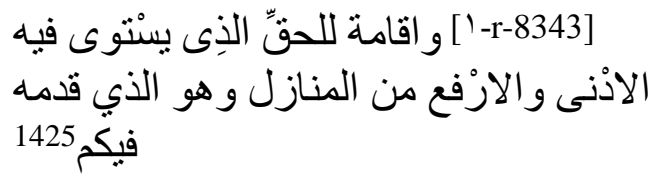

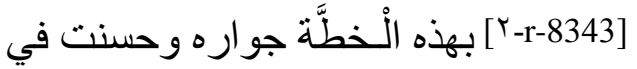

تمشيتها على اقوم طر قها طول اقامته

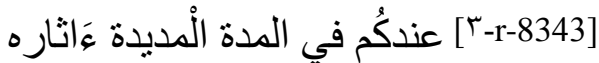

فِيْرف على مَرِّ السِّنبـن صنغير كم وكَبير كم

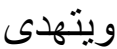

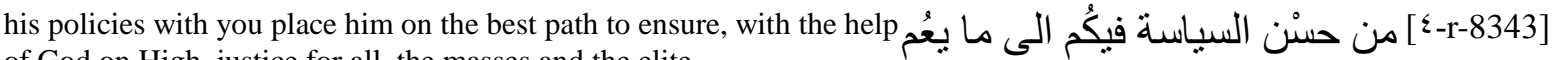
of God on High, justice for all, the masses and the elite.

بالمعدلة بحول الله تعلى خو اصكم وجماهيركم

Thus, when with the will of God on High we arrives among you, be with him brothers for the law and buttresses for enjoining good

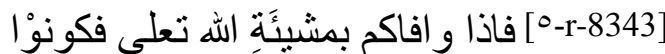

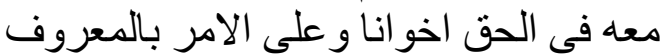

and forbidding evil. And spare with him no resource, nor means, to help him and to respond

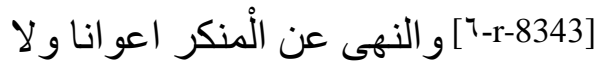

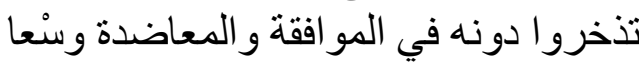

to his desires. Be sure that our solicitude will follow you, in any moment and at all times,

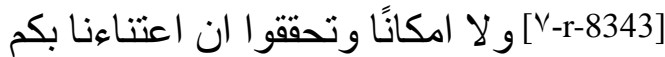

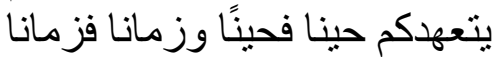

if God on High wills it...

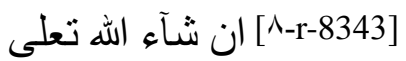

Taqdīm 67: Appointment of a judge

responsible for selecting instrumentary

witnesses. The foundations of the law are the

Koran, Tradition, and the consensus of the

Community ${ }^{1426}$

\section{[9-r-8343] \\ Áppointment allocution of a judge}

[مis is what we write - May God have written for you the guarantee of salvation and careful kindness, and the habit

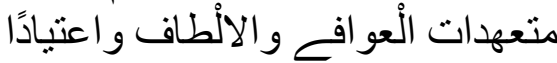

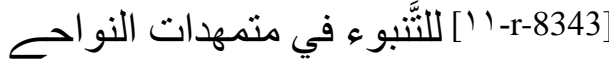

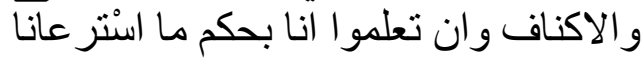

of anticipating what will organize the regions and countries. Know that we, in virtue of the fact that

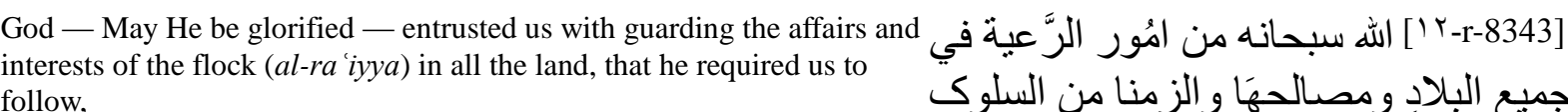
follow,

to govern it, the ancient and obvious paths and that He placed in our safekeeping the management

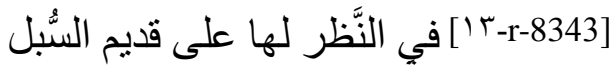

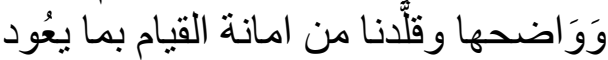

1425 'Azzāwī proposes وهو الذي قدم فيكم .... و هوار (wa-l-ladhĩ quddima fi-kum... jiwāru-hu): "he who has been appointed... is your neighbor", but our reading agrees better with the syntax of the sentence (wa-l-ladhi qaddama-hu fi-kum... jiwāru-hu).

1426 'Azzāwī, NLA, t. 1, 505. 
of that from which all, near and far, will profit, both in his [practice of] religion which is the first point where we lead him along

a direct path and on the straight road, and in daily life (dunya $\bar{a}-h \bar{a})$ where we ask him

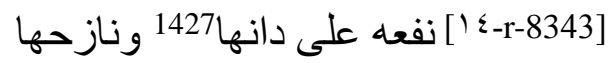

طورًا في دينها الذى هو اؤلى ما نقيمها فيه

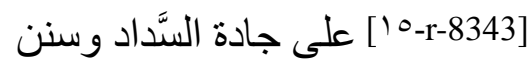

الاستقامة وتارة في دنياها التخ هي

مطلوبة

to act without ceasing to improve valorization and culture, [for all of this] we have not ceased - By God on High, He who lavishes

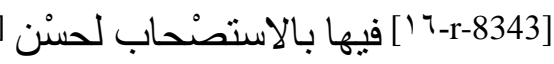

العمارة و الاستدامة وما زلنا والهه تعليهي

His aid and Who participates in everything that improves the religious and secular situation - to devote to benevolent

['v-r-8343] بالا عانة و الموفق لكل ما تصلح

عليْه احو ال الدنيا و الديانة تنخو لكم بجمبل

attention, and at no time have we denied you active solicitude for your affairs. We will appoint no one

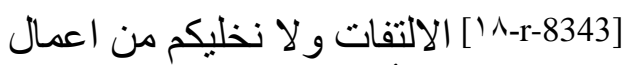

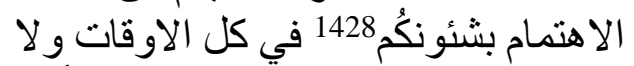
نُقََْدِّم

to render justice who has not already been designated for that by a choice founded on multiple offices in diverse regions. In

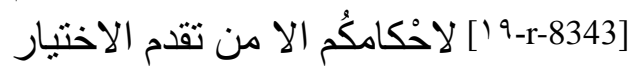

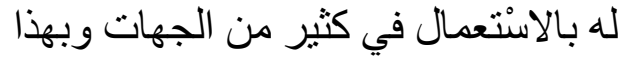
consideration of this, we have named Fulān to rule according to the law in your differences and disputes, to arbitrate

with justice the quarrels you bring before him when problems arise among you, to treat equally in applying

للفصنل بالثر ع في قضناياكم ونواز لكم

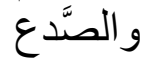

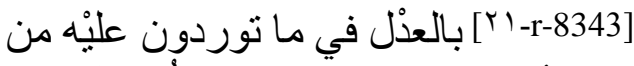

التخاصنم في طواري 1429 مسـاءكُم و التسوية فورنية في القضناء

the law the famous and the unknown. He showed himself worthy of this charge because of the reputation he gained by his

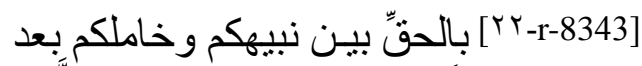

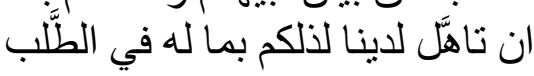
و الحسب

merit and education, and by the fact that in this education he followed the footsteps of his predecessors (li-salafi-hi) characterized by purity and virtue.

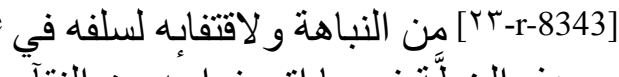
هذه الخطَّة في ما اتصفو البه من النقآه و النز اهنة أهن

We have counseled him to fear God on High, to keep His order and His prohibitions in awe, and to ask Him only to be exonerated

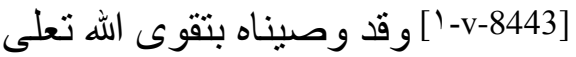
و مر اقبة امره ونهيه وان يقصر على 1430 طلب التخلص

of the consequences of all his work and each of his deeds. We have ordered him to found on the Book of God the Powerful, on the Tradition

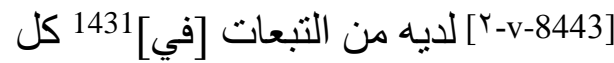

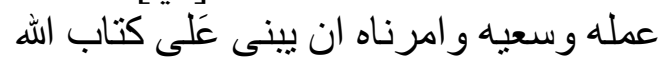
العزيز وسنة

1427 'Azzāwī: دانيها.

1428 'Azzāwī: بشؤونكم.

1429 'Azzāwī: طوى

1430 Error for 'an?

1431 Correction by 'Azzāwī. 
of his Messenger - Peace and the blessing of God upon him — on the consensus of the Community (wa ijmā i l-ummati) any judgment he pronounces or applies;

that his intentions and decisions never stray from these [principles] to [examine] the cases [submitted to him]; that he devote all his attention and thought to the instrumentary witnesses

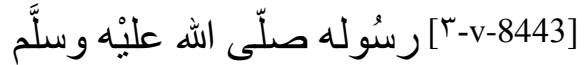

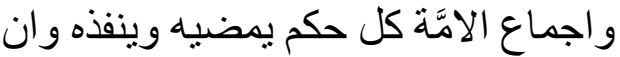
لا بعدل

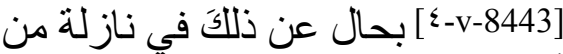

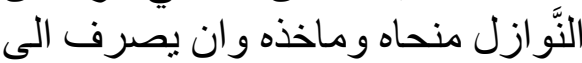

الثهود

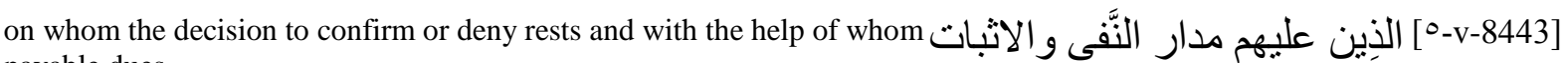
payable dues

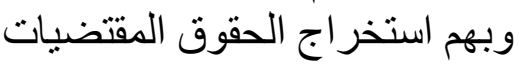

are calculated; that, among them, he accept he who has shown himself to be a truthful witness by the guarantees [he has granted], and that he exclude he who is infected

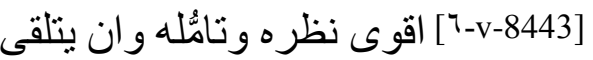

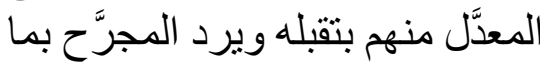

اقتضناه

with the consequences of his poor conduct. We have insisted that in all decrees presented to him and in

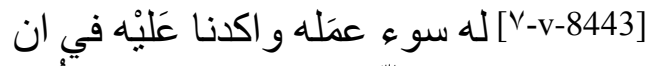

يسوى في كلّ حكم بمضنيه عند توجّهُهه

all decisions he makes once the [facts] have been elucidated and clarified he treat equally the strong and the weak, the man of the people and the nobleman;

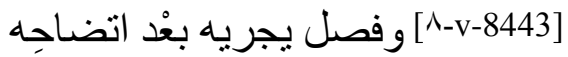

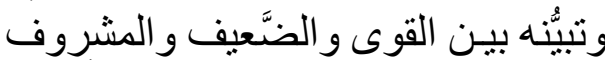

و الثَّريف

for in the law there should be no exception for rank and judgment between opposing parties should be only according to that which is obligatory.

[9-v-8443] فالحق لا بعتبر فبه تباين

المناصب و لا يقضى بيـن متخاذبيه

بالو اجب

Thus, when he arrives among you, with the will of God on High, submit to him as you should; cooperate with him

[انقاده

فانقادو ا اليّه احسن انقيادٍ وتعاونو ا معه إنه

in the virtuous and upright actions he entrusts you with and in carrying out the decrees he pronounces for you with [his] authority (min ișdār

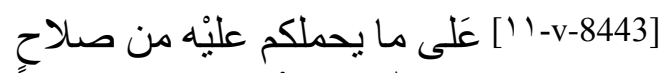

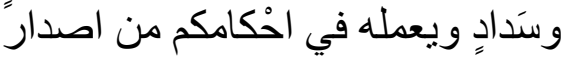

بالثر ع

wa $\bar{i} \bar{a} d_{i n}$ ) according to the law; if God on High wills it. And He - May $\mathrm{He}$ be glorified - He will grant you to find the welfare of this decision and $\mathrm{He}$ will bring together

your words and deeds to obey it. ${ }^{1433}$ By His grace...

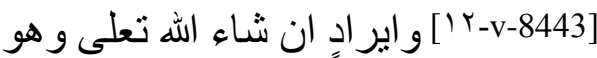

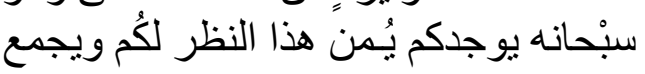

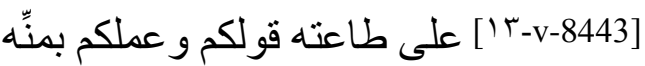

Taqdīm 68: Appointment of a judge responsible for choosing instrumentary witnesses. The foundations of the law are the Koran, Tradition, and the consensus of the Community ${ }^{1434}$

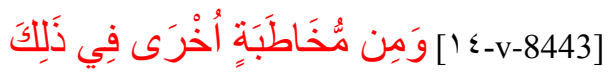

[Excerpt] from another allocution on the same subject

1432 'Azzāwī corrects with متجاذبيه.

1433 God's decision? More likely God: "Obey Him”.

1434 'Azzāwī, NLA, t. 1, 506. 
May God assure them always respect through the awe He inspires in them and may He help them for the actions he accepts and approves.

This is what we write - May God have written for you situations where virtue and righteousness are renewed and hopes

in which success and welfare come together. Know that the care taken for the interests of your lands

and [the concern] to govern you in all times according to the paths of justice and forbearance cause us to watch over you at all

times and to choose men of virtue and religion to assure [thes offices] with you. Because of our benevolence

for you in your affairs, large and small, and because of our desire to bring happiness to your elite and your masses, we have chosen

Fulān to assume your affairs having to do with the Law and to fulfill the direction we have planned for your

situation. As for him, his purity and his virtue have been tested, his methods and his intentions are well-known, and recognized

is the rank [he has reached] in science and in religion following the tracks and footsteps of his predecessors (salaf). We have counseled him to fear God

on $\mathrm{High}^{1437}$ in all his behavior and to fear His power in managing what he undertakes or will receive to judge [10-v-8443] [ادام الله كر امتهم بتقو اه و اعانهم على ما

يتقبله من الاعمال ويرضياه

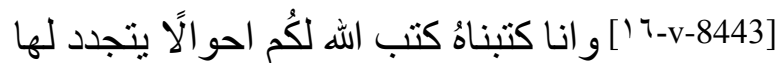

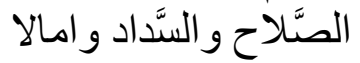

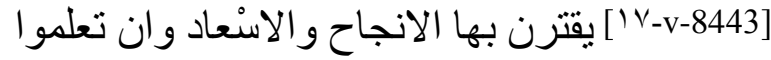

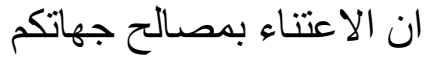

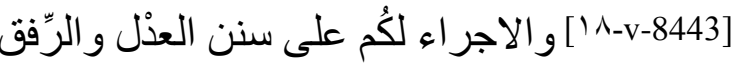

في كلّ اوقاتكم مِمَّا تتعهدكم 1435 بـه الحين الحين

[9-v-8443] [19 بعد الحين ونختار لاقامة ذلك فيكم اهل

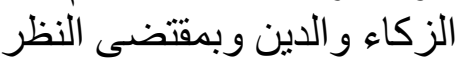

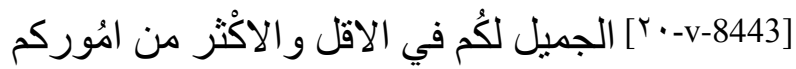

وقصد الخير لخاصنكم وجمهوركم تخيرنا

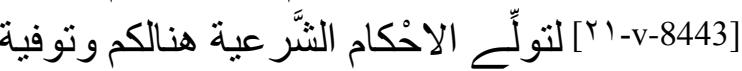

المقصُود في تسنديد احو الكم

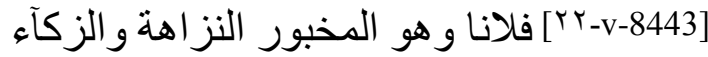

المشهور المذاهب و الأنحآء المعلوم 1436

[1-8544- ' ما لسلفه في العلم و الدّين من رنبة الاقتنداء

والاقتفآء وقد وصَّيناهُ بتقوى الله

[r-r-8544] تعلى 1438 في كل متصر فاته ومر اقبة أَمره

فيما يديره من محاو لاته في الفصنل بين

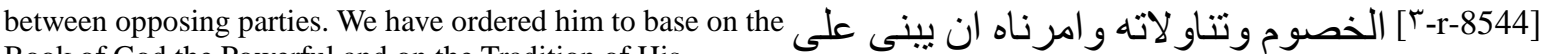

Book of God the Powerful and on the Tradition of His messenger

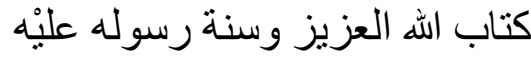

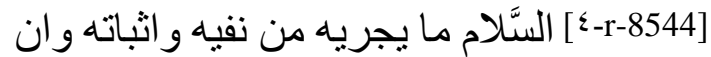

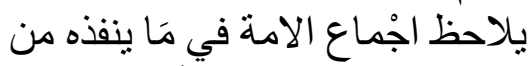

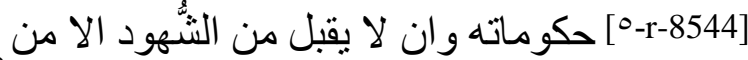

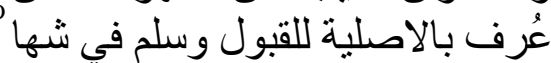

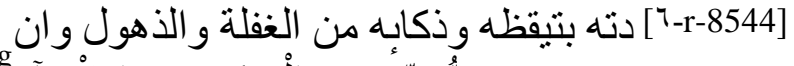

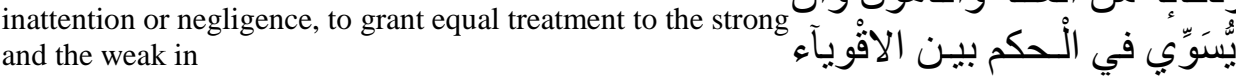

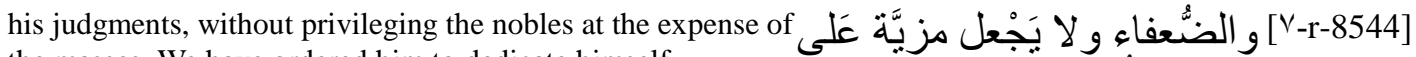

the masses. We have ordered him to dedicate himself

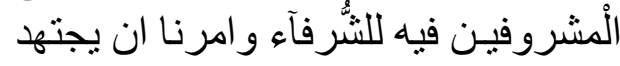

to eliminating new things not authorized by the law and to repress reprehensible actions that should be fled

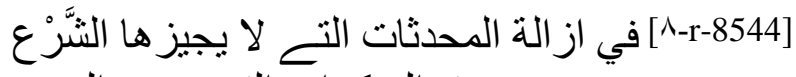

ومحق المنكر ات الته يجب الزجر لاتهر

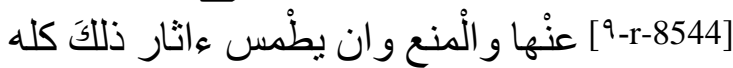

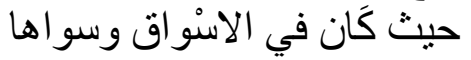

and forbidden, to erase all trace of them, whether in the markets or elsewhere,

1435 'Azzāwī corrects with نتعهُكم.

1436 Proposal by 'Azzāwī, for the last word on the page lost to a hole.

1437 Reference to Koran 4:131: "Verily we have directed the People of the Book before you, and you (o Muslims) to fear God."

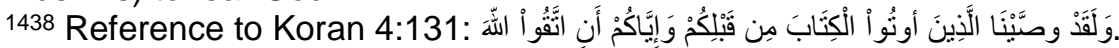


to follow the most direct and clearest paths to eliminate all abuses, to observe the law

in his decisions without fearing anyone in Creation and [finally] to not resort to forbearance where firmness [is

where forbearance [is expected] so that his watch unfurls according to a strict rule ( $\operatorname{sad} \bar{l} d$ ) and extends the farthest possible to accomplish justice, expected], nor to firmness

[-r-8544- · [ بسلك في رفع كل مظلْمة اقوم الطُّرق

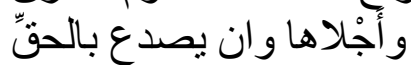

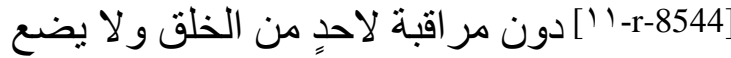

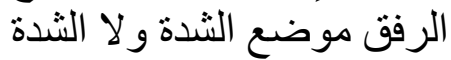

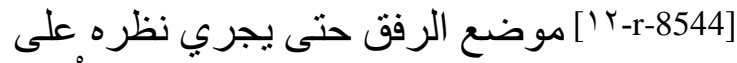

قتون سَديد وينتهى في توفية فئ الْعدل

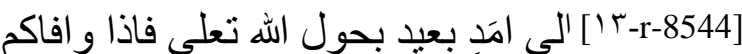

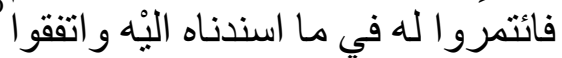

the force of God on High. Thus, when he arrives amon him. Agree

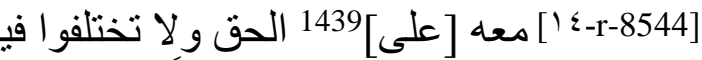

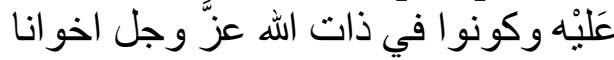
his own concerning it. Be brothers in the essence of God - May He be exalted and magnified.

[10-r-8544 ] واستنقبلو ا بالتعاون على البر و التَّقوى 1441

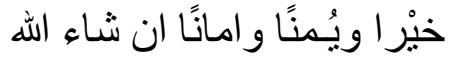
kindness, happiness, and security, if God on High

[17-r-8544 17 ] تعلى و هو سبْحانه ينجدكم على ما فيه

صلاح دينكم ودنياكم ويشتمل بالْعافية

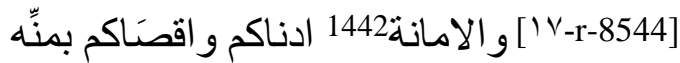

Taqdīm 69: Appointment -from

Marrakesh? - of a judge responsible for

choosing instrumentary witnesses. The

foundations of the law are the Koran,

Tradition, the consensus of the Community, and the words of the scholars ${ }^{1443}$

[1^-r-8544]

Another appointment

This is what we write - May God have written for you a vision that guarantees your religious interests and that chooses for you the [most qualified] person to

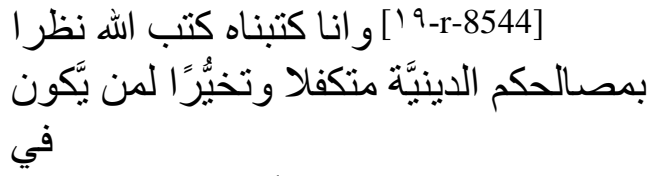

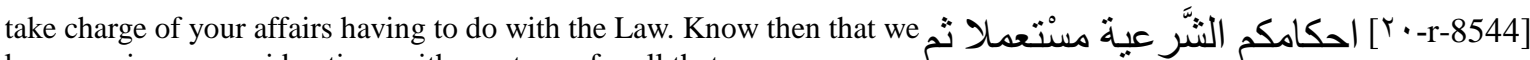
keep you in our considerations with great care for all that concerns you,

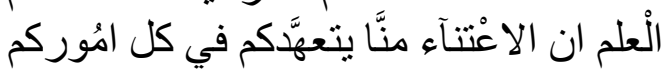

which leads you in such a way that, both the elite and the masses, you will go in the right direction and which treats you with such benevolence (jamīl al-iltifāt)

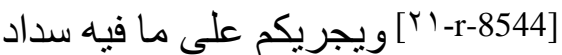

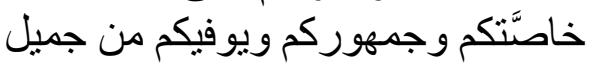

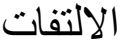

1439 Added by 'Azzāwī.

1440 Reference to Koran 5:2: “...Help ye one another in righteousness and piety...” (wa ta 'āwanū 'alá lbirri wa-l-taqwá).

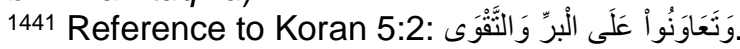

1442 'Azzāwī corrects with والأمنة.

1443 'Azzāwī, NLA, t. 1, 507. 
that joy fills your eyes with tears and swells your bosoms. This is because you have distinguished yourselves in the Presence of the Almohads

by the reports of neighbors whose protection has been confirmed and whose clauses with you have been respected and continue to be, and because you [show] in the ties of friendship

with the eminent Power and the shelter you seek near it a sincerity marked with brightness. We have decided, after having asked the help

of God on High, to choose to occupy the office of judge for you one on whose purity and virtue we can rely, someone who, in the responsibilitie

he exercises deserves confidence by the righteousness of his intentions. We appoint over you with this act Fulān - May God on High assure him always His assistance

and may he give him as a companion virtuous work - so that he might pass judgment in your disputes according to the rules of the law, so that he might devote himself

as much as possible to justice in the judgments he renders for you, that he might follow the path of the judges who preceded him to decide

and arbitrate according to the law/truth. We have counseled him to fear God on High, a fear which equips the faithful against all false steps.

We have ordered him in the judgments he confirms or annuls, in the accords ${ }^{1447}$ and injunctions [he pronounces], to rely on the clear and precise verses [of the Koran],

on the authentic words and deeds [of Muhammad], and on the consensus of the Community (wa ila ijmā i l-ummati) established in the works of the finest imāms,

and to not stray in the judgments he renders from the words of the scholars, his predecessors in this authority ( fi al-īrād

wa-l-ișdarr). We have insisted that he examine the condition of the instrumentary witnesses, that he distinguish which he should accept

and which he should dismiss, ${ }^{1448}$ that he assure with meticulous care the texts of acts and contracts, that he treat equally

both parties when he convokes them or asks them to sit, that he do all that is possible to have he who has a right to obtain

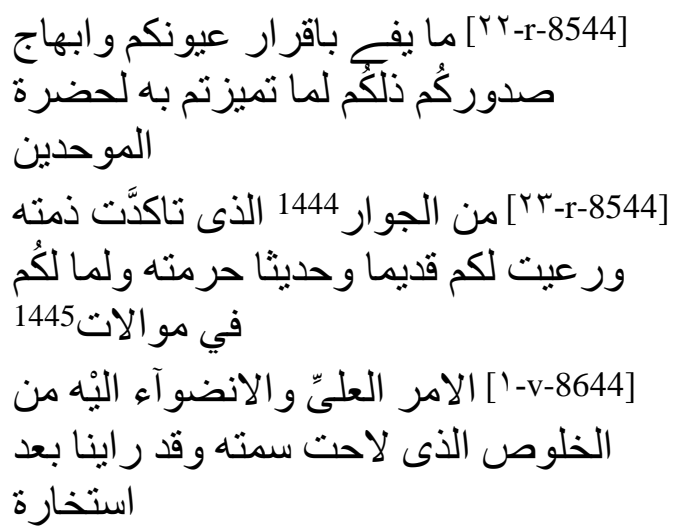

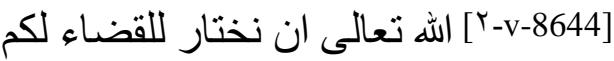

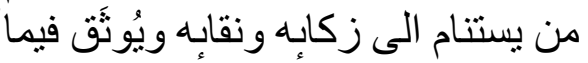

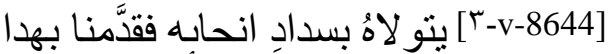

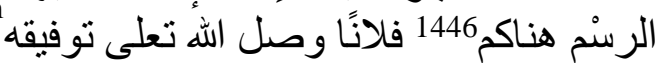

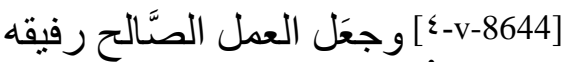

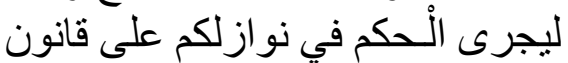
الثر ع ويلتزم عانت

[0-v-8644] العدل في احكامكم باقصى الوُسنع ويسلى مسلك القضاة من سلفه في الفصل

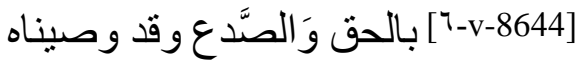

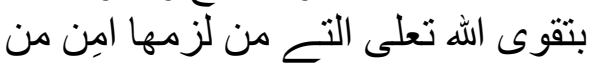
العثنار

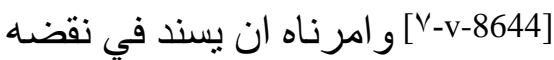

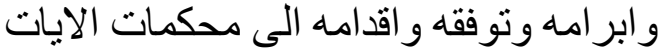

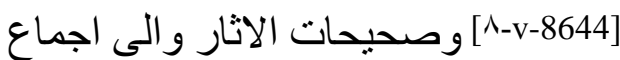
الامَّة الثابت في مصنفات الايمَّة الاخيار

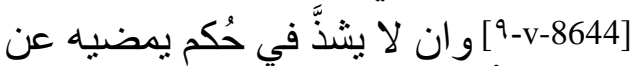
اقو ال الْعُلمآع الذين بهم يقتدى في الاير ادِ

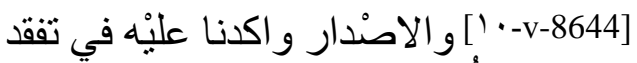

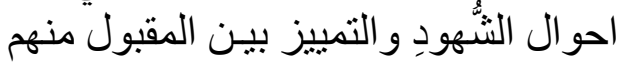

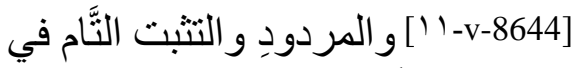
نصوص السَّجلات و العقود وان يسَوِّى ولى

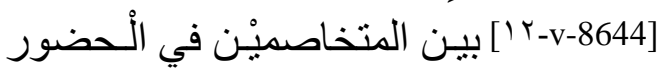

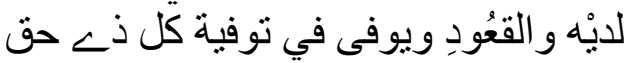

\footnotetext{
1444 Proposal by 'Azzāwī for two illegible words.

1445 'Azzāwī corrects with هو الاة 'Azzâw.

1446 'Azzāwī: هنالكم.

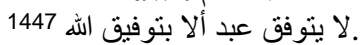

1448 This seems to concern the person, and not their testimony, for which we would expect 'an-hum. 
that which he is owed and that he enjoin that which is good, chase away evil and pursue all

that is contrary to the law. Thus, when with the will of God on High he arrives among you, submit to him as

you should, be with him as one hand united for that which he communicates to you from the tasks we have entrusted to him.

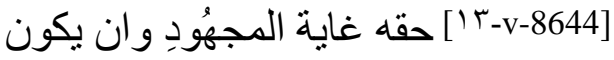

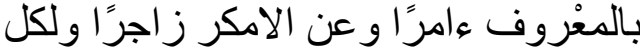
L

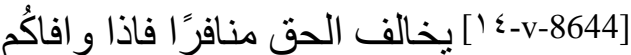

بمشينَةِة الله تعلى فانقادو ا احْسن انقيادٍ

[10-v-8644] النّهه وكونو ا معَه بدا و احِدة فيما

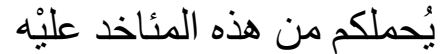

Taqdīm 70: (Incomplete) judicial appointment.

The foundations of the law are the Koran,

Tradition... ${ }^{1449}$

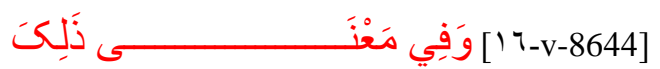

On the same subject

This is what we write - May God have written for you the recognition of what [our] benevolent watch holds to redress

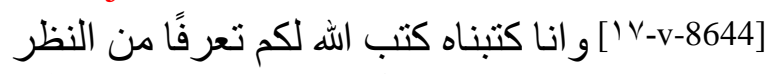

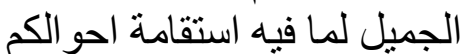

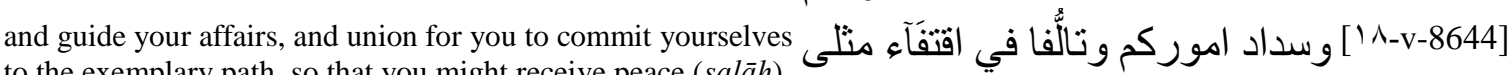

to the exemplary path, so that you might receive peace (salāh)

in return

السَّبيل على ما بعود بالصَّلناح

for your elites and your masses. Know that we take constant care of your

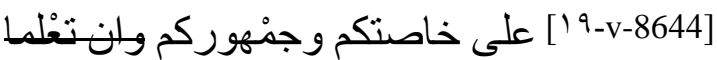

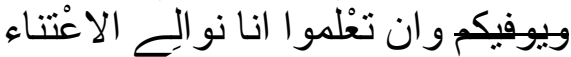

interests and important affairs and that we choose as well as possible those to whom we entrust a job in

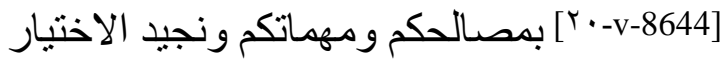

لكل من نستتعمله في شغل من اشغال

your regions, particularly the office of judge charged with leading according to precise rules affairs having to do with the Law

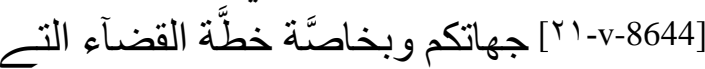

تجري الاخْكام الثر عية على قو انينها

and to weigh on the most just of scales religious differences to discern the law therein. We appoint to this office solely

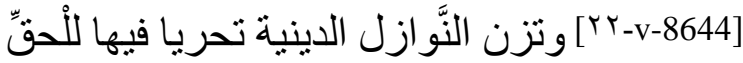

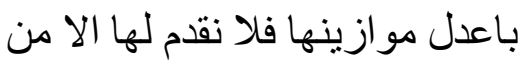

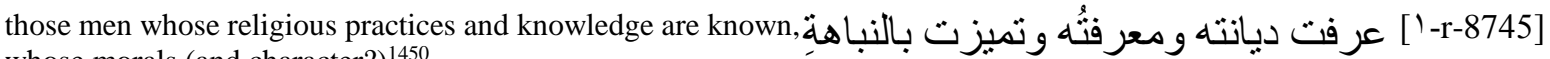
whose morals (and character?) ${ }^{1450}$

$$
\text { و النز اهة شيمته (... }
$$

have an excellent reputation of purity and whose listening and attention... (whole) to prefer justice in sentencing and discernment in examining [facts]. In terms of these

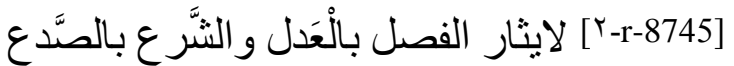
considerations

that reinforce the respect and aid [he will enjoy] and which direct his arrow (tafwīqa-hu) towards the targets of righteousness $^{1452}$ - may he take charge

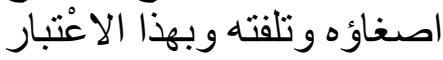

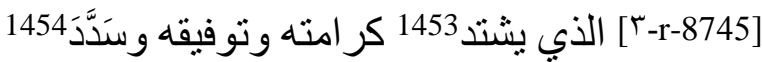

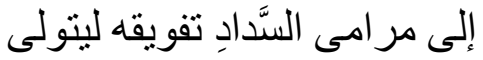

\footnotetext{
1449 'Azzāwī, NLA, t. 1, 508.

1450 Suggestion.

1451 Two words erased by humidity.

1452 See taqdīm 76 for an analog translation.

1453 Proposal: yushaddid.

1454 'Azzāwī corrects with ويسد.
} 
of the juridical decrees throughout your land and advance the demands of justice whenever he invalidates, confirms, binds,

or unbinds. His education is solid and his rank with us is wellestablished. We have tested him and he came out improved;

we have employed him and had nothing but praise for his conduct and the choices he followed, having recognized his search for the law/truth

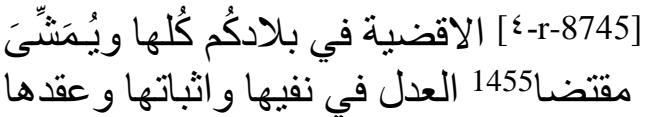

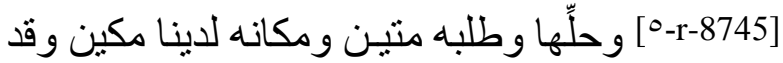
خبرناه فزَكى على الاختبار

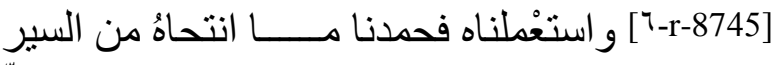

و الاثار وشكرنا توخيه للحقِّ منيّ

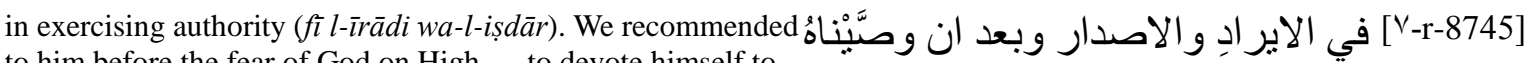

to him before the fear of God on High — to devote himself to that is to beautify it,

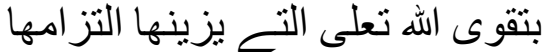

it is on that that he must base the judgments he confirms or annuls; [We have also counseled him] to follow in his sentences only that which is required by the Book of God

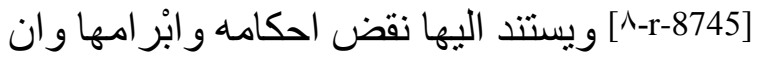

لا بفصل الا بما يوجبه كتاب الله

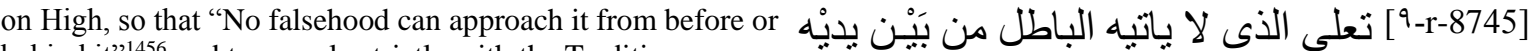

behind it" 1456 and to comply strictly with the Tradition

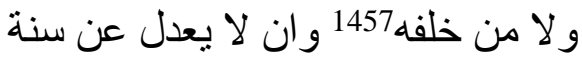

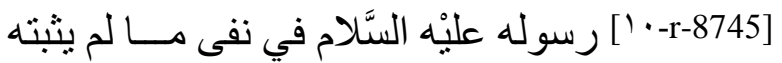

His messenger - Peace be upon him - to forbid what is not established and to establish what is not forbidden... Thus ends

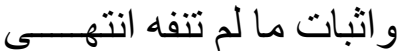

what was found of this allocution.

[ ['ll-r-8745] ما الفى من هــذا الْخطاب

Taqdīm 71: Appointment of a judge

responsible for choosing instrumentary

witnesses, assistants or secondary judges, and

the hisba (?). The foundations of the law are

the Koran, Tradition, and the consensus of the

Community ${ }^{1458}$

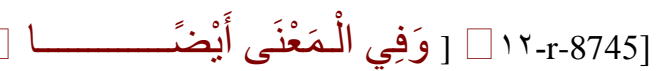

Still on the same subject

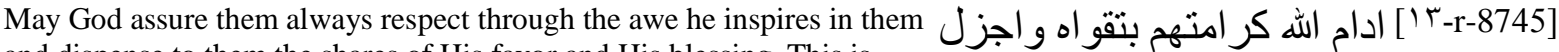
and dispense to them the shares of His favor and His blessing. This is

حظو ظهم من نعماهُ ور حماه

what we write - May God on High have written for you to know the privilege of a very benevolent watch, and to adopt a behavior that will ensure you a sound

and virtuous situation in the present and in the future. Know that our watch over you is benevolent and that the care we have

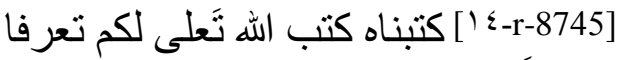

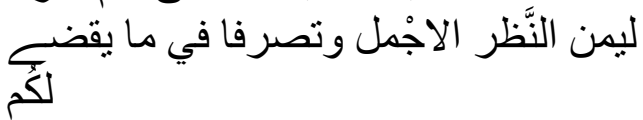
[10-r-8745] بصلاح الاخْو ال في الحال

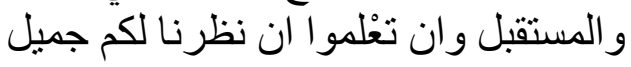
و اعتناءنا

1455 'Azzāwī: مقتضى.

1456 Koran 41:42: continuation "It is sent down by One Full of Wisdom, Worthy of all Praise".

1457 Koran 41:42: continuation تنزيلّ من حكيحٍ حميدِ

1458 'Azzāwī, NLA, t. 1, 509-510. 
for the interests of your elites and your masses is assured, that we take you along the ways of justice, and lead you

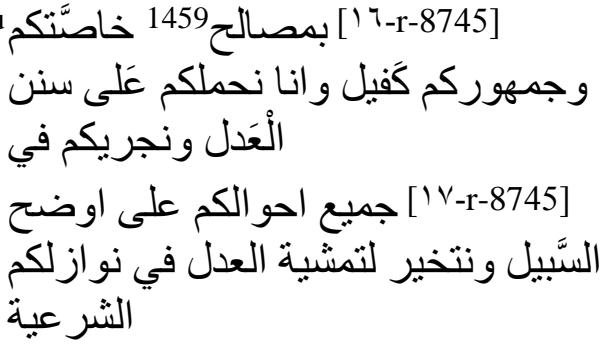

and in your religious affairs someone who enters therein like a blade. May God cause you to know at all times the privilege

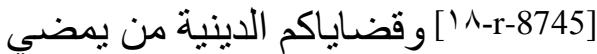

by the clearest path, no matter your situation, that we choose to promote justice in your disputes that have to do with the Law

فيها مضاء النصل و الله يعرفكم يمن هذا لائر القصد هن

of this project, may He grant you the grace and security that you hope for and may He obtain for you the profit of the choice

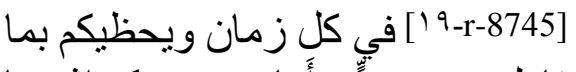

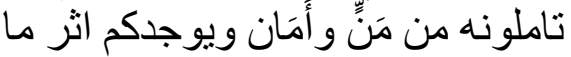

نوثره مان

we make of forbearance, justice and beneficence for you and for all Muslims. By His grace. In addition - May God assure you always respect -

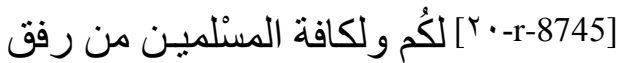

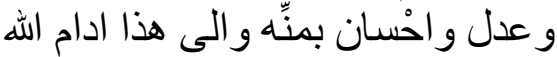

كر امتكم

the judgeship is relied upon to resolve questions in dispute; thanks to it

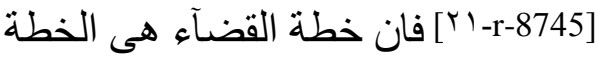

التهـ لهَا يفزع في مشكلات النوازل النهاء

وبحقها

and to the specific role it plays in the sciences of the Law unclear cases can be decided and distinction can be made between

[بr-r-8745]

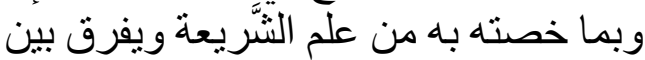

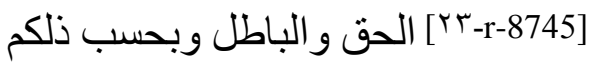

truth and error. Because of this, we employ for this position he who fulfills it the best, who carries it out

نستعمل 1460 لتوليها من يقو بها خير قيام

ويجريها

according to the most just rules and the best order. In consideration of which we have appointed to judge your disputes

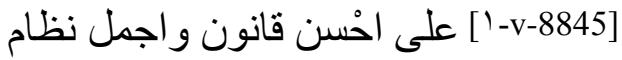

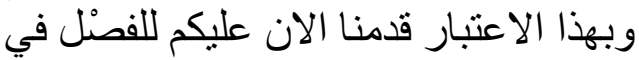

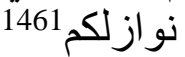

that have to do with the Law and to take charge of you according to the applicable rules Abū Fulān — May God assure him always his assistance

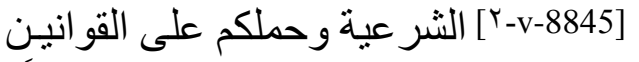

المر عية ابا فلان وصل الله توفيقه وسدَّد التحن

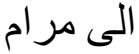

and direct his path towards the desired good and righteousness. He has already been tested and chosen, and we have verified that the purity and righteousness

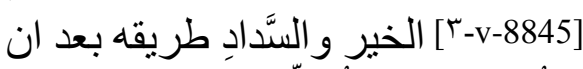

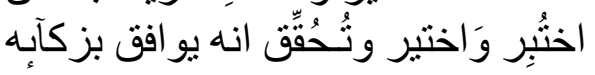

وسَداد

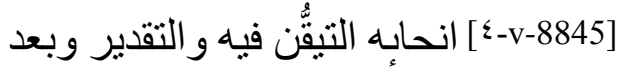

of his intentions agreed with the esteem and absolute confidence we had for him; we have already appointed him to a position for which we had nothing but praise for his (...ability?) and for his

ان تقدم استُعماله (وشكر .... 1462 بما اسْند

\footnotetext{
1459 Omitted by 'Azzāwī.

1460 Proposal by 'Azzāwī for an illegible word.

1461 'Azzāwī proposes مسائلكم but nawäzili-kum seems more likely because of a dot that appears above the hole in the paper.

1462 Two words erased.
} 
sense of responsibility in the functions entrusted to him; the virtue of his intentions and his behavior merited nothing but praise.

In addition, he has always grown in the bosom (hujr) of the services of this powerful and generous command, receiving sustenance, he and his father

- May God on High give him strength - at the teats of its immense beneficence and its universal favor. Moreover, we have counseled him to fear

God on High, to fear His orders and His prohibitions in all situations and to observe the law in his words

and his deeds. We have commanded that he make of the venerable Koran his imām, to place before him the Tradition of His messenger - Peace and

the blessing of God be upon him - , to base the judgments he confirms or annuls on the consensus of the Community ('alá ijmā' $i$ l-ummati) when there is no clear text

in the Book nor in the Tradition, to also examine the condition of instrumentary witnesses (al-shuhadá) and to employ

as secondary judges (al-musaddidinn) only pious and just men (almusaddadīn) and, in court (majlis al-ahkām), to grant equal treatment

to the strong and the weak, to the nobles and men of the people, to not privilege a party at the expense of the law,

without favoring his familiars, without pushing away those who are unknown, to fear God with an absolute fear

and to act as he who waits trembling for the retribution of God on the day of Judgment. In addition, we have ordered him to eliminate

all new things that should be eliminated, to discard any innovation not authorized by the law, to put an end

to any invention whose inventor has been the object of a decree of banishment or exile until there remains only that which the Law of

Muhammad authorized and the sublime path that it traced. Thus, the situation will remain

1463 'Azzāwī: ناشَأ

1464 'Azzāwī: ذلك.

1465 Absent from the manuscript.

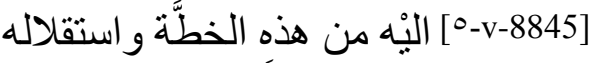

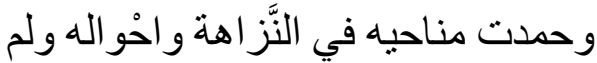

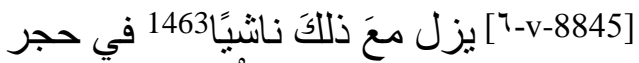

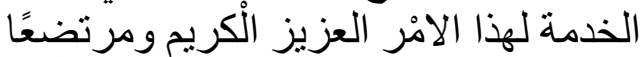
هو و أَبوه

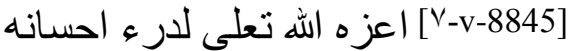

الْجسيم و فضله العميم وقد وصسى مع ذلكم

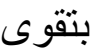

[^-v-8845] الله تعلى ومر اقبة أَّزر ه ونهيه في جميع أَحْو اله و ملاحظة الثَّرَ عَ في مقالهِ

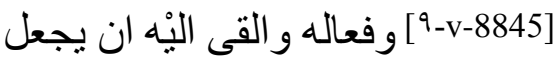

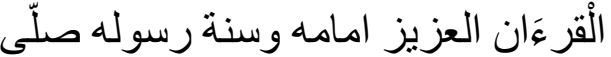

الله

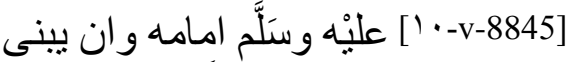
على اجْماع الامة اذا عدم النَّص الجلَِّ في الكتاب

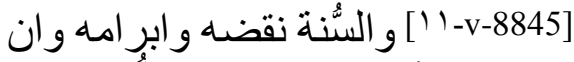

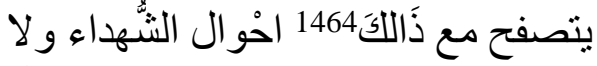
بستعمل

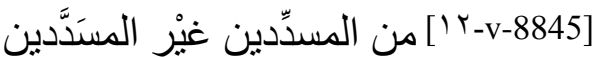

الاتقياء وان يسوِّى في مجلس الاحْكام

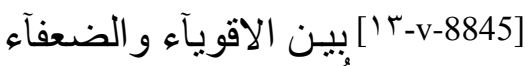

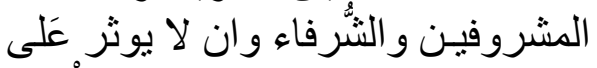

جانب الْحق لُون

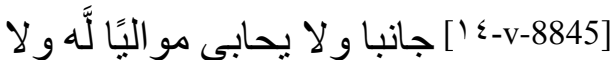

ينافي مجانبا وان بتقى الله حق اتقابه

[10-v-8845] ويعمل عمل المستشعر لجز آء

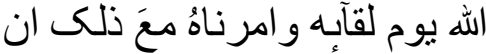
1465 يَّر [فع

[ ] T-v-8845 ] كل محدث يجب له الرفع

ويذهب كل مبتدع لم يبحه الثر ع ويزيل

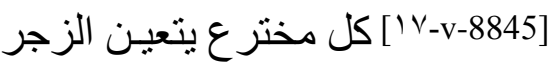

لمختر عه و الرَّدع حتى لا يبقى الا ما لاين

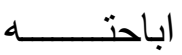

[^^-v-8845] الثربعة المحمَّدية و اقتفيت فيه

عَاثار ها السنيَّة فبذلكم تستمر الا 
on the path and course of virtue and the door of kindness will open after having trembled.

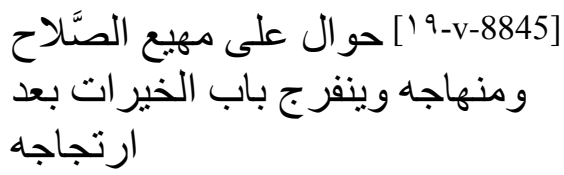

Thus, when with the will of God on High, this judge, yours, arrives among you, submit your affairs to him. Present to him

your nascent conflicts, obey him in all that we have charged him with among you, collaborate

with him and support him in following the firmest road, help him to render justice to the victim at the expense of

the oppressor, and know that justice resides in what allows situations to improve for a long time and lastingly, if God

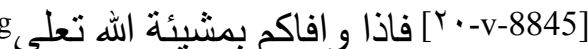

قاضيكم المذكور فارجعوا اليْه باحكامكم

و اعرضوا باهكا

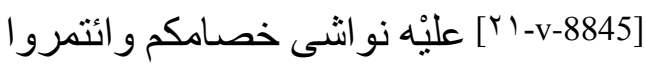

له في كل ما نمشيه فيكم من الحق و اسنْلكوا

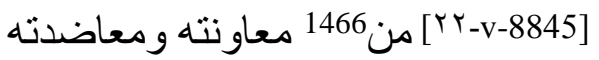

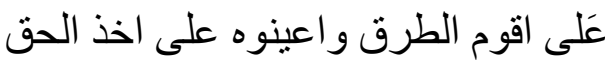

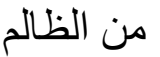

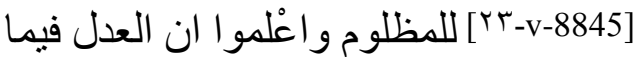

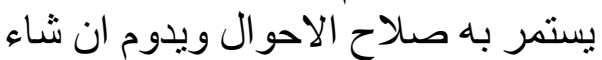

اللهاء

on High wills it. And $\mathrm{He}$ - May He be glorified - He will cause you to know the privilege of this appointment and will lead you along the luminous tracks

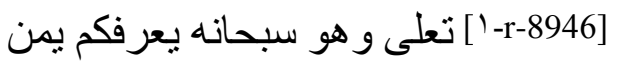

هذا التقديم ويَسْلِك بكم على المَّى المنهج

الو اضح النح

[ب-r-8946] و الصِّر اط المستقِيم بمنِّه

and the straight path. By His grace.

Taqdīm 72: Appointment of a judge

responsible for instrumentary witnesses. The

foundations of the law are the Koran,

Tradition, and the consensus ${ }^{1467}$

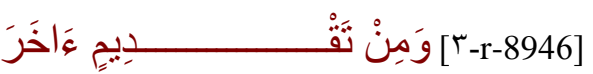

Another appointment

May God assure them always respect through the awe he inspires in them and grant them in abundance His favor and grace. This is what we write - May God have written

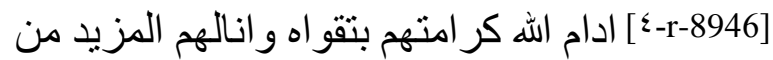

فضله و نعماه و انا كتبناه كتب اله وله اله

for you a watch that accomplishes for you the promise of

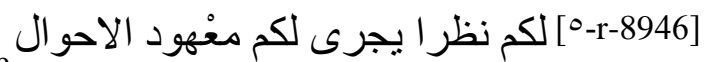

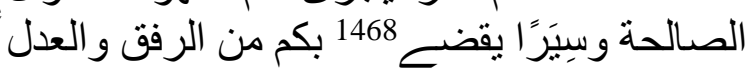
and justice to fulfill

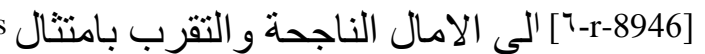

your hopes and to bring you closer to Him in obeying His orders and avoiding what He forbids. Know

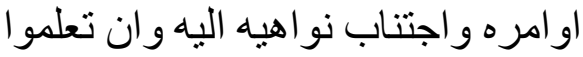

that our watch over you is attentive at all times and that your interests enjoy with us profound solicitude and care.

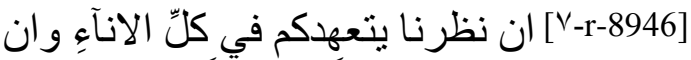

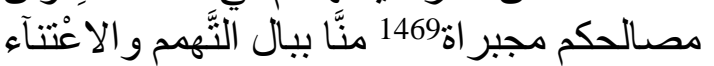

This is why we will choose to judge your problems someone who will weigh them with precise weights and we will employ for your affairs someone

1466 'Azzāwī: في.

1467 'Azzāwī, NLA, t. 1, 511.

1468 'Azzāwī corrects with تفضي.

1469 'Azzāwī corrects with تُجري 
who will direct them in a satisfying and rigorous manner showing the effects of equity among you and taking special care to protect

your regions and lands. Because of these objectives which are ours in all your affairs

[9-r-8946] يتو لاها بالكفاية و الضبط اظهارًا لاثار المعدلة فيكم و ايثار اللاحتياط

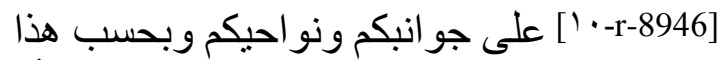

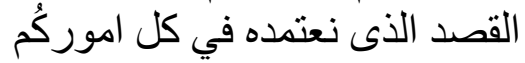

and which allow us to perpetuate an excellent [situation] for your elites and your masses, we have appointed Abū Fulān to the office of judge

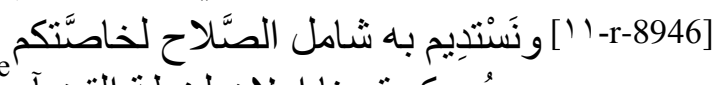

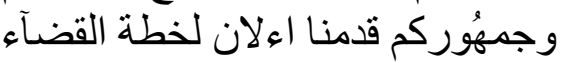

over you with the responsibility of settling cases having to do with the Law and to follow juridical questions according to

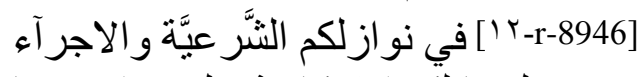

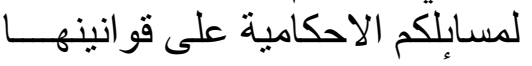

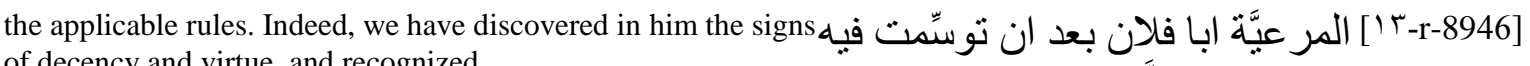
of decency and virtue, and recognized

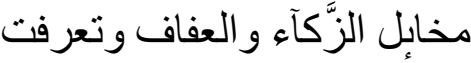

in his friendship and his capacities the qualities of one who has been formed to be a functionary; in addition he has merited

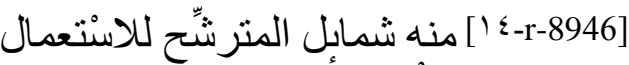

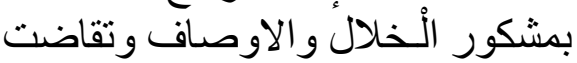

to be close and near to [Our Presence] because of the services rendered (was $\left.\bar{a}^{\prime} i l\right)$ by his father, a servant known and eminently respectable. ${ }^{1470}$ Furthermore,

[10-r-8946- لله وسابل ابيه الاثير الحرمة الثهير

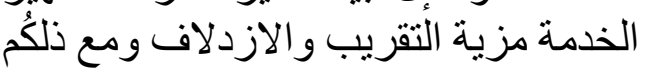

he have counseled him to fear God the Magnificent, to respect His design, and to tremble in fear before Him, in private as in public.

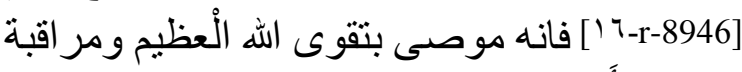

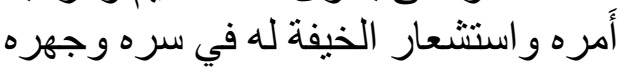

He has received the order to make of the Book, the Tradition and و مامور ان يجعل الكتاب و السنة [1V-r-8946] the consensus $(i j m \bar{a})$ the principle director (dawābit) of his authority (īrādi-hi wa ișdāri-hi) and the framework

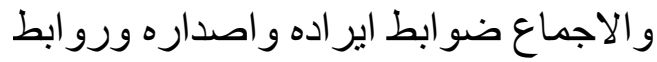

for that which he forbids or ordains: may he make no exception of that in any of his judgments and issue no sentence if it is not

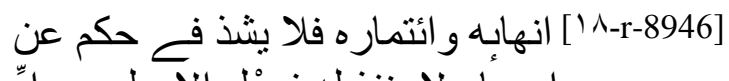

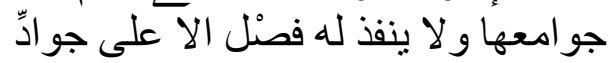

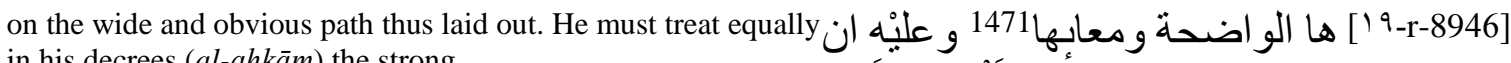

in his decrees (al-ahkām) the strong

and the weak and grant no privileges to the nobles to the detriment of the men of the people. As for instrumentary witnesses,

they are a support for him when he decides to carry out or postpone [a decree]; may he then apply himself to know and discover ${ }^{1472}$ their condition, and may he approve

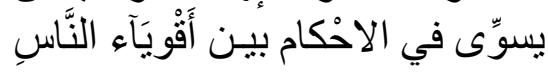

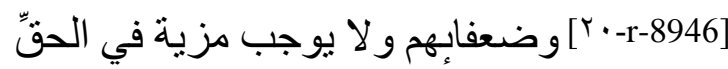

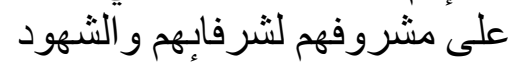

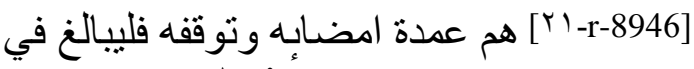

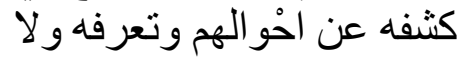

only he whose behavior and (...) are known for their equity.

Thus, when with the help of God on High he arrives among you,

collaborate with him in the projects we have ordered him to fulfill among you.

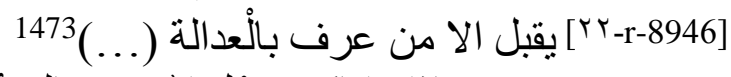

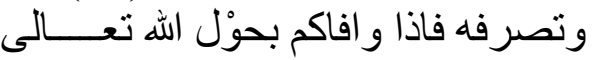

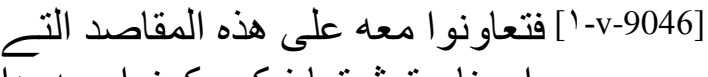

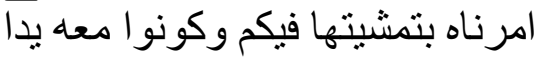

Be with him as one hand united for the responsibility of governing you which we have entrusted to him. You will [then] know the blessing that comprises the attentive and protecting watch

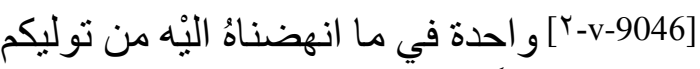

وستتعرَّفون بركة النظر الذي به به نعتمدكم

that we keep over you in all circumstances, if God wills it. And $\mathrm{He}$ - May He be glorified - He will grant that you find the privilege of this nomination
[?-v-9046] في كل الاحو ال وننتحيكم ان شآء الله
ورو سبحانه يوجدكم يمن هذا التقديم

1470 Hurma: allusion to a woman from the ruling family?

1471 Probably ومهائعها.

1472 Reverse gradation.

1473 One or two words are completely erased. 
in the present and in the future, and He will use you in causing you to collaborate through your virtuous actions [in the advent] of good and His awe.

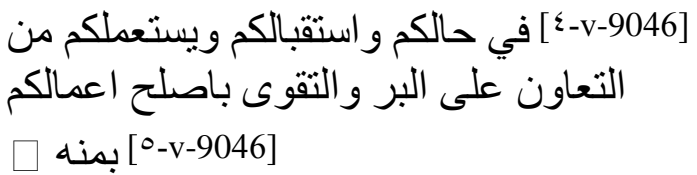

Taqdīm 73: Appointment of a judge responsible for choosing instrumentary witnesses and a worthy son of his father. The foundations of the law are the Koran, Tradition, and the consensus of the Community ${ }^{1474}$

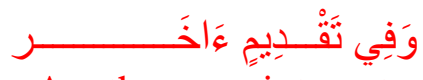 \\ Another appointment}

This is what we write - May God on High have written for you to know [our] benevolence and to adopt a behavior that will assure you

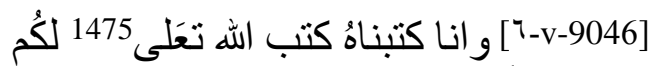
تعرفا للنَّظر الجميل وتصرفاً فيما فيما بحظيكم

much happiness. We have appointed Abū Fulān to manage your affairs that have to do with the Law and to lead you, for

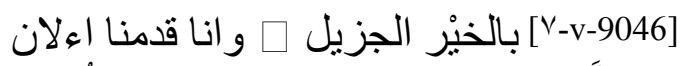
للنَّظر في احْكامكم الثر عية و اجر إكُم في

your religious questions, according to the applicable rules. In the past, we have appreciated his positions and approved

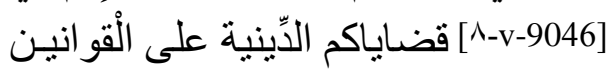

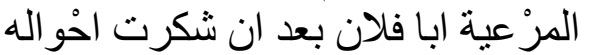
و استحسنت

his deeds in this office where he has been employed many repeated times; he has distinguished himself by his remarkable methods

[9-v-9046] عاثار ه في هذه الْخطَّة التح تُكرَّر

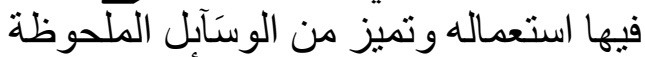

which added to his merits and facilitated the fulfillment of his hopes; he placed his feet in the footprints of his father, marking himself by [his] services

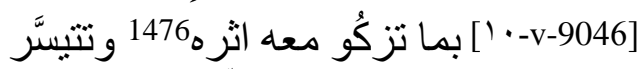

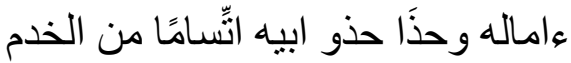

and enrolling himself among those who are responsible in the field wherein his capacities bloom, and where he attains and obtains the goodness

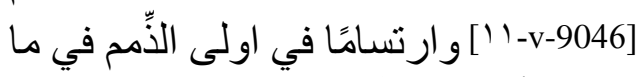

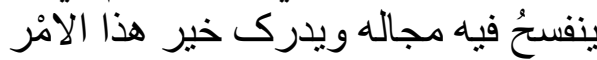

of this high commandment (hädha l-amr al- 'alī) in the present and in the future. We have counseled him to fear God on High in all situations that he provokes

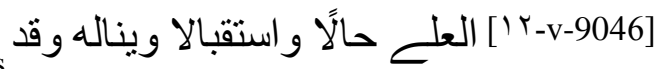
اوصى بتقوى الله تعلى في كل تصرف فيه or undergoes, to fear Him, He the Highest, in all that he forbids or ordains, to take the Book of God on High,

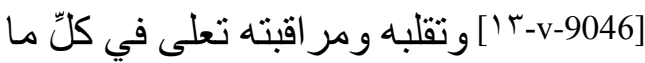

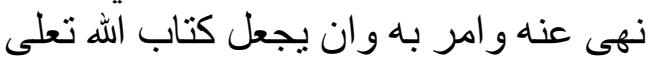

the Tradition of His messenger - Peace be upon him — and the consensus of the Community (ijmā'a l-ummati) as the direction (qibla) of his conduct (ihtida' $i$-hi), to accept

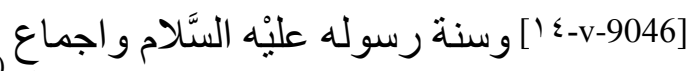

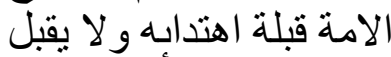

as instrumentary witnesses only those whose equity and virtue have been proven and to decide in differences between plaintiffs

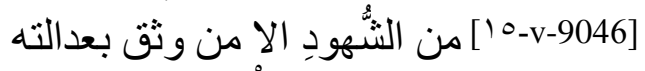

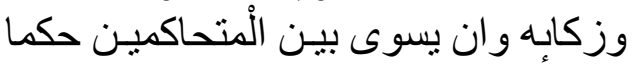

with lawful judgment and totally equitable arbitration. May, for him, the strong and the weak,

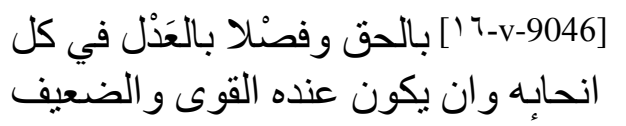

1474 'Azzāwī, NLA, t. 1, 512.

1475 Omitted by 'Azzāwī.

1476 'Azzāwī corrects with آناره. 
the noble and the [man of the people] be equal, no matter the decree he 1478[و المشروف [و الثريف] issues or receives. ${ }^{1477}$ Thus, when he arrives among you, address

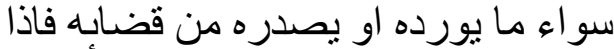

و افاكم فاقتصروز

him alone concerning the powers we have confided to him. Welcome him with submission and obedience on

[1^-v-9046] عليه ما اسندناه من احكامكُم البه

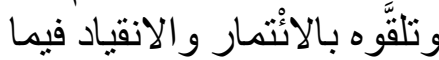

the paths of virtue and righteousness, on which he will bear you with

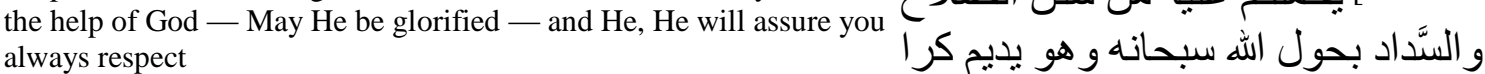

and will continue to bring you His assistance [founded] on the awe He متكم ويصل على تقو اه اعانتكم. - م-v-9046] inspires in you. By His grace...

بمنِّن

Taqdīm 74: Appointment of a judge responsible for choosing secondary judges and instrumentary witnesses as well as the hisba. The foundations of the law are the Koran, Tradition and the consensus of the Community ${ }^{1479}$

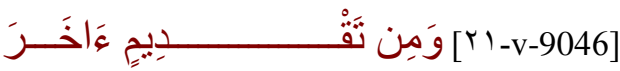

[Excerpt] from another appointment

May God on High assure them always respect through the awe He inspires in them (...) may he make their action sublime. This is

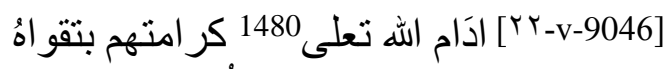

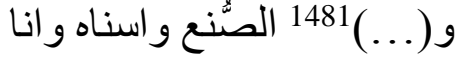

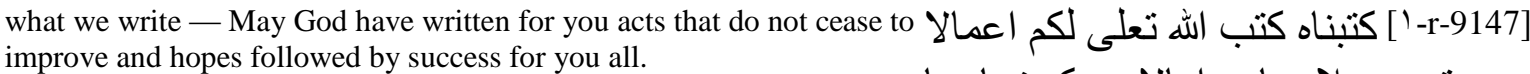

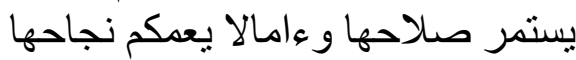

[ب-r-9147

Know that our benevolence will always bring you more support that is the best for you, that we seek

to lead you, the elite and the masses, along the clearest path of justice and that we want to perpetuate for you

a situation where your hopes will be crowned with success and where you will find a vast and wide shelter,

[enjoying] recognized security and a tranquil life. We choose to occupy an office with you someone who has distinguished himself by the uprightness of his method

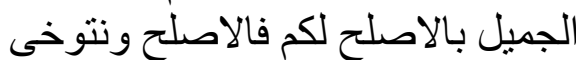

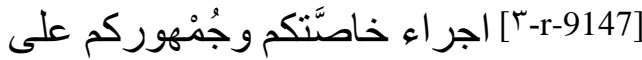

سنن العذْل و الاوضح ونقصد ان نستمر 1482

امور كم

[ـ-r-9147- على ما بحظيكم بالامل الانجح

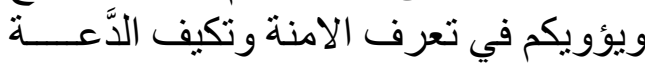

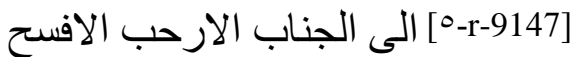

ونتخير للاشغال فيكم من تمبز بالمذهب

السيَّد

1477 "no matter theīrād or iṣdār of his decision" ?

1478 Added by 'Azzāwī, absent from the manuscript.

1479 'Azzāwī, NLA, t. 1, 513-514.

1480 Omitted by 'Azzāwī.

1481 Three words missing.

1482 'Azzāwī corrects with تسنمر. 
and the superiority of his reason. May God on High cause you to know the fortuitous consequences of our plans in all your situations

and satisfy your hopes with success in the present and in the future. By His grace. This is why - May God assure you always respect through the awe He inspires -

after having asked the help of God on High, we have appointed Abū Fulān

- May God grant him always His assistance and open for him the path towards desired goals — to take care

of your affairs that have to do with the Law and to take charge of religious questions according to the applicable rules. As soon as we had chosen, tested, and employed him,

our opinion of and esteem for him were confirmed, for he had followed the path of his father - May God exalt his worth - without passing by righteousness,

purity and goodness. From childhood, he sought sustenance in the kindness and favor of this eminent power,

through contact with it he became used to walking along the paths and ways that please [God] and he learned through

the reform of your situation what kind of support we do not cease to give you [in appointing people] like him. We have counseled him moreover to fear God

on High and to tremble before him, to follow the path and tracks of tradition and to adopt the Book of God

on High, the Tradition of his messenger - Peace and the blessing of God be upon him - and the consensus of the Community (wa ijmä $i l$ ummati) like a light (sirāj) that

will help to guide in any obscure matter, or like an imām thanks to whom he will neither stray nor deviate from the paths

of justice, or [even more] like a sign that is for him "direction from your Lord and a healing for the (diseases) in your hearts." ${ }^{1483}$ We have insisted

that in all circumstances he select and choose instrumentary witnesses, that he use secondary

judges (al-musaddidīn) in whom the confidence placed has never been faulted, that in court (majlis al-ahkām) and wherever

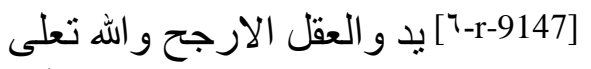

بعر فكم بمن قصدنا في كافة احو الكم

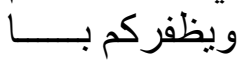

[V-r-9147] طِّر اد الامال في حالكم ومئسالكم

بمنِّه و الى هذا ادام الله كر امتكم بتقو اه اه

[^-r-9147 فانا قدمنا بعد الاستخارة لله تعلى فئم

للنظر هنالكم في الاحكام الثر عية

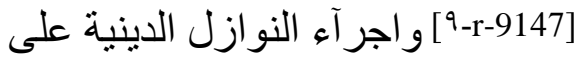

القو انين المر عية ابا فلان وصل الله تعلى اعلى الهى

تو فيقه

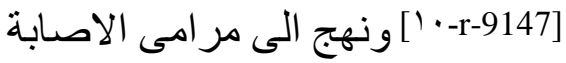

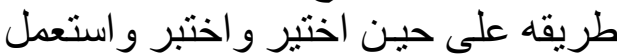

فصدق

[-r-9147-' ' ' الظن فيه و التقدير و اهتدى بسنن

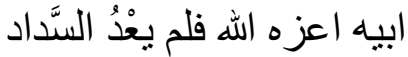

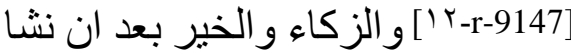

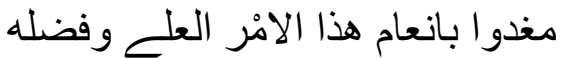

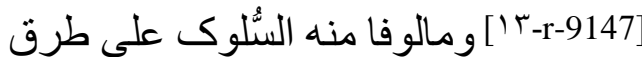

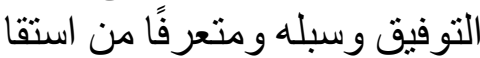

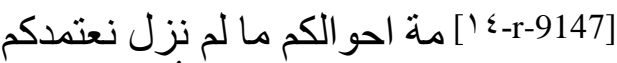

بمثلهله وقد وصيناه مع ذلكُم بتقوى الله

[10-r-9147] تعلى و استنعار ها و اقتفاء سنن

السنن و \&اثار ها و اتخاذ كتاب الله

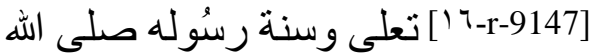

عليْه وسلم و اجماع الامة سر اجه الذِى

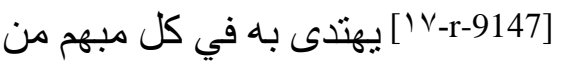

الامور و امامه الذى لن يعدل به عن سنن هن من من

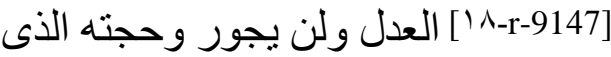

هى هدى وشفاء لما في المُّدور 1484 و اكدنا

[9-r-91479-3 علنيه في انتقاء الثهداء وتخير هم

في كل الانآء و استتعمال من تصح

[r-r-9147-r] امانته من المسدِّدين من الانتقاء

و التسوية في مجلس الاحكام

1483 Koran 10:57: "O mankind! there hath come to you a direction from your Lord and a healing for the (diseases) in your hearts,- and for those who believe, a guidance and a Mercy".

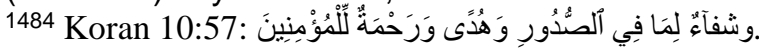


he annuls or confirms [decrees] (mahall al-naqd wa-l-ibräm) he treat equally the strong and the weak, the nobles and the men of the people so much so that

the strong does not expect help and the weak is not crushed with humiliation, so much so that justice Among the points on which advances along a luminous path (...) the group, if God on High wills it.

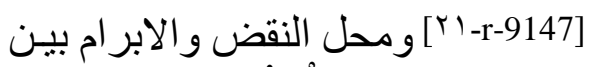

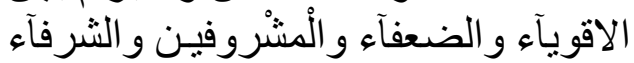

حتى

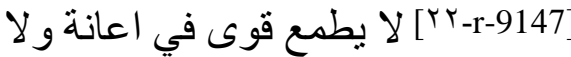
بغلب ضعيفٌ من اهانة وحتى يتمثى لئى

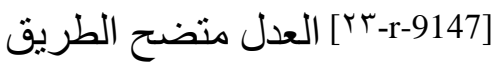

1485 و الفريق ان شاء الله تعلى مئح

و

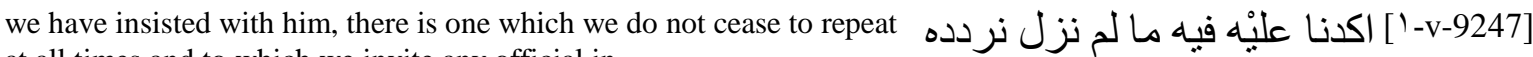
at all times and to which we invite any official in

في كل الانآاء ونحث عليْه كل مسنتعمل في

the provinces and regions: to eliminate innovations and abuses and to bring them back to the state of the erased remains,

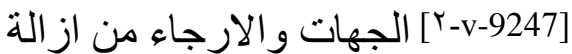

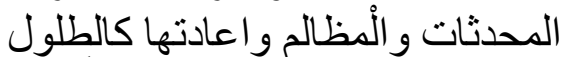
الطََّ اسم

to bring to light the obvious tracks and signs of the law, to apply the law on which

[بr-v-9247] و ايضاح ما للحق من الاثار

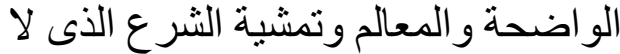
تاخذ

blame has no hold and to govern that which belongs to us in seeking permanent goodness. Thus, when with the help of God on High

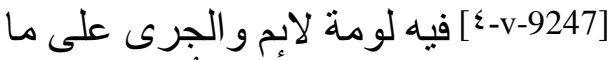

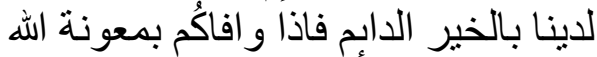
تعلى

[0-v-9247] فار جعو ا البّه باحكامكم و اقصروا

he arrives among you, refer to him for the matters that concern you, entrust to him alone the settlement of your conflicts, consider

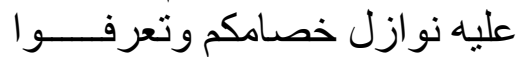

his arrival among you as the privilege of your life, know that through him we have distinguished you in appointing someone whose experience we have praised

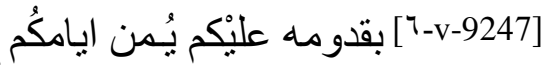

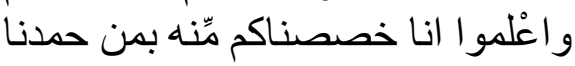

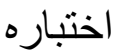

and whose actions we have praised in all circumstances. If God on High وشكرنا في جميع الاحو ال عاثثاره wills it. And $\mathrm{He}$ - May He be glorified - He will cause

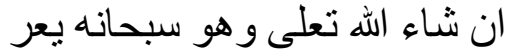

you to know the privilege of his arrival and appointment and He will lead you along a road wide and straight. By His grace. Written

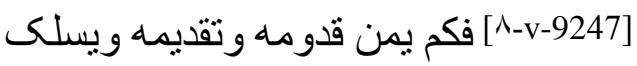

بكم على الاحب1486 السنى وقويمه بمنه

كتب

the first day of the moon of $d h \bar{u} l-q a$ 'da in the year 648 .

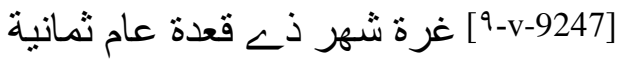

واربعين وستمائة

Taqdīm 75: Appointment of a judge

responsible for choosing instrumentary

1485 Two unclear words.

1486 'Azzāwī corrects with الألحب. 
witnesses. The foundations of the law are the

Koran, Tradition, and consensus ${ }^{1487}$

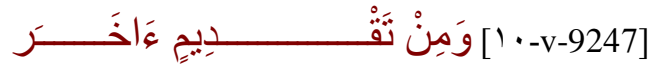

[Excerpt] from another appointment

This is what we write for you - May God on High have written for you conditions that improve without end and hopes followed with success that fulfill

You. Know that your interests are the object of [our] worries, that [our] care guarantees you affairs that are in order

and balanced situations, that the choice of people employed to treat your juridical or daily ${ }^{1489}$ (ashghāli-kum) problems

is one of the tasks to which we dedicate much attention and work. Thus we have appointed Abū Fulān

to take charge of deciding and judging among you, may he care only about justice when he postpones or carries out [a judgment] and may he not

leave the straightest path to bring back to it [those] among you [who have strayed]. Once his decency

and virtue were known, knowing that from childhood he had assimilated the art of prosecution and defense for [our] service and that he had distinguished himself by the merits, his own and those of this father,

the seeking of which multiplies efforts, we counseled him to fear God in [exercising] his authority (fì $\bar{r} \bar{r} d i-h i$

wa ișdāri-hi), we insisted that he adorn his deeds and works with virtue, we ordered him to take

the Book, Tradition, and consensus ( ijm $\left.\left.^{\prime}\right)^{\prime}\right)$ as the line of sight for his intuition and intelligence, to never let stray his gaze from

these three fundamental principles, to undershore testimony $(s h u h \bar{u} d)$ in justice with the excellent selection
[1 [1-v-9247

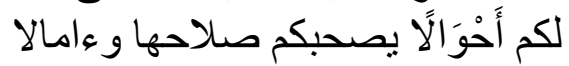

بحسبكم نجا

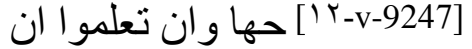

مصالحكم مجر اة بالبال وان النظر لكم

كفيل بانتظام الامور

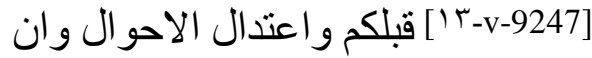

تخير المستعمليـن في احكامكم و اشغالكم

[ [ 1 [-v-9247 مدَّا نو فيكم فيه قسط الالتفات

و الاهتبال و انا قدمنا اءلان ابا فلان

[10-v-9247] ] لتولــ الفصل بينكم و القضاء

وتوخٍّ العدل في التوقف و الامضاء

و مالأ

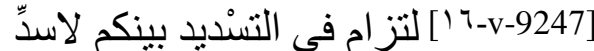

الانحاء بعد ان توسِّم فبه العفاف فيه

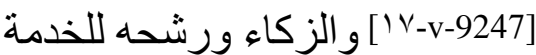

التجريح و الانشاء وتميز بما لابيه ولله

sis

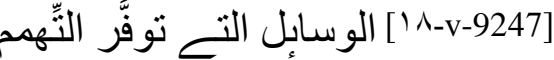

بها و الاعتناءء وصىى 1490 بتقوى الله في لونر اير اده اله

[9-v-9247 [ و اصداره و اكد عليْه في

تحسبن اعماله بالز كآه و أثار ه و امر ان

يجعل

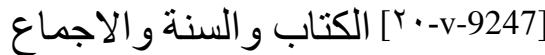

تلقاء بصيرته وبصره وان لا بعدل عن ولهال

هذه

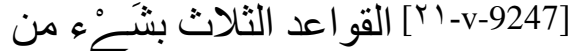

نظره وان بعتمد الثهود في الحقوق

باحسن

1487 'Azzāwī, NLA, t. 1, 515.

1488 Omitted by 'Azzāwī.

1489 Or "financial".

1490 'Azzāwī: ووصِّي. 
and choice he will make, to treat equally in (...?), the strong and the weak (...),

the noble and the man of the people in acting according to justice and in preferring it to anything else. Thus, when with the help of God

on High he arrives among you, collaborate with him for the most sacred of projects, and follow in all your affairs the clearest

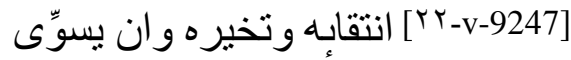

في (....1491 القوى و الضعبف

1492 (...)و

[-r-9348- [ ] المشروف و الثريف عملا

بالعدل و اقتفاءً لسيره فاذا و افاكم بحول

الله

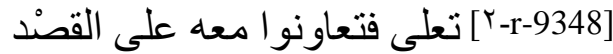

الاصلح وسيروزا في كل اموركم على أنى اعلى

السنن

and most obvious path, you will thus rejoice in the most profitable commerce and the success of your efforts, if God on High wills it.

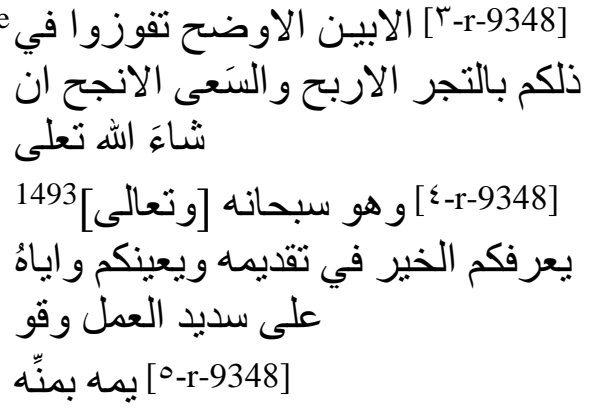

And $\mathrm{He}$ - the Highest, may He be glorified — with his appointment, $\mathrm{He}$ will cause you to know happiness, and He will bring you, to you and to him, His assistance for a just and well-done

Taqdīm 76: Appointment of a judge

Labor. By His grace..

\section{responsible for choosing instrumentary}

witnesses. The foundations of the law are the

Koran, Tradition, consensus and examples $(\text { athar })^{1494}$

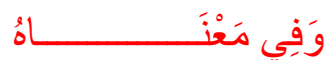

On the same subject

May God have written for you actions that carry your religious كتب الله لكم اعمَالا ]-r-9348]

and secular interests to their end thanks to the attention

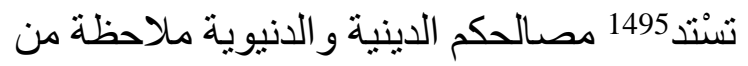

of he who brings you the support of the best defense and protection, which leads you with equity and forbearance as perfectly

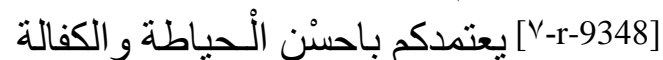

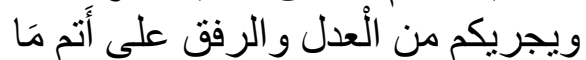

as just administration and government require and assures you all the benevolence that will obtain for you superabundant share

of [its] excellent (mustahsana) and desired (mustanāla) favors. Our always increasing care for your affairs is confirmed

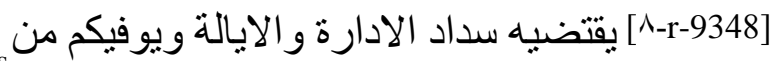

النظر الجميل ما يحظيكم

[9-9348-9 باوفر حظوظ النعم المستحسنة المستنالة

وبهذا الاعتبار بتاكَّد

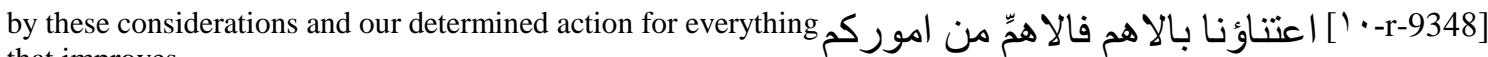
that improves

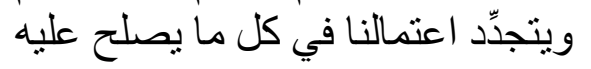

1491 Two words erased by humidity, perhaps: الاعدل من.

1492 One word erased.

1493 Added by 'Azzāwī.

1494 'Azzāwī, NLA, t. 1, 516-517.

${ }^{1495}$ Apparently missing bi-hā. 
the condition of your elites and masses is renewed. This is why, for the charge of judgeship among you, we have appointed Fulā

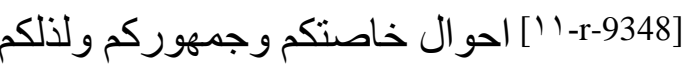

اخترنا اءلان لخطة القضاءِ بينكم فلانا

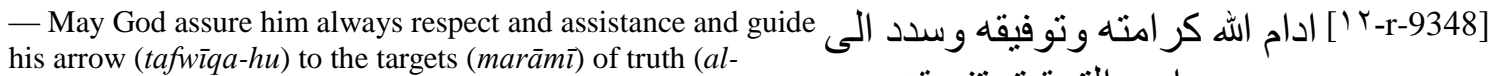
tahqi $q$ ). He is

مر امى التحقيق تفويقه و هو

someone who has been employed numerous times in this

capacity and in whom we have recognized competence and a

sense of responsibilities in the

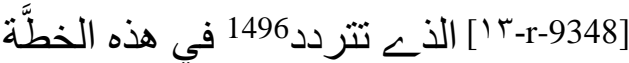

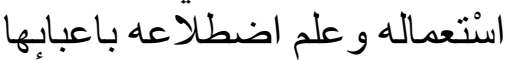

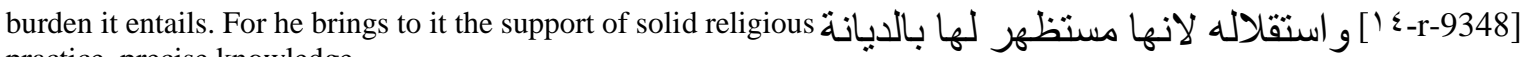

practice, precise knowledge,

المتينة و المعرفة المعينة

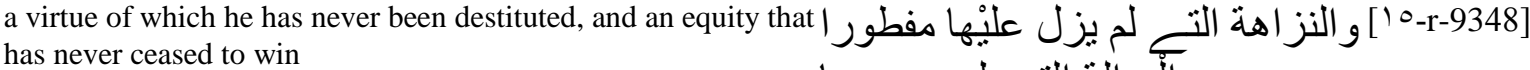

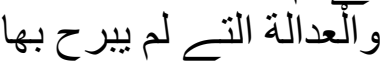

him praise. And, in addition to the fact that he is diligent in reciting the Book of God day and night and that he is known

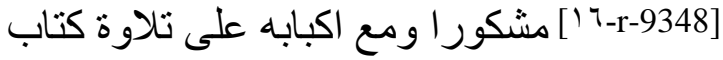

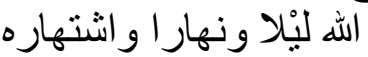

to scrupulously follow Tradition and to never stray from it, neither to the left nor the right, he has received from us the finest counsel ${ }^{1497}$

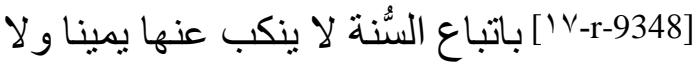

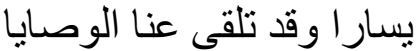

to fear God - May He be glorified and magnified - and he has understood. He has recognized and verified with certitude

[1/l-r-9348] البالغة بتقوى الله عز وجلَّ وتلقن

وتحقق ان مذهبنا العدل في الرعا

that our method is equity for [our] subjects. And he, with the help of God on High, he will commit to the clearest path of the Law in the decrees he issues for you

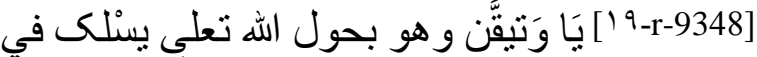

احكامكم سنن الثُريعة الابين

and he will consider what the positive verses and traditions say

concerning all your affairs; he will accept as instrumentary witnesses

[-r-9348-r-r] ويعتبر في جميع قضاياكم الايات

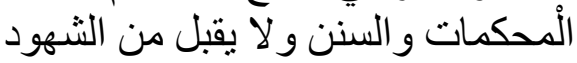

only [those men] whose obvious impartiality raises them above all doubt and suspicion. We have also given him the order that we give

[بr-r-9348]

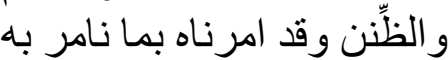

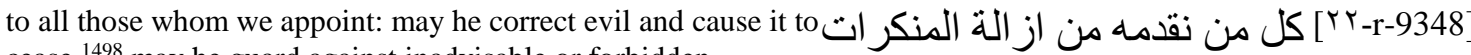

cease,${ }^{1498}$ may he guard against inadvisable or forbidden

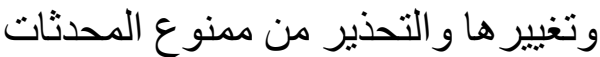

Innovations, ${ }^{1499}$ may he pronounce the law without fearing

blame nor considering the protections that an

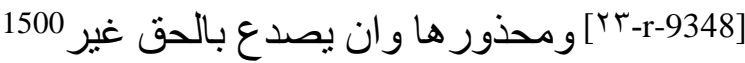

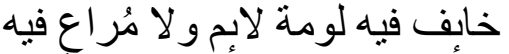

oppressor [may enjoy], may he see only, when issuing a judgment, the reward [that will be] in the hands of

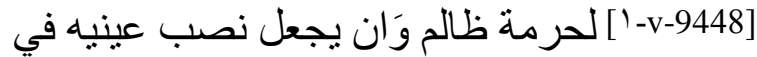

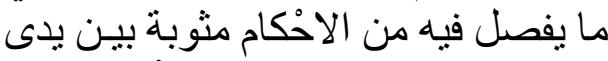

God - May he be exalted and magnified - on the day of

Judgment, and may he obey His order when the Highest - may

He be glorified - said: "when you judge

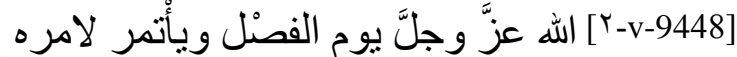

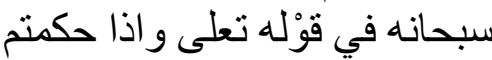

between man and man, judge with justice," ${ }^{1501}$ following in all

of this the clearest path and the best

[־-v-9448] بيـن الناس ان تحكمو ا بالعدْل 1502 سَالكا

في ذلك كُله على اوضنح السُّبل ورأَحْسَن

\footnotetext{
1496 'Azzāwī corrects with تردد.

1497 Lit. "that reaches [its goal]."

1498 Reverse gradation.

1499 Reverse gradation.

1500 Word completed by 'Azzāwī.

1501 Koran 4:48.

1502 Koran 4:58.
} 


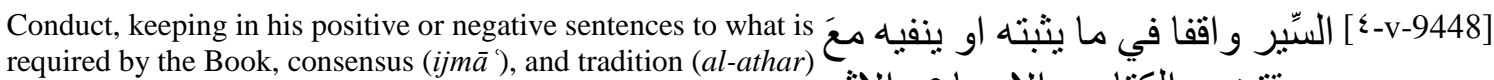

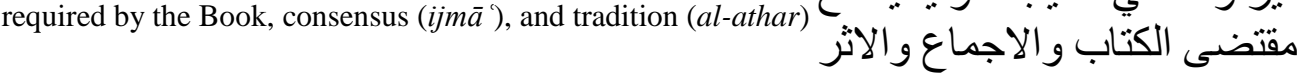

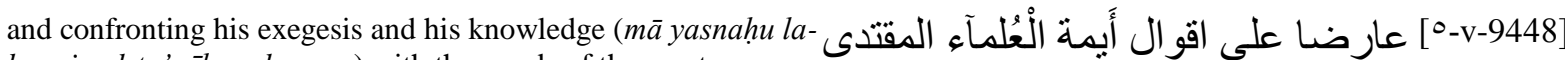
hu min al-ta'wīl wa-l-nazar) with the words of the great scholars, those who serve as examples.

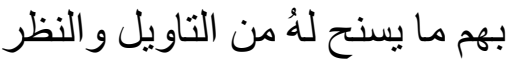

Thus, when with the will of God on High he arrives among you, فاذا و افاكم بمشيئة الله تعلى فالقو ا اليْهة offer him the reins of your judgments; submit

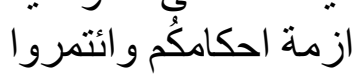

to all the measures he takes to resolve your differences; be as one hand untied with him in coming together

[V-v-9448]

وكونو ا معه يدا و احدة باتفاقكم

and agreeing on the service of the law; commit yourselves to obeying him and conforming perfectly [to his orders] for all you affairs that

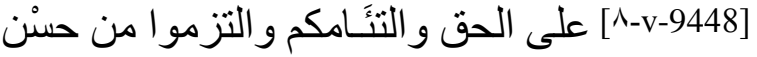

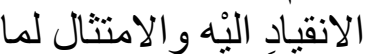

we have entrusted to him, a commitment the consequences of which will clearly appear.

If God on High wills it. And He

[9-v-9448] قصدناهُ من اموركم عليّه ما يظهر فيه

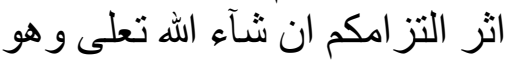

— May He be glorified - He will lead you, you and him, from سبحانه يحملكم و اياهُ على الطريقة

beginning to end, along the exemplary path, and He will facilitate

[the accomplishment] of good works, but not those that are unacceptable. By His grace.

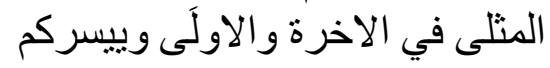

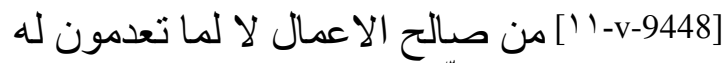

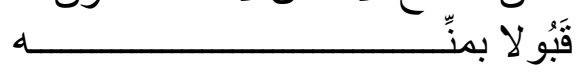

Taqdīm 77: Fragment of a judicial appointment ${ }^{1503}$

$$
\text { الحمد لله وحده }
$$

Appointment

May God have written for you security that spreads over all of your lands and a happiness that accompanies you in all circumstances and at all

Times. Know that your affairs receive from us profound attention and care, that they enjoy

at all times our total benevolence, and that we use to take care of them one who distinguishes himself in our presence by [his]

capabilities (bi-l-ittila $\left.\bar{a}^{\prime}\right)$ and [his] competence, in particular to [exercise] the office of judge in the case of differences, and to decide,

in accordance with the Law, in new juridical affairs. We will thus designate for this someone designated by his virtue and

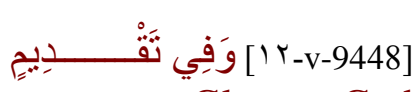
Glory to God alone

] [1\%-v-9448] كتب اله لكم امنًا يَعُدٌ جميع اوطانكم ويمْنًا بصحبكم في كل احْو الكُم و احيا

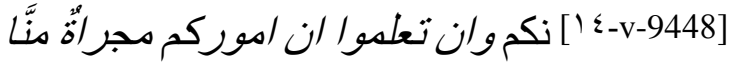
بيال الأْتمام والا عتناء ودوفاة

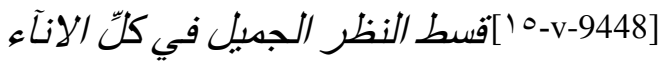

ومنتتعدل فيهَا من بتمبزيز لدبنيا بالا

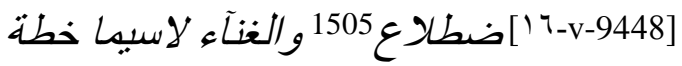

القضاء في نوازل الخصام والفصل

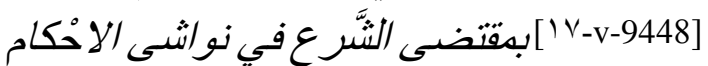

فاذا نقدِّم لذلّى من قدمه زو كاؤه

decency ( $a f a \bar{f} u$-hu); without setting aside for all that one in whom we have sensed - and recognized - qualities and character; and this to fully accomplish فُ1/1-v-9448]

1503 'Azzāwī, NLA, t. 1, 517.

${ }^{1504}$ Almohad inscription added next to the title in the same color but much finer, omitted by 'Azzāwī.

1505 'Azzāwī: بالاطّّلا. 
the choice and selection required by this responsibility, ${ }^{1506}$ and to judge as worthy of this appointment people of purity

and devotion. We ask of God, our master, that in this choice made for our subjects, He continue to accompany us with His help and His

Guidance, and that He make us one of the [agents] who establish the law of God - May He be exalted and magnified - in the interests of His servants.

After having asked of God on High the authority ( $f \grave{i} l-\bar{i} r \bar{a} d i$ wa-lișdār $\bar{\imath}$ ) for this and having asked for the gift of His

guidance in our government of the regions and districts, near and far, we have seen fit to appoint... [9-v-9448 19 ] تلكم الخطيَّة واجب التخيُّر والانتقاء ونو هل لتوليها اهل اجل النَّقاء

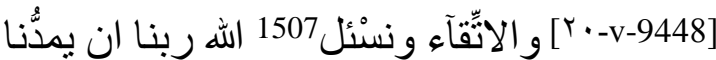
بالاختيار للر عايا بتوفيقه وتسد

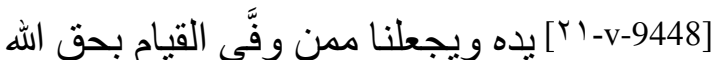
عز وجل في مصسالح عبيده وقد وند

[ ] ر اينا بعد تقديم استخارة الله تعلى في

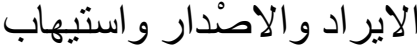

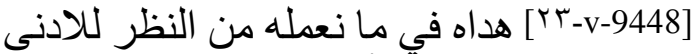
و الاقصنى من الْجهات و الانظلار ان نقدم هن

1506 Or: "to acquit ourselves concerning this charge (al-khutta) of obligation of the obligations of choosing and selecting".

1507 'Azzāwī: ونسأل 
Governing the Empire

Annexes 
Governing the Empire

\section{Annex 1: The Almohad Caliphs}

1- 'Abd al-Mu'min (1130 in the Maghrib, 1145 in al-Andalus, 1163)

2- Abū Ya qūb Yūsuf (1163-1184)

3- Abū Yūsuf Ya qūb al-Manșūr (1184-1199)

4- Abū 'Abd Allāh al-Nāṣir (1199-1213)

5- Abū Ya 'qūb al-Mustanșir (1213-1224)

6- Abū Muḥammad 'Abd al-Wāḥid b. Yūsuf I al-Makhlū' (1224, 8 months).

7- Abū Muḥammad 'Abd Allāh al-' Ādil (621/1224-624/1227)

8- Abū Zakariyyā' Yaḥyā b. al-Nāṣir al-Mu tașim (1227-1229)

9- Abū l- 'Alā' al-Ma'mūn (1227-629/1232), last Almohad ruler in al-Andalus

10- 'Abd al-Wāḥid al-Rashīd (629/1232-640/1242)

11- 'Alī Abū l-Ḥasan al-Mu' taḍid bi-Llāh al-Sa '̄id (640/1242-646/1248)

12- 'Umar al-Murtaḍá (646/1248-665/1266)

13- Idrīs Abū l- 'Ulá Abū Dabbūs al-Wāthiq (665/1266-668/1269) 
Annex 2: Periods of war and truce with the Christian kingdoms of the Iberian peninsula

\begin{tabular}{|c|c|c|}
\hline Dates & Treaties & Comments \\
\hline 1149 & $\begin{array}{l}\text { Peace treaty between Aragon and Ibn } \\
\text { Mardanīsh. Lasts ten years. }\end{array}$ & \\
\hline $\begin{array}{c}566 / 1170- \\
1171\end{array}$ & $\begin{array}{l}\text { Renewal of treaties with León at Zallāqa near } \\
\text { Badajoz (according to the Bayān). }\end{array}$ & $\begin{array}{l}\text { Muhammad Ibn Wazìr was the Almohad } \\
\text { ambassador. }\end{array}$ \\
\hline 1173 & $\begin{array}{l}\text { Castile and Portugal sue for peace. } 5 \text { years are } \\
\text { granted to Portugal, } 2,4 \text {, or } 5 \text { to Castile } \\
\text { (because of famines on both sides of the border). }\end{array}$ & $\begin{array}{l}\text { War with León (1173-78). The Almohads } \\
\text { take Cáceres and Alcántara. Giraldo } \\
\text { Sempavor enters the service of the } \\
\text { Almohads. }\end{array}$ \\
\hline 1178 & $\begin{array}{l}\text { End of the truce with Portugal who raids Seville } \\
\text { in } 1178 . \\
\text { Treaty with León until } 1183\end{array}$ & $\begin{array}{l}\text { Siege of Cuenca by Castile and Aragon } \\
(1177) .\end{array}$ \\
\hline $577 / 1183$ & $\begin{array}{l}\text { León breaks its traditional alliance and attacks } \\
\text { Cáceres }\end{array}$ & \\
\hline $1190->1195$ & $\begin{array}{l}\text { The caliph accepts treaties with Castile and } \\
\text { renews the peace with León }\end{array}$ & Almohad attack on Portugal \\
\hline 1191 & \multicolumn{2}{|c|}{ Treaties with Portugal after retaking Torres-Nova, Alcacer do Sal and Silves } \\
\hline 1195 & \multicolumn{2}{|c|}{ Refusal of Castilian peace proposal. Offensive alliance with León } \\
\hline 1197 & \multicolumn{2}{|l|}{ Peace treaties accepted with Castile and León } \\
\hline $\begin{array}{c}600 / 1203- \\
1204\end{array}$ & Treaties renewed & \\
\hline $\begin{array}{l}\text { 611/March } \\
1214-1215\end{array}$ & Treaties with Castile after Las Navas de Tolosa & \\
\hline $\begin{array}{c}\text { 618/February } \\
1221-1222\end{array}$ & Renewal under al-Mustanșir & \\
\hline 1228 & $\begin{array}{l}\text { Almohad treaty with Fernando III and caliphal } \\
\text { departure for Africa. }\end{array}$ & $\begin{array}{l}\text { End of the Almohad presence in the Iberian } \\
\text { peninsula. }\end{array}$ \\
\hline 1241 & Treaties broken by Ibn al-Aḥmar & $\begin{array}{l}\text { Al-Aḥmar tries to take Martos and Andújar } \\
\text { (1241). }\end{array}$ \\
\hline
\end{tabular}


Annex 3: List of governors inventoried in the narrative sources by 'Izz al-Dīn Mūsá (12241269)

\begin{tabular}{|c|c|c|c|c|c|c|}
\hline Gouvernorship\Caliphs & $\begin{array}{l}\text { Abd al-Wāḥid } \\
\text { b. Yūsuf I }\end{array}$ & $\begin{array}{c}\text { Al-' Ādil b. al- } \\
\text { Manșūr }\end{array}$ & $\begin{array}{l}\text { Al-Ma'mūn } \\
\text { b. al-Manșūr }\end{array}$ & Al-Rashīd & Al-Sa'īd & Al-Murtaḍá \\
\hline $\begin{array}{l}\text { Ifrīqiya } 1 . \text { The sayyid } \\
\text { Abū l-'Alā' } \\
\text { 2. his son } \\
\text { the sayyid Abū Zayd }\end{array}$ & $\begin{array}{l}\text { Abū b. Ab̄̄ } \\
\text { Muhammad b. al- } \\
\text { shaykh Abī Hafṣ al- } \\
\text { Hintātī }\end{array}$ & & & & & Cordova \\
\hline Sayyid Idrīs b. al-Manșūr & $\begin{array}{l}\text { The sayyid } \\
\text { 'Abd Allāh al-Bayāsī } \\
\text { then attached to } \\
\text { Seville }\end{array}$ & Sayyid Abū 1-rabī' & & & & Granada \\
\hline $\begin{array}{l}\text { Sayyid Abū l-Hasan b. al- } \\
\text { Manșūr }\end{array}$ & & & & & & Seville \\
\hline Sayyid 'Abd Allāh al-Bayāsī & $\begin{array}{l}\text { ÎtAbū l-'Alā' Idrīs al- } \\
\text { Ma'mūn }\end{array}$ & & & & & Malaga \\
\hline $\begin{array}{l}\text { Sayyid al-Hạan b. al- } \\
\text { Manșūr }\end{array}$ & & & & & & Murcia \\
\hline $\begin{array}{l}\text { Sayyid Abū Muhammad } \\
\text { b. al-Manșūr }\end{array}$ & $\begin{array}{l}\text { Sayyid 'Īsá b. Ab̄̄̄ } \\
\text { Mūsá b. 'Abd al- } \\
\text { Mu'min }\end{array}$ & & & & & Valencia \\
\hline $\begin{array}{l}\text { Sayyid Abū Zayd } \\
\text { b. Abī 'Abd Allāh al-Bayāsīi }\end{array}$ & $\begin{array}{l}\text { Sayyid Abū Zayd } \\
\text { b. Ab̄̄ 'Abd Allāh al- } \\
\text { Bayāsī }\end{array}$ & & & & & Jaén \\
\hline \multirow{2}{*}{$\begin{array}{l}\text { 1. Sayyid Abū Muhammad } \\
\text { b. Abī 'Abd Allāh al-Bayāsī } \\
\text { 2. Sulaymān b. Abī Hafș } \\
\text { 'Umar b. 'Abd al-Mu'min } \\
\end{array}$} & $\begin{array}{l}\text { 'Umar b. 'İsá b. Abī } \\
\text { Hafṣ b. Yaḥyā }\end{array}$ & & & & & Bougie \\
\hline & $\begin{array}{l}\text { 1. Ibn Yaghmūr } \\
\text { 2. Yahyā b. al-Ațās } \\
\text { al-Tinmālī }\end{array}$ & $\begin{array}{l}\text { Sayyid Abū 'Umrān } \\
\text { b. Ab̄̄ 'Abd Allāh } \\
\text { al-Harạāānī Ibn al- } \\
\text { Ațās }\end{array}$ & & & & Ceuta \\
\hline \multirow[t]{11}{*}{$\begin{array}{l}\text { Abū Ishāa Ibrāhīm b. Idrīs } \\
\text { b. Abī Isḥāq b. Jāmi }\end{array}$} & & $\begin{array}{l}\text { Sayyid Abū Mūsá b. } \\
\text { al-Manșūr }\end{array}$ & $\begin{array}{l}\text { Abū 'Alī } \\
\text { b. Khallāṣ al- } \\
\text { Balansī }\end{array}$ & & & Fez \\
\hline & & $\begin{array}{l}\text { Muhammad b. Abī } \\
\text { Zayd b. Yūjān }\end{array}$ & $\begin{array}{l}\text { Abū 'Abd Allāh } \\
\text { b. Wanūddīn }\end{array}$ & & & Tlemcen \\
\hline & & $\begin{array}{l}\text { Muhammad b. Abī } \\
\text { Zayd b. Yūjān }\end{array}$ & & & & Mallorca \\
\hline & & $\begin{array}{l}\text { Abū Yahyā } \\
\text { Muhammad b. 'Alīi } \\
\text { b. Ab̄̄ 'Umrān }\end{array}$ & & & & Salé \\
\hline & & & $\begin{array}{l}\text { Sayyid Abū l- } \\
\text { 'Alā' gendre } \\
\text { d'al-Rashīd }\end{array}$ & $\begin{array}{l}\text { Abū Hafș 'Umar (al- } \\
\text { Murtaḍa) }\end{array}$ & $\begin{array}{l}\text { Muhammad } \\
\text { b. Abīì Ya lá al- } \\
\text { Kūmī }\end{array}$ & Sijilmāssa \\
\hline & & & $\begin{array}{l}\text { 1. Abū Ya'qūb } \\
\text { Yūsuf b. 'Alī } \\
\text { b. Yūsuf } \\
\text { 2. 'Abd Allāh } \\
\text { b. Zakariyā al- } \\
\text { Hazrājīi }\end{array}$ & $\begin{array}{l}\text { 1. 'Abd Allāh } \\
\text { b. Zakariyā al- } \\
\text { Hazrājī } \\
\text { 2. Abū Zayd 'Abd } \\
\text { al-Raḥmān b. Ab̄̄ } \\
\text { Zakariyā al-Ğadmīwì }\end{array}$ & $\begin{array}{l}\text { Abū } \\
\text { Muḥammad } \\
\text { 'Abd al-Ḥaquq } \\
\text { al-Ğanfīsī }\end{array}$ & Sūs \\
\hline & & & $\begin{array}{l}\text { Sayyid Abū } \\
\text { Muhammad } \\
\text { b. Abī Zakariyā } \\
\text { b. Abī Ibrāhīm }\end{array}$ & & Ibn Yidir & Dar'a \\
\hline & & & $\begin{array}{l}\text { Abū } \\
\text { Muhammad } \\
\text { b. Wanūddīn }\end{array}$ & & & Tāzā \\
\hline & & & & $\begin{array}{l}\text { Sayyid Abū 'Alī } \\
\text { b. Muhamammad } \\
\text { b. 'Umar b. 'Abd al- } \\
\text { Mu'min }\end{array}$ & $\begin{array}{l}\text { Sayyid Abū 'Alī } \\
\text { b. Muhammad } \\
\text { b. 'Umar } \\
\text { b. 'Abd al- } \\
\text { Mu'min }\end{array}$ & Azemmūr \\
\hline & & & & Ibn Māksin & Ibn 'Ațūs & Aghmāt \\
\hline & & & & $\begin{array}{l}\text { Abū Hafș 'Umar (al- } \\
\text { Murtaḍa) before Salé }\end{array}$ & & \\
\hline
\end{tabular}


Annex 4: List of principal $k u t t a ̄ b$ from al-Mustanșir to al-Wāthiq

\begin{tabular}{|c|c|c|}
\hline Caliph & Name of $k \bar{a} t i b$ & Geographic origin \\
\hline Al-Mustanșir & $\begin{array}{l}\text { Muḥammad b. 'Abd al-Raḥmān b. 'Ayyāsh } \\
\text { Abū l-Hasan 'Alī b. 'Ayyāsh b. 'Abd al-Malik b. 'Ayyāsh } \\
\text { Muḥammad b. Yakhlaftān al-Fāzāzī } \\
\text { Aḥmad b. Muhammad b. 'Abd al-Raḥmān b. 'Ayyāsh }\end{array}$ & $\begin{array}{l}\text { al-Andalus } \\
\text { Cordova } \\
\text { Maghrib } \\
\text { al-Andalus }\end{array}$ \\
\hline 'Abd al-Wāḥid & $?$ & \\
\hline Al-'Ādil & $?$ & \\
\hline Al-Mu tașim & Abū l-Hasan al-Saraqusțī & Al-Andalus \\
\hline Al-Ma'mūn & $\begin{array}{l}\text { Abū Zakariyā al-Fāzāzī } \\
\text { Abū 'Abd Allāh b. 'Ayyāsh } \\
\text { Abū l-'Abbās b. 'Umrān } \\
\text { etc. }\end{array}$ & $\begin{array}{l}\text { Maghrib } \\
\text { al-Andalus } \\
\text { al-Andalus }\end{array}$ \\
\hline Al-Rashīd & 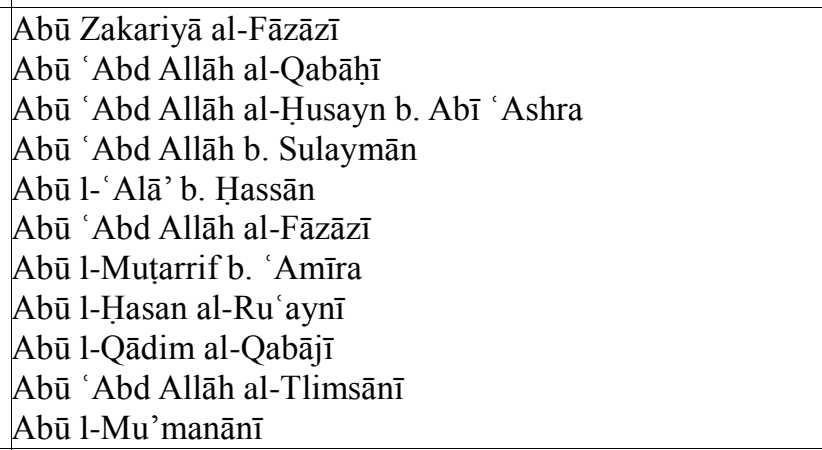 & $\begin{array}{l}\text { Maghrib } \\
\text { Maghrib } \\
\text { Maghrib } \\
\text { Maghrib } \\
\text { Maghrib } \\
\text { Maghrib } \\
\text { al-Andalus } \\
\text { al-Andalus } \\
\text { al-Andalus } \\
\text { Tlemcen } \\
\text { al-Andalus }\end{array}$ \\
\hline $\mathrm{Al}-\mathrm{Sa} \overline{1} \mathrm{~d}$ & $\begin{array}{l}\text { Abū l-Hasan al-Ru'aynī } \\
\text { Abū 'Abd Allāh al-Tlimsānī } \\
\text { Abū Bakr al-Fāzāzī } \\
\text { etc. }\end{array}$ & $\begin{array}{l}\text { Al-Andalus } \\
\text { Tlemcen } \\
\text { Maghrib }\end{array}$ \\
\hline Al-Murtaḍá & $\begin{array}{l}\text { Abū l-Hasan al-Ru'ayn̄̄ } \\
\text { Abū 'Abd Allāh al-Ru'ayn̄̄ } \\
\text { etc }\end{array}$ & $\begin{array}{l}\text { Al-Andalus } \\
\text { Tlemcen }\end{array}$ \\
\hline Al-Wāthiq & $\begin{array}{l}\text { Abū l-Hasan al-Ru'ayn̄̄ } \\
\text { Abū 'Abd Allāh al-Ru'ayn̄̄ } \\
\text { etc }\end{array}$ & $\begin{array}{l}\text { Al-Andalus } \\
\text { Tlemcen }\end{array}$ \\
\hline
\end{tabular}


Governing the Empire

Bibliography 
Governing the Empire

Primary Sources 


\section{Governing the Empire}

\section{Manuscripts}

Al-Balawī, Al- 'aṭā' al-jaz̄̄l, Hasaniyya Library in Rabat, manuscript 6148.

\section{Archivio di Stato di Pisa}

Atti Pubblici - dipl.cartaceo 1181 aprile $23(14,5 \times 20 \mathrm{~cm})$, edited by Michele Amari, Diplomi arabi del R. archivo fiorentino, Florence, 1863, Seconda Serie, n. 13, 269.

Atti Pubblici - Diplomatico cartaceo 1200 settembre 11, dimension $42 \mathrm{~cm}$ x 19,5 cm; edited by Michele Amari, Diplomi, 33-35, I serie, n. IX ; NLA, 215-216, letter 47 ; the Latin version (edited by Michele Amari, Diplomi, 278-279, II serie, n. XIX) is absent from the Pisan Archives catalogue.

Atti Pubblici - Diplomatico cartaceo 1200 settembre 9, dimension $38 \mathrm{~cm}$ x $25 \mathrm{~cm}$ (edited by Michele Amari, Diplomi, 23-28, I serie, n. VI) ; NLA, 212-214, letter 46 ; Latin version, Atti Pubblici - Diplomatico cartaceo 1200 settembre, dimension 30,5 cm x $21 \mathrm{~cm}$ (edited by Michele Amari, Diplomi, 276-277, II serie, n. XVIII).

Atti Pubblici - Diplomatico cartaceo 1201 giugno 4, dimension $23 \mathrm{~cm}$ x $21 \mathrm{~cm}$; edited by Michele Amari, Diplomi, 43-44, I serie, n.XII ; NLA, 222-223, letter 51.

Atti Pubblici - Diplomatico cartaceo 1202 marzo 23, dimension $40 \mathrm{~cm}$ x 21,5 cm ; edited by Michele Amari, Diplomi, 65-71, I serie, n. XXI ; éd. 'A. al-H. TAZI, 202-205 ; NLA, 226-228, letter n. 53.

Atti Pubblici-dipl.cartaceo, 1181 luglio 1 e 1182 maggio 19 (75x27 cm), Latin parts edited by Michele Amari, Diplomi, Seconda Serie, n. 14, p. 270 (19 mai 1181, erroneously for 19 mai 1182) ; Arabic parts edited by Michele Amari, Diplomi, Prima Serie, n. 3, p. 10-13, dated July $1^{\text {st }} 1182$, though the Pisan Archives catalogue lists 1181 ; NLA, n. 33, 165-166.

Atti Pubblici - dipl.cartaceo, 1182 aprile $23(41 \times 27 \mathrm{~cm})$, edited by Michele Amari, Diplomi, Prima Serie, n. 2, 7-9 ; NLA, n. 32, 163-164.

Comune di Pisa div.A n.80, ins.4: 1201 maggio 27, dimension $31 \mathrm{~cm}$ x $21 \mathrm{~cm}$ (edited by Michele Amari, Diplomi, 38-42, I serie, n. XI) ; NLA, 220-221, letter n. 50. An approximate French translation of this text is in Bresc et alii, La Méditerranée, 113-114, n. 52.

Comune di Pisa div.A n.80, ins.5: 1201 giugno 5, dimension $28 \mathrm{~cm}$ x $20 \mathrm{~cm}$; edited by Michele Amari, Diplomi, 45-47, I serie, n. XIII ; NLA, 224-225, n. 52.

Yaḥyā al-Khadhūj, Hasaniyya Library in Rabat, manuscript 4752

\section{Published}

'Abd al-Karīm, Gamal (trans.). La España musulmana en la obra de Yāqūt (s. XII-XIII). Repertorio enciclopédico de ciudades, castillos y lugares de al-Andalus, extraídos del Mu yam al-Buldān. Cuadernos de Historia del Islam 6. Granada, 1974.

'Abd al-Razzāq, see Al-Ṣan' ānī.

Abū Dāwūd. Al-Marāsīl, edited by Sayrawān. Beirut: Dār al-qalam, 1986.

Abū Dāwūd. al-Sunan. Ryad: al-Ma'ārif, 2000.

Al-Baghawī. Sharh al-Sunna. 16 vols. Edited by Shu 'ayb al-Arnā'ūṭ and Zuhayr al-Shāwish. DamascusBeirut: al-maktab al-islāmī, 1983 [2 ${ }^{\text {nd }}$ ed.].

Al-Bayḥaqī. al-Sunan al-kubrā. 10 vols. Edited by 'Abd al-Salām 'Allūsh, Ryad: Maktabat al-rushd, 2004. Al-Dārimī. al-Sunan. 2 vols. Edited by Musțafa al-Baghā. Damascus, 1996.

Al-Ghubrīn̄i. Abū l-'Abbās Aḥmad b. Aḥmad b. 'Abd Allāh, 'Unwān al-dirāyat fì man 'urifa min al- 'ulamāa' al-mā'it al-sābi 'a fì Bajāya. Algiers: Mațba' at al-tha'ālibiyya, 1328/1910.

al-Ghāfiqī al-Qabtūrī. Khalaf, Rasā'il dīwāniyya min Sabta fĩ l- 'ahd al- 'Azafĩ. Edited by M. al-Hayla, Rabat, 1979. 
Al-Ḥimyarī, Ibn 'Abd al-Mun im (d. 1326). La péninsule ibérique au Moyen Âge d'après le Kitāb al-Rawḍ al-Mi' țār fī akhbār al-Aqțār d'Ibn 'Abd al-Mun 'im al-Himyarī. Edition, French translation and glossary by É. Lévi-Provençal, Leiden (Publications de la "Fondation de Goeje", 12): E. J. Brill, 1938.

al-Idrīsī. Description de l'Afrique septentrionale et de l'Espagne texte arabe extrait du Kitāb Nushat al-mushtāq fi ikhtirāq al-afāq, edtion and French translation by R. Dozy and de Goeje, 1866 (re-edited by H. Pérès, Algiers: La maison du Livre, 1957).

Al-Maqqarī al-Tilimsān̄̄, Aḥmad b. Muḥammad (d. 1014/1631). Analectes sur l'histoire et la littérature arabes d'Espagne. 2 vols. Edited by R. Dozy, G. Dugat, L. Krehl and W. Wright. Amsterdam: Oriental Press, 1967.

Al-Maqqarī al-Tilimsānī, Ạ̣mad b. Muḥammad. Nafḥ al-țīb min ghusn al-Andalus al-rațīb wa dhikr waz̄̄frihä Lisān al-Dīn b. al-Khațīb. 10 vols. Edited by M. Qāsim Ṭawīl and Y. 'A. Ṭawīl. Beirut: Dār al-kutub al'ilmiyya, 1995.

Al-Marrākushī, 'Abd al-Wāḥid. Kitāb al-mu jỉb fì talkh̄̄s akhbār al-Maghrib, edited by R. Dozy. Leiden, 1881 (re-edition Amsterdam: Oriental Press, 1968).

Al-Marrākushī, 'Abd al-Wāḥid. Lo admirable en el resumen de las noticias del Maghrib, Spanish translation by Ambrosio Huici Miranda. Tétouan (Colección de crónicas árabes de la Reconquista, t. 4), 1955.

Al-Marrākushī, Ibn 'Abd al-Malik. Al-dhayl wa-l-takmila. 2 vols. Edition by I. 'Abbās. Beirut: Dār althaqāfa, 1973.

Al-Māwardī. al-Aḥkām al-Ṣulțāniyya wa-l-wilāyāt al-dīniyya. Beirut: Dār al-kutub al- ilmiyya, s.d.

Al-Nasā'ì. Al-Sunan. Ryad: al-Ma'ārif, 2000.

Al-Nāṣirī, Aḥmad b. Khālid. Kitāb al-istiqșā li-akhbār duwal al-Maghrib al-Aqșá, t. 3, "Les Almohades," French translation by I. Hamet. Paris: Honoré Champion (Archives marocaines, 22), 1927.

Al-Nawāwī. al-Minhāj sharḥ ṣaḥ̣̣̄ Muslim ibn al-Ḥajjāj. 18 vols. Beirut: Dār al-ma rifa, 1999 [cited Muslim, Șahīh].

Al-Qalqashandī. Șubḥ al-a 'shā fì șinā 'at al-inshā'. 14 vols. Cairo, 1913-1920.

Al-Ṣan'ān̄i, 'Abd al-Razzāq. Al-Muṣannaf. 11 vols. Beirut: al-Maktab al-Islāmī, 1987 [cited 'Abd alRazzāq].

Al-Tādilī, Abū Ya qūb Yūsuf b. Yaḥyá Ibn al-Zayyāt. Tashawwuf ilá rijāl al-taṣawwuf, edited by A. alTawfīq. Rabat: Presses de l'Université Mụ̣ammad V, 1984.

Al-Tādilī, Abū Ya 'qūb Yūsuf b. Yaḥyá Ibn al-Zayyāt. Regards sur le temps des soufis. Vie des saints du sud marocain des $V^{e}, V^{e}$, VII siècles de l'hégire. Casablanca: Eddif-Unesco, 1995.

Al-Tirmidhī. Al-Sunan. Ryad: al-Ma'ārif, 2000.

Al-Tujībī al-Ru 'aynī. Barnamaj, edited by 'Abd al-Ḥāfiz Manṣūr. Tunis, 1981.

Amari, Michele. Diplomi Arabi dell' archivio fiorentino. 2 vols. Florence, 1863-1867.

'Azzāwī, Aḥmad. Rasā̄il muwaḥhidiyya. Majmū' 'a jadīda (Nouvelles lettres almohades). Kénitra: Université Ibn Tofayl, 1995 [NLA].

'Azzāwī, Aḥmad. Rasā'il dīwāniyya muwaḥhidiyya. Rabat, 2006 [NLA, t. 2].

'Azzāwī, Aḥmad. al-Gharb al-islāmī (khilāl al-qarnayn 7 wa 8 H.). Fatrat al-inqisām al-siyā̄ī (620670H/1223-1272). 4 vols. (t. 1). Rabat, 2006.

Bruno, Henri and Maurice Gaudefroy-Demombynes, ed. and trans. Le livre des Magistratures (Kitāb alwilāyāt) d'el Wancherisi. Rabat: F. Moncho, 1937.

Buḥārī. al-Jāmi al-ṣaḥịh. 8 vols. Beirut: Dār al-ṭawq wa al-najāṭ̂, 1422/2001.

Canard, Marius, trans. Vie de l'ustadh Jaudhar (contenant sermons, lettres et rescrits des premiers califes fâtimides) écrite par Mansûr le secrétaire à l'époque du calife al-'Aîzz billâh (365-386/975-996). French translation of the Arabic edition by Kāmil Hụsayn and 'Abd al-Hādī Sha īra. Algiers: Publications de l'Institut d'Études Orientales de la Faculté des Lettres d'Alger, II 'Série, tome XX, 1958.

Finkel, Joshua, ed. Thalāthat rasā'il. Cairo, 1926, 40-51.

Hamidullah, Muhammad, and Michel Léturmy, trans. Le Saint Coran. Paris: Club français du livre Malakoff, impr. P. Dupont, 1959.

Hīla, M.H., ed. Rasā'il diwāniyya min Sabta fì l- 'ahd al- 'Azafí. Rabat, 1979.

Ibn 'Abd al-Barr al-Mālikī. Jāmi' bayān al- 'ilm wa fạ̣li-hi. 2 vols. Dammām: Dār Ibn al-Jawzī, 1997. 
Ibn 'Abdūn. "Un document sur la vie urbaine et les corps de métiers à Séville au début du XII ${ }^{\mathrm{e}}$ siècle: Le traité d'Ibn 'Abdūn.” Ed., introduction and glossary É. Lévi-Provençal. Journal asiatique 224 (1934): 177. 299.

Ibn 'Abdūn. Sevilla a comienzos del siglo XII. El tratado de Ibn 'abdūn. Spanish translation by Évariste LéviProvençal and Emilio García Gómez. Madrid: Moneda y crédito, 1948 (facsimile re-ed. 1998).

Ibn Abī Zar', Abū-l-Ḥasan 'Alī b. 'Abd Allāh al-Fāsī. Raw d al-qirțās. 2 vols. Spanish translation by Ambrosio Huici Miranda. Valencia (Textos Medievales, 12-13), 1964.

Ibn Abī Zar', Abū-l-Ḥasan 'Alī b. 'Abd Allāh al-Fāsī. al-Anīs al-muṭib bi-raw ḍ al-qirṭās fì akhbār mulūk al-Maghrib wa tārīkh madīnat Fās. Rabat: Dār al-Manșūr li-l-țabā'a wa-l-wāriqa, 1972.

Ibn al-Abbār. Al-takmila. t. 2. Edited by 'Abd al-Salām al-Harrās. Casablanca: Dâr al-Ma'rifa, s.d.

Ibn al-Abbār. Kitāb al-ḥullat al-siyarā’’ 2 vols. Edited by Ḥusayn Mu'nis. Cairo, 1963-1964.

Ibn al-Athīr. Al-Kāmil fĩ al-tārīkh. t. 9. Edited by Tornberg. Beirut: Dār Sādir, s.d.

Ibn al-Khatīb. Al-Iḥāta fì akhbār Gharnāṭa. 4 vols. Edited by Muḥammad 'Abd Allāh 'Inān. Cairo, 1973 1977.

Ibn al-Kardabūs. "Tarīkh al-Andalus l-Ibn al-Kardabūs wa wașfu-hu l-Ibn al-Shabbāt. Nașșān jadīdān," edited by A. M. al-' Abbâdī. Revista del Instituto de Estudios Islámicos de Madrid 13 (1965-1966): 7-126.

Ibn al-Kardabūs. Historia de al-Andalus. (Kitâb al-Iktifâ'). Spanish translation by Felipe Maíllo Salgado. Madrid: Akal, 1986.

Ibn al-Qaț̣̄ān. Abū Muḥammad Ḥasan b. 'Alī b. Muḥammad b. 'Abd al-Malik al-Kutāmī al-Marrākushī. "Six fragments inédits d'une chronique anonyme du début des Almohades," edited by Évariste LéviProvençal. In Mélanges René Basset. t. 2, 335-393. Paris, 1925.

Ibn al-Qațțān, Abū Muḥammad Ḥasan b. 'Alī b. Muḥammad b. 'Abd al-Malik al-Kutāmī al-Marrākushī. Nażm al-jumān li-tartīb mā salafa min akhbār al-zamān, edited by Mạ̣mūd 'Alī Makkī. Tétouan, 1964 (reed. Beirut: Dār al-Gharb al-Islāmī, 1990).

Ibn al-Zubayr. Kitāb șilat al-ṣila. 3 vols. Edited by 'Abd al-Salām al-Ḥarrās and S. A'rāb. Morocco: Ministère des Awqāf, 1993-1995.

Ibn Balabbān. Șaḥịh Ibn Ḥibbān bi-tartīb Ibn Balabbān. 18 vols. Beirut: Al-risāla, 1997 [cited Ibn Ḥibbān]. Ibn Khaldūn. Histoire des Berbères. 4 vols. French translation by de Slane. Algiers, 1847-1851 (re-ed. Paris: Geuthner, 1927).

Ibn Khaldūn. Kitāb al- 'ibar wa dīwān al-mubtada'wa-l-khabar. 8 vols. Edited by Kh. Shihāda and S. Zakkār. Beirut: Dār al-kitāb al-lubnān̄̄, 1959 [1988].

Ibn Khaldūn. Muqaddima, edited by D. al-Juwaydī. Beirut: al-Maktaba al-'Aṣriyya, 1996.

Ibn Hanbal. Al-Musnad. 20 vols. Edited by Ahmed Shākir. Cairo, 1995.

Ibn Ḥibbān, see Ibn Balabbān.

Ibn 'Idhārī. Bayān. "Los Almohades," Spanish translation by Ambrosio Huici Miranda, Colección de crónicas árabes de la reconquista. t. 2. Tétouan, 1953.

Ibn 'Idhārī. Bayān. 2 vols. Spanish translation by A. Huici Miranda. Valencia (Textos Medievales, 8), 1963. Ibn 'Idhārī. al-Bayān al-Mughrib fĩ akhbār al-Andalus wa-l-Maghrib. t. 4. Edited by Iḥsan 'Abbās. Beirut, 1967 [1983].

Ibn 'Idhārī. Al-Bayān al-Mughrib fĩ akhbār al-Andalus wa-l-Maghrib. t. 5. Almohad section. Edited by M. Ibn Tāwīt, M. Ibrāhīm al-Kīttān̄̄, M. Znaybar, and A.-al-Q. Zamāma. Beirut: Dār al-Gharb al-Islāmī, 1985. Ibn Māja. al-Sunan. Ryad: Dār al-ma'ārif, 2000.

Ibn Rushd al-Jadd. al-Muqaddamāt al-mumahhadāt. 2 vols. Edited by M. Ḥajjī. Beirut: Dār al-Gharb alIslāmī, 1988.

Ibn Șāḥib al-Ṣalā. Al-Mann bi-l-Imāma. Spanish translation by Ambrosio Huici Miranda. Valencia (Textos Medievales, 24), 1969.

Ibn Șāḥib al-Ṣalā. Al-Mann bi-l-Imāma, edited by 'Abd al-Hādī al-Tāzì. Beirut: Dār al-Gharb al-Islāmī, 1987.

Ibn Sa īd al-Maghrib̄i. Ikhtiṣār al-qidḥ al-mu lá fĩ l-tārīkh al-Muḥlá, edited by Abū 'Abd Allāh Muḥammad b. 'Abd Allāh b. Khalīl and Ibrāhīm al-Abyārī. Cairo: al-Hay'a al-' āmma l-shu'ūn al-mațābi' al-amīriyya, 1959. 
Ibn Simāk (attributed to). Al-hulal al-mawshiyya, edited by I. S. Allouche. Rabat, 1936.

Ibn Simāk (attributed to). Al-hulal al-mawshiyya. Crónica árabe de las dinastias almorávide, almohade y Benimerín, Spanish translation by Ambrosio Huici Miranda. Tétouan, 1951.

Ibn Simāk (attributed to). Kitāb al-ḥulal al-mawshiyya fĩ dhikr al-akhbār al-marrākushiyya, edited by S. Zakkār and 'A. al-Q. Zamāma. Casablanca: Dār al-rashād al-ḥadītha, 1979.

Ibn Tūmart. A a azz mā yuṭlab, edited by Denis Luciani. Le Livre de Mohammed Ibn Toumert, Mahdi des Almohades. Algiers, 1903.

'isā, Fawzī. Rasā'il andalusiyya. Alexandria: Kulliyat al-Adab, Jāmi 'at al-Iskandariyya, 1989.

Lévi-Provençal, Évariste, ed., French trans., and introd. Kitāb akhbār al-Mahdī Ibn Tūmart wa-bidāyat dawlat al-muwaḥhidīn, Documents inédits d'histoire almohade. Fragments manuscrits du legajo 1919 du fonds arabe de l'Escurial. Paris: Geuthner, 1928.

Lévi-Provençal, Évariste, ed. Majmū 'rasā’il muwaḥhidiyya min inshā' kuttāb al-dawla al-mu'miniyya. Rabat, 1941.

Lévi-Provençal, Évariste, ed. “Un recueil de lettres officielles almohades. Étude diplomatique et historique." Hespéris 28 (1941): 1-80.

Lupprian, Karl-Ernst. Die Beziehungen der Päpste zu Islamischen und Mongolischen Herrschern im 13. Jahrhundert anhand ihres Briefwechsels. Vatican: Biblioteca Apostolica Vaticana (Studi e testi, 291 ), 1981.

Makkī, Mạ̣mūd 'alī. "Wathā'iq tārīkhiyyat jadīda 'an 'aṣr al-Murabiṭin.” Revista del Instituto de Estudios Islámicos de Madrid 7-8 (1959-1960): 109-198.

Mālik b. Anās, al-Muwațta' (version by Yaḥya al-Laythī). 2 vols. Edited by Bashār 'awwād. Beirut: Dār alGharb al-Islāmī, 1997.

Mas Latrie, Jacques Marie Joseph Louis, comte de. Traités de paix et de commerce et documents divers concernant les relations des chrétiens avec les Arabes de l'Afrique septentrionale au Moyen Âge recueillis par ordre de l'Empereur. Paris: Henri Plon, 1866.

Muslim, see al-Nawāwī.

Radwān al-Ḍāya, M., ed. Ras̄̄̄il Ibn Ab̄̄ al-Khiṣāl. Damascus, 1987.

Qāra, Hayāt, ed. Rasā’il andalusiyya jadīda. Shafshawen: 1994.

Qāra, Hayāt, ed. Kanz al-kuttāb. Rabat, 2006.

Tisserant, Eugène and Gaston Wiet. "Une lettre de l'almohade Murțạ̣ā au Pape Innocent IV.” Hespéris 6 (1926): 25-53.

Yāqūt. Mu jam al-Buldān. 5 vols. Beirut: Dār Șādir, 1977.

\section{Secondary Sources}

Abou El Fadl, Khaled. Rebellion and Violence in Islamic Law. First Edition. Cambridge University Press, 2001.

Abū Rumayla, Hisham. 'Alaqat al-muwaḥhidīn bi-l-mamālik al-nașraniyya wa l-duwal al-islāmiyya fì lAndalus. 'Amman: Dār al-Furqān, 1984.

Acién Almansa, Manuel. "Cerámica y propaganda en época almohade”. Arqueología medieval, 4 (1996): 183-191.

Adang, Camilla. "Ẓāhirīs of Almohad times". In Biografías almohades, 2. Estudios Onomásticos Bibliográficos de Al-Andalus 10, 2000: 413-479.

Adang, Camilla, and S. A 'rāb. 'Mawqif al-muwaḥḥidīn min kutub al-furū' wa ḥaml al-nās 'alā l-madhhab al-ḥazmī”. Da'wat al-ḥaqq, 249 (1985): 26-30.

Aguilar Sebastián, Victoria. “Aportación de los árabes nómadas a la organización militar del ejército almohade". al-Qantara, 14 (1993): 393-415.

"Instituciones militares: el ejército". In El retroceso territorial de al-Andalus. Almóravides y Almohades. Siglos XI al XIII, 192-208. María Jesus Viguera Molíns. Historia de España Menéndez Pidal VIII/2. Madrid: Espasa Calpe, 1997.

—. "Tribus árabes en el Maghreb almohade". PhD Dissertation, Université Complutense, 1991.

Aigle, Denise, and Pascal Buresi, ed. Les relations diplomatiques entre le monde musulman et l'Occident latin (XIIe-XVIe siècle). Vol. 2. Oriente Moderno 88, 2008. http://halshs.archives-ouvertes.fr/halshs-00412117/fr/. 
al-Najjār, 'Abd al-Majīd. al-Mahdī Ibn Tūmart. Cairo: Dār al-Gharb al-Islāmī, 1983.

al-Tāzī, 'Abd al-Hādī. Al-tarīkh al-diblumāsī li-l-Maghrib. Vol. 6. 10 vol. Rabat, 1987.

al-Ṭībī, Amīn Tawfīq. "Al-Aghzāz wa qudūmu-hum ilá bilād al-Maghrib wa-l-Andalus". In Dirāsāt wa buhūth fí tārīkh al-Maghrib wa-l-Andalus, 2:87-100. Tunis: Dār al-'Arabiyya li-l-Kitāba, 1997.

"Banū Hilāl wa dūru-hum fī-l-jihād fī Ifrīqyā wa-l-Andalus ilá nihāyat al-qarn al-sādis/al-thānī 'ashar al-mīlādī’’. In Dirāsāt wa buḥūth fì tārīkh al-Maghrib wa-l-Andalus, 2:73-86. Tunis: Dār al-'Arabiyya li-l-Kitāba, 1997.

'Allām, 'Alī. al-Da 'wa al-muwahhidiyya bi-l-Maghrib. Cairo, 1964.

Amari, Michele. Diplomi Arabi dell' archivio fiorentino. 2 vol. Florence, 1864.

Aouad, Maroun. "La valeur épistémologique du témoignage selon Averroès". In Averroès et l'averroüsme. Un itinéraire historique du Haut Atlas à Paris et à Padoue, edited by André Bazzana, Nicole Bériou, and Pierre Guichard, 131-144. PUL. Collection d'histoire et d'archéologie médiévales 16. Lyon: 2005.

“Arabs and Berbers : from tribe to nation in North Africa / edited by Ernest Gellner and Charles Micaud". Texte imprimé, 1972.

Arkoun, Mohammed. Essais sur la pensée islamique. $3^{\text {rd }}$ ed. Islam d'hier et d'aujourd'hui 23. Paris: Maisonneuve et Larose, 1984.

Asín Palacios, Miguel. “Origen y carácter de la revolución almohade”. In Obras escogidas, 2-3:1-12. Miguel Asín Palacios. Madrid, 1948.

Ayache, Germain. "La fonction d'arbitrage du Makhzen”. Bulletin économique et social du Maroc, 138-139. Actes de Durham (1979): 5-21.

Azad, Gh.M. “Qualifications of a qāộ̄”. Islamic Studies, 23 (1984): 249-263.

'Azzawī, Ahmad. “Al- 'ilāqāt bayn diffatay al-baḥr al-mutawassat al-gharbī min khilāl wathā'iq 'arabiyya wasītiyya". In Philippe Sénac ed. Le Maghreb, al-Andalus et la Méditerranée occidentale (viiie-xiiie siècle), Toulouse, 2007: 271-283.

Barbour, Nevill. "La guerra psicológica de los Almohades contra los Almorávides”. Boletín de la Asociación de los Orientalistas Españoles, 2 (1966): 117-130.

Barceló, Carmén. “El sayyid Abū Zayd: príncipe musulmán, señor cristiano”. Awrāq, 3 (1980): 101-109.

Basset, René. “Ibn Toumert, chef d'État”. Revue de l'histoire des religions, 2 (1925): 438-439.

Bauden, Frédéric. "Due trattati di pace conclusi tra i Banū Ghāniya, signori delle isole Baleari, e il comune di Genova nel dodicesimo secolo". In Documentos y manuscritos árabes del Occidente musulman medieval, Ed. Nuria Martínez de Castilla, 33-87. DVCTVS 2. Madrid: CSIC, 2010.

Bazzana, André, Nicole Bériou, and Pierre Guichard, ed. Averroès et l'averroüsme, XIIe-XVe siècle: un itinéraire historique du Haut Atlas à Paris et à Padoue. 1 vol. Centre national de la recherche scientifique. Collection d'histoire et d'archéologie médiévales 16. Lyon: Presses universitaires de Lyon, 2005.

Bel, Alfred (1873-1945). "Le Sûfisme en Occident musulman aux xiie et xiiie siècles". Annales de l'institut d'études orientales, 1 (1935 1934): 145-161.

Ben Hamadi, Amor. "Y a-t-il une influence khariǧite dans la pensée d'Ibn Tûmart ?" In Mélanges offerts à Mohamed Talbi, 11-23. Tunis, 1993.

Bennison, Amira K, and Alison Gascoigne, ed. Cities in the pre-modern Islamic world: the urban impact of religion, state and society. 1 vol. Soas/Routledge Studies on the Middle East. London: Routledge, 2007.

Bennison, Amira K. "Power and the city in the Islamic west from the Umayyads to the Almohads". In Cities in the pre-modern Islamic world: the urban impact of religion, state and society, Ed. Amira $\mathrm{K}$ Bennison et Alison Gascoigne, 65-95. Soas/Routledge Studies on the Middle East. London: Routledge, 2007.

Benouis, Mustapha. "Le système juridico-judiciaire almohade en al-Andalus et au Maghreb, 542-668/11471269”. PhD Dissertation, University Lumière Lyon 2, 2002.

Benshrīfa, Muḥammad. Abū al-Muṭarrif Aḥmad b. 'Amīra. Rabat: University Muḥammad V, 1966.

Berque, Jacques. Structures sociales du Haut-Atlas... $2^{\text {nd }}$ ed. Sociologie d'aujourd'hui. Paris: Presses universitaires de France, 1978.

Bosworth, Clifford Edmund. “A Maqâma on Secretaryship: Al-Qalqashandî’s al-kawâkib al-Durriyya fî lManâqib al-Badriyya”. Bulletin of the School of Oriental and African Studies, 27 (1964): 294-305. 
Bourouiba, Rachid. “Abd al-Mu”min: flambeau des Almohades. Ed. Société Nationale D'Édition Et De Diffusion. [Alger.]. Algiers: S.N.E.D. [Société nationale d'édition et de diffusion], 1974.

\author{
- Ibn Tumart. Algiers: S.N.E.D, 1974. \\ —. "La doctrine almohade". Revue de l'Occident musulman et de la Méditerranée, 13-14 (1973): 141- \\ 158.
}

Bresc, Henri, Bernard Doumerc, Anne-Marie Eddé, Pierre Guichard, Françoise Micheau, Christophe Picard, and Philippe Sénac. "Aspects commerciaux entre Pisans et Almohades". In La Méditerranée entre pays d'islam et monde latin: milieu Xe-milieu XIIIe siècle textes et documents, 88-90. Regards sur l'histoire. Paris: SEDES, 2001.

Brett, Michael. “Le Mahdi dans le Maghreb médiéval”. Revue des mondes musulmans et de la Méditerranée, 91-94 (2000): 93-106.

Broadbridge, Anne F. "Diplomatic Conventions in the Mamluk Sultanate". Annales islamologiques, 41 (2007): 97-118.

Brunschvig, Robert. "Sur la doctrine du Mahdī Ibn Tūmart”. Arabica, 2 (1955): 137-149.

Buresi, Pascal. "Administration territoriale d'al-Andalus aux époques almoravide et almohade (fin xiemilieu xiiie siècles)". In Regards sur Al-Andalus : VIIIe-XVe siècle, Ed. François Géal, 129-145. ParisMadrid: Casa de Velázquez-Éditions Rue d'Ulm, 2006.

—. "D'une Péninsule à l'autre: Cordoue, 'Uțmān (644-656) et les tribus arabes à l'époque almohade (xiie-xiiie siècle)", al-Qantara 31, 1 (2010): 7-29.

_. "L'apogée almohade: la bataille d'Alarcos et son contexte historique". In Averroès et l'averroüsme, XIIe-XVe siècle: un itinéraire historique du Haut Atlas à Paris et à Padoue. Eds. André Bazzana, Nicole Bériou, and Pierre Guichard, 99-114. Centre national de la recherche scientifique. Collection d'histoire et d'archéologie médiévales 16. Lyon: Presses universitaires de Lyon, 2005.

—. "La réaction idéologique dans la péninsule Ibérique face à l'expansion occidentale aux époques almoravide et almohade (xie-xiiie siècles)". In L'expansion occidentale : XIe-XVe siècles : formes et conséquences. Société des historiens médiévistes de l'enseignement supérieur public (France). Congrès (33; 2002; Madrid). XXXIIIe Congrès de la SHMESP, Madrid, Casa de Velázquez, 23-26 mai 2002. Paris: Publications de la Sorbonne, 2003.

"Les documents arabes et latins échangés entre Pise et l'Empire almohade en 596-598/1200-1202: la chancellerie au cour des relations diplomatiques". In Documents et manuscrits arabes, Ed. Anne Regourd. Paris: EPHE, à paraître.

—. "Les plaintes de l'archevêque: chronique des premiers échanges épistolaires entre Pise et le gouverneur almohade de Tunis (1182)". In Documentos y manuscritos árabes del Occidente musulman medieval, Ed. Nuria Martínez de Castilla, Pascal Buresi, and María Jesús Viguera Molíns, 87-120. DVCTVS 2. Madrid: CSIC, 2010.

. “Traduttore traditore: à propos d'une correspondance entre l'Empire almohade et la cité de Pise (début xiiie siècle)". Eds. Denise Aigle and Pascal Buresi. Oriente Moderno 88, 2. Les relations diplomatiques entre le monde musulman et l'Occident latin (XIIe-XVIe siècle) (2008): 297-309.

- "Une relique almohade: l'utilisation du coran (attribué à 'Uțmān b. 'Affān [644-656]) de la Grande mosquée de Cordoue". In Lieux de cultes : aires votives, temples, églises, mosquées, 273-280. SEMPAM. Études d'Antiquités africaines. Paris: CNRS Éditions, 2008.

Buresi, Pascal, and Hicham El Aallaoui. "La chancellerie almohade". In Los almohades: problemas y perspectivas, Eds. Patrice Cressier, Maribel Fierro, and Luis Molina, 2:477-503. Madrid: CSIC-Casa de Velázquez, 2005.

Burton, John. The Sources of Islamic Law. Islamic Theories of Abrogation. Edinburgh: Edinburgh University Press, 1990.

Būtshīsh, I. al-Q. “Al-jāliya al-masīḥiyya bi-l-Maghrib al-islāmī khilāl 'aṣr al-muwaḥhịī̄n”. In Ta'rīkh alGharb al-islāmī, 87-105. Beirut, 1994.

Cahen, Claude. “À propos des Shuhūd”. Studia islamica, 31 (1970): 71-79.

—. "Notes de diplomatique arabo-musulmane". Journal Asiatique, 251 (1963): 311-325.

"Notes de diplomatique arabo-musulmane". In Les peuples musulmans dans l'histoire médiévale,

65-80. Damascus: IFEAD, 1977. 
Camargo, Martin. Ars dictaminis, ars dictandi. Typologie des sources du Moyen âge occidental 60. Turnhout (Belgium): Brepols, 1991.

Camps, Gabriel. "L'origine des Berbères". In Islam, société et communauté. Anthropologies du Maghreb, Ed. Ernest Gellner, 9-33. Paris: CNRS Éditions, 1981.

. Les Berbères. Encyclopédie de la Méditerranée. Aix-en-Provence/Tunis/Casablanca: Édisud Alif Toubkal, 1996.

- Les Berbères, mémoire et identité. $2^{\text {nd }}$ ed. Collection des Hespérides. Paris: Errance, 1987.

Carmona, Alfonso. "Le malékisme et les conditions requises pour l'exercice de la judicature". Islamic Law and Society 7, 2. Islamic Law in al-Andalus (2000): 122-158.

Carter, Michael G. "The Kâtib in Fact and Fiction". Abr Nahrain, 11 (1971): 46-47.

Castrillo Márquez. "Instituciones políticas". In El retroceso territorial de Al-Andalus: Almorávides y Almohades, siglos XI al XIII, Ed. María Jesús Viguera Molíns, 129-145. $2^{\text {nd }}$ ed. Historia de España 8, 2. Madrid: Espasa Calpe, 1998.

Chalmeta Gendrón, Pedro. El «Señor del zoco» en España, edades media y moderna: contribución al estudio de la historia del mercado. Ed. Instituto de cooperación con el mundo árabe. Madrid: Instituto hispanoarabe de cultura, 1973.

—. "El concepto de Taghr". In La marche supérieure d'al-Andalus et l'Occident chrétien, Ed. Philippe Sénac, 15-28. Série Archéologie XV. Madrid: Casa de Velázquez-University of Saragossa, 1991.

. "El Kitab fi adab al-hisba (Libro del buen gobierno del zoco) de al-Saqati". al-Andalus, 32 (1967): 125-162, 359-397.

—. "El Kitab fi adab al-hisba (Libro del buen gobierno del zoco) de al-Saqati". al-Andalus, 33 (1968): 143-195, 367-434.

—. "La figura del almotacén en los fueros hispánicos y su semejanza con el zabazoque hispanomusulmán”. Revista de la Universidad de Madrid, 19 (1970): 145-167.

. "La ḥisba en Ifriqiya et al-Andalus". Cahiers de Tunisie, 18 (1970): 87-105.

Chalmeta, Pedro. El zoco medieval: contribución al estudio de la historia del mercado. Estudios andalusíes. Almería: Fundación Ibn Tufayl de estudios arabes, 2010.

Chamberlain, Michael. Knowledge and social practice in medieval Damascus, 1190-1350. Cambridge studies in Islamic civilization. Cambridge: Cambridge University Press, 1994.

Constable, Giles. Letters and letter-collections. Typologie des sources du Moyen-Age occidental 17. Turnhout: Brepols, 1976.

Cornell, Vincent J. “Ribāṭ Tīṭ-n-Fițr and the origins of Moroccan Maraboutism”. Islamic Studies, 27 (1988): 23-36.

Cressier, Patrice, Maribel Fierro, and Luis Molina (eds). Los almohades: problemas y perspectivas. Vol. 2. Madrid: CSIC-Casa de Velázquez, 2005.

Dakhlia, Jocelyne. "Dans la mouvance du prince: la symbolique du pouvoir itinérant au Maghreb". Annales ESC, 3 (1988): 735-760.

_. L'empire des passions: l'arbitraire politique en islam. 1 vol. Collection historique. Paris: Aubier, 2005. Dandash, 'Ismat. "Dukkâla min khilâl al-Tashawwuf”. In Aḍ̂ā' jadīda 'alá l-murābị̣in, 187-203. Beirut, 1991.

Denoix, Sylvie, and Bruno Galland (eds.). "La constitution des 'corpus': rapport introductif”. In L'autorité de l'écrit au Moyen âge: Orient-Occident, 239-257. Société des historiens médiévistes de l'enseignement supérieur public. Histoire ancienne et médiévale 102. Paris: Publications de la Sorbonne, 2009.

Déroche, François. "L'emploi du parchemin dans les manuscrits islamiques. Quelques remarques préliminaires". In The codicology of Islamic manuscripts: proceedings of the second conference of Al-Furqān Islamic heritage foundation, 4-5 December 1993, Ed. Yasin Dutton, 17-57. Publication 15. London: AlFurquan Islamic heritage foundation, 1995.

- Le livre manuscrit arabe: préludes à une histoire. Conférences Léopold Delisle. Paris: Bibliothèque nationale de France, 2004. 
Diem, Werner. “Katabtu 'ilayka „Ich schreibe Dir“ und Verwandtes. Ein Beitrag zur Phraseologie des arabischen Briefes unter besonderer Berücksichtigung des Briefperfekts". Zitschrift der Deutschen Morgenländischen Gesellschaft, 154 (2002): 285-345.

Dozy, Reinhart Pieter Anne. Supplément aux dictionnaires arabes, par R. Dozy... 3e édition. 2 vols. Leiden/Paris: E.-J. Brill/G.-P. Maisonneuve et Larose, 1967.

Dufourcq, Charles-Emmanuel. L'Espagne catalane et le Maghrib aux XIII et XIV ${ }^{e}$ siècles: de la bataille de Las Navas de Tolosa (1212) à l'avènement du sultan mérinide Abou-l-Hasan (1331). Ed. Casa de Velázquez and University of Bordeaux. Bibliothèque de l'École des hautes études hispaniques 37. Paris: Presses universitaires de France, 1966.

Dutton, Yasin (ed.). The codicology of Islamic manuscripts: proceedings of the second conference of AlFurqān Islamic heritage foundation, 4-5 December 1993. Publication 15. London: Al-Furquan Islamic heritage foundation, 1995.

Eddé, Anne-Marie. “Documents et archives d'Orient: conclusions provisoires et tendances de la recherche actuelle". In L'autorité de l'écrit au Moyen âge: Orient-Occident, 385-400. Société des historiens médiévistes de l'enseignement supérieur public. Histoire ancienne et médiévale 102. Paris: Publications de la Sorbonne, 2009.

El Aallaoui, Hicham. "L'art du secrétaire entre littérature et politique: les actes des chancelleries almoravide et almohade (Maghreb et al-Andalus, fin $\mathrm{XI}^{\mathrm{e}}$-fin XIII ${ }^{\mathrm{e}}$ s.)". PhD Dissertation, Université Lumière Lyon 2, 2007.

. "Les échanges diplomatiques entre Islam et monde latin, milieu xie-milieu xiie siècle: la transition entre l'époque des Taifas et la dynastie almoravide". Ed. Denise Aigle et Pascal Buresi. Oriente Moderno 88, 2. Les relations diplomatiques entre le monde musulman et l'Occident latin (XII ${ }^{\mathrm{e}}$-XVI ${ }^{\mathrm{e}}$ siècle) (2008): 249 269.

Escovitz, J.H. "Vocational patternes of the scribes of the Mamluk chancery". Arabica, 23 (1976): 42-62.

Faraḥāt, Ḥalīmä̈. Sabta: des origines au XIVe siècle. Rabat: Al Manahil, 1993.

Faure, Adolphe. "Le Tasawuf et l'école ascétique marocaine: XI'-XII'-XIII siècles". In Mélanges Louis Massignon, 2:119-131. Damascus: IFEAD, 1957.

Favereau, Marie. "Comment le sultan mamlouk s'adressait au khan de la Horde d'Or. Formulaire des lettres et règles d'usage d'après trois manuels de chancellerie (1262-v.1430)". Annales islamologiques, 41. Annales islamologiques (2007): 59-96.

Ferhat, Halima. “As-Sirr al-Maṣūn de Ṭāhir aṣ-Șadafî: un itinéraire mystique au xiie siècle". al-Qanțara, 16 (1995): 237-288.

- Le maghreb au XII siècle-XIV siècle: les siècles de la foi. Casablanca, 1993.

"Saints et pouvoir au Moyen Âge au Maghreb. Entre le refus et la tentation". In L'autorité des saints: perspectives historiques et socio anthropologiques en Méditerranée occidentale, Ed. Mohamed Kerrou and Lucette Valensi, 239-247. Paris: Ministère des affaires étrangères. Recherche sur les civilisations. diff. ADPF, 1999.

—. "Souverains, saints et fuqahâ': le pouvoir en question". al-Qantara, 17 (1996): 375-390.

Ferhat, Halima, and Hamid Triki. "Faux prophètes et Mahdis dans le Maroc médiéval". Hespéris-Tamuda, 26-27 (1989 1988): 7-23.

Fierro, Maribel. “Algunas reflexiones sobre el poder itinerante almohade.” Ed. Georges Martin et Françoise Lainé. e-Spania, 8. Itinérance des cours (December 18, 2009). http://e-spania.revues.org/18653.

"Conversion, ancestry and universal religion: the case of the Almohads in the Islamic West (sixth/twelfth-seventh/thirteenth centuries". Journal of Medieval Iberian Studies 2, 2 (2010): 155-173.

. "La religión". In El retroceso territorial de Al-Andalus: Almorávides y Almohades, siglos XI al XIII, Ed. María Jesús Viguera Molíns et José María Jover Zamora, 435-546. 2nd ed. Historia de España 8, 2. Madrid: Espasa Calpe, 1998.

—. "Las genealogías de 'Abd al-Mu'min primer califa almohade”. al-Qantara 24, 1 (2003): 77-107.

—. "Le mahdi Ibn Tûmart et al-Andalus: l'élaboration de la légitimité almohade". Revue des mondes musulmans et de la Méditerranée, 91-94 (2000): 107-124.

—. "Sobre monedas de época almohade: I. EI dinar del cadí 'Iyāọ que nunca existió. II. Cuándo se acuñaron las primeras monedas almohades y la cuestión de la licitud de acuñar moneda". al-Qanțara 27, 2 (2006): 547-476. 
-. "Spiritual alienation and political activism: the ghuraba, in al-Andalus during the sixth/twelfth century". Arabica, 47 (2000): 230-260.

. “The Legal Policies of the Almohad Caliphs and Ibn Rushd's Bidāyat al-muğtahid". Journal of Islamic Studies 10, 3 (1999): 226-248.

—. "The qâdî as ruler". In Saber religioso y poder politico en el Islam : actas del Simposio Internacional (Granada, 15-18 octubre 1991), 71-116. Madrid: Agencia espanola de cooperacion internacional, 1994.

Fierro, Maribel, and Manuela Marín. Sabios y santos musulmanes de Algeciras. Colección Historia. Algésiras: FMC, 2004.

Fili, Abdallah, and Jean-Pierre Van Staevel. “'Wa waṣalnā 'alā barakat Allāh ilā İgīlīz': à propos de la localisation d'İgīlīz-des-Hargha, le ḥiṣn du Mahdī Ibn Țūmart”. al-Qanțara 27, 1 (2006): 153-194.

Fletcher, Madeleine. "Al-Andalus and North Africa in the Almohad Ideology". In The Legacy of Muslim Spain. Eds. Salma Khadra Jayyusi and Manuela Marín. Handbuch der Orientalistik 12. Leiden: E. J. Brill, 1992.

. "The Anthropological Context of Almohad History". Hespéris-Tamuda (1989 1988): 25-51.

Fontenla Ballesta, Salvador. "La numismática almohade". In I Jarique de estudios numismáticos hispanoárabes, 67-88. Saragossa, 1988.

. "Numismática y propaganda almohade". al-Qanțara, 18 (1997): 447-462.

Fricaud, Émile. “La place des țalaba dans la société almohade mu'minide". In Los almohades: problemas y perspectivas, Eds. Patrice Cressier, Maribel Fierro, and Luis Molina, 2:525-545. Madrid: CSIC-Casa de Velázquez, 2005. http://catalogue.bnf.fr/servlet/ListeNotices?host=catalogue.

—. "Les țalaba dans la société almohade (Le temps d'Averroès)". al-Qantara, 18 (1997): 331-387.

. “Origine de l'utilisation privilégiée du terme de amr chez les mu'minides almohades”.al-Qanțara, 23, 1 (2002): 93-122.

Fromherz, Allen James. "The Almohad Mecca. Locating Igli and the Cave of Ibn Tūmart". al-Qantara, 26, 1 (2005): 175-190.

- The Almohads: the Rise of an Islamic Empire. New York: I.B. Tauris, 2010.

García-Arenal, Mercedes. Messianism and puritanical reform: Mahdīs of the Muslim West. 1 vol. The medieval and early modern Iberian World, v. 29. Leiden: Brill, 2006.

Garcin, Jean-Claude, ed. États, sociétés et cultures du monde musulman médiéval: Xe-XVe siècle. 3 vols. Nouvelle Clio. Paris: PUF, 2000.

Géal, François, ed. Regards sur Al-Andalus : VIIIe-XVe siècle. Paris-Madrid: Casa de Velázquez-Éditions Rue d'Ulm, 2006.

Geertz, Clifford. Islam observed: religious development in Morocco and Indonesia. Chicago: University of Chicago Press, 1968.

- Observer l'Islam: changement religieux au Maroc et en Indonésie. French trans. Jean-Baptiste Grasset. Textes à l'appui. Paris: Éd. la Découverte, 1992.

Gellner, Ernest (1925-1995). Saints de l'Atlas. French trans. Paul Coatalen. Paris: Bouchêne, 2003.

Saints of the Atlas. London: Weidenfeld and Nicolson, 1969.

Gignoux, Philippe. “Lettres privées et lettres d'affaires dans l'Iran du viie siècle”. Asiatische Studien. Études Asiatiques 62, 3. Documentary Letters from the Middle East: The Evidence in Greek, Coptic, South Arabian, Pehlevi and Arabic (1st-15th CE) (2008): 827-842.

Grévin, Benoît. "Les mystères rhétoriques de l'État médiéval. L'écriture du pouvoir en Europe occidentale (xiiie-xve siècle)". Annales HSS 63, 2 (2008): 271-300.

Grévin, Benoît. Le Moyen Âge du langage. Chrétienté latine et Islam : une histoire comparée des cultures linguistiques (vie-xve s.). L'Univers historique. Paris: Seuil, forthcoming.

- Rhétorique du pouvoir médiéval: les "Lettres” de Pierre de la Vigne et la formation du langage politique européen, XIIIe-XVe siècle. 1 vol. Bibliothèque des écoles françaises d'Athènes et de Rome fascicule 339e. Rome [Paris]: École française de Rome [diff. de Boccard], 2008.

Guichard, Pierre. "Les États musulmans du Maghreb". In Maghreb médiéval: l'apogée de la civilisation islamique dans l'Occident arabe, Ed. Francesco Gabrieli, 79-226. Aix-en-Provence: Edisud, 1991.

- Les musulmans de Valence et la reconquête: XIe-XIIIe siècles, 1. Les musulmans de Valence et la reconquête. Damascus [Paris]: Institut français de Damas [diff. J. Maisonneuve], 1990. 
Les musulmans de Valence et la reconquête: XIe-XIIIe siècles, 2. Les musulmans de Valence et la reconquête. Damascus [Paris]: Institut français de Damas [diff. J. Maisonneuve], 1991.

Hallāq, Wael B. "Was al-Shāfi 'ī the master architect of islamic jurisprudence?" International Journal of Middle East Studies, 25 (1993): 587-605.

Hamés. "De la chefferie tribale à la dynastie étatique: généalogie et pouvoir à l'époque almohado-ḥafșide: xiie-xive siècles". In La quête des origines: anthropologie historique de la société tribale arabe [mélanges pour Mokhtar Ould Hamidoun], 101-141. Paris: Éd. de la Maison des sciences de l'homme, 1991.

Ḥammām, Muhammad. L'Occident musulman et l'Occident chrétien au Moyen Âge. Série Colloques et séminaires 48. Rabat, 1995.

Hammoudi, Abdellah. "Segmentarité, stratification sociale, pouvoir politique et sainteté". Hespéris, 15 (1974): 156-160.

Hopkins, John F.P. Medieval Muslim Government in Barbary Until the Sixth Century of the Hijra. London: Luzac \& Company Ltd, 1958.

Hopkins, John, F.P. "The Almohad Hierarchy". Bulletin of the School of Oriental and African Studies, 16 (1954): 93-112.

Houdas, Octave. "Essai sur l'écriture maghrébine". In Nouveaux mélanges orientaux: mémoires, textes et traductions publiés par les professeurs de l'École spéciale des langues orientales vivantes à l'occasion du Septième Congrès des orientalistes réuni à Vienne (septembre 1886), 83-112. Publications de l'École des langues orientales vivantes, IIe série 19. Paris: Imprimerie nationale, 1886.

Huici Miranda, Ambrosio. “El reinado del califa almohade al-Rashīd, hijo de al-Ma'mūn”. Hespéris, 41 (1954): 9-14.

Historia política del Imperio almohade. 2 vols. Tétouan: Editora Marroquí, 1956.

“La leyenda y la historia en los orígenes del imperio almohades". al-Andalus 14, 2 (1949): 339-376.

“La participación de los jeques en el gobierno del Imperio Almohade". Tamuda, 6 (1958): 239-267.

Hurlet, Frédéric, ed. “L'Empire almohade. Le Maghreb et al-Andalus (1130-1269)". In Les empires: Antiquité et Moyen âge analyse comparée, 221-237. Histoire. Rennes: Presses universitaires de Rennes, 2008.

- Les empires: Antiquité et Moyen âge analyse comparée. 1 vol. Histoire. Rennes: Presses universitaires de Rennes, 2008.

'Inān, Muḥammad 'Abd Allāh. 'Aṣr al-murābiṭin wa-l-muwaḥhidīn. 2 vol. Cairo, 1964.

Institut de recherche sur le Maghreb contemporain, ed. L'autorité des saints: perspectives historiques et socio anthropologiques en Méditerranée occidentale. Paris: Ministère des affaires étrangères Éd. Recherche sur les civilisations diff. ADPF, 1999.

Jayyusi, Salma Khadra, and Manuela Marín, eds. The Legacy of Muslim Spain. Handbuch der Orientalistik 12. Leiden: E. J. Brill, 1992.

Julien, Charles-André (1891-1991). Histoire de l'Afrique du Nord. 2, De la conquête arabe à 1830. Vol. 2. Paris: Payot, 1952.

—. "Les Africains". 139-165. Paris, 1977.

Juynboll, Gautier H. A. "Somes Notes on Islam's First fuqahā' distilled from early hadīt Literature". Arabica, 39 (1991): 287-314.

Kalās, Fāziya. “Al-jaysh 'inda l-muwaḥḥidîn”. Dirāsāt Tārīkhiyya 10, 31-32 (1989): 197-218.

Kaplony, Andreas. "What Are Those Few Dots For? Thoughts on the Orthography of the Qurra Papyri (709-710), the Khurasan Parchments (755-777) and the Inscription of the Jerusalem Dome of the Rock (692)". Arabica, 55 (2008): 91-112.

Kaplony, Andreas, and Eva Grob. "Introduction". Asiatische Studien. Études Asiatiques 62, 3. Documentary Letters from the Middle East: The Evidence in Greek, Coptic, South Arabian, Pehlevi and Arabic (1st-15th CE) (2008): 671-675.

Karmi Blomme, Mina. "La chute de l'Empire Almohade; analyse doctrinale, politique et économique". PhD Dissertation, Université Paris I Sorbonne, 1998.

Kassis, Hanna E. "Qāọ̄i 'Iyāẹ’’s rebellion against the Almohads in Sabtah (AH 542-3/AD 1147-8). New Numismatic Evidence". Journal of the American Oriental Society 103, 3 (1983): 505-514. 
Kazimirski Biberstein, Albin de. Dictionnaire arabe-français, contenant toutes les racines de la langue arabe, leurs dérivés, tant dans l'idiome vulgaire que dans l'idiome littéral, ainsi que les dialectes d'Alger et de Maroc. 2 vols. Paris: Maisonneuve, 1860.

Khan, Geoffrey. "Remarks on the Historical Background and Development of Early Arabic Documentary Formulae". Asiatische Studien. Études Asiatiques 62, 3. Documentary Letters from the Middle East: The Evidence in Greek, Coptic, South Arabian, Pehlevi and Arabic (1st-15th CE) (2008): 885-906.

L'autorité de l'écrit au Moyen âge: Orient-Occident. 1 vol. Société des historiens médiévistes de l'enseignement supérieur public. Histoire ancienne et médiévale 102. Paris: Publications de la Sorbonne, 2009.

Lagardère, Vincent. Les Almoravides: le djihad andalou, 1106-1143. Histoire et perspectives méditerranéennes. Paris: l'Harmattan, 1999.

Lambton, Ann Katherine Swynford. State and government in Medieval Islam: an introduction to the study of Islamic political theory the jurists. London oriental series 36. Oxford: Oxford University Press, 1981.

Langhade, Jacques, and Dominique Mallet. "Droit et philosophie au XII ${ }^{\mathrm{e}}$ siècle dans al-Andalus: Averroès (Ibn Rushd)". Revue de l'Occident musulman et de la Méditerranée 40, 2 (1985): 103-121.

Lanham, Carol. "Salutatio formulas in Latin Letters to 1200: Syntax, Style and Theory". Münchener Beiträge, 22 (1975): 89-94.

Latham, J.D. “The Beginning of Arabic Prose Literature: The Epistolary Genre". In Arabic Literature to the End of the Umayyad period, Ed. A.F.L. Beeston, T.M. Johnstone, and J.D. Latham, 154-179. The Cambridge history of Arabic literature 1. Cambridge, 1983.

Lentin, Jérôme. "Middle Arabic". Ed. Cornelis Henricus Maria Versteegh, Andrzej Zaborski, Manfred Woidich, Alaa Elgibali, and Mushira Eid. Encyclopedia of Arabic language and linguistics. Leiden: Brill, 2008.

Lentin, Jérôme, and Jacques Grand'Henry, eds. Moyen arabe et variétés mixtes de l'arabe à travers l'histoire: Actes du Premier Colloque International (Louvain-la-Neuve, 10-14 mai 2004). Peeters, s. d.

Lévi-Provençal, Évariste. "La naissance d'un Empire: Ibn Tûmart et 'Abd al-Mu'min: le "fakih du Sûs" et le "flambeau des Almohades"". In Mémorial Henri Basset. Nouvelles études nord-africaines et orientales, publiées par l'Institut des hautes études marocaines, 2:21-37. Chartres/Paris: impr. Durand/Libr. orientaliste Paul Geuthner, 1928.

—_. "La naissance d'un Empire: Ibn Tûmart et 'Abd al-Mu'min: le "fakih du Sûs" et le "flambeau des Almohades"”. In Islam d'Occident, études d'histoire médiévale, par É. Lévi-Provençal,..., 257-280. Paris: G.P. Maisonneuve (Mâcon, impr. de Protat frères), 1948.

—. "Un recueil de lettres officielles almohades. Étude diplomatique et historique". Hespéris, 28 (1941): 1-80.

Lirola Delgado, Jorge, ed. Biblioteca de al-Andalus. 5 vol. Enciclopedia de la cultura andalusí. Almería: Fundación Ibn Tufayl de estudios árabes, 2004.

Société des historiens médiévistes de l'enseignement supérieur public (France). Congrès (33; 2002 ; L'expansion occidentale: XIe-XVe siècles: formes et conséquences. XXXIIIe Congrès de la SHMESP, Madrid, Casa de Velázquez, 23-26 mai 2002. Paris: Publications de la Sorbonne, 2003.

Marçais, Georges. "La fonction d'arbitrage du makhzen”. In Mélanges d'histoire et d'archéologie de l'Occident musulman, 1:131-139. Algiers, 1957.

Marín, Manuela. "El califa almohade, una presencia activa y benéfica". In Los almohades: problemas y perspectivas, Ed. Patrice Cressier, Maribel Fierro, and Luis Molina, 1:451-576. Madrid: CSIC-Casa de Velázquez, 2005.

Marín, Manuela, Casa de Velázquez, and Consejo superior de investigaciones científicas, eds. Al-AndalusEspaña: historiografías en contraste siglos XVII-XXI. 1 vol. Collection de la Casa de Velázquez volume 109. Madrid: Casa de Velázquez, 2009.

Martínez de Castilla, Nuria ed. Documentos y manuscritos árabes del Occidente musulman medieval. DVCTVS 2. Madrid: CSIC, 2010.

Martínez Núñez, María Antonia. "El califato almohade. Pensamiento religioso y legitimación del poder a través de los textos epigráficos". In Ultra mare: mélanges de langue arabe et d'islamologie offerts à Aubert Martin, Ed. Frédéric Bauden, 195-212. Mémoires 3. Louvain Paris Dudley: Peeters, 2004. 
—. "El Corán en los textos epigráficos andalusíes". In El Corán ayer y hoy: perspectivas actuales sobre el Islam estudios en honor al profesor Julio Cortés, Ed. Salvador Peña Martín et Miguel Hernando de Larramendi, 125-144. La biblioteca del Polo Norte. Córdoba: Berenice, 2008.

—. "Epigrafía y propaganda almohades". al-Qantara, 18 (1997): 415-445.

Mas Latrie, Louis de. Traités de paix et de commerce et documents divers concernant les relations des Chrétiens avec les Arabes de l'Afrique septentrionale au Moyen âge. Paris, J. Baur et Détaille (Nogent-leRotrou, impr. de A. Gouverneur): Henri Plon, 1872.

Melchert, Christopher. The formation of the Sunni schools of Law, 8th-10th centuries. Leiden: E. J. Brill, 1997.

Merad, Ali. “'Abd al-Mu'min à la conquête de l'Afrique du Nord (1130-1163)". Annales de l'institut d'études orientales, 15 (1957): 109-165.

Messick, Brinkley Morris. The calligraphic state: textual domination and history in a Muslim society. Comparative studies on Muslim societies 16. Berkeley: University of California Press, 1996.

Miller, Kathryn A. Guardians of Islam: religious authority and Muslim communities of late medieval Spain. 1 vol. New York: Columbia University Press, 2008.

Millet, René. Les Almohades. Histoire d'une dynastie berbère. Mesnil (Eure): impr. Firmin-Didot et Cie Paris: Société d'éditions géographiques, maritimes et coloniales, 1923.

Molénat, Jean-Pierre. "Sur le rôle des Almohades dans la fin du christianisme local au Maghreb et en alAndalus". al-Qantara, 18 (1997): 389-413.

Molina López, Emilio. "De la Murcia musulmana a la Murcia cristiana (viii-xiii)". In Historia de la región murciana, 3:187-263. Murcia: Edición Mediterráneo, 1980.

—. "Economía, propiedad, impuestos y sectores productivos". In El retroceso territorial de Al-Andalus: Almorávides y Almohades, siglos XI al XIII, Ed. María Jesús Viguera Molíns, 213-300. 2nd ed. Historia de España 8, 2. Madrid: Espasa Calpe, 1998.

Molina Martínez, Luis. "Instituciones administrativas: visires y secretarios". In El retroceso territorial de Al-Andalus: Almorávides y Almohades, siglos XI al XIII, Ed. María Jesús Viguera Molíns, 149-167. 2nd ed. Historia de España 8, 2. Madrid: Espasa Calpe, 1998.

Montagne, Robert. Les Berbères et le Makhzen dans le sud du Maroc, essai sur la transformation politique des Berbères sédentaires (groupe chleuh). Paris: F. Alcan, 1930.

Morabia, Alfred. Le Ğihâd dans l'Islam médiéval: le "combat sacré" des origines au XIIe siècle. Bibliothèque Albin Michel Histoire. Paris: A. Michel, 1993.

Mūsá, 'Izz al-Dīn 'Umar. al-Muwaḥhidūn fĩ l-Gharb al-islāmī. Tanz̄imātu-hum wa nažmu-hum. Beirut: Dār al-Gharb al-Islāmī, 1991.

“Al-tanẓīmāt al-ḥizbiyya 'inda l-Muwaḥḥidīn fī l-Maghrib (510/1121-668/1269)". al-abhāth 23, 1-4 (1970): 53-89.

Patt, William D. “The Early 'Ars Dictaminis' as Response to a Changing Society”. Viator, 9 (1978): 135-155.

Picard, Christophe. La mer et les Musulmans d'Occident au Moyen âge : VIII ${ }^{e}$-XIII ${ }^{e}$ siècle. Paris: Presses universitaires de France, 1997.

Picard, Christophe. “De l'usage de l'écrit documentaire en Islam”. In L'autorité de l'écrit au Moyen âge: Orient-Occident, 127-141. Société des historiens médiévistes de l'enseignement supérieur public. Histoire ancienne et médiévale 102. Paris: Publications de la Sorbonne, 2009.

_. "L'échec maritime musulman ?" In La puissance maritime: actes du colloque international tenu à l'Institut catholique de Paris, 13-15 décembre 2001, Ed. Christian Buchet, Jean Meyer, and Jean-Pierre Poussou, 123-142. Histoire maritime. Paris: Presses de l'Université Paris-Sorbonne, 2004.

L'océan Atlantique musulman: de la conquête arabe à l'époque almohade navigation et mise en valeur des côtes d'al-Andalus et du Maghreb occidental Portugal-Espagne-Maroc. Paris: Maisonneuve \& Larose Éd. UNESCO, 1997.

—. La mer et les Musulmans d'Occident au Moyen Âge: VIII ${ }^{e}$-XIII ${ }^{e}$ siècle. Islamiques. Paris: Presses universitaires de France, 1997.

. "Les Arsenaux musulmans de la Méditerranée et de l'océan Atlantique (VII ${ }^{\mathrm{e}}-\mathrm{XV} \mathrm{V}^{\mathrm{e}}$ siècles)". In Chemins d'outre-mer: études sur la Méditerranée médiévale offertes à Michel Balard, 691-710. Byzantina Sorbonensia 20. Paris: Publications de la Sorbonne, 2004. 
Pistarino, Geo. “Genova e l'islam nel Mediterraneo occidentale”. Anuario de Estudios medievales, 10 (1980): 193-194.

Prémare, Alfred-Louis de. Aux origines du Coran: questions d'hier, approches d'aujourd'hui. L'islam en débats. Paris: Téraèdre, 2004.

Les fondations de l'islam: entre écriture et histoire. 1 vol. Points H407. Paris: Points, 2009.

Prieto y Vives, Antonio. "La reforma numismática de los Almohades”. Miscelánea de Estudios y textos árabes (1915): 13-114.

Qāra, Ḥayāt. "Ḥiwār al-diyānāt fī l-Andalus: bayn al-jadl al-dīnī wa-l-khilāf al-kalāmī min khilāı taqyīd liIbn Lubb al-Gharnāṭī fī l-qaḍā' wa-l-qadar”. al-Andalus Magreb. Estudios Árabes e Islámicos, 16 (2009): 185-208.

Rāghib, Yūsuf. "La parole, le geste et l'écrit dans l'acte de vente". Arabica 44, 3. Voix et calame en Islam médiéval (1997): 407-422.

. "Lettres arabes (I) [avec 6 planches]". Annales islamologiques, 14 (1978): 15-35.

. "Lettres arabes (II) [avec 6 planches]". Annales islamologiques, 16 (1980): 1-29.

Rodríguez Mediano, Fernando. “Instituciones judiciales: cadíes y otras magistraturas". In El retroceso territorial de Al-Andalus: Almorávides y Almohades, siglos XI al XIII, Ed. María Jesús Viguera Molíns, 171 186. 2nd ed. Historia de España 8, 2. Madrid: Espasa Calpe, 1998.

Rosenberger, Bernard. "Le contrôle du Détroit de Gibraltar (XII -XIII siècles)". In L'Occident musulman et l'Occident chrétien au Moyen Âge, Ed. Muḥammad Ḥammām, 15-42. Colloques et séminaires 48. Rabat: Publications de la Faculté des Lettres, 1995.

Sabbane, Abdellatif. "Le Gouvernement et l'administration de la dynastie almohade (XII ${ }^{\mathrm{e}}$-XIII ${ }^{\mathrm{e}}$ siècles)". PhD Dissertation, Université Paris I Sorbonne, 2004.

Sadki, 'Alī. "La montagne marocaine et le pouvoir central: un conflit séculaire mal élucidé". HespérisTamuda, 28 (1990): 15-28.

Saha, Mustapha. "Structures tribales et formation de l'État dans le Maghreb médiéval”. L'homme et la société, 39-40 (1976): 275-280.

Schacht, Joseph. The Origins of Muhammadan jurisprudence. Oxford: Clarendon Press, 1950.

Sempam. Lieux de cultes: aires votives, temples, églises, mosquées. SEMPAM. Études d'Antiquités africaines. Paris: CNRS Éditions, 2008.

Sénac, Philippe, ed. La marche supérieure d'al-Andalus et l'Occident chrétien. Casa de Velázquez, 1991.

. Le Maghreb, al-Andalus et la Méditerranée occidentale: VIII'-XIII siècles. Méridiennes. Toulouse: CNRS-Université de Toulouse-Le Mirail, 2007.

Sidarus, Adel, and Bruna Soravia. Literatura e cultura no Gharb al-Andalus. Lisbonne, 2005.

Soravia, Bruna. 'Les fonctionnaires épistoliers (kuttâb al-inshâ') en Espagne musulmane à l'époque des roitelets (ve s. h./xie s.)". PhD Dissertation, Université Paris III, 1998.

Sourdel, Dominique. "Le "Livre des secrétaires" de 'Abd Allāh al-Baghdādī”". Bulletin d'études orientales, 14 (1954 1952): 115-154.

Terrasse, Henri. Histoire du Maroc: des origines à l'établissement du protectorat français. 2 vol. Casablanca: Ed. Atlantides, 1949.

Le Tourneau, Roger. The Almohad Movement in North Africa in the Twelfth and Thirteenth Centuries. Princeton: Princeton University Press, 1969.

—. "Du mouvement almohade à la dynastie mu'minide: la révolte des frères d'Ibn Tûmart de 1153 à 1156". In Hommage à G. Marçais, 2:111-116. Paris, 1956.

—. "Sur la disparition de la doctrine almohade". Studia islamica, 32 (1970): 193-201.

Tribus et pouvoirs en terre d'Islam. Sociétales. Paris: A. Colin, 2004.

Tyan, Emile. Histoire de l'organisation judiciaire en pays d'Islam. Leiden: E. J. Brill, 1960.

“L'autorité de la chose jugée en droit musulman". Studia islamica, 17 (1962): 81-90.

Le notariat et le régime de la preuve par écrit dans la pratique du Droit musulman. Beirut, 1959.

Urvoy, Dominique. "Les divergences théologiques entre Ibn Tūmart et Ghazālī”. In Mélanges offerts à Mohamed Talbi, 11-23. Tunis, 1993. 
Pensers d'al-Andalus: la vie intellectuelle à Cordoue et Séville au temps des empires berbères fin XIe siècle-début XIIIe siècle. Toulouse [Paris]: Presses universitaires du Mirail [Ed. du CNRS], 1990.

Viguera Molíns, María Jesús. “Al-Andalus en época almohade”. In Andalucía entre Oriente y Occidente: 1236-1492. [actas del V Coloquio internacional de historia medieval de Andalucía, celebrado en Córdoba durante los días 27 al 30 de noviembre de 1986]. Córdoba [España]: Diputación provincial de Córdoba, Servicio de publicaciones, 1988: 9-29.

—. "Céremonias y símbolos soberanos en al-Andalus: notas sobre la época almohade". In Casas y palacios de Al-Andalus: [siglos XII y XIII], Ed. Julio Navarro Palazón, 105-115. Barcelona: Lunwerg, 1995.

"Las reacciones de los andalusíes ante los Almohades". In Los almohades: problemas y perspectivas, Eds. Patrice Cressier, Maribel Fierro, and Luis Molina, 2:705-735. Madrid: CSIC-Casa de Velázquez, 2005.

- Los reinos de Taifas y las invasiones magrebíes: (Al-Andalus del XI al XIII). Coleccion Al-Andalus 8. Madrid: MAPFRE, 1992.

Viguera Molíns, María Jesús, ed. El retroceso territorial de Al-Andalus: Almorávides y Almohades, siglos XI al XIII. Historia de España 8 2. Madrid: Espasa Calpe, 1997.

El retroceso territorial de Al-Andalus: Almorávides y Almohades, siglos XI al XIII. 1 vol. 2nd ed. Historia de España 8, 2. Madrid: Espasa Calpe, 1998.

Viguera Molíns, María Jesús, and Rafael López Guzmán. "La fuerza de la fe: la reacción almohade". In La arquitectura del islam occidental, 138-146. Granada, 1995.

Watt, William Montgomery. "Philosophy and Social Structure in Almohad Spain". The Islamic Quarterly 8, 1-2 (1964): 46-51.

Wiet, Gaston. "Les classiques du scribe égyptien au XV ${ }^{\mathrm{e}}$ siècle". Studia islamica, 18 (1963): 41-80.

Wright, William. A Grammar of the Arabic Language/Vol $1 \& 2$ in $1.3^{\text {rd }}$ ed. Cambridged: Cambridge University Press, 1967.

Yanagihashi, Hiroyuki. "The Judicial Functions of the Sultān”. Islamic Law and Society, 3 (1996): 63-66. Zaghlūl, 'Abd al-Hādī S. Muhammad Ibn Tümart wa harakat al-tajdīd fî l-Maghrib wa-l-Andalus. Beirut, 1973.

Zimmermann, Michel, ed. Auctor et auctoritas: invention et conformisme dans l'écriture médiévale. actes du colloque tenu à l'Université de Versailles-Saint-Quentin-en-Yvelines, 14-16 juin 1999. Mémoires et documents de l'École des chartes 59. Paris: École des chartes, 2001. 
Governing the Empire

List of Illustrations 
Illustration1: signs of manuscript restoration and modern page numbering. $\mathrm{f}^{\circ} 3 \mathrm{v}, \mathrm{p} .4 \ldots \ldots \ldots . . .96$

Illustration 2: Vertical margin, end of the line, elongation of letters. .....................................97

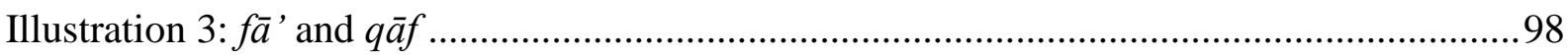

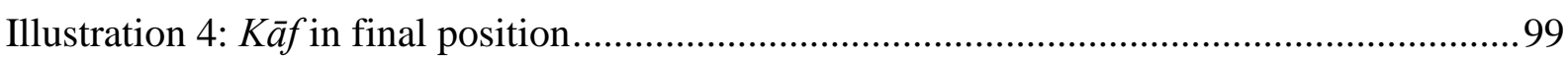

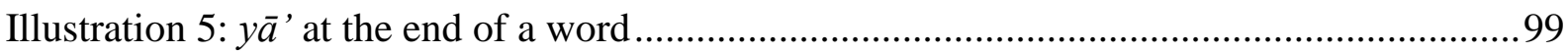

Illustration 6: Absence of the dots for final $y \bar{a}$ ' with shidda and damma ...............................99

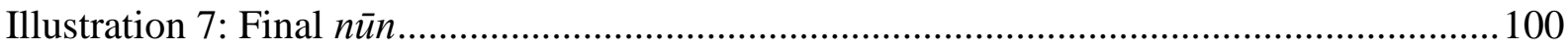

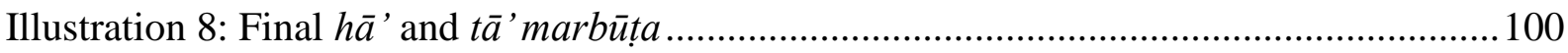

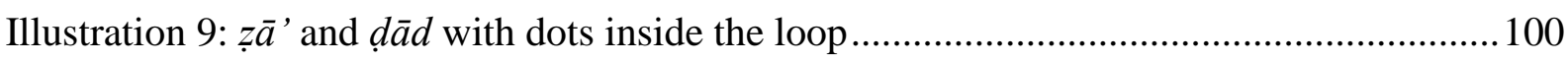

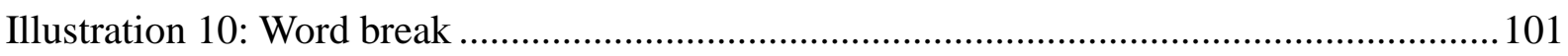

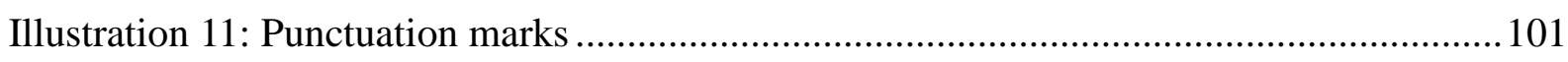

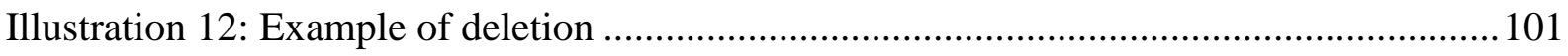

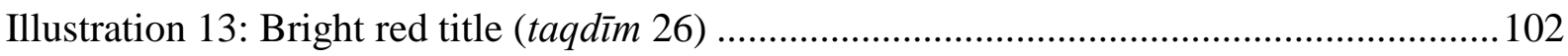

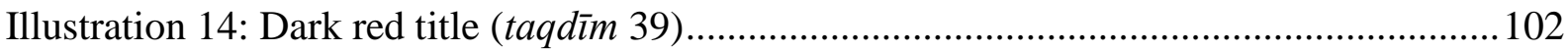

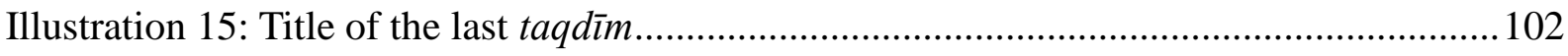

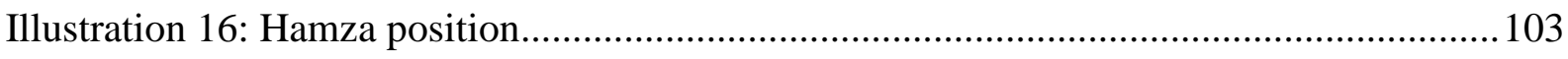

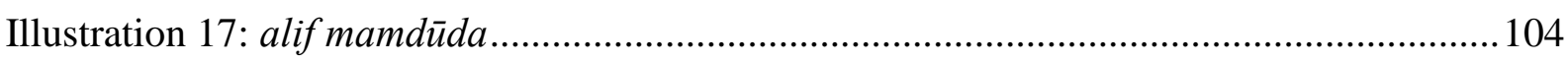

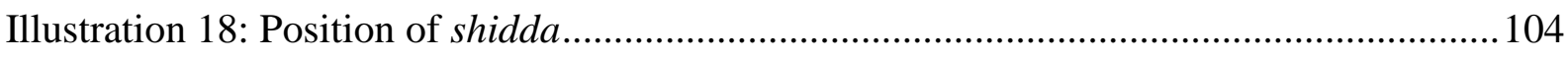

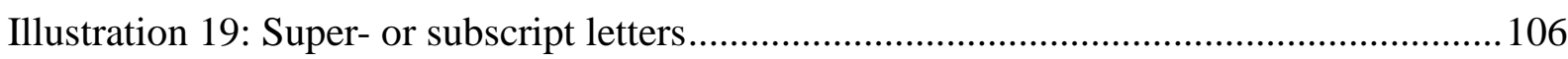


Governing the Empire

List of Maps 
Governing the Empire

Map 1: The Almohad governorships until the reign of al-Mustanșir (1214-1224)..................67

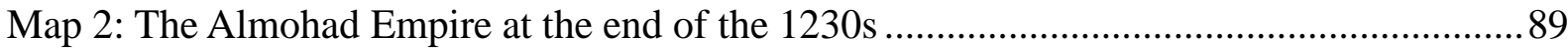

Map 3: Air of application for the Almohad taqādīm ......................................................... 116 
Governing the Empire

List of Tables 
Governing the Empire

Table 1: Phonetic transcriptions......................................................................................... iii

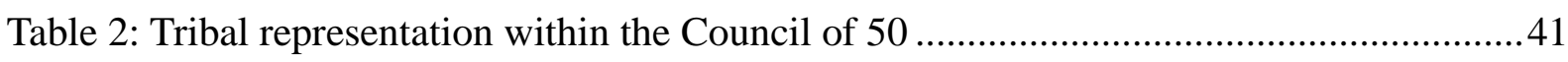

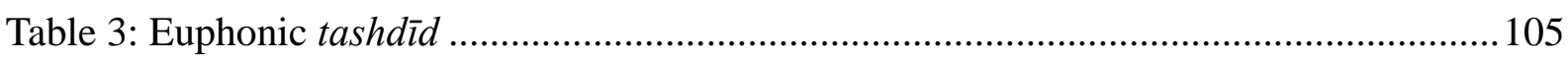

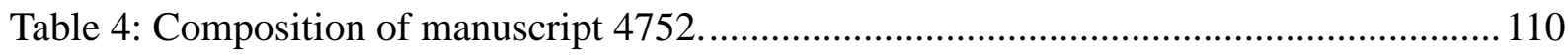

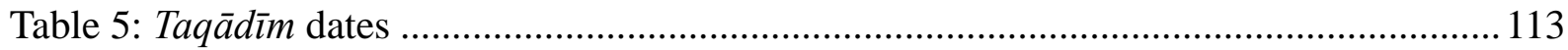

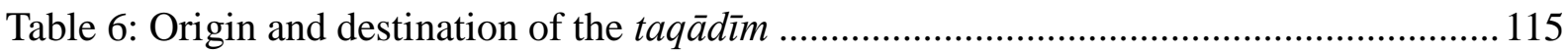

Table 7: Group origins for provincial governors. ……………………………………….....133

Table 8: Orders given to subjects in the final protocols of the taqādìm (imperative or

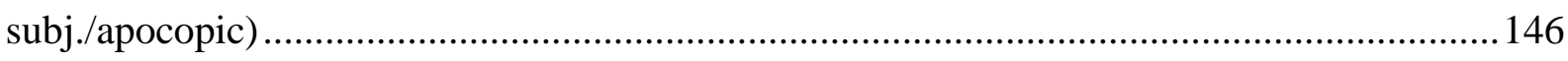

Table 9: Origin of the heads of the Almohad fleet.............................................................178

Table 10: example of the styling work developed by the Almohad secretaries......................217 
Governing the Empire

\section{Table of contents}




\section{Governing the Empire}

Acknowledgements

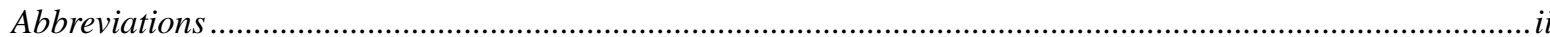

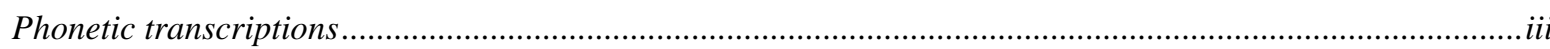

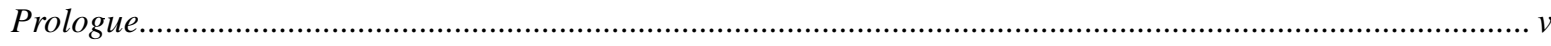

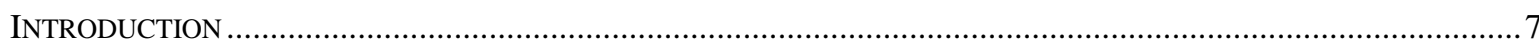

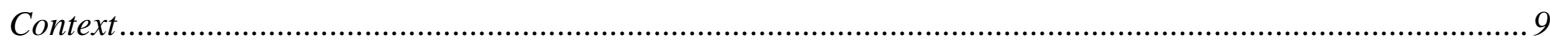

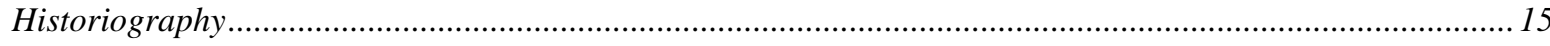

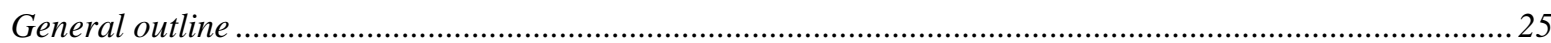

PART ONE

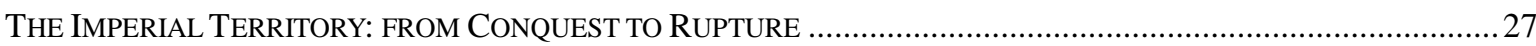

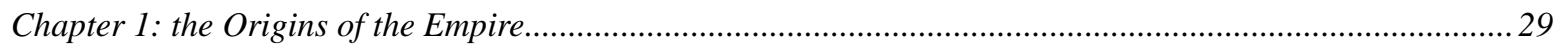

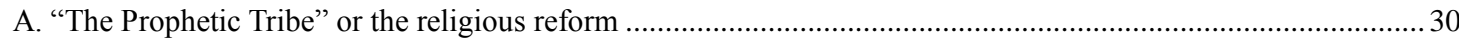

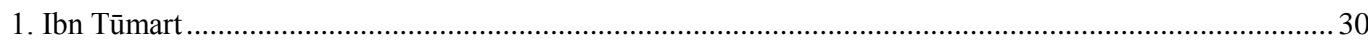

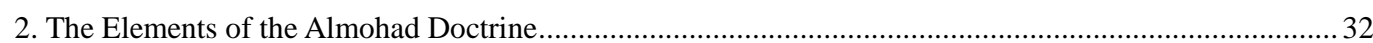

B. "The Party of Unicity" or the Almohad Revolution ......................................................................................... 35

1. The Partisan Organization: the pyramidal framing of the faithful ........................................................... 35

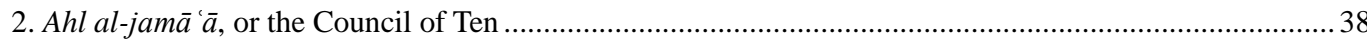

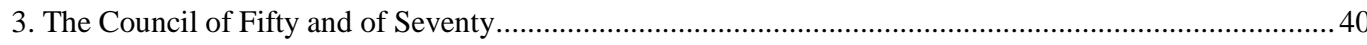

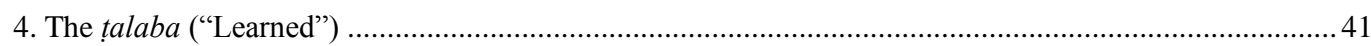

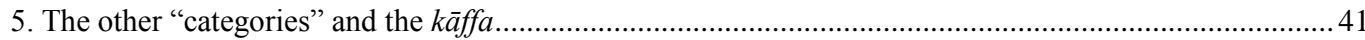

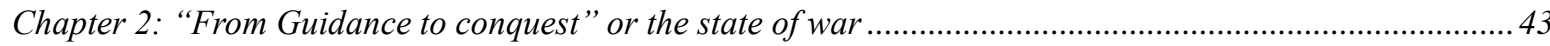

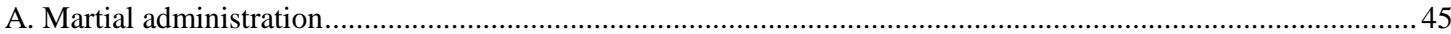

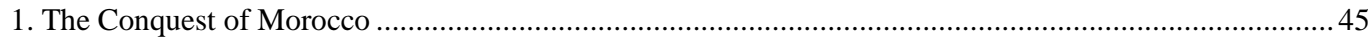

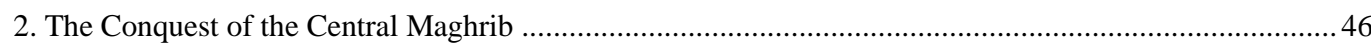

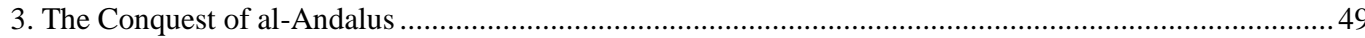

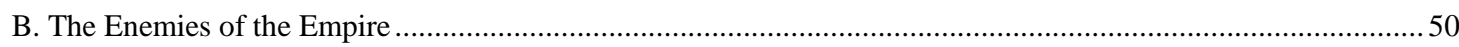

1. The Empire's borders with the Christian kingdoms: war and peace ....................................................... 50

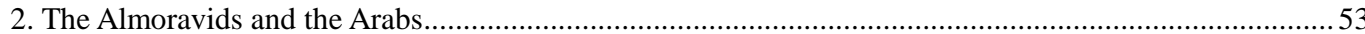

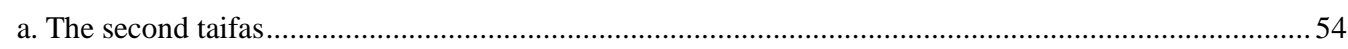

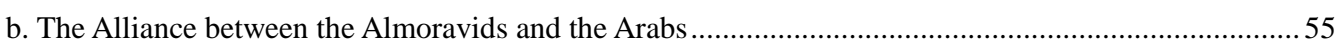

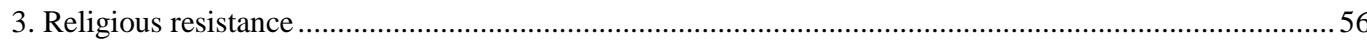

C. The Administrative consequences of the conquest .........................................................................................59

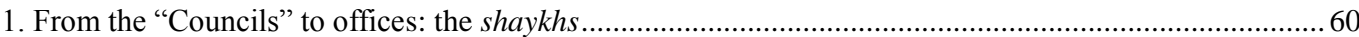

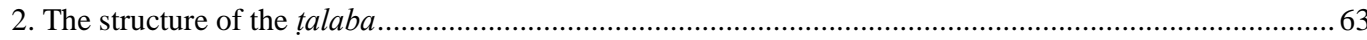

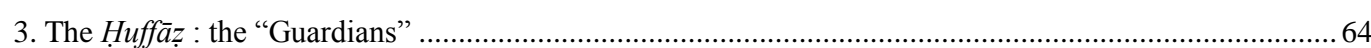

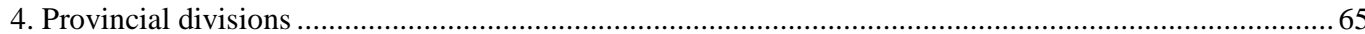

Chapter 3: The "Government of the Sons and the Brothers" or the Dynastic Empire ....................................6 68

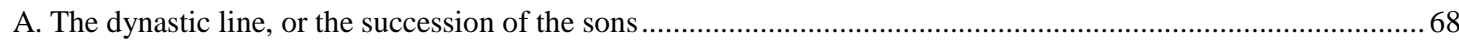

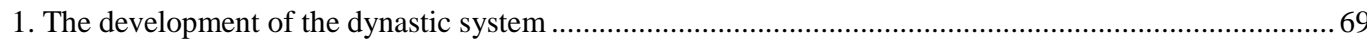

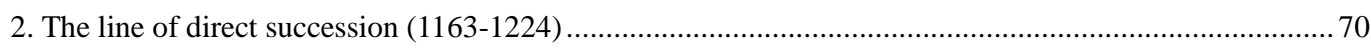

a. The son of 'Abd al-Mu'min: Yūsuf Abū Ya qūb (1163-1184) ……................................................... 70

b. The son of Abū Ya qūb Yūsuf: Abū Yūsuf Ya qūb al-Manșūr (1184-1199) ........................................... 71 
c. The son of Abū Yūsuf Ya 'qūb al-Manșūr: Abū 'Abd Allāh Muhammad al-Nāṣir li-Dīn Allāh (1199-

1214)

d. The son of Abū 'Abd Allāh Muhammad al-Nāṣir: Yūsuf II al-Mustanșir (1213-1224) ......................... 72

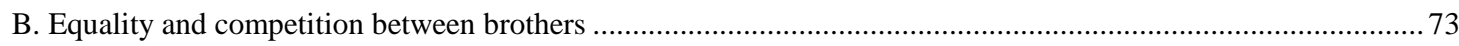

1. Under the authority of the father, the solidarity of brothers: the governor sons....................................... 73

a. The brothers of Abū Ya qūb Yūsuf (1163-1184) ................................................................................. 73

b. The brothers of Abū Yūsuf Ya qūb (1184-1199) ............................................................................. 75

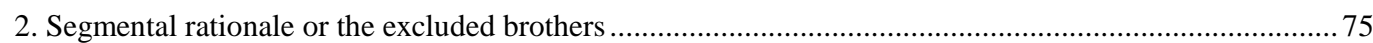

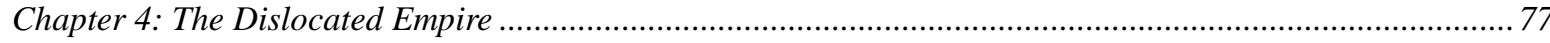

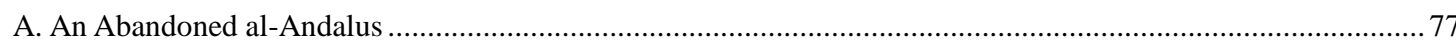

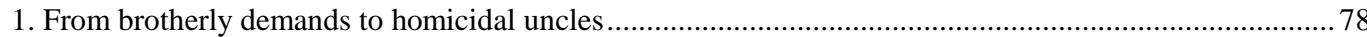

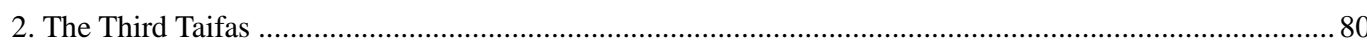

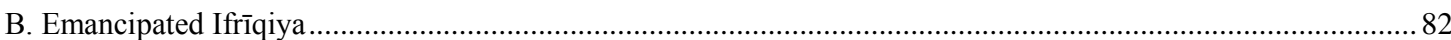

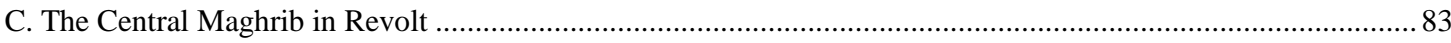

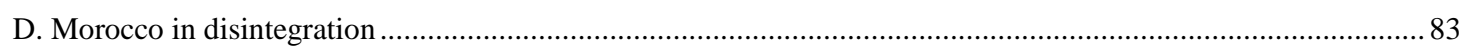

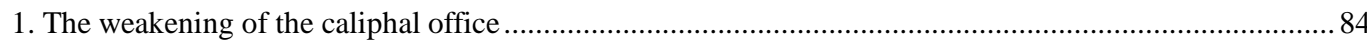

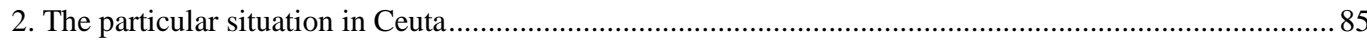

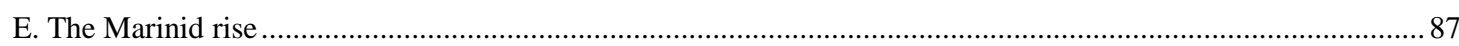

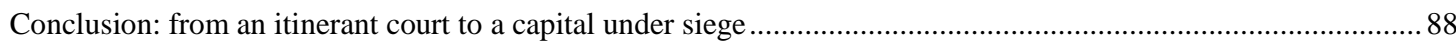

PART TWO

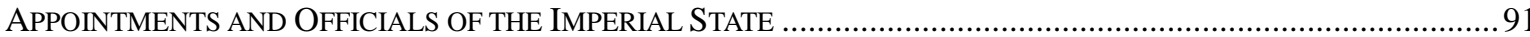

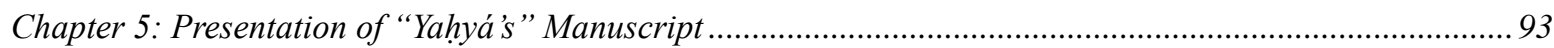

A. The Critical Edition of Arabic Manuscripts ................................................................................................ 94

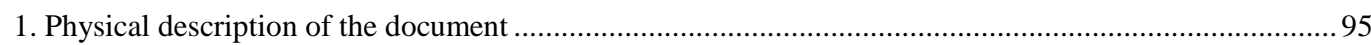

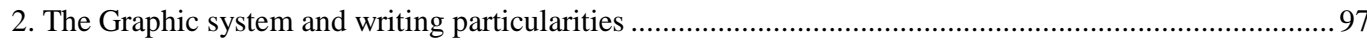

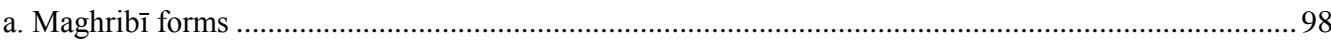

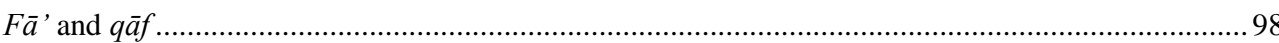

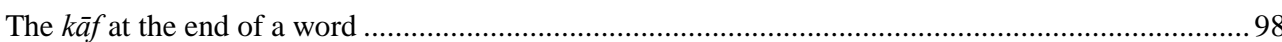

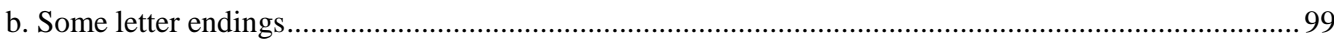

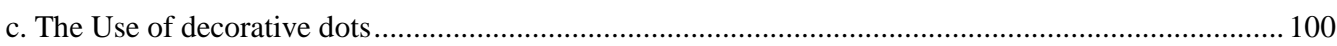

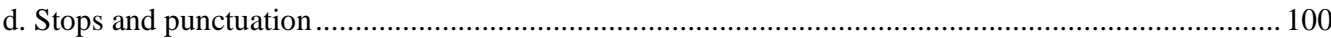

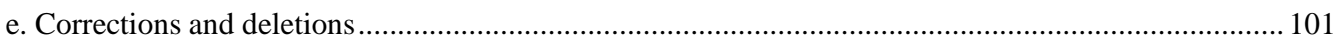

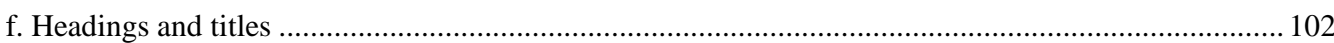

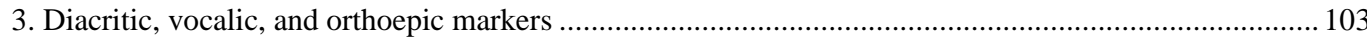

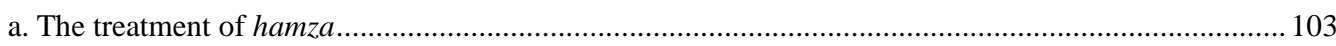

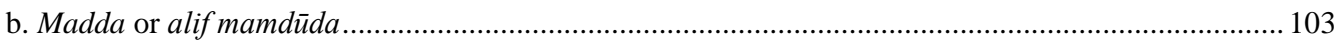

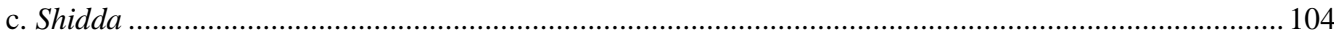

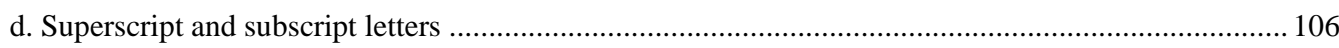

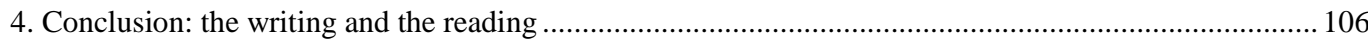

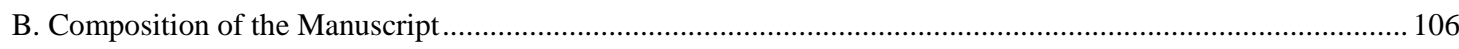

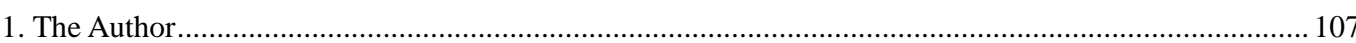

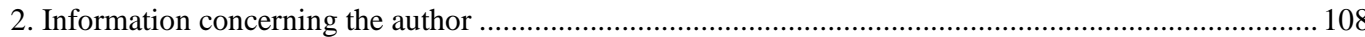




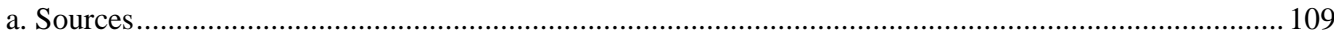

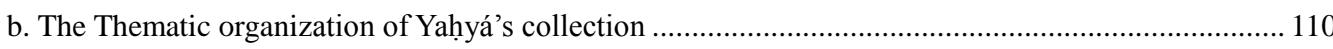

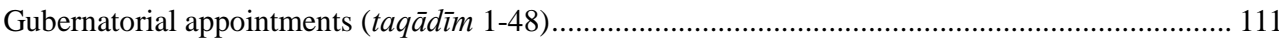

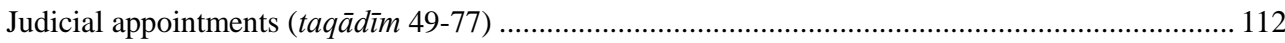

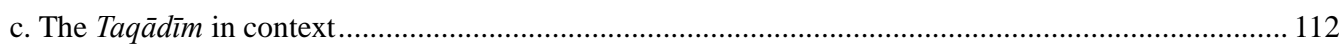

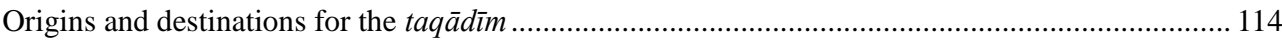

Potential air of application for the taqādìm depending on their context .......................................... 115

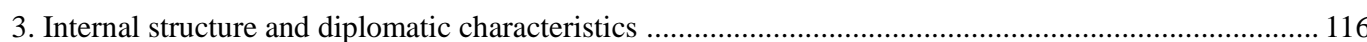

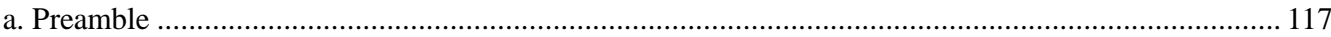

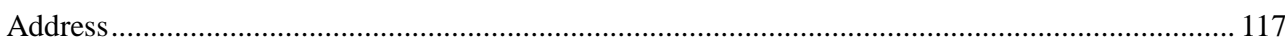

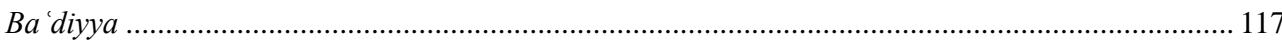

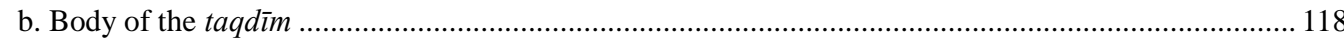

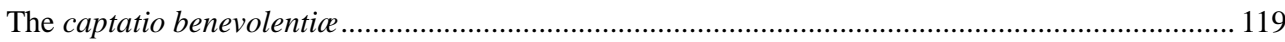

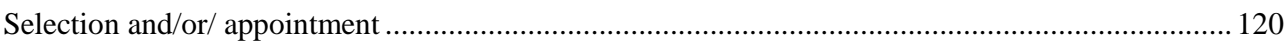

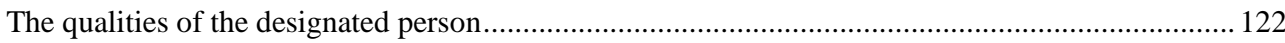

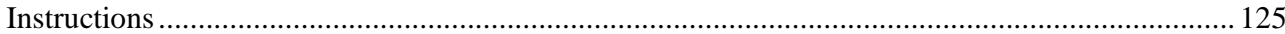

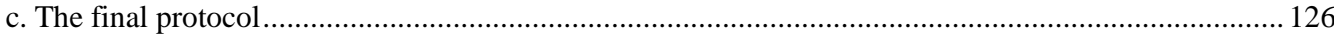

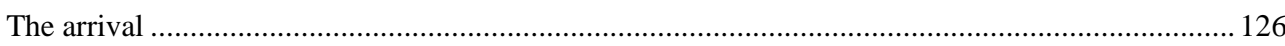

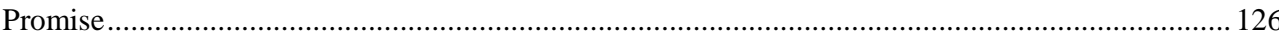

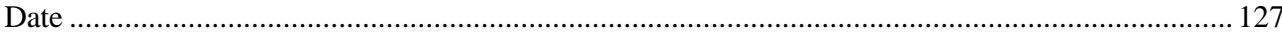

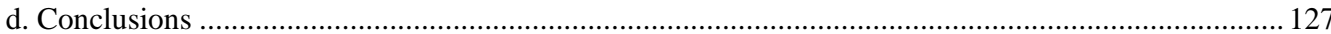

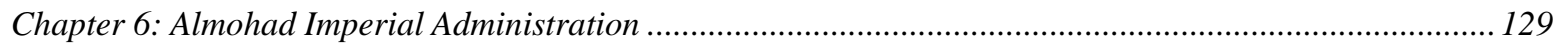

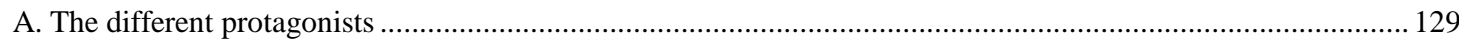

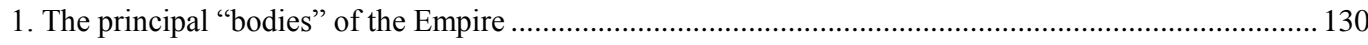

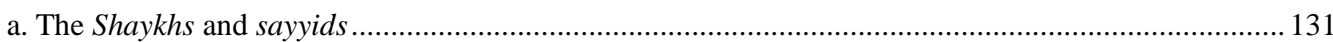

b. The Theorists of the regime (talaba) and the "Guardians" (häfiz) ................................................... 135

2. The population of the Almohad provinces ............................................................................................ 136

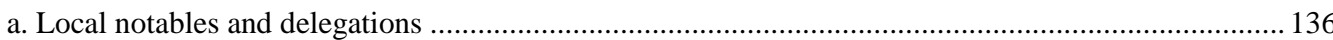

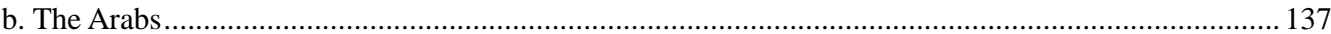

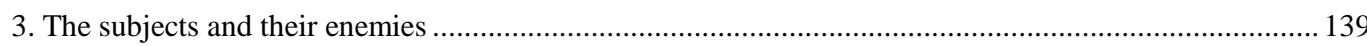

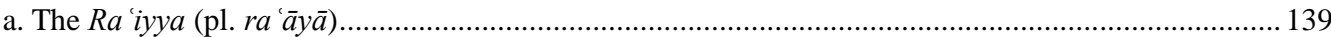

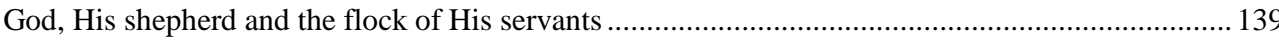

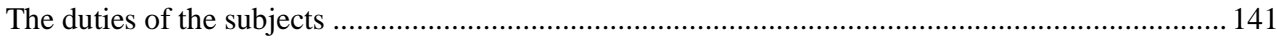

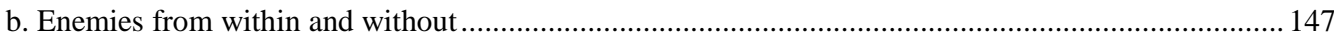

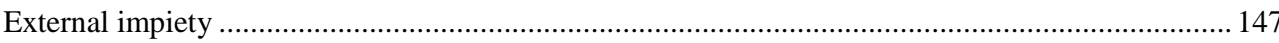

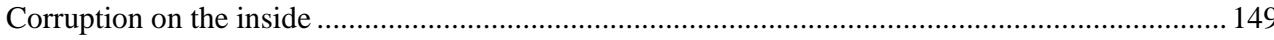

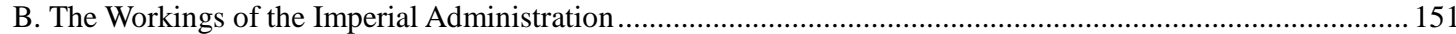

1. Centrality and Almohad caliphal authority .................................................................................. 151

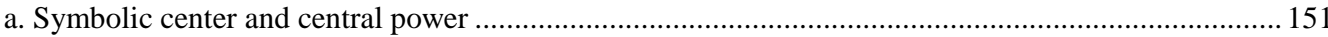


The development of a decisional structure

The Almohad vizierate

The sedentarization of the caliphate under al-Mustanșir................................................................... 155

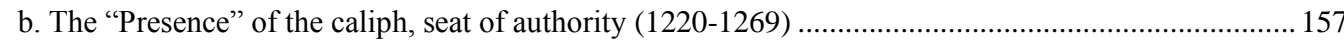

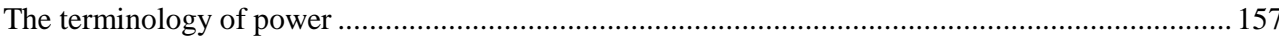

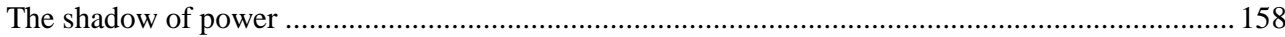

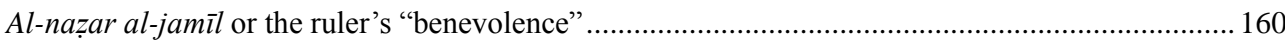

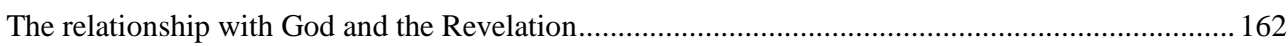

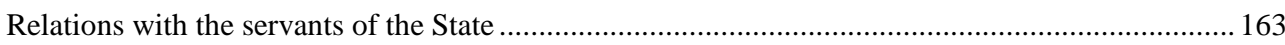

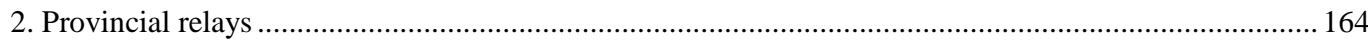

a. The regional representatives of the ruling power: order and taxation .............................................. 165

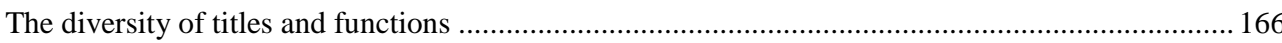

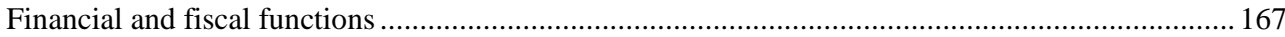

Terminological imprecision: wülät, 'ummāl, nāzir and mushtaghil .............................. 168

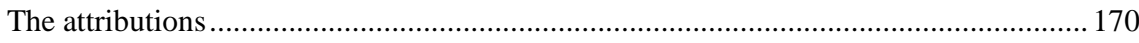

Levies: Haqq, pl. Huqūq, Majba, pl. Majābī and Rusūm .......................................... 170

The muhtaṣs and specific caliphal domain taxes........................................................... 174

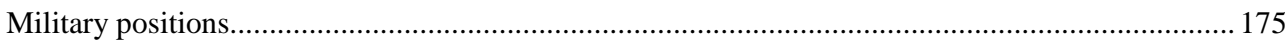

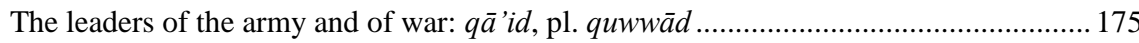

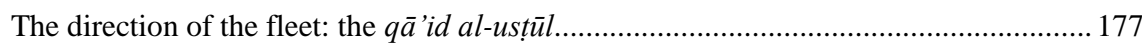

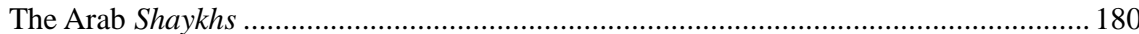

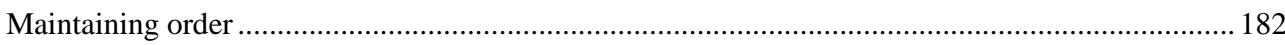

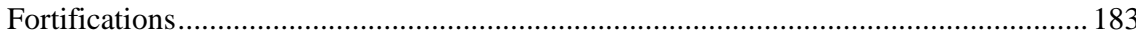

Maẓālim, muḥdathāt and munkarāt: the struggle against abuse and "innovations"......... 183

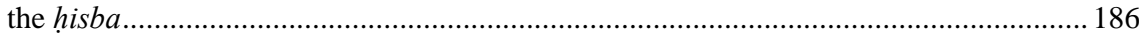

b. The Judiciary institution in the provinces: the qud̄at and delegates ................................................. 188

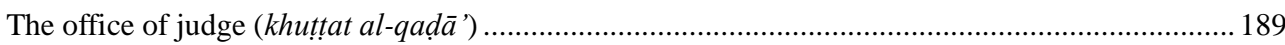

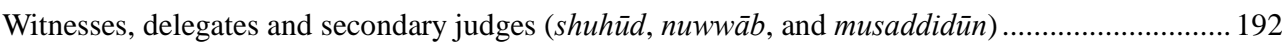

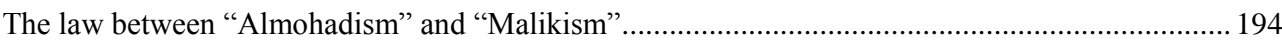

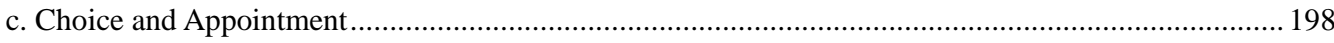

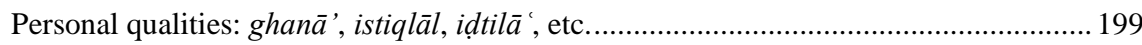

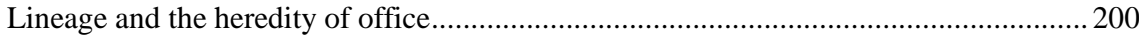

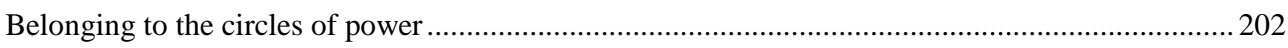

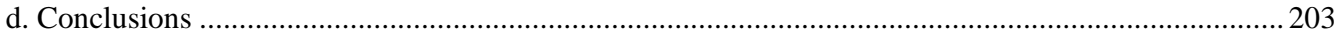

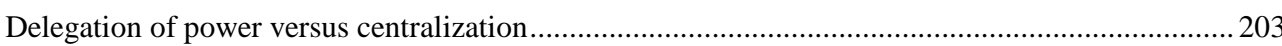

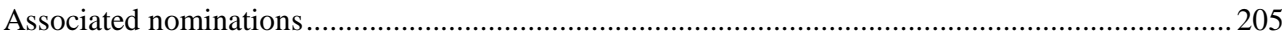

The respective place of judges and territorial administrators.......................................................... 205

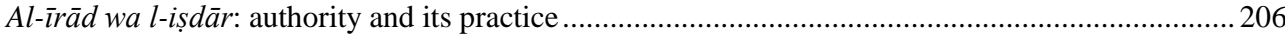

3. The chancellery, central mechanism of the imperial power ...............................................................2 207 
a. The Kitāba, the kuttāb, and the dīwān al-inshā'

The juridical education of the kuttā $b$ under the Almohads ................................................................ 208

The geographic origin of the kuttāb: al-Andalus and the Maghrib .................................................209

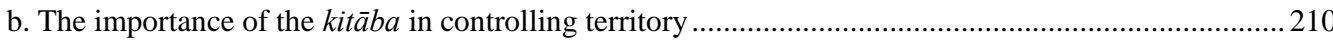

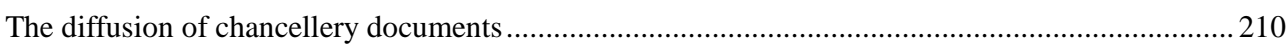

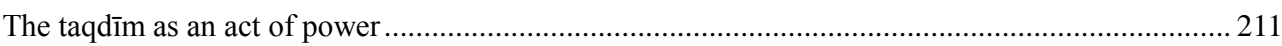

c. Chancellery writing: between tradition and innovation................................................................ 212

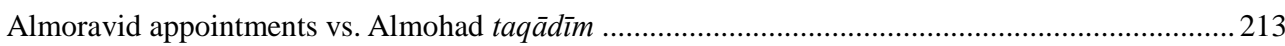

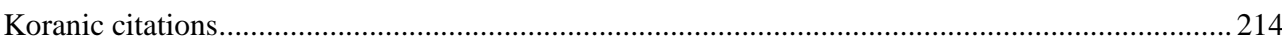

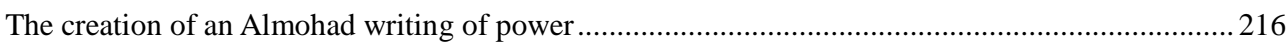

Conclusion 221

PART THREE

EDITION AND TRANSLATION OF YAHYĀ’S FORMULARY .

Taqdim 1: In response to a delegation carrying the allegiance of a region in al-Andalus, recognition, written after 1224, of already constituted authority with a delegation of the power to appoint (excerpt from the "collection of the shaykh"). 232

Taqdim 2: Appointment (excerpt from the "collection of the shaykh") of an admiral of the fleet, probably in Ceuta, by the caliph al-Rashīd (629/1232-640/1242), with great military, fiscal, and monetary attributions.

Taqdìm 3: appointment of an important governor (excerpt from the "collection of the shaykh")......238

Taqdìm 4: From Cordova, the appointment of a governor with fiscal attributions (wālin) by Abū 1- Alá al-Ma'mūn before his ascension to the caliphate (summer 1226-September 1227).

Taqdīm 5: From Granada, Ibn Hūd al-Mutawakkil recalls his vizier, Ibn al-Ramaymī, from Almería, and replaces him with the vizier's son at the head of the region, ramaḍann 630/June 181233 (Act complete).

Taqdīm 6: Recognition, solicited by the population of Ceuta, of the appointment of Abū 1-Qāsim al'Azafî as governor by the caliph al-Murtaḍa on 14 rajab 648/12 October 1250 .................................247

Taqdīm 7: Gubernatorial appointment ( 'ämil), with fiscal and military attributions..........................258

Taqdìm 8: Gubernatorial appointment ( 'âmil), with fiscal and military attributions and the hisba....260

Taqdīm 9: Gubernatorial appointment (wālì or 'ämil), with fiscal and military attributions and the hisba. Revenue from taxes is destined for the defense of the Muslims 261

Taqdìm 10: Appointment of a Guardian (hâfiz) as governor (wāli $)$, with military attributions and the hisba.

Taqdīm 11: Irrevocable or absolute appointment (mutlaq) of a governor ( $' \bar{a} m i l)$ in a frontier zone, with fiscal and military attributions 265

Taqdìm 12: "Complete" appointment (taqdìm tāmm) in favor of a member of the local elite to defend a frontier zone, with fiscal and military attributions....

Taqdīm 13: Appointment of a "Scholar" (talaba) who had already served as governor (wāl $\bar{l})$ in other regions, with administrative and military attributions. Specific Koranic citation

Taqdìm 14: Gubernatorial appointment with fiscal and military attributions.

Taqdìm 15: Gubernatorial appointment (wāli ), with fiscal and military attributions, in collaboration with Abū Fulān for the affairs of the Treasury 
Taqdìm 16: Appointment of a shaykh as governor ('āmil?) with fiscal and military attributions and the hisba

Taqdīm 17: Joint appointment of a shaykh as governor ('āmil ?) of Sijilmāssa and its region, with fiscal and military attributions, and of an official responsible for taxes (nāzir fí l-majbá).

Taqdìm 18: Gubernatorial appointment (wālì), with fiscal and military attributions, along with an official responsible for the Treasury

Taqdìm 19: Appointment of a governor with fiscal and military attributions, and collaboration with the official (mushtaghil) of Fulāna

Taqdīm 20: Delegation decree to maintain Fulān (mushtaghil or 'āmil ?) in his post, with military attributions. Fulān, an Almohad notable, is to serve alongside him, to work with him in repairing the walls

Taqdīm 21: Appointment of a military governor $(q \bar{a} ' i d)$ in a border zone, with fiscal and military attributions.....

Taqdīm 22: Appointment of a governor (wāli $)$ with fiscal and military attributions. An army accompanies the governor to bring order back to this southern region.....

Taqdīm 23: Appointment of Fulān as governor, with military attributes.

Taqdīm 24: Appointment of a governor, probably in Tinmāl.....

Taqdīm 25: Appointment of Abū Fulān as governor with fiscal and military attributions

Taqdìm 26: Appointment of Fulān as governor, with fiscal and military attributions 292

Taqdīm 27: Appointment of Abū Fulān as governor with military attributions 294

Taqdīm 28: Appointment of Abū Fulān as governor with fiscal and military attributions

Taqdìm 29: Appointment of Fulān as governor with fiscal and military attributions

Taqdìm 30: Appointment written in Fulāna, end of ramaḍān 635 / May 1238, of a governor (wālī) in Algésiras by Ibn Hūd al-Mutawakkil (Complete act) .

Taqdìm 31: Appointment of a governor with military attributions. 300

Taqdìm 32: Appointment of a governor to reestablish order. 301

Taqdìm 33: Appointment of a governor to reestablish order in a region 302

Taqdīm 34: Appointment of Fulān to lead the temporal affairs of a region and practice hisba there.303

Taqdìm 35: Appointment of Fulān as governor (identical to taqdìm $\mathrm{n}^{\circ} 44$ )

Taqdìm 36: Confirmation of a governor (wāl $\bar{l})$ after a complaint probably concerning his management of the Treasury (makhzan)......

Taqdīm 37: Renewal of Abū Fulān as governor, with fiscal attributions.

Taqdìm 38: Appointment or confirmation of a shaykh from an Arab tribe 308

Taqdīm 39: Appointment or confirmation of an Arab shaykh, dismissal of the deceased predecessor's son for his brother

Taqdìm 40: Appointment or confirmation of an Arab shaykh at the head of two armies to be united under his command.

Taqdìm 41: Appointment of the son of an Arab shaykh at the head of the Sufyān Arabs, with authority over the Anfā territory (modern Casablanca)

Taqdìm 42: Appointment of a tax collector.

Taqdīm 43: Appointment of shaykh Abū Fulān as governor ('āmil), with fiscal, military, and perhaps judicial attributions, in the name of the caliph al-Murtaḍa from Fulāna in Jumāda I 657/may 1259.314 
Taqdìm 46: Appointment of Fulān as governor responsible for the Domain (mukhtașs and hisba, with fiscal and military attributions.

Taqdīm 47: Appointment from Fulāna, just after the conquest of the city, of a governor by the caliph alMurtad̄a (649/1251-650/1252)

Taqdīm 48: Appointment of a governor with fiscal attributions

Taqdìm 49: Appointment of a judge, responsible for choosing instrumentary witnesses and secondary judges, in the name of the caliph al-Ma'mūn, before the renunciation of the Almohad doctrine (2 shawwāl 624/1227-626/1229). The bases of the law are the Koran and Tradition

Taqdīm 50: Appointment of a judge, responsible for the choice of instrumentary witnesses. The bases for law are the Koran and Tradition.....

Taqdìm 51: Appointment of a judge responsible for choosing instrumentary witnesses and secondary judges, after the abandonment of the Almohad doctrine. The person appointed follows in the footsteps of his father and his uncle. The foundations of the law are the Koran, Tradition, community consensus and juridical consultations of the imāms.

Taqdīm 52: Appointment of the jurist Abū Muhammad as judge of Jérez by the Caliph al-Ma'mūn, middle of the month of shawwāl 626/beginning of September 1229. The judge is responsible for choosing instrumentary witnesses and assistants or secondary judges. The foundations of the law are the Koran, Tradition and the consensus of the Community

Taqdìm 53: Appointment from Seville of the jurist Abū Muhammad as judge in Algeciras by the Caliph al-Ma'mūn (safar 626/January 1229). The judge is responsible for choosing instrumentary witnesses. The foundations of the law are the Koran, Tradition, and the consensus of the Community

Taqdīm 54: Appointment by Ibn Hūd al-Mutawakkil of a judge in Malaga (rabī̄ II 634/December 1237). The judge is responsible for the market police and choosing assistants, or secondary judges, and instrumentary witnesses. The foundations of the law are the Koran, Tradition, the consensus of the Community, and the juridical consultations of the imāms

Taqdīm 55: Appointment by Ibn Hūd al-Mutawakkil of a judge responsible for choosing instrumentary witnesses. The foundations of the law are the Koran, Tradition, the consensus, and the words of the imāms. Many Koranic quotations (1228-1238)

Taqdīm 56: Appointment of a judge, responsible or choosing assistants or secondary judges and instrumentary witnesses. The foundations of the Law are the Koran, Tradition, the consensus of the Community and the sayings of the greatest scholars

Taqdīm 57: Appointment of Abū Muhammad as judge of Jérez by the caliph al-Rashīd on the first of dhū l-qa'da 636/June 5, 1239. The judge is responsible for choosing substitutes and instrumentary witnesses. The foundations of the law are the Koran, Tradition, consensus of the Community and the "path of the imāms of religion and the scholars of Islam."

Taqdìm 58: Appointment by the caliph al-Rashīd of a judge responsible for choosing instrumentary judges. The foundations of the law are the Koran, Tradition, consensus and the words of the scholars based on reflection and personal interpretation .....

Taqdìm 59: Appointment by al-Rashīd, before the reestablishment of the Almohad doctrine, of a judge responsible for choosing instrumentary witnesses. The foundations of the law are the Koran, Tradition, consensus and the juridical consultations of the scholars of the Community and the most learned imāms

Taqdìm 60: Appointment of a judge responsible for choosing instrumentary witnesses ..................350

Taqdīm 61: Appointment of a judge responsible for selecting instrumentary witnesses

Taqdim 62: Appointment of a judge responsible for selecting instrumentary witnesses. The foundations of the law are the Koran and Tradition ............................................................................ 352

Taqdīm 63: Incomplete excerpt of a judicial appointment 
Taqdìm 65: Renewal by al-Mu tadid of a judge responsible for choosing delegates and instrumentary witnesses. The foundations of the law are the Koran, Tradition, and the consensus of the Community (mid shawwāl 640/beginning of April 1242) . .354

Taqdìm 66: Appointment of a judge to a post where he had already served. The foundations of the law are the Koran, Tradition, and the consensus of the Community

Taqdìm 67: Appointment of a judge responsible for selecting instrumentary witnesses. The foundations of the law are the Koran, Tradition, and the consensus of the Community.....

Taqdìm 68: Appointment of a judge responsible for choosing instrumentary witnesses. The foundations of the law are the Koran, Tradition, and the consensus of the Community.

Taqdìm 69: Appointment - from Marrakesh? - of a judge responsible for choosing instrumentary witnesses. The foundations of the law are the Koran, Tradition, the consensus of the Community, and the words of the scholars

Taqdim 70: (Incomplete) judicial appointment. The foundations of the law are the Koran, Tradition...

Taqdìm 71: Appointment of a judge responsible for choosing instrumentary witnesses, assistants or secondary judges, and the hisba (?). The foundations of the law are the Koran, Tradition, and the consensus of the Community....

Taqdìm 72: Appointment of a judge responsible for instrumentary witnesses. The foundations of the law are the Koran, Tradition, and the consensus

Taqdìm 73: Appointment of a judge responsible for choosing instrumentary witnesses and a worthy son of his father. The foundations of the law are the Koran, Tradition, and the consensus of the Community

Taqdìm 74: Appointment of a judge responsible for choosing secondary judges and instrumentary witnesses as well as the hisba. The foundations of the law are the Koran, Tradition and the consensus of the Community.....

Taqdìm 75: Appointment of a judge responsible for choosing instrumentary witnesses. The foundations of the law are the Koran, Tradition, and consensus

Taqdìm 76: Appointment of a judge responsible for choosing instrumentary witnesses. The foundations of the law are the Koran, Tradition, consensus and examples (athar) 371

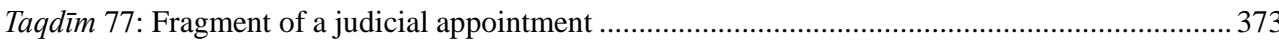

ANNEXES

Annex 1: The Almohad Caliphs.

Annex 2: Periods of war and truce with the Christian kingdoms of the Iberian peninsula 378

Annex 3: List of governors inventoried in the narrative sources by 'Izz al-Dìn Mūsá (1224-1269).

Primary Sources.

Published 
